UNIVERSIDADE DE BRASÍLIA PÓS-GRADUAÇÃO EM GEOGRAFIA

\title{
DE ALDEAMENTO JESUÍTICO A PERIFERIA METROPOLITANA: CARAPICUÍBA/SP COMO RUGOSIDADE PATRIMONIAL
}

Rafael Fabricio de Oliveira

Tese de Doutorado

Brasília-DF: Dezembro / 2016 
UNIVERSIDADE DE BRASÍLIA PÓS-GRADUAÇÃO EM GEOGRAFIA

\section{DE ALDEAMENTO JESUÍTICO A PERIFERIA METROPOLITANA: CARAPICUÍBA/SP COMO RUGOSIDADE PATRIMONIAL}

Rafael Fabricio de Oliveira

Orientador: Prof. Dr. Everaldo Batista da Costa 
Universidade de Brasília

Instituto de Ciências Humanas

Departamento de Geografia

Programa de Pós-Graduação em Geografia

UNIVERSIDADE DE BRASÍLIA

PÓS-GRADUAÇÃO EM GEOGRAFIA

\title{
DE ALDEAMENTO JESUÍTICO A PERIFERIA METROPOLITANA: CARAPICUÍBA/SP COMO RUGOSIDADE PATRIMONIAL
}

\begin{abstract}
Rafael Fabricio de Oliveira
Tese de Doutorado submetida ao Departamento de Geografia da Universidade de Brasília, como parte dos requisitos necessários para a obtenção do Grau de Doutor em Geografia, área de concentração Gestão Ambiental e Territorial, opção Acadêmica.
\end{abstract}

Aprovado por:

PROF. DR. EVERALDO BATISTA DA COSTA (GEA-UNB)

(Orientador)

PROFA. DRA. BERNADETE AP. CAPRIOGLIO DE CASTRO (DEPLAN-UNESP)

(Examinador Externo)

PROFA. DRA. ROSALINA BURGOS (DGTH-UFSCAR)

(Examinador Externo)

PROF. DR. NEIO L. DE OLIVEIRA CAMPOS (GEA-UNB)

(Examinador Interno)

PROFA. DRA. REBECCA FORATTINI LEMOS IGREJA (CEPPAC-UNB)

(Examinador Interno)

PROF. DR. FERNANDO LUIZ ARAÚJO SOBRINHO (GEA-UNB)

(Examinador Interno - Suplente) 
Ficha catalográfica elaborada automaticamente, com os dados fornecidos pelo(a) autor(a)

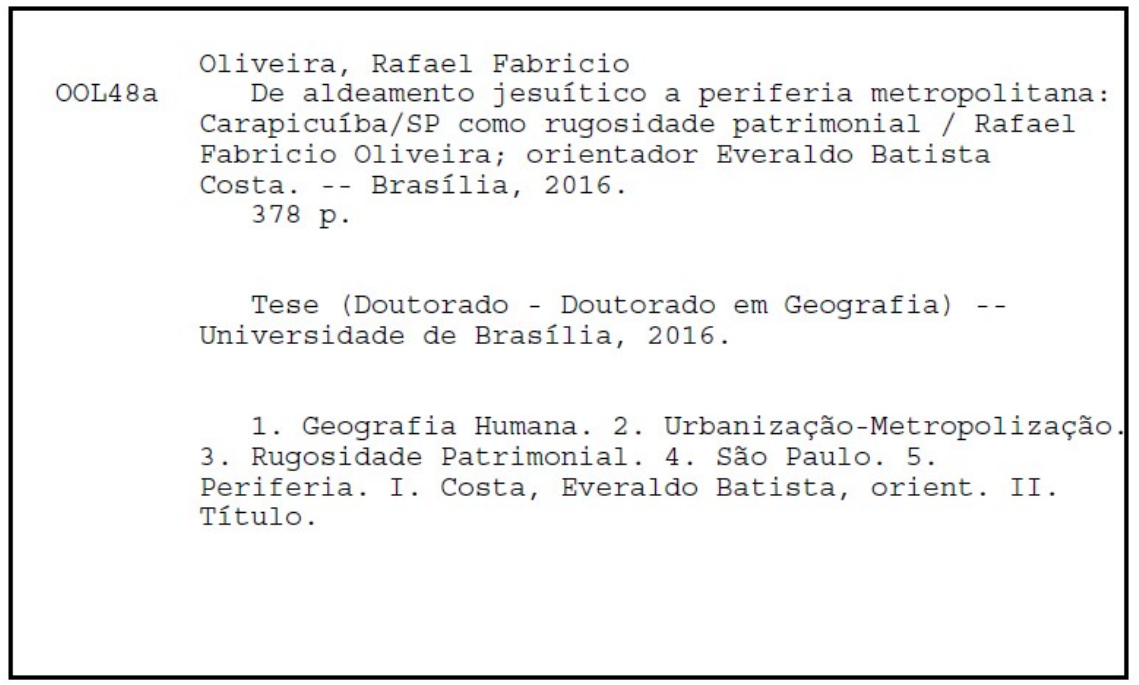


Dedico esta tese aos munícipes de Carapicuiba $e$ periferias, que fazem do cotidiano uma luta diária, resistindo historicamente às diferentes formas $e$ conteúdos de exploração, que abraçaram carinhosamente a proposta de pesquisa e fizeram disso um dos muitos motivos de escolha deste recorte. 


\section{AGRADECIMENTOS}

No contexto de desenvolvimento desta tese, diversas pessoas e instituições foram determinantes para a sua concretização. Por isso, agradecer, mais que uma mera formalidade, é reconhecer o esforço coletivo, o fortalecimento da cooperação, as amizades construídas no processo de pesquisa, a compreensão da família e amigos pelas ausências. Para além, é prestar homenagem aos mestres que sabiamente cativaram, com paciência e sabedoria, nossas aprendizagens, estimulando cuidadosamente a produção do conhecimento, além de nossos alunos, com quem ensinamos aprendendo. É ainda considerar o trabalho de servidores que mesmo diante das adversidades históricas realizam heroicamente suas essenciais atividades diárias, dando sustentação e qualidade à universidade e aos órgãos governamentais. Agradecer é também lembrar de pessoas especiais, que marcaram o curso da pesquisa, da tese e de nossas vidas como um todo. Por isso, agradeço:

Ao mestre/orientador Prof. Dr. Everaldo B. da Costa, pelo carinhoso acolhimento, a amizade, o apoio em todos os momentos, a dedicação e profissionalismo com que conduz seu trabalho e a quem dedico grande admiração, respeito e gratidão.

Aos professores do Departamento de Geografia e do Programa de Pós-Graduação em Geografia da Universidade de Brasília pelos diálogos e o contínuo estímulo, especialmente a Profa. Dra. Nelba Azevedo Penna, o Prof. Dr. Dante Reis Júnior, Profa. Dra. Lúcia Cony Faria Cidade, Profa. Dra. Marília Luiza Peluso, o Prof. Dr. Fernando L. Araújo Sobrinho e o Prof. Dr. Juscelino Bezerra.

Aos professores do Departamento de Geografia da USP, Prof. Dr. Francisco Capuano Scarlato e a Profa. Dra. Simone Scifoni pelas preciosas dicas e orientações no exame de qualificação. Ao professor do Departamento de Geografia da Unesp, Prof. Dr. Paulo Godoy pelo diálogo e prontidão diante das questões acerca das rugosidades espaciais.

Aos professores da Banca Final de Doutorado, Profa. Dra. Bernadete Ap. Caprioglio de Castro (DEPLAN-UNESP), Profa. Dra. Rosalina Burgos (DGTH-UFSCAR), Prof. Dr. Neio L. de Oliveira Campos (GEA-UNB), Prof. Dra. Rebecca Forattini Lemos Igreja (CEPPACUNB), pela apurada leitura, críticas, orientações e análise crítica do trabalho.

Aos servidores da UnB, especialmente os da Diretoria de Desenvolvimento Social, da Moradia Estudantil da Colina e Restaurante Universitário, pelas essenciais condições de provimento e permanência ao longo das atividades em Brasília. Aos servidores da Secretaria de Pós-Graduação em Geografia, sobretudo a Simoní Hiargles, ao Jorge Luís, ao Agnelo Pereira e ao Jorginho pelo apoio integral. Aos servidores da Biblioteca Central e demais trabalhadores que cotidianamente mantém em pé a instituição.

Aos colegas do Programa de Pós-Graduação em Geografia, do GECIPA, da UnB, da Unesp, de Brasília, São Paulo, Carapicuíba e de Itu: Gilvan Araújo, Ronei Coelho, Márcio Benalussy, Tatiana Terra, André Sartori, Rubia Rúbio, Demerson Lima, Abbul Mahmebb, Bismarc Pereira, Rafael Dias, Sidelmar Kunz, Isabel Moraes, Luana Nunes, Renan Boscariol, Janaina Mourão, Ilka Hostensky, Eduardo Marcusso, Bruno Leite, Timoté (Tim Kaunan), Tiago Magalhães, Demétrius Viana, Leandro Alves, Ivan Benevenuto, Julio Fontes, pela amizade, companheirismo e apoio em diferentes momentos desta pesquisa.

Ao historiador Rafael Araújo Oliveira, pelo auxílio prestado na pesquisa documental nos arquivos do IPHAN de São Paulo. Agradeço também a estagiária do IPHAN do Rio de Janeiro, Vanessa Almeida, pelo apoio e disponibilização das referências documentais do 
tombamento da Aldeia de Carapicuíba. Agradeço ainda ao Téc. do IPHAN em São Paulo, Sr. José Saia Neto, pelas informações pronta e gentilmente disponibilizadas.

Ao André Sartori pela análise crítica dos mapas, ao Leidson Pelissari e Marcelo Cizaurre pela revisão do abstract, a Jane Aparecida pela revisão de língua portuguesa, ao Celso Domenice na parte de informática.

Aos membros da Associação Sarabaquê de Difusão Cultural da Aldeia de Carapicuíba, especialmente a Helenice Camargo Henne, Vinicius Camargo Henne, Marcia Komatsu Henne e Otto Henne Júnior, pelo precioso apoio ao longo da pesquisa, esclarecimentos, diálogos e amizade.

Aos membros da OCA Escola Cultural da Aldeia de Carapicuíba, especialmente ao Fofão, Paulinho e a Vera pela receptividade, diálogos e amizade.

Aos servidores da Prefeitura de Carapicuíba, Marcos Barits e Alaide de Pietro, pelas conversas, informações, alegrias e o trabalho apaixonado que desenvolvem na periferia de São Paulo.

Ao Rafael Felipe pelo convite e possibilidade de registro das manifestações culturais de São Benedito e Nossa Senhora do Rosário na Vila Menck, em Carapicuíba. Aos violeiros, percussionistas, festeiros e caipiras da Festa de Santa de Cruz, Santa Cruzinha e Festival de Viola pelo acolhimento, diálogos e energia de suas músicas, danças e prosas.

Ao Luiz Roberto, pelas informações despendidas, o apoio e estímulo a pesquisa.

Aos colegas do Ministério das Cidades, da UAB (UnB) e da Secretaria de Educação do GDF, no apoio ao estudos e sincronização das atividades técnicas-profissionais junto às acadêmicas, especialmente ao Paulo Rogério, Valmir Moraes, Nathan Oliveira, Tatiana Santana e Romeu Gadotti.

Aos colegas do IFSP pelo apoio no trajeto final de pesquisa, especialmente ao Prof. Dr. Ricardo Coelho, a Téc. em Assuntos Educacionais Roseli Costa, o Prof. Dr. Rogério Souza e o Prof. Msc. Rafael Novaes.

Aos estudantes de Tecnologia em Gestão Ambiental do IFSP que me acompanharam nos trabalhos em campo pelas periferias e quebradas da Grande São Paulo, destacadamente o Antônio Silva, Dayana Rosa, a Tainã Rezende, Sidnei Souza, a Carol, o Lucas, a Isabela e a Tainá. Além do estudante secundarista, morador de Carapicuíba, Luan Seabra por todo o apoio.

Por fim, um agradecimento muito especial a minha família, notadamente a minha esposa Ana Carla M. de Aguiar por minhas ausências e sempre ponderar conjuntamente acerca de nossos projetos de vida. Ao Balaio, Herbert, Raimundo, Márcia, Mathilde, Rosana e Mariah pelas incontáveis alegrias e estímulos. A minha querida mãe, Jane Aparecida de Oliveira, pelo incondicional apoio ao longo de toda a vida.

A todos e todas, minha mais sincera gratidão. Rafael F. de Oliveira 


\title{
RESUMO
}

Esta tese analisa as rugosidades patrimoniais frente ao processo de metropolização, tomando como recorte empírico o caso da Aldeia de Carapicuíba, na Região Metropolitana de São Paulo, Brasil. A premissa principal reside na centralidade de processos sociais ligados às tradições e o uso cotidiano como razão prática de existência na preservação do patrimônio cultural, diante das modernizações concentradas e desiguais operadas pela urbanização generalizada no Brasil. Os argumentos consistem em revelar que o drama periférico de Carapicuíba compõe um dos mais emblemáticos casos de permanência cultural diante de supressões, superposições e acumulações de formas-conteúdo em diferentes regimes de tempo. O que potencializa uma perspectiva crítica singular de apreender a dinâmica metropolitana desde sua periferia e a partir das relações entre os sujeitos, seus bens culturais e as políticas urbanas e patrimoniais que as permeiam.

Palavras-chave: Metropolização; São Paulo; Periferia; Carapicuíba; Patrimônio Cultural; Rugosidade Patrimonial

\begin{abstract}
This thesis analyzes the heritage roughness in the process of metropolization by approaching the empirical case of the Aldeia de Carapicuíba, in the São Paulo Metropolitan Region. The central hypothesis lies on the centrality of social processes linked to traditions and the quotidian use as practical reasons for existence in the preservation of cultural heritage in the concentrated and uneven modernizations operated by the generalized urbanization of Brazil. The arguments show that the peripheral drama of Carapicuíba is one of the most emblematic cases of cultural permanence carried out by suppressions, superpositions and accumulations of the content-forms in different periods. This analysis helps to built a singular critical perspective through it we can better understand the metropolitan dynamics from its periphery, based on the relations between subjects, their cultural assets and the urban and heritage policies.
\end{abstract}

Key-words: Metropolization; São Paulo; Periphery; Carapicuíba; Cultural Heritage; Heritage Roughness 


\section{LISTA DE FIGURAS}

\begin{tabular}{|c|c|}
\hline FIGURA 1 Contribuição do conceito de rugosidade espacial na apreensão do fenômeno urbano & p. 50 \\
\hline FIGURA 2 Rugosidade como resultado da supressão parcial das formas espaciais - Barra Funda em São Paulo & p. 51 \\
\hline FIGURA 3 Rugosidade como resultado da acumulação e co-presença das formas espaciais Panamá & p. 54 \\
\hline FIGURA 4 Entre passado e presente, riqueza e pobreza, o viver e o trabalhar nos limites de São Paulo & p. 54 \\
\hline FIGURA 5 Rugosidade como resultado da superposição de formas espaciais & p. 56 \\
\hline FIGURA 6 Instalação do condomínio Alphaville em Carapicuíba (2011-2014) & p. 57 \\
\hline FIGURA 7 Monumento ao trabalhador de limpeza urbana - San José (Costa Rica) & p. 59 \\
\hline FIGURA 8 Modernizações e as rugosidades patrimoniais entre o mercado global e as comunidades locais & p. 61 \\
\hline FIGURA 9 Povos testemunhos vendem artesanatos nas ruas do centro de Antígua Guatemala & p. 81 \\
\hline FIGURA 10 Áreas ritualísticas e centrais de Tikal - Guatemala & p. 82 \\
\hline FIGURA 11 Cordilheira dos Andes e a cidade de Santiago - Chile & p. 83 \\
\hline FIGURA 12 Patrimônio natural das paradisíacas praias no Caribe - Varadero/Cuba & p. 83 \\
\hline FIGURA 13 Núcleos coloniais de Ouro Preto e Diamantina - Minas Gerais & p. 83 \\
\hline FIGURA 14 Sítio da área onde se localiza a Aldeia de Carapicuíba & p. 115 \\
\hline FIGURA 15 Perspectiva da Aldeia de Carapicuíba em 1937 & p. 117 \\
\hline FIGURA 16 Aldeias Jesuíticas - Modelos projetados conforme Lei das Índias & p. 118 \\
\hline FIGURA 17 Os arredores de São Paulo em meados do século XIX & p. 135 \\
\hline FIGURA 18 Caipira Picando Fumo (1983) e o Violeiro (1899) - Almeida Júnior & p. 139 \\
\hline FIGURA 19 Aldeia de Carapicuíba - 1913 & p. 141 \\
\hline FIGURA 20 População na Aldeia de Carapicuíba - Festejos de Santa Cruz em 1913 & p. 143 \\
\hline FIGURA 21 Mancha urbana de São Paulo - Fins do Século XIX & p. 144 \\
\hline FIGURA 22 Expansão Metropolitana Oeste -1921 & p. 148 \\
\hline FIGURA 23 Loteamentos na Vila Teresinha - Expansão Urbana no Entorno das Estações em Carapicuíba & p. 155 \\
\hline FIGURA 24 Loteamentos no entorno da EFS - Carapicuíba, 1949 & p. 155 \\
\hline FIGURA 25 Modernismo e as novas dimensões culturais propostas pelo resgate indigenista às avessas & p. 166 \\
\hline FIGURA 26 Estrutura do telhado da sacristia - Igreja de São João Batista em 1936 & p. 170 \\
\hline FIGURA 27 Nova estrutura do telhado da sacristia - Igreja de São João Batista em 2016 & p. 170 \\
\hline FIGURA 28 Detalhe do mastro que inaugura as festividades de Santa Cruz na Aldeia de Carapicuíba - 2016 & p. 171 \\
\hline FIGURA 29 Estação Sylviânia em Carapicuíba - década de 1930 & p. 180 \\
\hline FIGURA 30 São Paulo e Arredores em 1962 & p. 181 \\
\hline FIGURA 31 Arredores de São Paulo - Ônibus Suburbanos Intermunicipais - 1965 & p. 183 \\
\hline FIGURA 32 Intervenções nos bens imóveis da Aldeia de Carapicuíba - 1956 & p. 191 \\
\hline FIGURA 33 Perspectiva da COHAB Castelo Branco em Carapicuíba - década de 1970 & p. 199 \\
\hline FIGURA 34 Áreas Urbanizadas Zona Oeste da RMSP - Emplasa (1975) & p. 201 \\
\hline FIGURA 35 Paisagens de Carapicuíba - Conversão do Subúrbio em Periferia de São Paulo & p. 215 \\
\hline FIGURA 36 Tensões exercidas pela metropolização de São Paulo na Aldeia de Carapicuíba & p. 220 \\
\hline FIGURA 37 Impactos resultantes da metropolização na Aldeia de Carapicuíba - 1991 & p. 222 \\
\hline FIGURA 38 Impactos resultantes da metropolização na Aldeia de Carapicuíba - 1991 & p. 223 \\
\hline FIGURA 39 Jogo final do mundial interclubes da FIFA em Tóquio (Japão): "the favela is here" - 2012 & p. 234 \\
\hline FIGURA 40 Distribuição das classes sociais por localizações na RMSP - 2010 & p. 240 \\
\hline FIGURA 41 Vila Municipal nos trilhos da CPTM - Carapicuíba/SP & p. 249 \\
\hline FIGURA 42 Cidade precária e ilegal justaposta a modernização e sofisticação dos serviços em Carapicuíba & p. 252 \\
\hline FIGURA 43 Padrões de ocupação e assentamentos precários em Carapicuíba - 2010 & p. 254 \\
\hline FIGURA 44 Intervenções na Aldeia de Carapicuíba - 1985 & p. 258 \\
\hline FIGURA 45 Intervenções no Conjunto da Aldeia de Carapicuíba em 1998 & p. 270 \\
\hline FIGURA 46 Projeto Básico de Restauro da Aldeia de Carapicuíba - 2003/2004 & p. 281 \\
\hline FIGURA 47 Postal Rota Carapicuíba do Circuito Taypa de Pilão & p. 284 \\
\hline FIGURA 48 Conjunto da Aldeia de Carapicuíba & p. 285 \\
\hline FIGURA 49 Ordem e número das casas na Aldeia de Carapicuíba & p. 286 \\
\hline FIGURA 50 Distribuição irregular e insuficiente de equipamentos culturais no município de Carapicuíba. & p. 295 \\
\hline FIGURA 51 Diferentes momentos da festa de Santa Cruz na Aldeia de Carapicuíba. & p. 302 \\
\hline FIGURA 52 Permanência em diferentes momentos da festa de Santa Cruz na Aldeia de Carapicuíba. & p. 303 \\
\hline FIGURA 53 Entrecruzam o sagrado e profano nas festividades de Santa Cruz da Aldeia de Carapicuíba & p. 306 \\
\hline FIGURA 54 Preparo das Festividades de Santa Cruz na Aldeia de Carapicuíba & p. 307 \\
\hline FIGURA 55 Congada de São Benedito e N. S. do Rosário de Carapicuíba & p. 309 \\
\hline FIGURA 56 Roda de capoeira homenageia S. Benedito e a libertação dos e & p. 310 \\
\hline
\end{tabular}


FIGURA 57 Índios de diversas etnias na Festa de S. Benedito em Carapicuíba

FIGURA 58 Jongo nas festividades de S. benedito, N. S. do Rosário e Libertação dos Escravos

p. 310

FIGURA 59 Parque da Aldeia de Carapicuíba em um domingo de primavera

p. 311

FIGURA 60 Festa de batuques do maracatu na Aldeia

\section{LISTA DE ABREVIATURAS E SIGLAS}

\begin{tabular}{|c|c|}
\hline RMSP & Região Metropolitana de São Paulo \\
\hline SIMPURG & Simpósio Nacional de Geografia Humana \\
\hline IBGE & Instituto Brasileiro de Geografia e Estatística \\
\hline EFS & Estrada de Ferro Sorocabana \\
\hline COHAB & Conjunto Habitacional \\
\hline CEPAL & Comissão Econômica para América Latina \\
\hline IGC & Instituto Geográfico e Cartográfico do Estado de São Paulo \\
\hline SPHAN & Serviço do Patrimônio Histórico e Artístico Nacional \\
\hline IPHAN & Instituto do Patrimônio Histórico e Artístico Nacional \\
\hline CONDEPHAAT & Conselho de Defesa do Patrimônio Histórico, Arqueológico e Artístico e Turístico \\
\hline EMPLASA & Empresa Paulista de Planejamento Metropolitanos S.A \\
\hline PIB & Produto Interno Bruto \\
\hline CEM & Centro de Estudos da Metrópole \\
\hline ZEIS & Zonas Especiais de Interesses Sociais \\
\hline СТPM & Companhia Paulista de Trens Metropolitanos \\
\hline UIT & Unidades de Informações Territorializadas \\
\hline IDH & Índice de Desenvolvimento Humano \\
\hline IDHM & Índice de Desenvolvimento Humano Municipal \\
\hline PNUD & Programa das Nações Unidas para o Desenvolvimento \\
\hline IPEA & Instituto de Pesquisa Econômica Aplicada \\
\hline FJP & Fundação João Pinheiro \\
\hline PRRNH & Programa de Recuperação e Revitalização de Núcleos Históricos \\
\hline ZPH & Zona de Preservação Humana \\
\hline ZPP & Zona de Preservação Paisagista \\
\hline$\overline{Z U C}$ & Zona de Urbanização Controlada \\
\hline SRIPHAN & Seção Regional do Instituto do Patrimônio Histórico e Artístico Nacional \\
\hline FNPM & Fundação Nacional Pró Memoria \\
\hline PDDI & Plano Diretor de Desenvolvimento Integrado \\
\hline PPP & Plano de Pavimentação Participativa \\
\hline IBPC & Instituto Brasileiro do Patrimônio Cultural \\
\hline APA & Área de Proteção Ambiental \\
\hline MPF & Ministério Público Federal \\
\hline BID & Banco Interamericano de Desenvolvimento \\
\hline ZEIC & Zonas Especiais de Interesse Cultural \\
\hline IBPC & Instituto Brasileiro do Patrimônio Cultural \\
\hline CDHU & Companhia de Desenvolvimento Habitacional e Urbano do Estado de São Paulo \\
\hline UNESCO & Organização das Nações Unidas para a Educação, a Ciência e a Cultura \\
\hline DPHAN & Departamento do Patrimônio Histórico e Artístico Nacional \\
\hline PMDI- GSP & Plano Metropolitano de Desenvolvimento Integrado da Grande São Paulo \\
\hline Minc & Ministério da Cultura \\
\hline RIDE & Região Integrada de Desenvolvimento Econômico \\
\hline
\end{tabular}




\section{LISTA DE TABELAS}

TABELA 01 - Evolucão de número de municípios brasileiros entre 1872 e 1920

TABELA 02 - Evolução das cidades no Brasil no período pré-industrial e industrial

p. 133

TABELA 03 - Evolução da população e taxa de crescimento geométrico anual da ci

Paulo, RMSP e estado de São Paulo

\section{LISTA DE QUADROS}

\begin{tabular}{|l|l|}
\hline QUADRO 01 - Evolução urbana e UIT's de Carapicuíba & p. 31 \\
\hline QUADRO 02 - Notas acerca dos primeiros núcleos, vilas e cidades no Brasil & p. 96 \\
\hline QUADRO 03 - Evolução Administrativa dos Aldeamentos & p. 112 \\
\hline
\end{tabular}

\section{LISTA DE GRÁFICOS}

\begin{tabular}{|l|l|}
\hline GRÁFICO 01 - Evolução do quadro populacional - Aldeamento de Carapicuíba (1736-1803) & p. 123 \\
\hline $\begin{array}{l}\text { GRÁFICO } 02 \text { - Evolução populacional das maiores capitais na fase pré-industrial do Brasil (1870- } \\
\text { 1950) }\end{array}$ & p. 134 \\
\hline GRÁFICO 03 - Evolução da população de Carapicuíba entre 1950 a 2010 & p. 196 \\
\hline GRÁFICO 04 - Evolução da população urbana e rural do Brasil. & p. 209 \\
\hline $\begin{array}{l}\text { GRÁFICO } 05 \text { - Processo Urbano-Industrial: Quadro Evolutivo da População Brasileira nas } \\
\text { Maiores Capitais Estaduais (1960-2010) }\end{array}$ & p. 211 \\
\hline GRÁFICO 06 - Taxa de Crescimento Populacional (\% a.a.) em Carapicuíba. & p. 251 \\
\hline GRÁFICO 07 - Desconhecimento das instituições e políticas de preservação do patrimônio cultural & p. 275 \\
\hline $\begin{array}{l}\text { GRÁFICO } 08 \text { - Resultado dos entrevistados que disseram conhecer ou não a história de } \\
\text { Carapicuíba }\end{array}$ & p. 290 \\
\hline $\begin{array}{l}\text { GRÁFICO } 09 \text { - Entrevistados que disseram utilizar ou não equipamentos públicos e culturais de } \\
\text { Carapicuíba }\end{array}$ & p. 293 \\
\hline $\begin{array}{l}\text { GRÁFICO } 10 \text { - Entrevistados por UIT1s que utilizam ou não equipamentos públicos / culturais de } \\
\text { Carapicuíba }\end{array}$ & p. 293 \\
\hline $\begin{array}{l}\text { GRÁFICO } 11 \text { - Espaços de encontro se realizam nos bairros e no cotidiano das estações e do } \\
\text { comércio local }\end{array}$ & p. 294 \\
\hline $\begin{array}{l}\text { GRÁFICO } 12 \text { - Espaços de encontro se realizam majoritariamente nos bairros e nos espaços do } \\
\text { cotidiano }\end{array}$ & p. 296 \\
\hline GRÁFICO 13 - Festividades principais da Aldeia, segundo os moradores das UIT's em Carapicuíba a & p. 298 \\
\hline GRÁFICO 14 - Representação dos usos do espaço da Aldeia pelos entrevistados & p. 314 \\
\hline GRÁFICO 15 - Como as transformações afetaram a vida da população de Carapicuíba entrevistada & p. 317 \\
\hline GRÁFICO 16 - Mudanças importantes lembradas por moradores entrevistados de Carapicuíba & p. 319 \\
\hline GRÁFICO 17- População entrevistada aponta o que mais gosta em Carapicuíba & p. 320 \\
\hline
\end{tabular}

\section{LISTA DE MAPAS}

\begin{tabular}{|l|l|}
\hline MAPA 01 - Mancha Urbana (RMSP-2010) - Carapicuíba & p. 21 \\
\hline MAPA 02 - Divisões Políticas RMSP - Carapicuíba, Zona Oeste & p. 22 \\
\hline MAPA 03 - Localização dos Aldeamentos nos Arredores de São Paulo & p. 91 \\
\hline MAPA 04 - Localização dos Aldeamentos em São Paulo (Séc. XVI-XIX) & p. 107 \\
\hline MAPA 05 - Sistema de Administração dos Aldeamentos & p. 111 \\
\hline MAPA 06 - Mancha Urbana (RMSP, 2000) & p. 246 \\
\hline MAPA 07 - Evolução Urbana RMSP (1881-2010) & p. 247 \\
\hline MAPA 08 - Zonas Especiais de Interesse Social & p. 248 \\
\hline MAPA 09- Ordenamento Territorial da Aldeia de Carapicuíba (1986) & p. 257 \\
\hline MAPA 10 - Parques e Espaços Públicos - Carapicuíba & p. 265 \\
\hline MAPA 11 - UIT Fazendinha-Aldeia (limites entre áreas nobres e populares em Carapicuíba) & p. 264 \\
\hline
\end{tabular}




\section{SUMÁRIO}

INTRODUÇÃO.

\section{PARTE 01 \\ DIMENSÃO METROPOLITANA DO PATRIMÔNIO \\ CULTURAL ENQUANTO RUGUGOSIDADE}

\section{CAPÍTULO 01:}

Rugosidades patrimoniais

1.1 Rugosidade: conceito geográfico para pensar o patrimônio cultural.

1.2 Rugosidade patrimonial: o caminhar do conceito entre teoria e empiria

1.3 Categorias analíticas da rugosidade patrimonial: supressão, acumulação e superposição. 48

\section{CAPÍTULO 02:}

Dialética das escalas.

2.1 Fragmentos universais-particularidades da totalidade urbana-metropolitana. .63

2.2 Metrópole-fato, metropolização-processo: dimensões do patrimônio cultural .68

2.3 Busca do concreto: pensando as rugosidades patrimoniais na América Latina. .77

\section{PARTE 02 \\ DA GÊNESE COLONIAL AO SUBÚRBIO: CARAPICUÍBA E SUAS RUGOSIDADES PATRIMONIAIS}

\section{CAPÍTULO 03:}

Gênese colonial das rugosidades patrimoniais de Carapicuíba

3.1 Notas acerca dos primeiros núcleos, vilas e cidades no Brasil. .90

3.2 Sistema de aldeamentos e a colonização do planalto paulistano.

3.3 O aldeamento de Carapicuíba na colonização dos campos de Piratininga. 


\section{CAPÍTULO 04:}

Rugosidades patrimoniais na consolidação suburbana de Carapicuíba

4.1 O vilarejo de Carapicuíba na formação do cinturão caipira em São Paulo.

4.2 A cristalização do núcleo "suburbano ex-vilarejo" em Carapicuíba

4.3 Aldeia de Carapicuíba: de bem cultural à monumento nacional 159

\section{PARTE 03 \\ CARAPICUÍBA DE SUBÚRBIO A PERIFERIA: RUGOSIDADES PATRIMONIAIS NOS LIMITES DA METRÓPOLE}

\section{CAPÍTULO 05:}

As rugosidades patrimoniais de Carapicuíba no contexto de transição urbana entre subúrbio e periferia.

5.1 Emancipação de Carapicuíba: rugosidades patrimoniais do subúrbio paulistano. 172

5.2 Implosão-explosão urbana e as rugosidades-monumentos-documentos .203

5.3 Os conceitos de subúrbio e periferia para pensar as rugosidades na metrópole de São Paulo

\section{CAPÍTULO 06:}

Múltiplas e atuais temporalidades sobrepostas em Carapicuíba.

6.1 Carapicuíba entre a urbanização da sociedade e a urbanização do território.

6.2 Intervenções urbanas e o novo contexto do Aldeia de Carapicuíba (1980-1990) .253

6.3 De rugosidade-monumento-documento a rugosidade-instrumento (2000-2014) .270

6.4 A rugosidade patrimonial hoje: o novo espaço da Aldeia, o novo tempo de Carapicuíba 


\section{cidadecitycité}

atrocaducapacaustiduplielastifeliferofugahistoriloqualubrimendimultipli organiperiodiplastipublirapareciprorustisagasimplitenaveloveravivaunivora

cidade city cité 


\section{INTRODUÇÃO}

Frente aos desdobramentos do processo de metropolização, em que os impactos podem ser traduzidos por meio da ampla generalização do sistema produtivo em escala global, reordenando espaços industriais e arranjos urbanos, mudanças estruturais passam a ser operadas nas cidades para atender as demandas dos fluxos nacionais e internacionais de produção, distribuição e consumo de mercadorias. Os desafios colocados pelas novas relações produtivas com a globalização se deslocam e se intensificam com a industrialização e modernização conservadora ${ }^{1}$ em grande parte da América Latina, com a independência das nações africanas e com o afloramento econômico no sudeste asiático. As suas principais cidades, convertidas em metrópoles, passariam a uma função de centro de controle e também nódulos dos fluxos financeiros e culturais em diferentes lugares do país e do mundo. $\mathrm{O}$ que sugere um novo esquema hierárquico decisório e de regulação da acumulação capitalista, calcado em pontos específicos do planeta e estes relativamente integrados por uma intensa rede de fluxos materiais e imateriais por meio dos sistemas técnicos de informações. Esta situação altera a estrutura econômica e política das cidades, redistribui ganhos, o consumo e cria novos padrões de desigualdade social, colocando em xeque, inclusive, as noções clássicas de centro e periferia (SASSEN, 1998; BEAVERSTOCK et al., 2000; GHORRA-GOBIN, 2009).

As cidades são incorporadas ao movimento dinâmico e contínuo de sujeição ao capitalismo, que transforma metabolicamente suas formas e, fundamentalmente, as relações dos sujeitos com seus lugares, com os bens produzidos pelo fruto do trabalho, com suas representações da natureza e a própria natureza de suas representações. Estas transformações são operadas numa totalidade urbana-metropolitana, numa escala mundo em interação com as ordens nacional e local. Fato que requer um esforço teórico e metodológico, essencialmente de reflexão acerca das variáveis e dos eventos que suprimem, superpõe e acumulam formasconteúdo diante das forças de atração e resistência no âmbito do movimento total das universalidades e particularidades (SANTOS, 2012d).

\footnotetext{
$1 \mathrm{O}$ termo remete às muitas categorizações do processo de modernização em países subdesenvolvidos, especialmente o Brasil. "Desigual e combinado, ruptura e continuidade, modernização do atraso, modernização conservadora, capitalismo travado, são algumas das definições que explicam o paradoxo evidenciado por um processo que se moderniza alimentando-se de formas atrasadas e, frequentemente, não capitalistas, strictu senso.” (MARICATO, 2015, p. 26).
} 
Este esforço revela problemas (que são muito diversos, desde a degradação ambiental, ou a desigualdade social, até problemas de desenraizamento e perda das referências culturais básicas de autonomia e sobrevivência), que não existiam ou já estavam solucionados e que agora passam a ser recorrentes nos mais longínquos rincões do planeta. Como bem apontara Harvey (2011) a respeito do caso das novas cidades na China, Macau e Hong-Kong, onde a conversão das vilas e pequenos povoados do delta do rio Pérola em megacidades modernas e centros nodais do capital internacional, desponta as forças de transformação do atual modo de produção nestes lugares. "Se, como Marx certa vez afirmou, nossa tarefa não é tanto compreender o mundo como transformá-lo, então, tem de ser dito, o capitalismo tem feito um bom trabalho em seguir seu conselho." (HARVEY, 2011, p. 19). Na África do Sul, Vivant (2007) lança análise da passagem em Johanesburgo de um processo de urbanização e metropolização característico do apartheid para outro de auto-segregação. Nele, as famílias brancas e ricas se refugiam do centro urbano, agora ocupado por negros e grupos sociais empobrecidos. A autora ainda evidencia que esta passagem é possibilitada pela transformação de um contexto de segregação étnica, para o contexto de segregação em que o poder econômico é mais pujante, ainda que o racismo permaneça. As famílias ricas e brancas isolam-se nas áreas suburbanas, abandonando, como o Estado, o centro da cidade, culminando com sua "periferização" (VIVANT, 2007). Esboçando, talvez, uma clara morfologia do processo de gentrificação às avessas e, o que de certa forma, ajuda pensar a situação de outras cidades e metrópoles subdesenvolvidas ${ }^{2}$ e, portanto, propriamente as brasileiras.

As cidades nos países subdesenvolvidos tiveram no decorrer da segunda metade do século vinte um ritmo de crescimento acelerado e jamais observado, qualificado pela aglomeração e densidade em áreas urbanas macrocéfalas. No Brasil, urge pensar os efeitos desses fenômenos em relação a diversas metrópoles, porém é São Paulo o caso mais emblemático e, sem dúvida, um dos mais complexos pelas dimensões dos problemas, dos seus espaços periféricos, das contradições e desigualdades sociais, além da carência de pesquisas ligadas aos múltiplos temas da metropolização. O clássico estudo do Centro Brasileiro de Análise e Planejamento (CEBRAP) realizado na década de 1970 por vários autores, denuncia

\footnotetext{
2 O sentido de subdesenvolvimento aqui empregado associa-se "à consciência da sobrevivência", que como defendido por Santos (2001) é uma reafirmação dos países periféricos na globalização, das condições históricas herdadas do terceiro mundo. Esta reafirmação é parte do reconhecimento supranacional de uma história que pode aproximar países e regiões. Com as teorias do subdesenvolvimento praticamente abandonadas pós-dissolução soviética, esta consciência de "inferioridade" estrutural é quem talvez possa engendrar uma unidade que conduza a determinadas mudanças importantes nas relações internacionais.
} 
o espraiamento da cidade de São Paulo aos subúrbios, formando uma das maiores periferias e zonas de pobreza no mundo. Ao explicitar o caráter emergencial das periferias, a obra justifica como estas áreas são acometidas por todo tipo de problema, especialmente os cortiços e favelas, os espaços de vida das populações trabalhadoras, permeados pela pobreza e carência dos serviços e equipamentos urbanos (CAMARGO et al., 1976). Desde então, esses bairros periféricos não estão mais limitados ao território de São Paulo e passam a ocupar horizontalmente os subúrbios e dar outra dimensão de escala à metrópole. Esses "bairros pobres", convertidos muitas vezes em "cidades-pobres", com a reestruturação metropolitana na última década do século passado e ao longo dos últimos anos, têm agora suas localizações generalizadas, inclusive em áreas centrais das grandes cidades.

Novamente, tal fenômeno implica em redefinições geográficas numa escala metropolitana de centro e periferia, centro urbano e subúrbio, que considerem a complexidade que estes espaços atingiram. Não são apenas as áreas suburbanas e periféricas das grandes cidades as únicas tensionadas pela metropolização, seu poder onipresente é expandido a todas as cidades e áreas produtivas (SANTOS, 2013b). Esta articulação faz com que remotas condições pensadas enquanto barreiras, percalços ou resistências a reprodução das relações capitalistas, sejam reconvertidas propriamente numa nova possibilidade de desenvolvimento do próprio modo de produção. Em posse de uma primitiva estrutura urbana, a pressão sobre os antigos núcleos e centros de povoamento passa a pôr em risco as últimas concretudes materiais do passado das cidades. As rugosidades, formas cristalizadas pelo trabalho, referências históricas e geográficas da memória coletiva, passam a um gradativo descompasso entre o tempo urbano (veloz, menor que de uma geração), com o tempo social (lento, de algumas gerações), causando distúrbios na ordem cultural e nas relações com os bens materiais e intangíveis dos grupos sociais. Dialeticamente, o tema do patrimônio cultural torna-se uma das peças-chave neste processo, com novas proporções e capacidades de alterar profundamente os lugares; ora em favor da realização humana e do empoderamento sobre o espaço por sua comunidade, ora transfigurando-se na própria mercadoria de consumo das massas, fragilizando as relações locais por meio da reificação e fetichização dos espaços de memória coletiva (ORTIZ, 1994). De tal maneira que os efeitos e determinações do sistema global serão maiores ou menores a depender das relações estabelecidas com os territórios, em que convivem espaços de esperança (HARVEY, 2013 [2000]) e de utopismos patrimoniais (COSTA, 2016), entre o aprofundamento da espoliação urbana (KOWARICK, 1979), ou a ausência do direito à cidade (LEFÈBVRE, 2) ante a urbanização crítica (DAMIANI, 2006) e 
a globalização perversa (SANTOS, 2001). Se interessa apreender a produção do espaço, de suas formas-conteúdos, indo da totalidade e retomando-a após dissecação dos fatos concretos, de seus fragmentos, finalmente pensar a cidade, ou uma região metropolitana contemporânea, exige captar as configurações de existência de sua população, já que ela “[...] atua, também através de suas formas de existência, na produção das formas espaciais e estas, concomitantemente, atuam nos modos de existência" (SANTOS, 1986, p. 61). Este, portanto, "é um relacionamento dialético, e não um simples jogo de causa e efeito, que só pode ser entendido através do conceito da totalidade" (SANTOS, 1986, p. 61). As formas de existência favorecem diferentes vivências e simbolismos em relação aos espaços da cidade, a expressão das experiências realizadas nos bairros, praças e ruas da cidade.

O legado histórico e cultural, além das condições concretas de organização material, das formas pretéritas estáveis no presente das cidades, é um meio de viabilizar o entendimento sobre os processos que movimentam e que deram feição estrutural às próprias regiões metropolitanas. Como explica Costa (2015, p. 29), "o método de investigação dialético requer uma criteriosa apropriação do fenômeno, pleno domínio histórico do material, exigenos a análise de cada forma de desenvolvimento do próprio objeto (...)”, sobretudo quando o resultado concreto e empírico de um processo permanece resignificado em outro momento e situação. Este ponto, no limite, pode alcançar a própria condição de consciência à espoliação imperialista do sistema mundial, calcado historicamente no dinheiro, na mercadoria e, sobretudo, no lucro, mas também, no papel da ideologia e da reificação das relações sociais graças à fragmentação da produção e do trabalho, da mediação tecnológica e, ainda, uma divisão mais complexa e compartimentada dos territórios.

Estas problematizações são reveladoras do papel central que certas narrativas ainda possuem a propósito dos sentidos da formação territorial e nacional do Brasil. Em São Paulo, especialmente, sobre a fase fundacional, controversa, a narrativa histórica oficial reside no "descobrimento" português das "novas terras americanas", do "serviço de cristianização" da Igreja, bem como sobre a imagem do bandeirante, substancialmente assumida na representação mítica da formação nacional. Nestas representações, o bandeirante emerge oficialmente nos livros escolares, museus e instituições estatais enquanto herói, líder militar, que expandiu as fronteiras nacionais e galgou as grandes riquezas naturais ao povo brasileiro. Ao longo do tempo, este preceito foi sendo erigido por diversos mecanismos políticos e ideológicos, pela transmissão e difusão de seus nomes em ruas, cidades, mais particularmente 
nas grandes estradas de São Paulo ou nas interestaduais (Fernão Dias BR-381, Raposo Tavares SP-270, Anhanguera SP-330 e Bandeirantes SP-348), estátuas que os reverenciam em cidades, onde teoricamente fundaram ou ali se estabeleceram, entre outras estratégias. Mais que a concreticidade de sua produção, este personagem evoca elementos simbólicos que designam força e bravura, reproduzidos historicamente nas cidades-símbolos do bandeirantismo.

O caso de Carapicuíba é emblemático na Região Metropolitana de São Paulo (RMSP). Antigo aldeamento jesuítico, sua subordinação à São Paulo e a "metrópole" portuguesa deriva desde remotos tempos do Brasil Colônia. No contexto de desenvolvimento metropolitano de São Paulo, Carapicuíba arrasta consigo todas as contradições sociais que o modo de produção revelou, desde o poder colonial à industrialização tardia do país. Igualmente, na reestruturação da metrópole pela expansão e desconcentração produtiva, bem como um novo momento de modernizações territoriais, intervenções cirúrgicas e precisas em determinados espaços. Uma destas dimensões contraditórias está na permanência do conjunto histórico e colonial do antigo aldeamento jesuítico (último reduto de ruinas jesuíticas em São Paulo - da primeira fase de ocupação do território brasileiro), que se mantém no contraste com uma paisagem de suburbanização e densa periferização local. Compreendidas enquanto rugosidades (SANTOS, 1977; 2012d [1996]; 2012 [1978]; 2012c [1978]; 2013a [1978]), as formas dinâmicas deste conjunto despontam como fragmento da totalidade, de uma parcela síntese do movimento urbano e, mais especificamente, das relações sociais em espaços históricos metropolizados ${ }^{3}$.

A patrimonialização (JEUDY, 2006) destas áreas perpetua estruturas de complexas ordens, lógicas e escalas, pois, ao carregar múltiplos contextos, estas incluem por meios superpostos e acumulativos as formas, funções, tradições e simbolismos do passado junto às

\footnotetext{
${ }^{3} \mathrm{O}$ espaço histórico aqui tratado delineia-se no seu reconhecimento normativo e institucional. Considerando a historicidade de cada e qualquer objeto situado, com seus tempos espaciais diferenciados (SANTOS, 2012), é necessário reconhecer a existência seletiva de determinados monumentos e conjuntos. Estes, configurados como matriz-símbolo da identidade nacional, portanto com uma relação diferenciada e particularizada do restante do espaço urbano. De modo que, portanto, toda cidade é histórica, independente da diferença de tempo na formação relativa a outras aglomerações. Apesar disso, o termo "núcleo histórico", "conjunto histórico" ou "cidade histórica" utilizados ao longo da tese remetem a áreas centrais adotadas pelas políticas públicas patrimoniais e, consequentemente, pela normatização de seus bens e recorrente turistificação/dinamização de atividades produtivas. No limite, a opção por esta designação remete a própria concepção terminológica que o sentido "histórico" ganhou na sociedade, ainda que muitas vezes não se perceba conscientemente que o termo "histórico", além do passado ou antigo, remete ao presente e ao futuro indissociavelmente (LOWENTHAL, 1998a; 1998b). Para Paes Luchiari (2005, p. 96) "a cidade, natureza transformada e artificializada pela ação social, acumula nos seus artefatos o tempo humano." Assim também, lembramos Costa e Steink (2013, p. 165) para quem "toda cidade faz-se produto da história, do vir a ser universal que a constitui enquanto obra de arte, coletiva ou particularmente. Leite (2001, p. 42) ajuda esclarecer que as cidades históricas, enquanto lugares que integram o patrimônio cultural, são meios operados pelo Estado que corroboram para a construção e invenção das tradições, expressando uma "forma modelar" da memória e a identidade nacional, eis aí seu sentido mais fiel na tese.
} 
inovações técnicas, científicas e informacionais do presente. Onde sua manipulação, no último meio século, deriva de intensa verticalidade, dialeticamente suprimindo ao mesmo tempo que denotando novos conteúdos aos bens, ora pela generalização do sistema urbano através do planejamento e gestão da região metropolitana, ora nas políticas patrimoniais - ao retomar ciclicamente os mitos fundadores e intervenções precisas, visando expressar um sentido de cultura que englobe a diversidade étnica do território brasileiro numa identidade de nação. Fenômeno que tenciona o fato urbano inscrito pela cidade aos limites do processo de metropolização, bem como a memória coletiva dos grupos sociais afetada pela generalização dos preceitos identitários da memória nacional. Ortiz (1994) compreende que ao contrário da memória coletiva, tida sobre a ordem da vivência, a memória nacional, catalisada no patrimônio cultural normatizado e institucionalizado pelo Estado, vincula-se à história e pertence ao âmbito da ideologia. A memória nacional não é propriedade particularizada de nenhum grupo social restrito, mas “[...] ela se define como um universal que se impõe a todos grupos. [...] Ela não possui uma existência concreta, mas virtual, por isso não pode manifestar imediatamente enquanto vivência." (ORTIZ, 1994, p. 13).

Mesmo sugerindo muitos desafios e variáveis, em que áreas históricas possuem suas peculiaridades, e ciente das limitações de uma pesquisa científica e do grau de generalização da abordagem, Carapicuíba insere-se enquanto representativo caso emblemático de aglomerações antigas tomadas em sua totalidade pela metropolização (Mapas 01 e Mapa 02), tornando-se fato concreto do urbano no Brasil e que favorece uma apreensão especial e significativa de algumas dimensões deste fenômeno. Neste caso, implicando, para além do caráter normativo e regulatório obtido pela Aldeia de Carapicuíba com seu tombamento federal, no limite, o questionamento sobre a própria legitimidade destes espaços enquanto elementos universais da modernidade e particulares do Brasil, sendo que o balizamento do trabalho parte de um desdobramento contextual e multiescalar, com a subsequente questão formulada: como núcleos históricos são afetados, em sua totalidade, pelo fenômeno de metropolização? Depreendendo outras questões, que residiriam em como estes antigos núcleos coloniais resistiram às necessidades de fluidez do capital dadas pela metropolização? Ou como sucumbiram diante deste mesmo fenômeno? Para então pensar mais precisamente em um recorte empírico preciso, desdobrando na questão central de partida: Quais eventos e processos materiais e intangíveis favoreceram ou impediram a permanência do patrimônio cultural em Carapicuíba? 


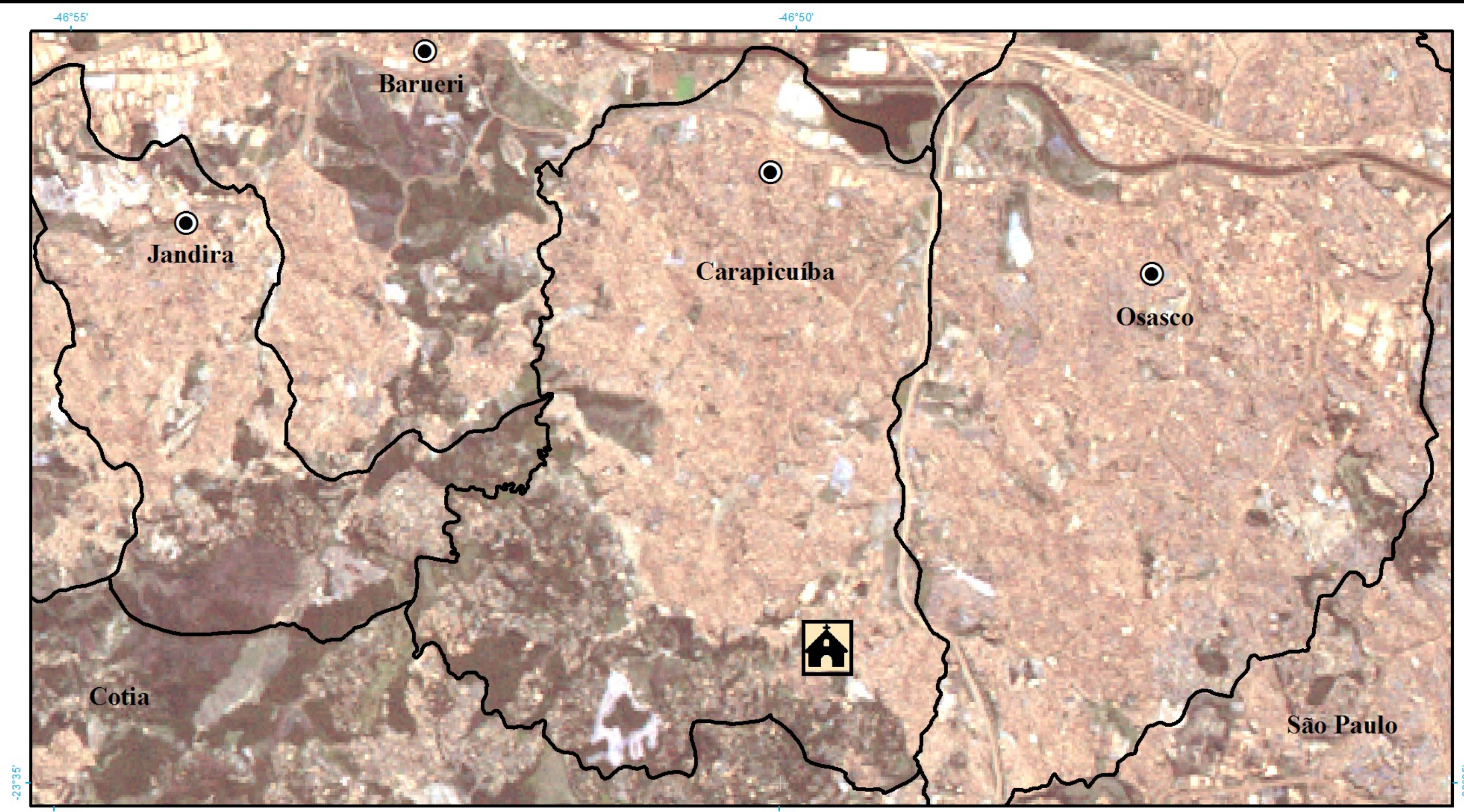

Mapa 01:

Mancha Urbana (RMSP-2010)

Zona Oeste - Carapicuiba

Aldeia de Carapicuiba

Autor: Prof. Msc. Rafael F. de Oliverira

Orientador:
Prof. Dr. Everaldo B. Costa

Prof D.

Base Cartográfica IBGE, 2015

Projeção Geográfica (LAT/LONG)

Datum: SIRGAS-2000

Mosaico com imagens Landsat-5
Elaboraçẫo: CIGI/CPLA/SMA

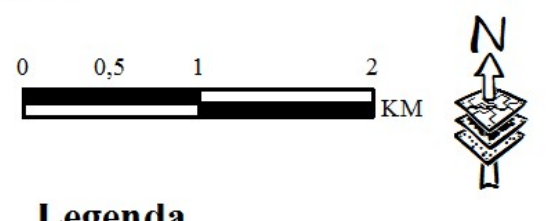

Legenda

O Sede de Municípios (RMSP)

Legião Metropolitana de São Paulo

Aldeia de Carapicuiba (1580-2016)
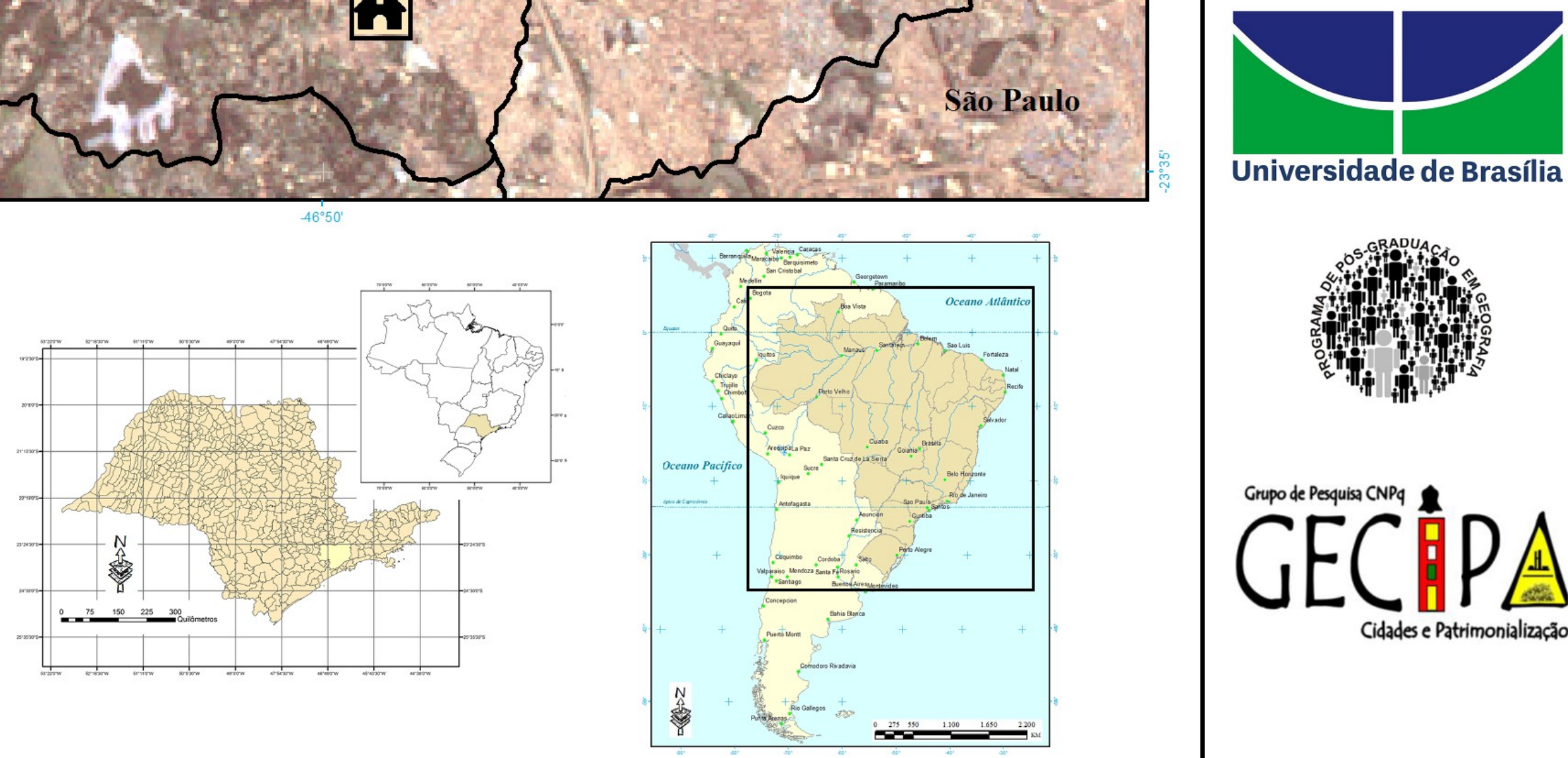

Universidade de Brasília

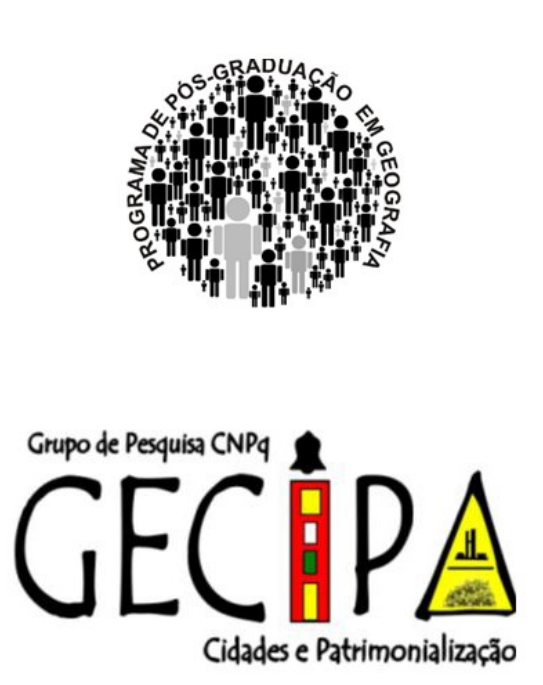




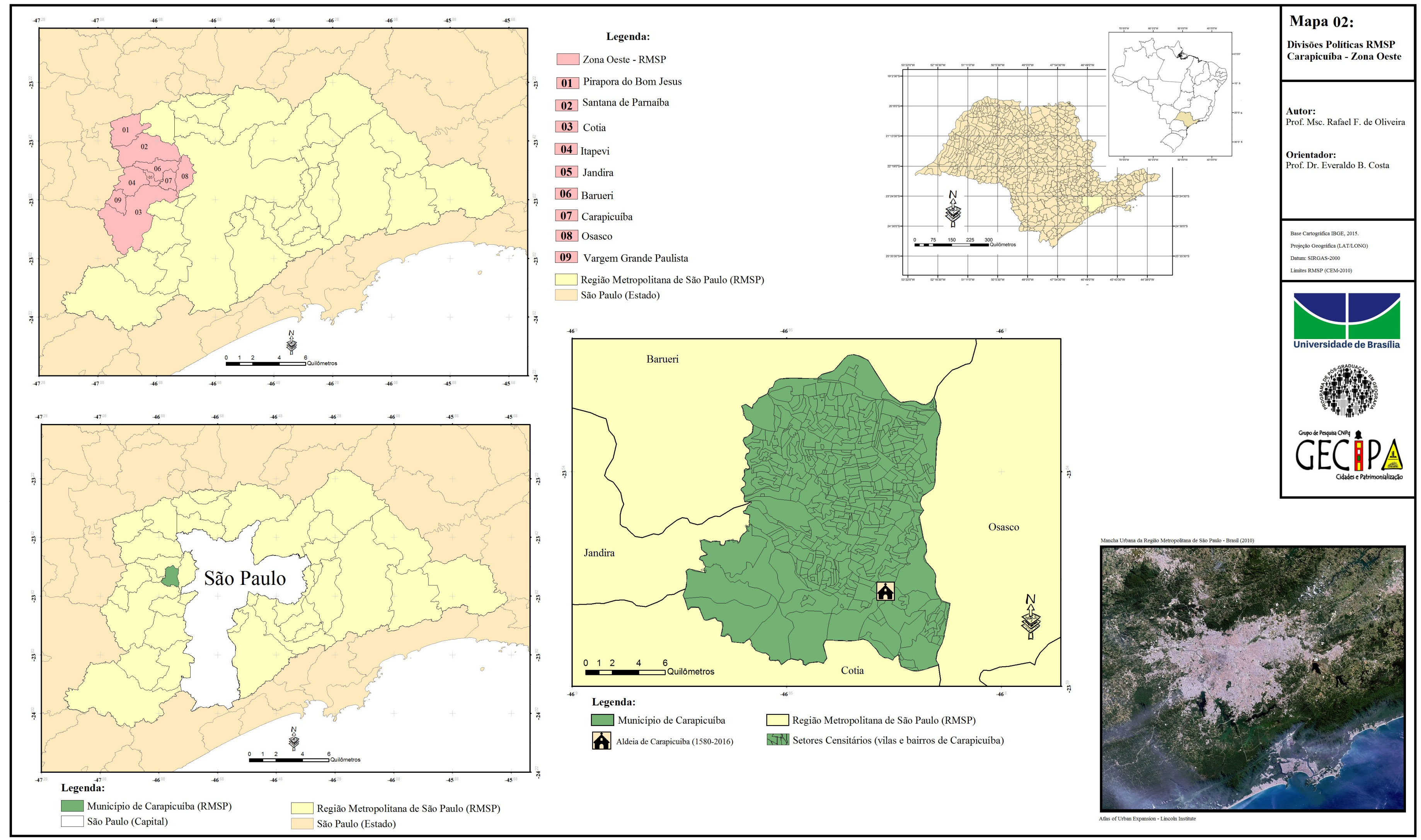


Para Cosgrove (2004) o papel do investigador na organização e representação dos resultados destas referências é permeado por uma compreensão "informada por nossos valores, crenças e teorias [...]". Como ele, explica Gonçalves (1995, p. 368) que "[...] um método não possui por si só autonomia. Ele está fundamentalmente ligado ao sujeito do conhecimento, que o utiliza para aproximar-se do seu objeto de estudo". A problematização, as questões de partida, logo residem da imersão e experiência do pesquisador com o tema e com o próprio objeto de pesquisa, assim como as angústias compartilhadas com os sujeitos que vivem cotidianamente nos espaços representativos da memória, intimamente regulados pela ação institucional dos órgãos patrimoniais. Vislumbra-se assim apreender uma complexa dinâmica dialética entre escalas e ações desenvolvidas nos territórios e operadas no e pelo espaço geográfico (enquanto condição e reflexo do social). Buscando, de forma mais específica, examinar a permeabilidade do fenômeno urbano nas práticas cotidianas, traduzindo a experiência de vida, as resistências ao processo e os múltiplos olhares sobre a cidade, das suas formas-conteúdos, além dos significados empreendidos e difundidos acerca de sua produção material. No entanto, sem perder o próprio papel de quem, como pesquisador e sujeito ativo do processo de pesquisa, conduz a prática acadêmica e científica afim de propiciar uma pequena, mas ambiciosa produção do conhecimento.

Estas condições, sem cair em modelos estanques e genéricos da realidade, parecem subsidiar o conhecimento da lógica metropolitana pelo viés espacial do patrimônio cultural. Isto em favor de leituras, desde os sujeitos que vivenciam cotidianamente seus territórios, até as instituições que os normatizam, desde a periferia ao centro, pois entende-se, como Martins (1992), a existência permanente do lastro colonialista das pesquisas e análises pautadas nos valores dos prédios maiores, nas casas grandes, nas centralidades do poder, que consideravam as reminiscências do passado numa hierarquia cujo entendimento dos fatos sempre foi a perspectiva das elites e classes dirigentes. E, pois, uma visão que dificulta olhar ao subúrbio sem que esteja subordinado ao centro, ainda que o primeiro só exista em relação ao segundo ${ }^{4}$. Seguir esse rumo é precisar mecanismos intelectivos e práticos de embasar, qualificar e até

\footnotetext{
4 “Até aqui a história de São Paulo tem sido escrita do centro para a periferia: a perspectiva elitista do centro domina a concepção que se tem do que foi o subúrbio no passado. Mesmo quando se estuda a história da classe operária, que sempre viveu nos bairros e no subúrbio, prevalece essa orientação fora de contexto. Essa perspectiva vem da tradição colonial e absolutista e mostra, entre nós, que ela não se emancipou da rígida hierarquia que centralizava no rei e seus funcionários não só um modo de viver, mas também um modo de olhar, inclusive um modo de ver a História.” (MARTINS, 1992, p. 09).
} 
estimular novas resistências aos processos verticais impostos às cidades, às rugosidades patrimoniais, aos seus grupos sociais. Tratando de preservar e divulgar os bens culturais junto com suas comunidades, de forma metabólica entre os objetos técnicos criados e os sujeitos responsáveis por sua produção. Tudo, no entanto, prescinde a crítica dos fundamentos institucionais que destacam bens, fatos e atores, ao mesmo tempo em que escamoteiam outras facetas da realidade, que resulta na invisibilidade e esquecimento dos sujeitos e de suas produções. Embora a salvaguarda dos bens possa ser concretizada pelo tombamento, tornando determinadas práticas e áreas da cidade em organismos que sugerem ideias e imaginários, usos e funções, outras atividades são paralelamente desenvolvidas realçando nova centralidade e uma dinâmica complexa de relações cotidianas com esses lugares.

Estas sentenças prerrogativas se interpõem, onde em certos momentos prevalece uma ou outra instância, gerando conjuntamente questionamentos complementares, que foram pensados da seguinte maneira: (a) enquanto disciplina científica, como a Geografia pode contribuir com essa perspectiva de trabalho e, simultaneamente, agregar um expressivo legado teórico e metodológico em seu labor? (b) quais os impactos trazidos pela emergência da questão cultural e do temário patrimonial nos núcleos históricos metropolizadas em relação (i) aos usos e apropriações dos territórios do patrimônio, (ii) a geração e difusão de valores, (iii) imagens e imaginários dos espaços de memória? (c) a partir destas constatações, quais os desafios e possibilidades de desenvolvimento dos espaços suburbanos/periféricos inseridos nas regiões metropolitanas no reconhecimento, preservação e promoção da diversidade de seus bens culturais? (d) por fim, será possível as comunidades locais conquistarem maior autonomia e poder decisório sobre seus territórios resistindo por meio da cultura às imposições verticais e universalizantes do sistema produtivo global?

Enquanto objetivo geral a pesquisa buscou analisar o patrimônio cultural como rugosidade espacial face às transformações de Carapicuíba pela metropolização de São Paulo. Tomando alguns objetivos específicos, que se desdobram desta busca mais ampla: (a) analisar como o ideário patrimonial associa-se a noção de inércia dinâmica, representando novas significações sociais da natureza e da cultura em núcleos históricos metropolizados; (b) compreender a permanência do conjunto tombado da Aldeia de Carapicuíba antes de sua institucionalização e frente ao atual processo de metropolização; (c) debater como os espaços de memória atuam historicamente na produção social do urbano, procurando avançar por base empírica sobre o legado teórico e metodológico estruturado por Milton Santos acerca da 
noção de rugosidade espacial; (d) buscar estabelecer um diálogo entre as diferentes perspectivas teórico-metodológicas da Geografia, no sentido de realizar uma leitura mais qualificada e totalizante da realidade que envolve núcleos históricos metropolizados; (f) captar ações e práticas cotidianas que favoreçam o ajuste, a resistência e reorganização da cidade a partir de articulações horizontais e solidárias pelo viés do patrimônio cultural.

Ainda que pela razão desta ser uma pesquisa calcada na criticidade da produção do espaço urbano contemporâneo e, portanto, intencionalmente convertida num instrumento político-científico, algumas premissas ao longo dos levantamentos de dados, leituras, visitas técnicas, aplicação de questionários e entrevistas, foram plenamente refutadas, parcialmente reafirmadas, definitivamente aceitas ou descartadas. Trata-se de possibilidades que estão circunscritas num plano complexo e relacional em que se insere um dado recorte empírico da realidade marginal e periférica da metrópole nacional brasileira. De onde mesmo o pesquisador possuindo papel ativo nas escolhas e decisões da abordagem, o critério mais ortodoxo no prospecto metodológico sempre foi a priorização da leitura da cidade por seus habitantes, da experiência suburbana e periférica de viver em RMSP São Paulo.

A construção aversiva da imagem e representação do primitivo - simbolizada pelo índio e pelas ruinas na Aldeia de Carapicuíba - revela a historicidade do drama colonial, mas também das resistências na reprodução da vida, que implica na própria conservação das rugosidades patrimoniais pelos nativos que ali permaneceram mesmo com a mudança do aldeamento pelos jesuítas para Itapecerica da Serra no século dezoito. Fatores que constituídos há mais de quatro séculos permanecem na condição marginal dessas cidades e núcleos de povoamento, seja no desenvolvimento posterior do aldeamento para as necessidades rurais que a cultura caipira imprimia, ou na sustentação da cidade-polo ou centro metropolitano pelos recursos extraídos e operados pelas mãos de milhares de trabalhadores, até alcançar tempos menos remotos, de consolidação do drama periférico, que perpassa a marginalidade do trabalho composta numa massa de reserva, porém, onde a manutenção da sobrevivência é realizada a cada dia e comemorada nos simbolismos que perduram secularmente. Tal realidade desdobra-se na respectiva premissa central: de que a Aldeia de Carapicuíba e a carga simbólica e memorial contida e manifestada pela população local, traduziriam um dos casos mais emblemáticos da permanência, ou da rugosidade patrimonial, frente à metropolização de São Paulo. A essência desta questão reside em eventos e relações onde o patrimônio cultural tem papel central - aqui avaliando os resíduos das primitivas 
formas coloniais (o sitio, o quadrilátero, as formas das habitações, as técnicas de construção, a centralidade do templo religioso), bem como as tradições que das rugosidades derivam e se perpetuam na atualidade das crenças, dos ritos e festejos caipiras (como os de Santa Cruz, que advém do século dezoito ou antes), como também os novos conteúdos e funções adquiridos enquanto espaço público (Parque da Aldeia).

No caso da Aldeia de Carapicuíba, a sua manutenção, além do papel normativo efetivado no tombamento pela Secretaria do Patrimônio Histórico e Artístico Nacional (SPHAN) em $1940^{5}$, decorre de eventos ainda pouco compreendidos pela literatura correlata, ou mesmo pelos próprios órgãos de preservação. No entanto, insurgem como elos de preservação pré e pós-tombamento, no sentido da manutenção do conjunto histórico e de determinados simbolismos que perduram, inclusive aos dias atuais. O que, no entanto, com a emergência da patrimonialização (JEUDY, 2006) e avançando para além do discurso da perda (GONÇALVES, 2002), faz com que respectivamente o conjunto destes bens culturais se pronuncie a uma condição própria de "desaparecimento", ou melhor, supressão. Esta condição pode ser concreta, ainda que suas formas por ventura transpareçam uma pseudoconcreticidade (KOSIK, 1976 [1963]) da condição de permanência das rugosidades patrimoniais. Nos dias atuais, a dimensão dos conteúdos, associada numa assimilação massiva e parcial da cultura (ADORNO, 1975 [1974]), parece projetar-se em favor do entretenimento e espetáculo (DEBORD, 2005 [1967]) do que numa dimensão territorial identitária ${ }^{6}$. Trata-se de uma tensão permanente, contínua e dinâmica, a suprimir, mas também a acumular e sobrepor objetos e ações nos territórios, com mais permeabilidade ou resistência em certos contextos. O plano de trabalho reside substancialmente em torno da rugosidade patrimonial no que tange a tríade "supressão" - "superposição" - "acumulação", a partir de contextos históricos específicos, mais precisamente a partir do período técnico-científico-informacional (SANTOS, 2012 [1996]). Esta dinâmica apoia a apreensão de um processo por qual passa os

\footnotetext{
5 Submetido o processo ainda em 1939, o tombamento se efetiva em 1940. Consta no Livro Tombo Arqueológico, Etnográfico e Paisagístico, instituído pelo Decreto-Lei 20, de 1937, a inscrição na folha 03 do "conjunto arquitetônico e urbanístico da Aldeia de Carapicuíba", cuja data refere-se a 13 de maio de 1940. Notificação 316 - Anexo 01 (sem efeito) e Anexo 02.

${ }^{6}$ Este risco é muito bem sintetizado por Paes-Luchiari (2005, p. 102), ao apontar que "ao se tornar alvo de uma fruição apenas circunstancial e essencialmente estética, a revitalização do patrimônio arquitetônico cria uma nova territorialidade, descompromissada com o lugar e com as populações locais. Mesmo que as antigas formas permaneçam, o conteúdo social dos bens tombados submete-se às mudanças de conteúdo e de significado social, agora impulsionados pela nova vocação turística destas áreas".
} 
elementos culturais no atual contexto do modo de produção capitalista e das cidades. Esta contradição residiria justamente no potencial de consciência despertado pela identidade dos sujeitos com seu trabalho, ou seja, com as próprias rugosidades patrimoniais edificadas por seus antepassados, ao mesmo tempo em que as razões no atual contexto tendem a obediência dos interesses de forças hegemônicas, ou de modo ainda mais amplo, ao próprio "mundo do capital” (HORKHEIMER, 1975).

\begin{abstract}
Para os sujeitos do comportamento crítico, o caráter discrepante cindido do todo social, em sua figura atual, passa a ser contradição consciente. Ao reconhecer o modo de economia vigente e o todo cultural nele baseado como produto do trabalho humano, e como a organização de que a humanidade foi capaz e que impôs a si mesma na época atual, aqueles sujeitos se identificam, eles mesmos, com esse todo e o compreendem como vontade e razão: ele é o seu próprio mundo. Por outro lado, descobrem que a sociedade é comparável com processos naturais extra-humanos, meros mecanismos, porque as formas culturais baseadas em luta e opressão não é a prova de uma vontade autoconsciente e unitária. Em outras palavras: este mundo não é o deles, mas sim o mundo do capital. Aliás a história não pôde até agora ser compreendida a rigor, pois compreensíveis são apenas os indivíduos e grupos isolados, e mesmo esta compreensão não se dá de uma forma exaustiva, uma vez que eles, por força da dependência interna de uma sociedade desumana, são ainda funções meramente mecânicas, inclusive na ação consciente. Aquela identificação é portanto contraditória, pois encerra em si uma contradição que caracteriza todos os conceitos da maneira de pensar crítica. Em outras palavras: este mundo não é o deles, mas sim o mundo do capital (HORKHEIMER, 1975, p. 138).
\end{abstract}

Muito se discute da necessidade de projetos de conservação, preservação e promoção dos elementos históricos no âmbito das novas políticas culturais e econômicas da cidade. No entanto, pouco se aprofunda analiticamente em suas origens e constituição, permanência e atual valorização. Essa carência analítico-reflexiva impede o pleno desenvolvimento de projetos que, de fato, possam permitir a sua realização enquanto fruto do trabalho da comunidade que os produziu. Nesta proposta de pesquisa, a questão prerrogativa - sobre quais processos favoreceram ou inibiram a presença de um representativo patrimônio cultural do país, e mais especificamente da RMSP em Carapicuíba - suscita questionamentos a um debate ligado ao papel exercido pelas cidades históricas, os monumentos, as relíquias, as antigas construções e a amplitude do plano imaterial face ao papel exercido na conservação e preservação dos bens culturais. Trata-se assim de um estudo cujos desafios são os de captar o modo como esses elementos materiais e imateriais permitiram ou permitem a resistência e consolidação de antigos redutos, como a da Aldeia de Carapicuíba, além das tradições e festejos singulares do lugar frente à metropolização e atuais relações. A partir disso, apoiar estratégias nas diversas perspectivas, que são ou podem ser operacionalizadas a favor do 
desenvolvimento urbano e de uma utópica democracia cultural, sendo neste sentido, enquanto disciplina científica, que a Geografia pode contribuir ao agregar e agregando simultaneamente um expressivo legado teórico e metodológico em seu labor.

\section{PROCEDIMENTOS METODOLÓGICOS DE PESQUISA}

Pela delimitação temática da tese, realizada na interface entre metrópole, patrimônio e rugosidade, enquanto conceitos-chave do processo de produção do espaço urbano em sítios coloniais, foi necessário agregar alternativas metodológicas que, entre outras práticas e estratégias, acarretaram em: (a) levantamento de fontes e dados documentais, iconográficos e bibliográficos; (b) sondagens exploratórias, reconhecimento de campo e observações sistemáticas; (c) diálogos com a governança local e com técnicos do patrimônio; (d) aplicação de questionários qualitativos semiestruturados; (e) entrevistas semiestruturadas com a população de Carapicuíba. Estes procedimentos foram permeados por trabalhos de campo em diferentes setores do município ao longo de toda pesquisa, com observação direta (estruturada/sistemática) e participante, com registro das atividades desenvolvidas (fotografias, filmagens, anotações) e diálogos constantes com moradores, especialmente no espaço da Aldeia de Carapicuíba.

(a) Levantamento de fontes e dados documentais, bibliográficos e iconográficos

Os levantamentos documentais, iconográficos e bibliográficos foram realizados ao longo de todo processo de desenvolvimento da pesquisa. Em sua fase inicial, o foco esteve pautado no levantamento de obras clássicas, teses e artigos correlatos ao tema de pesquisa nas bibliotecas da UnB, UNESP, USP e Unicamp, além do acervo digital disponível no diretório de periódicos da CAPES e dos convênios da UnB e do IFSP, os quais destacam-se: Directory of Open Access Journals (DOAJ), o Scientific Electronic Library Online (SciELO), Dialnet, OneFile (GALE), o SciVerse ScienceDirect e Scopus (Elsevier). Deve-se ressaltar a relevância do levantamento de dados em repositórios digitais de dissertações e teses, além de bibliotecas físicas (USP, UNESP, UNICAMP, UNB, Bibliotecas municipais de Carapicuíba). As 
principais obras e materiais foram induzidos pela orientação dos docentes do Programa de Pós-Graduação em Geografia da UnB e ao longo de cursos realizados em outros departamentos, além das leituras nas disciplinas e no âmbito do Grupo de Pesquisa Cidades e Patrimonialização (GECIPA/CNPq), bem como das necessidades pontuais e estratégicas do recorte empírico no âmbito do próprio município de Carapicuíba (cabe destacar, por exemplo, o acervo disponibilizado do Prof. Miguel Costa Júnior, oferecido pela Biblioteca Municipal Castro Alves, com materiais acumulados sobre a cidade, destacando-se documentos datilografados, recortes de jornais, postais, fotografias, mapas e panfletos).

Em um segundo momento, os levantamentos documentais e iconográficos em arquivos públicos tiveram maior centralidade no desenvolvimento da pesquisa, pautando-se o Arquivo Público do Estado de São Paulo, os arquivos digitais da EMPLASA, o acervo do arquivo da 9a.SRIPHAN/SP e o arquivo central do IPHAN/RJ. Nestas bases, físicas e digitais, os levantamentos pautaram-se em mapas, registros fotográficos, plantas de bairros e cidades da RMSP, croquis, processos de tombamento, intervenções urbanas em sítios históricos, processos de licitação e contratação de empresas para serviços públicos, planos e projetos de gestão territorial e planejamento urbano. Estes materiais foram estratégicos e mais efetivamente utilizados nas fases exploratórias e na caraterização do objeto, tanto entre os contextos dos fenômenos gerais, como aos múltiplos rebatimentos das particularidades de Carapicuíba.

\section{(b) Sondagens exploratórias, reconhecimento de campo e observações sistemáticas}

Subsequentemente, por base dos fundamentos teóricos elementares, foram realizadas incursões empíricas pela RMSP e Carapicuíba, na busca da apreensão da lógica e relação diante de suas unidades territoriais com o processo de metropolização. Nesta fase, objetivou-se a observação de áreas pré-selecionadas, com registro fotográfico, demarcações, descrição e incipiente análise da problemática por uma proto-composição conceitual e categorial, destacadamente no que se refere a relação do fenômeno urbano-metropolitano em São Paulo com 
as rugosidades patrimoniais em Carapicuíba. Tal procedimento exploratório foi circunstancial, inclusive, à demarcação de um referencial empírico que ainda se fazia duvidoso entre outras cidades e núcleos históricos na RMSP.

As áreas sondadas foram setorizadas conforme o referencial histórico e estrutural de desenvolvimento urbano (elaborado no Plano Diretor Participativo de Carapicuíba com dados do IBGE, desde o princípio do aldeamento até a consolidação dos condomínios mais novos), sobreposto com as unidades territoriais de Carapicuíba, segundo as Unidades de Informações Territorializadas (UIT's), elaboradas pela EMPLASA. Isto com apoio de imagens orbitais e fotografias áreas no dimensionamento de cada unidade. Nesta etapa foram precisamente realizadas doze visitas, em todas as unidades demarcadas: UIT 1 Carapicuíba; UIT 2 - Cidade Ariston/COHAB; UIT 3 - Vila Dirce; UIT 4 Fazendinha; UIT 5 - Aldeia de Carapicuíba (Quadro 01). Além de Carapicuíba, as virtuais fronteiras municipais da RMSP permitiram a incursão por vários trechos de Osasco, Barueri, Itapevi, Cotia, Embu das Artes e São Paulo. Com demarcação geográfica por GPS dos principais pontos e áreas, diversos registros fotográficos e conversas não controladas com a população, o que resultou no delineamento de estratégias de pesquisa, além de apropriação embrionária da dinâmica urbana nas principais centralidades do município e sub-regiões. Uma delas foi justamente reconhecer a coerência da regionalização pela EMPLASA das UIT's, utilizando como referencial o tipo de uso e ocupação do solo urbano, e por conseguinte, na possibilidade de desmembramento do conjunto UIT COHAB e Cidade Ariston em alguns dos levantamentos em relação a infraestrutura urbana, ou da união das UIT's Fazendinha e Aldeia em outras abordagens pela proximidade geográfica e relações históricas que possuem alguns de seus setores. 
Município de Carapicuíba - RMSP

Evolução urbana (1580-2000) e Unidades de Informações Territoriais

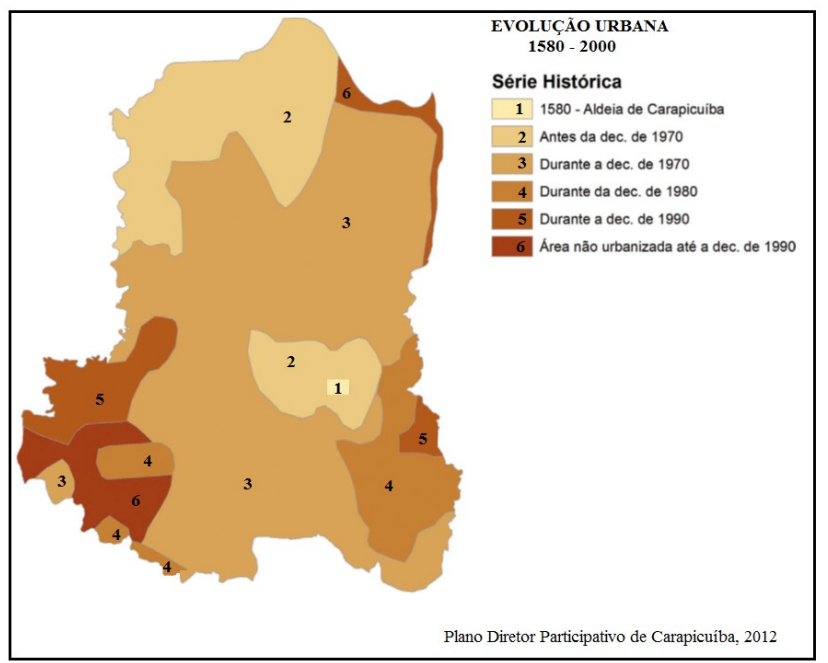

1 Limite UIT CARAPICUÍBA

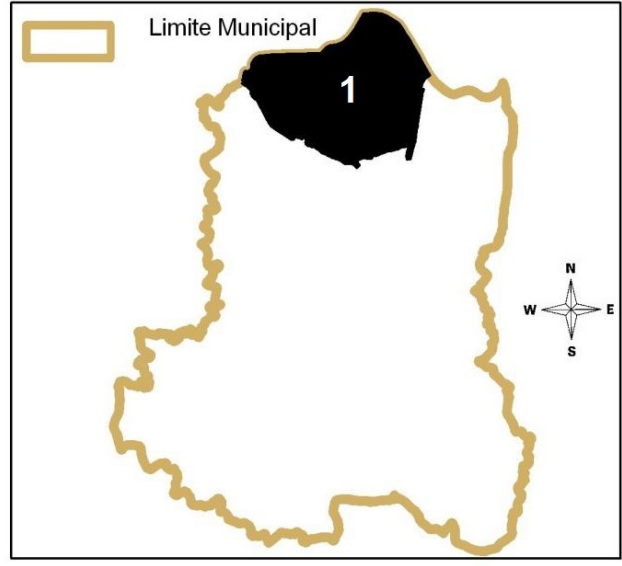

Projeçāo Universal Transversa de Mercator - UTM * sem escala definida
Datum:SAD 69

Empresa Paulista de Planejamento Metropolitano S/A - EMPLASA
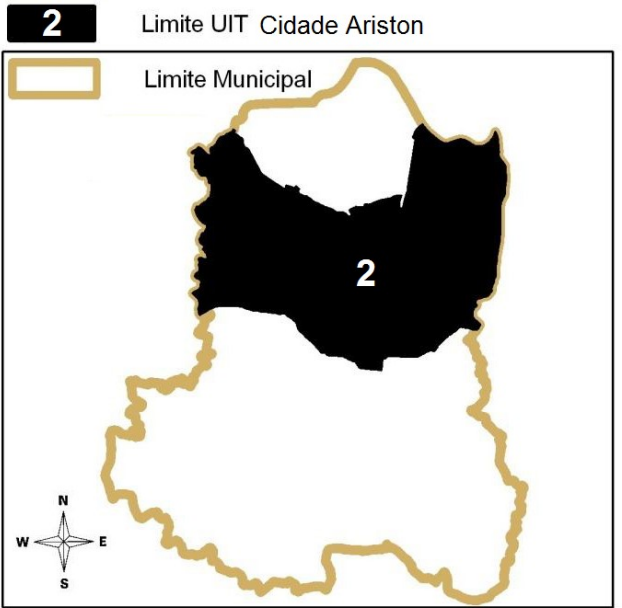

Projeção Universal Transversa de Mercator - UTM * sem escala definida Empresa Paulista de Planejamento Metropolitano S/A - EMPLASA

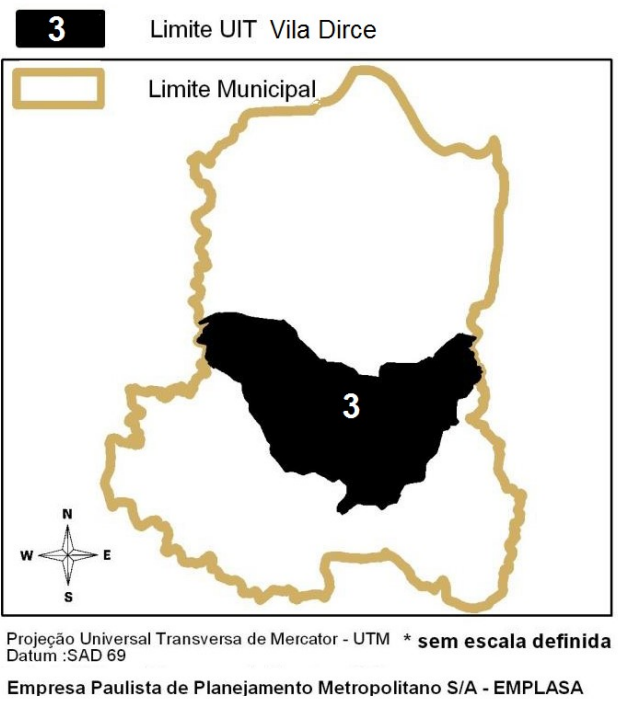

4

Limite UIT Fazendinha

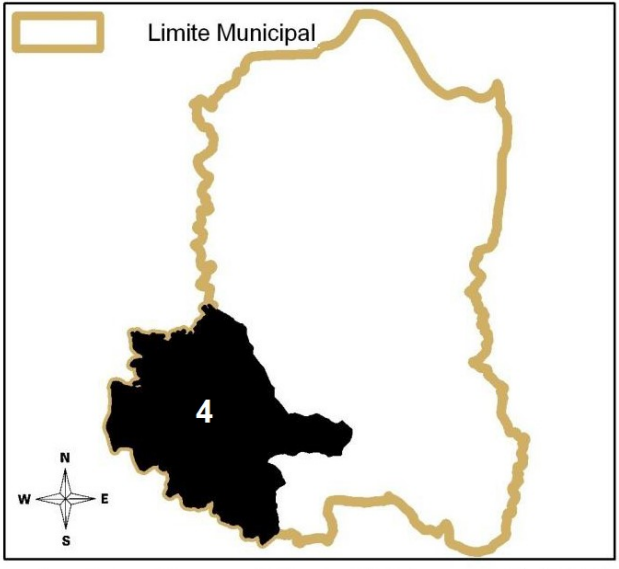

Projeção Universal Transversa de Mercator - UTM * sem escala definida
Datum :SAD 69 Empresa Paulista de Planejamento Metropolitano S/A - EMPLASA

5

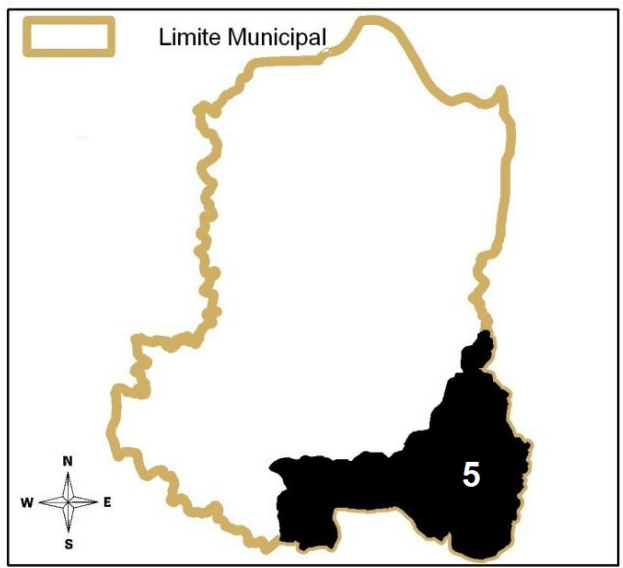

Projeção Universal Transversa de Mercator - UTM * sem escala definida Empresa Paulista de Planejamento Metropolitano S/A - EMPLASA

Quadro 01: Evolução urbana e UIT's de Carapicuíba.

Fonte: EMPLASA, 2014; Carapicuíba, 2012. 


\section{(c) Diálogos com a governança local e com técnicos do patrimônio}

Este procedimento metodológico foi pensado a partir das possibilidades de respostas do poder público no que tange ao planejamento e gestão de bens culturais representativos para o município. $\mathrm{Na}$ esfera federal, o objetivo foi interpretar o olhar e o entendimento de razões que justificariam as permanências pré e pós-tombamento, sobretudo a partir do processo de metropolização pós1950. Ainda que de grande relevância ao diálogo aqui estabelecido, este procedimento se apresentou difuso e pouco profícuo ao longo da pesquisa no que se refere ao plano da gestão municipal. Primeiro pelas condições de acolhimento aos pedidos de entrevista que não foram plenamente atendidos, segundo pela ausência de servidores de carreira capacitados a substanciar as questões trazidas, terceiro pela fragmentação dos órgãos na cidade, separados e distantes, que impedem uma sistemática ágil e eficaz de trabalho. Alternativamente, os diálogos foram sendo concretizados por caminhos menos formais, estabelecidos no dia-dia com os servidores da cultura e turismo principalmente, além de pessoas envolvidas que solicitamente num esquema de "bola de neve" iam indicando outras possíveis referências. No âmbito dos órgãos patrimoniais, a referência principal é o IPHAN, além do CONDEPHAAT, considerando ser somente o conjunto da Aldeia de Carapicuíba tombada no município como patrimônio nacional. Mas a atuação do órgão desde a consagração da Aldeia em 1940 pelo ato de tombamento se deve ainda a especificidade desta ser o primeiro conjunto de bens protegidos institucionalmente em São Paulo e, sobretudo, ter sido objeto de estudo e promoção de Luís Saia à direção regional do IPHAN durante toda sua vida. Neste sentido, um dos técnicos do IPHAN que mais atuou naquela área, Luís Saia Neto, concedeu preciosas informações que são devidamente apresentadas no capítulo 06. 


\section{(d) Aplicação de questionários qualitativos semiestruturados}

Por base das informações levantadas via questionários, enquanto meio objetivo e primário de obtenção de dados para a concretização dos objetivos de pesquisa, estas ferramentas consolidam parcialmente uma base quantitativa segura para uma análise da relação entre a cidade e seus munícipes, dos espaços representativos de Carapicuíba para seus moradores. Este levantamento tem um caráter incipiente de obtenção de dados primários. Neste caso, pelo tema, optou-se por um procedimento qualitativo com menor controle estatístico, considerando metodologicamente para amostragem o "critério de exaustão", uma abordagem que pondera a repetição de respostas como critério de amostra suficiente e que não requer uma quantidade exata ou fechada de aplicações. Ainda assim, somou-se um total de 205 participantes, com idade superior a dezoito anos e moradores das unidades territoriais visitadas. Quanto ao universo da pesquisa, foi adotado como referência as unidades territoriais anteriormente aludidas, pela necessidade de compreensão do objeto de pesquisa na sua totalidade, além do entorno, ou do próprio núcleo histórico tombado. Em relação a sua estruturação, o questionário explorou questões abertas e fechadas, além de questões com níveis ponderáveis numericamente. A análise prévia se estabeleceu já na fase de tabulação dos dados, que quantificados e estruturados em gráficos e tabelas, apoiaram a avaliação final em conjunto com dados secundários obtidos anteriormente. Esta ferramenta contribuiu para dimensionar a ligação dos moradores com a região metropolitana, o uso de equipamentos públicos, a participação em festas populares, o reconhecimento do patrimônio cultural, as dimensões históricas e das transformações da cidade pela metropolização (Apêndice 01). Todas as exigências éticas e institucionais foram atendidas, utilizando Termo de Consentimento Livre e Esclarecido (TCLE - Apêndice 03) e aprovação em parecer consubstanciado (número: 1.642.352) do Conselho de Ética e Pesquisa da Universidade de Brasília (CEP/UnB - Apêndice 04). A leitura de Carapicuíba pelos mesmos, traduzida pelos dados levantados e a análise qualitativa, resultou no estabelecimento de referenciais para as entrevistas semiestruturadas num segundo momento. 


\section{(e) Entrevistas semiestruturadas com a população de Carapicuíba}

As entrevistas semiestruturadas foram realizadas no último ano do estudo, considerando como universo de pesquisa as mesmas unidades territoriais anteriores, porém com uma delimitação de idade, ou seja, com moradores mais antigos e capazes de relatarem as mudanças no modos de vida, das rugosidades patrimoniais decorrentes da metropolização e periferização de Carapicuíba. Este pressuposto não foi impeditivo que alguns entrevistados possuíssem idade inferior a quarenta anos, desde que as falas agregassem aos principais objetivos e questões da tese. No entanto, a maioria dos entrevistados possuía idade superior a cinquenta anos, que perpassa vivências entre as dimensões de subúrbio e periferia. Na primeira etapa de estruturação das entrevistas, estas foram fundamentadas por meio de procedimentos anteriores já descritos (a, b, c). Sua organização foi baseada numa sistemática em blocos, visando facilitar o desenvolvimento das falas e do pensamento, contendo: (i) dados pessoais elementares dos entrevistados; (ii) um bloco para caraterização de Carapicuíba e a região no passado (subúrbio, ruralidades, relação com São Paulo e outras cidades da região, mudanças experimentadas e vividas); (iii) depois, um grupo de questões em relação ao cotidiano na metrópole, ao presente (espaços culturais que frequenta, transformações verificadas, opinião sobre as mudanças); (iv) por fim, uma questão sobre as utopias futuras para Carapicuíba, o vir a ser, sintetizado numa única questão sobre os problemas das cidade e as possibilidade de sua superação (Apêndice - 02). Além do questionário, outro meio de acesso aos moradores abordados foram contatos estabelecidos, com indicações, onde foi possível defrontar algumas lideranças e pessoas diretamente envolvidas com as atividades culturais de Carapicuíba, da OCA, da Aldeia, das festividades de São Benedito, da prefeitura, do futebol de várzea. Algumas das entrevistas foram concedidas em meio a ambientes pouco favoráveis a gravações (como nos festejos e em áreas de risco), ou então, optou-se por um diálogo aberto sem o recurso das ferramentas técnicas considerando a inibição verificada em alguns dos casos onde fora feito uso da câmera de filmagem e o gravador de voz. Em outras situações, aproveitouse a própria abordagem do questionário para empreender a entrevista, o que resultou numa maior profundidade de diálogo. As entrevistas gravadas foram 
transcritas e analisadas individualmente, junto as anotações realizadas nos casos não filmados e gravados. Para efeito de quantidade, pressupomos vinte participantes inicialmente, o que em termos controlados chegaram a doze, e não controlados (com uso máximo de caderneta de campo), por volta de quarenta e cinco pessoas, o que pode ser considerado relativamente suficiente aos preceitos de pesquisa. Assim como os questionários, as entrevistas respeitaram toda as exigências éticas e institucionais, utilizando Termo de Consentimento Livre e Esclarecido (TCLE - Apêndice 03) e aprovação em parecer consubstanciado (número: 1.642.352) do Conselho de Ética e Pesquisa da Universidade de Brasília (CEP/UnB - Apêndice 04).

Por fim, as possibilidades metodológicas refletem os fundamentos teóricos de busca continua de apreensão da realidade, do detour entre abstrato e concreto (KOSIK, 1976 [1963]), pela passagem da lógica formal, dos dados estatísticos e das confabulações tautológicas, à lógica de razão dialética (LEFEBVRE, 1975 [1969]), num contínuo esforço de apreender as ordens universais e particulares numa totalidade, onde o conhecimento estruturado do mundo pressupõe movimento e uma dimensão de espaço geográfico que é inseparavelmente a condição, o fator, o meio e o qualificado produto da história (SANTOS, 1977, 2012d [1996], 2012 [1978], 2012c [1978], 2013a [1978]). Sistematicamente, essa totalidade é cindida em fragmentos, partes que juntas compõe uma unidade buscada pela tese, a partir de um diálogo teórico na primeira parte, um esforço de cissiparidade do fenômeno pela periodização histórico-estrutural desde a gênese nos primeiros capítulos até a atualidade do objeto de tese nas partes finais, junto a retomada dos preceitos teóricos e às análises das suas contradições e sínteses. 


\section{PASSOS DA PESQUISA}

Parte 01 (cap. 01 e 02). Assume-se aqui uma visão de mundo que observa e percebe pela ótica da Geografia, tanto enquanto ciência - como prática da existência - e o olhar da geografia urbana - como uma unidade da Geografia - a possibilidade de abordagem acerca das metrópoles, do patrimônio e das resistências de forma conjunta. No entanto, essa resistência não é vista no patrimônio como um reflexo de forças contrárias ao sistema produtivo e da ordem vertical denotada pelo fenômeno urbano, mas enquanto rugosidade patrimonial, capaz de dinâmica e simultaneamente suprimir, superpor e acumular formasconteúdos. Ela se revela contraditoriamente como um elemento capaz de seletivamente absorver os fluxos e os novos fixos do capital, ao mesmo tempo em que permite o resgate do passado e uma possível reconversão dos espaços de memória segundo estratégias de enfretamento e de realização social. Na trajetória de ampliação valorativa dos bens históricos e elementos culturais, as cidades e as grandes metrópoles cumprem um papel espacial diferenciado. São essas aglomerações, como grandes nódulos da rede mundial de informações, na transmissão das técnicas e dos costumes, dos modos de vida e das relações humanas de forma generalizada, que permitiram o alcance da Modernidade em todo planeta, e que agora, metamorfoseada, ainda é capaz de nutrir a propagação e difusão da grande e massificada cultura. Essa mesma cultura é a que rebate na patrimonialização, na consagração hierárquica de espaços delimitados, de lugares e objetos selecionados para suplantarem ideologias que, por vezes, colocam em xeque a autonomia de populações e territórios. O combate e superação a essa seletividade espacial, produzida muitas vezes por falsas e/ou fantasiosas narrativas em razão prática do setorialismo econômico da abordagem do patrimônio em destacar paisagens, heróis, vilões e jecas, perpassa justamente a ampliação e aceitação de outras vozes e olhares destoantes. Estas ações podem ser ratificadas por seus habitantes como de fato um produto próprio, ou seja, dos sujeitos que a vivem, dos que ali tanto trabalharam pela sua existência. Assim também, das inter-relações existentes em escalas mais amplas, permitindo um pensamento crítico capaz de ver o espaço da metrópole enquanto um todo patrimonial, um palimpsesto com diferentes atribuições de valores e memórias coletivas entre os munícipes.

Parte 02 (cap. 03 e 04). Fundamentada pelos preceitos que acompanham o desenvolvimento da pesquisa, esta parte da pesquisa trata da gênese das rugosidades patrimoniais de Carapicuíba face ao processo de colonização do planalto paulistano nos primórdios da formação territorial brasileira. Trata-se do avanço da teoria para a análise dos 
fragmentos históricos e estruturais dos primeiros núcleos de assentamento, com notas balizadoras das primeiras vilas, cidades e o apoio de unidades extraoficiais (destacadamente os aldeamentos) responsáveis pela consolidação seminal de São Paulo. No caso dos aldeamentos, sua interdependência com as centralidades coloniais, através das vilas principais e a metrópole portuguesa, estabelecida basicamente pelas funções de trabalho compulsório e estratégias militares de defesa. Os conteúdos são elos supressivos do modo de vida até então estabelecido pelas sociedade pré-colombianas, cujos conteúdos passam a ser gradativamente combatidos em favor da moral cristã, operada especialmente pelos jesuítas e outras ordens religiosas ligadas à Igreja. As permanências residem fundamentalmente de superposições, da adequação de rituais às necessidades de conversão no plano espiritual, ou nas formas geográficas com a apropriação e ampliação de antigas rotas, caminhos e abrigos que perfazem a interiorização do território americano. Pela extensão deste processo no tempo e pela importância despendida ao período colonial das incipientes políticas patrimoniais brasileiras, esta rugosidade patrimonial ganha uma narrativa mítica e fundacional que agrega todas as etnias e relações que substanciam o sentido de nação, ideologicamente construída para o país. Esta parte da pesquisa ainda revela a passagem do período colonial ao Brasil independente, compreendendo as bases da formação do cinturão caipira, superposto e acumulado nestes antigos espaços de exceção e litigiosos dos aldeamentos. O que conformaria e reproduziria não apenas as formas, mas ainda parte das funções e conteúdos pretéritos, que no caso da particularidade de Carapicuíba preservaria o antigo núcleo, suas formas mais basilares, do mesmo modo algumas das tradições compreendidas de determinadas acumulações ou superposições anteriores. Os limites do cinturão caipira são tencionados pela concretização dos subúrbios com a expansão metropolitana e do tecido urbano de São Paulo, o que perfaz uma dinâmica relativamente nova e acumulativa sobre os antigos núcleos do entorno, fragmentando-os político-administrativamente e ordenando normativamente seus espaços conforme os interesses ampliados do modo de produção em curso. O limite entre o período do cinturão caipira e a consolidação suburbana de Carapicuíba (marcada pela sua emancipação), no plano patrimonial é efetivada pelo tombamento federal da Aldeia (último conjunto remanescente de ruinas jesuíticas dos aldeamentos em São Paulo), que reverberaria a um movimento mais amplo em que se conformavam além do aldeamento, outros territórios estratégicos à modernização tardia do país pela díade industrialização-urbanização concentradas. 
Parte 03 (cap. 05 e 06). Trata do desenvolvimento urbano-metropolitano em São Paulo, tomando a passagem do subúrbio a periferia em Carapicuíba, cujo foco recai sobre as rugosidades patrimoniais da Aldeia frente a esse processo. Além de discutir as atuais dimensões conceituais de subúrbio e periferia na RMSP, verifica-se uma série de intervenções realizadas, as políticas de preservação no âmbito nacional e em relação a particularidade do aldeamento (rugosidade monumento), o planejamento urbano e os planos de gestão metropolitanos (rugosidade-documento), além das contínuas tentativas de dinamização por novas atividades produtivas no espaço da Aldeia (rugosidade-instrumento) e os conflitos potencializados com a população moradora e do entorno. Nesta perspectiva, evidencia-se as rugosidades patrimoniais da Aldeia de Carapicuíba frente a metropolização de São Paulo nos limites entre a urbanização da sociedade e a urbanização dos territórios. Revela-se os limites do drama cotidiano de viver na periferia de São Paulo e as possibilidades concretas de sua superação. Condição esta que projeta a Aldeia e suas rugosidades em relação à cidade, continuamente permeadas pelas contradições entre a preservação do conjunto arquitetônico e o reconhecimento das tradições que resistem, junto às destruições decorrentes da modernização perversa do território e do próprio fenômeno da patrimonialização. 


\title{
PARTE 01
}

\section{DIMENSÃO METROPOLITANA DO PATRIMÔNIO CULTURAL ENQUANTO RUGUGOSIDADE}

\section{CAPÍTULO 01: Rugosidades patrimoniais}

\begin{abstract}
O espaço portanto é testemunho; ele testemunha um momento de um modo de produção pela memória do espaço construído, das coisas fixadas na paisagem criada. Assim o espaço é uma forma, uma forma durável, que não se desfaz paralelamente à mudança de processos; ao contrário, alguns processos se adaptam às formas preexistentes enquanto outros criam formas para se inserir dentro delas (Milton Santos, 2012c [1978], p. 173)
\end{abstract}

Este capítulo avalia a noção de rugosidade espacial, ao estabelecer uma proposta conceitual assentada na atual dinâmica da patrimonialização, a qual designa-se rugosidade patrimonial, a partir do diálogo com Milton Santos. Este conceito foi basilar no entendimento provisório das formas e conteúdos urbanos em núcleos históricos metropolizados ao longo de todas as atividades de pesquisa. Trata-se de um esforço teórico que subsidia uma releitura de espaços metropolitanos pela ótica das resistências locais frente a reprodução do capital, mas também de suas adaptações e contradições para o desenvolvimento da vida no espaço urbanometropolitano. Neste sentido, acredita-se que as rugosidades patrimoniais podem melhor apoiar este conhecimento, situando eventos e períodos de ocorrência dos fenômenos, a abrangência de suas múltiplas escalas e determinações, tangenciando a discussão sobre os processos de supressão, acumulação e superposição das formas e conteúdos espaciais. E, por fim, dos sentidos e significados culturais das manifestações que hoje se estabelecem ou que permanecem nestes mesmos lugares a longo tempo, mais especificamente, o papel dos espaços de memória às demandas da tríade capital, Estado e mercado simultânea e contraditoriamente, enveredando ao fortalecimento da oposição e da adaptabilidade do próprio sistema às formas e conteúdos dos lugares. 


\subsection{Rugosidade: conceito geográfico para pensar o patrimônio cultural}

Conceitos são generalizações que possuem propriedades suficientes de contribuírem com a apreensão parcial e momentânea do real, sendo usados na resolução de problemas práticos e questões diversas do cotidiano. São também relacionais e dinâmicos, ou seja, podem sofrer incrementos ao longo do tempo que alteram o núcleo da teoria, ou de se diluírem com o desuso ao longo do desenvolvimento científico. Apesar da discussão conceitual anteceder na tese o resultado da empiria, este é continuamente retroalimentado (para usarmos uma expressão caracteristicamente sistêmica) e estruturado conforme o desenvolvimento da pesquisa. Tão logo, pois, finalizado o trabalho em torno de sua composição final, a dinâmica dos fenômenos se altera, resultando a necessidade de novas elaboração a partir da realidade então produzida. Em parte, como Becker (2008, p.146), entende-se que “[...] desenvolver conceitos, porém, é um diálogo contínuo com os dados empíricos. Como conceitos são maneiras de sumarizar dados, é importante que eles sejam adaptados aos dados que vamos sumarizar."

A respeito dos conceitos, pensando mais disciplinarmente no âmbito da Geografia, Santos (2013a) advoga que para além da sua universalidade, quase sempre pensados e importados dos países desenvolvidos centrais, estes tomem contornos particulares diante das remotas realidades geográficas. Mas, sobretudo, que sejam repensados sobre a ótica dos fatos, peculiares em cada unidade do sistema mundo. Reformulando-se, pois, não somente os conceitos, mas as próprias teorias e metodologias da Geografia. Somente neste sentido, o compasso entre as dinâmicas transformações sociais, sua análise e explicação poderão alcançar a fugidia concreticidade do real. E, no limite, penetrar a esfera da práxis social e, portanto, conciliar metabolicamente teoria e prática.

Antes de propriamente tratar da noção de rugosidade espacial, é necessário que se esclareça algumas categorias do método geográfico utilizadas ao longo da pesquisa no sentido de apreender os fenômenos da realidade social numa dimensão espacial. Esta nota é necessária pelo uso contínuo de termos como espaço geográfico, formas, conteúdos, funções, estrutura e processo. Assim, quando há referência ao termo espaço geográfico, significa que ele traduz a ideia de um conjunto indissociável de sistemas de objetos e sistemas de ações (SANTOS, 2006 [1996]). Portanto, uma instância complexa do social: um meio, uma 
condição, mas também um substrato de todas as relações sociais. Em relação às categorias: forma, função, processo e estrutura, cada uma possui características próprias, sendo, no entanto, utilizadas sempre de forma conjunta, ou seja, de maneira simultânea e inseparada, já que "para se compreender o espaço social em qualquer tempo, é fundamental tomar em conjunto a forma, a função e a estrutura, como se tratasse de um conceito único" (SANTOS, 1985, p. 56), isso ainda com base no processo histórico de cada período ou recorte analisado (OLIVEIRA; SILVA, 2009, p. 03).

A categoria forma, no contexto anteriormente citado, seria também uma categoria desse todo, o visível, o objeto em si, o arranjo, por fim um padrão. Enquanto a função seria o papel esperado de uma forma, sugerindo, portanto, uma tarefa a determinada coisa. E, enfim, o tempo estaria representado pela categoria processo, num movimento dinâmico e comum entre todas as outras categorias, para então conquistarmos a apreensão da realidade, por meio da "totalidade concreta e dialética" do mundo. (SANTOS, 1985, p. 58). No que diz respeito à categoria de estrutura, Perroux (1969, p. 371 apud SANTOS, 1985, p. 16) vai defini-la como uma "rede de relações, uma série de proporções entre fluxos e estoques de unidades elementares e de combinações objetivamente significativas dessas unidades”. Gurvitch (1971, p. 112) versando sobre a questão da estrutura nas ciências sociais, esclarece o dinamismo de processos atuantes que sempre a modificam conforme o período histórico, onde as estruturas não são simplesmente "preestabelecidas", pois "estão sujeitas a uma contínua recomposição, porque o seu equilíbrio é precário", jamais estão estáveis, em perfeita ordem; pelo contrário, pressupõem um perpétuo movimento de estruturação, desestruturação e reestruturação, no qual participam todos os elementos do fenômeno social total.

Buscando evidenciar a inseparabilidade entre espaço e sociedade, Santos (1985, p. 50) esclarece que a estrutura "implica a inter-relação de todas as partes de um todo; o modo de organização ou produção". Portanto, a noção de totalidade (SANTOS, 2012a [2005]; 2006 [1996]) empregada deriva paralelamente do sentido de estrutura e mais genericamente das perspectivas analíticas do processo de globalização. Abarca, pois, na Geografia a busca filosófica matriz de apreender a dinâmica realidade em seu estado de fracionamento e totalização, como na prática acerca das operações e adaptabilidades do modo de produção, das divisões territoriais do trabalho, das formações econômicas e sociais, bem como do papel destas diferentes partes numa contínua relação de transformações do todo. Pelo dinamismo do real, da totalidade, as periodizações históricas tornam-se elementos centrais para a compreensão de um dado momento ou a fração da totalidade. Mesmo fracionada, esta não 
deve ser simplesmente tomada em separado da totalidade geográfica, o que implica a busca de um método localizado, situado, em que se operam as forças do tempo, mas também a instância social do espaço geográfico.

Neste sentido é que Santos (1985) defende a inseparabilidade analítica pelas categorias supracitadas, pois conforme se aprofunda em cada uma delas a inevitabilidade de sobreposições as tornam em uma só unidade complexa, porém objetivas e esclarecedoras. Outra categoria importante para o desenvolvimento do conceito de rugosidade e, posteriormente, de sua adjetivação patrimonial, reside nos conteúdos geográficos, ou nas formas-conteúdos (SANTOS, 2012d [1996]). Conforme o autor citado, não se pode entender uma dialética hierarquizada em “[...] estrutura (essência, totalidade nua), processo, função e forma segundo um movimento linear, ou de maneira unívoca pois, de um lado, a estrutura necessita da forma para tornar-se existência e, de outro, a forma-conteúdo tem um papel ativo do todo social" (SANTOS, 2012d, p. 126). Portanto, essa forma-conteúdo, carregada de símbolos e ideologias, exige apenas superar a oposição entre essência e aparência, mas estimular o pensamento a confrontar essência e existência. Segundo o autor, "[...] a ideologia é também essência, aparece como realidade e assim é vivida" e, “[...] a essência se transforma em existência [...]. Deste modo, há objetos que já nascem como ideologia e como realidade ao mesmo tempo. Nestas condições, a totalidade social é formada por mistos de realidade e ideologia." (SANTOS, 2012d, p. 127).

Tratar da realidade contemporânea é considerar os pressupostos categoriais anteriormente sintetizados, mas também de conceitos auxiliares pensados por base destas mesmas categorias. A esse preceito, em teoria, a noção de rugosidade espacial nada mais é que uma forma-conteúdo. Carregada de símbolos e ideologias, a rugosidade possui relevância quando são experimentadas intensamente por uma frenética busca pelas excepcionalidades, monumentalidades e tantas razões que incluem a reprodução do modo de produção em atividades diversas a elas associadas. Como teoria, contudo, não se trata ainda essencialmente de um conceito, já que Milton Santos a utilizou mais como uma noção, um balizamento que, de certa maneira, foi deixada de lado, quando no entendimento dos fluxos, será o conceito de fixo que passará a tomar maiores esforços intelectivos dos geógrafos, destacadamente os brasileiros.

No esforço inicial de Santos (2013a [1978]), a diferença entre fixos e rugosidades é praticamente inexistente, no entanto sobressaindo em "por uma geografia nova..." (2012c 
[1978]) uma dimensão mais substancial, mostrando desde o século dezenove como suas premissas já se desenvolviam pelo materialismo histórico e dialético com Engels até mais recentemente pelo espanhol M. Castells. No exterior, a terminologia rugosidade espacial não converge com a reflexão de Santos (2012a; 2012c; 2012d [1996]; 2013b), ao se apresentar numa perspectiva mais pragmática, ou seja, aplicada aos desígnios do planejamento e do ordenamento territorial. Toma assim um outro sentido, uma matriz epistemológica que não está compassada com a Geografia Crítica, mesmo que suas bases assentem-se na influência francesa. No Brasil é utilizada de forma secundária nas análises geográficas, ligada fundamentalmente ao legado de Milton Santos e que se conjuga enquanto formas espaciais oriundas de múltiplos períodos de tempo. Este preceito vincula-se àquilo que o autor teorizou do espaço como acumulação desigual de tempos históricos. Avança, contudo, em obras mais recentes, para uma definição elaborada de rugosidades em relação aos fixos, atrelando a primeira noção às dimensões categoriais do espaço geográfico e ligadas aos diferentes contextos históricos, fundamentalmente às permanências espaciais individuais ou em conjuntos $(2012 \mathrm{~d})^{7}$.

Godoy (2004, p. 37) aponta que a busca de conceitos como os de rugosidade, ou mais precisamente de "(des)construção", é decorrente do “[...] processo de urbanização da sociedade. As cidades, sobretudo as metrópoles, tornaram-se os lugares de experimentação de um novo urbanismo e de uma nova estética arquitetônica.”. A dimensão strictu sensu de rugosidade enquanto forma, amplia-se nas dimensões históricas de outras necessidades e relações, constituindo-se particularidades materiais dos sonhos e desejos humanos, tanto como da opressão e do medo. Torna-se, de fato, um elemento fundamental da particularidade de grupos sociais, de seus modos de vida, da produção cultural e dos múltiplos simbolismos. Buscados pela ciência, pelas artes e a filosofia, estas rugosidades despertam amplos interesses, desde o entendimento e novas interpretações do passado, até o desenvolvimento de novas atividades produtivas, como eventos culturais e celebrações religiosas. Esses objetos, formas e conteúdos espaciais, transformados pelo trabalho social em diferentes fases e regimes de tempo, comportam resíduos concretos dos modos de produção e da aventura humana em sua existência, permitindo mostrar o dinamismo do tempo e espaço, sugerindo

\footnotetext{
7 No livro "A natureza do espaço" de 1996, Milton Santos define rugosidade como substrato de formas, individuais ou conjuntas, que resultam das divisões de trabalho pretéritas e que pela acumulação, superposição e supressão dos objetos geográficos implicam num espaço fator.
} 
pensar as rugosidades como barreiras ou mesmo catalisadoras concretas dos projetos de mundo. Assim também, revelar as diferenças, as desigualdades e aspectos contraditórios da produção do espaço, materialmente sintetizados na cidade e escancarados nas metrópoles.

\begin{abstract}
Esse objeto e essa realidade não são em si. Eles expressam sim, ao contrário, uma atribuição coletiva de sentido (portanto social), que deriva de um princípio de convenções. Este último traduz um acordo social implícito (muitas vezes institucionalizado e territorializado) sobre valores coletivamente admitidos; testemunha tácita de uma inegável identidade compartilhada. Para que haja patrimônio, são necessários processos (sociais no sentido completo do termo) de patrimonialização, sejam das modalidades bens precisos de transformação de um objeto, de uma ideia, de um valor em sua dupla simbólica e distinguido, rarificado, conservado, constituído de certa intemporalidade (mesmo se seja datado, paradoxo?), cuidadosamente selecionado (DI MEO, 2014, p. 05).
\end{abstract}

Concluindo, a noção de rugosidade espacial aqui desenvolvida reside, em grande medida, neste legado analítico-reflexivo de Milton Santos, fundamentada enquanto teoria e conceito na realidade urbana contemporânea, em que as formas espaciais pretéritas engendram a cada dia novos usos do território e que altera profundamente a dinâmica da vida nas cidades em todo planeta. Conceitos como os de território, paisagem, região e lugar, embasados pelas categorias do método geográfico (SANTOS, 1985) são basilares para a apreensão das rugosidades, desde sua condição particular-universal, até os resultados atuais que se dilatam em torno de sua institucionalização e as operações ideológicas e econômicas mediadas pelas mesmas. Sua estruturação conceitual auxilia a compreender como as pretéritas formas espaciais, das cidades coloniais, ou mais especificamente de primitivos núcleos de aglomeração como os aldeamentos, se desenvolveram, transformando-se em grandes regiões metropolitanas na atualidade. Metodologicamente, apoiam e explicam como as permanências concretas e intangíveis resistiram às modernizações e a própria Modernidade, resultando hoje num atrativo monumental e excepcional do patrimônio cultural, assim também em unidades de coesão e relações de pertencimento dos grupos sociais relacionados aos seus territórios. Mais que as dimensões valorativas e significantes dos objetos técnicos, a rugosidade patrimonial permeia a própria noção de exuberância e permanência da natureza, enquanto novo desígnio categorial da cultura, porém traduzida pelo patrimônio natural (PAES, 2001; SCIFONI, 2006; COSTA et al., 2015). 


\subsection{Rugosidade patrimonial: o caminhar do conceito entre teoria e prática}

Há necessidade, pois, de avançar sobre a noção de rugosidade espacial, visando estabelecer uma sistematização a priori e mais conjectural do fato analisado, assim como analisar e explicar uma realidade diferenciada dos contextos em que essa noção foi pensada, mas que continua dinamicamente a se desenvolver. A noção de "rugosidade" que permanece ou que relativamente resiste, ao ser adjetivada pelo termo "patrimonial" - uma teoria, uma narrativa e uma prática social - converte-se em possível conceito estruturante. Logo, a rugosidade, uma noção particularizada da produção geográfica, ainda esparsa, carregada de sobreposições, seria capaz de incluir continuações calcadas nas bases materiais dos objetos técnicos processados, como também dos elementos simbólicos e culturais manifestados pelas tradições e modos de vida locais. Contudo, a leitura da noção de rugosidade tende a ser ampliada, sob a dimensão histórica de natureza e sociedade (LEFÈBVRE, 1975; 1979; SMITH, 1984a; 1984b), em que os desígnios da patrimonialização inserem-se como parte da lógica da produção espacial contemporânea.

Portanto, além de compreender os contextos e regimes de tempo, a rugosidade patrimonial enquanto conceito permearia o plano material das formas, como de suas funções práticas e, fundamentalmente, seus conteúdos pretéritos e contemporâneos. Como as paisagens, as rugosidades patrimoniais, ainda mais acentuadas pela normatização ou reconhecimento coletivo de seu valor histórico e cultural, expressam-se materialmente como mecanismos de persuasão e reprodução das relações sociais. Ora pelo papel alegórico difundido pela agregação de uma identidade, ora pelas narrativas associadas aos desígnios dos mitos fundadores, como pelos interesses estratégicos dos poderes ligados à produção do espaço urbano. Neste caso, as rugosidades patrimoniais acentuam os significados das paisagens, revelando além dos simbolismos e a intertextualidade da produção escrita (narrada) e a da concretude dos bens, confirmam da mesma maneira as disputas, conflitos e contradições do espaço geográfico estabelecidos em relação às instâncias políticas e culturais em torno do poder (DUNCAN, 2004).

Pela revisão de literatura e contínuo diálogo com especialistas brasileiros, o sentido de rugosidade espacial pode ser traduzida por uma noção referencial de barreira, ou seja, independentemente da matriz filosófica de pensamento, da disciplina, ou do método científico, a terminologia é sempre empregada no sentido de resistência, como obstáculo, empecilho, ou até mesmo distância. Essa noção ainda é ajustável ao contexto dos limites entre 
o natural, quanto ao cultural, nos meandros dicotômicos e especializados que as disciplinas e suas subáreas tomaram no decorrer dos anos. Observa-se no levantamento, desde os estudos franceses de modelos urbanos, como os de Cécile Helle (1993), ligados às teorias de centralidade inspiradas em Thünen e Christaller (e sob influência de geógrafos como Berry e Haggett), quanto estudos de climatologia aplicada e de sistemas de informações geográficas (PENEAU,1996). Com Milton Santos (2013a [1978]), a noção de rugosidade orginalmente empregada à Geografia como possibilidade analítica de fenômenos contemporâneos dos fatos sociais. Estes, imbricados em temas que vão das desigualdades econômico-sociais, dos processos históricos de formação territorial e, atualmente, ligadas ao temário do patrimônio cultural.

Na língua inglesa, a noção mais próxima identificada refere-se a surface roughness, utilizada com maior propriedade pela engenharia de materiais para fins diversos, sobretudo a relação do atrito e resistência dos materiais entre superfícies. Na língua francesa, além da associação do termo às ciências e engenharias dos materiais, na Geografia aparece normalmente expressa por rugosité de l'espace, ou seja, adjetivada pelo termo espacial (PENEAU,1996). Portanto, a rugosidade, na sua acepção matriz, continua derivando da condição de resistência. Esta condição, no entanto, se estabelece como espaço ou objeto absoluto, tomado pelas condições exclusivas do modelado natural ou cultural dos artefatos. Ou seja, observa-se que sua atribuição conceitual está imersa no sentido espacial neokantiano apriorístico de ambiente e sociedade, num viés em que tempo e espaço são segregados em polos distintos de análise. Outro fato comum é o caráter usual do conceito no planejamento urbano e regional, considerando os elementos naturais, técnicos e culturais aos projetos e indicadores de resistência, pragmaticamente atendendo certas demandas sociais, mas sem necessariamente realizar uma análise destas unidades para além dos modelos resultantes. No Geografia brasileira, no entanto, a noção é mais comum, utilizada justamente nas periodizações e análise das temporalidades materializadas nas paisagens em razão de uma tradição inspirada nas obras de Santos (1977, 2012d [1996], 2012 [1978], 2012c [1978]).

Nos termos da Geografia, deduz-se, já que não há qualquer referência mais precisa do uso da noção, que a rugosidade espacial foi uma expressão inicialmente utilizada por Jean Tricart, para a descrição de aspectos visíveis da natureza. Ao menos é a direção dada por Santos (2013a [1978]), quando dedica uma dimensão de espaço geográfico mais ampla, ligada 
às formas, mas também aos seus conteúdos. Ao fazer isso, critica os geógrafos que se apegam apenas ao espaço absoluto ${ }^{8}$, das formas, ou "[...] apelam frequentemente para a noção de rugosidades do espaço" (2013a [1978], p. 72). Pois segundo ele, a rugosidade espacial deveria ser considerada como elemento fixo, cuja condição é relativa às funções e conteúdos de uma dada estrutura social, sobressaindo a instância econômica e as dimensões inertes dos objetos (rugosidades, fixos) e dinâmicas do espaço geográfico (fluxos de pessoas, mercadorias, informações). A expressão em especial, no entanto, não é referenciada a nenhum autor ou literatura específica em toda obra de Milton Santos, a não ser em "O Trabalho do Geógrafo no Terceiro Mundo" (2013a [1978]), onde se refere ao geógrafo francês Jean Tricart.

[...] Expressão criada por Tricart para a geomorfologia no intuito de mostrar como, tendo o passado geográfico e histórico modelado paisagens diferentes, tudo o que nelas se superpõe não pode ser indiferente a essa aquisição. É a isso que os geógrafos chamam espaço 'espaço concreto', como para opô-lo ao dos economistas, considerado 'espaço abstrato'. Ora, 'se o espaço econômico não é o espaço concreto preenchido pelas relações econômicas', parece natural que os geógrafos reivindiquem o estudo dessa forma de espaço [...] (SANTOS, 2013a, p. 72).

Na continuação da obra (2013a), no capítulo dedicado aos "fluxos e rugosidades", expõe o papel da rugosidade enquanto forma espacial e dos fluxos como movimento. Ao tratar da materialidade e do movimento, Tavares e Silva (2011) explicam que é nesta obra que “[...] a concepção de espaço que será amplamente desenvolvida [...], tanto é assim que o autor intitula uma seção do $9^{\circ}$ capítulo de 'fluxos e rugosidades', no qual traz à tona a importância do movimento e da materialidade para a análise do espaço geográfico." (TAVARES; SILVA, 2011, p. 145). No entanto, nas obras futuras a atenção dada a noção de rugosidade espacial se dilata na de fixos, sendo melhor retomada em "Por uma Geografia Nova..." (2012c [1978]) e com maior profundidade em "A Natureza do Espaço" (2012d [1996]). Nesse transcorrer, o

\footnotetext{
${ }^{8} \mathrm{O}$ conceito de espaço é, sem dúvida, um dos mais polêmicos na ciência contemporânea. Na Geografia, buscando a natureza do espaço para entender processos urbanos sob a égide do modo de produção capitalista, $\mathrm{D}$. Harvey (2006) estabelece três categorias de espaços: absoluto, relativo e relacional, que juntos podem servir aos diferentes propósitos de compreensão dos fenômenos geográficos contemporâneos. "Se considerarmos o espaço como absoluto ele se torna uma 'coisa em si mesma', com uma existência independente da matéria. Ele possui então uma estrutura que podemos usar para classificar ou distinguir fenômenos. A concepção de espaço relativo propõe que ele seja compreendido como uma relação entre objetos que existe pelo próprio fato dos objetos existirem e se relacionarem. Existe outro sentido em que o espaço pode ser concebido como relativo e eu proponho chamá-lo espaço relacional - espaço considerado, à maneira de Leibniz, como estando contido em objetos, no sentido de que um objeto pode ser considerado como existindo somente na medida em que contém e representa em si mesmo as relações com outros objetos." (HARVEY, 2006, p. 10).
} 
espaço geográfico, tem nas rugosidades uma síntese do tempo cuja paisagem revela. "A partir da noção de espaço como um conjunto indissociável de sistemas de objetos e sistemas de ações podemos reconhecer suas categorias analíticas internas. Entre elas, estão a paisagem, a configuração territorial, a divisão territorial do trabalho, o espaço produzido ou produtivo, as rugosidades e as formas-conteúdo" (SANTOS, 2012d, p. 12-13). Evidencia-se, pois, que a noção de rugosidade está situada pelo autor à mesma importância de categorias como a paisagem, ou a divisão territorial do trabalho. Todavia, a particularidade da noção reside na carga histórica dos objetos nela organizados, enquanto formas do passado que se fazem atuais no presente, mas que revelam as distintas divisões do trabalho pretérito, bem como as técnicas utilizadas e seus resultados.

\begin{abstract}
Os modos de produção se realizam por intermédio dos meios de produção, cuja longevidade, porém, só é conhecida a posteriori; porém, essa duração pode ultrapassar a um ou vários momentos do modo de produção ou até mesmo a duração total do modo de produção [...]. Os modos de produção cedem lugar a outros, os momentos de cada modo se sucedem enquanto os objetos sociais por eles criados continuam firmes, e muitas vezes com uma função na produção (SANTOS, 2012c [1978], p. 174).

Chamemos rugosidade ao que fica do passado como forma, espaço construído, paisagem, o que resta do processo de supressão, acumulação, superposição, com que as coisas se substituem e acumulam em todos os lugares. As rugosidades se apresentam como formas isoladas ou como arranjos. É dessa forma que elas são uma parte desse espaço-fator. Ainda que sem tradução imediata, as rugosidades nos trazem os restos de divisões do trabalho já passadas (todas as escalas da divisão do trabalho), os restos dos tipos de capital utilizados e suas combinações técnicas e sociais com o trabalho (SANTOS, 2012d [1996], p. 91-92).
\end{abstract}

Santos (1996, p. 140) ainda lembra que "em cada lugar, pois, o tempo atual se defronta com o tempo passado, cristalizado em formas. Para o tempo atual, os restos do passado constituem aquela espécie de 'escravidão das circunstâncias anteriores' de que falava John Stuart Mill". De tal maneira que o trabalho passado condiciona portanto o trabalho presente, cujas heranças compõem uma complexa teia de propósitos funcionais de nossos antepassados, afora as técnicas conjugadas na produção do espaço e os usos estabelecidos nos mais diversos regimes de tempo. "É nesse sentido que falamos da inércia dinâmica do espaço [...]." (SANTOS, 1985; 2012d, p. 140) - ou seja, uma força territorial que congrega neste caso da acumulação formas do passado e presente numa totalidade. 
O meio ambiente construído constitui um património que não se pode deixar de levar em conta, já que tem um papel na localização dos eventos atuais. Desse modo, o meio ambiente construído se contrapõe aos dados puramente sociais da divisão do trabalho. Esses conjuntos de formas ali estão à espera, prontos para eventualmente exercer funções, ainda que limitadas por sua própria estrutura. $\mathrm{O}$ trabalho já feito se impõe sobre o trabalho a fazer. A atual repartição territorial do trabalho repousa sobre as divisões territoriais do trabalho anteriores. E a divisão social do trabalho não pode ser explicada sem a explicação da divisão territorial do trabalho, que depende, ela própria, das formas geográficas herdadas (SANTOS, 2012d [1996], p. 141).

Para Corrêa (1995), o processo de inércia e áreas cristalizadas depende simultaneamente da permanência dos usos e formas, diferenciando-se das rugosidades patrimoniais, que comportariam novas funções e usos territoriais das formas geográficas. No limite, as rugosidades extravasam a necessidade de permanência até mesmo das formas geográficas. Importa destacar, portanto, a relevância destes conceitos no atual período histórico, em que a permeabilidade do capital em antigas áreas está dinamicamente a suprimir, acumular e superpor formas geográficas com outras funções e formas diante dos novos conteúdos travados e incorporados pela sociedade. Em verdade, o fato da rugosidade estar atrelada às formas pretéritas e acumuladas no presente, a torna um conceito central para os estudos da Geografia histórica, cultural e urbana. Para Godoy (2004), o sentido de rugosidade remete a definição de "[...] formas espaciais do passado, produzidas em momentos distintos do modo de produção e, portanto, com características sócio-culturais específicas. [...] Constituem-se em paisagens técnicas que podem ser periodizadas segundo o desenvolvimento do modo de produção ao longo do tempo histórico". Ainda segundo ele, ao refletir acerca da noção de produção do espaço, o conceito de rugosidade espacial pode ser encontrado sob diferentes perspectivas na literatura desde o século dezenove, se tratando basicamente das heranças espaciais constituídas em diferentes tempos do processo histórico (GODOY, 2014). 


\subsection{Categorias analíticas da rugosidade patrimonial: supressão, acumulação e superposição}

Por ser visível, como as marcas do uso nos objetos, ou da idade no rosto dos sujeitos, as rugas além de fundamento da experiência vivida, ou do desgaste às distintas resistências, podem ser mecanismos metodológicos que nos permitem apreender diversos fenômenos, como ao da atual urbanização, a valorização e desenvolvimento produtivo das áreas citadinas de relevante carga patrimonial, assim como os movimentos e ações que imprimem outras lógicas sobre aquelas hegemônicas. Neste sentido, o modelo seguinte (Figura 01), mostra uma das facetas do conceito de rugosidade, a partir das materialidades das formas. Já que, como tratado anteriormente, compreende-se que as rugosidades não estão restritas apenas aos elementos fixos de diferentes contextos históricos, mas também à memória e às subjetividades do plano simbólico que as mesmas despertam. Em todos os casos ilustrados, as forças verticais da urbanização exercem pressões diferenciadas, seletivas e adequadas ao contexto e à própria realidade dos territórios.

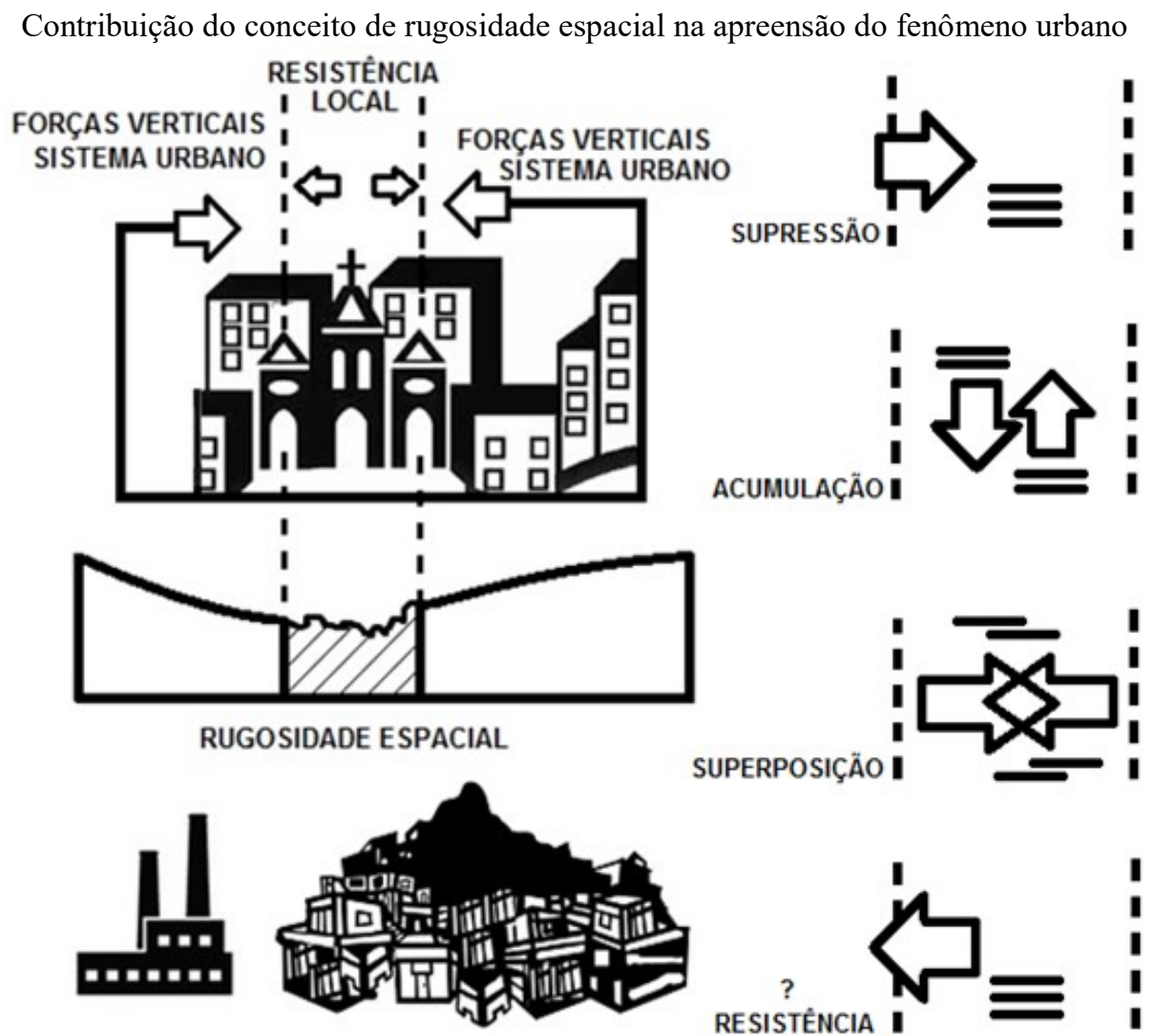

Figura 01: Elementos da paisagem traduzidos pelo conceito de rugosidade espacial assumem novas funções e significados por meio de processos como a da supressão, acumulação e superposição das formas geográficas. Os bens materiais mais expressivos destes grupos podem representar resistências territoriais expressivas às imposições verticais ligadas a interesses alheios ao desenvolvimento local.

Fonte: Santos (1977, 2012d [1996], 2012 [1978], 2012c [1978], 2013a [1978]). Elaborado pelo autor, 2015. 
Reside na análise do modelo algumas questões teóricas centrais em relação à rugosidade proposta por Santos (2013a [1978]) daquelas tratadas nestas laudas. Enquanto elementos materiais, a demonstração baseada nas ideias de Santos (1977, 2012d [1996], 2012 [1978], 2013a [1978]) sobre a permanência das formas torna-se no caso da supressão um dos pontos principais. Justamente, ao ser eliminada (simples sinônimo de suprimida), resulta no esquecimento, na não-permanência. No entanto, a supressão pode ser efetivada em dois planos principais: o primeiro pela destruição das formas, cuja extinção material não significará determinantemente o esquecimento de suas funções e usos pretéritos; o segundo, por preservação ou conservação das formas (menor complexidade de modelagem), que pode não ser suficiente para a lembrança, ou a um efetivo uso contemporâneo. Destes planos, podem desdobrar-se outros, mas todos eles estarão ligados às implicações dinâmicas de experiências com espaços e conteúdos espaciais que permanecem ou não.

Ainda que dinâmicas, as rugosidades devem oferecer certa barreira às modernizações, ou mesmo ao próprio movimento histórico do esquecimento e da efemeridade temporal. De fato, a supressão das formas nem sempre é concretizada sem haver tensões, conflitos e até lutas pela sua destruição, conservação ou preservação. E mesmo que suprimida, ou parcialmente destruída - como evidencia a Figura 02 seguinte - a forma só será mesmo uma rugosidade quando esta permanecer presente num dado local, ou atual na memória coletiva e nacional.

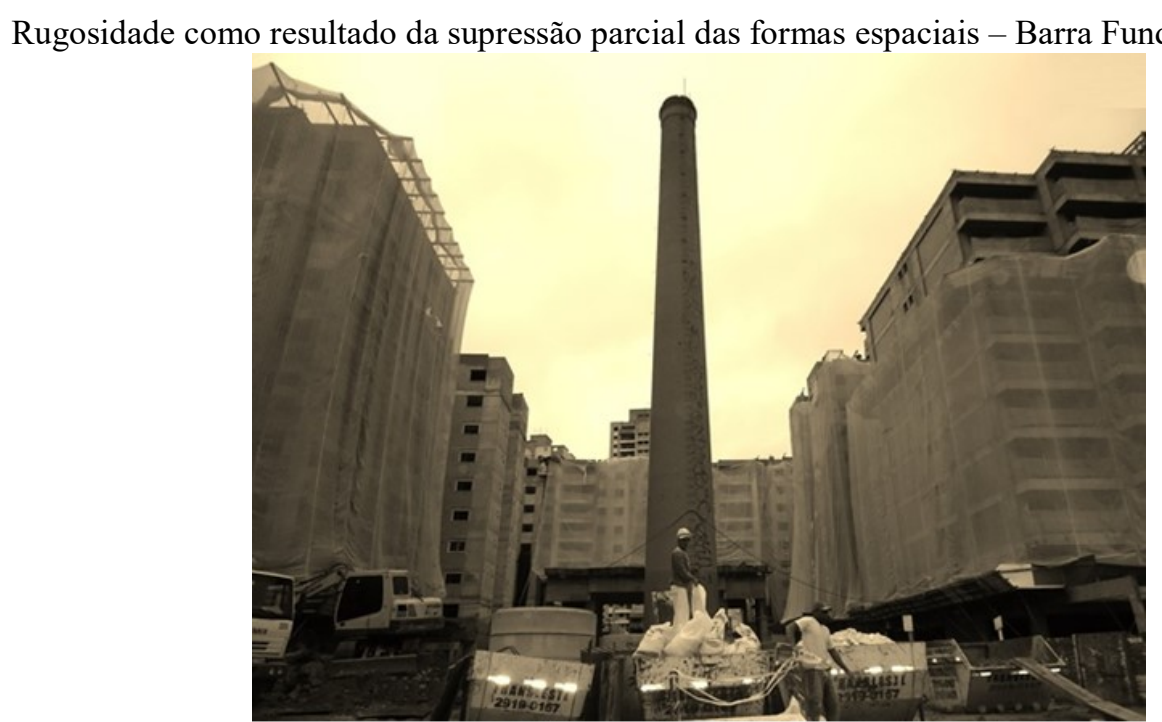

Figura 02: No caso da cidade de São Paulo as antigas olarias e fábricas localizadas em áreas estratégicas e centrais da capital passam a ter funções cada vez mais habitacionais, sobretudo em sistemas condominiais, e que se apropriam esteticamente das rugosidades espaciais. No caso, a antiga chaminé preservada representa um fragmento da estrutura produtiva suprimida. Se agrega valor estético-arquitetônico à construção pós-moderna em relação aos incorporadores, agentes imobiliários e consumidores, para seus antigos trabalhadores é um marco de vidas dedicadas à construção da metrópole, agora à (des)construção num movimento contínuo e dinâmico de reestruturação do espaço geográfico. Fonte: Foto do autor, 2013. 
A supressão é categoria estruturante do conceito de rugosidade patrimonial. $\mathrm{Na}$ entidade metropolitana, o caso de Carapicuíba é emblemático. Primeiro pela ausência, do qual o campo da boiada e as relações de trabalho pretéritas, encontram-se apenas na memória coletiva, já que esses espaços foram extintos para o uso na construção das COHAB's, do parque dos Paturis e áreas residenciais e comerciais adjacentes ao centro da cidade. Nos relatos colhidos, nos diálogos desenvolvidos, nas profundezas das lembranças dos moradores, emergem memórias das funções desempenhadas com a lide pecuária, desde a criação, o abate, até o transporte ao centro metropolitano e região, além das relações estabelecidas ao longo de todo este percurso produtivo. Recordam-se dos espaços ocupados pelos frigoríficos, matadouros e de organização da boiada nos limites de Osasco. Das atividades desempenhadas pelos familiares, amigos e compadres em cada um desses espaços. Do mesmo modo, ressoam estórias anedóticas das peripécias e aventuras, de um passado vivo e presente na memória de muitos moradores. Estas conversas não estão restritas apenas aos velhos moradores, ainda que se destaquem. Fica então estabelecida uma dimensão de rugosidade sem que esta exista ou não plenamente em sua integralidade material. Pode, no entanto, ser transmitida às gerações vindouras que nunca as presenciaram, ou simplesmente as viram ilustradas por meios imagéticos, textuais, ou pela transmissão de narrativas orais.

O segundo embasamento que pressupõe a supressão da rugosidade patrimonial se estabelece na presença, parcial ou integral, das formas geográficas. Sem dúvida, estas mantém mais vivas as recordações e referências simbólicas da cidade. O que não impede, necessariamente, que as antigas práticas sejam abandonadas, banalizadas e incompatibilizadas pelas condições modernas. Neste caso, a veemência das formas, pujantes de restauros e proteções contínuas, como é o caso da Aldeia, podem perder paulatinamente seus conteúdos pretéritos, dados desde a dessacralização do espaço, até mesmo pela função de habitar e viver cotidianamente naquele lugar. No caso da presença de certos fragmentos, essas condições são ainda mais efetivas na passagem da rugosidade à qualidade de patrimônio, pois potencializam e aguçam os meios interpretativos da realidade. E, como tal, as relações com os elementos são diferenciadas e tão complexas quanto as subjetividades emersas nas emoções de cada ser humano. Em verdade, compreendendo que todas as organizações espaciais cujas rugosidades estejam contidas, mesmo as rugosidades suprimidas revelam algum nível de resistência, onde suas condições devem ser particularizadas, exploradas qualitativamente e compreendidas a partir de questionamentos menos ortodoxos e determinísticos da realidade social - lembrando sempre que os bens culturais não possuem valor semelhante a todos os sujeitos, grupos ou 
classes sociais ${ }^{9}$. Do mesmo modo, a apropriação das formas geográficas não é realizada apenas pelo privilégio exclusivo e privado do solo urbano, principalmente no que se refere às rugosidades patrimoniais tombadas. Os conflitos neste caso são ainda mais complexos, pois envolvem interesses diretos do Estado a partir de um bem privado tornado público.

O segundo esquema de organização das rugosidades tratado por Santos (2012d [1996]) é dado pelo processo de acumulação das formas espaciais. A acumulação aqui tratada implica num mosaico heterogêneo de ambientes construídos e de funções desempenhadas. Esta característica, apesar de trazer a diversidade de contextos, de técnicas e de intervenções realizadas histórica e geograficamente pelo trabalho social, ao longo da política institucional do patrimônio, tornou-se um componente negativo. Portanto, capaz nesta lógica de subtrair a excepcionalidade e consistência homogênea do conjunto, sobretudo pela depreciação do convívio das rugosidades com novos elementos modernizantes, constituintes de paisagens atuais. No entanto, contraditoriamente, a própria condição de reprodutibilidade técnica (BENJAMIN, 1985) destas rugosidades patrimoniais para a contemplação atual, enxerta novos materiais e simula atividades que, de fato, nunca existiram realmente.

A acumulação das rugosidades patrimoniais não deve ser pensada separadamente da supressão. Para que haja acumulação deve haver supressão, senão das formas, dos próprios conteúdos. Ao agregarem antigas estruturas que resistiram ao tempo, ou unidades pretéritas de paisagens, bem como suas funções diversificadas, há acumulação de formas-conteúdos que se arranjam no ambiente atual das cidades ou do campo. Em ambientes fabris pré-industriais são muitos os casos da instalação de academias, supermercados, centros culturais modernos que se organizam por bases destas formas antigas. É nesta premissa teórica que melhor se revela a acumulação desigual de tempos (SANTOS, 2012d [1996]). Permeados, por sua vez, por conflitos ou tensões, já que são inerentes ao processo de reestruturação do espaço. Observações da Cidade do Panamá (Figura 03), revelam aos olhos na mesma orla marítima a convivência dos telhados e antigos sobrados coloniais do casco antíguo com outro plano que desponta no skyline a capital moderna, verticalizada e de ampla fluidez econômica pela centralidade regional que ocupa. Trata-se da co-presença, acumulada, de contextos distintos, cristalizados numa mesma cidade. No caso de Carapicuíba esta acumulação desigual de tempo

\footnotetext{
${ }^{9}$ Mesmo diante das fetichizações por qual passa o espaço, do qual compete um certo nível de padronização da cultura, tornando-se uma espécie de commoditie (HARVEY, 2005) e com grande potencial de reificação, as relações com os bens e a cidade são diferentes e complexas às generalizações abstratas que as ciências tentam agrupar.
} 
se perpetua tanto na escala do intra-urbano, como regionalmente, considerando sua integração da malha urbana com Osasco e Barueri. Neste caso, esboçando uma paisagem tipicamente popular, de habitações dos trabalhadores, periférica e horizontalizada, frente aos edifícios empresariais de Barueri e Alphaville na Região Metropolitana de São Paulo (Figura 04).

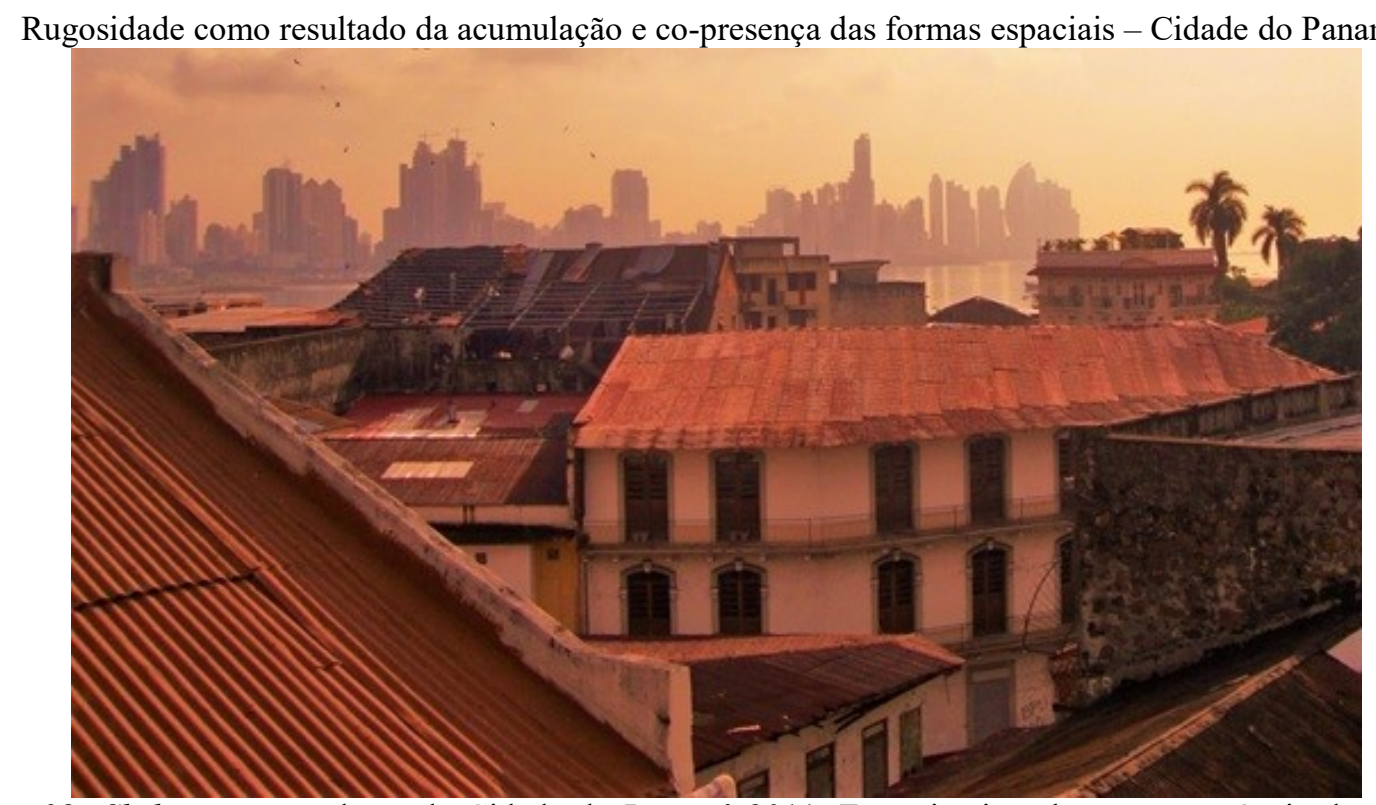

Figura 03: Skyline ao entardecer da Cidade do Panamá 2011. Em primeiro plano, permanência dos edifícios coloniais. Antiga estrutura construtiva à direita com grandes cascalhos, rochas e inúmeras partículas orgânicosedimentares assentadas para dar liga aos materiais. Fato que, segundo relato de seus moradores, fez com que muitas construções resistissem aos sismos e conflitos naquela área e que hoje atraem muitos turistas e diversas atividades culturais no local. No segundo plano, ao alto da imagem, a moderna região financeira e comercial do Panamá, com sofisticados segmentos de serviços, cuja as transações são facilitadas pela dolarização monetária de sua economia. Fonte: Foto do autor, 2011.

Entre passado e presente, riqueza e pobreza, o viver e o trabalhar nos limites de São Paulo

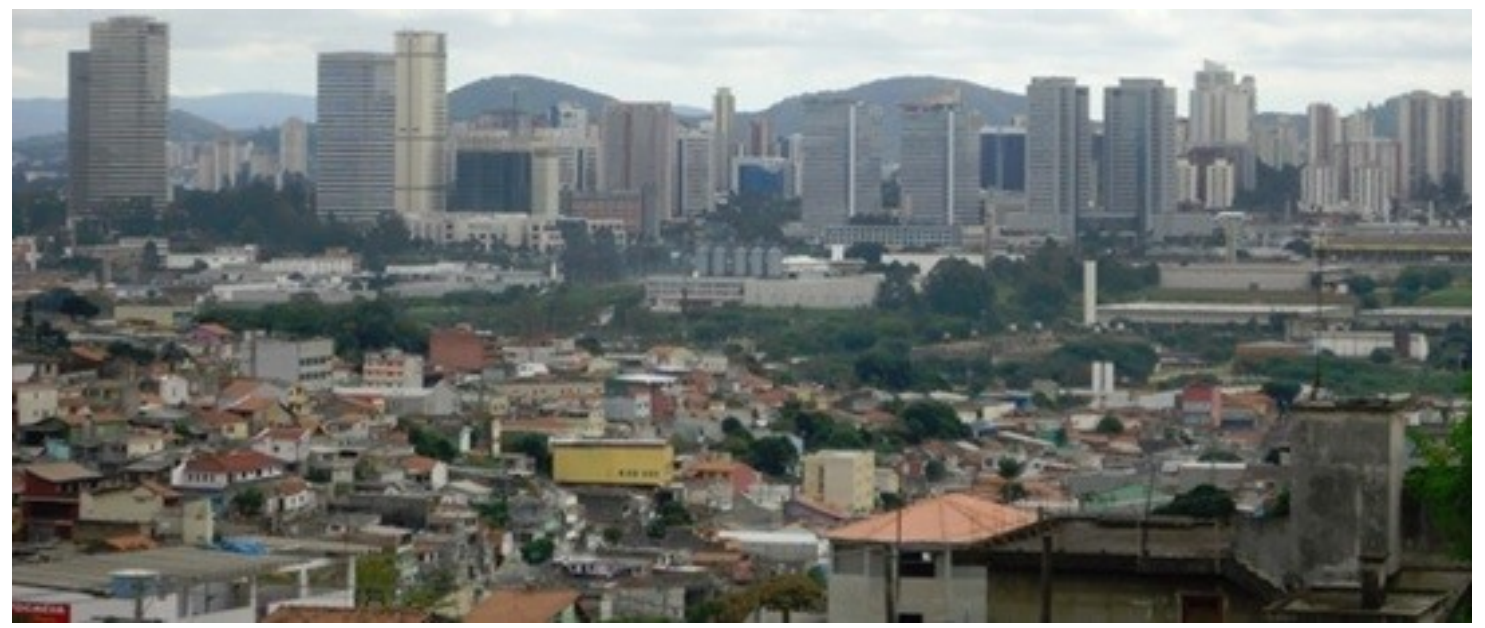

Figura 04: Limite entre as cidades de Carapicuíba (habitações abaixo) e Barueri/Alpaville (edifícios acima), zona oeste da Região Metropolitana de São Paulo (RMSP). As diferenças entre as formas revelam diferentes conteúdos e modernizações da metrópole no século vinte e um.

Fonte: Foto do autor, 2014. 
A terceira categoria, apontada por Santos (2012d [1996]), usada para pensar e alicerçar o conceito de rugosidade patrimonial é a superposição das formas e conteúdos geográficos, ou seja, o resultado agregado de um dado conjunto material e adaptável no âmbito intangível às vivências e novas relações produtivas em diferentes contextos. No séculos de assentamento, os caminhos indígenas foram continuamente utilizados e apropriados pelos colonizadores em todo território da América Latina. Estes caminhos foram estratégicos, marcaram pontos nodais das aldeias, aldeamentos, missões, reduções, vilas e cidades (PETRONE, 1955; 1995). Depois, foram superpostos pelos trilhos da ferrovia, que enveredavam as pioneiras fazendas no sertão (MONBEIG, 1998) e alcançado as atuais rodovias que conectam cidades e metrópoles (AZEVEDO, 1958; LANGENBUCH, 1971; SANTOS, 2013b [1993]). Apesar das contínuas modernizações operadas (alterando as rústicas trilhas seculares, batidas pelos pés descalços), as funções essenciais de deslocamento e o própria localização do traçado permanecem cristalizados. As categorias de função e conteúdo, neste momento, relevam importantes diferenças. No primeiro caso permanece a mobilidade e o deslocamento, no segundo as razões passam a ser outras do contexto précolombiano e colonial. Se no entanto, os conteúdos foram radicalmente alterados entre este encontro de mundos, o mesmo fenômeno já não será tão profundo até, pelo menos, a efetiva urbanização dos territórios na segunda metade do século vinte.

Ainda sobre a superposição trata-se do edifício da Sociedade Italiana de Rio Claro, na região de Campinas, interior de São Paulo. Sua sede fundada início do século vinte, apoiou a organização dos imigrantes que chegavam ao país e região. Serviu como espaço de apoio e estabelecimento de diversas relações destes grupos. No século vinte e um, no entanto, a sede foi parcialmente demolida, sendo superposto no seu terreno um arranha-céus com funções de alojar modernos escritórios empresarias, que nenhuma relação direta possui com aquela matriz fundadora (Figura 05). A fachada antiga do edifício, no entanto, permanece totalmente revitalizada. A superposição do arranha-céus de concreto e aço, trás no conjunto uma fachada secular do tipo neoclássica. Neste caso, a superposição é dada entre diferentes formas e conteúdos simultaneamente. Em Carapicuíba, as formas do aldeamento jesuítico permaneceram entre a formação do subúrbio e periferização, por sua vez atendo sobreposição de diferentes atividades e funções, que foram de habitação, comércio, serviços e usos institucionais do território. 


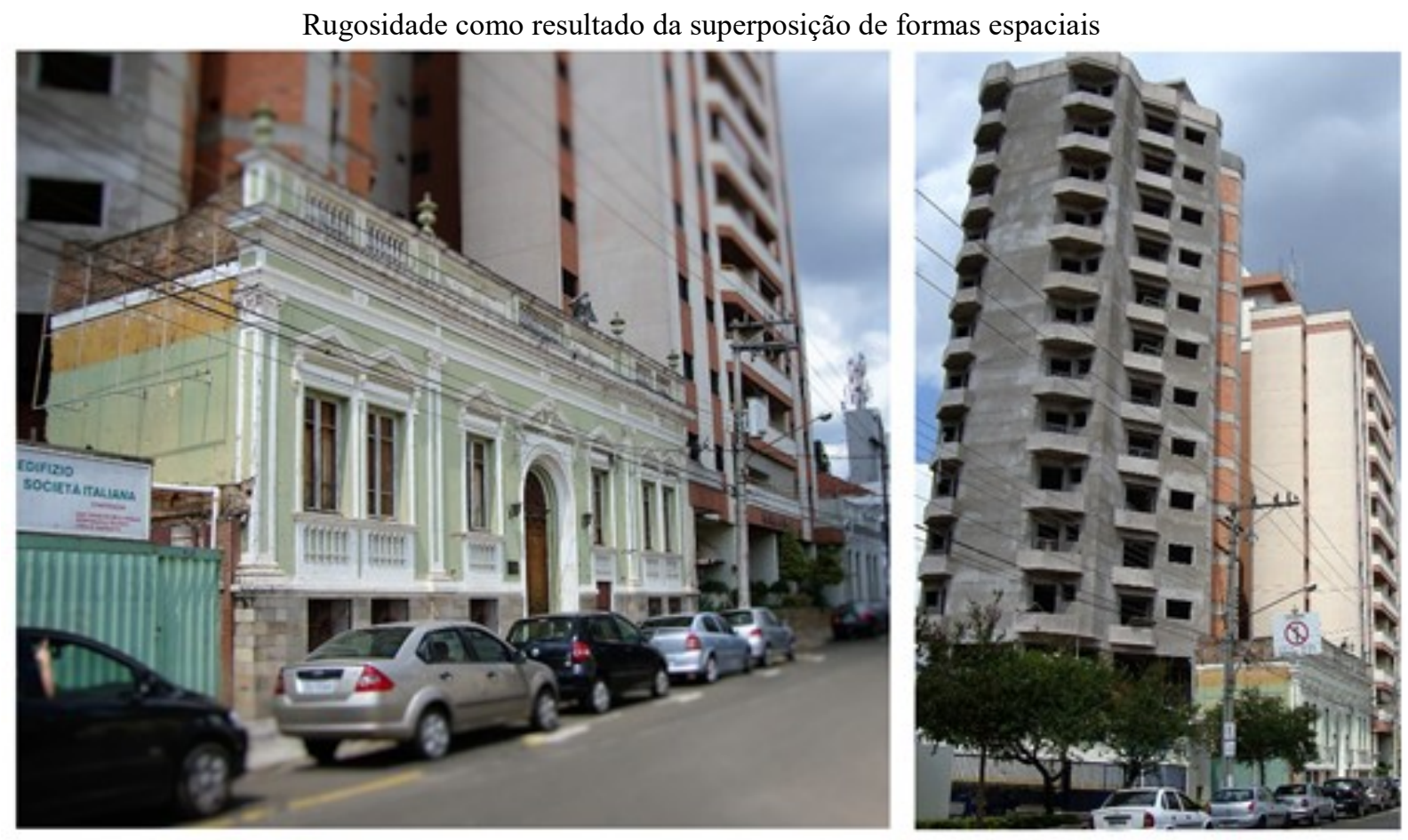

Figura 05: No detalhe, à esquerda fachada do Edifício da Sociedade Italiana em Rio Claro - com os grandes edifícios ao fundo, localizados na zona central da cidade, na rua 04 . Na imagem à direita perspectiva do edifício sede atual da Sociedade Italiana e a pequena fachada secular à frente.

Fonte: Fotos do autor, 2011.

As pressões de supressão, acumulação e superposição se desenvolvem, por exemplo, através de normatizações, como a regularização do uso do solo urbano, que tenciona as ocupações ilegais, pressionando os moradores e forçando sua adequação aos dinâmicos fluxos operados pelas empresas imobiliárias. Ou mesmo áreas tradicionais de classe média, em que o processo de gentrificação (SMITH, 2006) faz com que se efetive uma transformação das formas e conteúdos do lugar. Ilustrativa também é a valorização de áreas verdes nos centros metropolitanos. O inchaço das cidades, a escassez de espaços verdes e a necessidade de qualidade de vida associada à salubridade ambiental, fazem com que a busca pela natureza na metrópole se acentue. Neste caso, os últimos redutos naturais da cidade ganham centralidade dos agentes imobiliários, gestores públicos e das classes sociais capazes de financiar novos condomínios, loteamentos ou parques que incorporem os benefícios das áreas verdes urbanas à sua vida cotidiana. Agrava-se, no entanto, os conflitos em torno destes últimos redutos, verdadeiros enclaves urbanos. Estes vão desde a desocupação de moradias irregulares - cuja justificativa se assenta na preservação dos recursos naturais: mananciais, matas ciliares, fauna - até a contravenção dos sentidos em que as próprias leis foram concebidas, como na metrópole de Brasília, onde a expansão dos habitações luxuosas se estendem irregularmente ao lago Paranoá. De fato, os agentes interessados possuem mecanismos burocráticos a seu 
favor, ainda que a contradição possa se estabelecer, como a presença do patrimônio cultural instituído, emerge enquanto uma condição de acesso e desfrute desigual. Em Carapicuíba, as Unidades Informações Territoriais (UIT's-EMPLASA) da Aldeia e Fazendinha concentram a maior parte de áreas verdes do município, assim como a população de maior renda relativa, sendo instalado em 2011 o condomínio de Alphaville na região (Figura 06), suprimindo grande parte de um remanescente de mata atlântica e se apropriando de forma privada do que restou.

Instalação do condomínio Alphaville em Carapicuíba (2011-2014)
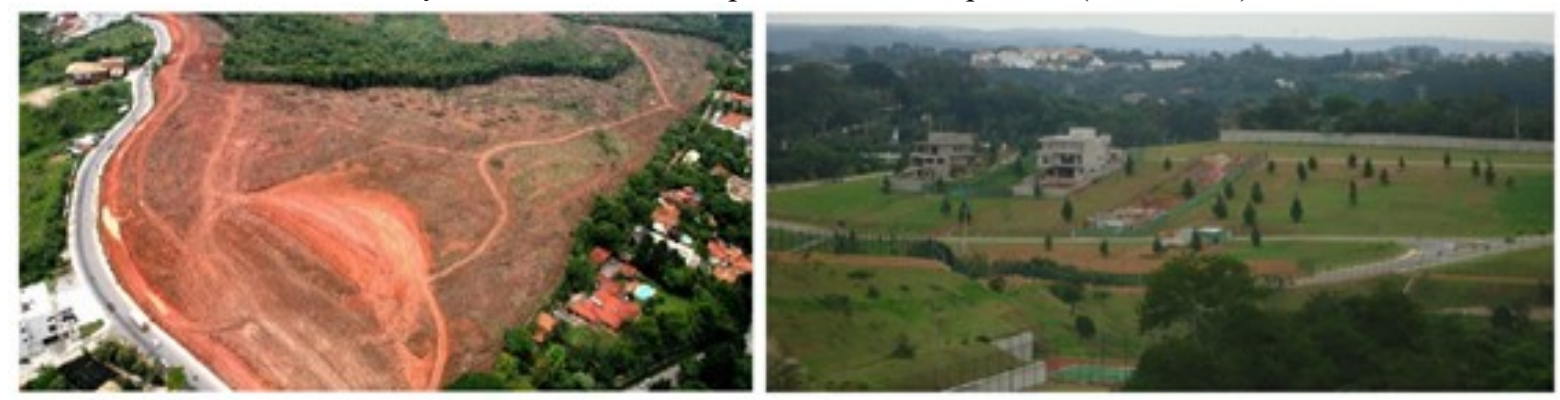

Figura 06: Um dos últimos redutos de natureza em Carapicuíba foi transformado em 2011 na sede do condomínio Alphaville (foto à esquerda). No detalhe, pequenos fragmentos ainda permanecem como bosques e são utilizados atrativamente para agregar valor ao projeto. Em meio a uma série de disputas judiciais entre a população local e os incorporadores imobiliários do condomínio, a área foi reduzida e apropriada pela rede Alphaville. Observa-se em 2014 as instalações completas ao sul de Carapicuíba e casas construídas (foto à direita).

Fonte: Foto à esquerda do Movimento em Defesa da Granja Viana, 2011. Foto à direita do autor, 2014.

O caso da natureza na cidade é emblemático, apresentando-se segundo um sistema de ideias e símbolos que permite a própria reprodução do capital com valores agregados, além de justificar certas condições de um padrão ou qualidade de vida a ela associados. Como no caso do Alphaville em Carapicuíba, em que ao mesmo tempo a maior parte destes redutos naturais foram devastados, pequenos fragmentos estão esteticamente dispostos e valorizam o empreendimento na área, o que segundo Henrique (2004, p. 04) seria "uma natureza carregada de ideologia que não mostra toda a história da sua construção social [...]”. Junto à natureza associam-se modelos de família, de habitar e viver. Portanto, além de mero fixo, a noção de rugosidade expressa esses momentos distintos que agora se integram a uma narrativa e ações calcadas nas teorias patrimoniais que vão da natureza à cultura, mas principalmente no processo de patrimonialização que vincula os objetos ao Estado-nação, ao mercado e às múltiplas identidades coletivas.

A rugosidade patrimonial, em seu arranjo espacial absoluto mais complexo (como conjuntos de construções, núcleos urbanos, metrópoles inteiras e grandes parques naturais), 
ou isoladamente (monumentos, obras de arte, construções diversas), ou ainda como pressupomos a sua imaterialidade (as festas, ritos, costumes e o saber-fazer) é peça-chave para uma consciência mais integrada e relacional do presente em relação ao passado e futuro, ou como discorre D. Lowenthal (1998, p. 65), uma "consciência do passado como um âmbito que coexiste com o presente ao mesmo tempo que se distingue dele. [...] Mas união e separação estão em contínua tensão; o passado precisa ser sentido tanto como parte do presente quanto separado dele”. E, afinal, como sugere Santos (2012d), as rugosidades não limitam-se tão somente aos recursos materiais, sendo substrato capaz de rebater e impelir o alargamento de contextos, já que "[...] as condições preexistentes em cada lugar, o seu estoque de recursos, materiais ou não, e de organização - essas rugosidades - constituem as coordenadas que orientam as novas ações." (SANTOS, 2012d [1996], p. 203 - grifo nosso).

Essas ações podem se tornar mais evidentes com as diferenciações valorativas de territórios e objetos culturais por políticas e práticas patrimoniais, que devidamente esmiuçadas pela análise crítica trazem outros conteúdos além daqueles narrados oficialmente. As rugosidades, pela análise dos objetos e seus conjuntos técnicos, produtos do trabalho ou das significações dadas à natureza, permitem a apreensão dos diferentes sistemas técnicos e do trabalho social cristalizados espacialmente ao longo do tempo histórico. Nesse processo, o espaço é e sempre foi atuante e não simples receptáculo físico ou palco na produção da cidade e do urbano. Como categoria do social, é o espaço geográfico condição do desenvolvimento dos mais controversos projetos humanos.

Ao tratar da "totalidade do diabo", de como as formas geográficas difundem o capital, Milton Santos (1977) mostrou o quanto os objetos geográficos são instrumentais às transformações nas estruturas sociais. Apresentando nesta perspectiva o poder das modernizações nos países subdesenvolvidos, como tentáculos dos interesses internacionais, ora no meio rural pela revolução verde, ora no urbano - lembrando casos emblemáticos, como os de renovação do antigo centro de Maracaibo na Venezuela e do mercado de Kariakoo em Dar es Salaam, antiga capital da Tanzânia. A força das formas espaciais são incisivamente postuladas por Santos (1977), daí depreendendo-se que quando superadas dificuldades de compreensão pela empiria, para além dos sentidos humanos mais imediatos, as rugosidades patrimoniais permitem sua ressignificação por novos usos e, portanto, a possibilidade de redescoberta de antigos conteúdos associados à própria história da comunidade que a produziu (Figura 07). Afinal, como evidenciado por Gravari-Barbas (2014) as possibilidades despertadas mais recentemente ampliaram os méritos do patrimônio da periferia urbana, 
multiplicados e valorizando-os. "Este fenômeno exigiu uma mudança conceitual, conduzida não somente sobre a extensão espacial, mas também sobre a extensão temática do campo patrimonial." (GRAVARI-BARBAS, 2014, p. 30).

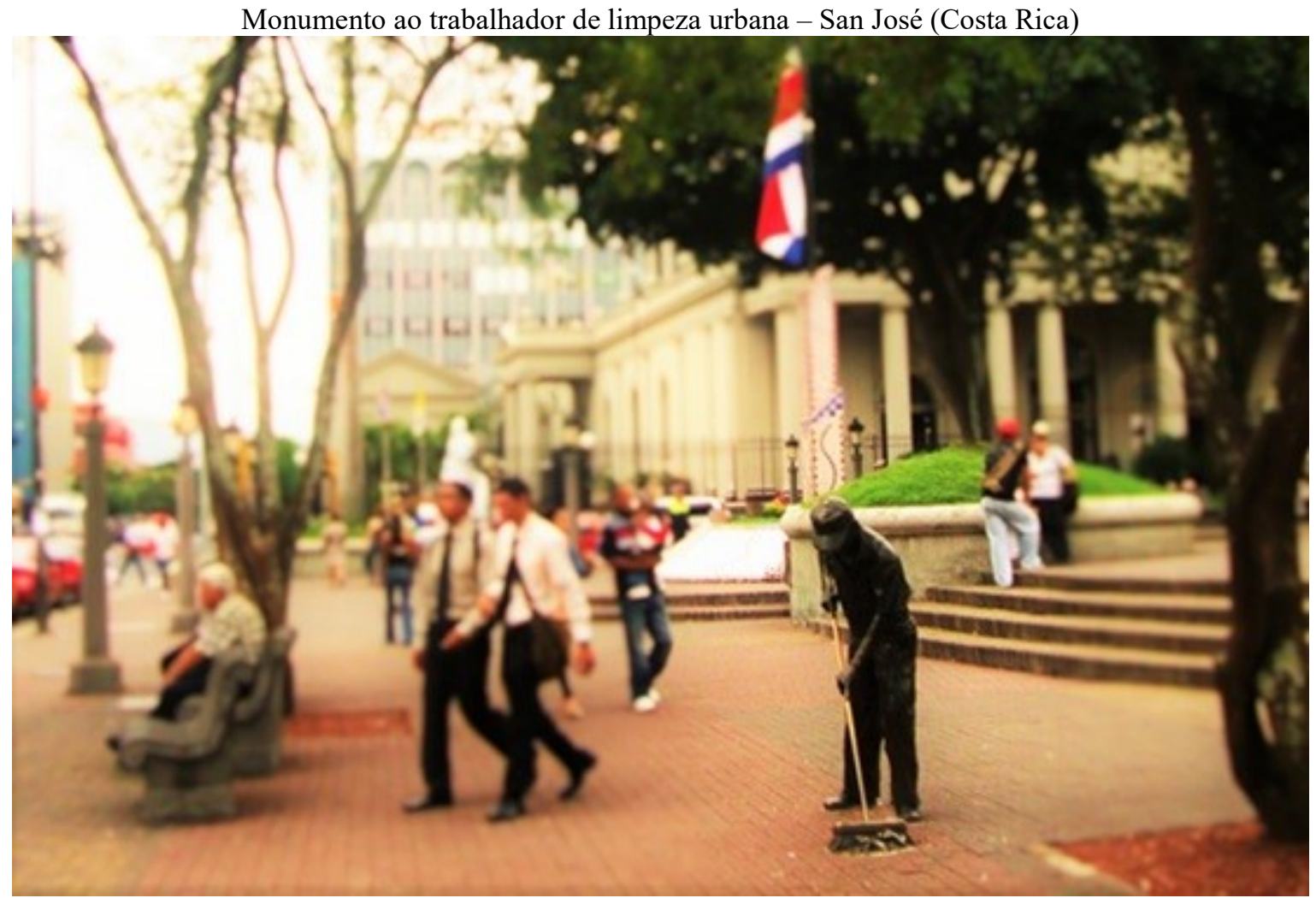

Figura 07: Monumento simboliza o trabalhador urbano, na Plaza Central em San José, capital da Costa Rica, América Central. No detalhe, sujeito ativo na produção do urbano, como toda a comunidade que participa ativamente da vida urbana e metropolitana. Incomum até poucos anos nas políticas patrimoniais, que reverenciavam apenas as hegemonias e heróis nacionais: padres, oligarcas, militares, entre outros representantes destacados.

Fonte: Foto do autor, 2011.

A simplicidade deste monumento, expressa contraste com a razão não menos importante do papel do trabalhador na produção da cidade. Mais que isso, contradiz com um passado onde "houve uma época em que os monumentos eram, ao lado de escolas e museus, um cenário legitimador do culto tradicional. Seu tamanho gigantesco, ou sua localização destacada contribuíram para enaltece-los.” (CANCLINI, 2012d, p. 291). A passos curtos, sem dúvida, a valorização de outras referências passam a estar presentes não apenas na retórica patrimonial, mas como neste caso, entre tantos outros, revela a nova condição prática, jurídica e institucional de significação dos monumentos, das construções materiais e a produção cultural intangível. Na perspectiva latino-americana, isto é ainda mais emblemático, diante de longo tempo de colonização, dos regimes ditatoriais e repressivos, bem como das atuais dificuldades institucionais de realização democrática da cultura. 
Na Geografia brasileira, no âmbito da agenda de pesquisas acerca do patrimônio, apesar da recente produção que tange a temática, deve-se destacar resultados importantes, de autores como Simone Scifoni, Tereza Paes, Eduardo Yazigi, Rafael Ribeiro, Everaldo Costa e Bernadete Castro, que utilizam corriqueiramente, direta ou indiretamente, da noção de rugosidade para evidenciar as contradições na preservação, apropriação e difusão dos bens culturais e naturais, orientando trabalhos e pesquisas dos quais incluem bases à Geografia política, a Geografia cultural e, sobretudo, a Geografia urbana. Tal contribuição tende a ser ampliada, pois sob uma lógica dialética, e ainda considerando um dos argumentos de Santos (1977, p. 32) onde "[...] as coisas adquiriram um tipo de poder que nunca haviam possuído anteriormente", estas rugosidades também podem ser mais profundamente apropriadas por novas atividades produtivas, ou criar resistência às forças globalizantes, seja por meio dos múltiplos mecanismos de organização e apropriação dos espaços, ou ainda as próprias condições das formas-conteúdos numa dada estrutura social. Também em diálogo com Milton Santos, Costa (2008, p. 59) afirma que,

\footnotetext{
Podemos herdar formas do passado cuja gênese vincula-se a outros propósitos, que não os nossos. Sendo legadas ao presente, estas formas podem ser adaptadas às necessidades atuais. Formas herdadas do passado e apropriadas no presente, na organização atual apresentam uma funcionalidade efetiva em termos econômicos ou um valor simbólico que justifica sua permanência. [...] O que demonstra a eficácia de materialidades pretéritas, objetos construídos social e historicamente, na manutenção da sociedade, de valores, do capital e na produção de novos espaços, que devem ser seriamente analisados (COSTA, 2008, p. 59).
}

Estas condições podem dificultar em demasia a dispersão do capital inerente ao processo, e mesmo que este se propague com eficiência, certas tradições, hábitos e memórias continuam a se perpetuar na reprodução prática da vida, convivendo espaços e tempos heterogêneos e desiguais, dos quais as rugosidades patrimoniais permeiam seu lócus material e imaterial, particular e coletivo, sagrado e profano, moderno e retrógrado, erudito e popular, belo e feio, enfim os múltiplos polos contraditórios da realidade. São, portanto, bens culturais que se perpetuam funcionais mesmo quando a estrutura é totalmente outra, ou quando simplesmente há necessidade de novas escolhas de futuro para além das verticalidades impostas pelo modo de produção. Trata-se assim de um processo conflituoso e permeado pelas tensões inerentes às classes sociais e seus interesses. Esse último caráter é o que alimenta algumas possibilidades da consagração das formas na construção de outras cidades e, 
portanto, de novos conteúdos associados à realização do conjunto da sociedade e não apenas de poucos privilegiados. Eis aí duas faces da mesma moeda. Na Figura 08, algumas rugosidades patrimoniais que simbolizam a formação da matriz territorial brasileira em diferentes fases, desde a casa bandeirante em Santana de Parnaíba e os aldeamentos em Embu das Artes e Carapicuíba, até a pré-industrialização com a presença da indústria têxtil em Salto. As imagens remetem a bens culturais patrimonializados em cidades influenciadas diretamente pela metropolização de São Paulo.

Modernizações e as rugosidades patrimoniais entre o mercado global e as comunidades locais
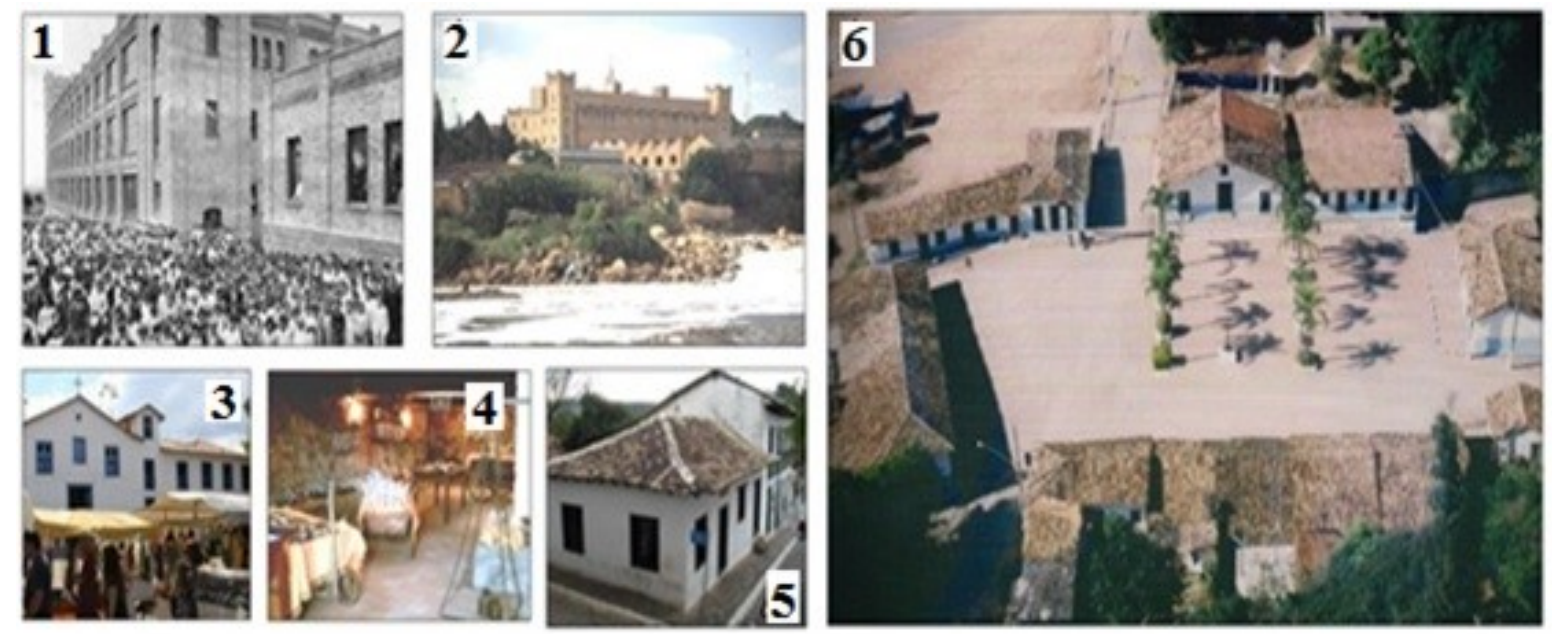

Figura 08: Nas imagens 1 e 2 a antiga fábrica têxtil Brasital de Salto, hoje refuncionalizada, abriga diversos cursos universitários. Na imagem 3 o centro histórico de Embu das Artes, com igreja colonial e a tradicional feira de artesanatos. Na imagem 4 a senzala (cativeiro do escravo negro no século XIX) na Fazenda da Serra em Itu. O espaço hoje é destinado a visitação, cuja função converteu-se numa boutique de souvenires. Na imagem 5 o centro histórico de Santana de Parnaíba requalificado. Por fim, a imagem 6 mostra a Aldeia de Carapicuíba, único remanescente concreto dos aldeamentos jesuíticos em São Paulo, que remetem aos séculos XVI e XVII.

Fontes: Brasital - Prefeitura de Salto, 2011; Santana de Parnaíba e Itu - Fotos do autor, 2009; Centro Histórico de Embu - Prefeitura de Embu das Artes, 2016.

A velocidade das transformações empreendidas na atualidade coloca em xeque as formas do passado, o que leva a dimensão de tempo da metrópole transparecer pelo espaço geográfico cada vez mais descompassado com o tempo da vida, marcado pela geração. Mesmo que as paisagens, com suas formas e concretudes, sejam normativamente protegidas pelo Estado, tal condição em si muda o conteúdo de cotidianidade da mesma em relação à população local. A paisagem passa a ser promovida como patrimônio cultural, dando-lhe imediatamente um status capaz de exploração, de desenvolvimento produtivo e de amplo interesse aos bens locais, antes limitados a uma região e seus munícipes, que passam a estranhar seus espaços significativos de memória, ou a adotar narrativas diferentes das que realmente vivenciaram. O que segundo Godoy $(2011$, p.35) traduziria 
[...] O processo de (des)construção de formas espaciais vinculadas à intensidade e à multiplicidade de funções atribuídas em períodos de tempo cada vez mais restritos, e, por outro, em virtude do aumento na velocidade de giro do capital e da expansão do 'império do consumo efêmero' e massificado, os lugares tornar-se-iam a condição e o resultado da mundialização da economia e da cultura técnica (GODOY, 2011, p. 35).

Utilizando-se da rugosidade, patrimonializada pelo Estado e manipulada pelas forças hegemônicas, o modo de produção potencializaria na metrópole a sua reprodução, levando em conta a multiplicidade cultural na constituição de seus territórios. Isto mesmo sem necessariamente suprimir as formas espaciais, mas conservando e valorizando-as, tanto nos processos de acumulação, quanto de superposição. Explica Costa (2008) que as rugosidades são "[...] muito bem representadas pela materialidade presente nos núcleos urbanos coloniais brasileiros, organizados segundo um padrão urbanístico de época, que atendem, hoje, a lógica do mercado global." (2008, p. 57). A materialização do capital nestes lugares é variável e relativa aos interesses dos grupos e sujeitos, além da própria cultura local como um todo. Tornou-se em prática, base das estratégia horizontais de planejamento e gestão dos territórios, cujo patrimônio cultural material e imaterial padece numa condição provisória de desvalorização e esquecimento, ou sob a égide dos interesses verticais da acumulação e do lucro capitalistas. Nesse sentido importa destacar o papel do conceito de rugosidade patrimonial tanto para expor e desmascarar estas contradições do atual fenômeno urbano na escala da metrópole (esquecimento/desvalorização - espetacularização/mercantilização), como também vislumbrar novos caminhos para a história e a Geografia dos lugares, num devir mediado pelo reconhecimento e valorização da cultura em sua diversidade. Afinal, como destaca Santos (2012d [1996], p. 140) "as divisões anteriores do trabalho permitem rever as formas herdadas segundo uma lógica que as restabelece no momento mesmo de sua produção". Por conseguinte, reestabelecem os sentidos da experiência vivida, ou das representações estabelecidas pela transmissão oral e intertextual. Neste sentido, "as rugosidades, vistas individualmente ou nos seus padrões, revelam combinações que eram as únicas possíveis em um tempo e lugar dados." (SANTOS, 2012d [1996], p. 140) - mas também, no entender revigorado das rugosidades patrimoniais, em novas possibilidades alavancadas por seus conteúdos.

Na Geografia, mesmo a noção de rugosidade espacial pensada por Milton Santos estar friccionada mais às formas que os conteúdos geográficos, no limite de abordagens históricoestruturais ou de uma possível tendência neokantiana, sua acepção não está limitada apenas aos objetos, ao empírico imediato, ou a uma racionalidade fragmentária do todo. Ao contrário, 
sua preocupação estava pautada em preencher uma lacuna analítica dos processos que dão concreticidade às atuais formas geográficas, recorrendo às periodizações e estabelecendo relações articuladas e explicativas do atual desenvolvimento histórico. Justifica-se que mesmo a dialética requer metodologicamente uma cisão, no entanto esta lógica a faz de maneira provisória, retomando rapidamente o dinamismo do real pela práxis (KOSIK, 1976 [1963]). Ou, no limite, como aponta Lefebvre (1975 [1969]) acerca da importância da lógica formal como base para a passagem ao pensamento complexo, a lógica dialética. No caso do esforço desta tese, de conceituar e aprofundar a noção de rugosidade, reflexão que dialoga com Santos (1977; 2012a; 2012d), se desenvolve numa espécie de derivação conceitual, em que propomos uma eliminação momentânea dos seus conteúdos clássicos, sendo retomados analiticamente por meio de periodizações e suas correlações com a estrutura social pretérita. Esta estratégia do método pode ser considerada como uma espécie de "negação dialética" (LEFÈBVRE, 1976), que permite captar as qualidades do fenômeno em sua forma e conteúdo resultante de uma síntese provisória dentro de uma totalidade. Assumindo esta postura, cabe retomar o conceito com maior profundidade da relação passado-presente na metrópole por meio da patrimonialização global (COSTA, 2011) e de estudos que contemplem lugares e experiências, subsidiando, portanto, novas teorias e práticas na construção e apoio de outras realidades possíveis. 


\title{
CAPÍTULO 02: Dialética das escalas
}

\begin{abstract}
O lugar é a oportunidade do evento. E este, ao se tronar espaço, ainda que não perca suas marcas de origem, ganha características locais. É como se a flecha do tempo se entortasse no contacto com o lugar. O evento é, ao mesmo tempo, deformante e deformado. Por isso fala-se na imprevisibilidade do evento, a que Ricoeur chama de autonomia, a possibilidade, no lugar, de construir uma história das ações que seja diferente do projeto dos atores hegemônicos. É esse o grande papel do lugar na produção da história, e aponta-lo é grande tarefa dos geógrafos neste fim de século (SANTOS, 2012b [1996], p. 163).
\end{abstract}

A pressão da metrópole sobre antigos núcleos coloca em risco as últimas heranças materiais do passado, seja pela modernização técnica e destruição concreta das formas, como pela incorporação de novos usos e funções, assim também por distorção dos conteúdos culturais a partir da patrimonialização. A instância espacial, no âmbito categorial das estruturas sociais, produz uma reorganização, cujos limites e funções de antigas formas e as relações estabelecidas por seus novos conteúdos se apresentam diretamente subordinados e subordinantes a uma lógica complexa, com variáveis e elementos difusos e efêmeros frente ao atual movimento da história. Elementos que exigem o rigor teórico-reflexivo, mas também prático-analítico. O primeiro em favor do dimensionamento objetivo das estruturas, das escalas, dos regimes de espaço/tempo. O segundo na perspectiva das observações diretas, descrições, abordagens dialógicas e prospectivas, além da ativa participação nos processos que se realizam cotidianamente nos lugares. Realidade que, sendo produzida por intencionalidades e estratégias materiais, justifica uma investigação sumária em sua totalidade. No âmbito das escalas, cada vez mais permeadas pelos fluxos globais, por fim, cabe estimar como os eventos se desenvolvem regionalmente, as relações que se estabelecem, para assim qualificar algumas possibilidades construtivas de uma história diferente, utópica, fundada pela crítica e para além da submissão do lugar pelas forças verticais e hegemônicas. 


\title{
2.1 A escalas dos fragmentos universais-particularidades da totalidade urbana- metropolitana
}

\begin{abstract}
A geografia, cuja metodologia está em permanente mutação, está por exigir uma reflexão de caráter mais filosófico, a fim de objetivar sua produção acadêmica e científica, de maneira a atender às demandas sociais relativas à disciplina e resgatála do limbo em que foi colocada pela sua pretensa ambiguidade quando contraposta aos estudos sociais (SOUZA, 1994, p. 2).
\end{abstract}

O fenômeno a que nos dedicamos a apreender na totalidade é o da metropolização em sua realização com o patrimônio cultural e as permanências que conceituamos em diálogo com Milton Santos por rugosidades patrimoniais. Isto significa buscar sua essência provisoriamente. A forma desta busca baseia-se na decomposição do todo, do fenômeno urbano, no qual resultam a atual formação dos países latino-americanos, do Estado-nação brasileiro, da região metropolitana de São Paulo e seus desígnios escalares superiores (dados pelas relações globais), pela cisão de uma realidade única e estática - tomando a cidade de Carapicuíba e seu aldeamento na RMSP, transpostos pela teoria e a prática numa realidade em movimento, recomposta, e capaz de ser adentrada, analisada e explicada (KOSIK, 1976 [1963]).

A rugosidade patrimonial traduz unidades ou conjuntos de formas geográficas, com seus sistemas próprios de funções e conteúdos, articulados às múltiplas escalas e dimensões espaciais. Variações escalares do foco analítico num dado objeto ou grupo social fazem com que as categorias propostas para a apreensão e análise das rugosidades sejam mais ou menos intensas, dependendo do processo histórico em curso. Por isso, falar da metrópole pressupõe escalas estruturais do modo de produção desde a remota globalização nas origens do capitalismo comercial e das grandes navegações (SANTOS, 1985), ou seja, quando o poder dos núcleos de assentamento na América, Ásia e África passaram a ser controlados pela união entre a Coroa e Igreja nas "metrópoles" imperialistas da Europa, dando posterior origem às atuais formações econômicas e sociais (SANTOS, 2012) em todo continente. Analisar a metrópole demanda pensar o rebatimento dos lugares em ações de resistência e assimilação, destarte de supressão, acumulação e superposição de formas-conteúdos. A preponderância de uma categoria está sempre estabelecida em relação às outras, por isso a relevância dos regimes de tempo e escalas no desenvolvimento da análise. 
Na mesma escala (global) e período (capitalismo comercial) apontados anteriormente, a categoria supressão insurge na análise como a mais latente, sobretudo pelas formas de opressão e as contínuas tentativas de extinção da cultura material e dos modos de vida nos territórios pré-existentes. A arbitrariedade na escolha do período exemplificado resulta da concentração das rugosidades daquele regime no território de Carapicuíba, dado materialmente pela presença do aldeamento jesuítico, além das tradições seculares que rementem, inclusive, a categoria de superposição em favor dos ritos católicos com a mescla de ritos indígenas na atual dança do Sarabaquê. Outras características deste passado que ainda permanecem como rugosidades nestes lugares são aprofundadas posteriormente na periodização, assim como o detalhamento das funções e estrutura que devem escancarar contradições e superar narrativas fetichizadas.

$\mathrm{Na}$ Geografia, diferente do local, lugar é um espaço dotado de significado, um espaço localizado, mas fundamentalmente vivido (SOUZA, 2013). Para Bourdieu (1999) a amplitude do conceito de lugar é ampla e pode ser definida “(...) como ponto do espaço físico onde um agente ou uma coisa se encontra situado, tem lugar, existe". A análise de ambas dimensões não é uma necessidade empírica de constatação do fenômeno, ou mesmo da crença em um discurso que legitime tais condições encontradas, e sim de um entendimento mais amplo, referenciado na análise por meio primeiro das condições imbricadas do espaço físico, enquanto localização (relacional) ou posição (ordem), portanto pela "exterioridade mútua das partes", com o espaço social, este definido pela "exclusão mútua", que se distingui do primeiro pela apropriação e funcionamento segundo aspectos dirigidos por uma sociedade ou grupo social específico ${ }^{10}$ (BOURDIEU, 1999). Nisso, o lugar passa a não comportar fronteiras fixas, que impeçam os objetivos de compreensão da análise proposta de suas rugosidades, seja na particularidade de Carapicuíba frente a escala global, seja na sua universalidade urbanametropolitana.

Tais perspectivas permitem aproximações analíticas, cujo resultado admite conceber qualificações e condições de lugares, variantes desde a honra, o patrimônio, a segurança e o moderno até o limite do risco, do arcaico, ou do próprio subjugo generalizado. Em que a categorização de um ou outro elemento não pode ser esclarecida sem a existência de espaços

\footnotetext{
10 "Efetivamente, o espaço social se traduz no espaço físico, mas sempre de maneira confusa: o poder sobre o espaço que a posse do capital proporciona, sob suas diferentes espécies, se manifesta no espaço físico apropriado sob a forma de uma certa relação entre a estrutura espacial das distribuições dos agentes e a estrutura espacial da distribuição dos bens e serviços, privados ou públicos.” (BOURDIEU, 1999).
} 
sociais e espaços físicos que estão em relação entre si, ou seja, não existem se não em função um ao outro ${ }^{11}$. A capital só pode existir em relação ao estado, não simplesmente por um fator exclusivamente de localização ou ordem, mas pela concentração do capital, dos serviços, atividades, bens, dos indivíduos e grupos que a ela estão ligados (BOURDIEU, 1999). Assim decorre, numa outra escala, a própria periferia em relação ao centro metropolitano, ou mesmo dos lugares do tempo lento daqueles dinamizados pela fluidez e pelas intervenções do capital, ou ainda, das rugosidade patrimoniais em relação às modernas formas geográficas e novas funções que as preenchem. Assim também, o espaço físico, substrato material muitas vezes subestimado em alguns estudos das ciências sociais ${ }^{12}$, não pode ser renegado em favor da redução da análise ao espaço social. Uma leitura multidisciplinar dos fenômenos é reveladora por permitir um entendimento preciso do papel da Geografia no contexto da produção científica e intelectual contemporânea.

Seemann (2005, p. 70) ajuda vislumbrar esta tradição, pelos limites impostos desde o período clássico de institucionalização moderna do conhecimento em Geografia, tomando o antigo pensamento de Otto Schlüter (1872-1959), para quem alguns artifícios e objetos analíticos como a religião, língua ou arte, deslocariam os limites da disciplina para o infinito, incluindo ciências inteiras, como a sociologia ou a economia no âmago da mesma. Beira o absurdo ignorar elementos como estes na atualidade dos estudos e pesquisas em Geografia, a configuração dos procedimentos ou da escolha de recortes empíricos para análise estão arraigados numa dada tradição, de epistemologia própria. Mesmo quando os estudos abarcam escalas como os limites de bairros e seus setores, estes na maioria dos casos se relacionam ao pragmatismo do planejamento e respaldados em estudos técnicos (como a modelagem e simulações futuras da realidade), mas ainda em menor proporção do que aqueles ligados às razões e propósitos político-partidários. A sua maneira, Ana Ribeiro (2006) estimula essa reflexão quando explica haver grande carência teórico-analítica na ciência contemporânea em

\footnotetext{
${ }^{11}$ Exemplo disso, também colocado por Bourdieu (1999), se observa no indivíduo despossuído de endereço ou residência fixa "sem eira nem beira", que enfrenta sérias dificuldades de existência, desde a procura de um trabalho, até abertura de contas em bancos, crediários e financiamentos para fins de consumo dos bens e serviços necessários.

12 Ver a diferenciação da abordagem entre a geografia e a sociologia, sob crítica de Demangeon (1956) desta última relegar os fenômenos apenas ao espaço social, dissociado do espaço físico, como se as coisas pairassem sobre o ar. Ver ainda Souza (2013) que utiliza a expressão substrato espacial material, como o "espaço geográfico na sua materialidade", interroga se o uso da noção de rugosidade, como estamos buscando, "[...] seria válido para pensar nas próprias fronteiras e imagens espaciais como 'rugosidades', ainda que em sentido não material? Não vejo porque não.” (SOUZA, 2013, p. 74 - grifo nosso). Muito antes, porém, Santos (2006) já havia sinalizado de tal maneira, como citado integralmente no tópico anterior.
} 
função do utilitarismo técnico, que impediria a "consciência dos lugares", em que o cotidiano nos escaparia e onde o "tempo lento" (SANTOS, 2012d) seria deixado de lado pelas generalizações e amplitudes das escalas e dos regimes de tempo. Neste exato momento, é recorrente interrogar sobre qual o ponto, ou recorte da realidade, que de fato subsidiaria o conhecimento de suas particularidades e universalidades? Milton Santos (2012d) ajuda a refletir e responder essa questão a partir da ideia de totalidade, enquanto possibilidade de ponderar essas múltiplas escalas em sua realização nos lugares, inclusive do papel das rugosidades nestas ações.

\begin{abstract}
A totalidade como latência é dada pelas suas possibilidades reais mais histórica e geograficamente irrealizadas. Disponíveis até então, elas se tornam realizadas (historicizadas, geografizadas) através da ação. É a ação que une o Universal ao Particular. Levando o universal ao Lugar, cria uma particularidade. E esta sobrevive como Particular, ao movimento do Todo, para ser ultrapassada pêlos novos movimentos. A particularidade ultrapassada precede a universalidade atual e sucede à universalidade defunta. Há, pois, um movimento interativo no qual particularidade e universalidade fertilizam-se mutuamente. [...] A particularidade resultante combina algumas das possibilidades atualmente oferecidas pelo Todo e mais o que resta da particularidade ultrapassada. Daí essa resistência do espaço quando do impacto dos novos eventos, esse papel de inércia dinâmica das formas-conteúdo (SANTOS, 2012d, p. 80).
\end{abstract}

Nesta seara teórica, Abreu (1998, p.12) explica que “(...) é necessário reconhecer, primeiramente, que cada lugar é, ao mesmo tempo e em cada momento histórico, o ponto de intersecção de processos sociais que se desenvolvem em diversas escalas”. Mas Doreen Massey (2009), ao ver criticamente a narrativa globalizadora atual como ambígua e não espacializada, auxilia entender a importância da escala do lugar, sem reduzir, no entanto, a teoria social "à insistência sobre variações locais". Para ela o ato de espacializar a globalização prescinde levar em consideração a multiplicidade do espaço e de teorias não redutíveis a uma dada superfície, devendo ser metabolicamente relacionada com a temporalidade em questão. Por isso um esforço que se conjuga até aqui e antecede a empiria da imersão à dimensão do lugar, das rugosidades patrimoniais de Carapicuíba e da metrópole.

As variáveis que permeiam o espaço urbano, compreendido sob a ótica do modo de produção capitalista, sintetizam uma dinâmica complexa, atrelada à cidade por uma organização fragmentária, articulada, reflexo e condição do social (CORREA, 1995). Isso significa que na totalidade urbana, as suas partes mantém relações intensas entre si e que numa dada estrutura social possibilitam a mobilidade de pessoas e mercadorias, a circulação 
do capital, a valorização ou não do solo urbano, numa densa rede hierárquica de centralidades funcionais e simbólicas. Estas relações tornam as cidades capitalistas desiguais, ou seja, criam mecanismos diferenciais de exclusão e segregação, mas contraditoriamente também condicionam campos de lutas e resistências. A permeabilidade vertical das instâncias globais se concretiza nas menores escalas espaciais, desde o restrito âmbito da casa ou da instituição familiar, quanto nas relações de produção estabelecidas nas multinacionais ou através da conexão com a rede mundial de computadores. No limite, gera-se a metrópole como um nódulo espacial ainda mais dinâmico, e onde o processo de regionalização se generaliza ainda mais, competindo à própria condição urbana flexionar-se aos processos agora metropolitanos. É nesse sentido que o lugar ganha ainda mais centralidade pelas contínuas tensões que sofre. Todas essas escalas e dimensões conceituais da realidade perfazem a totalidade urbanametropolitana. Esta totalidade, considerada por um referencial abstrato, geral e externo, corresponde as universalidades globais que repercutem nos menores fragmentos locais, em todos os lugares - "mundo como norma" (SANTOS, 2012, p. 169). As cidades singularizam empiricamente essa influência global, fundindo as particularidades de uma dada formação econômica e social, ou seja, com temporalidades e dinâmicas espaciais específicas e em comum. Os lugares transformam o global, praticamente na mesma medida em que são transformados, se abandonarmos essa dimensão singular e interescalar poderemos até recuperar o urbano, mas não a cidade (ABREU, 1998, p.12). 


\subsection{Metrópole-fato, metropolização-processo: dimensões do patrimônio cultural}

A metrópole estaria situada no encontro das cidades com a região (SCOTT, 2010), ou seja, num aglomerado de lugares reunidos nas cidades, cujas funcionalidades são metabolicamente articuladas aos centros metropolitanos (SANTOS, 2012). Ao integrar a metrópole, como o lugar, a cidade não deixa plenamente sua singularidade frente ao movimento global, mas assegura por via de suas formas e conteúdos espaciais elementos representativos da história local, nacional e da formação universal. As rugosidades patrimoniais metropolitanas são, ao mesmo tempo, representativas dos simbolismos concebidos em termos da memória nacional, que articula a universalidade dos processos econômico e sociais concatenados geograficamente no território, do mesmo modo que integra a memória coletiva pelas vivências cotidianas. No limite, no sistema de tempo atual, as rugosidades patrimoniais são consagradas por novas atividades produtivas ligadas à cultura e de uma generalização universal da busca pelo singular.

Nisto, compreende-se a metrópole como fato da metropolização e do fenômeno urbano contemporâneo no mesmo âmbito (reitera-se a permanência e sobreposição da sociedade industrial e urbana). No encontro entre urbanização e metropolização, as cidades tornam-se unidades principais, quantitativa e qualitativamente somadas em regiões metropolitanas. No limite da urbanização e mesmo diante de outras denominações que buscam assinalar a suntuosidade de grandes núcleos populacionais justapostos (megalópolis, megacidades, ou metápolis), tanto o processo de metropolização, quanto a produção do fato metropolitano, ainda respondem e justificam mais plenamente o sistema de aglomeração e de cultura que permeia o urbano em diferentes escalas de tamanho ou localizações do planeta. A diferenciação entre metrópole e metropolização é uma necessidade de explicitação conceitual entre o fato, considerado em sua particularidade histórica e geográfica (metrópole), e o processo, que qualifica a forma e permeia um conteúdo de universalização do fenômeno urbano em escala global (metropolização). Diante da qualificação banalizada de cidade em metrópole, simplesmente pelas condições de aglomeração, torna-se fundamental além do fato social, político-administrativo, econômico, ou cultural, entender o desenvolvimento e os efeitos deste processo (ASHER, 1998). Dialeticamente, esta diferenciação entre metrópole e metropolização é momentânea e ambos conceitos devem ser retomados. Concorda-se com Robert Moraes (2016, p. 23), para quem “a metrópole é uma forma histórica de organização do espaço geográfico.” Ela é, portanto, localizada, podendo ser analisada por múltiplas 
dimensões e vários níveis, o que justifica a articulação entre planos e escalas de análise (do lugar, da cidade).

A ideia de metrópole assume diferentes significados ao longo do desenvolvimento histórico, mas pensá-la fora de parâmetros da Modernidade parece pouco fértil, ainda que grandes aglomerados humanos estivessem presentes desde a Antiguidade. Ou até mesmo pela simplicidade de seu sentido etimológico, onde metrópole traduz a ideia de uma "cidade mãe" (LEMOS, 1999), responsável por suas colônias, áreas de influência, exportando seus guerreiros e deuses (ASHER, 1998). Na atualidade, ainda tem sido comum classificar de metrópole aglomerações humanas mais importantes, levando em consideração, entre outras variáveis, a centralidade, a multifuncionalidade assumida, as relações com escalas supranacionais e sua densidade populacional. Para tanto não existe um padrão, coexistindo normativamente metrópoles com pouco mais de vinte mil e outras que ultrapassam os vinte milhões de habitantes. A designação de "metrópoles" aos centros imperiais no capitalismo comercial é, ao mesmo tempo, generalizada ao considerar nestes casos o poder exercido sobre os territórios coloniais naquele período. Se não remetem necessariamente a tríade indústriaurbano-metrópole, associam-se aos preceitos de controle que hoje é uma das variáveis estruturantes de seu sentido ou definição.

Para justificar o entendimento embrionário da atual metrópole, este fenômeno não pode ser confundido com aquele ocorrido em Atenas, Roma, Alexandria, ou qualquer caso na Antiguidade. Choay (2005) ajuda a pensar numa certa permanência, onde realizações e problemas enfrentados neste longínquo passado são os mesmos da atualidade, perseverando a existência de uma razão comum, uma pertinência concreta de experiências semelhantes, do viver, existir e resistir na cidade, mesmo que essas comparações sejam separadas por um largo período de tempo e passíveis de riscos analíticos. Justamente, para a autora, uma das grandes diferenças entre estas aglomerações de antes e as metrópoles de hoje reside que no passado a grande cidade, ou mesmo a Cidade-Estado, era uma exceção, um caso extraordinário, o que “(...) poderíamos, pelo contrário, designar o século vinte como o da era das metrópoles." (CHOAY, 2005, p. 5).

Entende-se que a metropolização deve ser mais profundamente explorada e situada enquanto momento do modo de produção. Como faz Choay (2005), que estabelece o fenômeno consolidação do capitalismo industrial, no início do século passado, a partir de sua generalização (sociedade industrial). Leitura convergente com a de Lefèbvre (2004; 2012), 
explicando que a "sociedade urbana" nasce da industrialização, não sendo, porém, apenas um subproduto dela. E é desta condição que o modo de produção capitalista efetivamente rompe com o modelo de cidade medieval, sobretudo no século dezenove, mas também com a própria sociedade industrial em favor da urbana (sociedade urbana). Onde o trabalho mecanizado e repetitivo passa a moldar a vida cotidiana, numa indissociável relação entre fábrica-casa, e cuja temporalidade do trabalho na cidade ia gradativamente diferindo do campo. No decorrer desta realidade o tempo e espaço iam sendo arrancados na cidade, gerando a angústia e solidão: as pessoas desconhecem umas às outras, as casas funcionam como meros autômatos, máquinas de repouso para um novo dia de trabalho. Esta cidade arranca o homem da terra, expropria a vida em comunidade, para direcionar o homem-máquina no espaço urbano (BENJAMIN, 2006).

No limite do processo de urbanização-metropolização, a cidade metropolizada, capturada plenamente pela órbita vertical dos adventos técnicos e informacionais da globalização (além, portanto, da metrópole industrial pensada por Benjamin), faz destes espaços a própria condição de acumulação. O que para Otília Arantes (2002) se resumiria na cidade como a própria mercadoria, geridas e consumidas a todo momento (ARANTES, 2002, p. 26). Não mais um instrumento intermediário, o cotidiano, os lugares, a cidade e, no limite, a metrópole tornam-se propriamente os fins da reprodução ampliada do capital. Como Arantes (2002), Scott (2010) entende que o motor de crescimento econômico continua sendo as atividades industriais e os serviços que se articulam a esse arranjo. A sociedade urbanametropolitana ainda está calcada na sociedade industrial, bem como os conceitos de classes sociais na relação capital/trabalho, onde a desigual apropriação dos excedentes produzidos permanece no mesmo curso do passado (SCOTT, 2010). Neste prospecto, Soja (1993, p. 223) demonstra por duas noções a nova realidade metropolitana que intensifica e estende os lucros e o controle sobre a sociedade, reafirmando aspectos centrais da sociedade urbana e metropolitana. A primeira é traduzida pela intensificação: dos lucros, do aprofundamento da divisão social de trabalho, da ampliação de novas necessidades e desejos de consumo, além da concentração e centralização monopolizada de capitais, da legitimação das ideologias dominantes/dirigentes, bem como a fragilização de organizações trabalhistas e movimentos sociais. A segunda pela noção de extensificação: da divisão do trabalho, criação de novos mercados, drenagem de matérias-primas e mão de obra, exploração das condições desiguais do desenvolvimento geográfico por meio de trocas desiguais e das transferências de valor (SOJA, 1993, p. 223). Se a condição colocada pelas ciências, as técnicas e as comunicações 
são revolucionárias, esta continua a ser operada em favor das modernizações seletivas, desiguais e perversas (SANTOS, 2001).

Esta concepção da metrópole assenta-se nos preceitos categoriais recentes dos estudos do urbano nas ciências sociais, o que talvez seja resultado do próprio momento por qual este regime de tempo (ultramoderno, pós-moderno, moderno...) vem passando. Independente das terminologias, as formas urbanas constituídas desde a fase industrial do modo de produção capitalista, remetem concomitantemente a emergência de conteúdos ligados à produção de novas mercadorias e a adequação subordinada de novos desejos criados na sociedade por padrões de consumo. As formas possuem relação fundamental, já que "[...] as construções assumem o 'papel do subconsciente' [...]" (BOLLE, 1994, p. 65), além de reestruturar áreas inteiras, no sentido de adequá-las aos padrões necessários exigidos pela seletividade do capital. Na visão de Santos (2012, p. 146), "mesmo os objetos culturais tendem a tornarem-se cada vez mais técnicos e específicos, e são deliberadamente fabricados e localizados para responder melhor a objetivos previamente estabelecidos", sobretudo o setor econômico. Trata-se do mesmo processo que Harvey (2005) designa de transformação da cultura em commoditie, seja pela atividade de turistificação (KRIPPENDORF, 1989), ou pelo modelo de empreendedorismo urbano revelado nas novas modalidades do planejar e gerir a cidade, cuja ênfase é dada no planejamento estratégico (CASTELLS; BORJA, 1996). Outro mecanismo de dinamização dos fluxos dos espaços da mundialização salientado por Santos (2012a) são os sinais de verticalidades estabelecidos pelo sistema global, por meio de adaptações das formas às normas, em que o patrimônio cultural toma centralidade analítica. Ainda segundo Santos (2012a), a otimização da forma geográfica, ou do objeto técnico, pelo estabelecimento de normas jurídicas e financeiras, são capazes, cada vez mais, de competirem em múltiplas escalas num mercado cada vez mais disputado e procurado (SANTOS, 2012a, p. 151).

Se a gênese desse processo decorre de fato da Modernidade e se pensado o século vinte como a "era das metrópoles" (CHOAY, 2005), a perplexidade de Richard Rogers e Philip Gumuchdjian (2001) com a dimensão do fenômeno urbano atual é certamente justificável, relembrando que a pouco mais de um século, no ano de 1900, apenas um décimo da população mundial vivia em cidades, considerando que "[...] hoje, pela primeira vez na história, metade de toda população mundial vive em cidades [...]” (GUMUCHDJIAN, 2001, 
p. 5$)^{13}$. Isso equivale a um aumento da taxa de população urbana da ordem de 250 mil pessoas por dia, concentrando graves problemas sociais e ambientais ${ }^{14}$ (ROGERS E GUMUCHDJIAN, 2001). Ao mesmo tempo que captura as pequenas e médias cidades circunvizinhas, tornando-as potencial de renda especulativa da terra e geração de valores, a metrópole se estende aos limites dos territórios exercendo seu controle e poder. No caso, Sevcenko (1995) é ilustrativo ao demonstrar que mesmo havendo um centro pulsante, não significa que a metrópole circunscreva exclusivamente a esta ou aquela região e grupo de cidades. Ao contrário,

[...] A interface temporal tem uma vigência onímoda. A sede de uma grande empresa agrícola, em plena zona rural, conectada por telecomunicações com os menores movimentos da bolsa de valores internacionais, com a principais redes informativas e com os mais avançados laboratórios tecnológicos, compartilha de uma intensa experiência metropolitana. $\mathrm{O}$ mesmo ocorre com os grandes condomínios fechados instalado fora das grandes cidades, por exemplo. Assim como as lutas por reformas agrárias encontram seu correlato nas reivindicações dos sem-teto nas metrópoles. Ademais, aparelhos de rádio, TV e bancas de jornais e revistas não tem raízes, e as informações, assim como os desejos, não param nas fronteiras. [...] Outra forma mais ilustrativa e dramática de propor essa visão, usando de uma imagem grandiloqüente, é dizer que ao invés de terem se tornado uma aldeia global, como sugeriu McLuhan, o que se passou com as sociedades humanas no planeta foi teremse transformado numa única e imensa megalópole mundial (SEVCENKO, 1995, p. 196).

Dialeticamente, a pressão psicológica negativa exercida pela metrópole (SIMMEL, 1997), é sanada numa perspectiva funcional do planejamento, quando há certo nível de

\footnotetext{
${ }^{13}$ Num balanço sobre as cidades atuais, realizado pela Organização das Nações Unidas (ONU) na reunião da Rio + 20 (2012), há previsão de que mais de $70 \%$ da população mundial viverá em cidades até 2050 . "Cerca de metade da humanidade vive hoje em cidades. Populações urbanas cresceram cerca de 750 milhões em 1950 para 3,6 bilhões em 2011. Até 2030, quase $60 \%$ da população mundial viverá em áreas urbanas" (ONU, 2012).

14 “As cidades estão produzindo uma instabilidade social desastrosa e levando a um declínio ambiental adicional. Apesar do aumento global da riqueza, que ultrapassa em muito o aumento da população, cresce o grau de pobreza e o número de pobres no mundo." (Rogers e Gumuchdjian, 2001, p.7). Assim também explica Milton Santos $(1979$, p. 222), que a tecnocracia e a modernização são as responsáveis por uma organização urbana concentrada e apoiada por uma argumentação técnica à difusão geográfica e social do crescimento. "O resultado, entretanto, é o contrário: pobreza urbana difundida por toda a parte, pobreza concentrada nos pontos de crescimento." De tal maneira, a concentração espacial da população, em pontos específicos do planeta e cujos padrões são difundidos de forma particular (a depender das singularidades regionais) e globalmente (já que este modelo é necessário a reprodução ampliada do capital) na segunda metade do século XX é dado na forma e no conteúdo de metrópoles, qual seja, uma aliança entre o Estado e as hegemonias monopolistas do mercado internacional, sendo esta última preponderantemente decisória na modernização tecnológica e determinante de outras obrigações. Portanto, já que "[...] a modernização completa do aparelho de Estado não é possível, a realização das tarefas atinentes à modernização do país é cada vez mais atribuída a uma administração paralela, formada de organismos mais ou menos autônomos e dependentes da autoridade centralizadora do governo [...]" (SANTOS, 1979, p. 222).
} 
compactação $^{15}$ que potencializa a melhor oferta de serviços públicos (água, esgoto, energia, resíduos, transporte, limpeza), reduz impactos ambientais, além de usos mistos do território com o fortalecimento da diversidade social, que fogem ao modelo tradicional de zoneamento e facilitam à população o acesso de bens e consumo, além de encontros não programados, provocados pela condição do caminhar e o trabalhar nas proximidades da habitação (JABAREEN, 2006). Essa condição é potencializada quando a relação com as formas urbanas e seus conteúdos associam-se a uma memória social significante para os grupos e classes. Mais que isso, permitam a reprodução prática da vida em conformidade com seus valores, considerando a alteridade das relações e a afirmação da própria identidade neste processo.

Esse elo entre a cidade e a cultura, que não se separa de outras categorias do social, converge nas possibilidades concretas de transformação pela simples existência do ser no urbano, com a condição de produzir formas e conteúdos significantes que o represente na sua luta diária pela sobrevivência. "A cidade é, portanto, a condição especial da realização dos valores de liberdade, de igualdade, de fraternidade, de solidariedade. A cidade produz o estímulo intelectual. A cidade produz a inteligência." (SOUZA, 1999, p. 16). A realização desta cidade deve contrapor aquele espaço do esquecimento do qual Lefèbvre $(1991 ; 2006)$ entende como o da fetichização (desconhecimento de que ele implica relações sociais) na escala da metrópole, que afugentam a memória e causam estranheza não apenas pelo descompasso entre o tempo de vida e da cidade em constante aceleração, mas também pelos conflitos com as novas manifestações e padrões estabelecidos no cotidiano por esse movimento.

Neste plano, o papel das rugosidades patrimoniais é central pelas condições de reencontro da sociedade com sua produção material e intangível. Porém, a crescente disseminação dessa consciência ao longo do século vinte, trouxe um despertar político e econômico (por processos já salientados no plano de atividades modernas), catalisado em ações de preservação e divulgação dos bens culturais em todo planeta, que como outros fragmentos urbanos, ganharam novos status e relações com os grupos sociais. Destas relações, importante lembrar a convivência entre atração (por exemplo pelo turismo, pela infraestrutura que passa a moldar um "novo ambiente", pela centralidade e mobilidade) e repulsa

\footnotetext{
${ }^{15}$ Em grande parte das metrópoles em países subdesenvolvidos a forma urbana é qualificada pelo espraiamento, ou "sprawnling" em língua inglesa. Em estudo deste modelo por diversas variáveis funcionais e indicativos (mobilidade, gastos energéticos, relações sociais, custos), Jabareen (2006) conclui ser um dos menos eficientes cultural e ambientalmente.
} 
(gentrificação causada pela valorização do solo urbano e aumento dos custos de vida, relações conflitantes entre antigos e novos usuários e moradores). Fator que desencadeia transformações na dinâmica das cidades, com núcleos salvaguardados, ou fragmentos e conjuntos de bens que alcançam alguns quilômetros quadrados de proteção e, em outras situações, a quase totalidade de objetos e atividades que agora configuram o crescente patrimônio cultural urbano-metropolitano. Se se generaliza o urbano, a metropolização enquanto processo, capaz de permear os mais distantes rincões do planeta, também o fenômeno da patrimonialização (JEUDY, 2005) abrange porções e conjuntos cada vez maiores.

É na metrópole que se comprova a força, diversidade e expressividade do patrimônio cultural na sociedade contemporânea. É nela que se processam intenções, estímulos e a busca por aqueles bens mais distantes de seu arranjo, sobretudo o patrimônio natural-cultural de longínquas cidades, vilas e espaços reconhecidos e valorizados. Mesmo o patrimônio que em tese é a negação do urbano, por meio do mito da natureza intocada, não se efetiva na prática, onde aspirações e comportamentos continuam próximos aos da cidade (DIEGUES, 2001, p. 7). Conjectura ratificada em pesquisa na região sudeste do Brasil por Scifoni (2006) acerca do tombamento da serra do mar e do seu papel paisagístico na conformação de uma barreira entre setores periféricos da metrópole e as praias do litoral norte paulista, estas últimas frequentadas por segmentos abastados da população residente na RMSP. Na região centro-oeste sobre a dinâmica turística e do patrimônio natural na Chapada dos Veadeiros, uma das áreas mais exuberantes do cerrado brasileiro, Costa et al. (2015) revelam que mesmo numa região de difícil acesso, em que Brasília guarda o aeroporto mais próximo ${ }^{16}$, com cerca de quatrocentos quilômetros de distância, a visitação de turistas internacionais, de São Paulo e Rio de Janeiro predominam massivamente, além de moradores de diversas capitais estaduais e estrangeiros de distintas nacionalidades. “[...] O ‘isolamento’ de outrora, de um parque pouco acessível e

\footnotetext{
16 “Um dos maiores desafios ao turismo na Chapada dos Veadeiros refere-se aos custos e dificuldades de acesso e deslocamento para visitação ao Parque. Grande parte dos turistas são oriundos da região Sudeste, o que implica em uma viagem cara: deslocamento aéreo até Brasília e necessidade do uso de carros ou jipes para se chegar até São Jorge e seus principais pontos atrativos. Contudo, com a redefinição econômica do país, nos últimos anos, a popularização do transporte aéreo civil, a expansão dos aeroportos e rodovias, as promoções de operadoras aéreas, agências de turismo e de locadoras de automóveis favorecem frequentes e intensos fluxos à localidade. Ainda que alguns comerciantes locais entrevistados reclamem do baixo movimento de turistas, informações da Secretaria de Turismo mostram que, na última década, multiplicaram-se hotéis, pousadas, campings e em toda região, além do aumento gradativo do número de lojas, restaurantes, cafés, bares e estabelecimentos comerciais diversos.5 Proprietários no entorno do Parque utilizam o potencial de suas terras ao turismo, cobrando pela entrada e visitação ao cerrado; eles munem a área de infraestrutura de acessibilidade e sinalização, caso da Cachoeira dos Cristais e Vale da Lua.” (COSTA; et al., 2015, p. 3).
} 
distante das grandes cidades, é invertido pelo seu encadeamento na rede turística nacional e internacional." (COSTA et al., 2015, p. 8). A pesquisa ainda constatou que, embora distante dos grandes centros urbanos e metropolitanos, a conversão da área em Parque Nacional pelo IPHAN e Patrimônio da Humanidade pela Unesco, a transformou num reduto de novos moradores que se refugiam das mazelas urbanas das grandes cidades, em busca de uma vida "mais natural", porém levam ao novo habitat uma carga cultural calcada na experiência urbano-metropolitana, que reflete nas relações sociais e que evocam ao olhar paisagens de bancos, hotéis, restaurantes, comércios e serviços diversificados no entorno.

\begin{abstract}
A patrimonialização da natureza natural supõe a emergência da cultura do estético que a alinha à natureza social. Essa cultura traduz-se em consumo visual e representa empoderamento (às avessas) massivo da e na natureza natural, cuja consciência ou imaginários são reproduzidos no contexto do discurso de fuga das novas angústias ou tormentos urbanos. A natureza natural ativada como recurso patrimonial entra na esfera de um consumo gradual, que se diferencia em intensidade e em exposição de produtos, em relação às ações transformativas industriais tradicionais de grande porte e impacto imediato, as quais resultam no mundo tecnificado de objetos. Ao fazer-se paisagem de uso e consumo coletivo, a natureza natural constitui-se em atributo pela vida de grupos seletos, hibridiza vida natural orgânica e relações culturais mediadas pelas artes da renda e do lucro via encantamento concretizado in loco." (COSTA et al., 2015, p. 3).
\end{abstract}

Apesar deste entendimento - que não é o reducionismo do natural pelo cultural, mas pressupõe uma relação metabólica e crítica entre ambos (LEFEBVRE, 1975 [1969]; 1979; SMITH,1984a; COSGROVE, 2004 [1989]; SANTOS, 2012d [1996]; PAES LUCHIARI, 2001; EAGLETON, 2005), classificar os bens patrimoniais em "histórico", "natural", "cultural", justifica formalmente seu valor mais pujante segundo uma ótica determinada, como aqueles descritos aos monumentos por Riegl (2014 [1903]), ou das instituições estatais de preservação que estabelecem critérios lógico-formais para incluir objetos em suas políticas e ações. No caso específico da Aldeia de Carapicuíba, emerge formalmente o "conjunto arquitetônico e urbanístico", que colocou à margem outras perspectivas de valores encontrados, inclusive pelo estudo de Luís Saia em 1937. Essa dimensão de valor material, histórico e de antiguidade, priorizou as formas em detrimento dos conteúdos. Focalizou-se no poder colonial da Igreja e Coroa, reservando ao índio e ao caipira quiçá uma escolha futura de sustentar os mitos fundadores (CHAUÍ, 2000) de uma possível unidade harmônica entre etnias e culturas. O caso de Carapicuíba não está isolado, perpetuando-se em toda América Latina e outros rincões do planeta situações que trazem mais semelhanças do que diferenças. 
Kosik (1976 [1963]) ensina que o conhecimento adequado do mundo deriva de um pensamento que destrói as invenções fetichizadas e reificadas das coisas ideais, tornando-se num método revolucionário de transformação da realidade. Permite o entendimento da ordem própria das coisas. Pensar, portanto, a metrópole, o patrimônio e as rugosidades em conjunto permite vislumbrar um todo indivisível de instâncias e significados, onde este é criado simultaneamente pela interação das suas partes, que se desenvolve e se produz. Esta relação entre o todo e a parte, a parte e o todo, simultaneamente, converge numa abordagem dialética, em que a compreensão conceitual da realidade é dada em pares: fenômeno e essência, aparência e realidade, práxis utilitária e práxis revolucionária... Sem que haja um abandono da totalidade, mas em razão propriamente do processo de totalização, entende que sem decomposição do real não existe possibilidade da produção do conhecimento. Ou seja, a separação é ela própria a realização do conhecimento (KOSIK, 1976 [1963]). Esta perspectiva previamente apontada não traduz o pressuposto construtivo de uma metateoria dos temas em questão, ou de uma abordagem exaustiva, epistemológica e, por fim, de uma contribuição capaz de esgotar a amplitude que o fenômeno desperta. Menos ainda uma totalidade metageográfica. Mas sim de entendê-la em sua totalidade a partir do aprofundamento analítico de momentos e frações de fatos, onde esta ação deve ser concomitantemente restituída ao conjunto de relações universais. Neste caso, Lefèbvre (1975 [1969], p. 204) é elucidativo ao apontar que "a interação universal eleva a nível superior as noções de relação, de identidade e diferença, de oposição e contradição. É no quadro dessa interação que as relações, as contradições, aparecem unidas e atuando umas sobre as outras". 


\subsection{Busca do concreto: pensando as rugosidades patrimoniais na América Latina}

A estrutura das cidades possui histórica e geograficamente uma estreita relação com o dinamismo econômico regional. Na maior parte da América Latina, até meados do século dezenove, a regulação administrativa sobre seus territórios vinculava-se diretamente ao poder imperial da Espanha e Portugal. Ao longo do século vinte, os países se modernizam, mas esse processo, diferentemente do quadro dos países desenvolvidos, acompanha os interesses ampliados do capital, em suas diversas revoluções técnico-científicas e de expansão rumo a novos mercados e profunda exploração do trabalho e recursos naturais. Este crescimento se verifica mediante a superexploração do trabalho e, podemos explicitar e complementar, do meio natural. "Exacerbam-se, assim, as contradições, os conflitos sociais, os conflitos com a natureza. [...] Viabiliza-se um estado paralelo e um novo poder econômico marginal, nascido do capitalismo periférico, mas estranho ao próprio capitalismo" (CARVALHO, 1997, p. 28).

O contexto periférico, das ex-colônias, ou mesmo das grandes cidades em desenvolvimento, ainda remete concomitantemente a um processo de marginalização cultural e dependência. Segundo Moraes (2005, p. 73), “as argumentações de índole geográfica ganham destaque no contexto periférico, com o território muitas vezes suprimindo carências que a história e a estruturação da vida social negam ao processo de afirmação das identidades estatais pós-coloniais". Isso significa que pensar os subúrbios empobrecidos e as periferias metropolitanas requer a compreensão e o sentido core destas problemáticas, que servirá de base teórica e metodológica para a análise mais particularizada dos fatos, do recorte empírico. Principalmente porque a gênese de Carapicuíba, como será detalhadamente analisada, possui em si um conteúdo marginal, cujas funções, no entanto, eram fundamentais aos propósitos coloniais. Esse desígnio é reproduzido posteriormente, ora no subúrbio empobrecido, ora na periferia metropolitana. Movimento que engendra a cada momento transformações circunstanciais da dinâmica espacial, reorganizando os lugares a cada contexto e fragilizando os processos de construção identitárias. No entanto, hipóteses trazidas por autores como Di Méo (2008), Gravari-Barbas (2014) e Costa (2016), defendem que questões ligadas às identidades se delinearão mais intensamente na periferia, ou nas áreas novas da metropolização. As formas e os conteúdos instrumentais, porém pautados em outras lógicas passíveis de, inclusive, resignificar as velhas narrativas e em ampliar criativamente as condições de interlocução com as rugosidades patrimoniais. 
Ainda que fundamentais neste processo, as rugosidades patrimoniais demandam articulação política dos grupos sociais, com soluções coletivas cultivadas frente as pressões das forças repressoras, econômicas e institucionais, que são a essência da patrimonialização global. Para que elas sejam, verdadeiramente, mecanismos de integração dos territórios, de ampliação das vozes, de difusão dos múltiplos significados que possuem, sobretudo de um processo histórico e geográfico posto à margem pela seletividade da memória nacional (ORTIZ, 1994). Estas possibilidades são concretas, naquilo que Darcy Ribeiro (2006 [1995]) conjecturou sobre a unidade latino-americana, sonhada por Bolívar. "Hoje, somos 500 milhões, amanhã seremos 1 bilhão. Vale dizer, um contingente humano com magnitude suficiente para encarnar a latinidade em face dos blocos chineses, eslavos, árabes e neobritânicos na humanidade futura.” (RIBEIRO, 2006, p. 411).

Contraditoriamente, a outra face dessa unidade identitária, política e econômica, é dificultada pelas diferenças étnicas e culturais das regiões e países reconhecidos pelo mesmo autor supracitado: (a) dos países cuja identidade nacional deriva das civilizações e povos primitivos, como o México, Peru e grande parte dos países da América Central - "povos testemunhos"; (b) dos "povos transplantados", que procedem de uma massiva e repressora invasão europeia, representados por países como Estados Unidos, Canadá, Argentina e Uruguai; (c) por último, os "povos novos", estabelecidos por diferentes culturas e etnias, como o Brasil. Nesse caso, "somos povos novos ainda na luta para nos fazermos a nós mesmos como um gênero humano novo que nunca existiu antes. Tarefa muito mais difícil e penosa, mas também muito mais bela e desafiante” (RIBEIRO, 2006, p. 411). Numa síntese, equacionar estas diferenças numa unidade estratégica de integração identitária é algo complexo, pois não se reservam apenas às questões étnicas ou culturais, mas de dependência econômica e interesses externos, graves problemas sociais e de um Estado instituído que prevarica contra os direitos humanos e a cidadania ${ }^{17}$.

Mesmo nos casos onde as rugosidades patrimoniais se sobressaem pelo conjunto material remanescente, como os centros memoriais dos povos Maia, a maior parte instituída

\footnotetext{
17 "Nesse contexto, as identidades não são evidentes nem se amparam numa história imemorial ou numa cultura bem diferenciada. A sobrevivência de relações sociais muito assimétricas, herdadas da organização colonial, torna difícil falar em bem comum ou em vontade geral nestas sociedades, onde vigoram formas de trabalho compulsório (entre elas, o escravismo) e impedimentos sociais extra-econômicos (de raça, por exemplo). Em tais sociedades, o 'povo' não abarca a totalidade da 'população' do país, pois ali vigoram regras de exclusão na distribuição de direitos de cidadania (tendo por situação-limite a dos escravos, que se caracterizam como 'propriedades' e não como sujeitos políticos). Enfim, a legitimação do Estado emerge problemática nestes contextos." (MORAES, 2005, p. 73).
} 
como Patrimônio da Humanidade, prevalece a instrumentalização dos bens para o consumo turístico e a cultura convertida em commoditie. Tanto que, na América Central, a entrada em parques nacionais como Tikal ao norte da Guatemala, ou Copán à oeste de Honduras, são raros os grupos formados de visitantes guiados em língua espanhola. Do mesmo modo que de relevante importância econômica para os países em questão, as rugosidades patrimoniais, no plano da cultura, funcionam alegoricamente numa atmosfera museificada, promovidas por agências de turismo internacionais e freneticamente experimentadas por uma massa de visitantes estrangeiros. Em que cidades como Flores e Copán, ligadas respectivamente em rede pelas agências de Cidade da Guatemala e Tegucigalpa (capitais/metrópoles nacionais), dão sustentação aos serviços básicos, além de ambientarem com seus centros históricos o entretenimento noturno dos turistas. Contrasta neste processo um sentido de distanciamento da produção dessas rugosidades com os povos maias indígenas remanescentes, deslocados de suas heranças patrimoniais e vivendo às margens desse arranjo, na informalidade do circuito inferior da economia (SANTOS, 1979) e nas ruas dos centros urbanos sobre o olhar de desconfiança e repúdio do estrangeiro (Figura 09).

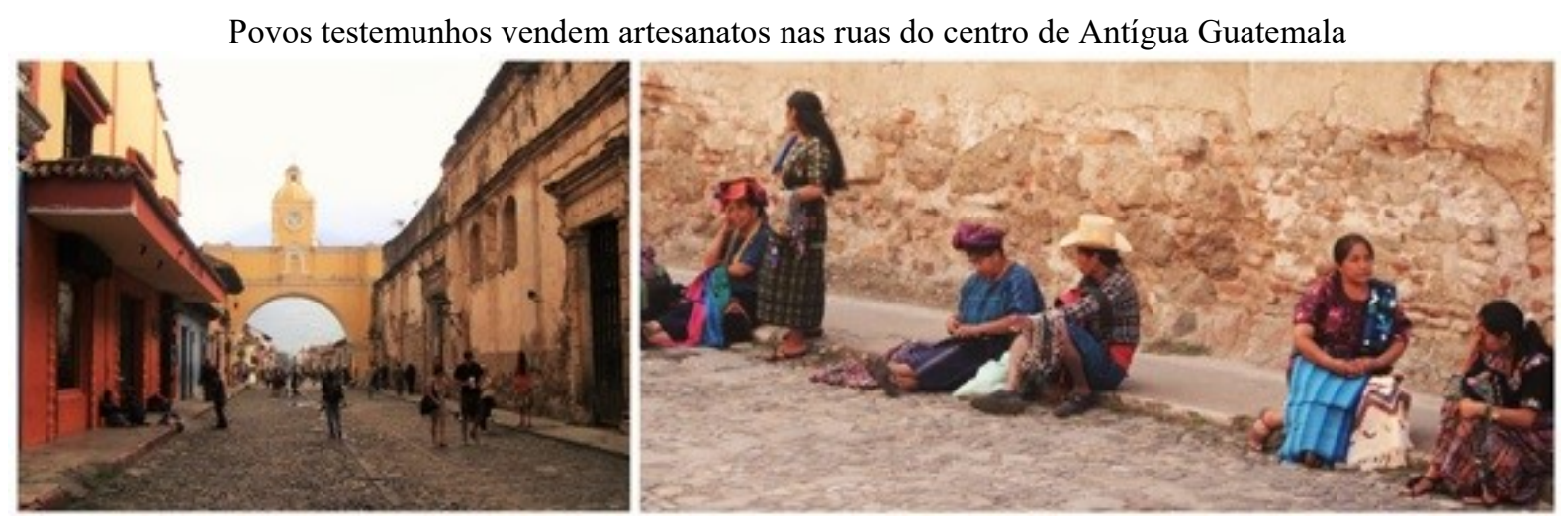

Figura 09: Povos testemunhos nas ruas da cidade de Antígua Guatemala vivem do trabalho informal, circuito inferior da economia, convivendo com boutiques e lojas de artesanatos locais. A apropriação econômica da cultura indígena (maia) é dada pelas redes internacionais de turismo, pelos agentes hegemônicos regionais e visitantes predominantemente dos Estados Unidos e Europa.

Fonte: Fotos do autor, 2011.

Contraditoriamente, ainda que exista entre as populações indígenas mediação e negociações com o governo e as empresas turísticas, ampliam-se as condições dos bens e das novas relações estabelecidas por um projeto político e econômico de cultura, já que esta última se adequa ainda aos preceitos de usos tradicionais das rugosidades patrimoniais. Em Tikal, a presença das exuberantes rugosidades pré-colombianas, abandonadas antes da colonização espanhola e tomadas pela densa selva tropical, foram praticamente reconstruídas nos últimos anos, tornando-se um dos maiores centros turísticos de toda América Central. A 
vultuosidade das intervenções empregaram recursos e a cooperação internacional junto a países desenvolvidos. Muitos dos monumentos ali presente são frutos das condições capitalizadas de reprodutibilidade técnica (BENJAMIN, 1985), cujas tradições perpassam por simbólica reinvenção (HOBASBAWN; RANGER, 2002) e espetacularização (DEBORD, 1997). Em visita ao parque, observa-se além da continuidade das intervenções ainda ativos espaços ritualísticos dedicados às fogueiras (Figura 10), em que se apoia e rememora antigos atos sagrados da população indígena ainda remanescente na região.

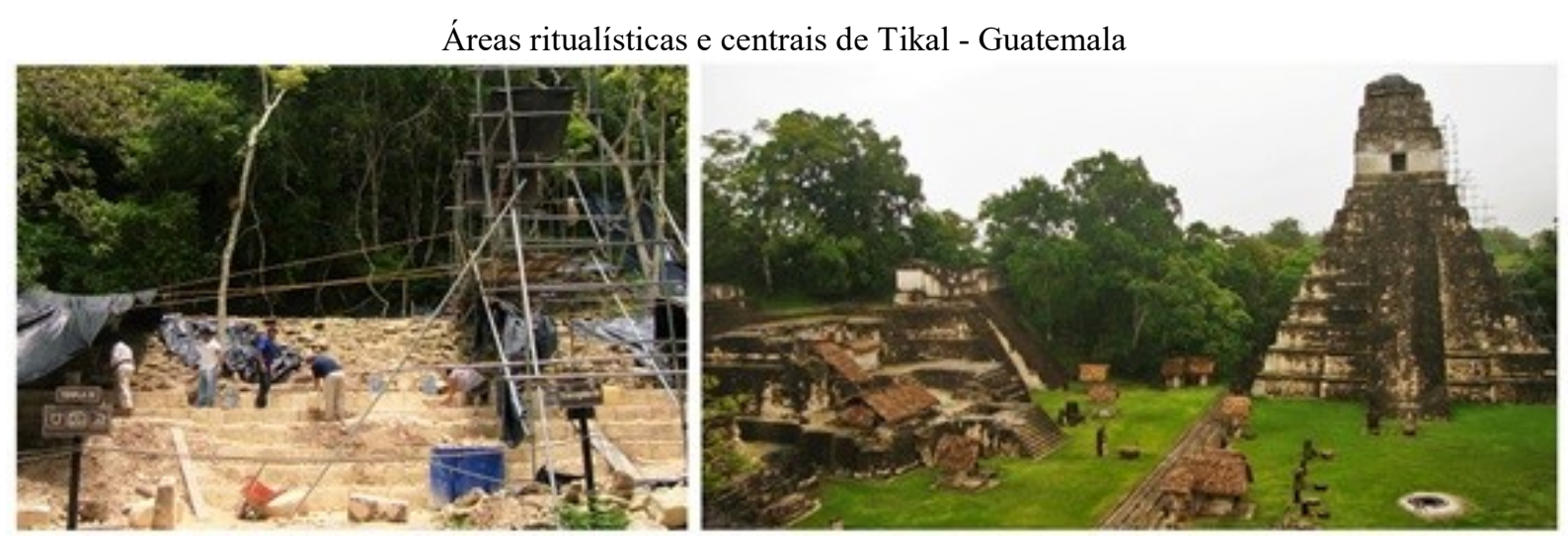

Figura 10: Imagem à esquerda do Parque Nacional de Tikal, Guatemala - Patrimônio da Humanidade. Boa parte das rugosidades patrimoniais foram e ainda estão sendo reconstruídas ou restauradas. Na segunda imagem, parte inferior direita da foto, área de rituais com fogo, realizados por antigos descendentes indígenas guatemaltecos.

Fonte: Fotos do autor, 2011.

Um dos maiores desafios políticos contemporâneos parece residir, como no Brasil, em contemplar uma complexa diversidade étnica e cultural de populações e seus territórios. Em Honduras, onde a população indígena representa um total menor de $10 \%$ da população nacional, o Parque Nacional de Copán, Patrimônio da Humanidade, abarca a maior parte dos esforços e recursos públicos destinados à cultura e o turismo no pais. No país, as instabilidades constantes, sobretudo pelo golpe político ao governo do presidente José Manuel Zelaya Rosales em 2009, dificultam estas ações e minam a já baixa institucionalidade gerada em relação aos institutos nacionais de preservação e pesquisa do patrimônio cultural e os grupos étnicos organizados (EURAQUE, 2010, p. 310).

A criticidade das novas funções e conteúdos das rugosidades patrimoniais na América Latina é fruto das próprias condições históricas expressadas anteriormente. Afinal, como advoga Canclini (2006, p. 291), a monumentalidade de grande parte dos espaços históricos no subcontinente latino-americano deriva de sistemas sociais autoritários no mundo précolombiano, juntamente com o imperialismo espanhol e português suprimindo historicamente os arranjos socioespaciais indígenas. Quando mantidas algumas das formas e objetos 
geográficos, os novos conteúdos culturais, funções econômicas e sociais foram superpostos, cuja a incipiente acumulação que se busca com o resgate das tradições locais está condicionada a paisagem e sua arquitetura, bem como atender a demanda crescente de visitantes aptos a pagar por simbólicos e singulares espetáculos. Soma-se ainda, a centralidade dos bens consagrados pela ótica autoritária das classes sociais dirigentes destes países, as quais alicerçam a memória e o patrimônio nacional. "Seria preciso analisar, enfim, de que modo os processos de independência e construção de nossas nações geraram novos edifícios e murais, retratos de heróis nacionais e calendários de efemérides, destinados a instaurar uma iconografia representativa do tamanho das utopias.” (CANCLINI, 2006, p. 291).

No caso em que as rugosidades patrimoniais não revelam uma aptidão econômica de exploração, as alternativas logo se concentram no patrimônio natural. Em países, como o Chile ou a Nicarágua, sobressaem respectivamente as paisagem das cordilheiras e os parques nos vales nevados dos Andes (Figura 11), bem como vulcões e aventuras em meio aos exuberantes cenários do Estreito de Magalhães ao sul, ou o Deserto do Atacama ao norte. No segundo caso, sobressaem as praias e a paisagem tropical, grandes lagos, parques naturais que guardam importantes vulcões ativos do círculo do fogo e uma beleza cênica singular.

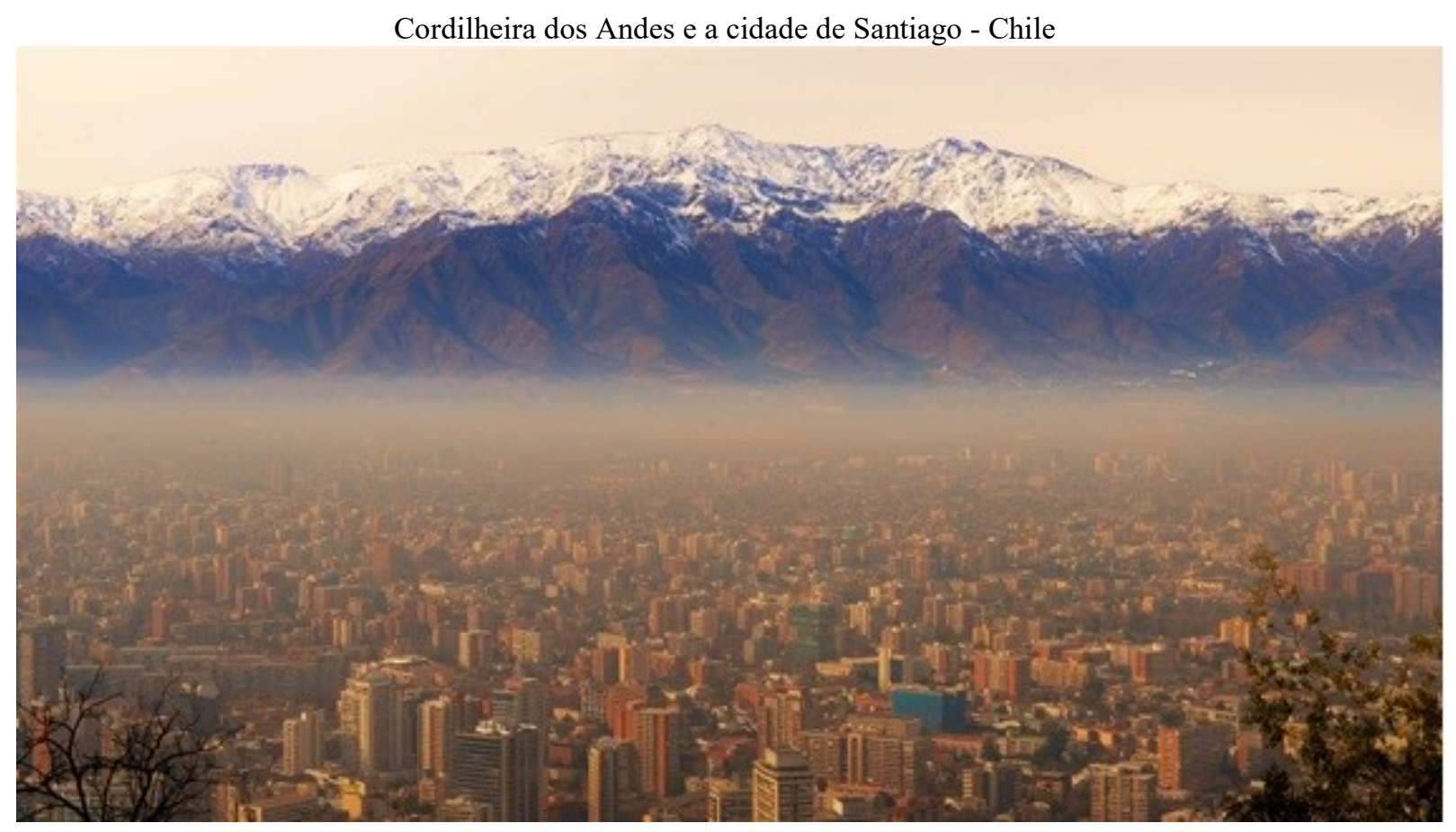

Figura 11: Um dos mais destacados patrimônios naturais chilenos reside na exuberância da cordilheira dos Andes. Além de compor a paisagem cultural de diversos núcleos urbanos do país, a apropriação das montanhas por redes e franquias de parques e estações de esqui se avolumam.

Fonte: Foto do autor, 2015. 
Cuba é um caso muito particular, e mesmo avançando em relação à justiça social e relativa democratização cultural, as tantas contradições observadas no continente igualmente estão presentes na ilha. As rugosidades patrimoniais de Havana se agigantam para além de "Havana Vieja", porém o núcleo revitalizado concentra-se estritamente na rua Obispo e paralelas, pontos específicos do território da cidade, que convivem com ampla massa sucateada de antigos casarões e edifícios centenários distribuídos. A homogeneidade da arquitetura reitera a acumulação de formas que derivam dos séculos dezenove e vinte nos limites da revolução. Havana é o núcleo metropolitano de um governo centralizado e que se articula às múltiplas atividades produtivas, inclusive com os internacionalizados e luxuosos resorts no mar do Caribe, que dinamizam economicamente o país e onde o acesso da população local é segregado, inclusive a setores das praias ocupadas pelos equipamentos de lazer dos empreendimentos hoteleiros, como o caso de Varadero (Figura 12).

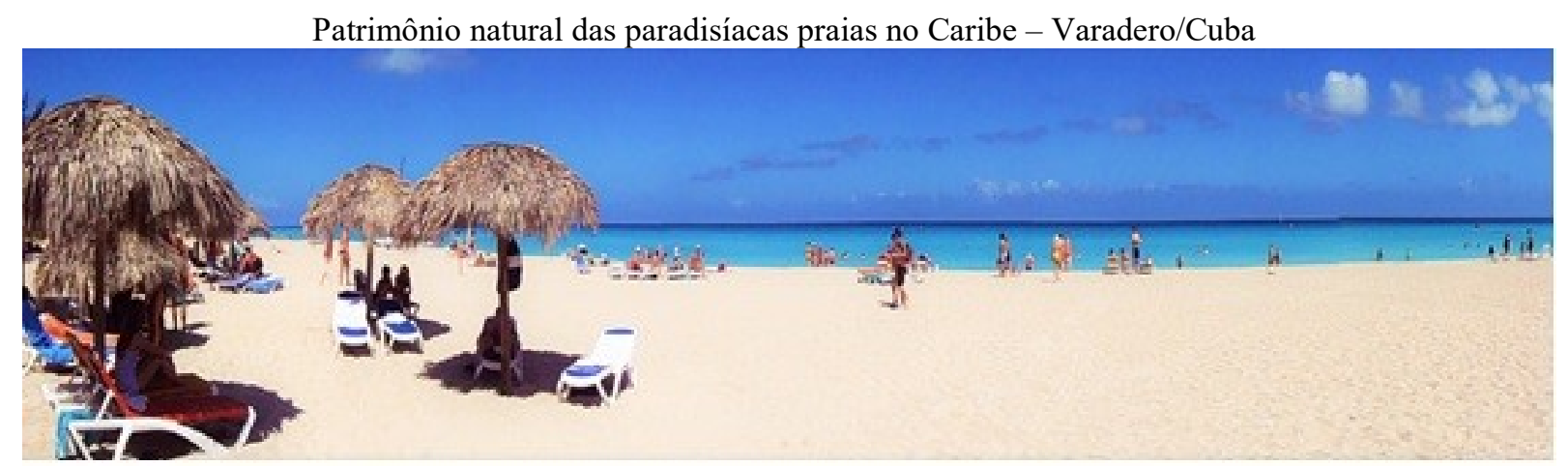

Figura 12:Varadero, no litoral norte da ilha de Cuba, conta com as mais belas praias do Caribe e luxuosos resorts com turistas canadenses e europeus em sua maioria. Mesmo diante de um regime político diferenciado do restante da América Latina, o país convive com problemas semelhantes, como a internacionalização de seu território e a segregação dos bens de serviços e de consumo à população local.

Fonte: Foto do autor, 2015.

No caso das cidades brasileiras às questões culturais são emblemáticas, pois a heterogeneidade que caracteriza a formação de um "povo novo" - nos dizeres de Ribeiro (2006) - em conjunto com as políticas públicas nacionais e orientações internacionais marcam um processo de valorização seletiva dos espaços e, pois, das próprias manifestações culturais. Como explica Costa (2010, p. 56) "valorização essa que produz contradições e que tem o poder de transformar o conjunto urbano e a própria cultura em gêneros de mercadorias; valorização que dá um novo rumo para cidades como Salvador, Olinda, Ouro Preto, Diamantina [...]”. As cidades já consagradas como monumentos nacionais (Figura 13), agora chanceladas pela UNESCO e convertidas em Patrimônios da Humanidade, convergem para 
um processo irreversível de revalorização econômica, guiadas pela atividade do turismo e o reconhecimento internacionalizado da formação histórica e da identidade territorial vinculadas ao Brasil Colônia, ao barroco e os edifícios maiores em áreas centrais.

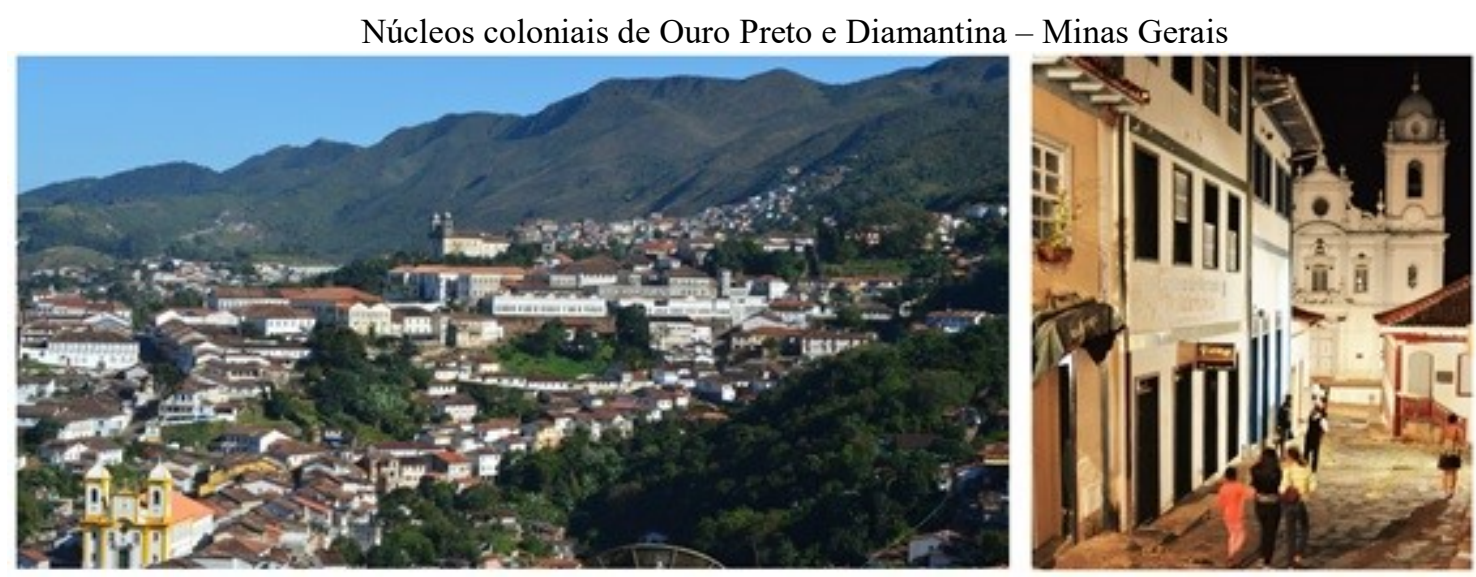

Figura 13: Imagem à esquerda, perspectiva da primeira cidade-monumento do Brasil - Ouro Preto. Na imagem à direita, o centro da cidade de Diamantina. Ambas tombadas Patrimônio Nacional e Cultural da Humanidade, atraindo anualmente milhares de turistas e revelando uma das escolhas patrimoniais identitárias possíveis para representar o povo brasileiro.

Fonte: Fotos do autor, 2016.

Mais complexas são as regiões metropolitanas, que em países como Brasil, México, Colômbia e Argentina tomaram proporções em que os agrupamentos humanos facilmente ultrapassam milhões de habitantes. Além disso, concatenam simultaneamente as marcas das populações primitivas com a estrutura colonial estabelecida, convivendo tantas temporalidades pretéritas, quanto foi possível a essas comunidades ao longo dos últimos séculos produzir alternativas econômicas, políticas e culturais para a sua sobrevivência. Mesclam-se, em meio às áreas que chegam a 15 mil habitantes por quilômetros quadrados, uma rica heterogeneidade de hábitos, costumes e modos de viver. Ainda que as teorias da globalização protelem tendências sociais à homogeneização, e mesmo considerando a velocidade das difusões nos hábitos culturais contemporâneos pelos meios de informação, Canclini (2006) ajuda explicar que habitar uma grande cidade não necessariamente restrinja a vida numa clausura diluída na massa e no anonimato. Tão pouco o domínio da televisão e computadores contemplem totalmente as necessidades e os anseios sociais que os espaços públicos e a convivência permitem. Trata-se muito mais de relativizar esse processo, no sentido dado do "jogo de ecos" pensado pelo autor supracitado, metaforicamente exemplificada onde "a publicidade comercial e os lemas políticos que vemos na televisão são os que reencontramos na ruas, e vice-versa: umas ressoam nas outras." (CANCLINI, 2006, p. 290). 
Não é possível negar que a patrimonialização tencione as rugosidades nas metrópoles em termos de padrões essenciais à sua apropriação por novas atividades produtivas. Estratégia que normatiza as formas e potencializa seus conteúdos. Que compassa a vida moderna com a agenda de cultura, lazer e entretenimento da cidade. Sistema que se ajusta à racionalização do tempo e das formas visando a fluidez espacial, ora para transitar mercadorias, ora fazendo destas rugosidades patrimoniais o produto de consumo basilar. Estas premissas gerais, no entanto, não resultam de uma teoria impressa em tábula rasa. Os processos de mercantilização da cultura (HARVEY, 2005) ligados às rugosidades patrimoniais não se efetivam plenamente sem resistências, tensões, conflitos, ou consensos, que no limite podem inviabilizar ou dar outros encaminhamentos aos projetos primitivos. Enfim, no desenvolvimento geográfico desigual e da globalização, a aceleração do tempo de giro do capital, acaba por causar grandes tensões entre as demandas de mercados, com as temporalidades dos sistemas sociais e ecológicos (HARVEY, 2013). Nesta conjectura, as barreiras espaciais devem ser eliminadas, adequando às cidades e territórios no empreendimento de acumulação. Lógica, no entanto, a análise mais detalhada acaba por evidenciar barreiras e uma permeabilidade questionável. As rugosidades patrimoniais evidenciam, porém, que os fatos sociais não são redutíveis exclusivamente ao plano econômico, mas do mesmo modo das relações estabelecidas entre os grupos, sujeitos e o todo social. Significa que mesmo a efetiva articulação entre o capital e o Estado (nas inovações produtivas, das infraestruturas instaladas e a organização política e ideológica do poder corporativo), o resultado da globalização se apresenta diferenciado, multifacetado, onde as temporalidades nem sempre obedecem plenamente as demandas verticais e especulativas dos mercados financeiros, ou das grandes corporações industriais e de empresas.

Igualmente, mais que reserva de mão-obra, as condições de vida nas metrópoles podem apresentar significativos redutos das permanências culturais, ou na perspectiva criativa e híbrida de novas construções e práticas, cujo papel mais que acumular capital se insere no plano essencial das necessidades de reprodução e existência. Desponta que, mesmo nas intempéries condições de urbanização da América Latina e das negligenciadas políticas no âmbito do patrimônio cultural, as formas e conteúdos universalmente institucionalizados ou universalizados, no plano da proposta do "utopismo patrimonial singularista" (COSTA, 2016), avançariam em favor das rugosidades representativas da memória coletiva. Tal fundamento traz a discussão do patrimônio cultural para uma inversão do desenvolvimento das ideias, que sempre se localizaram e estiveram enraizadas no núcleo político e econômico 
da metrópole. Mas esse não seria, além da dimensão urbana de análise, o próprio caso do patrimônio cultural? Sempre valorizado na ótica hegemônica das classes sociais, monumental de pedra e cal, cuja localização historicamente residiu nas centralidades do poder. Buscar apreender a dinâmica das rugosidades patrimoniais de Carapicuíba frente a metropolização de São Paulo, estabelece o deslocamento analítico do centro para a periferia, um exercício de situar geográfica e historicamente os dramas e as conquistas dos trabalhadores (escravos, forçados e relativamente livres) que desde a colônia aos dias atuais alicerçam o fato da metrópole nacional brasileira. 
PARTE 02

\section{DA GÊNESE COLONIAL AO SUBÚRBIO: CARAPICUÍBA E SUAS RUGOSIDADES PATRIMONIAIS}

\section{CAPÍTULO 03: Gênese colonial das rugosidades patrimoniais de Carapicuíba}

Quando realizado um questionamento sobre analisar o passado com os olhos do presente (MUMFORD, 2008), ou da fundamentação em fontes secundárias, por vezes imprecisas e passíveis de questionamentos, faz-se necessário ainda incluir os direcionamentos ideológicos e as condições proto-científicas de viajantes, ou representantes oficiais das instituições interessadas (Coroa e Igreja). De fato, em meio a estas circunstâncias documentais e iconográficas é que se estabelece uma base analítica que, fundamentada no rigor reflexivo, permite avanços, porém sem necessariamente se desvincular das pretéritas fontes, as quais merecem crédito, mas sempre o cuidado. Se é importante retomá-las, simultaneamente necessário é triar criticamente e reconhecer os contextos históricos e geográficos de suas produções. Para isso, além do esforço reflexivo de estabelecer interconexões temporais entre múltiplas escalas geográficas, prevalecem três planos referenciais para a construção destas unidades da tese. A primeira associada às análises científicas ${ }^{18}$. Numa segunda faceta, residem as obras regionalistas, muitas com interface entre as supracitadas. Sem qualquer perda de mérito, ou importância, acredita-se tão somente necessário diferenciá-las dos primeiros, já que estes autores ao viverem intensamente e por terem uma ligação marcante com os lugares passam a carregar muitas particularidades nas análises ${ }^{19}$. Por fim, o terceiro alicerce está fincado nas bases documentais e iconográficas de

\footnotetext{
${ }^{18}$ Oriundas de disciplinas como a História, a Economia, Artes ou o Urbanismo, por exemplo. Destacando-se a Geografia, por base das obras de Aroldo de Azevedo, Pasquale Petrone e Richard Langenbuch, mas não limitando-se exclusivamente a estes, como os fundamentos de Luís Saia ou Américo Pellegrini a título de exemplo.

${ }^{19}$ Destacam-se Eduardo Escalante, Miguel Costa Junior, Pedro Tenório, Helenice Henne, Alexandre Pimentel, entre outros.
} 
origem primária, tanto de fotos de moradores, jornais ou folhetins cotidianos, quanto de arquivos, como o do estado de São Paulo, ou as bases dos institutos do patrimônio.

Num passado mais remoto, são estes elementos documentais que fundamentam a periodização e a análise particularizada do passado de Carapicuíba em relação à "metrópole", ou mesmo escalas mais amplas, como a difusão de missões religiosas e a organização colonial em toda América Latina. Na prática, ao tomar como recorte empírico a cidade de Carapicuíba (RMSP) no contexto de metropolização, utilizando da periodização histórico-estrutural enquanto abordagem metodológica para apreender sua formação territorial e a gênese das atuais rugosidades patrimoniais, uma das preocupações emergentes residiu precisamente nos limites das narrativas e da ambígua clareza da razão histórica oficial - tanto na origem temporal e espacial da aglomeração, como no seu desenvolvimento. Dos documentos primários e obras clássicas que retratam sem grande precisão da área, apontam como marco histórico o ano de 1580, quando uma determinada gleba com três léguas de terra (supostamente onde foi instalado o aldeamento) é doada pelo capitão-mor Jerônimo Leitão aos índios Guaianases da aldeia de Pinheiros e Carapicuíba. Por volta desta mesma data é atribuída a criação dos doze aldeamentos em São Paulo por Anchieta (inclusive o de Carapicuíba). Nesta mesma região, possivelmente sobreposta às terras doadas, Afonso Sardinha e sua esposa Maria Gonçalves instalaram um sistema de aldeamento em sua propriedade, visando o confinamento indígena, que foi administrado e doado posteriormente à Companhia de Jesus em 1615 (REIS FILHO, 1982; COSTA JÚNIOR, 1987; HENNE, 2015). A primeira doação, portanto, relaciona-se ao sítio da Aldeia de Carapicuíba (onde hoje está o Parque da Aldeia e o vilarejo sede do antigo aldeamento homônimo). A segunda doação seria, portanto, a mesma área onde atualmente está circunscrito o município de Carapicuíba (HENNE, 2015). Não se trata, porém, de uma gênese inconteste, mas de consensuais suposições originárias que, de qualquer forma, dão sentido histórico, ainda que precário e harmônico, simultaneamente ao atual arranjo do aldeamento e do município de Carapicuíba.

Mais que o aprisionamento da descrição das singularidades locais frente ao movimento global, criticamente denunciado por Massey (2009), a apreensão das atuais dimensões urbanas deve buscar o fragmento ou a parte desta totalidade, no movimento dialético de aproximação empírica e de generalização teórico-conceitual, que aqui resume-se ao foco da formação econômica e social (nacional-regional) e que está sintetizado num movimento de recomposição ulterior com o todo (a estrutura global). E, ao nosso entender, o mais desafiador, congregar a abordagem econômica e política às perspectivas críticas 
espaciais, que carregam dimensões da cultura, em que os territórios e unidades se constituem numa complexa trama em torno das rugosidades patrimoniais. Como ainda explica Santos (1985) a compenetração histórica não tem uma finalidade prospectiva em si, autônoma e desvinculada das relações do presente. Estes fundamentos devem apoiar incondicionalmente a apreensão da contemporaneidade, cuja clarividência do futuro e suas forças podem ser, igualmente, estimadas. Nesse sentido, Carapicuíba, independentemente dos novos conteúdos associados às suas formas, é o único município ainda a possuir um conjunto de elementos, ou propriamente, a rugosidade patrimonial em suas concreticidades, que remete morfologicamente ao modelo de aldeamento estabelecido no atual território de São Paulo. Elemento sugestivo das mais dilatadas narrativas históricas, fundadas nos rincões do Brasil Colônia e expandidas aos limites da urbanização-metropolização do país.

Em meio as intervenções realizadas, tanto pela população em causa da necessidade de sua própria permanência, ou dos órgãos e instituições públicas ao longo do século passado, no sentido de sua preservação, o fato é que o aglomerado possui não apenas o desenho, mas algumas tradições que, se não pensadas no início da fundação em 1580, ao menos em sua segunda fase, quando da reconstrução do núcleo por volta de 1736. Em verdade, alguns elementos derivativos dos aldeamentos podem ser ainda observados in locu nas atuais cidades da RMSP, porém sem a integralidade que o antigo conjunto da Aldeia de Carapicuíba possui (Mapa 03). Mesmo com a relevância do sistema de aldeamentos nos primeiros períodos da colonização do Brasil, sobretudo nos arredores de São Paulo, materialmente nada restou, a não ser alguns poucos documentos, relatos de viajantes, livros e outros resíduos que podem ser mais bem observados justamente em Carapicuíba. Nisto, observa-se a latente condição de patrimonialização que tenciona este território durante o século aos dias atuais, tornando-se um dos casos mais emblemáticos no que tange o estudo do patrimônio cultural em São Paulo. Ele perpassa todas as fases do desenvolvimento territorial, que vai dos aldeamentos aos subúrbios pré-metropolitanos e dos subúrbios à fragmentação e periferização da metrópole paulista, as quais esta unidade da tese busca ilustrar e fundamentar os preceitos analíticos e reflexivos posteriores. 


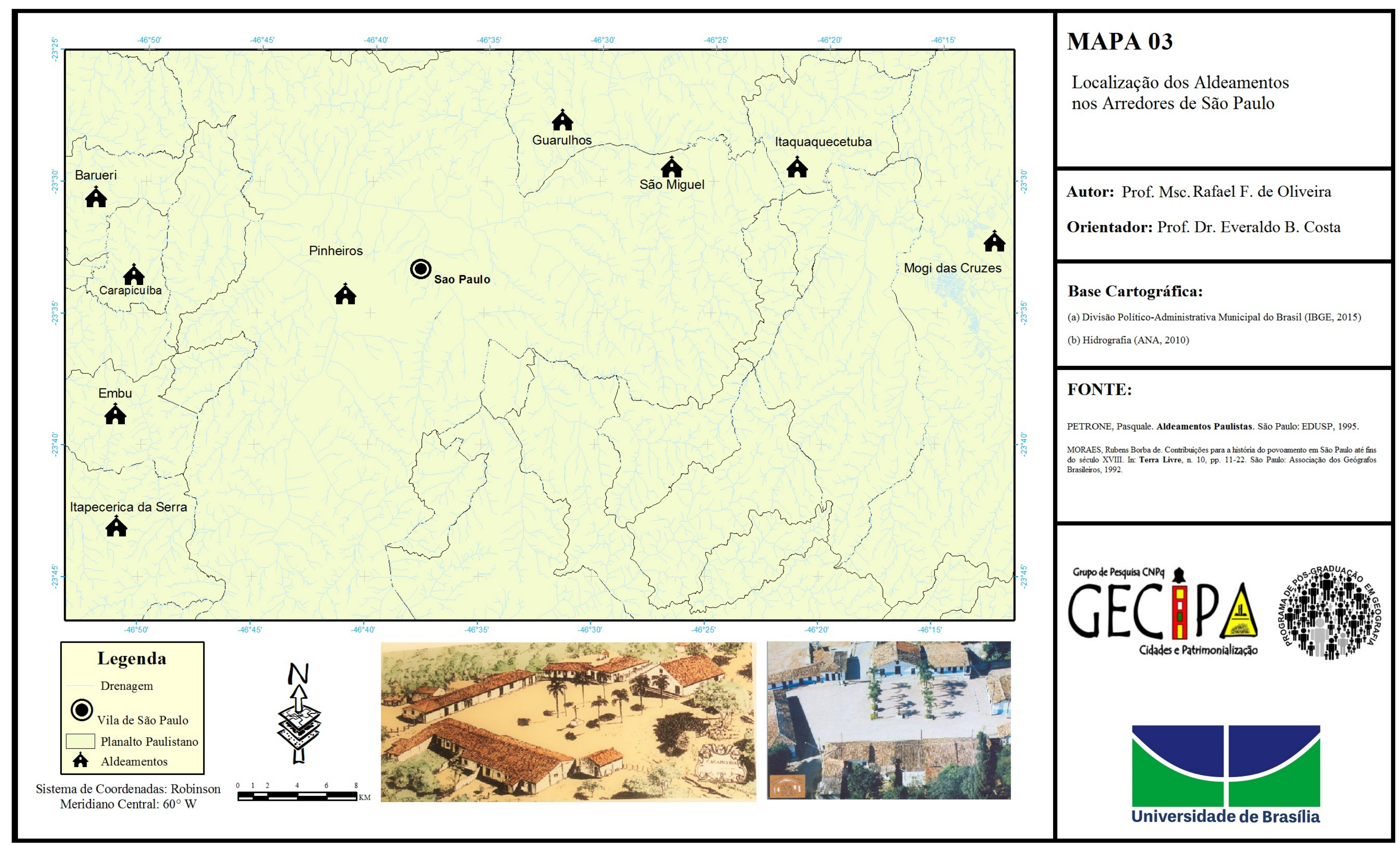




\subsection{Notas acerca dos primeiros núcleos, vilas e cidades no Brasil}

Os primeiros momentos da formação territorial brasileira (ciclos de assentamento e o bandeirantismo), trazem dois efeitos cruciais ao desenvolvimento dos grandes ciclos econômicos. A primeira, sem dúvida, compreende o conhecimento sobre o território, com a consolidação de bases e pontos de interiorização. A segunda, que deriva deste saber, precisa as localizações das fontes de recursos metal-minerais e leva a cabo as expansões produtivas agropecuárias (principalmente a exploração do ouro em Minas Gerais e Goiás e instalação da cultura canavieira no nordeste e sudeste da costa atlântica), que acabaram por romper as barreiras contratuais na divisão territorial-colonial estabelecida entre Portugal e Espanha no Tratado de Tordesilhas e, pois, a da própria ampliação física territorial do Brasil e o “estreitamento" das posses hispânicas. Depois, mas não menos importante, altera-se o raio de ação do colonialismo português da África e Ásia para a América, especialmente para Pernambuco e São Vicente. Aí se pronuncia o alicerce efetivo das raízes da formação colonial brasileira, muito bem apontada por Gilberto Freyre (1996 [1936]):

\footnotetext{
Organizada a sociedade colonial sôbre base mais sólida e em condições mais estáveis que na Índia ou feitorias africanas, no Brasil é que se realizaria a prova definitiva daquela aptidão. A base, a agricultura; as condições, a estabilidade patriarcal da família, a regularidade do trabalho por meio da escravidão, a união do português com a mulher índia, incorporada assim à cultura econômica e social do invasor (FREYRE, 1996 [1936], p. 05).
}

Em relação às vilas e cidades quinhentistas, estas eram fruto de uma organização proto-urbana, orientadas pelas leis reais, mas determinadas sobremaneira pelas forças da natureza e da pré-estrutura de caminhos, núcleos e conhecimentos indígenas. As localizações limitadas às regiões costeiras justificam-se não apenas às ameaças, mas ainda pela dificuldade de extravasar a escarpa serrana, como a densidade da mata atlântica. Azevedo (1992) então regionaliza três grandes áreas de aglomerações no período quinhentista brasileiro, todas litorâneas: (a) Região Vicentina; (b) Região Pernambucana; (c) Região Bahiana. Nesses primeiros núcleos de cidades, a união entre Estado e Igreja "desempenhou papel fundamental na fundação e na elaboração de políticas urbanas" (GODOY; BRAY, 2005, p. 188). Mesmo que evidenciada a ligação entre ambos na gênese destes núcleos, segundo Murilo Marx (1991) tal fato permaneceu esquecido, ou bastante desconsiderado. É certo que tanto a constituição das vilas e cidades, como das práticas urbanísticas realizadas, tiveram influência direta dos modelos praticados na península ibérica, numa certa coesão de funções exercidas entre Estado e Igreja (DEFFONTAINES, 1944; AZEVEDO, 1957; REIS FILHO, 1968; MARX, 1980; 
1991; IANNI, 1996; GODOY; BRAY, 2003). Além destes, “(...) também a população estabeleceu e procurou oficializar novos povoados, não só acatando instrumentos normativos eclesiásticos, como utilizando-os para garantir e ampliar seu lugar ao sol” (MARX, 1991, p. 17). Essa coalização tripartite (coroa-colonizador-igreja), permitiu a concretização primeira da estratégia do projeto imperial e seu financiamento, segunda da apropriação e exploração das riquezas, a terceira da fundamentação e harmonização legitimadora. Vilas e cidades são geradas como condições centrais deste processo, destinadas aos civilizados, aos negócios e a religião. Às margens, os nativos indígenas correspondiam os aldeamentos e seu entorno próximo, lugares de exceção, cativeiros, que estavam distantes socialmente do campo ou da cidade, mas estrategicamente postos aos propósitos de sustentação de cada subunidade destes outros espaços.

No século dezessete, novas aglomerações passam a ser produzidas em áreas de interior, ao sul e destacadamente em São Paulo. Ianni (1996) ressalta a mescla e assimilação de técnicas e soluções indígenas, ou a reformulação daquelas trazidas pelos portugueses, no confronto com a cultura indígena e que principia a tradição caipira que se estenderia a todo sertão brasileiro (IANNI, 1996, p. 18). Além das três cidades e das quatorze vilas criadas no século dezesseis, agora no dezessete somam mais quatro povoados que ganham título de cidades: São Luís (MA), Cabo Frio (RJ), Belém (PA) e Olinda (PE) ${ }^{20}$. Constituem, pois, até o fim deste mesmo século um total de cinquenta e cinco o número de vilas e de sete cidades no Brasil. Assim também, a regionalização dos aglomerados se reconfigura e passa para três grandes áreas ou eixos: (a) Eixo PE-BA (Nordeste); (b) Eixo RJ-SP (Sudeste); (c) MA-PA (Norte). Destaque para maior concentração populacional em São Paulo, ao mesmo tempo com maior quantidade de vilas, totalizando 17 ou 33\% do total (AZEVEDO, 1992). No entanto, no período, as maiores cidades brasileiras não chegam a cinco mil habitantes. A maior cidade era a de Salvador (“capital da Colônia" com 8.000 habitantes), depois Rio de Janeiro, Recife e Olinda, que possuíam expressividade populacional (aproximadamente 3.000 a 4.000 habitantes), São Paulo possuía à época por volta de 2.000 habitantes (AZEVEDO, 1992). Este quadro de relativa estagnação dos aglomerados populacionais brasileiros seria dinamizado nos séculos seguintes, com a efervescência econômica de algumas regiões, proporcionada pela alta produção agrícola, a mineração no interior de Minas Gerais e, fundamentalmente, as

\footnotetext{
${ }^{20}$ Como explica Abreu (1997, p. 214) "A diferenciação entre vilas e cidades era, pois, de caráter jurisdicional e não hierárquico. [...] O status de vila não diminuía importância de um centro urbano”.
} 
demandas emergentes do mercado externo e da nova realidade despertada pelos princípios da Revolução Industrial na Europa.

O século dezoito, apesar da interiorização colonial, teve a criação de poucas cidades, no total de três: São Paulo (SP), Mariana (MG) e Oeiras (PI). As vilas, porém, se multiplicam, junto com várias aglomerações e pequenos povoados ligados aos seus respectivos hinterlands. De maior relevância, no entanto, é a mudança do eixo regional político-administrativo e econômico de Salvador para o Rio de janeiro, sobretudo em razão da importância do centro aurífero de Vila Rica. Com base em Azevedo (1992), nestas áreas auríferas ${ }^{21}$ se entulhavam todo o tipo de aventureiro e "[...] em menos de 50 anos havia atingido a população que o Rio de Janeiro levara dois séculos para alcançar.” (AZEVEDO, 1992, p. 51). A importância geopolítica do Brasil para a sobrevivência de Portugal era tamanha que resultou na ideia do império "luso-brasileiro" no final do mesmo século. "Essa 'interiorização da metrópole' atuou em vários processos da formação brasileira, entre eles o de afirmação de uma identidade da colônia (agora alçada à situação de 'reino unido' a Portugal)" (MOARES, 2005, p. 112). O que com a decadência posterior destas cidades, comportará a permanência das mais preciosas rugosidades patrimoniais eleitas e ligadas ao barroco-rococó e direcionará a valorização, perpetuando nestas unidades e fragmentos coloniais símbolos representativos do patrimônio cultural brasileiro. Se um bem só é especial e representativo frente a outro comum e pouco expressivo, a dialética do valor, de uso ou troca, se é que possível separá-los, será dada numa dimensão patrimonial de inclusão-exclusão, que no Brasil incluiu os bens materiais, sobretudo os maiores, institucionais ou das oligarquias nacionais, bem como da etnia branca e num contexto de gênero decisivamente masculino - ponto que será mais dedicado à terceira parte da tese.

As transformações na rede urbana brasileira no século dezoito (interiorização, criação de novos povoados e adensamento dos núcleos pré-existentes) evidenciam uma nova política econômica em curso na Colônia, em que a cidade ganhava cada vez mais centralidade na regulação do império português sobre as riquezas extraídas da terra. Explica Freyre (1996) que é em São Paulo e nas Minas onde se faz sentir maior a exploração das riquezas pelo império português no período. Não apenas o legado da atual rede de cidades, ou mais propriamente dos fatos associados ao fenômeno urbano, o século dezoito deixa profundas

\footnotetext{
${ }^{21}$ Apesar da centralidade de Minas Gerais, “a base geográfica da economia mineira estava situada numa vasta região compreendida entre a serra da Mantiqueira, no atual Estado de Minas, e a região de Cuiabá, no Mato Grosso, passando por Goiás." (FURTADO, 1971 [1959], p. 78).
} 
rugosidades do que se instituiria por cultura nacional. Ribeiro (2006 [1995]) delineia com precisão o sentido de constituição das cidades no Brasil ao longo do período colonial, como um movimento civilizatório, com um modo específico de pensar, agir e, portanto, de ser a partir da empresa do extrativismo, agrário-mercantil sob controle e da ordem metropolitana europeia e das instituições religiosas.

\begin{abstract}
Essas cidades e vilas, grandes e pequenas, constituíam agências de uma civilização agrário-mercantil, cujo papel fundamental era gerir a ordenação colonial da sociedade brasileira, integrando-a no corpo de tradições religiosas e civis da Europa pré-industrial e fazendo-a render proventos à Coroa portuguesa. Como tal, eram centros de imposição de ideias e das crenças oficiais e de defesa do velho corpo de tradições ocidentais, muito mais que núcleos criadores de uma tradição própria (RIBEIRO, 2006 [1995], p. 181).
\end{abstract}

Como assinala Prado Júnior (1972 [1945]) mesmo com a independência em 1822, a era colonial para o Brasil praticamente se encerra em 1808, com a chegada da família real no Rio de Janeiro. Esse fato faz com que o Rio de Janeiro tome outros contornos, que trará a seu entorno grande centralidade político-administrativa, do qual terá detalhamento adiante o caso de São Paulo. A criação na Colônia de 3 cidades e 118 vilas no século dezoito (AZEVEDO, 1992), além da expansão ao interior do território, ainda contrastam com a desintegração, concentração dos núcleos nas áreas costeiras e irregularidade de povoamento entre áreas produtivas específicas: principalmente gado, ouro e cana-de-açúcar (PRADO JUNIOR, 1972 [1945]). No século dezenove entre a transição de Colônia, Reino Unido e Império, há criação de duas cidades interiorizadas apenas nas duas primeiras décadas, no Centro-Oeste: Cuiabá e Goiás Velho. Antes da independência (1822) são doze cidades no Brasil: Porto Alegre em 1822 é elevado a cidade. Mais seis cidades são criadas logo após a independência (1823): Ouro Preto (MG), Recife (PE), Natal (RN), Florianópolis (SC), Fortaleza (CE) e Aracaju (SE). Para Azevedo (1992), as cidades brasileiras no período colonial tiveram basicamente três funções: função político-administrativa (da Coroa sobre o território colonial), função comercial (nem sempre baseado no sistema mercadoria-dinheiro, mas de escambos, permuta de serviços e favores) e religiosa. A industrialização foi proibida, o que acabou por não ser significante neste período. Para o autor, mesmo o Brasil sendo um país colonial, com grandes dimensões e onde as populações indígenas possuíam outro estágio de desenvolvimento, houve a criação de muitas cidades, vilas e povoados (Quadro 02). 


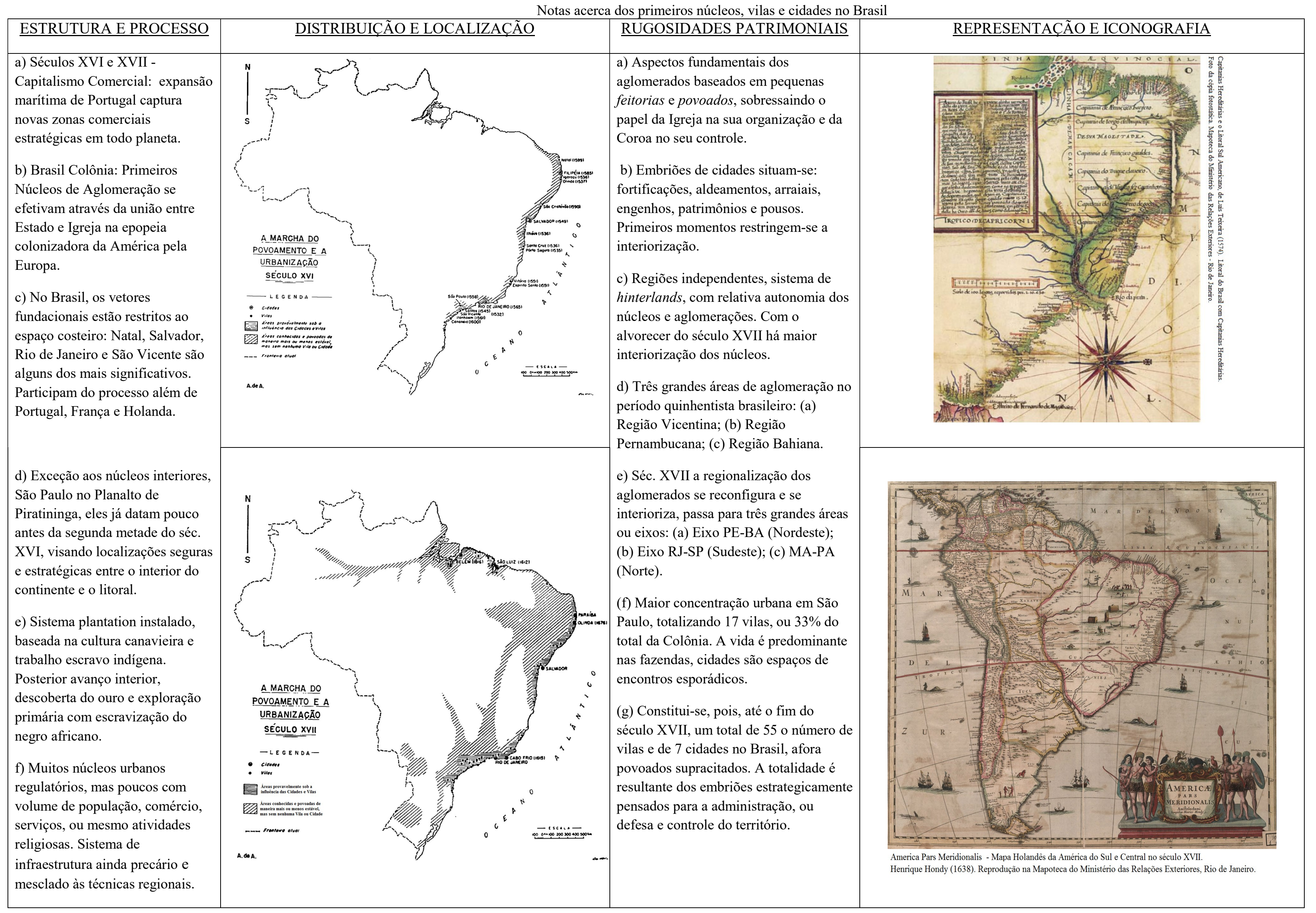




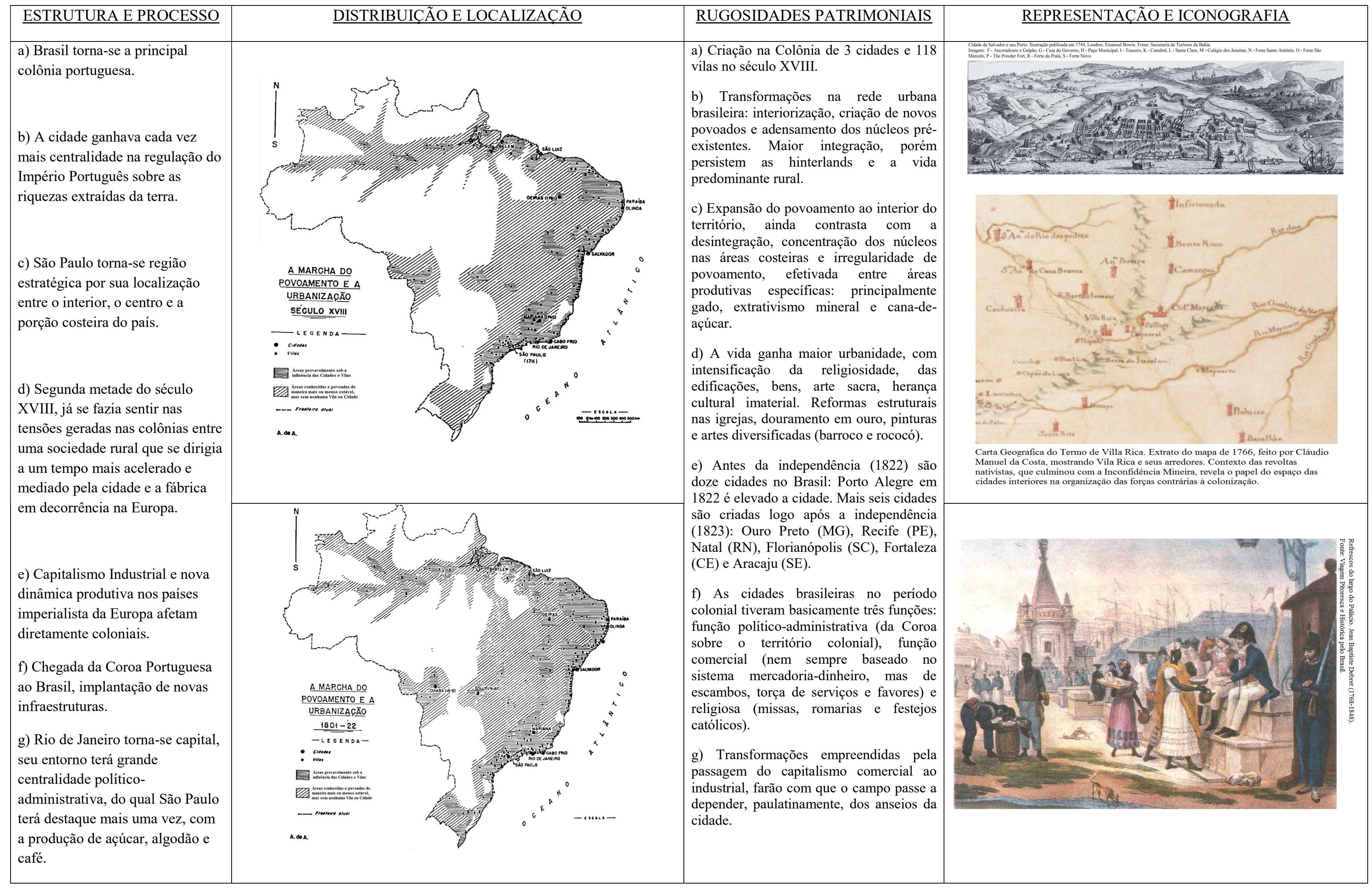

Quadro 02: Povoamento e urbanização no Brasil Colonial.

Fonte: Prado Júnior (1971[1942]), Azevedo (1992), Reis Filho (1968), Furtado (1971 [1959]). Organizado pelo autor, 2015. 
Estas unidades, em termos institucionais, são as que melhor caracterizariam uma ordem normativa tipicamente ordenada, de um capitalismo primitivo e de características comerciais, em que as cidades ou núcleos de adensamento com funções administrativas é quem irão regular as atividades, desde a defesa até os impostos pelos produtos extraídos. Como defende Abreu (1996), apesar das polêmicas em torno das funções da cidade neste período, deve-se relativizar pontos de vista que desprezam estes espaços como centros de controle do território pela $\mathrm{Coroa}^{22}$, bem como que sua estrutura não seria fruto de planejamento (Sergio B. de Holanda em Raízes do Brasil dá vários indícios da aleatoriedade da produção da cidade colonial no Brasil). "Os controles exercidos pelo Estado Português não se limitaram, entretanto, às questões do plano da cidade. Eles fizeram-se sentir também em outras dimensões da vida urbana, ainda que isto não seja muito aparente à primeira vista." (ABREU, 1996, p. 155). Deve-se ressaltar que os meios de controle exercidos sobre a colônia pela Coroa portuguesa decorrem de um contexto onde o tempo de difusão das informações era outro. Compreensível é que muitas soluções adotadas na estrutura dos núcleos urbanos fugissem da regulação direta da Coroa, já que os imperativos cotidianos exigiam intervenções instantâneas da administração local. Fato que não significa, necessariamente, que seus representantes deixassem de lado as orientações estruturais vindas da Europa. Não se tratava, como quer Bruand (1981, p. 325), de "deixar guiar pela natureza dos locais" ao exemplificar a ocupação de áreas de várzea desde o Brasil Colônia.

Numa síntese, conforme Godoy e Bray (2003, p. 188), o empreendimento colonizador implicava justamente no desenvolvimento de uma expansão territorial calcada na maximização das possibilidades de exploração dos recursos naturais. A busca por riquezas em áreas extremas da colônia portuguesa na América levou a constituição futura de uma série de núcleos populacionais em margens de rios e, principalmente, na costa litorânea. Fundaram nessas terras um modelo agro-exportador, sistema extrativo - minérios, madeiras e o trabalho escravo indígena e, posteriormente, africano. Uma organização que colapsou a ordem territorial primitiva e traçou um projeto ocidental e imperialista na América, que ativamente dará sustentação necessária à formação dos grandes Estados-nações contemporâneos. Criticamente, para Prado Jr. (1971 [1942]) “se vamos na essência de nossa formação, veremos

\footnotetext{
22 Yves Bruand no clássico "Arquitetura Contemporânea no Brasil” (1981), desfecha sua obra analisando historicamente a estrutura urbana das principais cidades brasileiras. Neste ínterim reforça algumas noções de aleatoriedade e espontaneidade de natureza local na regulação do tecido urbano colonial, ideias tomadas principalmente de Sergio Buarque de Holanda, mas bastante questionadas por Reis Filho (1968) e Abreu (1996), entre outros autores e as quais somos propenso criticamente a defender.
} 
que na realidade nos constituímos para fornecer açúcar, tabaco, alguns outros gêneros; mais tarde ouro e diamantes; depois algodão, e em seguida café, para o comércio europeu. Nada mais que isto." (1971, p. 26). O Brasil carrega sim a particularidade do processo colonial, isso no entanto nos faz relativizar a ideia de "povo novo" (RIBEIRO, 2006 [1995]) na qual Moraes (2005) entende que “[...] a edificação de algo novo do que a apropriação de uma estrutura preexistente, como em outras partes do mundo colonial e da própria América", pois o que veremos é que mesmo prevalecendo a supressão de grande parte das rugosidades précolombianas, a estrutura primitiva serviu compulsoriamente de apoio incondicional e desarmônica da criação desse "povo novo" que se denominou ao brasileiro (acumulando e superpondo formas-conteúdos).

\subsection{Sistema de aldeamentos e a colonização do planalto paulistano}

Ao longo da colonização portuguesa da América, a concentração das cidades, vilas e outras unidades territoriais de apoio político-administrativo, realizou-se na faixa litorânea continental, até aproximadamente cem quilômetros do mar, a depender da extensão e dos recortes da planície costeira. Lembrando a clássica frase de Frei Vicente do Salvador, Pereira (2014, p. 03 - grifo nosso) explica que "diferentemente dos espanhóis na América, os portugueses contentavam-se com 'arranhar as terras ao longo do mar feito caranguejos', limitando-se a permanecer e defender o espaço ocupado da faixa litorânea". A ocupação colonial do Brasil por Portugal, desenvolvida nesta porção do território, evidencia o primitivo "controle metropolitano" da Colônia, articulando desde então as relações multiescalares que se faziam verticalmente do poder global ao local.

O planalto paulista foi uma exceção à regra, já que para além da faixa litorânea, se constituiu ali uma incipiente organização colonial, ainda no século dezesseis. Este empreendimento arrolado pelo colonizador e o sucesso que dele resultou na maior aglomeração humana do hemisfério sul do planeta, é o princípio condicionante do arranjo urbano e do embrionário sistema de cidades nesta região (PETRONE, 1995; 1998; AZEVEDO, 1992; MORAES, 1992). As primeiras formas de ocupação no interior do território americano pelos portugueses, estava baseada em pequenas feitorias ${ }^{23}$ e povoados,

\footnotetext{
${ }^{23}$ Ao longo da organização da tese nos esforçamos em usar denominações próximas das atuais, buscando evitar confusões ou a excessiva discussão terminológica existente ontem e hoje. Neste caso, feitorias eram pequenos núcleos de povoamento, com formas de galpões rústicos, envoltos a estacas. Suas funções restringiam-se ao
} 
sobressaindo inicialmente a organização de aldeamentos, núcleos formados por indígenas em áreas coloniais administradas por jesuítas, ou outras ordens religiosas, como a dos capuchinos - sendo estas uma das "sementes embrionárias" na gestação das vilas e cidades brasileiras (AZEVEDO, 1992).

Conforme Petrone (1995), os primeiros aldeamentos no planalto paulistano associamse à conformação colonial, onde as ação dos padres jesuítas, em sua missão catequizadora, complementavam os desígnios de apropriação e exploração do território pela Coroa. Se estendendo ao longo do planalto, possuíam relações complexas entre si, ora fundados por iniciativa de colonos com a intermediação da Companhia de Jesus, ora pelos próprios jesuítas e outras ordens religiosas, ou ainda doados a estes e pelos primeiros através dos regimes do padroado real (PEREIRA, 2014, p. 07). Na verdade, um e outro interesse se conjugam, fundidos, são oficialmente instituídos em São Paulo por meio de Nóbrega e Anchieta, além do governo de Men de Sá na criação posterior do "Regime das Missões". Os esforços dos colonos são destacados, desde as alianças estabelecidas, passando pelo preamento e aprisionamento, além do transporte dos nativos desde os limites do novo território. Em suas propriedades no planalto continuavam o empreendimento, agora de confinar e, com apoio religioso, cativar os indígenas que serviriam aos seus projetos, na forma de trabalho compulsório.

\footnotetext{
Segundo tudo faz indicar, os primeiros aldeamentos a se definirem foram os localizados mais próximos a São Paulo, ou, então, no litoral vicentino. Isso, apesar de a primeira tentativa mais séria no sentido de aldear os indígenas ter sido feita em um ponto impreciso, mas indiscutivelmente distante, como Maniçoba. É natural que eles se definissem em função do próprio processo de colonização, e fossem sendo criados à medida que este se expandia e se estabilizava. Sendo São Paulo de Piratininga o centro mais significativo desse processo no planalto, compreende-se que a política de aldear tenha frutificado antes nos seus arredores (PETRONE, 1995, p. 113).
}

Diferentemente das aldeias indígenas, os aldeamentos são unidades territoriais conjuntamente administradas pelo Estado (Coroa) e a Igreja (AZEVEDO, 1957; 
ESCALANTE, 1981; MORAES, 1992; PETRONE; 1995) ${ }^{24}$ e em certa medida pelo colono que destina parte de suas terras para esse fim e passa a obter certo poder sobre eles. Em relação comparativa às missões, os aldeamentos não estavam isolados como elas, sendo esta a principal característica diferenciadora apontada por Azevedo (1959 apud PETRONE, 1995). No entanto, Saia (1937) evidencia que mesmo havendo a preocupação dos jesuítas de que os índios estivessem separados dos colonos, esse fato em São Paulo parece ter sortido efeito parcial. O papel dos colonos (incluindo os bandeirantes) possui centralidade nas administrações. Mesmo os aldeamentos, provavelmente, surgindo sobre antigas estruturas das aldeias originais (superposição de formas-conteúdos), inclusive no mesmo sítio e utilizando dos conhecimentos primitivos locais, denota uma organização já criada e administrada pelo colono, pelo jesuíta e outros grupos religiosos. Tanto que para Pereira (2014, p. 07) tornam-se espaços com importante função produtiva e de acumulação, além de condutas impositivas e verticais no controle do espaço e das diferentes etnias que ali eram aglomeradas.

Por isso, aldeamento não é aldeia. A terminologia aldeamento "avança" da qualidade de aldeia. Aldeia, no contexto colonial, remete a uma toponímia carregada de significado pejorativo, associado ao índio, ao retrógrado e oposto do civilizado (PETRONE, 1995). Ainda neste contexto, o aldeamento transcende a aldeia e remete a um processo de conversão profunda, em que os preceitos de civilidade pela religião católica são centrais. A compreensão dessa passagem da aldeia ao aldeamento, é essencial pela supressão da primeira em favor dos conteúdos que permearão as superestruturas impostas nos sentidos de trabalho, família e religião, além dos novos modos de viver aos índios brasileiros. Infelizmente, poucos são os estudos analíticos a retratar esses núcleos de exceção (até mesmo pela condição perversa de sua prática, da dificuldade documental, das dimensões temporais...), o que gera inquietações, já que se considera esta uma das formas de organização mais duradoura no Brasil - iniciada nos primórdios da colonização e só abandonada em princípios do século dezenove (PETRONE, 1995).

Deve-se reafirmar que, além da sua longevidade, o aldeamento não implica numa significação positiva da permanência (já que se considera este um espaço de exceção), mas da

\footnotetext{
${ }^{24}$ Conforme o Atlas Digital da América Lusa, é possível a distinção de ao menos três sentidos do termo "aldeia" nas fontes do período quinhentista: (a) o primeiro relacionado às "tabas" - conjunto de casas construídas, administradas e ocupadas exclusivamente pelos índios; (b) o segundo sentido de "aldeia" já com a presença de ermidas, em que eram visitadas regularmente pelos padres; (c) o terceiro se caracteriza mais propriamente ao aldeamento de que tratamos, ou seja, definido pelas autoridades coloniais.
} 
própria superposição que condicionou à Grande São Paulo nestes territórios, além da permanência acumulada na metrópole de um conjunto de rugosidades mais específico e singular em Carapicuíba. Exatamente, estes conhecimentos, bem como as permanências, justificam as forças do empreendimento colonial na fase de assentamento em São Paulo (ao longo dos séculos dezesseis e dezessete), que nos campos de Piratininga foram protuberantes nos quadros da formação territorial do Brasil. Não se trata exclusivamente da origem das rugosidade patrimoniais de Carapicuíba, mas de diversas cidades que hoje compõe a região metropolitana de São Paulo e, de forma universal, das localidades que se formaram deste epicentro e que substanciaram futuramente a região como a de maior centralidade econômica do país.

Esses preceitos de superposição são referenciados por Moraes (1992), minuciosamente apontando como os assentamentos coloniais foram justapostos às aldeias indígenas. Fato confirmado criticamente por Petrone (1995), ao mostrar que apesar da sazonalidade do habitat das tribos, que ocorriam por volta de mudanças que se verificavam em torno de quatro anos aproximadamente, elas eram restritas a um determinado território, uma área comum de onde tiravam seu sustento e satisfaziam suas necessidades, assim como estabeleciam contatos e relações com outras comunidades por meio de uma rede de caminhos e trilhas. As mudanças deste sistema, mudam todo o plano de vida do nativo, suas relações com o meio, o colocando em risco e suscetibilidade frente à nova realidade imposta pelos invasores. Para Ribeiro (2006 [1995]), seria essa uma das principais razões da mortandade de grande parte do indígena naquele período, que perde as referências comunitárias, a capacidade de subsistência e as práticas culturais que perpetuavam sua reprodução.

\footnotetext{
Os gêneros de vida que caracterizavam os grupos indígenas explicam a mobilidade. Esta se verifica, entretanto, para cada grupo, dentro de um espaço que poderia ser considerado como sua área de subsistência. No espaço compreendido pelos limites necessariamente pouco precisos dessa área de subsistência, alguns pontos teriam se tornado, por uma seleção, fruto da experiência, sítios de eleição para as aldeias. Não que fossem utilizados com continuidade, mas geralmente utilizados com um caráter de permanência no sentido de que a espaços de tempo voltariam a ser aproveitados. O papel do colono, em alguns casos, teria sido o de tornar contínua aquela permanência que antes era intermitente. Aliás, no caso, seria preferível falar em permanência de áreas com vocação cristalizadora do povoamento, dentro das quais eram escolhidos os sítios (PETRONE, 1995, p. 110).
} 
Estes núcleos são estratégicos ao empreendimento colonial, o que põe abaixo qualquer defesa ortodoxa de aleatoriedade na ocupação dos territórios americanos ${ }^{25}$. O empreendimento serra acima tinha importante fundo estratégico que justifica tamanho esforço numa união difusa entre interesses econômicos, políticos e ideológico-culturais que permeiam o colonialismo, o capitalismo comercial, a expansão da religião cristã e seus respectivos sistemas significativos de crendices e moral. O sistema de aldeamento é expressão desses esforços ligados a múltiplos interesses, que surpreendem os desafios travados pelo colonizador no território em condições naturais e de resistências sociais pouco favoráveis. A primeira destas dificuldades residia na diferença topográfica - do nível do mar à escarpada serrania, que sobe abruptamente alcançando mais de 800 metros de altitude entre litoral e planalto cristalino. A segunda, pela presença de uma natureza pouco receptiva, que se esparrama nas grandes declividades do terreno e sob constante controle e ofensivas indígenas. Terceira, a ausência de infraestrutura e condições técnicas de avanço, ainda que algumas trilhas já existissem elas eram controladas e ofereciam riscos. Nesse processo, o papel da Coroa portuguesa é fundamental ao patrocinar a colonização e ter na função do aldeamento pela Igreja uma vinculação idealista com os propósitos de catequização do índio, escamoteando a escravização que já se afirmava sobre o nativo (PETRONE, 1995 p.126). E isso não se efetivou sem o posterior conflito entre os mesmos interesses da Igreja, a Coroa e colonos, convergindo, inclusive, com a expulsão dos jesuítas de São Paulo por um período no século dezessete e, ainda que não declarada, a contínua e gradativa escravização do índio, utilizado tanto na interiorização, no preamento de mais pares e, pois, na exploração metalista, conforme argumenta Bueno (2009).

Esse estímulo a interiorizarem-se no sertão, em busca de metais preciosos e escravos, gerou intermináveis conflitos com a Companhia de Jesus, que dominava, na época, vastos territórios subtraídos da jurisdição metropolitana, administrando-os economicamente de maneira autônoma, conforme seus próprios interesses. Tendo como fundamento assegurar a "liberdade" do índio, os jesuítas subtraíam abundante mão-de-obra, contrariando brutalmente os interesses metropolitanos de então. $\mathrm{Na}$

\footnotetext{
25 Como defende Abreu (1996), apesar das polêmicas em torno das funções dos núcleos coloniais neste período, deve-se relativizar pontos de vista que desprezam estes espaços como centros de controle do território pela coroa, ou que sua estrutura não seria fruto de planejamento (Sergio B. de Holanda em "Raízes do Brasil" dá vários indícios dessa aleatoriedade). Deve-se ressaltar que os meios de controle exercidos sobre a colônia pela coroa decorrem de um contexto onde o tempo de difusão das informações era outro. Contextualizado isso, compreensível é que muitas soluções adotadas na estrutura dos núcleos fugissem da regulação direta da coroa, já que os imperativos cotidianos exigiam rápidas intervenções/soluções da administração local, que sugere inclusive apropriação técnica dos grupos indígenas. Isso não significa, necessariamente, que seus representantes deixassem de lado as orientações estruturais vindas da Europa. Não se tratava, como quer Bruand (1981, p. 325), de "deixar guiar pela natureza dos locais" ao exemplificar a ocupação das áreas de várzea desde o Brasil Colônia.
} 
década de 1620, agudizou-se o antagonismo. Em 1624, os paulistas destruíram algumas aldeias e reduções jesuíticas. De 1630 a 1635, fizeram novas incursões ao Paraguai. Sedes de colégios dos padres jesuítas - no Rio de Janeiro, Santos e São Paulo - vivenciaram violentos motins, que culminaram com a expulsão dos padres de São Paulo e Santos. Regressaram a São Paulo em 1640 e 1653; no entanto, em 1658, os paulistas voltaram a atacar as missões do Paraguai. A sociedade civil paulista, ansiosa por viabilizar a colonização mesmo às custas da escravização dos indígenas, pôs-se em luta contra o Estado teocrático aqui estabelecido. Como deixariam de entrar em conflito, em tempos de crise, se já no século XVI tantas vezes os interesses e orientações dos missionários chocavam-se com aqueles dos leigos, colonos e mercadores. A crise de todo o império hispano-português agravou tensões e desencadeou enfrentamentos (BUENO, 2009, n.p.).

Como argumenta Moraes (1992) os primeiros povoadores europeus derivam de aventureiros e náufragos que já se estabeleciam no litoral e áreas de serra acima antes mesmo da missão de Martin Afonso chegar ao continente. Estes, portanto, já encontraram certa organização espacial que subsidiou parte do empreendimento colonial posterior. A missão de Martin Afonso não foi a de fundar um núcleo de povoamento, mas de aproveitar daquilo que já existia, ou seja, “(...) de se servir da base, de lhe dar uma vida oficial e localizar dentro desses núcleos os povoadores importados. Não é fundador, é colonizador.” (MORAES, 1992, p. 13). Para Petrone (1995), aqui de forma muita sintética, o empreendimento colonial planáltico, fundamentalmente nos campos de Piratininga, conduzido entre Estado e Igreja, justifica-se pelo: (i) estabelecimento de localizações estratégicas entre o interior do continente (cabeça do antigo caminho do Peabiru) visando a descoberta de riquezas minerais, e entre o litoral para o escoamento e comercialização dos produtos extraídos; (ii) não menos importante é a apropriação de solos e terrenos em maior quantidade e mais propícios para o desenvolvimento da grande lavoura monocultora (que o autor supracitado designa de plantages ${ }^{26}$ ); (iii) por fim, o interesse na doutrinação, no apresamento e escravização indígenas (força de trabalho no apoio à prospecção de riquezas, na lavoura e nos embriões de povoamento: aldeamentos, arraiais, pousos). Para isso cabe pensar na necessidade de proteção desses novos núcleos maiores que se estabelecem em favor do que é pontuado, gerando uma hierarquia sobre eles, onde os aldeamentos teriam estratégica função de defesa e sustentação.

\footnotetext{
${ }^{26}$ Ao longo do trabalho designamos de plantation, em razão da usualidade terminológica atual, compreendida como uma estrutura produtiva calcada no tripé: monocultura, grande extensão de terra (latifúndio) e força de trabalho escrava - que irá perdurar desde então até os dias atuais em grande parte do território brasileiro e é onde reside os maiores problemas agrários contemporâneos.
} 
Quanto ao primeiro e terceiro fatos, da geografia estratégica e da densidade demográfica, talvez sejam estes elos fundamentais na fase de assentamento que explicam diretamente a fundação e desenvolvimento de São Paulo e, de alguma maneira, de sua atual condição concreta de região metropolitana. Visto que o planalto paulistano em princípios da ocupação era densamente habitado por tribos indígenas, destacadamente os grupos Tupinambá, Tupiniquim e Carijó, que seguiam para a costa sazonalmente em busca do pescado e, pois, estabelecendo caminhos e trilhas que faziam destas duas áreas uma interconexão dinâmica de fluxos e relações. São estes mesmos caminhos os utilizados pelos invasores para depois estabelecerem as rotas das monções pelos cursos de rio, do apresamento indígena e a corrida do ouro e pedras preciosas, no sentido de oeste para o Mato Grosso, ao norte para Goiás e Minas Gerais, ao sul com as tropas e o comércio de muares no sentido de Sorocaba.

Esse espaço fazia parte de um fluxo de tráfico que envolvia, também, espanhóis e precisava ser coibido. Estaria ai a razão para o apoio a fundação do colégio, à transferência do pelourinho, já em 1560, com a elevação do povoado a Vila de Piratininga de São Paulo respondendo a necessidade de instituir um espaço de controle para o controle do espaço e das pessoas que ali viviam. A criação dos aldeamentos indígenas foi um espaço que também reforçava essa interpretação porque não se dissociava desses conflitos entre colonos e jesuítas pela mão-de-obra indígena dentro do projeto metropolitano português, que precisava de braços para o trabalho compulsório e, cada vez mais, de terras disponíveis para a viabilização dos seus empreendimentos comerciais. $\mathrm{O}$ aldeamento atraia e disciplinava o indígena para o trabalho e, simultaneamente, destribalizava as suas terras criando disponibilidade de ambos os elementos ao controlar as pessoas e o espaço, que passavam a ser disciplinados e organizados para a produção (PEREIRA, 2014, p. $06)$.

De tal maneira que a conquista desta posição inter-planáltica pelos colonos e jesuítas se deu na distribuição de aglomerados circundantes ao centro principal que era São Paulo (Mapa 04), tornado vila desde 1560. Tal como esclarece Petrone (1995), esta distribuição de núcleos populacionais, sobretudo de indígenas vivendo em redutos de aldeamentos, tiveram funções estruturantes que cristalizaram o povoamento dos campos de Piratininga (PETRONE, 1995, p. 126). É neste contexto que, em termos de localização geográfica, esta região se tornaria um estratégico espaço de interconexão entre interior e litoral, mas também em outras direções como já citado. Ou seja, da anexação de novos territórios, de mais força de trabalho, de mais riquezas e recursos obtidos, como também de uma estreita ligação com o plano internacional, do fluxo interoceânico, de expansão do comércio ultramarino, de comunicação 
com a metrópole e com os primitivos processos de globalização ${ }^{27}$. A interiorização da colônia teve no papel do apresamento indígena um dos fatores mais importantes nos dois primeiros séculos da conquista portuguesa. O aldeamento era o cativeiro capaz de discipliná-lo, armazená-lo e, gradativamente, aproveitá-lo aos seus interesses. Perpetuava-se, assim, a consolidação do modelo colonial português em São Paulo e, mais generalizadamente, no Brasil em construção.

\footnotetext{
Os primeiros colonizadores, sobretudo os vindos com Martim Afonso, obtiveram sesmarias e, nelas, aos poucos criaram agrupamentos, e os agrupamentos geraram a necessidade de auxílio espiritual (necessário para aqueles homens estabelecidos em universo tão inóspito). Assim foram fundadas as primeiras povoações no planalto além da vila de São Paulo de Piratininga.” (BUENO, 2009, n.p.).
}

Se na atualidade São Paulo torna-se geograficamente elo articulador de grandes estradas, trilhos, portos e dos principais fluxos aéreos, estas vias estão justapostas aos muitos caminhos e trilhas já estabelecidos primitivamente no território pelas diferentes etnias indígenas. Na retrospectiva de Petrone (1998) acerca da trilha dos Tupiniquins, este observa a polivalência tanto para os primórdios da colonização portuguesa, quanto para atualmente das interligações de São Paulo a São Vicente, ou a metrópole nacional ao maior porto do país.

O paralelo acerca da rede de transporte atual e do contexto dos vetores fundacionais, no limite com o ciclo de assentamento, pode ser transposta ainda aos diferentes contextos produtivos, que perpassam a monocultura canavieira (cujo auge em São Paulo varia entre $1750-1850)^{28}$ e que antecipa a cultura do café em São Paulo no século dezenove e a modernização do território brasileiro. "Na verdade os primeiros e principais eixos de comunicação definem-se a partir de caminhos abertos pelos indígenas, a partir de tênues trilhas de pé-posto. [...] O primitivo caminho define-se a partir desses elementos" (PETRONE, 1998, p. 56).

\footnotetext{
${ }^{27}$ A idéia de globalização aqui compreendida remete ao plano histórico e geográfíco de desenvolvimento do modo de produção capitalista, que neste período se desenvolve pela díade colonialismo-imperialismo através da expansão ultramarina e a anexação europeia de vastos territórios da América, África, Ásia e Oceania. Alcançando no século XXI o ápice de internacionalização do modo de produção (SANTOS, 1985; 2001; HARVEY, 2013).

${ }^{28}$ Caio Prado Jr. (1972 [1945]), Maria T. Petrone (1968), Ianni (1996), Oliveira (2012) referem-se à importância do açúcar para a economia colonial em São Paulo entre 1750-1850, inclusive como condição da acumulação primitiva para o café no "quadrilátero da açúcar".
} 


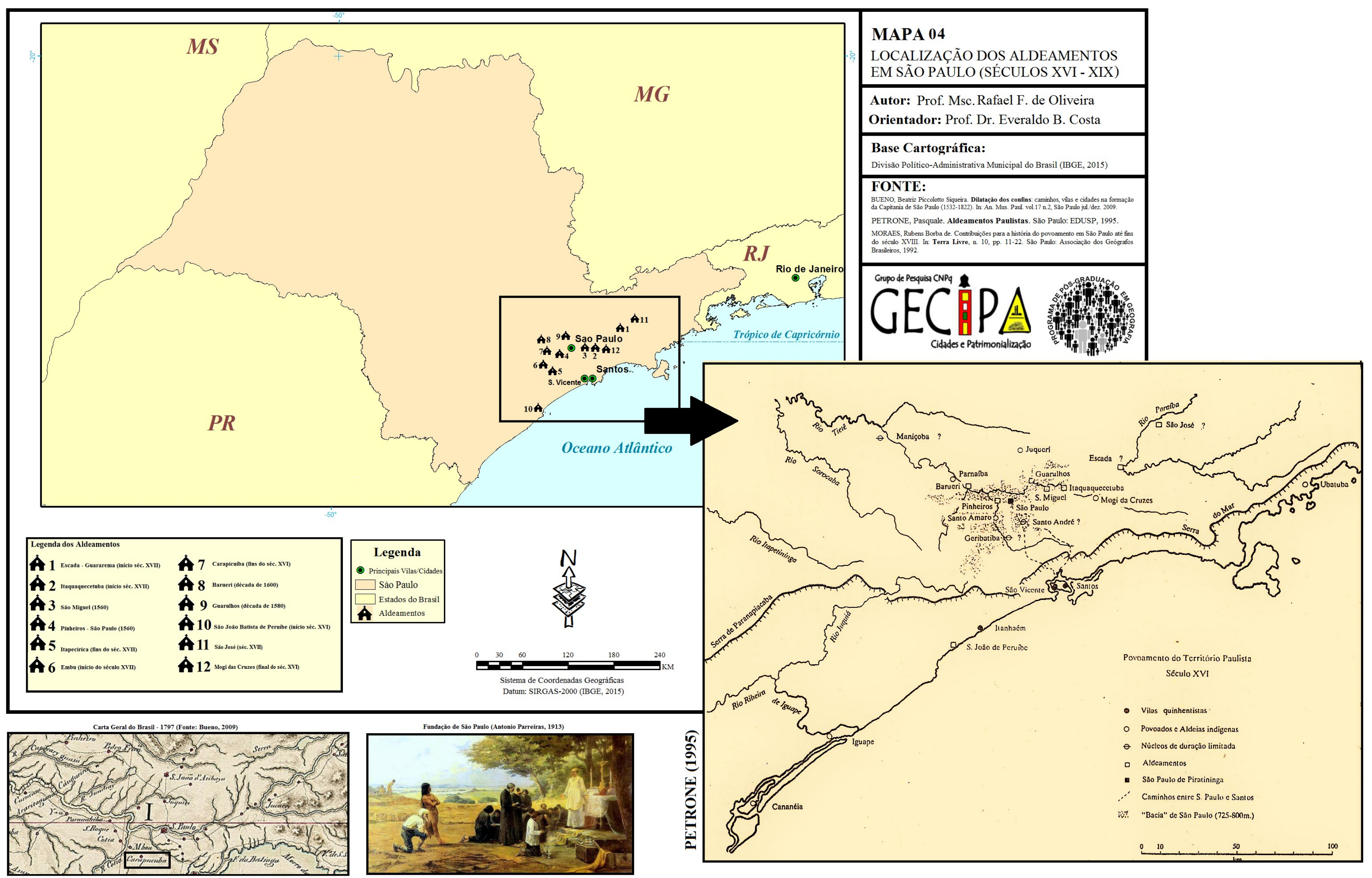


A apropriação dos territórios indígenas pressupõem rugosidades que funcionam como elo de superposições realizadas pelos colonizadores, numa acumulação de paisagens que, gradativamente, vão suprimindo as heranças passadas, a partir de novas formas e conteúdos estabelecidos. Por exemplo, o caminho feito pelo padre Anchieta que “[...]sofre sucessivas embora lentas melhorias, torna-se a Estrada da Maioridade, logo a Calçada do Lorena, o Caminho do Mar, a Via Anchieta, soma a Rodovia dos Imigrantes, antes já compondo-se com a Estrada de Ferro Santos-Jundiaí e, porque não, enriquecendo-se com a construção do transporte." (PETRONE, 1998, p.57). Estas novas soluções e dinâmicas, trazidas pelo colonizador ao nativo, sintetizam a ampliação dos caminhos, a utilização de novas ferramentas e técnicas, os choques decorrentes da coerção, da farsa e ações que os indígenas desconheciam. Dinâmica que gradativamente, mesmo diante dos embates e tensões, afetou toda a lógica do sistema cultural das populações primitivas, mas, sobretudo, as relações com seus territórios e correlatos grupos tribais.

Mesmo que houvesse resistência (e houve, por meio de guerras, fugas, mortes, ou outros atos pacíficos e eficientes de resistência frente a escravização), o impacto de longos anos dessa imposição do "processo civilizatório" ao nativo se efetivou desde alterações de seu regime alimentar, propiciado pelo desmatamento de seus gêneros alimentícios e a extinção de sua caça, até a difusão de doenças e parasitas que o sistema imunológico do índio não estava preparado para combater, além de conflitos intensificados com seus pares e dentro da totalidade explicativa do mundo, permeada por outras razões e lógicas, que foram rapidamente combatidas pelos colonizadores.

[...] A simples presença desses europeus, trazendo consigo uma bagagem cultural bastante diferente daquela dos grupos indígenas, implicando uma organização de quadros de povoamento que significavam a introdução de modificações sensíveis nos preexistentes, trouxe inevitavelmente repercussões não descuráveis para a vida do indígena. Quer se trate da ocupação de terras, quer se trate da rápida destruição da vegetação, quer se trate da perturbação introduzida nos quadros do habitat, tudo só poderia implicar uma sensível crise de sobrevivência para os grupos indígenas. Se alguns aceitaram, mais ou menos pacificamente, modificar alguns de seus hábitos aceitando a convivência com o colono, não foram poucos os que recuaram frente à sua expansão (PETRONE, 1995, p. 60).

Tendo estas razões pontuadas e esboçadas no limite das nossas condições analíticas, deve-se considerar, possivelmente, outros elementos que explicam a fixação, ou ao menos, os sentidos da ocupação do planalto paulistano. De tal maneira, além da expansão das 
plantations, emergem outras razões, questionáveis, porém interessantes de serem pontuadas: (a) condições climáticas e ambientais menos severas que as encontradas nas regiões litorâneas do trópico sul; (b) semelhanças ambientais com a Europa, considerando os vastos campos planálticos, além de um clima mais ameno pela altitude e uma atmosfera mais salubre conforme a crença da época; (c) segurança em relação aos ataques de piratas e indígenas. Acerca destas últimas razões, exemplos das investidas na América Central são numerosas, assim como no âmbito dos conflitos indígenas, Petrone (1995) por diversas fontes e documentos evidencia que as três grandes tribos, em maior ou menor intensidade, investiram duramente contra os colonos, como também atesta Nardy Filho (1999), à exceção dos Guaianases mais ao sul, que segundo Moraes (1992) já eram aliados dos vicentinos desde os princípios da colonização.

Ao longo do século dezesseis o quadro sistemático de povoamento paulista se estabelece entre a parte central e sul do litoral, com a criação pela Coroa das vilas litorâneas de São Vicente (1532), Santos (1537), Itanhaém (1561) e Cananéia (1600) respectivamente, além de outros aglomerados já existentes sem ainda serem qualificados de vilas (AZEVEDO, 1992; REIS FILHO, 1968). O caso mais emblemático reside na criação da vila de São Paulo, a única no planalto, em 1554 (REIS FILHO, 1968, p. 85), quando em meio às disputas territoriais pela aliança franco-carijó (estabelecida na baia de Guanabara) e a aliança luso-tupi dividida entre Santo André (sobre a gerência de João Ramalho) e São Paulo (aldeamento administrado pela Companhia de Jesus), reúnem-se nesta última localidade e passam então a congregar um aglomerado maior e mais seguro do ponto de vista geopolítico.

A frequência dessas circunstâncias de grave ameaça significavam dificuldades permanentes para a ocupação do território. A administração do governo-geral, representando o poder reinol na Colônia, propôs concentrar as forças portuguesas ordenando a transferência de toda a população de Santo André para o núcleo de São Paulo de Piratininga, em razão de a área proporcionar maior segurança e estabilidade. Nesse mesma ordem, o Governador alçou o núcleo criado pelos jesuítas à categoria de Vila de São Paulo de Piratininga. Assim, além do colégio jesuítico, instalou-se nesse povoado um aparelho administrativo mais sofisticado que o consagrava como espaço de controle, pois nessa categoria urbana passa a ser uma representação do poder metropolitano português contando com as significativas instituições de controle representadas nas vilas coloniais pela existência do pelourinho e da Casa da Câmara e Cadeia (PEREIRA, 2014, p. 05). 
Assim também, em razão da ameaça dos índios Tamoios, era pequena a aglomeração no litoral norte. $\mathrm{Na}$ área do planalto, apenas São Paulo havia obtido a qualificação de vila, no entanto Moraes (1992) evidencia os núcleos adjacentes, dando dimensão regional de uma unidade mais complexa e maior do que simplesmente a vila em si expressa. "No planalto o núcleo principal era São Paulo. Em torno da futura capital inúmeras aldeias de índios fundadas pelos jesuítas: M'Boy, Santo Amaro, Pinheiros, Guarulhos, Carapicuíba, Itaquaquecetuba, São Miguel, etc. e mais as primeiras vilas de fundação particular já citadas." (MORAES, 1992, p. 14). Saia (1937), inclusive, traça uma circunferência dos aldeamentos no entorno de São Paulo, evidenciando a posição estratégica das unidades em relação ao centro. Além da posição geográfica, numa área relativamente alta e estratégica para possíveis conflitos, São Paulo ainda possuía como elemento aglutinador um entorno de aldeamentos aliados, ou seja, um arsenal humano capaz de antever e atenuar possíveis invasões, assegurando certa tranquilidade ao núcleo central.

Enquanto cativeiro, espaço de aprisionamento e doutrinação do indígena, os aldeamentos não são necessariamente considerados unidades político-administrativas. Asseveram Saia (1937), Petrone (1995; 1992) e Moraes (1992) que apesar de servir aos colonos nas mais diversas atividades e trabalhos, os índios aldeados eram confinados do convívio com o branco pelos padres jesuítas. O espaço dos aldeamentos era então regido num esquema de cessão cuja autoridade era dos religiosos e ligados ao poder políticoadministrativo dos núcleos como vilas e cidades. Ficavam ainda relativamente isolados, sem nem poder servir de pouso aos viajantes. Existe, no entanto, outra complexidade, primeiro porque os aldeamentos eram distintos entre si e passaram a ser divididos administrativamente entre os do padroado real (papel central do Estado, porém com a mediação dos religiosos) e entre os administrados pelos jesuítas nas fazendas doadas ou dos colonos (Mapa 05). Com a expulsão do jesuíta, pelos conflitos já brevemente retratados, outras ordens religiosas tornam ainda mais complexa a situação das unidades. Mesmo não constituindo unidades políticoadministrativas do Estado, eram unidades essenciais do desenvolvimento colonial, pela função estratégica que possuíam, desde o controle da indígena população, até seu uso exigido em atividades produtivas as mais diversas. 


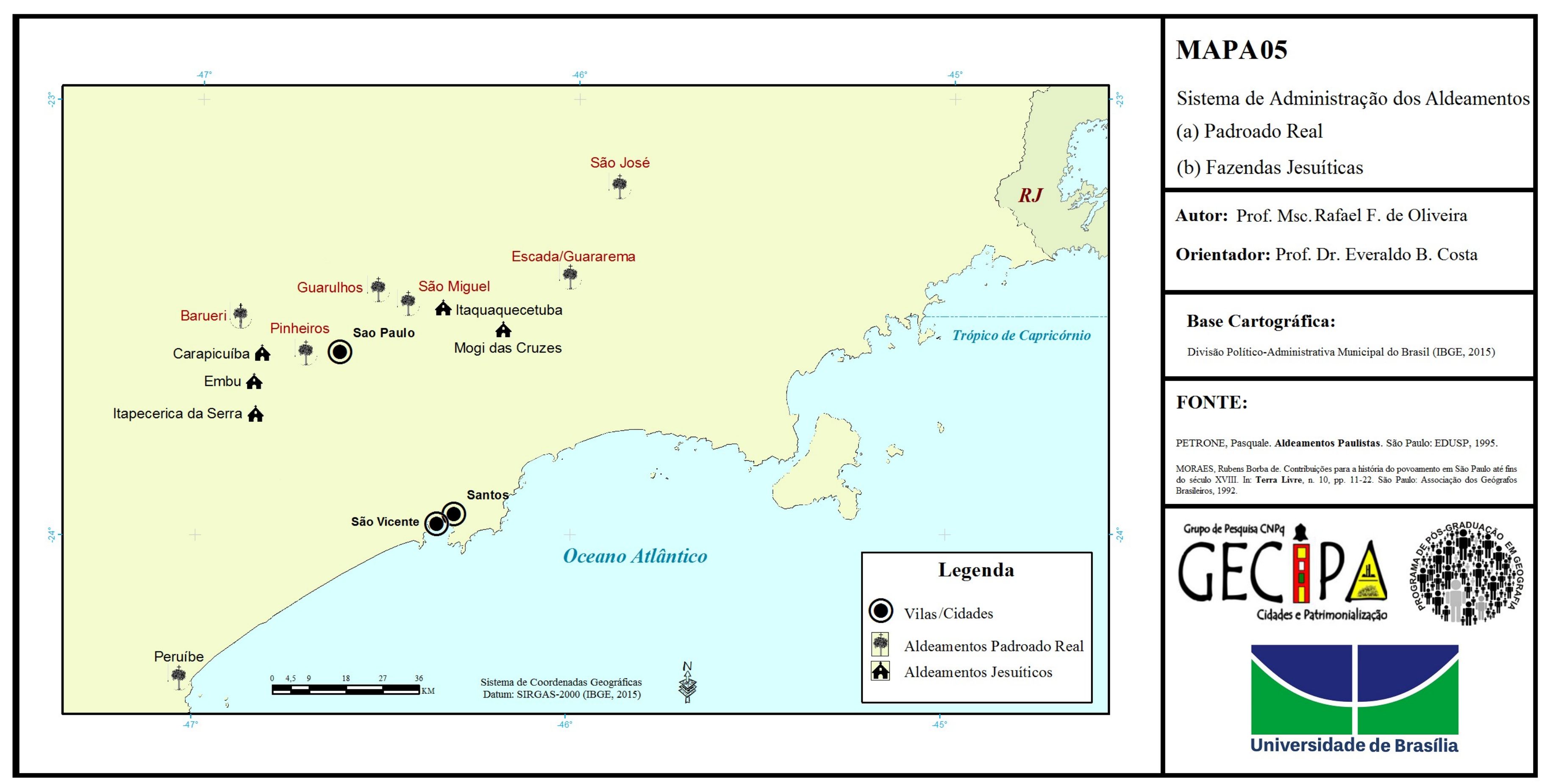


A decadência do sistema de aldeamentos, em fins do século dezoito e começo do dezenove, principia quando é reduzido seu quadro populacional em meio a precariedade e abandono das unidades. Outro fator a se considerar é a emergente acumulação dos colonos agora capazes de importar o negro africano como mão-de-obra. Juntos aos esforços governamentais, que diante desta situação, não veem saída senão a extinção dos aldeamentos e, neste prospecto, seus limites e normas se mesclam cada vez mais com as unidades existentes. Igualmente, ocorrerá com os indígenas, gradativamente, a hibridização com brancos e negros. $\mathrm{O}$ quadro 03 sintetiza a evolução administrativa que remete a diversidade e longevidade dos aldeamentos no planalto paulistano na história do Brasil Colônia.

Evolução Administrativa dos Aldeamentos

\begin{tabular}{|l|l|l|}
\hline Fase & Período & Características \\
\hline $\begin{array}{l}\text { Fase } \\
\text { Quinhentista }\end{array}$ & $1500-1610$ & $\begin{array}{l}\text { Definição dos primeiros quadros coloniais-administrativos. Núcleos de } \\
\text { catequese formados e controlados pelos jesuítas, ora em propriedades da } \\
\text { Companhia de Jesus, ora nas propriedades particulares. }\end{array}$ \\
\hline $\begin{array}{l}\text { Fase } \\
\text { Seiscentista }\end{array}$ & $1611-1697$ & $\begin{array}{l}\text { Dualização entre as fazendas jesuítas e as aldeias do padroado real, com } \\
\text { predominância dos jesuítas. Subsídios da Coroa à Igreja na sustentação do } \\
\text { "projeto catequizador". }\end{array}$ \\
\hline $\begin{array}{l}\text { Fase dos } \\
\text { Procuradores }\end{array}$ & $1698-1757$ & $\begin{array}{l}\text { Regimentos normatizam os aldeamentos. Procurador-Geral torna-se } \\
\text { governante dos aldeamentos do padroado real até 1734, depois passando para } \\
\text { as ordens religiosas (capuchos). Jesuitas permanecem em sua condição } \\
\text { administrativa. }\end{array}$ \\
\hline $\begin{array}{l}\text { Fase do Diretório } \\
\text { do Pará }\end{array}$ & 1757 até fins do sec. XVIII & $\begin{array}{l}\text { Padronização administrativa, inclusive das fazendas jesuítas. Administração } \\
\text { política do Estado, orientação dos religiosos. }\end{array}$ \\
\hline $\begin{array}{l}\text { Fase da } \\
\text { Decadência }\end{array}$ & Fins séc. XVIII - meados do XIX & $\begin{array}{l}\text { Grande desorganização, posterior implementação do Plano Rendon, } \\
\text { orientando o fim dos conflitos com os índios e a conversão dos aldeamentos } \\
\text { em freguesias ou vilas. }\end{array}$ \\
\hline
\end{tabular}

Quadro 03: A complexidade administrativa na evolução dos aldeamentos paulistas.

Fonte: Petrone, 1995. Organizado pelo autor, 2016.

Os aldeamentos, portanto, podem ser considerados embriões ${ }^{29}$ na conformação da capital paulista, como dos principais municípios suburbanos e região metropolitana de São Paulo, que deram origem as cidades atuais, como Carapicuíba, Barueri e Embu, além de

29 Ao considerarmos os aldeamentos como embriões das cidades contemporâneas, fazemos aqui duas advertências julgadas importantes. A primeira de que nem todas unidades podem ser desta forma observadas. Ainda que a generalização seja possível, as particularidades devem sempre ser ressaltadas como ora fazemos. Segundo, o sentido de embrião não significa absolutamente uma centralidade, em que a cidade tenha crescido ou se expandido deste núcleo ou a partir do aldeamento, ao contrário: trata-se de um elemento embrionário capaz de subsidiar as cidades, especialmente São Paulo e região, com força de trabalho e gêneros alimentícios por exemplo, além de preservarem um conjunto demográfico e sustentarem ordens religiosas que eram fundamentais na organização pretérita do espaço proto-urbano. Não limitando-se, porém, necessariamente às vilas ou cidades, mas aos grandes latifúndios, ou aos projetos coloniais sertão adentro. Inclusive, o aldeamento deve ser sempre referenciado como não-cidade, uma espaço de exceção dificilmente enquadrado até como rural. 
outras, nas mais diversas áreas onde hoje se inscreve a RMSP: Pinheiros, Guarulhos, Osasco, Itaquaquecetuba e Itapecerica. Mesmo diante da especificidade dos aldeamentos, ou da concentração das unidades em determinadas porções territoriais, eles desempenharam uma importante função estratégica, nutrindo e fazendo permanecer o primitivo núcleo embrionário de São Paulo. Além de constituírem mais recentemente no cinturão caipira, que subsiste, como será defendido posteriormente, às múltiplas temporalidades existentes na metrópole.

\footnotetext{
O mais importante, entretanto é que os aldeamentos constituíram instrumentos dos mais significativos no processo da dinâmica de valorização e organização do Planalto Paulistano, nesse sentido devendo ser considerados não apenas quanto à própria valorização do sítio de São Paulo ou quanto à organização e evolução de um sistema de povoamento do Planalto Paulistano, mas também, e principalmente, quanto à vocação dessa área em relação ao processo de povoamento daquela que é hoje a região geoeconômica paulista (PETRONE, 1995, p. 351).
}

Se o modelo de aldeamentos entra em estagnação, culminando com sua gradativa extinção, o índio convertido continua carregando na memória a culpa e os pré-conceitos que lhes são comuns desde os períodos remotos da colonização. A condição indígena gera no europeu o repúdio a sua condição de animalidade, que se configurava pelo canibalismo, o incesto e a nudez (MOREAU, 2003). Mesmo cristianizados não eram considerados cristãos, condição fundada e também reproduzida pela educação jesuítica nos aldeamentos que, conforme Daher (2001, p. 49), terá papel central em sua culpabilidade existencial, da condição de bestialidade, o vício e a distância do Bem.

\begin{abstract}
A fim de integrar o índio na ordem hierárquica do corpo místico imperial, o missionário, no interior das normas escritas do catolicismo, produz a consciência do índio como memória de culpa, arrependimento dos pecados passados, inaugurando seu presente contrito. Desse modo, faz com que o índio participe legitimamente, como todos os homens, do pecado adâmico (DAHER, 2001, p. 49).
\end{abstract}

Nos mais de três séculos do modelo de aldeamentos em São Paulo, a doutrinação do nativo dada pela educação cristã, conforme referenciado, tem na difusão da ideia do pecado adâmico ou original a necessidade não apenas de fazer com que o índio sinta-se culpado por sua condição, mas fundamentalmente que busque sua resignação na submissão do trabalho, do colonizador, ou das necessidades dos representantes religiosos. O que implicava nas palavras de Petrone (1995, p. 254) na condição indígena de "motores animados" ou de uma estrutura colonial que funcionava como "máquina de moer gente" usando expressão de Darcy Ribeiro. 
De fato, nos remotos tempos, quando a acumulação não era suficiente para importar braços africanos, o índio tornou-se importante alternativa nos mais diversos usos e necessidades do empreendimento colonial. A sangria dos aldeamentos, causando desequilíbrios, restando em largos períodos apenas crianças, mulheres e anciões, dava-se em razão das empreitadas de trabalho em várias escalas: (i) em atividades internas ligadas ao aldeamento; (ii) atividades nas propriedades particulares em regiões circunvizinhas; (iii) atividades em locais distantes, com obras vultosas de interiorização e no desbravamento do sertão, sobretudo em monções que percorriam os grandes canais fluviais da bacia do Paraná e adjacências.

Logo, o apoio a interiorização dado por Portugal aos bandeirantes e colonos deriva não apenas da anexação de terras ao império, mas de seres humanos, de seus conhecimentos, de sua força de trabalho. Entre sangrentas vitórias ou parciais derrotas, o genocídio das populações primitivas também se fez com o desenvolvimento de outra civilização, a brasileira. A relação entre o colonizador e o religioso no "processo civilizatório brasileiro" é amplamente explorada por Darcy Ribeiro (2006 [1995]), sobretudo em analogia dos efeitos catastróficos sobre as populações indígenas que já ocupavam o território, igualmente da mestiçagem étnica que daria origem aos brasileiros. Segundo ele, na colonização “configuram-se, assim, duas destinações cruamente opostas, desfrutando, cada qual, o predomínio na dominação do Novo Mundo. De um lado, a dos colonos, à frente de seus negócios. De outro lado, a dos religiosos, à frente de suas missões” (RIBEIRO, 2006 [1995], p. 54). Esta nova unidade não extinguiu às bases conhecidas do território pelo indígena, mas as adequou às necessidades de exploração, se apropriou do seu trabalho, fazendo de São Paulo um nódulo, um lugar central da rede que se estabelecia na prospecção do interior, com as relações constituídas entre espanhóis a oeste, com as minas ao norte e com os insumos que vinham do sul. Permanecendo por mais de três séculos, os aldeamentos chegaram ao limite de seu tempo, de todas as forças, carregando em seus habitantes o peso de sustentar os alicerces da maior metrópole do trópico sul e das maiores aglomerações humanas do planeta.

\subsection{O aldeamento de Carapicuíba na colonização dos campos de Piratininga}

O aldeamento de Carapicuíba foi uma das doze unidades fundadas por Anchieta em São Paulo (TENÓRIO, 2003). Hoje denominado de Aldeia de Carapicuíba, está localizado à aproximadamente trinta quilômetros ao oeste do centro de São Paulo, nas coordenadas $23.56^{\circ}$ sul e $46.83^{\circ}$ oeste. Trata-se de um dos poucos aldeamentos distantes das principais rotas 
fluviais e terrestres do período colonial. Como explica Azevedo (1957), a preocupação com a defesa fazia com que o assentamento dispusesse de trechos mais elevados, porém não muito distantes dos cursos fluviais. O rio Tietê, mais próximo, fica a aproximadamente dez quilômetros da área, o que para época seria relativamente distante, considerando os meios técnicos primitivos e a localização dos núcleos humanos sempre adjacentes ou nos arredores dos rios e caminhos. No entanto, obedece o rigor e orientações coloniais modernas do período, com o sítio situando-se topograficamente a 750 metros de altitude (entre o interflúvio e o fundo de vale), numa vertente suavizada, que não ultrapassa os trinta graus de declividade e que converge no fundo de vale com o encontro de dois canais de drenagem: o córrego da Aldeia e o córrego da Fazenda. A aproximadamente 500 metros também localiza-se outro importante canal de drenagem, o ribeirão Carapicuíba (Figura 14). Portanto, apesar da distância do canal de primeira ordem, o aldeamento além de ficar numa altitude consideravelmente segura de enchentes, contava com outros importantes canais, o que talvez tenha originado seu próprio nome, que deriva de peixe espinhento, ou peixe ruim $^{30}$.

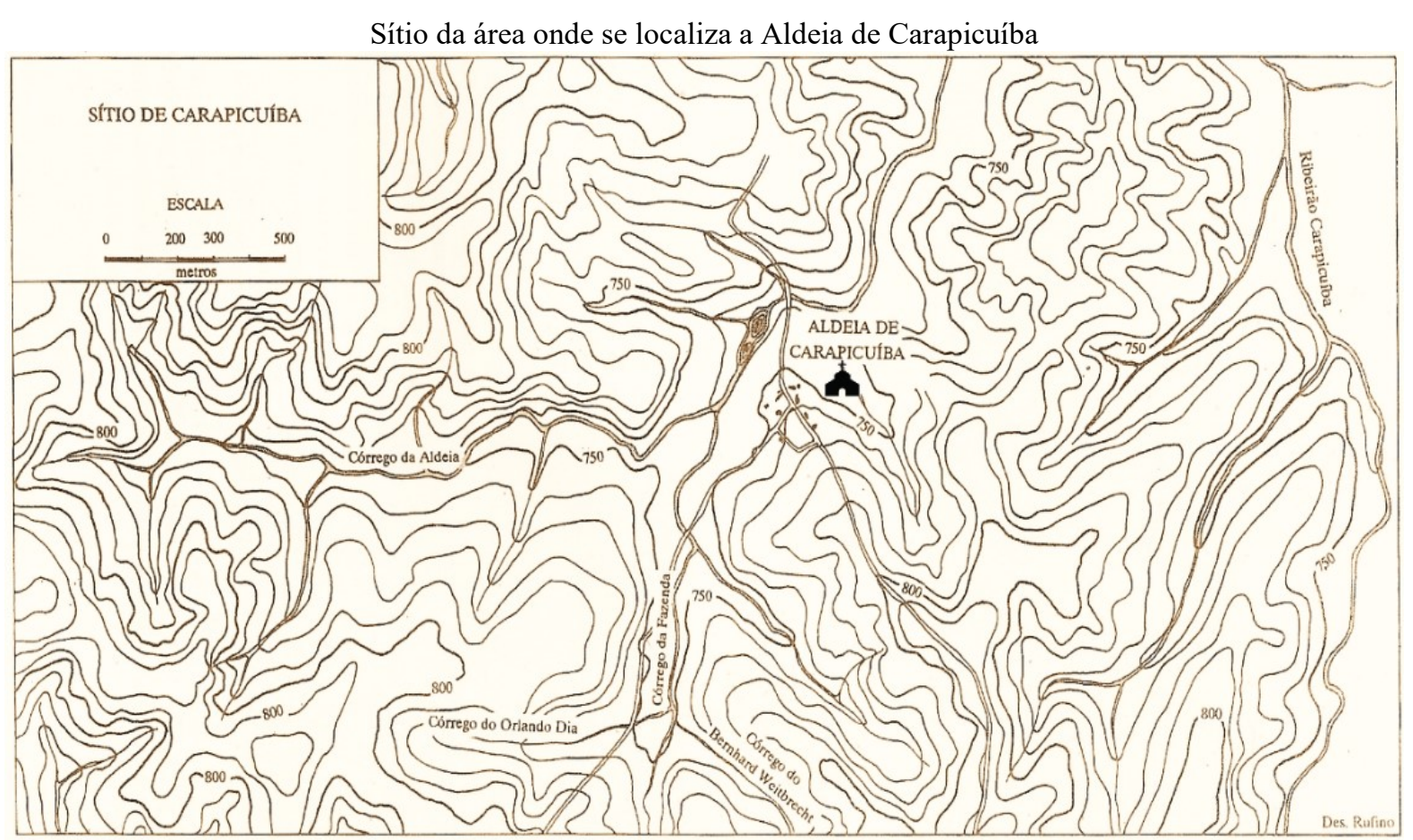

Figura 14: Carta topográfica síntese da área onde se localiza a Aldeia de Carapicuíba, na RMSP. Fonte: Extraído de Petrone. Editado pelo autor, 2016.

${ }^{30}$ Carapicuíba na língua Tupi significa: o prefixo Cara deriva de cará ou acará - espécie de peixe comum em grande parte dos rios paulistas, Picu deriva de picú ou pucú, que significa longo ou comprido e o sufixo Iba que remete para aquilo que não é bom de ser comido, ou ruim. Portanto, peixe ruim de ser comido (COSTA JUNIOR, 1985; PIMENTEL, 2014). 
Por situar-se nos trópicos, a região toda atinge pluviosidade anual por volta ou superior a $1.500 \mathrm{~mm}$, com níveis médios a elevados de umidade relativa do ar e uma biogeografia original dominada por mata latifoliada atlântica. Antes do estabelecimento dos aldeamentos, é provável a densa ocupação da área por índios Guaianases, sendo possível acessá-la pelo rio Tietê e depois por trilhas terrestres, ou ao sul pelas trilhas secundárias ligadas ao antigo caminho do Peabiru e, mais tarde, o caminho de Itu. A densa rede de rios permite acreditar num refúgio autossuficiente de alimentos e caças e, pois, relativa autonomia frente aos grandes canais de drenagem ou núcleos arredores. Para Petrone (1995, p. 150), “a distância destas rotas poderia contribuir para explicar sua maior permanência”. Por fim, também se configura funcionalmente à defesa do centro regional, ou seja, a vila de São Paulo, fornecendo insumos essenciais ao seu desenvolvimento, além da força de trabalho, mas concomitantemente permitindo uma sociabilidade calcada na ordem institucional da Coroa e da Igreja. O que não impede, porém, a incorporação e alternativas de elementos culturais indígenas no cotidiano e na hibridização dos ritos, como observado nas festividades de Santa Cruz.

No plano morfológico, o aldeamento de Carapicuíba reflete em sua organização as Leis das Índias ${ }^{31}$, baseada no modelo urbanístico já praticado na península ibérica, sendo um conjunto moderno de normas e orientações, que entre outras regras racionalizavam um modelo ortogonal da cidade, com um plano pré-elaborado, considerando a centralidade dos prédios públicos e destaque dos templos religiosos. Se o aldeamento sugere dúvidas e questionamentos de ser ou não embrião de cidade, já que tinha uma função muito específica, sua composição revigora o caráter urbano já que foi idealizada no modelo de concentração praticado largamente nas cidades europeias. Ou seja, o aldeamento de Carapicuíba é “exemplo de instalação projetada de acordo com as Leis das Índias” (SAIA, 2012, p. 17), como corrobora a Figura 15.

Pela sua localização e estrutura, Carapicuíba parece refletir mais uma escolha de padre da Companhia, que de colono. A sua posição não tem dúvida que se enquadra perfeitamente nas determinações e dispositivos das leis das Índias. Pelo menos os detalhes de localização das aldeias e obediência às normas pré-estabelecidas. $\mathrm{O}$ processo de situar a povoação em relação aos grandes rios, por exemplo, coincide

\footnotetext{
31 "Depois de alguns anos de realizações do modelo espanhol, Filipe II, no ano de 1573, institui a primeira legislação urbanística da idade moderna, a chamada Lei das Índias. Com esta lei, torna-se possível uma associação entre os princípios idéias renascentistas, as influências do Tratado de Vitrúvio e as realizações concretizadas na América. Na verdade, a Lei de Filipe II, não fez mais do que consagrar a planta ortogonal, que na prática já estava sendo realizada." (DANTAS, 2004).
} 
perfeitamente com a redação de um dispositivo encontrável nas leis da Índia [...] (SAIA, 1937, p. 06-07).

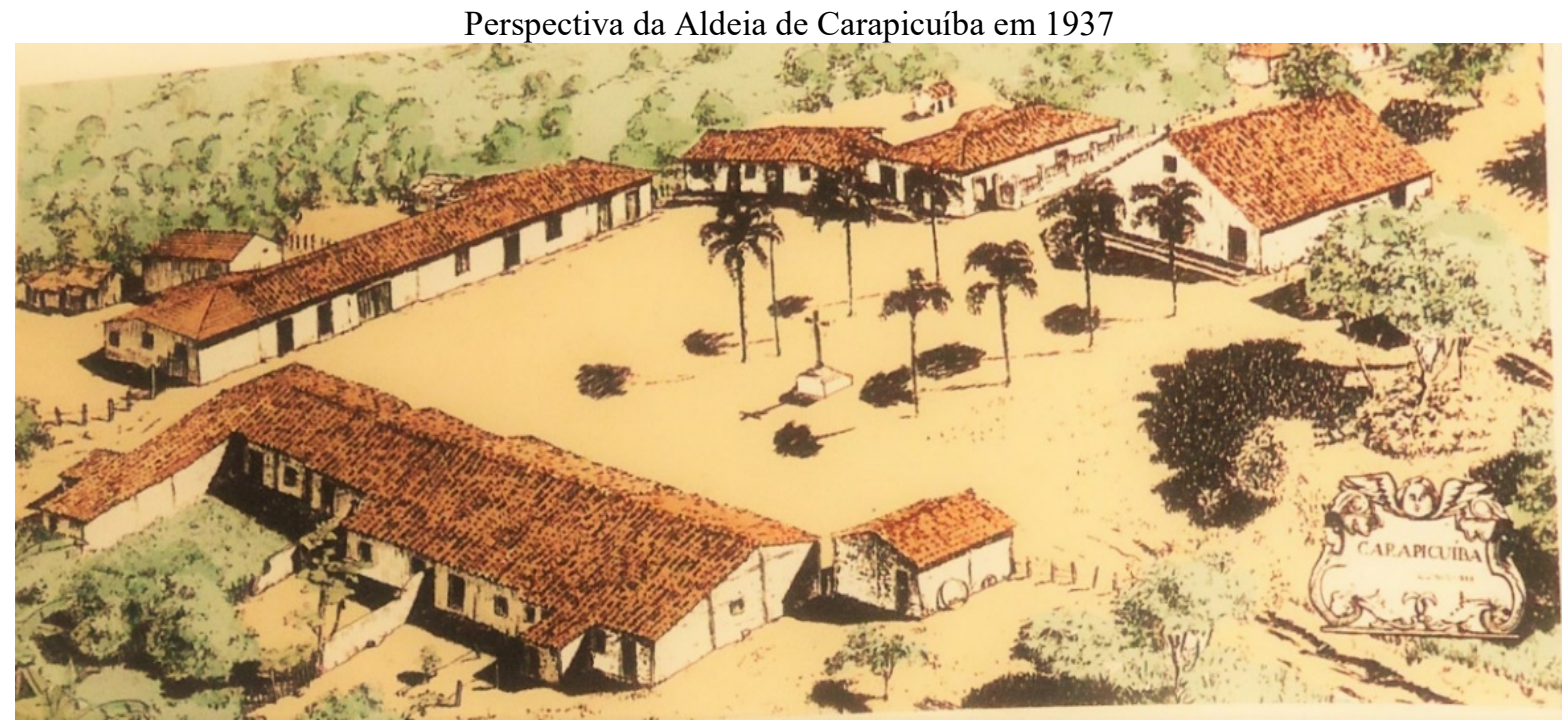

Figura 15: Planta regular ortogonal da Aldeia de Carapicuíba, em conformidade com os padrões das Leis das Índias, também implementados em outros aldeamentos jesuíticos na América.

Fonte: $9^{a}$. SR/IPHAN-SP - Luís Saia (1937).

O plano estandardizado, de forma quadrangular racional, objetivo à proposta defensiva e relacional catequizadora do espaço, baseado na permanência e cativeiro do nativo, evidencia o conhecimento dos jesuítas de organização e normas urbanas. Para Saia (1937) “o quadrilátero bem projetado, de ângulos retos, desobediente muitas vezes à topografia local tem mesmo bastante sabor jesuítico.” (SAIA, 1937, p. 10). Sem necessariamente reduzir os núcleos coloniais criados à mercê dos colonizadores, ou propriamente pela Coroa, como no caso da planta da cidade de Salvador $^{32}$, o arranjo espacial sob o desígnio da Igreja, especialmente os jesuítas e dos aldeamentos, respeitará traços característicos da cultura e das técnicas construtivas e organizacionais mais acuradas e planejadas para durarem no tempo. De tal maneira explica Saia (1937) a respeito de Carapicuíba a esse favor:

Carapicuíba foi fundada precisamente numa época em que se firmavam na Capitania de São Vicente os traços da cultura jesuítica, tão marcadamente diversos daqueles com os quais os colonos haviam inaugurado o trabalho de colonização e povoamento. Traços que traduzidos em termos de arquitetura, iriam representar o advento de um critério pré-estabelecido e racional na escolha dos assentos dos núcleos, em contraposição ao processo tradicional, imediatista e quase sempre precário dos colonos. Sobretudo iriam instituir nas povoações nas povoações o plano

32 A preocupação com o controle e o ordenamento do território fez com que Salvador, a primeira capital da colônia, fosse fruto dos desígnios técnicos do arquiteto Luiz Dias, contratado pela Coroa portuguesa para o desenho da nova cidade (ABREU, 1996, p. 152). 
quadrangular, enquanto os núcleos especificamente de colonos, apresentavam um aspecto desordenado e infixo. A Aldeia de Carapicuíba vai refletir essa nova orientação do trabalho colonizador (SAIA, 1937, p. 02-03).

Assim também, outras instalações em diferentes partes do atual território brasileiro e latino-americano (Figura 16), evidenciam os mesmos padrões. Para o autor, Carapicuíba além da relevância histórica, indica na atualidade importantes elementos posteriores e mesclados da arquitetura popular desenvolvida. Afinal, a aldeia é resultado da mescla de diferentes contextos construtivos e técnicas que permeiam a edificação da casa no Brasil. "Sobre o desenho primitivo, a aldeia evoluiu de então para cá, aceitando os diferentes condicionamentos técnicos e sociais que influíam na habitação" (SAIA, 2012, p. 19).

Os traços primitivos do aldeamento devem ter permanecido por um século desde sua criação, quando foram destruídos por volta de 1698, na tentativa de transferir os indígenas aldeados em Carapicuíba para o aldeamento de Itapecerica (TENÓRIO, 2003). "Por volta de 1698, os índios de Carapicuíba foram transferidos para a aldeia de Itapecerica, sendo a primeira parcialmente destruída pelos inacianos, para que os índios abandonassem o local." (REIS FILHO, 1982, p. 09).

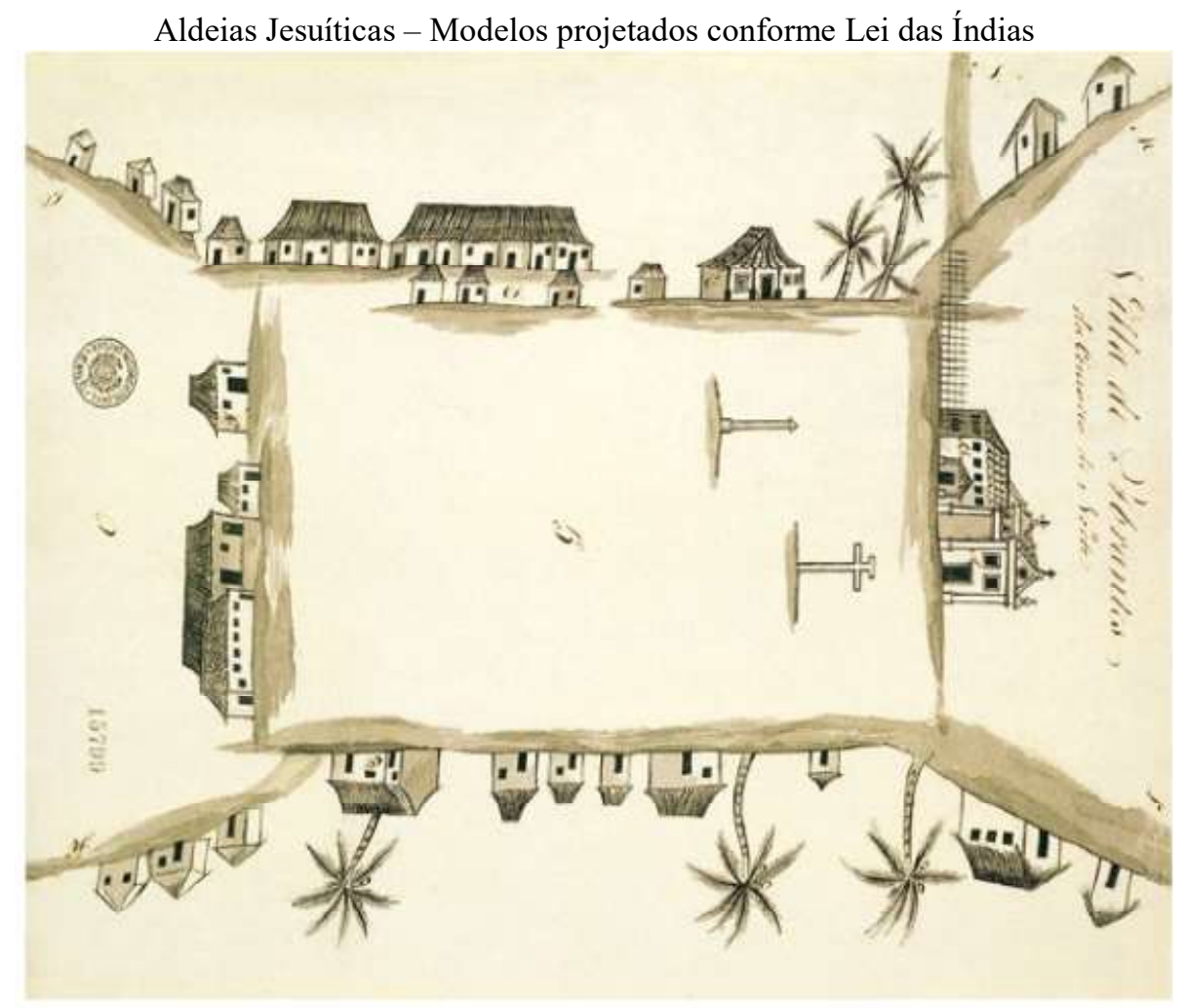

Figura 16: "Villa de Abrantes" - aldeamento jesuítico no sul da Bahia.

Fonte: Arquivo Histórico Ultramarino, Lisboa. Extraído de Reis Filho (1968). 
Apesar da formal reconstrução da aldeia logo em 1736, com a nova igreja edificada, seu uso e ocupação parece que jamais fora abandonado totalmente. Primeiro em razão de que nem todos os índios concentravam-se necessariamente nas habitações do aldeamento e, portanto, nunca migraram efetivamente. Segundo, mesmo aqueles que se dirigiram até Itapecerica, retornavam gradativamente ao local de origem. Não restando, pois, às missões evangelizadoras apoiadas pelo poder colonial se reestabelecer no antigo sítio.

Os indígenas, moradores da Aldeia, se apegaram tanto a esse lugar que, mesmo quando foram retirados e transferidos para Itapecerica, insistiram e retornaram para lá. Na ocasião, a Aldeia havia sido queimada e poucas paredes restavam em pé, mas isso não foi obstáculo para eles, que a reconstruíram por volta de 1736 (HENNE, 2015, p. 29).

Escalante (1974) defende que as características do aldeamento foram mantidas, pois "quando a nova igreja edificada em 1736, o traçado original foi respeitado, o mesmo devendo-se dizer das casas que, em 1769, por ordem do 'Diretor da Aldêa de Carapicuyba", Pedro José Francisco de Andrade, foram reconstruídas e a aldeia devidamente arruada.” (1974, p. 15). No caso do aldeamento de Carapicuíba, como na maioria dos aldeamentos, a igreja fica numa posição topográfica mais elevada, com amplo espaço que se assemelha aos largos ou praças das cidades brasileiras. Conforme Petrone (1995, p. 229) repete-se “[...] alguma coisa da ocara indígena, com tênue casamento com o fórum ou a ágora, ou com a piazza italiana". No olhar de Saia (1937), a organização interna das casas, bem como a disposição das paredes, do assoalho, se assemelham de forma idêntica às das missões jesuíticas encontradas ao sul do Brasil. Para o autor, esta evidência mostra que a fundação, o terreno como um todo, foi aproveitado para a reconstrução do aldeamento no século dezoito. Ainda segundo Saia (1937), além da semelhança com as missões, também pela experiência, esta organização foi encontrada em outros aldeamentos, como a distribuição da igreja em relação às casas, ou mesmo a divisão interna de cada unidade, como descreve especificamente do caso da Aldeia de Carapicuíba.

Não há dúvida que a capela é a construção mais notável da aldeia, não só pelo seu tamanho e importância que transparece através de certos detalhes construtivos, como sobretudo pela localização dela no lado mais alto do páteo, encostada e protegida pela colina que lhe fica atrás. Os restantes dezenove edifícios, quando não estão ladeando a capela se dispõem em série nos lados do páteo. A construção residencial seriada é sistemática em Carapicuíba, assim como em todas as outras aldeias jesuíticas que pude visitar. Dona Quirina, deu as casa X e XI como inexistentes há vinte anos, enquanto as outras da série XII, XIII, XIV, XV, XVI e XVII já eram construções antigas. Além de mostrar que há vinte [1916] a estrutura da população permanecia fiel ao desenho primitivo, atraindo os edifícios para o plano fundamental 
em torno do páteo, esses espaços desaproveitados sugerem que as construções de pau-a-pique, dessas duas casas, embora aceitando ainda uma porção de soluções procedentes da arquitetura da antiga aldeia, já se libertara, nesse tempo, do compromisso de geminação (SAIA, 1937, p. 14-15).

Ainda segundo Escalante (1974, p. 15), "todas as características do aldeamento indígena conservam-se na Aldeia de Carapicuíba: seja na disposição da igreja, no terreiro fronteiriço ou na colocação das casas [...]”. Com ele, em grande medida, concorda Petrone (1995), explicando que dos aldeamentos que mais conservaram a arquitetura do núcleo é Carapicuíba, que remete do século dezoito, em um plano que deve chegar ao século dezesseis. [...] Constitui-se em um dos mais expressivos documentos do passado paulista, digno das atenções de historiadores, arquitetos, urbanistas, geógrafos, sociólogos, artistas e outros. [...] É evidente que deve ser considerado extraordinário o fato de se ter considerado intacto o conjunto arquitetônico de Carapicuíba" (PETRONE, 1995, p. 617-618).

As técnicas construtivas eram vernaculares, baseadas em pau-a-pique cobertas por sapê (PETRONE, 1995) ou na taipa de pilão com telhas (SAIA apud PETRONE, 1995), com estrutura de palanques alinhados e permeado por barro compactado. No local, é ainda possível observar grossas paredes, com mais de 50 centímetros de espessura, bem como as casas que mantém estes aspectos arquitetônicos. Embora na maioria dos casos a habitação servisse de simples abrigo, considerando a dificuldade de fixação do indígena no local, bem como das instabilidades pelos serviços forçados como a própria condição do jesuíta diante dos colonos, sua organização espacial era suficiente por suprir os serviços catequizadores, bem como estabelecer preceitos políticos, econômicos e culturais do pensamento ocidental naquele contexto (como o trabalho, propriedade privada e as relações sociais). Também na forma quadrangular estrutural da sede, bem como das casas geminadas, pode-se pensar na facilitação da defesa, com a igreja, possivelmente, comportando-se enquanto fortificação, considerando a espessura de suas paredes.

O aldeamento de Carapicuíba, desde sua criação em 1580, não teve por objetivo ser um espaço destinado ao confinamento de índios conversos, ou seja, já cristianizados (LEMOS et al., 2008; FACCIO, 2010). No âmbito da Coroa, sua função destinava-se basicamente à mão-de-obra necessária, a exploração do território e ao apoio nas circunstâncias de defesa. Antes, porém, cabia a Igreja doutrina-los, torna-los “civilizados”. Sobre Sardinha, cujas terras viriam a se constituírem no aldeamento de Carapicuíba, Petrone (1995) explica que "a exemplo de Fernão Dias Paes e outros, contava a seu serviço com uma verdadeira aldeia de 
administrados, porque na prática era essa a condição dos indígenas, embora não sancionada por lei.” (PETRONE, 1995 p. 120). Devendo recorrer esporadicamente aos jesuítas para que houvesse assistência espiritual necessária. Tratava-se, pois, de um passo anterior, de aglutinamento dos nativos para sua doutrinação, servindo posteriormente aos desígnios religiosos, do trabalho e das possibilidades que a colonização aventava a estas populações. Conforme Tenório (2003, p. 44), a aldeia de Carapicuíba era uma das mais populosas de São Paulo nos idos das primeiras décadas de 1600, sendo a "Aldeia Velha" um reduto de prisioneiros. Subsiste sobre os desígnios coloniais na plena apropriação territorial, além do conhecimento basilar de suas características, à força de trabalho e, no limite, alianças militares e de defesa contra constantes investidas dos inimigos, tantos de outras etnias indígenas, como piratas ou colonizadores europeus. No caso de Carapicuíba, Petrone (1995) compreende haver nos primeiros momentos de sua fundação uma diversidade étnica de índios concentrada, considerando que estes vinham de lugares distantes, portanto, das mais variadas áreas e dos mais distintos grupos.

\begin{abstract}
As origens do aldeamento de Carapicuíba apresentam alguns curiosos elementos de semelhança com as de Embu. Em Carapicuíba, Afonso Sardinha possuía uma propriedade, nela tendo reunido um número não descurável de indígenas descidos do sertão. O núcleo deve ser quinhentista, sobre tal fato quase não devendo subsistir dúvidas. [...] Dado que nesses casos o núcleo indígena não constituía, de forma necessária, uma força de trabalho aplicada e intensa continuamente a serviço do senhor rural, mas apenas a intervalos irregulares, e não sempre na sua totalidade, não é difícil aceitar a ideia de que seriam os padres a assisti-los mais de perto, mantendo com eles contactos freqüentes e mais significativos, de tal sorte que, na prática, os administravam (PETRONE, 1995, p. 120-121).
\end{abstract}

Por tratar-se de um aldeamento jesuítico, Carapicuíba pela sua singularidade diferenciava-se não apenas de seus pares, mas sobretudo de um segundo modelo de aldeamento denominado padroado real, o qual destinava-se diretamente ao trabalho em obras públicas ou de grande vulto, cuja administração era diretamente assistido pela Coroa. Coexistiam também aldeias particulares instituídas nas propriedades rurais, que provavelmente antecedem o aldeamento oficial de Carapicuíba. No entanto, estas fragmentações de diferentes unidades não devem ser pensadas como algo estanque. Ao contrário, o correto é considerar a mobilidade que havia entre elas, até mesmo servindo aos moradores da região e aos propósitos distantes, como as prospecções metalistas no sertão, consistindo na mais pura forma de reserva de trabalho. E, ainda que escamoteados, a condição de exploração e do trabalho escravo são evidentes, o que no desenvolvimento histórico 
passam a rivalizar com os propósitos jesuíticos, culminando com a expulsão da Companhia do Brasil.

\begin{abstract}
Os aldeamentos ou fazendas jesuíticas caracterizavam-se, antes de mais nada, pela estabilidade de sua vida. Alguns criados ainda nessa fase, a exemplo de Carapicuíba e Embu, mantiveram-se, como é natural, com condições muito próximas das que desfrutavam antes, dentro dos quadros das propriedades a que pertenceram. De resto, o fato de esses aldeamentos serem administrados dentro das conhecidas normas jesuítas, que chegavam a evitar 'com penas rigorosíssimas a communicação não só entre Indios e os brancos, como de uma para outras que não fossem mesmo grei', contribuía para que não fossem perturbados em sua evolução (PETRONE, 1995, p. 181-182).
\end{abstract}

Em relação à função militar, como defende Saia (1937) há de se considerar Carapicuíba como um aldeamento estratégico à proteção e defesa de Piratininga. Conforme explica, "com efeito, observa-se que a localidade de Pinheiros bem como o forte de Umbiaçaba formam uma como que a primeira linha de defesa situada ao longo do rio Pinheiros. Só depois que cessaram os ataques dos selvagens contra Piratininga, vêem-se aparecer novos aldeamentos mais avançados, Carapicuíba, Barueri [...]”. (SAIA, 1937 p. 06). No entanto, a não ser a uma batalha em Pinheiros contra índios inimigos, a história não reserva a Carapicuíba qualquer conflito ou, propriamente, a concretização desta função militar específica. Vê-se neste retrospecto, que a expulsão dos jesuítas no século dezoito ${ }^{33}$ impacta diretamente os quadros demográficos das populações aldeadas, mesmo naquelas já administradas pela Coroa. Se numa primeira fase, que vai do quinhentismo até metade do século dezessete, os quadros populacionais crescem, junto ao sucesso empreendedor dos jesuítas, após esse período, quando passam a não mais regular as relações, verifica-se aumento na mortalidade dos aldeados, com deslocamentos para outras regiões, ou fugas empreendidas diante da precarização da vida naquele momento. "Entre 1610 e 1670, a Aldeia passou por uma fase de estagnação, servindo de ponto de encontro entre clero e autoridades, os quais procuravam traçar normas para a ocupação das terras e o aproveitamento do trabalho indígena" (PIMENTEL, 2014, p. 43). Um terceiro período ainda retoma maior equilíbrio, como podemos considerar a reconstrução da igreja em 1736 e de grande parte do aldeamento

\footnotetext{
33 "Na prática, os jesuítas constituíram-se, durante todo o século XVII, excetuando-se o curto período em que foram expulsos de São Paulo (1640-1653), nos únicos elementos estáveis da administração dos aldeamentos." (PETRONE, 1995, p. 163).
} 
encabeçados pelo Padre Belchior de Pontes, período que culmina com a extinção dos aldeamentos ainda na primeira metade do século dezenove ${ }^{34}$ (PETRONE, 1995).

Em estimativas deste mesmo autor, a população aldeada em Carapicuíba deveria estar próxima de 100 indivíduos após o ano de 1736, período que se estabelece a sua reconstrução e desenvolvimento, após meio século de queda populacional e junção à Itapecerica. Os aldeamentos paulistas possuem aproximadamente 15 mil aldeados até 1640, diminuindo radicalmente para uma população total de 1 mil em 1700. No ano de 1766, Morgado de Mateus organiza um recenseamento, identificando uma população de 2.524 aldeados. Carapicuíba, neste ano, possui 132 aldeados, estando presentes 130 e dois ausentes, com predominância do sexo feminino. Em 1798 serão 138 aldeados, passando em 1803 a 168 (PETRONE, 1995), como ilustra o Gráfico 01.

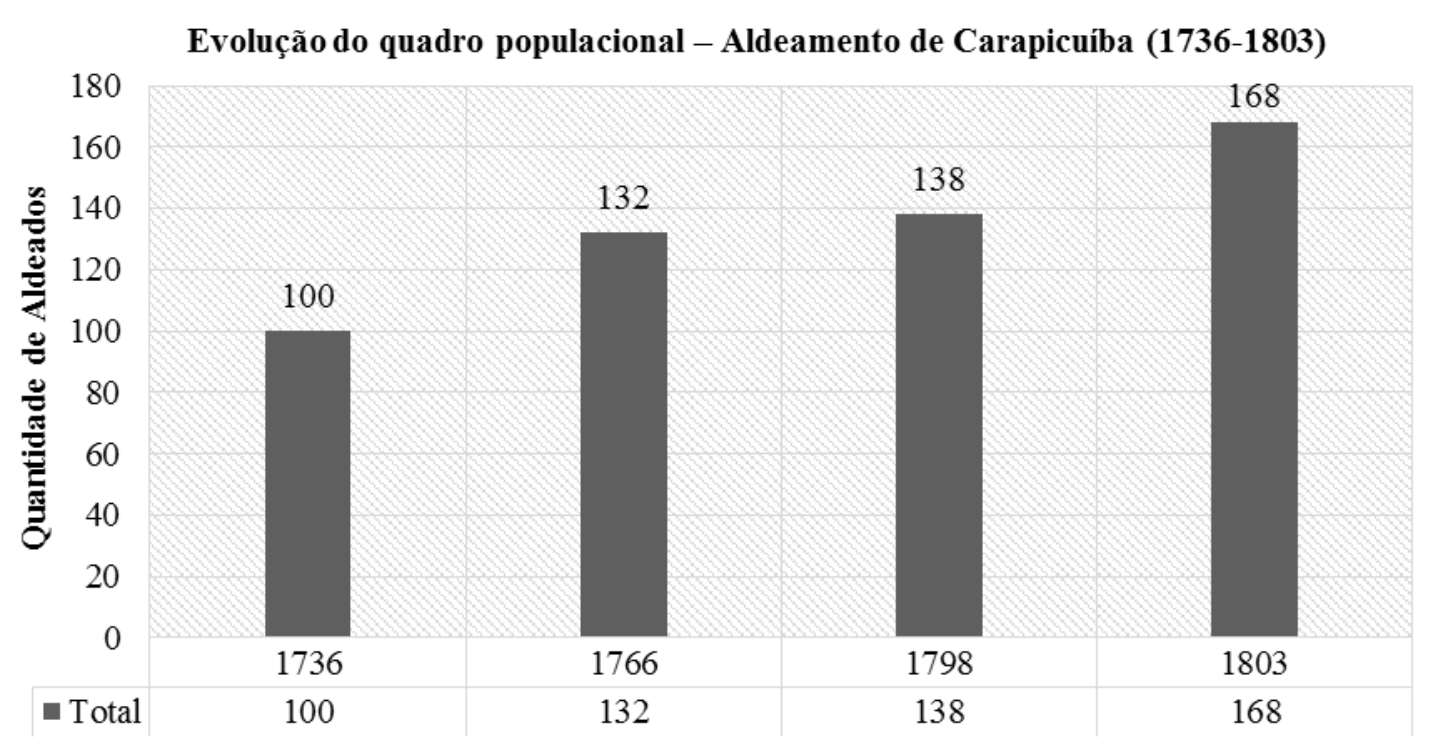

Gráfico 01: Evolução do quadro populacional - Aldeamento de Carapicuíba (1736-1803).

Fonte: Petrone (1995).

No século dezenove, a situação era de abandono dos aldeamentos, sendo descrita nos relatórios oficiais e que com o Plano Rendon acabam por se assimilarem aos "[...] quadros normais de povoamento europeu ou luso-brasileiro". Ainda que com expressivo crescimento demográfico em relação a maioria dos aldeamentos neste período, deve-se compreender que o caso de Carapicuíba era emblemático, considerando sua relativa estagnação entre os séculos dezoito e dezenove, em decorrência não apenas dos desequilíbrios populacionais causados

\footnotetext{
${ }^{34}$ A última tentativa de reestabelecer os aldeamentos paulistas foi em 1845, o que acabou por não ocorrer (PETRONE, 1995).
} 
pelo trabalho compulsório a que eram submetidos seus habitantes, mas também pelo esgotamento de suas terras. No entanto, sempre se caracterizou a um tipo de aldeamento agrícola, ou seja, com as unidades familiares dedicadas à produção de gêneros alimentícios importantes, como o milho e o feijão, também o algodão, que era o mais importante produto deste aldeamento (PETRONE, 1995).

Algumas características do cotidiano no aldeamento de Carapicuíba são importantes para compreender a sua função no quadro mais regional em que se inseria, como também observar possíveis permanências contemporâneas. Sem dúvida, no âmbito alimentar o consumo de gêneros como o feijão e o milho na dieta diária são influências importantes, porém não restritas particularmente à Carapicuíba, porém importante assinalar. No que tange a linguagem, a população aldeada fazia do uso do tupi, da qual aprendiam os padres e, no limite, faziam conjuntamente o uso bilíngue no cotidiano. De certo, grandes contribuições derivam desta mescla, se não propriamente com palavras ou na sintaxe da língua portuguesa, certamente na entonação, no ritmo da fala, bem como no sotaque e regionalismos deste idioma. O que mais chama atenção, sem dúvida, revela-se nas festividades religiosas, que como a de Santa Cruz, assumiu um caráter peculiar em Carapicuíba, sendo registrada desde o ano de 1714 conforme Arroyo (apud PETRONE, 1995) e realizada até os dias atuais. O casamento entre os aldeados respeitava a unidade familiar, condicionado pelos sacramentos da igreja, realizados entre indivíduos do mesmo aldeamento ou aqueles que possuíam espacialmente contato. No caso de Carapicuíba essa relação se estabelecia principalmente com Embu e Itapecerica. De tal maneira, constituíram os aldeamentos até meados do século dezenove "[...] ilhas de populações indígenas relativamente puras; pela natureza de sua organização, se não totalmente, ficaram em grande parte à margem do processo de miscigenação que teve lugar no planalto e a que se referem Cassiano Ricardo e Alcântara Machado.” (PETRONE, 1995, p. 969).

Em princípios do século dezenove, com o Plano Rendon e com vista a abolição dos aldeamentos pelo governador da capitania Antonio Jose Franca e Horta, foi dada liberdade aos aldeados. Conforme Petrone (1995, p. 349), o aglomerado de Carapicuíba praticamente não evoluiu desde então, ficando abandonada a sede do aldeamento, com terreno devoluto e alguns posseiros. "Talvez seja essa a razão por que, inteiramente olvidada, ou quase, não apenas se conservou como conjunto arquitetônico praticamente intacto, mas também trouxe até os dias atuais o nome Aldeia ou Aldeia Velha de Carapicuíba." (PETRONE, p. 349). De fato, Carapicuíba relativamente isolada das principais rotas, estradas e trilhos, a não ser 
quando chega a ferrovia Sorocabana, porém com estação muito distante do antigo aglomerado (COSTA JUNIOR, 1986). O que poderia contribuir, de certo modo, para a preservação de suas antigas estruturas das modernizações que passaram a operar as cidades no entorno de São Paulo, continuamente dando-lhes uma função suburbana.

Pelo relativo isolamento em que ficou Carapicuíba, este espaço se converte num pequeno vilarejo, no contexto de consolidação dos cinturões caipira e de chácaras. O primeiro associado à formação de uma cultura hibridizada entre as etnias presentes até então no território, caracterizada pelo distanciamento dos núcleos citadinos. Enquanto, as chácaras serviriam de segunda residência, que incluíam sítios e fazendas que permeavam as necessidades de lazer e de alimentos básicos à população paulistana. As propriedades e estabelecimentos nos arredores de São Paulo no século dezenove revelam uma diversidade de aspectos, das quais Langenbuch (1971) destaca além dos aldeamentos em decadência, as colônias de imigrantes, chácaras, sítios, terras de ordem religiosa e grandes extensões de terras devolutas. Neste caso, o fim do aldeamento irá convergir plenamente, com a chegada de posseiros, a mescla étnica e o isolamento que se fazia mesmo com o desenvolvimento das linhas férreas na segunda metade do século dezenove. A ferrovia Sorocabana se instalará apenas em 1875 nesta região e próxima às margens do rio Tietê e, pois, há aproximadamente dez quilômetros do núcleo da Aldeia, sem servi-lo diretamente com uma estação, ou necessariamente ser um fator inicial de atração no seu entorno próximo. O fim dos aldeamentos converge na análise de Langenbuch (1971) com as modernizações que engendrariam a efetiva metropolização de São Paulo, cujos efeitos, além das infraestruturas, rebatem em Carapicuíba no tombamento da sua antiga Aldeia.

Seria difícil dimensionar a totalidade daquilo que o processo de colonização suprimiu, superpôs ou acumulou exatamente nos campos de Piratininga ou no atual território de Carapicuíba. Porém, o resgate deste período histórico é metodologicamente capaz de sintetizar que a gênese das rugosidades patrimoniais em questão perfazem sobremaneira a supressão da cultura e modo de vida indígenas, em favor de sobreposições externas, cujas funcionalidades e conteúdos atenderam as necessidades de acumulação primitiva em curso no desenvolvimento do capitalismo comercial. No caso de Carapicuíba, a instalação do aldeamento é um marco, inclusive simbólico, do poder colonial em relação à organização de uma estrutura de apoio aos desígnios imperialistas, como das forças produtivas. Se a supressão das formas-conteúdos é latente, a categoria de superposição sintetiza a ação colonizadora calcada na ampliação dos caminhos, a criação de aldeamentos, vilas e cidades 
sobre antigas tabas e núcleos indígenas, afora os esforços de "civilização" que perturbaram a visão de mundo e a organicidade do nativo com seus territórios. Se suprimidas gradativamente as rugosidades indígenas, dialeticamente foram estas a alimentar continuamente os núcleos com seu capital humano e cultural, a perpetuar a hibridização e traços importantes desse nosso "povo novo". Disso, em menor expressão, há assimilação de técnicas e conhecimentos que nortearão o efetivo assentamento, conhecimento e apropriação do território. Destas assimilações, outra vez mirando empiricamente Carapicuíba, perpetua-se as tradições religiosas sincréticas, destacadamente a de Santa Cruz e subsidiando o modo de vida caipira, que será o próximo foco de análise. 


\section{CAPÍTULO 04: Rugosidades patrimoniais na consolidação suburbana de Carapicuíba}

A tradição clássica da Geografia Urbana brasileira contribuiu com uma diversidade de análises individualizadas das cidades da Grande São Paulo, como aquelas pioneiramente reunidas por Azevedo (1958), ou mais generalizadamente acerca da estruturação metropolitana, como o estudo de Langenbuch (1971). Numa perspectiva mais ampla dos estudos geográficos da metrópole paulista, cabe destacar, entre outros autores, Ab'Saber (1956), Seabra (1987) e Ribeiro (2016) com suas particularidades nas análises ao tematizarem criticamente questões de ordem ambiental. Estes autores citados, junto a outros do mesmo contexto e de análise de outras metrópoles (como no Rio de Janeiro com Fany Davidovich e Lobato Corrêa), buscaram compreender algumas das principais interelações da capital com seus subúrbios e congregam as principais premissas teóricas e analíticas da formação e desenvolvimento regional da Grande São Paulo. Ainda no âmbito da Geografia, mais recentemente, destacam-se estudos que agregam analiticamente múltiplas escalas e a criticidade reflexiva sobre o processo de urbanização e metropolização, como em Santos (2012b; 2013b), Lencioni (2015) ou nas compilações de Carlos e Oliveira (2004; 2015; 2016) que trazem sínteses das produções atuais, como as de Damiani (2015), Scarlato (2015), Silveira (2015), Seabra (2015), Suzuki (2015), Souza (2016), Lemos (2016), Alves (2016), ou nas publicações de simpósios, como o de Geografia Urbana (SIMPURB).

Neste capítulo, em especial, a preocupação será com a estruturação da região metropolitana de São Paulo a partir de Carapicuíba. Pois é este fenômeno a dinamizar o modo de vida e, portanto, as rugosidade patrimoniais geradas no período anterior e em gradativo desenvolvimento pelas modernizações e práticas operadas nos lugares. A delimitação temporal marca o fim dos aldeamentos paulistas, no século dezenove, e limita-se até a efetiva metropolização a partir de 1950. É este período, de aproximadamente cem anos, que marca a pré-industrialização brasileira. É nele também que São Paulo será favorecido pelos dividendos da produção cafeeira, pela concentração espacial de capitais e a gradativa centralidade na produção de mercadorias no processo de substituição de importações, a tornar-se o eixo espacial articulador da economia brasileira.

Em razão do relativo isolamento e da condição política-administrativa de Carapicuíba ser um distrito de Cotia e depois de Barueri, quando se emancipa apenas no ano de 1964, 
dados e informações no período são escassos, o que leva aqui a uma síntese de fontes secundárias e que se referem aos anos mais recentes. Para efeito de situar os momentos e condições de gênese e transformação das rugosidades estas bases são relativamente suficientes, considerando ainda o apoio de análise iconográfica, de mapas, documentos e outros materiais que os complementam. A estruturação metropolitana de São Paulo deriva das diferentes funcionalidades que seu espaço regional passa a executar desde então. Portanto, áreas como o $\mathrm{ABC}$ e Osasco, onde predominaram atividades industriais diversas, as rugosidades estarão diretamente associadas a esse processo. No caso de Cotia, Vargem Grande e até parte de Carapicuíba, será a agricultura a dinamizar as rugosidades patrimoniais, servindo a capital com seus produtos "caipiras", que agora sobrepõe os aldeamentos, mas sem necessariamente deixar conteúdos ou formas que se cristalizaram naqueles territórios. Assim, pensar a metrópole paulistana é, pois, entendê-la em seus diferentes contextos, já que mesmo considerando estruturas diferentes de produção e novos modos de viver, subsistem singulares e múltiplas temporalidades, cujas rugosidades patrimoniais expressam espacialmente.

Por fim, Carapicuíba representará no espaço da Aldeia a particularidade construtiva, ou a rugosidade patrimonial atinente ao regime temporal pretérito, cujas narrativas nacionais e a busca por uma identidade (que será calcada neste momento nas raízes coloniais), permitirão sua escolha simbolizadora da mítica fundacional brasileira. O "conjunto urbanístico", especificamente, torna-se em um achado central das mais amplas características da brasilidade, fundamentado nos preceitos defendidos pela Semana de Arte Moderna, do qual resultará o reconhecimento nacional daquela rugosidade como um dos primeiros bens patrimonializados no Brasil e especialmente em São Paulo (com estudos realizados desde 1937 e com o tombamento federal em 1940). 


\subsection{O vilarejo de Carapicuíba na formação do cinturão caipira em São Paulo}

\footnotetext{
Durante um século, caipiras marcaram a paisagem cultural dos arredores de São Paulo, seus contactos com a metrópole sendo feitos às custas de uma atividade comercial modesta: utilizando cargueiros isolados, tropas pequenas, ou carros de boi, levaram suas mercadorias para a cidade e contribuíram para criar um capítulo pitoresco que então caracterizou algum dos ângulos metropolitanos [...] (PETRONE, 1995, p. 375).
}

No século dezenove, com a independência do país, junto às novas vilas e povoados, emergem modernos sentidos para o desenvolvimento da cidade, traduzidos basicamente por intervenções estruturais nos espaços já construídos segundo as demandas produtivas em questão. Este será continuamente munido de infraestrutura, intensificadas pela industrialização na Europa que passa a demandar fontes primárias, do mesmo modo pela racionalização do planejamento e profundas mudanças das relações rurais e urbanas (ABREU, 1996; SUZUKI; COSTA, 2012). Intensificam-se hierarquias espaciais e diferenças sobre as instâncias sociais consolidadas ao longo dos primeiros séculos da colonização. Essas mudanças farão com que as rugosidades produzidas nos séculos anteriores atuem a partir de forças inerciais, que ora impulsionam o crescimento e expansão dos núcleos, ora impedem o desenvolvimento das novas atividades produtivas em jogo. Em Carapicuíba, no entanto, este processo terá algumas singularidades, responsáveis até o meio do século vinte pela manutenção e preservação do conjunto da Aldeia e a latência da acumulação de uma diversidade de rugosidades patrimoniais ligadas à chegada do negro africano e do imigrante europeu.

Com a interiorização da rede de aglomerados populacionais, bem como as transformações empreendidas nesta passagem de quase cem anos do capitalismo comercial ao industrial, farão com que o campo passe a depender, paulatinamente, da cidade, que permite concomitantemente a sua modernização e regulação. Nas ideias de Prado Júnior (1972 [1945]), este é um tempo revolucionário pela nova distribuição das atividades produtivas, no caso brasileiro principalmente as ligadas ao café. Cultivado em fins de século dezoito, o café tornar-se-ia o principal gênero agrícola da economia brasileira no século seguinte. Fugindo do litoral para o interior, em partes elevadas do terreno, a produção cafeeira daria fôlego providencial à decadência das minas, da produção de algodão e açúcar nas regiões tradicionais da colônia.

Como destaca Furtado (1971 [1959]), a gestação da economia cafeeira, que integraria mais efetivamente o país ao comércio internacional, acompanha a produção canavieira e de algodão, como é o caso do quadrilátero do açúcar, que em São Paulo concorreu paralelamente ao ciclo cafeeiro e que vê florescer sua produção especialmente entre 1750 e 1850 (PRADO JUNIOR, 1972 [1945]; PETRONE, 1968; IANNI, 1996; OLIVEIRA, 2012). Estes produtos, no entanto, com preços ainda estagnados pela baixa competitividade com outras regiões, como as 
Antilhas, estavam aquém da rentabilidade que o café passava a obter. As tradicionais fazendas canavieiras em São Paulo passavam a gradativamente substituir sua produção, ou no caso de áreas mais interiores a principiar a produção de café (MONBEIG, 1998).

Um problema que se estabelece com o fim dos aldeamentos e o aumento produtivo de gêneros primários é a carência de mão de obra, que como explica Furtado (1971 [1959]) passa a ser gradativamente resolvido com a chegada de mais escravos africanos e colonos europeus. Os rendimentos da lavoura e a expansão da economia paulista passaram a substituir a mão de obra indígena pelo escravo africano. Considerando a baixa expectativa de vida destes trabalhadores, diante de condições precárias de sobrevivência no país, estima-se em 1,5 milhões de escravos integrados no empreendimento colonial até 1800 (número oficial, portanto muito questionável levando em consideração o contrabando e a ocultação para não pagamento de impostos), número muito semelhante se somados aos índios integrados, por volta de 500 mil e índios isolados por volta de 1 milhão, que compunham a população brasileira no período (RIBEIRO, 2006 [1995], p. 137). Mais que o trabalho, ao escravo também cabia a função de investimento, como renda capitalizada fixa, sendo fator privilegiado da produção, pois garantia novos investimentos pelos proprietários de terra, fazendeiros, pelo penhor junto aos bancos, comerciantes de café e insumos e, até mesmo, como garantia aos traficantes de negros para novas investidas (MARTINS, 1990, p. 26).

Além das importações, a migração interna destes escravos foi intensificada de norte a sul, onde o dinamismo da produção cafeeira era atrativo. Com a proibição da importação de escravos, assim como a intensificação no controle ao tráfico humano, “[..] a questão de mão-de-obra se agravava, e passava a exigir urgente solução. [...] Sugeria-se fomentar uma corrente de imigração europeia." (FURTADO, 1971 [1959], p. 119-123). O projeto foi iniciado, patrocinado pelos dividendos do governo imperial na forma de crédito aos grandes proprietários de terra no Brasil. Processo que se acentua no avançar do século dezenove e adentra o primeiro quartel do século vinte, com mais de cinco milhões de pessoas vindas principalmente de Portugal, Itália, Espanha, Japão e Alemanha (RIBEIRO, 2006 [1995]).

Esta contextualização é fundamental ao entendimento das rugosidades patrimoniais de Carapicuíba, exatamente em função de que grande parte desses escravos africanos e trabalhadores livres de origem europeia, concentravam-se nas cidades e áreas rurais dos centros mais dinâmicos de produção, que neste período já principiavam a ser São Paulo e, sobretudo, Rio de Janeiro. Com eles, traziam modos de viver, crenças e saberes que juntos a uma união difusa com os caipiras locais passariam a influenciar e a ser influenciados nas cidades e suas regiões de alcance. No caso de Carapicuíba, além do contorno cultural como um todo, sobretudo em relação aos traços mais 
urbanos dessas populações, a marca dos novos habitantes está materialmente gravada por toda paisagem da cidade. Nas propriedades rurais do entorno da Aldeia, nos fins do século dezenove, já estão presentes italianos e japoneses, com suas tradições e modos de viver, mais tarde revelam-se construções da Igreja Ortodoxa Russa, as comunidades da Igreja de Santo Antonio na Vila Anita Caldas, com a presença de portugueses e italianos (TENÓRIO, 2003). Do mesmo modo, as tradições africanas, reveladas nos sincretismos dos festejos de Nossa Senhora do Rosário e de São Benedito ainda perduram anualmente na cidade e região.

No findar do século dezenove, ainda que em meio a crises econômicas contínuas no país, exceção ao café em São Paulo e a borracha na Amazônia, como atestado por Prado Júnior (1972 [1945]), há aceleração das aglomerações urbanas, no sentido em que se expandem as cidades, chegando em 1900 o país a ter uma população citadina de aproximadamente $10 \%$ do total. Apesar de relativamente irrisória em relação aos quase $81 \%$ da população urbana contemporânea (IBGE, 2010), avançara-se praticamente em quase cem por cento entre 1870 e 1900 o número de residentes em cidades, agora com certa confiabilidade de dados pelos recenseamentos realizados pelo governo imperial.

Trata-se, nas palavras de Moreira (2005, p. 14) de tempos transicionais da "[...] colônia para a independência, da escravidão para o capitalismo e da monarquia para a república, assim antecipando o momento instaurador da grande transformação que ocorrerá na formação espacial brasileira com o advento da industrialização e urbanização do agora país”. Estas mudanças também são apontadas por Ianni (1996) “[...] assim, ao trabalhador escravo sucedeu o trabalhador livre, ao negro sucedeu o branco, à senzala sucedeu a colônia.” (IANNI, 1996, p. 57). Essas sucessões, inclusive de rugosidades, superpõe formas e conteúdos que mais tarde subsidiarão as políticas patrimoniais em moldar uma identidade nacional, bem como fundamentar os sentidos de identidade cultural ligados em parte desses preceitos históricos fundacionais.

Conforme Moreira (2005) e Santos (2013b) ainda não é possível necessariamente pensar em um processo de urbanização, já que este se associará somente mais tarde com a industrialização efetiva do país. Mais que condição urbana, as cidades configuravam-se como centros nodais das novas necessidades produtivas, surgindo novos núcleos ou expandido antigos centros. Fazendo com que São Paulo e Rio de janeiro tomassem a dianteira, já que a dinâmica produtiva se acentuava sem seus territórios. A proposição deste quadro pode ser embasada pela realidade demográfica relativamente baixa dos principais centros urbanos no país: São Luís, Salvador, Recife, São Paulo e Rio de Janeiro. Neste período de passagem entre os séculos, as maiores cidades, somavam apenas 5,7\% dos 2,85 milhões da população total brasileira (SANTOS, 2013b, p. 22). 
Não apenas o plano econômico era latente nas propriedades rurais, mas a organização da vida social, nos latifúndios e propriedades, que aglomeravam milhares de trabalhadores e que passavam continuamente a receber as linhas férreas e estações para escoamento da produção. Em 1872, apenas três capitais brasileiras contavam com mais de 100 mil habitantes: Rio de Janeiro (274.972), Salvador (129.102) e Recife (116.671). Somente Belém (61.997) contava com população entre 50 e 100 mil residentes. São Paulo neste período tinha uma população de 31.385 pessoas, o que evidencia em fins do século dezenove sua irrisória centralidade no que tange o aglomerado populacional e a centralidade econômico-política no país. Número que em praticamente duas décadas dobraria o valor, passando a população da cidade de São Paulo em 1890 para 64.934 habitantes. Ainda em 1890, eram apenas três as cidades com mais de 100 mil habitantes: Rio de Janeiro com 522.651, Salvador com 174.412 e Recife com 111.556. Além de São Paulo, duas outras cidades passavam da casa dos 50 mil: Porto Alegre: 52.421 e Belém: 50.064. São Paulo já havia passado Belém, continuando a crescer expressivamente com o incremento de milhares de imigrantes que chegavam dia após dia na cidade (SANTOS, 2013b, p. 23).

Em 1872, o número de municípios em São Paulo era o maior do Brasil, com 89 no total, seguido por Minas Gerais e Bahia, ambos com 72. Tal fato revela que, mesmo a capital não possuindo uma das maiores aglomerações, seu território já vinha passando por espessa fragmentação político-administrativa em razão da alta produtividade de gêneros agrícolas e maior controle dos grupos oligarcas das respectivas regiões. É possível pensar neste período em vários núcleos florescentes em São Paulo, e não apenas sua capital. Principalmente porque no ano de 1900 o número de municípios sobe para 172, num ritmo constante, que chega a 204 municípios no ano de 1920 e a população da capital sendo a segunda maior do país, com 579 mil habitantes, atrás apenas do Rio de Janeiro com mais de 1 milhão de habitantes. Mesmo que os níveis de urbanização pouco se alterem, em verdade, entre o fim do século dezenove e princípios do vinte, o caso de São Paulo passa ser emblemático (Tabela 01 e Gráfico 02). 


\begin{tabular}{|c|c|c|c|c|c|c|c|}
\hline $\begin{array}{c}\text { Províncias } \\
\text { Brasileiras } \\
1872\end{array}$ & $\begin{array}{c}\text { Número de } \\
\text { Municípios } 1872\end{array}$ & $\begin{array}{c}\text { Unidades da } \\
\text { Federação } \\
1900\end{array}$ & $\begin{array}{c}\text { Número de } \\
\text { Municípios } \\
1900\end{array}$ & $\begin{array}{c}\text { Unidades da } \\
\text { Federação } \\
1911\end{array}$ & $\begin{array}{c}\text { Número de } \\
\text { Municípios } \\
1911\end{array}$ & $\begin{array}{c}\text { Unidades da } \\
\text { Federação } \\
1920\end{array}$ & $\begin{array}{l}\text { Número de } \\
\text { Municípios } \\
1920\end{array}$ \\
\hline & & & & Territorio do Acre & 3 & Territorio do Acre & 5 \\
\hline Amazonas & 7 & Amazonas & 24 & Amazonas & 27 & Amazonas & 28 \\
\hline Pará & 32 & Pará & 50 & Pará & 54 & Pará & 56 \\
\hline Maranhão & 37 & Maranhão & 53 & Maranhão & 54 & Maranhão & 64 \\
\hline Piauhy & 22 & Piauhy & 34 & Piauhy & 37 & Piauhy & 39 \\
\hline Ceará & 46 & Ceará & 79 & Ceará & 83 & Ceará & 86 \\
\hline Rio Grande do Norte & 22 & $\begin{array}{l}\text { Rio Grande do } \\
\text { Norte }\end{array}$ & 37 & $\begin{array}{l}\text { Rio Grande do } \\
\text { Norte }\end{array}$ & 37 & \begin{tabular}{|l|} 
Rio Grande do \\
Norte
\end{tabular} & 37 \\
\hline Parahyba & 24 & Parahyba & 36 & Parahyba & 39 & Parahyba do Norte & 39 \\
\hline Pernambuco & 39 & Pernambuco & 58 & Pernambuco & 59 & Pernambuco & 59 \\
\hline Alagôas & 19 & Alagôas & 34 & Alagôas & 35 & Alagôas & 35 \\
\hline Sergipe & 24 & Sergipe & 33 & Sergipe & 34 & Sergipe & 34 \\
\hline Bahia & 72 & Bahia & 126 & Bahia & 129 & Bahia & 136 \\
\hline Municipio Neutro & 1 & Districto Federal & 1 & Districto Federal & 1 & Districto Federal & 1 \\
\hline Minas Geraes & 72 & Minas Geraes & 124 & Minas Geraes & 176 & Minas Geraes & 178 \\
\hline Espirito Santo & 13 & Espirito Santo & 29 & Espirito Santo & 29 & Espirito Santo & 31 \\
\hline Rio de Janeiro & 33 & Rio de Janeiro & 48 & Rio de Janeiro & 48 & Rio de Janeiro & 48 \\
\hline São Paulo & 89 & São Paulo & 173 & São Paulo & 174 & São Paulo & 204 \\
\hline Paraná & 16 & Paraná & 40 & Paraná & 44 & Paraná & 49 \\
\hline Santa Catharina & 11 & Santa Catharina & 26 & Santa Catharina & 28 & Santa Catharina & 34 \\
\hline Rio G. do Sul & 28 & Rio G. do Sul & 66 & Rio G. do Sul & 66 & Rio G. do Sul & 71 \\
\hline Matto Grosso & 9 & Matto Grosso & 13 & Matto Grosso & 18 & Matto Grosso & 21 \\
\hline Goyaz & 26 & Goyaz & 37 & Goyaz & 45 & Goyaz & 49 \\
\hline BRASIL & 642 & BRASIL & 1121 & BRASIL & 1220 & BRASIL & 1304 \\
\hline
\end{tabular}

Tabela 01: Evolução de número de municípios brasileiros entre 1872 e 1920

Fonte: IBGE - Evolução da Divisão Territorial do Brasil (1872-2010). Organização do autor, 2016. 
Evolução populacional das maiores capitais na fase pré-industrial do Brasil (1870-1950)

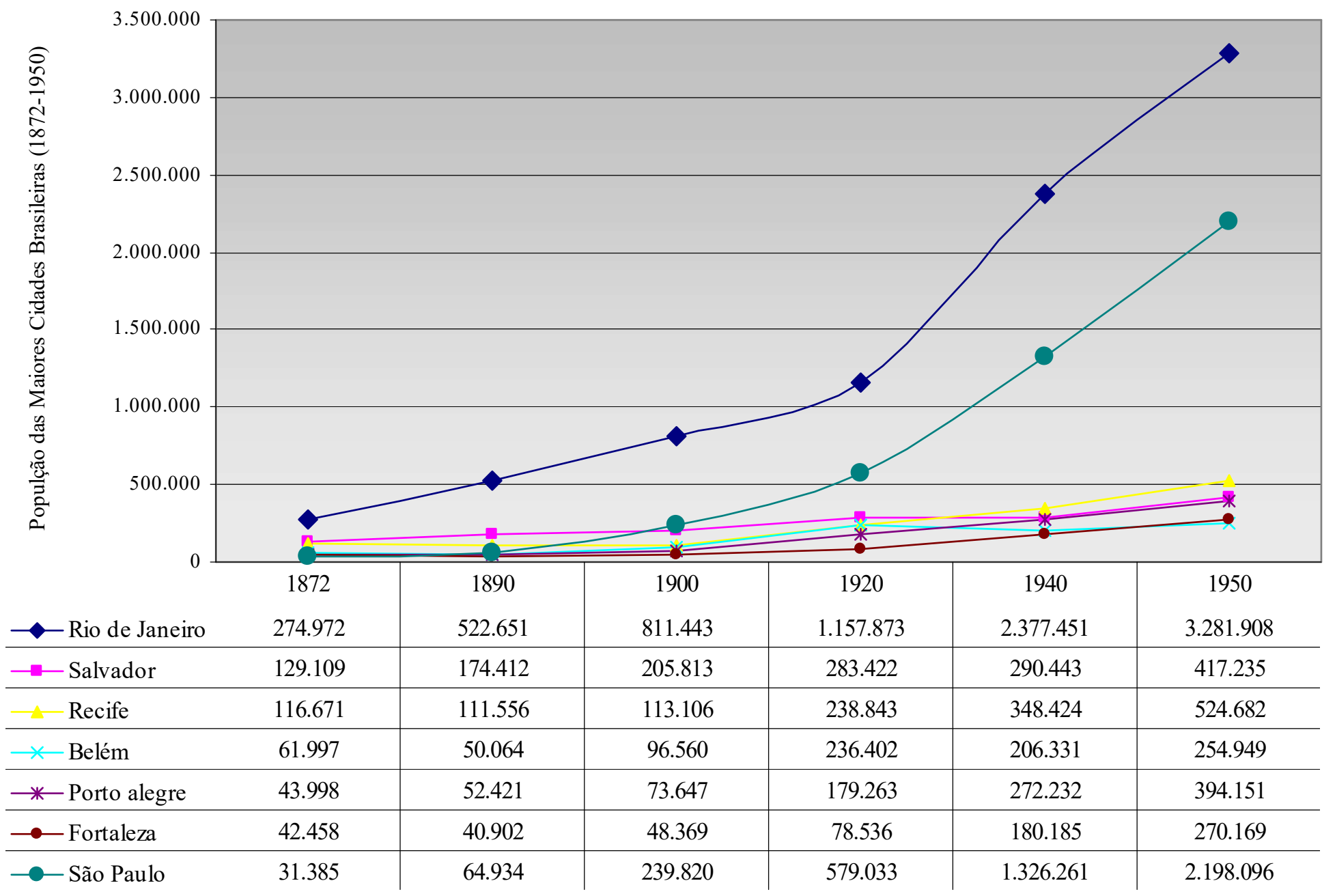

Gráfico 02: Evolução populacional das maiores capitais na fase pré-industrial do Brasil (1870-1950).

Fonte: (a) IBGE - Evolução da Divisão Territorial do Brasil (1872-2010) - 2011; (b) Censo 2010; (c) Santos (2013b, p. 153) segundo anuários estatísticos e censos demográficos do IBGE. Organização do autor, 2016. 
É no contexto das mudanças políticas e econômicas operadas globalmente e rebatidas no território brasileiro que o processo de conformação do cinturão caipira e de chácaras converge propriamente com o fim dos aldeamentos em São Paulo. Sua caracterização é, destacadamente, realizada por Azevedo (1958), Petrone (1995) e Langenbuch (1971), que servem de base para pensar o desenvolvimento urbano de São Paulo e, fundamentalmente, de Carapicuíba. Trata-se do período no qual Langenbuch (1971) principia sobre a própria estruturação da RMSP, onde a capital, com sua localização estratégica entre o interior e o porto, continuará a regular os fluxos econômicos traduzidos ora pela produção primárioexportadora, ora na redistribuição dos produtos manufaturados importados ao restante do país (Figura 17).

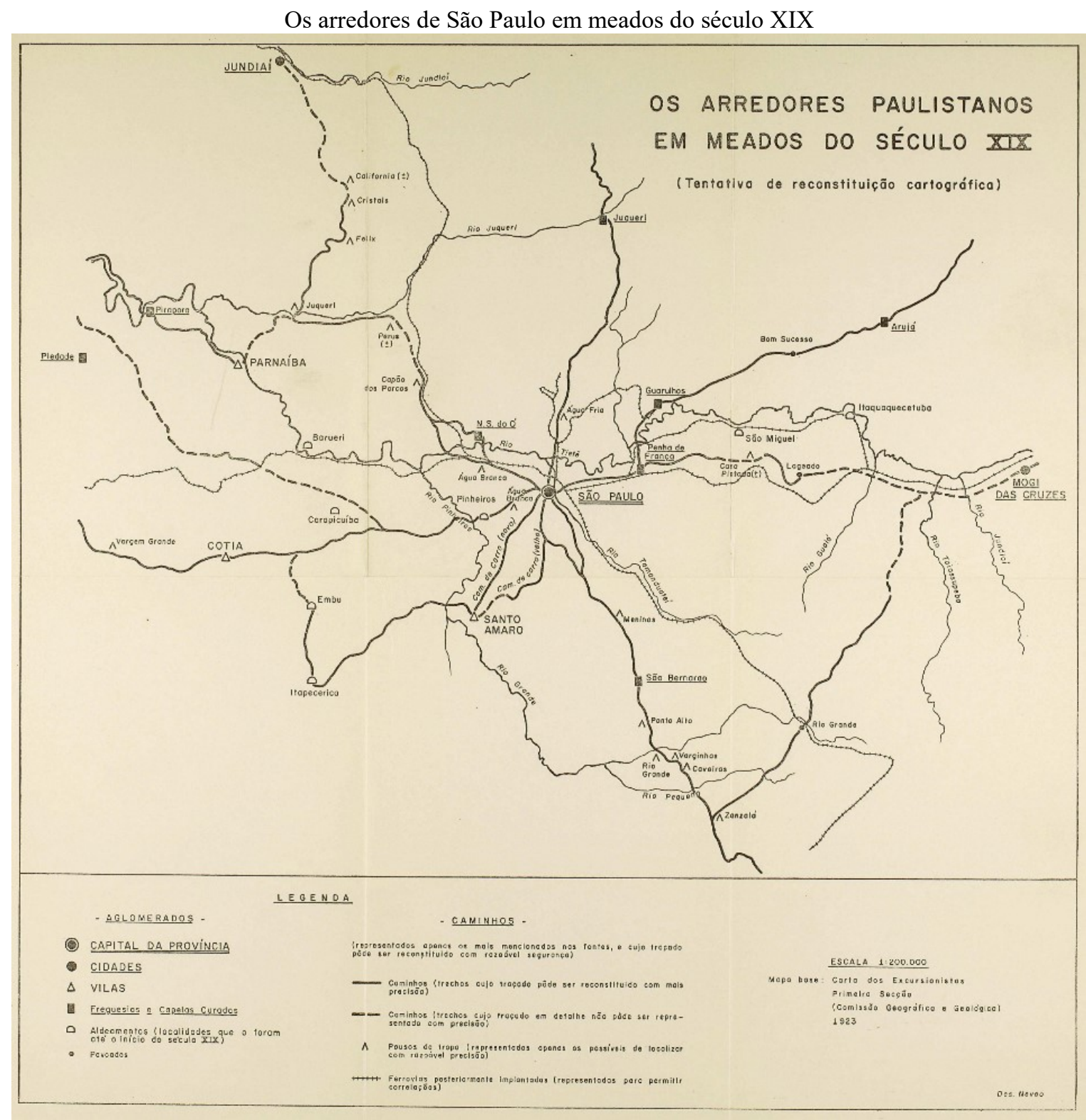

Figura 17: Caminhos e núcleos populacionais nos arredores de São Paulo em meados do século dezenove. Fonte: Langenbuch, 1971. 
No entanto, o desenvolvimento pela alta produtividade é concentrado em espaços de dinâmica produção agrária, ou propriamente na cidade de São Paulo, que faz a regulação e centraliza atividades políticas e administrativas. Isso faz com que Carapicuíba fique à margem das infraestruturas instaladas no território. O tempo no espaço fica cristalizado, em momentos que parecem não corresponder com o florescimento das proto-indústrias e do modo de vida urbano em curso no centro metropolitano paulista. Tão perto e tão distante de uma das maiores cidades brasileiras, a Aldeia de Carapicuíba à margem da modernização preservara relações e modos de vida, tradições e uma relativa organicidade com a unidade designada caipira, na ruralidade ainda pouco tensionada pelos desígnios das inovações técnicas em amplas escalas. A pujança de São Paulo era contrastante não apenas em relação aos seus subúrbios, mas com as unidades territoriais localizadas no interior e que se articulavam pela centralidade estabelecida das linhas de trens na capital e em sentido ao porto de Santos.

Em seus levantamentos Langenbuch (1971) conclui que a metamorfose dos aldeamentos em povoados caipiras se opera durante os dois quarteis intermediários do século dezenove. Seus limites, pois, antecedem a suburbanização propriamente, ou seja, a integração maior com São Paulo pelas estações e os trilhos ferroviários. Concêntricos à São Paulo, estes espaços, em verdade, não constituiriam necessariamente um cinturão, tão pouco seriam determinados pelas distâncias, mas sim uma conjugação de fatores, que remetem à valorização e especialização residencial no caso das chácaras, até o abandono e ostracismo dos vilarejos caipiras - este último mais apropriado para qualificar Carapicuíba. "O 'cinturão das chácaras' apresentava propriedades menores que o 'cinturão caipira', onde ainda era incomum uma certa indefinição fundiária, sendo freqüentes os litígios e as invasões, estas, às vezes, relacionadas com a prática da rotação de terras pelo sistema de 'roça', outras vêzes à antiga estrutura ligada aos jesuítas e aos aldeamentos" (LANGENBUCH, 1971, p. 74).

De difícil delimitação, o cinturão caipira se diferencia fundamentalmente do cinturão das chácaras apenas pelo ostracismo e isolamento que o primeiro se estabelece em relação ao segundo. Seu arranjo é de complexa espacialização, considerando mesmo a indefinição política-administrativa dos limites entre cidades e vilas naquele período, variando espaços por vezes mais distantes e dinâmicos, ou mais próximos de São Paulo e relativamente abandonados. Tanto são as denominações quanto a diversidade de lugares e culturas: vilarejos, distritos, pousos, freguesias, arraiais, aldeias, convivendo áreas dinâmicas e outras estáticas sobrepostas nas mesmas unidades territoriais. Trata-se de uma grande diversidade funcional das unidades no plano dos subúrbios paulistanos em gestação naquele momento. 
Considerar, no entanto, algumas diferenças entre eles permite ampliar a diversidade de relações que havia então e que, de todo modo, condicionou posteriormente a forma de desenvolvimento da própria metrópole.

No que tange mais propriamente aos cinturões caipira e de chácaras, estas classificações são funcionais e caracterizam diretamente alguns importantes conteúdos dos arredores de São Paulo ao longo do século dezenove até as primeiras décadas do vinte. Em relação às pequenas propriedades rurais, fazendas e sítios, englobados no cinturão de chácaras, teriam por função não apenas o lazer, mas o fornecimento de insumos alimentícios aos núcleos centrais e localizavam-se mais próximos da capital. Associam-se às chácaras, também os sítios e pequenas fazendas. Sua produção limitava-se muito mais ao mercado local do que a produção de açúcar ou café ao mercado internacional, então podendo considerar o cinturão enquanto celeiro de São Paulo, função que também desempenhava em grande medida junto com o cinturão caipira. Essas seriam as características mais essenciais do cinturão de chácaras nos arredores de São Paulo, lembrando conforme Langenbuch (1971) outros aspectos:

O cinturão das chácaras achava-se visivelmente organizado pela cidade para a cidade. Além das chácaras com sua função de residência, e secundariamente de produção frutícola, o cinturão encerrava uma série de elementos funcionalmente ligados à cidade, e que aí se situavam por requererem muito espaço - por seu caráter repulsivo (recomendando seu isolamento), ou por ser a localização campestre considerada ideal. Trata-se daqueles pousos de tropa destinados a propiciar alojamentos junto a São Paulo, dos cemitérios, de hospitais, de colégios, do depósito de pólvora (LANGENBUCH, 1971, p. 76).

Em relação ao cinturão caipira, tratavam-se de pequenos núcleos de aglomeração de economia decadente, agricultura de subsistência, roçado, ou ainda um ou outro gênero a ser comercializado na capital. No ostracismo, serviram-se da criação de alternativas próprias de subsistência, vivendo a poucos quilômetros de São Paulo, que apesar de expressividade no quadro regional, ainda era uma pequena vila no século dezenove (PETRONE, 1995). O vilarejo, da Aldeia de Carapicuíba, achava-se assim como no passado, um conjunto de casas que se encerravam entre si, ou seja, se no passado assim dispostas pressupunham separação entre o índio e o branco, ou mesmo a própria segurança do núcleo, agora dispunham em seus conteúdos a rusticidade do caipira que tão bem descreve Antônio Cândido (2010), fechado em seu núcleo familiar e de compadrio, vivendo apartado em um sistema social que está 
relativamente alheio às transformações em São Paulo. A detalhada descrição de Cândido (2010) da cultura caipira anos mais tarde (1948), na região de Bofete, interior de São Paulo, converge compassadamente com parte da cultura indígena e dos aldeamentos tão bem precisado por Petrone (1995) em citação subsequente, que vão dos hábitos alimentares, às vestimentas, assim como as relações sociais mais complexas em torno da religiosidade e da agregação familiar.

Os referidos núcleos, aldeamentos ou não, de qualquer forma testemunhos do passado, sempre abrigavam uma população relíquia sob muitos aspectos. Vivendo em casas de pau-a-pique ou de taipa, sempre modestas e pouco confortáveis; cultivando um pouco de milho ou de feijão, algumas touceiras de cana-de-açúcar e um ou outro pé de fumo; queimando anualmente uma área sempre maior do que a cultivada de fato; praticando a coleta onde ainda era possível; recolhendo lenha ou fazendo carvão, e vestindo pobremente, de pé no chão, calças pula-brejo, camisas de algodão, barbinha rala e toco de cigarro de palha na orelha, conforme o estereótipo, o morador dessas áreas com frequência representava bem o caipira dos arredores de São Paulo (PETRONE, 1995, p. 374).

Os núcleos do cinturão caipira guardam ainda maior relação com os aldeamentos, considerando a hibridização cultural que se efetivava nestas regiões (IANNI, 1996), o "caipiramento" ou "acaipiração" como denominado por Antônio Candido (2010 [1958]), expressada por Almeida Junior em uma de suas mais famosas obras a retratar o cotidiano do caipira $^{35}$ (Figura 18), segundo aquilo que observara, mas também os preceitos detalhados por viajantes como Saint Hilaire, ainda que muitas vezes pejorativas, precisas no entanto eram as descrições que situam-se desde o século dezenove aos dias atuais. Além do branco e o índio, havia a introdução recente do negro na miscigenação étnica, que junto a um modo de vida adaptado ao meio rural, realizado no campo, qualificaria a tradição, a rusticidade, aspectos que sintetizam modos de ser "caipira", e não exclusivamente um "tipo racial” (CÂNDIDO, 2010 [1958]; LANGENBUCH, 1971; PETRONE, 1995; IANNI, 1996).

\footnotetext{
35 "Mesclaram-se os portugueses e os índios, escravos e forros, mestiços ou não, nas bandeiras, monções, roças ou criações. Assim, enquanto se estendia a rede de povoamento e negócios, pelas longas lonjuras, formava-se a base de uma sociedade peculiar, a sociedade caipira. (IANNI, 1996, p. 16).
} 
Caipira Picando Fumo (1983) e o Violeiro (1899) - Almeida Júnior
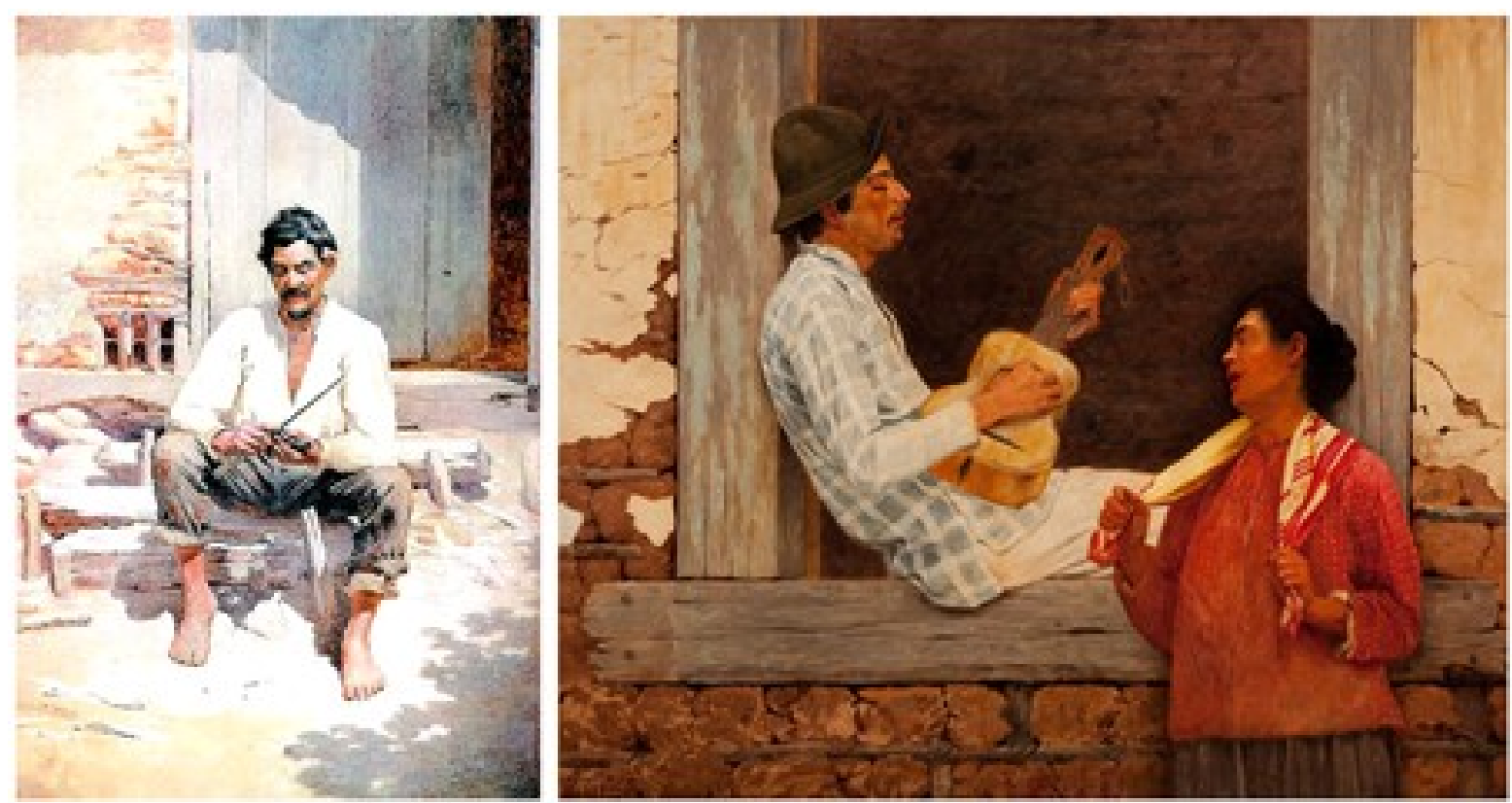

Figura 18: A esquerda, "Caipira Picando Fumo" (1983) e à direita "O Violeiro". Telas do pintor realista Almeida Júnior, retratando o modo regional de vida do caipira em São Paulo no século dezenove.

Fonte: Pinacoteca do Estado de São Paulo.

Estes núcleos caipiras, como veremos em laudas posteriores, guardam acumulações, rugosidades patrimoniais, em relação a efetiva cristalização suburbana de Carapicuíba, ou revelam diferenças espaciais do desenvolvimento de São Paulo até implosão-explosão urbana que sugere a periferização como concreticidade contemporânea. De fato, falar de São Paulo não é o mesmo que falar de Carapicuíba, onde mesmo unidos por funções vitais, estavam diametralmente distantes socialmente, como hoje despontam territórios de chácaras e sistemas condominiais nos limites periféricos e das favelas em ambas cidades.

A proximidade física, de localização, reverbera o distanciamento social, cultural e econômico, que depõe a favor do desenvolvimento geográfico desigual e combinado, do qual Marx protelava no século dezenove e que se observará detalhadamente nos territórios em questão. Como assevera Cândido (2010), há que se descriminar desde sempre as diferenças básicas da vila de São Paulo com as do povoados em seu interior, a do fazendeiro em relação da "gente de prol", a do sertanista, do povoador e do caipira. Neste sentido a vinculação do cinturão de chácaras era sempre maior com São Paulo, devido a interdependência comercial e desfrute recreativo, enquanto o cinturão caipira subsistia por longos períodos sem haver necessariamente o contato direto com o centro proto-metropolitano, ainda que grande parte de sua produção excedente rapidamente fosse absorvida pela capital. 
O 'cinturão caipira', que se seguia aos das chácaras se caracterizava pela cultura de subsistência e pela produção agrícola extrativa (lenha, madeira, pedras de cantaria e produtos cerâmicos) e artesanal (objetos de barro) destinados ao abastecimento de São Paulo. Alguns aglomerados desta faixa são procurados pela população paulistana para fins recreativos e religiosos. Estabelecimentos, instalações e atividades ligadas à circulação são bastante numerosos no 'cinturão caipira', em vista do papel de foco concentrador exercido pela cidade de São Paulo, o que provoca uma grande densidade de estradas e de circulação em seus arredores. Este cinturão, ao contrário do anterior [o de chácaras], não é inteiramente organizado em função de São Paulo, dada a importante presença da agricultura de subsistência e de extensas áreas incultas, e do relativo papel polarizador exercido por algumas vilas aí situadas. Contudo, as importantes atividades de abastecimento da capital evidentemente se organizaram em relação a esta, o mesmos e verificando, pelo menos em grande parte, com a aludida função religiosa e de recreação (LANGENBUCH, 1971, p. 76).

Os núcleos mais característicos da cultura caipira nos arredores de São Paulo seriam conforme Petrone (1995) Itaquaquecetuba, Escada, São Miguel, Guarulhos, Carapicuíba e Itapecerica. Ele destaca "[...] a existência de uma relação entre a presença dessa população caipira e o cinturão de aldeamentos das vizinhanças de São Paulo.” (PETRONE, 1995, p. 374). Carapicuíba é um registro emblemático da paisagem rural que predominava até princípios do século vinte, com a paisagem dos campos sujos e o vazio demográfico, contrastante com seu panorama urbano-metropolitano atual. No limite temporal do cinturão caipira, a descrição de Saia (1937) acerca de Carapicuíba, já na altura da quarta década do século passado, evidencia a prevalência de uma "aldeia caipira", a menos de 25 quilômetros de São Paulo, com conflitos e disputas pela posse de suas terras, como também apontado por Tenório (2003). Para Saia (1937) a própria forma "fechada" do quadrilátero, ou do retângulo que envolve todas as casas para si mesmo e a igreja, contribuiria pela manutenção de uma unidade. O cenário que o autor encontra no fim da década de 1930 é marcado por ranchos de pau-a-pique, roças de milho e outros gêneros alimentícios para a subsistência dos moradores (Figura 19). Ainda conforme Saia (1937), “o tom predominante da paisagem é dado pelos pastos, apenas interrompendo por alguma capoeira sem importância.” (SAIA, 1937, p. 14). 


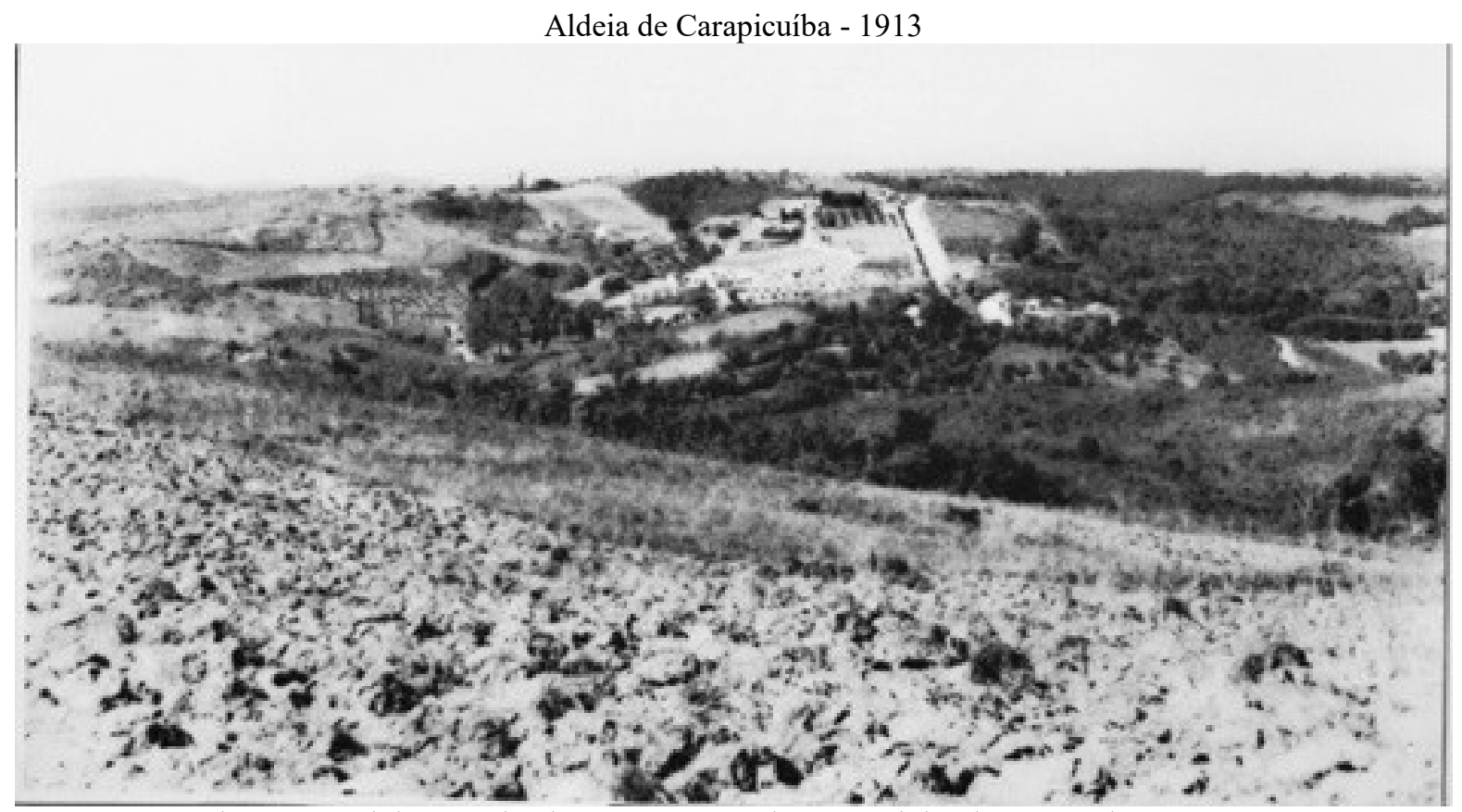

Figura 19: A paisagem rural de Carapicuíba em 1913, no cinturão caipira de São Paulo. Fonte: Acervo Fotográfico da Casa da Cultura de Carapicuíba.

Além dessa área em especial, a cultura caipira se desenvolve no interior de São Paulo como um todo, alcançando áreas do sul de Minas Gerais, norte do Paraná, sul de Goiás e até mesmo partes do Mato Grosso do Sul (CÂNDIDO, 2010; IANNI, 1996). Sem dúvida, esta relação não restringe a cultura caipira a uma pura continuidade da mescla indígena com o branco e o negro, ou aos espaços dos aldeamentos, mas a um amplo fenômeno que fundiu consideráveis elementos em torno deste modo de viver. Se naquele momento foi relegada a uma cultura atrasada, considerando o pensamento da época, hoje se revela como possibilidade de um elemento híbrido e multicultural da brasilidade. Emerge como uma identidade capaz de ser, cada vez mais, exaltada de um passado cujas marcas evidenciam a presença de diversas rugosidades patrimoniais, desde a forma do falar, os hábitos e tradições, até as construções mais simples nas muitas cidades brasileiras. Se os aldeamentos trazem condição de uma narrativa crítica em favor das supressões de seus sistemas de crenças, da sua organização espacial, do seu modo de vida, o cinturão caipira é uma vertente que processa uma latência acumulativa das diferentes raízes culturais, as quais criticamente devem ser desmitificadas em favor da concreticidade do real. Ou seja, de revelar as contradições que se operam especificamente neste caso das permanências e das transformações em curso.

Diante do ostracismo, estes núcleos preservaram importantes conteúdos, dos quais, como Langenbuch (1971), pode-se avultar a permanência da função religiosa. Esta desempenhava importante papel ao atrair uma massa de pessoas na participação de festas, 
como a do Espírito Santo, além de romarias e outras atividades culturais. Luís Saia (1937) assinala especificamente sobre as tradições festivas de Santa Cruz e Santa Catarina na Aldeia de Carapicuíba, descrevendo as relações nesta etapa da força dos mutirões nos empreendimentos locais, como a construção ou reformas das pequenas habitações, ou nas festividades cuja devoção aflora como força que capaz de movimentar as pessoas da região e dar cabo aos objetivos mais singelos.

\begin{abstract}
As festas de Santa Cruz e Santa Catarina atraem para a Aldeia grande número de caipiras das vizinhanças e alguns moradores de São Paulo aparentados aí. Em volta do páteo os sírios vendedores de bugigangas armam barraquinhas de lona, tabuleiros de quentão, arroz doce, cocada e batata doce em calda, se dispõem nos pontos onde possam chamar a atenção do caipira (SAIA, 1937, p. 15).
\end{abstract}

Além do papel da religiosidade, era comum, com certa periodicidade, afastar-se da segurança e relativo convívio da habitação e seu entrono para fazer-se presente em feiras e espaços onde se realizavam o comércio de utensílios essenciais as atividades cotidianas. Nos arredores de São Paulo, nos primórdios do novecentos, Tenório (2003) ressalta a importância de Pinheiros ao concentrar um grande mercado caipira, que oferecia mercadorias trazidas de toda região e que eram comercializadas numa interface entre distantes produtores e os consumidores locais, cuja predominância eram os frutos da terra.

Em 1910, Pinheiros já era um bairro muito conhecido de São Paulo. Para lá ocorriam os tropeiros de Ibiúna, Piedade, São Roque, Cotia, Itapecerica da Serra, M'Boy (atual Embu), Una e Carapicuíba, trazendo mercadorias para vender, quase tudo produto da terra. [...] No mercado dos caipiras de Pinheiros [...] podiam vender, além das mercadorias comuns: fazendas, sítios, chácaras, terras agrícolas e de criação, colheitas, animais vivos isolados ou em manadas, tijolos, telhas, pedregulhos, areia, madeiras, lenha, veículos, instrumentos agrícolas, etc. Os tropeiros, vindos do sertão, costumavam parar em sítios existentes nos bairros próximos e, por onde passavam, soltavam as mulas para pastar e eles mesmo, depois de uma boa refeição, iam dormir. De madrugada, saiam para o 'Mercado dos Caipiras', levando as bagagens. [...] Carapicuíba, havia muitos pousos de tropeiros, venda e local para o descanso dos animais. [...] Em Carapicuíba a venda do Antônio Zamella era um ponto de parada obrigatória para os tropeiros e viajantes [...] (TENÓRIO, 2003, p. 105-106).

Isso implica apontar uma condição relativa de isolamento, pois mesmo havendo o contato com o "mundo exterior" ainda permaneciam a parte, em seu próprio ritmo de vida, mas sem necessariamente ignorar as dinâmicas a sua volta. O que não era puramente negativo quando se considera que estabeleceram "[...]condições mais favoráveis para a preservação de uma soma não descurável de traços culturalmente residuais, em certos casos quase relíquias.” 
(PETRONE, 1995, p. 374). Em Carapicuíba, a festa religiosa mais tradicional realizada era e continua sendo a de Santa Cruz. Numa junção entre ritos religiosos católicos e danças profanos indígenas, ascenderam os passos do Sarabaquê e da Zagaia, que remetem às tradições dos setecentos e que veio se manifestando gradativamente até os dias atuais, como evidenciam os registros históricos e materiais iconográficos os mais diversos (Figura 20).

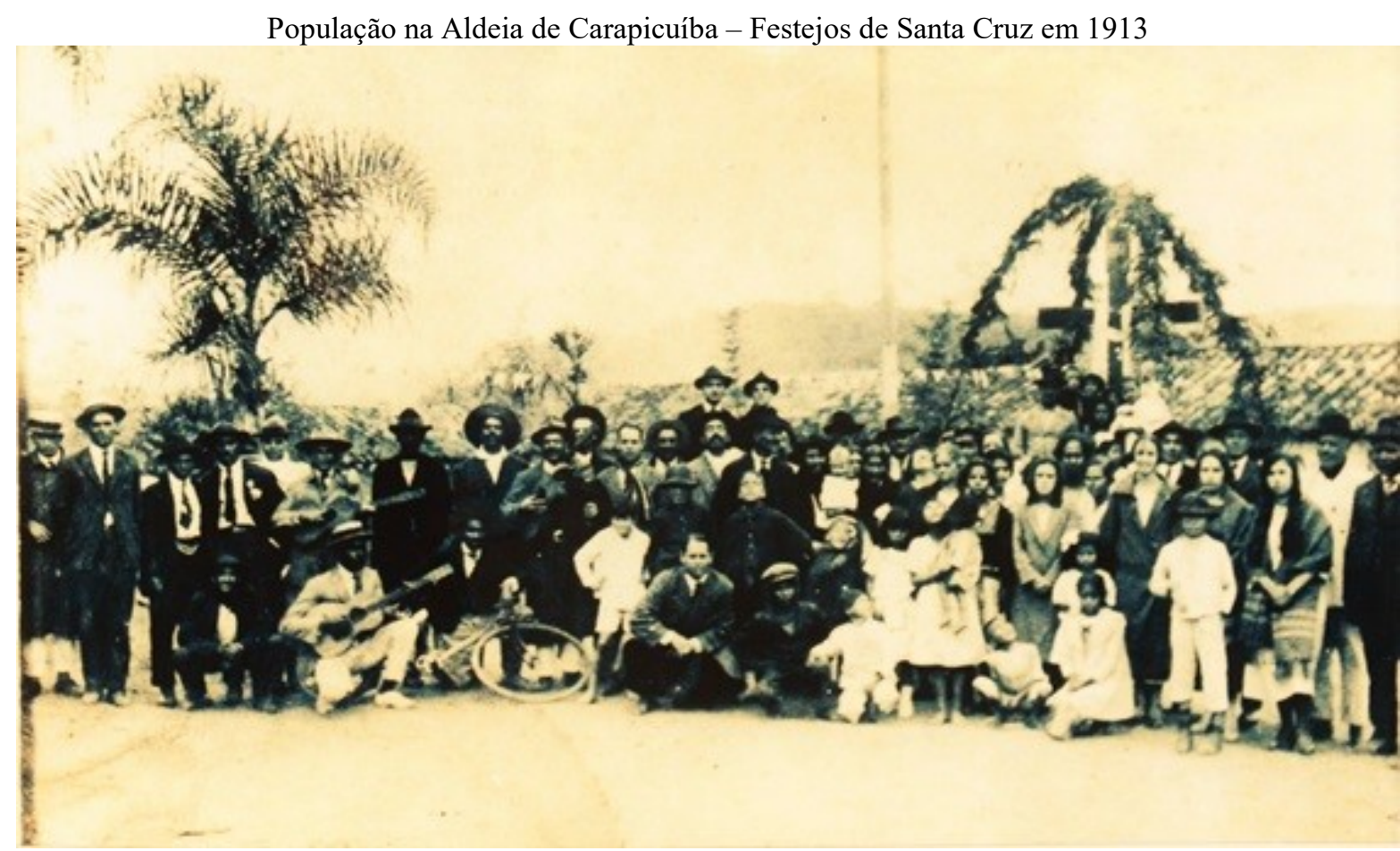

Figura 20: A religião era uma das mais importantes funções exercidas nos subúrbios paulistanos em fins do século dezenove e princípios do vinte. Ali permaneciam as tradições, que alicerçavam atividades diversas, como os festejos de Santa Cruz, em Carapicuíba, realizados no mês de maio, nesta foto em 1913.

Fonte: Acervo Fotográfico da Associação Sarabaquê de Difusão Cultural e Social.

Sendo pejorativamente qualificada como retrógrada pela sociedade de então, conforme resumida pelos relatos de viagem ao Brasil no século dezenove, como os de Saint-Hilaire (1972), mesmo em dias atuais o termo caipira ainda pode representar em certos casos um sentido negativo, o revés do moderno, da cidade e seus ares. A rugosidade Carapicuíba, herança do aldeamento expressa obviamente em fins do oitocentos e início dos anos novecentos uma unidade espacial tipicamente caipira. Sua passagem da "não cidade", já considerada na constituição de aldeamento, permanece na condição do novo isolamento do vilarejo. Isso mesmo quando a capital, a apenas alguns quilômetros, já se desenvolvia com os frutos da cultura canavieira e agora plenamente com os dividendos do café, além da instalação de infraestruturas que sedimentariam, se não totalmente, grande parte de sua industrialização, da qual Carapicuíba também ficaria relativamente à parte (Figura 21). 


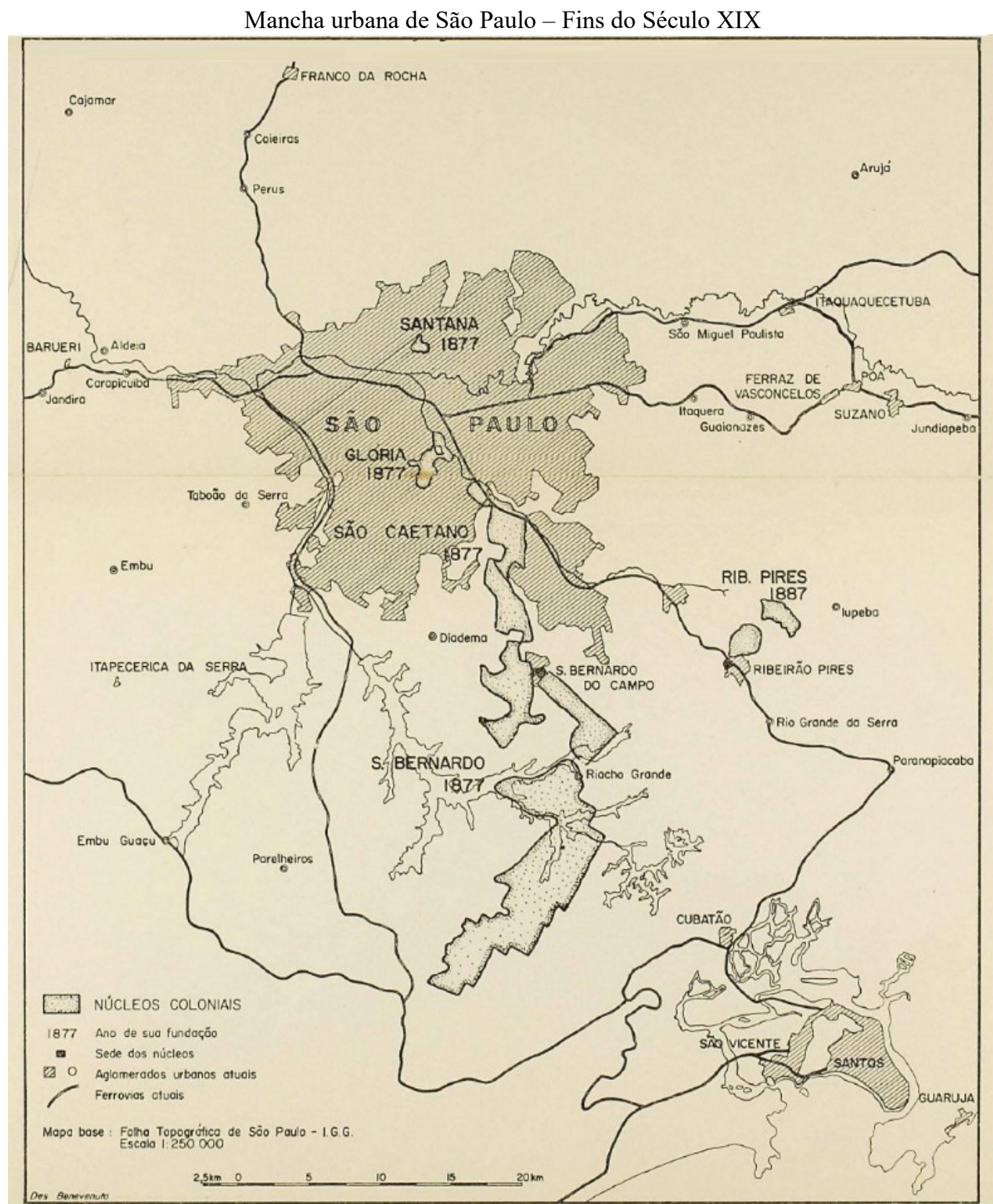

Figura 21: Carapicuíba no limite da mancha que se segue pelos trilhos da Sorocabana sentido oeste. Fonte: Mapa das Colônias Oficiais (Final do Século XIX) - elaborado por Langenbuch (1971).

Mesmo com o primeiro trecho da Estrada de Ferro Sorocabana (EFS) em 1875, a estação mais próxima instalada localizava-se justamente em Barueri, sede administrativa da unidade Barueri-Carapicuíba ${ }^{36}$, portanto distante do pequeno aglomerado da Aldeia. Conforme Tenório (2003, p. 91) “[...] o trem não parava em Carapicuíba para o embarque de

${ }^{36}$ Formalmente o distrito de Carapicuíba é instituído quando da criação do município de Barueri, em 1948 - pela Lei 233 de 24/12/1948. Carapicuíba torna-se município emancipado em 1964, pela Lei 8092 de 28/02/1964, tendo agregados territórios de Cotia e Osasco, possuindo os distritos de Carapicuíba (centro), Aldeia de Carapicuíba e Vila Dirce. 
passageiros. Porém, em 1921, foi construído um embarcadouro de gados que seguiam para o descanso de 15 por 15, em nove currais, no Campo da Boiada, atual COHAB, de onde eram conduzidos para o abate no Frigorífico Municipal do Km 21.” (TENÓRIO, 2003, p. 91). Entre o fim do século e a primeira estação de Carapicuíba, o transporte predominante ainda era dominado pelos carros de boi, charretes, igualmente comum era uso de muares no transporte de cargas. A locomoção e os fluxos de mercadorias e pessoas era ainda, basicamente, efetuado pelo transporte de tração animal. Costa Junior (1986) ratifica este quadro de tempo moroso, lento e longo, porém já evidencia que mesmo antes da chegada da EFS os arredores da estrada de Itu, nas proximidades do Tietê, onde hoje se localiza a rodovia SP-280, já despontava "uma ou outra habitação longe do Tietê".

\footnotetext{
Após o matadouro e as olarias, mais antigos, os compradores dos lotes da Vila Silvânia iam erguendo suas casinhas. Nos altos dos morros aparecem as igrejas e pouco a pouco esta velha Carapicuíba foi tomando ares de Cidade. A construção da estação em 1921, pode ser considerada o germen deste novo núcleo habitacional edificado a mais ou menos quatro quilômetros de distância do velho núcleo da aldeia de índios (COSTA JUNIOR, 1986).
}

Destarte, como no passado, sua população subsidiará o crescimento e expansão de São Paulo, servindo a cidade com seus produtos e recursos, suas chácaras com seus braços, e no âmbito imaterial com suas festas e tradições. Perpetua-se a reprodução da condição de alicerce de Carapicuíba aos desígnios do desenvolvimento capitalista no território paulista. Dá-se continuidade a um patrimônio que é fruto do trabalho, da função que serve ao empreendimento pré-urbano e industrial que se desencadearia na capital. Seus recursos serão essenciais ao centro metropolitano e marcarão o próximo período de consolidação suburbana. Em comparação com as chácaras, o cinturão caipira é que melhor caracterizará os atuais subúrbios de São Paulo, considerando que as primeiras foram rapidamente tomadas pelo processo de metropolização.

\footnotetext{
A porção dos arredores que mais será abrangida pela expansão suburbana do metrópole é precisamente o 'cinturão caipira', uma vez que o 'cinturão das chácaras', mais restrito que o limite da atual cidade de São Paulo, será afetado pela expansão mais propriamente da Capital (LANGENBUCH, 1971, p. 76).
}

Longe de um reconhecimento consensual, a cultura caipira, no berço moderno e da economia pulsante do Brasil, é uma rugosidade patrimonial essencial e significativa do processo de consolidação da metrópole paulista e do atual município de Carapicuíba. Carrega 
a historicidade do aldeamento, por dele ter derivado, mas sobretudo pelas vivências que se perpetuaram carregando os mais agudos traços da cultura material. Esta, como prática de sobrevivência foi capaz de preservar o conjunto jesuítico, com soluções arquitetônicas precárias e com as ferramentas disponíveis, o que sustentou por mais de um século o antigo aglomerado de pau-a-pique e taipa de pilão, reforçando sua unidade em segurança das intempéries sociais e ambientais. Também as tradições mais antigas foram perpetuadas, resistindo às banalizações e os contínuos choques impostos pelas verticalidades das formas e conteúdos globais, ora pelas dificuldades puramente de estar integrados, ora por simplesmente ignorarem o mundo externo, ignorarem os ensejos modernizantes da produção e das relações que delas derivam.

No transcorrer das políticas patrimoniais, sempre em busca da exuberância, unicidade, singularidade diferencial, esses preceitos tão significativos foram relativamente ignorados. Mesmo o levantamento de Luís Saia em 1937 destacando emblematicamente estes preceitos, como as crenças, os costumes e tradições, o favorecimento das formas arquitetônicas e do conjunto de pedra e cal projetado frente o intangível, condicionou o esquecimento e abandono de importante parte desta cultura singular. Mesmo com os avanços de uma visão sobre os conjuntos, ou de elementos da cultura popular, a generalização do patrimônio foi pouco pragmática aos objetivos que poderiam resultar da preservação e divulgação dos bens culturais, com possíveis ganhos econômicos ou o pleno reconhecimento identitário e de respeito pelos grupos sociais.

As limitações decorrem de uma mentalidade a ser desenvolvida e que depende do fortalecimento, mas sobretudo do empoderamento das comunidades e grupos sociais inseridos nestes espaços. Neste sentido, cabe destacar, a título de exemplo, o caso da festa de Santa Cruz, que talvez seja um dos elementos mais importantes para o reconhecimento e manutenção do patrimônio cultural da Aldeia de Carapicuíba. Ele emerge em todas as análises realizadas como presença concreta e significativa daquela rugosidade patrimonial. Porém, tanto os documentos e arquivos em órgãos federais e estaduais pouco ou nada traduzem desta manifestação. Cabendo ao trabalho pioneiro de pesquisadores como Pellegrini (1979), Escalante (1981), ou mais recente de Henne (2015).

De fato, os órgãos têm um papel fundamental na preservação da Aldeia após 1940, como será debatido, porém cabe antecipar dura crítica a respeito da negligência das tradições e da cultura imaterial, que indissociavelmente incorporadas ao próprio conjunto da Aldeia 
(inclusive de sua manutenção por mais de um século), foram relativamente "marginalizadas" pelas políticas do patrimônio. Mesmo que o conjunto (material e imaterial) carregue importante historicidade da memória nacional, ora do Brasil Colônia (com os aldeamentos jesuíticos), ora do Reino Unido, Império e Brasil República (com as oligarquias rurais), como também da memória coletiva que perfaz a formação da região metropolitana de São Paulo (de seus núcleos mantenedores), ou mesmo das próprias vivências pelos grupos sociais de Carapicuíba, este foi relativamente deixado a sorte no movimento da história e cuja comunidade teve papel central na permanência das rugosidades patrimoniais.

\subsection{A cristalização do núcleo "suburbano ex-vilarejo" em Carapicuíba}

O período ora em tela marca o crescimento exponencial de São Paulo, estruturalmente situado no contexto do ápice da produção cafeeira e de outros gêneros agrícolas, como a canade-açúcar ou algodão, e que engendram sua pré-industrialização e expansão regional (Figura 22). Esta fase marca, cada vez mais, a integração de Carapicuíba à São Paulo que, guardadas as permanências e devidas rugosidades, discutidas ao longo destes capítulos, cristalizam o subúrbio, culminando até meados das décadas de 1950 e 1960, com a emancipação dos municípios e, contraditoriamente a integração geográfica da metrópole e a fragmentação das unidades administrativas.

Este tempo consolida muitos dos atuais subúrbios paulistanos, com ampliação das linhas férreas e, particularmente em Carapicuíba, com a criação das estações para passageiros. $\mathrm{O}$ transporte predominante, antes restrito aos antigos caminhos e rotas de chão batido, carros de boi, charretes e mulas, a partir de 1926 em Carapicuíba passam a ter o predomínio das ferrovias, com arranjos produtivos e aglomerações em suas proximidades, dividindo a centralidade da antiga aldeia com a nova estação. Tenório (2003) detalha como a nova estação atraiu passageiros, como novos moradores que vinham junto aos novos empreendimentos imobiliários iniciados em seu entorno. E junto aos novos moradores, também a instalação de um terminal rodoferroviário, conforme crescia a demanda dessa população. 


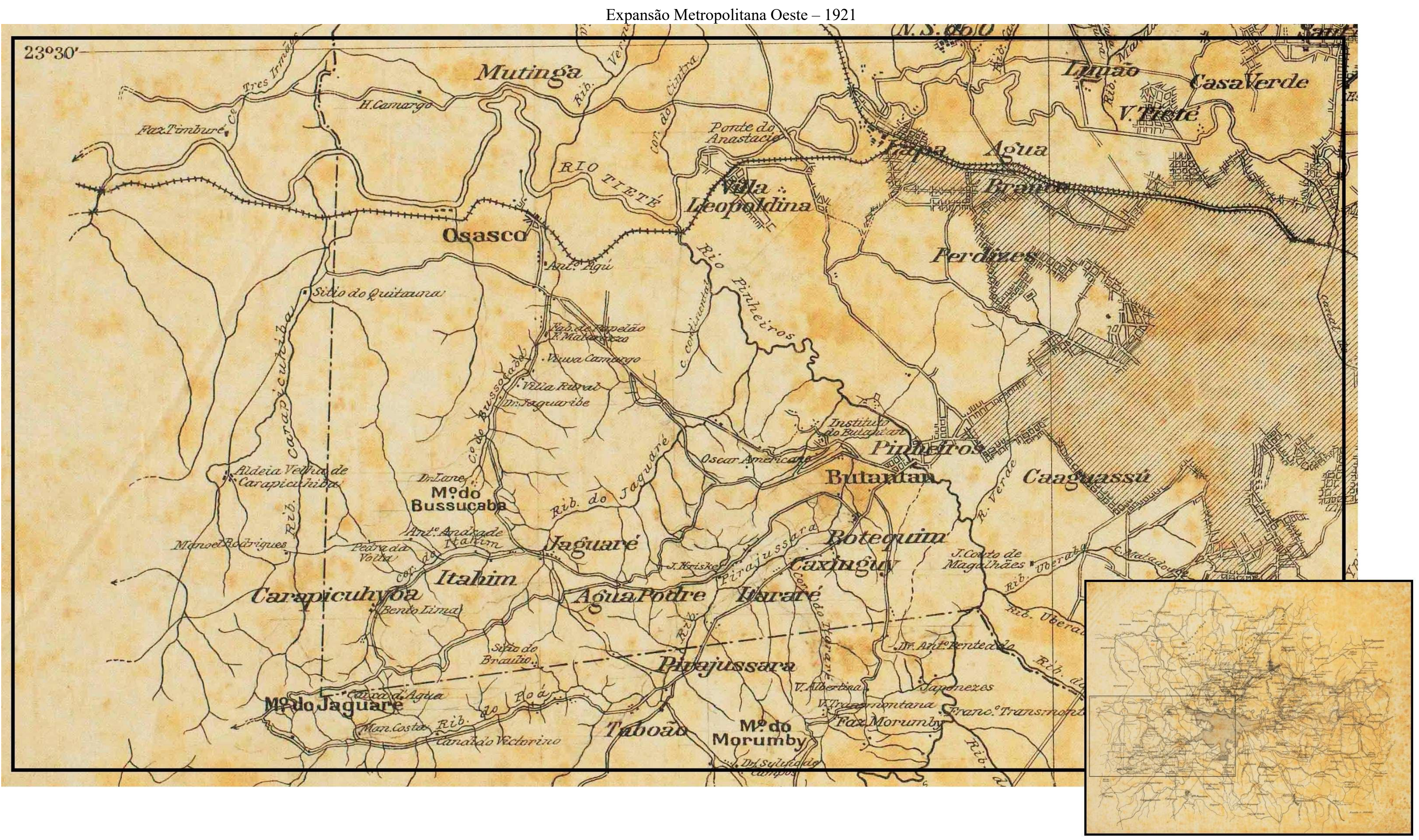

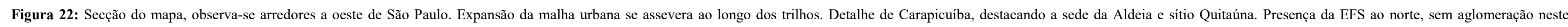

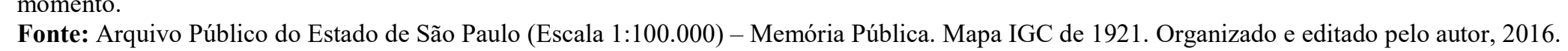


Em 1890 a cidade de São Paulo possuía população de 64.934 habitantes, passando concretamente ao processo de metropolização quando chega a 579.033 em 1920 e, por fim, a mais de 1.326.261 habitantes em 1940 (IBGE, 2011). Trata-se, pois, nas palavras de Langenbuch (1971, p. 131), onde a "[...] pressão e consequente tendência expansionista exercida pela cidade sobre sua periferia, naturalmente, seria mais intensa. De fato, o que se observa no fragmento do mapa na Figura 22 "Expansão Metropolitana Oeste - 1921", é o amplo espraiamento da mancha urbanizada da capital, conduzida pelos caminhos e as estradas de ferro. Os terrenos valorizados na cidade de São Paulo obrigam novos moradores a procurarem loteamentos cada vez mais distantes, fazendo da especulação imobiliária um dos condutores principais da expansão suburbana da região metropolitana (LANGENBUCH, 1971, p. 132-135). Na porção oeste, em que situam-se Osasco, Carapicuíba, Barueri e Itapevi a EFS marcará a gradativa mudança dos arraiais, vilarejos e pequenos núcleos, que passam a conviver com as novas dinâmicas territoriais induzidas pela metrópole.

A estrada de ferro, na realidade, não se limitou a orientar a suburbanização
residencial, mas continuou a fazê-lo com relação a suburbanização industrial.
Ambos os processos de ocupação suburbana dos arredores de São Paulo assumem
grande importância no período $1915 / 1940$. O desenvolvimento de subúrbios
residenciais, anteriormente apenas incipiente, agora se inicia de modo amplo e ganha
corpo. Já a industrialização suburbana conhecera um expressivo início no período
anterior a 1915, mas o processo se acelera de tal ordem que o desenvolvimento
anterior se nos afigura extremamente modesto (LANGENBUCH, 1971, p. 140).

Santos (2013b) explica categoricamente que a expansão econômica obtida pela região sudeste desde a segunda metade do século dezenove, não apenas resulta da modernização e integração das diversas cidades, mas também o aprofundamento da divisão do trabalho, implicando numa dinâmica de maior urbanização, onde sinergicamente "[...] foi possível acolher as novas e sucessivas modernizações." (SANTOS, 2013b, p. 70). Deve-se destacar o papel da indústria têxtil, com grandes maquinários, ampla mão-de-obra e concentração de capital. Assim também considerar que o fenômeno enquanto uma "industrialização periférica" é dependente das economias centrais, das demandas internacionais e marcada pela ausência de indústrias de bens de capital, ou mesmo, de indústrias nacionais independentes (MELLO, 1975). Cano (1975) defende que no processo ainda incipiente de industrialização há como resultante relações modernas e capitalistas oriundas da produção cafeeira em São Paulo. Em verdade, antes de 1920 a indústria brasileira ainda estava concentrada, praticamente, na produção de bens de consumo básicos. Mesmo que dada as condições pré-industriais contextualizadas, o censo de 1907 aponta oficialmente 326 estabelecimentos industriais em São Paulo, gestados principalmente nas duas últimas décadas do século dezenove, 
destacadamente no segmento de móveis, chapéus, calçados, bebidas, alimentos, serrarias, sabão, velas e medicamentos. Ao contrário do restante do país, até 1919 o autor supracitado destaca um importante salto quantitativo da indústria paulista, crescendo e se expandindo, inclusive para o interior. Uma das razões, além da bolha de crédito que gerou uma grande crise econômica entre a Monarquia e República, e que corroborou para aquisição e investimentos em fábricas numa organização produtiva da indústria em pequena escala, também pesou a imigração em práticas associadas a estas atividades (MARTINS, 1990, p. 115).

Na fase posterior da economia, considerada entre 1919 e 1929 pela periodização realizada por Cano (1975), com o estabelecimento da prévia atmosfera industrial, houve ganhos qualitativos importantes, tanto na diversificação, como na dinamização das atividades e produtos industrializados. O período revela um gradativo processo de empresariamento como cultura industrial difundida e consolidada (DEAN, 1971). São Paulo passa a suprir também a crescente demanda do mercado em escala nacional e a tornar-se definitivamente o centro industrial do país (CANO, 1975, p. 263). Ainda segundo Cano (1975), mesmo preocupado em compreender precisamente as raízes da industrialização de São Paulo e os desequilíbrios regionais provocados, ao exibir quadros comparativos entre o Brasil e suas regiões, ratifica crescimento, de certa forma, generalizado da indústria brasileira. Isso também corresponde a expansão dos quadros de urbanização revelados pela Tabela 02 e, sobretudo, de população total, conforme o Gráfico 02 anteriormente posto.

O período que vai de 1929 até fins da guerra em 1945 é marcado contraditoriamente por uma produção industrial ligada a consolidação do mercado interno, que no âmbito de produção intelectual da CEPAL se associa a um processo de substituição das importações em decorrência de choques adversos no âmbito econômico. "A produção industrial, que se destinava em sua totalidade ao mercado interno, sofre durante a depressão uma queda de menos de 10\%, e já em 1933 recupera o nível de 1929” (FURTADO, 1971 [1959], p. 198). Este período marca efetivamente a entrada do Brasil na era da industrialização. No contexto urbano, as taxas de crescimento permanecem altas, tanto da criação de novos municípios e cidades, como da população total. A maior aglomeração continua sendo a do Rio de Janeiro, que centralizava o poder político e uma densa base de serviços e de atividades ligadas ao comércio em diferentes condições. A economia em franca recuperação fazia com que a cidade de São Paulo ultrapassasse entre as décadas de 1940 e 1950 mais de 2 milhões e meio de habitantes, com 258 cidades em 1933, alcança em 1950 o número de 369 cidades no estado. 
Evolução das cidades no Brasil entre o final da $1^{\text {a }}$. Guerra Mundial e princípio da II Guerra Mundial

\begin{tabular}{|c|c|c|c|c|c|c|c|}
\hline $\begin{array}{c}\text { Estados da } \\
\text { Federação } \\
1933 \\
\end{array}$ & $\begin{array}{c}\text { Número de } \\
\text { Municípios } \\
1933 \\
\end{array}$ & $\begin{array}{c}\text { Unidades da } \\
\text { Federação } \\
1940 \\
\end{array}$ & $\begin{array}{c}\text { Número de } \\
\text { Municípios } \\
1940 \\
\end{array}$ & \begin{tabular}{|c} 
Unidades da \\
Federação \\
1950 \\
\end{tabular} & $\begin{array}{c}\text { Número de } \\
\text { Municípios } \\
1950\end{array}$ & $\begin{array}{c}\text { Unidades da } \\
\text { Federação } \\
1960 \\
\end{array}$ & $\begin{array}{c}\text { Número de } \\
\text { Municípios } \\
1960 \\
\end{array}$ \\
\hline & & & & Território de Guaporé & 2 & Território de Rondônia & \\
\hline Território do Acre & 6 & Território do Acre & 7 & Território do Acre & 7 & Território do Acre & 7 \\
\hline \multirow[t]{2}{*}{ Amazonas } & 28 & Amazonas & 28 & Amazonas & 25 & Amazonas & 44 \\
\hline & & & & Rio Branco & 2 & Rio Branco & 2 \\
\hline \multirow[t]{3}{*}{ Pará } & 37 & Pará & 53 & Pará & 59 & Pará & 60 \\
\hline & & & & Território do Amapá & 4 & Território do Amapá & 5 \\
\hline & & & & Fernando de Noronha & 1 & Fernando de Noronha & \\
\hline Maranhão & 53 & Maranhão & 65 & Maranhão & 72 & Maranhão & 91 \\
\hline Piauhy & 27 & Piauí & 47 & Piauí & 49 & Piauí & 71 \\
\hline Ceará & 51 & Ceará & 79 & Ceará & 79 & Ceará & 142 \\
\hline Rio G. do Norte & 41 & Rio G. do Norte & 42 & Rio Grande do Norte & 48 & Rio Grande do Norte & 83 \\
\hline Parahyba do Norte & 37 & Paraíba & 41 & Paraíba & 41 & Paraíba & 88 \\
\hline Pernambuco & 83 & Pernambuco & 85 & Pernambuco & 90 & Pernambuco & 102 \\
\hline Alagôas & 33 & Alagoas & 33 & Alagoas & 37 & Alagoas & 69 \\
\hline Sergipe & 40 & Sergipe & 42 & Sergipe & 42 & Sergipe & 62 \\
\hline Bahia & 125 & Bahia & 150 & Bahia & 150 & Bahia & 194 \\
\hline Districto Federal & 1 & Distrito Federal & 1 & Distrito Federal & 1 & & \\
\hline Minas Geraes & 215 & Minas Gerais & 288 & Minas Gerais & 387 & Minas Gerais & 483 \\
\hline Espirito Santo & 30 & Espírito Santo & 32 & Espírito Santo & 33 & Espírito Santo & 37 \\
\hline \multirow[t]{2}{*}{ Rio de Janeiro } & 48 & Rio de Janeiro & 50 & Rio de Janeiro & 56 & Rio de Janeiro & 61 \\
\hline & & & & & & Guanabara & 1 \\
\hline São Paulo & 258 & São Paulo & 270 & São Paulo & 369 & São Paulo & 503 \\
\hline Paraná & 52 & Paraná & 49 & Paraná & 80 & Paraná & 162 \\
\hline Santa Catharina & 36 & Santa Catarina & 44 & Santa Catarina & 52 & Santa Catarina & 102 \\
\hline Rio G. do Sul & 83 & Rio G. do Sul & 88 & Rio Grande do Sul & 92 & Rio Grande do Sul & 150 \\
\hline Matto Grosso & 25 & Mato Grosso & 28 & Mato Grosso & 35 & Mato Grosso & 64 \\
\hline \multirow[t]{2}{*}{ Goyaz } & 56 & Goiaz & 52 & Goiaz & 77 & Goiás & 179 \\
\hline & & & & & & Distrito Federal & \\
\hline BRASIL & 1365 & BRASIL & 1574 & BRASIL & 1890 & BRASIL & 2766 \\
\hline
\end{tabular}

Tabela 02: Evolução das cidades no Brasil no período pré-industrial e industrial.

Fonte: IBGE - Evolução da Divisão Territorial do Brasil (1872-2010) - 2011. Organização do autor, 2016 
Monbeig (1998) mostra que, com a crise de 1929, a queda nos preços do café favoreceu a diversificação agrícola e produtiva em São Paulo. Milliet (1982), por suas pesquisas, demonstra também como os efeitos da crise fundamentaram a fragmentação das fazendas e o aumento no número de pequenas propriedades, geradas pelas dívidas entre patrões e colonos. Conforme Santos (2013b, p. 25) "nesse período a população ocupada em serviços cresce mais depressa que o total da população economicamente ativa. Enquanto esta aumenta mais de 60\%, passando de 9,150 milhões, para 14,661 milhões, os ativos do terciário mais que dobram, crescendo quase $130 \%$, pois eram 1,509 em 1920 e são 3,412 milhões em 1940”. O quadro socioeconômico, baseado na forma de vida rural, passava a sofrer significativas transformações.

O papel do Estado em subsidiar acordos e tratados internacionais no sentido de facilitar a entrada de máquinas e equipamentos ao Brasil é importante de ser considerado, além da manutenção e relação entre a burguesia industrial que se confundia com a própria oligarquia agrário-exportadora (CARDOSO; FALETTO, 1970). A década de 1930 é a responsável pela mudança no processo de substituição das importações, fato que não implica necessariamente assumir uma ou outra das diversas fundamentações teóricas que hoje rivalizam sobre as razões desta mudança, como as teorias da dependência, do crescimento econômico, ou a crítica da razão dualista e do ciclo endógeno, todas bem descortinadas por Fonseca (2003). Importa o papel que elas terão na expansão da indústria e urbanização em vias de desenvolvimento.

No contexto regional, esses acontecimentos proporcionaram o desenvolvimento dos setores industriais, ainda retrógrados no país. Mais uma vez o conceito de rugosidade permite compreender as permanências históricas na condição não apenas de resistência das formas espaciais, mas também na permissividade da fluidez dos mecanismos de produção. Independente da polêmica sobre as razões determinantes da concentração do processo industrial em São Paulo ${ }^{37}$, o peso da acumulação primitiva, nas diferentes fases econômicas arroladas no território brasileiro, pensando no capital instalado e na infraestrutura composta, permite a São Paulo não apenas uma vertiginosa expansão demográfica e proto-urbana na fase pré-industrial, como também a assumir o controle e administração de diferentes processos em períodos mais recentes.

\footnotetext{
37 Apesar de alguns consensos sobre a subordinação do processo de industrialização à produção cafeeira, o mesmo não ocorre sobre as razões da concentração industrial no estado de São Paulo.
} 
As infraestruturas territoriais não eram restritas à expansão das linhas férreas, elas se estendem aos canais de drenagem que agora são controlados pelas empresas de energia, com retificações do rio Tietê e Pinheiros em escala mais ampla (SEABRA, 1987). Nos subúrbios, há o represamento dos canais secundários e terciários a fim de regular e intensificar a produtividade cada vez mais intensiva e mecanizada dos insumos e recursos. De tal maneira, em 1929 as águas do ribeirão Carapicuíba são represadas para a utilização do frigorífico municipal e a vila militar, que também já eram usadas para o abastecimento de Osasco (TENÓRIO, 2003, p. 164).

Luís Saia ao retratar a Aldeia em 1937 explica que mesmo diante dos trilhos, a predominância da produção agrícola ainda é transportada por caminhão, sendo "pouca a mercadoria que sai pela Sorocabana. E se hoje os caipiras vão vender os produtos das suas roças fora da aldeia, antes não acontecia isso: só produziam o necessário para o consumo caseiro e mais um pequeno acréscimo cuja venda os aparelhava para gastos com sal, roupa e farina." (SAIA, 1937, p. 16). Observa-se mais efetivamente que junto as modernizações, importantes mudanças decorrem na articulação escalar da comunidade da Aldeia em torno de relações fora dos seus limites espaciais pretéritos. Tenório (2003) ainda lembra uma condição pouco ou nada urbanizada de Carapicuíba na década de 1920, em que minas brotavam em vários pontos das vertentes, sendo mais tarde disciplinadas e contidas, resultando na forma do lago reservatório onde hoje se localiza o parque dos Paturis. Mas são as linhas férreas que consolidam a expansão e articulação do espaço metropolitano, as mesmas dinâmicas traduzidas pelo "progresso" em Carapicuíba, conforme escreveu Tenório quando da fundação da primeira estação de passageiros.

\footnotetext{
A inauguração no dia 25 de janeiro de 1926, trouxe inúmeras pessoas para esperar o trem na pequena estação de Carapicuíba, pois esse acontecimento deu grande impulso ao progresso da terra, com a inauguração do trecho da estrada de ferro entre Carapicuíba e São Paulo. [...] A área inicialmente urbanizada teve sua estrutura condicionada à três elementos principais: o vale do rio Tietê, Estrada de Ferro Sorocabana e a antiga Estrada de Itu. À margem esquerda do rio Tietê, encontravamse áreas mais densas de edificações acompanhando a ferrovia. Já a presença da Estrada de Itu, atraiu o povoamento em direção ao Sul, enquanto em Carapicuíba, era a via férrea o principal elemento de atração (TENÓRIO, 2003, p. 93).
} 
As antigas vilas e pequenos povoados, concentrados nos limites do cinturão das chácaras e caipira, cedem cada vez mais espaço aos "loteamentos residenciais suburbanos" 38 . Uma das principais características deste novo arranjo espacial reside justamente no fato da extrapolação da unidade político-administrativa do município de São Paulo. A conurbação neste período, que vai até pouco antes da década de 1950, quando se efetiva a moderna industrialização e urbanização do planalto paulistano, limita-se às aglomerações da capital com Santo Amaro, Guarulhos e São Bernardo. Há necessidade de se avaliar a condição de cada caso no processo de metropolização, pois nem todos serão necessariamente condicionados pelos trilhos, lembrando as rodovias, condições do terreno e mesmo as condições pretéritas de desenvolvimento (LANGENBUCH, 1971).

Junto às ferrovias instalavam-se empresas e firmas. Em Carapicuíba, menos expressiva que o vizinho Osasco, recebeu algumas unidades e instalações, das quais, referem-se a indústria de fiação Sul-Americana e ao Matadouro Municipal. A primeira marca a chegada dos imigrantes italianos, a formação do operariado local e uma população tipicamente citadina em Carapicuíba. O segundo que, ao longo do tempo, tornou-se um dos principais matadouros à abastecer a capital, subúrbios e, de forma geral, a região metropolitana que se consolidava. Estas serão as "novas rugosidades patrimoniais" ligadas ao subúrbio, às indústrias, atividades agroindustriais e de recursos primários-extrativistas. Estas acumulam-se, sobrepondo antigas relações de trabalho associadas ao meio rural com a contínua inserção de técnicas e modernizações que perpassam desde a forma de habitar (nos novos loteamentos - Figuras 23 e 24), ou de se movimentar pela cidade (os bondes elétricos, ônibus e os trens suburbanos). Uma nova centralidade se desenvolve no entorno dos trilhos da Sorocabana em Carapicuíba, em que a abertura de loteamentos compassava-se com as necessidades dos operários da própria ferrovia, como aqueles cujos custos de São Paulo o pressionaram gradativamente a morar no subúrbio e trabalhar no centro da capital. Os novos loteamentos, que a princípio seriam procurados pelos trabalhadores da Sorocabana, depois foram sendo gradativamente ocupados por uma infinidade de grupos e classes sociais (TENÓRIO, 2003).

\footnotetext{
${ }^{38}$ Conforme Langenbuch (1971), seria este o período entre 1915 e 1940, marcado pela expansão centrípeta de São Paulo através das linhas dos trens e caminhos, sobretudo pela especulação imobiliária em curso e os altos impostos governamentais nas áreas consolidadas. Ainda segundo ele, sobressaindo os interesses especulativos, as áreas loteadas ficaram rapidamente defasadas às funções modernas que desenvolveriam.
} 
Loteamentos na Vila Teresinha - Expansão Urbana no Entorno das Estações em Carapicuíba
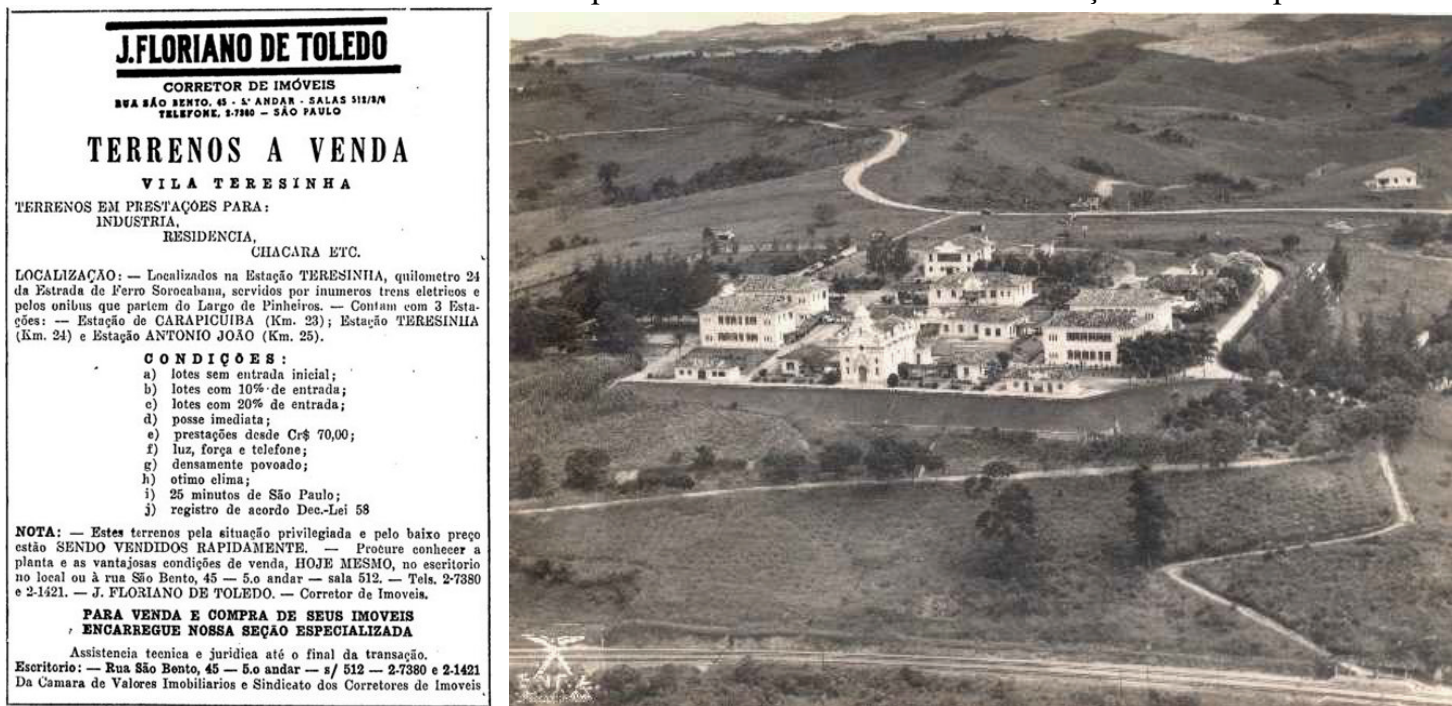

Figura 23: À esquerda, classificado de loteamento Vila Teresinha na Folha de São Paulo em 1946. À direita, a estação de Santa Terezinha em 1939, que passa operar oficialmente em 1951 pela EFS, porém já fazia parada na região desde uma década atrás.

Fonte: Estações Ferroviárias do Brasil. In: <http://www.estacoesferroviarias.com.br/s/staterezinha.htm>. Instituto geográfico e Cartográfico (IGC) - Aerofotos oblíquas de São Paulo em 1939/1940.

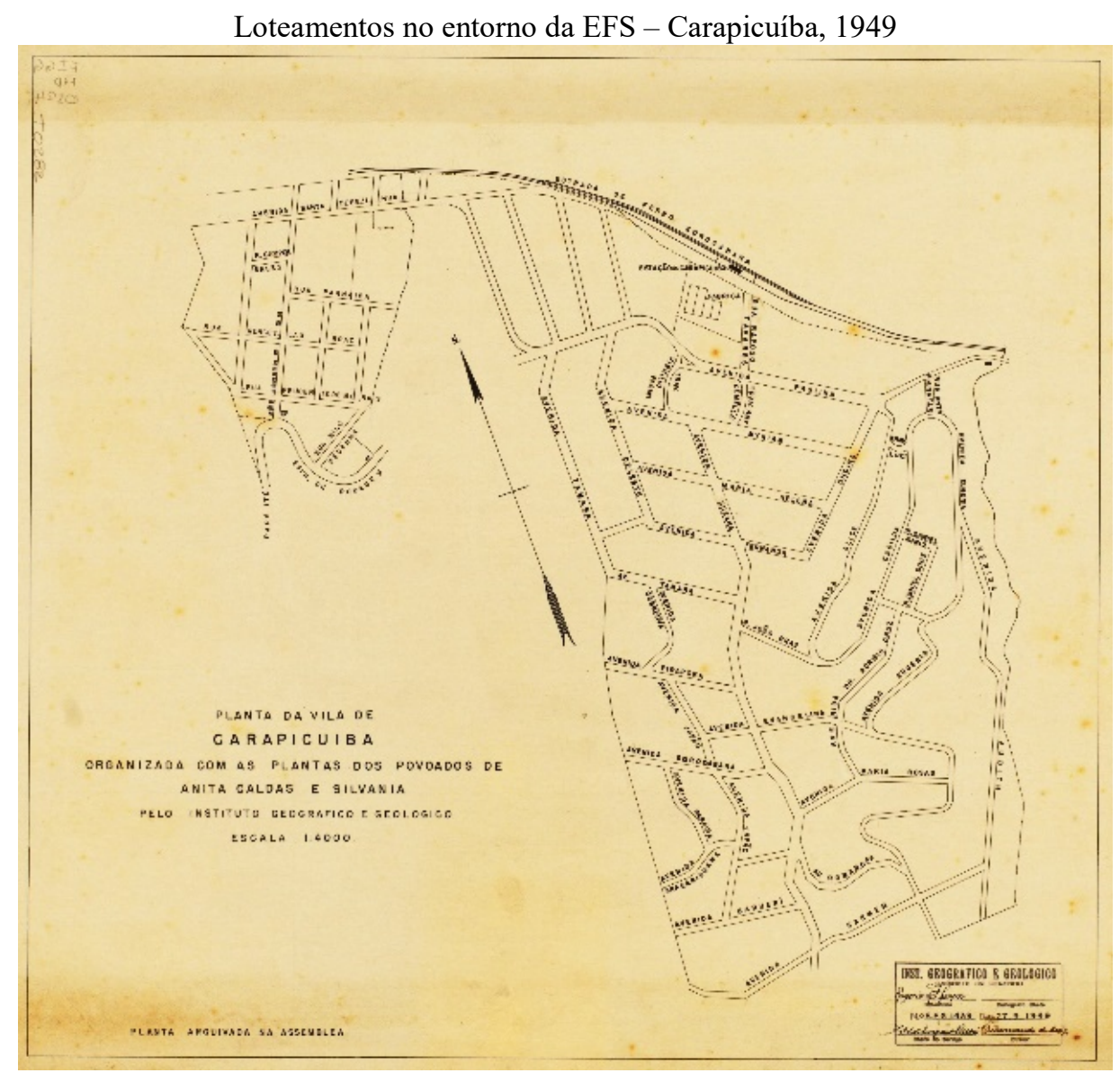

Figura 24: Planta da Vila de Carapicuíba, nas proximidades da estação central de passageiros. Mostra os loteamentos instalados ao longo da ferrovia que marcam nova centralidade e dimensões urbanas no lugar.

Fonte: Fonte: Arquivo Público do Estado de São Paulo - Memória Pública. Mapa do Instituto Geográfico e Geológico - de 1949. 
Se verifica o "progresso" em Carapicuíba, conforme escreve Tenório (2003) sobre a nova estação e expansão de loteamentos produzidos ao longo da ferrovia, o mesmo não se apura mais ao sul, na Aldeia. Tudo leva a crer, considerando as entrevistas realizadas com antigos moradores, além de dados, mapas e documentos secundários, que a sede da Aldeia continuava a ser precariamente servida por veículos automotores, quando não por cavalos e outros animais de tração, considerando sua distância dos trilhos e da estação.

Apesar da dinamização dada pela extensificação do fenômeno metropolitano em toda região do entorno de São Paulo, sua influência direta está dirigida aos setores norte do município, nas proximidades da linhas férreas e do rio Tietê, enquanto que as áreas ao sul eram preenchidas por propriedades rurais e o núcleo da Aldeia, em que permaneciam os velhos caminhos, como a estrada de Itu. Este é mais um dos elementos circunstanciais da permanência da Aldeia, considerando seu isolamento e distanciamento das principais vias de circulação, além do desenvolvimento de técnicas e soluções locais que iam gradativamente sustentando a vida cotidiana neste espaço. Num segundo plano, também a função religiosa, de um espaço simbolicamente sagrado, em que a cultura caipira de forte religiosidade se esforçará para manter, inclusive aos dias atuais, como apontam os próximos capítulos. Para Saia (1937, p. 16), no cinturão caipira, a situação relativa de isolamento da Aldeia que prescinde de sua subsistência na autoprodução agrícola e da morfologia dos habitats teria agido na manutenção nítida das especificidades arquitetônicas destes espaços. Mas, além disso, teria agido na própria condição psicológica e comportamental de seus habitantes, que continuaram relativamente fechados, o que em certa medida explicaria que "resguardou" e "preservou" a Aldeia dos tempos modernos.

\footnotetext{
Esta atividade no sentido quase exclusiva de auto-abastecimento, penso que deve ser interpretada de um modo muito especial entre os habitantes de Carapicuíba, pois parece refletir um elemento muito forte da psicologia deles. Elemento que me impressionou bastante porque traduz com muita lógica um aspecto característico da arquitetura da aldeia. É verdade que as restantes localidades jesuíticas dos arredores de S. Paulo também conservam um ou outro traço, tanto na arquitetura como nos costumes, encontráveis em Carapicuíba, porém nunca com tamanha nitidez. [...] Penso que milhormente se explicaria o fenômeno que resguardou e conservou Carapicuíba, com a psicologia dos seus moradores. Fechada, arredia, voltada sobre si mesma, quase sem tomar conhecimento do que se passa fora do seu âmbito limitado. Esse caráter psicológico se retrata fielmente na disposição urbanística das casas, voltada uma para as outras, num quadrado que jamais se vira para fora (SAIA, 1937, pp. 16-17).
}

Portanto, a expansão metropolitana de São Paulo desenvolvida neste momento, apesar de conduzir a urbanização em toda sua órbita regional e até nacional, munirá parcialmente os 
territórios com infraestruturas. O fenômeno resultaria na consolidação da macrocefalia urbana que já se fazia ao longo da costa atlântica, mas que agora se concentraria multipolarizada na região sudeste, especialmente em São Paulo. Trata-se dos mesmos nódulos centrais, cujas rugosidades cristalizadas no passado, de uma forma ou outra reproduziam as condições privilegiadas que já possuíam, mais densamente interconectadas pelos modernos sistemas de transporte e de comunicações que se asseveravam. Conforme Moreira (2005) "a lei do desenvolvimento desigual e combinado passa então a reger a nova formação, progressivamente desigualando e invertendo a forma das relações espaciais até então existentes" (MOREIRA, 2005, p. 17).

Esta mudança fundamental, que exige a modernização das cidades, se estabelecerá por uma "perturbação traumática do meio tradicional” e exigiria um repensar da condição histórica dos núcleos antigos, onde a "noção de patrimônio histórico constitui-se na contramão do processo de urbanização dominante" (CHOAY, 2006, p. 179). Mais precisamente no caso brasileiro, são as décadas que antecedem a efetiva industrialização (1950) que gestarão os quadros institucionais e o pensamento sobre as teorias patrimoniais aplicadas às cidades e aos bens culturais. Lembrando neste caso as contradições entre a preservação e práticas urbanas, além do descompasso e a ausência de legislações que adequassem de forma centralizada as políticas, ou que permitissem dinamismo sobre as especificidades de cada situação. A modernização do país implica simultaneamente na defesa dos bens nacionais em risco, tendo no movimento modernista brasileiro a sua gênese, pensados sob influência europeia e praticamente em função de critérios artísticos do que propriamente históricos $^{39}$ (FONSECA, 1997).

Neste ponto há condição de responder com certa segurança a razão da rugosidade patrimonial da Aldeia permanecer relativamente preservada até seu pedido de tombamento em

\footnotetext{
${ }^{39}$ Fonseca (1997) detalha os aspectos mais relevantes do enfoque preservacionista do SPHAN de1937 até o fim da década de 1960, destacando, entre outras perspectivas as seguintes: (a) O principal instrumento de legitimação das escolhas realizadas era a autoridade dos técnicos, sendo desnecessário formular justificativas mais elaboradas; (b) Prevaleceu nitidamente uma apreciação de caráter estético, baseada nos cânones da arquitetura modernista; (c) A consideração do valor histórico dos bens não era objeto de maior atenção, a não ser relativamente à autenticidade das fontes; (d) a prioridade era assegurar a proteção legal dos bens através de sua inscrição dos livros do tombo, ficando em segundo plano a questão do critério nas inscrições. Esta fase é consagrada na literatura do patrimônio cultura como "fase heróica" - evidenciando o enfoque de pedra e cal.
} 
1937 e inscrição em 1940 no Livro do Tombo (SPHAN) pelas seguintes circunstâncias que se interpenetram: (i) sua origem funcional de cativeiro e segurança, necessária do aldeamento como organização espacial capaz de aprovisionar força de trabalho compulsória ao empreendimento colonial e proteção ao centro, que incluía a evangelização da igreja e a utilização do nativo em suas necessidades no processo em curso; (ii) o ostracismo do mundo caipira, que se configura na aldeia até os primórdios da industrialização, urbanização e a metropolização de São Paulo; (iii) função religiosa que passou a desempenhar, consagrando o espaço, com a conservação de ritos, tradições e festejos, que passaram a exercer não apenas uma centralidade ao espaço ao longo do desenvolvimento da cultura caipira, mas a sua constante adoração e preservação até os dias atuais; (iv) soluções técnicas locais ou informalismos $^{40}$ (PELLEGRINI, 1979), onde o relativo isolamento do sítio fez com que sua preservação derivasse de soluções construtivas simples, dos quais eram mantidos métodos antigos e dependentes diretamente das condições das estruturas construídas e da natureza regional, como a presença de barro e argila; (v) coesão social, capaz de empreender coletivos nas reformas comunitárias dos bens comuns e particulares.

A função germinal, de aldeamento para subsidiar o empreendimento colonial, além de sua relevância embrionária, consiste na extensão temporal e na força de captura cultural e dos choques gerados por mais de três séculos de intensas relações entre as múltiplas etnias indígenas com a dos colonizadores e das ordens religiosas. Esta convivência resultou numa amplitude menor dos deslocamentos indígenas e, ainda que não se possa seguramente antever que os nativos tenham se fixado efetivamente, tornando-se mais sedentários nesses cativeiros, conservando residência nas proximidades do núcleo central. Também implica pensar na sua contínua preservação, com soluções simples, das quais, inclusive, oriundas mesmo dos tantos conhecimentos que reservavam os índios. Nos períodos de decadência, como nas transferências ou junções de aldeamentos, ou com a expulsão dos jesuítas em algumas décadas do período colonial, não foi suficiente para a extinção destas unidades. Deve-se

\footnotetext{
${ }^{40}$ Estas qualidades eram diferenciadas, no entanto, das missões, que seguiam maior rigor e controle urbanísticos. Assim, missões e aldeamentos diferenciavam-se basicamente pelas polos de concentração e dispersão, padrão/formalismo e soluções individualizadas, assim como praticamente grande parte dos povoados e núcleos da fase de assentamento colonial português na América. Apesar da dispersão, as aldeias estavam relativamente próximas umas das outras, o que em São Paulo, no planalto de Piratininga, constituiriam doze institucionalizadas por Anchieta e controlada pela Companhia de Jesus. Além de São Paulo, os aldeamentos também se desenvolveram em outras regiões do Brasil, como Pernambuco, Rio de janeiro e Bahia. A construção das igrejas, no entanto, eram mais fortificadas, seguindo as orientações de Roma de perpetuidade do bem, que refletia nas construções de Taipa e Pilão, enquanto o restante do conjunto de pau-a-pique (PELLEGRINI, 1979).
} 
considerar que mesmo os conflitos entre religiosos com colonos acerca do trabalho compulsório e da escravização indígena, sempre há concílios entre os interesses, permanecendo esta forma de organização espacial até metade do século dezenove, inclusive após as orientações de sua extinção.

A decadência e extinção do aldeamento de Carapicuíba em razão de diversos fatores desde aspectos formais ligados ao plano governamental de sua extinção, a decadência, pobreza e flagelo por que passavam os índios explorados ao longo de tantos anos, ou a substituição e maior aceitação social da escravização do negro africano - não implica, como sugere Petrone (1995), necessariamente no seu abandono, ou ausência de uso. Pelo contrário, mesmo isolada, tudo leva a crer que a área jamais ficou efetivamente abandonada. Sobretudo quando se observa a permanência de festas que chegam aos dias atuais, mas que também já eram muito representativas, inclusive bem documentadas, em princípios do século vinte. Seu isolamento deve ser relativizado, pois mesmo distante geograficamente das principais vias modernas de transporte, bem como dos centros econômicos mais dinâmicos, considerando o papel da própria vila de São Paulo até fins do século dezenove, a área sempre foi um importante elo do trajeto que se fazia do interior para capital. Essa relação só será efetivamente afetada e, assim mais dinamizada, quando a metropolização passará a tencionar as rugosidades patrimoniais.

Outro elemento de relativização faz-se necessário às questões que implicam duas críticas contundentes aos desígnios patrimoniais que encaminham na atualidade numa narrativa sobre a aldeia. A primeira da condição indígena ao longo do tempo nestes núcleos. A clareza e profundidade dos levantamentos realizados no âmbito da Geografia por Pasquale Petrone (1995) e da História por Rubens B. Moraes (1992) evidenciam a condição e aprisionamento do nativo, de cativeiro, um espaço de exceção, que reprimiu e de forma coercitiva buscou historicamente transformá-lo numa base escrava de trabalho ou compulsória às estratégias coloniais, incluindo aí os da própria Igreja. Que não se confunda, pois, uma convivência harmoniosa nestes espaços, o que, de fato, não deve jamais ter existido, ainda que a mediação jesuítica ou outras ordens religiosas tenham em certo período se contraposto aos interesses dos colonos instalados no território. Observa-se em algumas das entrevistas, ou mesmo em obras como as de Tenório (2003) e Henne (2015), uma narrativa que romantiza, por exemplo, o retorno do nativo de Itapecerica da Serra para Carapicuíba, quando da sua reconstrução e retorno no século dezoito traduziria uma ligação emocional com o lugar dos nativos. De fato, as narrativas regionais, por vezes, objetivam traçar uma dimensão histórica e geográfica que 
agreguem valor aos seus espaços identitários, suas tradições e ampliar as possibilidades de desenvolvimento que por ventura se mostram com essas crenças, porém, as afirmativas são pueris, pois as razões deste regresso tende ao infinito, inclusive como fuga e aversão aos próprios religiosos que forçosamente tentavam integrá-los a outro sistema regimental.

Outro ponto é a respeito da frenesi pelas técnicas construtivas-arquitetônicas, inspiradas numa tradição atinente aos intelectuais e corporações profissionais que habitam as instituições públicas e o debate sobre o patrimônio. Nesta tradição, o destaque do espaço está no desenho da estrutura, na especificidade técnica da construção, no assédio às formas... ao concreto que ali é o barro sustentado pelas armações primitivas de madeira - a famosa taipa de pilão. No contexto temporal, a valorização remonta ao Brasil colônia, agregando as glórias da história factual, dos famosos bandeirantes, oligarcas, ou religiosos como Anchieta. Quando em verdade, são as tradições religiosas e profanas que emergem explicativas e centrais na própria condição de preservação. Introduzidas como mecanismos de coerção pelos jesuítas aos nativos, as manifestações tiveram que ser flexíveis em certos pontos, comportando elementos da tradição indígena e cristã. Por conseguinte, se de um lado a religiosidade expressa o poder institucional da Igreja, de outro as marcas da influência indígena são latentes. Os festejos de Santa Cruz, que ocorrem na cultura cristã em todo planeta, são realizadas na Aldeia pelo menos desde o século dezoito, consequentemente acabam por favorecer a hipótese de que mesmo diante da decadência do aldeamento, jamais ocorreu totalmente o abandono do local. O ostracismo pode ser considerado real, já o abandono não. Mesmo que as festas mostrem um ponto alto de concentração em um período específico do ano, os espaços que as sediavam deveriam ter condições mínimas de receberem os viajantes e de sustentarem toda organização. Estes fenômenos, que marcam o primeiro período da gênese e desenvolvimento destas rugosidades patrimoniais, serão friccionados pela dinâmica urbana em curso, cujo marco será o tombamento da Aldeia em 1940. Este ato, no conjunto, altera profundamente as relações da comunidade com seu lugar, instaurando uma outra realidade cada vez mais dinamizada pela metropolização de São Paulo. 


\subsection{Aldeia de Carapicuíba: de bem cultural à monumento nacional}

De meros elementos apreciados por intelectuais, religiosos e amantes das artes, o temário do patrimônio cultural, dinamizado basicamente pelas (i) transformações decorrentes das revoluções burguesas, (ii) criação do Estado moderno, (iii) e os contornos da Revolução Industrial, alcança na contemporaneidade uma nova face, que provoca impactos profundos no cerne da sociedade. Com as revoluções burguesas instauradas no continente europeu, a concepção tomada a partir dos Estados modernos - expressão da organização política e social da classe burguesa - o conceito de patrimônio assume uma vinculação direta com símbolos e manifestações culturais numa incessante busca pela materialização da ideia de nação. Residindo neste processo um conjunto de dificuldades permeado pelo direcionamento de políticas e ações de representação seletiva dos artefatos e de elementos imateriais e intangíveis de uma sociedade (OLIVEIRA, 2012). No que Fonseca (1997, p. 12) associa, a partir da produção de um universo simbólico enquanto objeto de ação política, como desafios principais da legitimidade do patrimônio: “(...) ao mesmo tempo, buscar o consenso e incorporar a diversidade". Incorporar à produção de vínculos identitários a questão da cultura nacional, no entanto, é algo duvidoso e complexo, levando em consideração a diversidade de seus membros e, portanto, a representatividade da cultura por uma face unificada segundo esta perspectiva $^{41}$.

A formatação de uma nova ordem jurídico-institucional, submetida pelo ideário burguês por intermédio do Estado-nação, revoluciona de forma universalizada os processos de seleção, proteção e divulgação do patrimônio cultural. Mesmo não solapando a diversidade cultural, essa nova ordem passou a "costurar" as diferenças culturais (HALL, 2006), onde as classes hegemônicas "[...] conseguiram traduzir seus interesses como interesses gerais da sociedade, $[\ldots]$ criando instituições que reforçavam seu lugar de poder na estrutura social, e padrões racionalizados de condutas que englobassem as práticas dos indivíduos." (CASTRO, 2012, p. 38). Em que pese à função normativa do Estado no tocante às políticas patrimoniais,

\footnotetext{
${ }^{41}$ Hall (2006) nos lembra que a ideia de nação se refere tanto ao Estado-nação moderno, quanto algo mais antigo e ligado a comunidades locais por meio da noção de natio. Evidenciando assim o próprio caráter dual entre as escalas e pouco unificador de uma possível cultura nacional, já que o próprio conceito, em seu bojo, revelaria essa diversidade de locais. Portanto, a força revelada por um processo unificador implica no questionamento sobre sua eficácia no sentido de anular ou subordinar as diferenças culturais. "Para dizer de forma mais simples: não importa quão diferentes seus membros possam ser em termos de classe, gênero ou raça, uma cultura nacional busca unificá-los numa identidade cultural, para representá-los todos como pertencendo à mesma e grande família nacional. Mas seria a identidade nacional uma identidade unificadora desse tipo, uma identidade que anula e subordina a diferença cultural?" (HALL, 2006, p. 59).
} 
no decorrer do século dezenove e princípio do vinte, em muitos casos, sua ação foi limitada a áreas ou elementos em processos litigiosos, sobretudo naqueles de caráter mais monumental. Tais evidências podem ser exemplificadas pela observação de amplas intervenções realizadas em cidades europeias, como as promovidas por Haussmann, na França, já na segunda metade do século dezenove, em que grande parte de conjuntos antigos medievais e populares foi destruído (OLIVEIRA, 2012).

Soma-se a isso, no decorrer do século vinte, conforme destaca Carlos Lemos (2006), a influência de diretrizes internacionais na regulação do tema, sintetizadas em reuniões de arquitetos e urbanistas, intelectuais ligados aos respectivos órgãos estatais de seus países, despontando no período sob a auspiciosa missão de concretizar as normas e especificações na abordagem do tema ${ }^{42}$. O que daria origem às cartas patrimoniais e novas perspectivas de abrangência do Estado para a tutela da cultura. Passando ao longo do século de uma abordagem mais restritiva do patrimônio, como na Carta de Atenas (1931), até um enfoque amplo em que se inserem, por exemplo, a paisagem cultural e o patrimônio imaterial.

No Brasil, antes do decreto-lei n. 25/1937, que criou e sustentou as bases e diretrizes do SPHAN no Estado Novo (FONSECA, 1997; CHUVA, 2012; GONÇALVES, 2012), vários projetos foram elaborados entre 1917 e 1934, visando a proteção patrimonial que já permeava uma cultura preservacionista na Europa, com rebatimentos no território brasileiro (SANT'ANA, 2003). Como explica Chuva (2012), na Primeira República a ideia de "país civilizado" associava-se ao gosto europeu, que visava superar a rusticidade e os costumes populares que haviam se estabelecido no Brasil. Enquanto que, a partir da década de 1920 e ao longo de 1930 “[...] essa visão entra em confronto com a valorização do popular [...], que buscava recolocar a brasilidade como algo moderno e singular (CHUVA, 2012, p. 69-70). Este do furor dos debates e discussões ao longo da década de 1920, resultaria no plano cultural com o modernismo consolidado no país, junto a emergência da burguesia nacional em curso. Marcadamente, como um todo, é um período de busca pela brasilidade entre os intelectuais e da identidade nacional forjada pelas instituições.

\footnotetext{
42 Entende-se como Fonseca (1997, p. 12) que "os intelectuais que estão direta ou indiretamente envolvidos com uma política de preservação nacional fazem o papel de mediadores simbólicos, que já que atuam no sentido de fazer ver como universais, em termos estéticos, e nacionais, em termos políticos, valores relativos, atribuídos a partir de uma perspectiva de um lugar no espaço social. E são também os intelectuais que, ao apontarem, no exercício de sua função crítica, o caráter arbitrário da representação vigente do patrimônio, atuam no sentido de sua transformação.”.
} 
A década de 1930 torna-se um marco na política nacional voltada ao patrimônio cultural, primeiro pelo tombamento da cidade de Ouro Preto como monumento nacional em 1933 pelo Decreto n. 22.928, assim como em 1934 o decreto n. 24.735 que criava o Serviço de Proteção de Monumentos (SANT’ANA, 2003). Depois em 1937, com implantação de instituições e normas regidas pelo Estado em favor da proteção do patrimônio cultural brasileiro (CHUVA, 2012). Cabe destacar que do embate entre intelectuais defensores de uma perspectiva de valor cultural ligado aos padrões europeus e aqueles que defendiam aspectos mais tradicionais da cultura brasileira, sobressaem estes últimos, sobretudo aqueles ligados ao movimento modernista. Destacam Rubino (1996), Fonseca (1997), Sant'Ana (2003), Gonçalves (2012) que destas políticas germinais foram consagrados e reconhecidos os bens patrimoniais ligados a experiência colonial, utilizando-se a noção de risco e, de tal maneira, direcionando as ações de preservação ao patrimônio arquitetônico. "As representações de um Brasil colonial - o Brasil das Bandeiras e das Minas - tornaram-se a expressão dominante da ideia de modernidade e também de brasilidade, nos anos de 1930" (CHUVA, 2012, p. 71).

Se sobressaem os modernistas, compondo a frente do SPHAN e da política nacional do patrimônio cultural, os bens eleitos e consagrados por estas mesmas políticas fugiam da amplitude despertada pelos diálogos e manifestações decorrentes da brasilidade em voga. $\mathrm{O}$ anteprojeto de Mario de Andrade para as políticas do patrimônio foram de difícil aplicação, considerando como explica Sant'Ana (2003), a inviabilidade justamente por não atender aos interesses políticos em jogo. Criado o SPHAN em 1937, Mario de Andrade irá compor neste ano o cargo de Assistente Técnico da $6^{a}$ Região Administrativa, em São Paulo, em que se destaca Luís Saia como um dos principais membros de sua equipe. Além dele, compunham a equipe Nuto Sant'Ana e o fotógrafo Germano. Em 1937 é produzido o "primeiro relatório", no qual vinte e quatro bens inventariados foram tombados. O SPHAN/SP ainda funcionava neste período na casa de Mario de Andrade. Em 1938 ele recomenda Paulo Duarte para assumir seu lugar no posto de direção regional do SPHAN, porém é seu discípulo Luís Saia que, colocado à prova com estudo da Aldeia de Carapicuíba, assume a direção do serviço (LEMOS, MORI, ALAMBERT, 2008, p. 28-30).

Como parte destas políticas, o caso do tombamento da Aldeia de Carapicuíba converge, ao mesmo tempo, para corroborar com as teorias gerais propugnadas da ação institucional brasileira das décadas de 1930 e 1940 (reduzida a pedra e cal e aos cânones arquitetônicos reconhecidos pelo movimento modernista), com algumas peculiaridades no tocante ao elemento folclórico e das tradições que foram aportes inovadores do anteprojeto de 
Mario Andrade. Com fundamentos que destacavam-se dos preceitos importados da Europa, as aspirações do material não afluíram necessariamente para conversão em leis concretas. O que, no entanto, foi suficiente, como um dos mentores de Luís Saia, no exímio detalhamento de seus estudos sobre a Aldeia de Carapicuíba, em 1937, enfocando, inclusive, como já adiantado, o caráter psicológico do habitante local, determinado pelo ambiente fechado, bem como as crendices, o folclore e as principais manifestações culturais. Configurando-se, portanto, como um dos mais emblemáticos estudos para a preservação deste período incipiente do SPHAN.

O direto do SPHAN [Rodrigo de Andrade] sempre achou o jovem estudante Luís Saia imaturo demais para ocupar o lugar de um intelectual do peso de Mario de Andrade. O desafio proposto por Mário e acatado pelo amigo Diretor foi fazer um teste de capacitação ao Saia, que seria julgado pelo próprio Rodrigo. O trabalho versaria sobre a Aldeia Jesuítica de Carapicuíba nos arredores da capital paulista. Como incentivo ao discípulo, Mário se comprometeu publicar posteriormente a monografia na Revista do SPHAN (LEMOS, MORI, ALAMBERT, 2008, p. 28-30).

Luís Saia fez o trabalho e assumiu a direção do SPHAN de São Paulo, sem nunca publicar o trabalho ${ }^{43}$. Em carta de Mário de Andrade à Luís Saia em 1938, ele explica que o relatório tratava-se de um texto literário, inclusive podendo ser confundido como por ele realizado, aconselhando pela sua não publicação. Contudo, destaca os elementos imateriais que Saia chama atenção, sobretudo ligado às festividades de Santa Cruz. Seria sua experiência adquirida no planejamento e chefia da Missão Folclórica, além do convívio direto com o mentor, que permitiu a Luís Saia essa visão mais total do patrimônio, que aflorou como nenhum outro neste trabalho (LEMOS et al., 2008). Por base dessa pesquisa é que a Aldeia de Carapicuíba concorrerá ao tombamento nacional pelo SPHAN, e Luís Saia se consagraria diretor do SPHAN regional de São Paulo, cargo que ocuparia até o fim da vida, em 1975.

As notificações de número 316 de 1939 e 1940 emitidas por Rodrigo M. F. de Andrade, então diretor do SPHAN, aos prefeitos de São Roque e de Cotia respectivamente, informam às autoridades responsáveis pela gestão territorial a determinação do tombamento do conjunto arquitetônico e urbanístico da Aldeia de Carapicuíba. O envio às duas prefeituras se deve muito provavelmente ao fato das imprecisas delimitações político-administrativas daquele período, ainda que a maioria da população da Aldeia pagasse foro a municipalidade

\footnotetext{
43 O estudo nunca foi publicado, porém pode ser encontrado integralmente para consulta no arquivo da
} $9^{\mathrm{a}}$.SRIPHAN/SP. 
de Cotia. Consta no Livro Tombo Arqueológico, Etnográfico e Paisagístico, instituído pelo Decreto-Lei 20, de 1937, a inscrição na folha 03 do "conjunto arquitetônico e urbanístico da Aldeia de Carapicuíba", cuja data refere-se a 13 de maio de $1940^{44}$. Justamente o Livro Tombo com uma concepção de registro e preservação que se transformara numa marca de Mario de Andrade e que incluía uma vasta possibilidade de enquadramentos.

[...] Segundo sua definição, essas artes não estariam representadas apenas por artefatos colecionáveis, mas incluiriam também monumentos, paisagens e folclore. Surgem, então, como objetos de preservação, as jazidas funerárias, os sambaquis, as cidades lacustres, os aldeamentos, os caminhos, as grutas, a arquitetura popular, as capelas e cruzes na beira da estrada, um agrupamento de mocambos, um morro do Rio de Janeiro, vocabulários, cantos, lendas, medicina e culinária indígenas, música popular, contos, superstições, provérbios, ditos e danças dramáticas, entre outras manifestações. [...] Deixa perceber que o critério fundamental de seleção desses bens seria estabelecido de acordo com noções bem definidas de qualidade artística, autenticidade e caráter nacional (SANT'ANA, 2003, p. 104 - grifo nosso).

O caráter de tombamento é ex-officio, ou seja, capaz de recair sobre ofício aos poderes estaduais e municipais, sendo simbólico considerando não apenas a data de inscrição, mas como relevante monumento representativo da cultura nacional. Trata-se de um dos mais antigos tombamentos nos Livro do Tombo, geridos então pelo recém criado SPHAN. Além do conjunto da Aldeia de Carapicuíba, inscreve-se no Livros do Tombo Histórico e de Belas Artes a Capela de São João Batista, no ano de 1941, sob a inscrição 151 e 293 respectivamente em cada livro. Conforme detalhamento do Arquivo Noronha Santos "O tombamento inclui todo o seu acervo, de acordo com a Resolução do Conselho Consultivo da SPHAN, de 13/08/85, referente ao Processo Administrativo $n^{\circ}$ 13/85/SPHAN." (IPHAN, 2016c).

O tombamento da Aldeia de Carapicuíba é um dos casos mais simbólicos da história do patrimônio nacional em São Paulo por tratar-se do conjunto e de enquadrar-se nas controversas projeções modernas de cultura de Mario de Andrade. Os esforços de Luís Saia e outros agentes institucionais envolvidos com a sua patrimonialização derivam de uma nova ordem cultural no Brasil, que ficou conhecida popularmente como movimento modernista. Numa de suas correntes de maior influência intelectual no século passado, que buscava valorizar as origens ligadas às sociedades indígenas, a Aldeia de Carapicuíba representava um marco material e simbólico estruturante. Como concreticidade, era capaz de substanciar outra narrativa controversa, mas relativamente conectada com os mitos fundadores, que vão da

\footnotetext{
${ }^{44}$ Documento integral disponibilizado pelo Arquivo do IPHAN, seção Rio de Janeiro. Anexo - 02.
} 
derrocada do romantismo indigenista em "Iracema" de José de Alencar às polêmicas obras da imagem indígena às avessas, como "Macunaíma" de Mario de Andrade e o "Manifesto Antropofágico" de Oswald de Andrade. Este pensamento trouxe também uma proposta de novo sentido identitário, difundido nas mais diversas correntes do saber, da literatura às artes, da história a edificação de novas propostas culturais refletidas pela materialidade das primitivas comunidades indígenas do país, como expressado em Tarsila do Amaral (Figura 25).

Modernismo e as novas dimensões culturais propostas pelo resgate indigenista às avessas
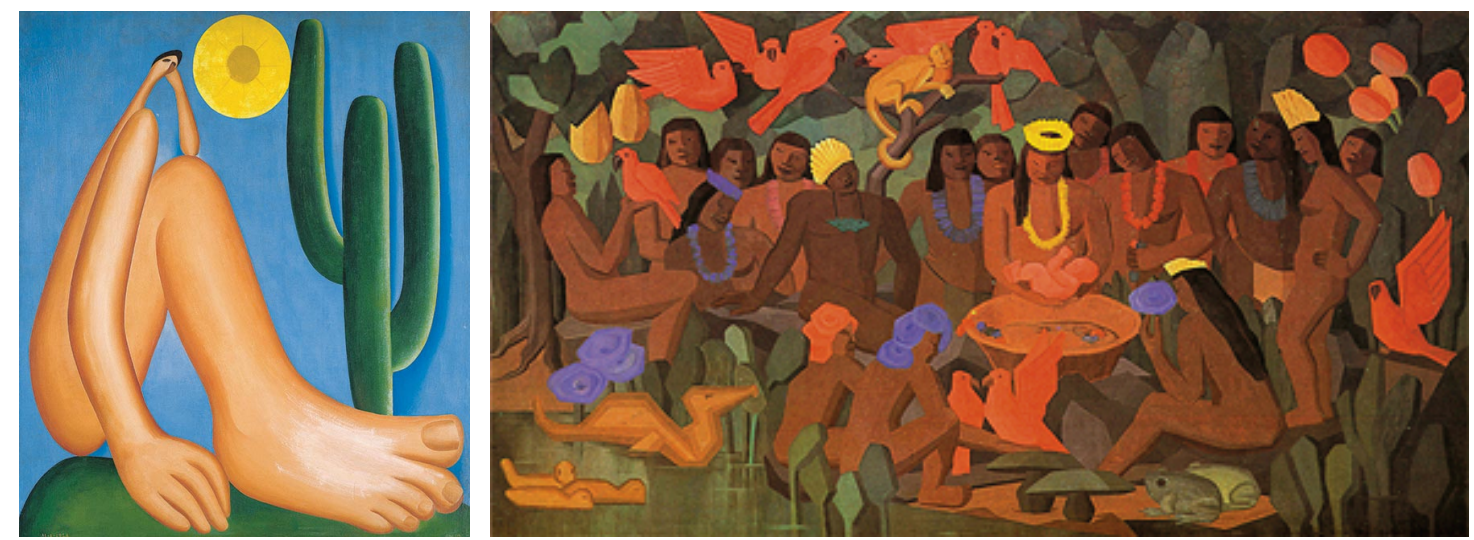

Figura 25: Obras de Tarsila do Amaral - (Esquerda) Abaporu (1928), em tupi significa "homem que come gente", referência do Modernismo no Brasil, ligado ao movimento antropofágico de Oswald de Andrade, Antônio de Alcântara Machado e Raul Bopp. Postulava a ingestão das tradições exteriores com as internas para a criação de uma cultura nova e tipicamente brasileira. (Direita) O batizado de Macunaíma (1956), inspirado na obra Macunaíma (1928) de Mario Andrade, fase avançada da artista e de técnicas utilizadas.

Fonte: (Esquerda) Abaporu (1928), óleo sobre tela, $85 \mathrm{~cm} \times 72 \mathrm{~cm}-$ Museo de Arte Latinoamericano de Buenos Aires (MALBA); (Direita) O batizado de Macunaíma, óleo sobre tela 132.5 x $250 \mathrm{~cm}$ - Enciclopédia Itaú Cultural.

De tal maneira, pensar Carapicuíba neste momento, no entanto, não remete a uma dimensão urbana, considerando o pequeno conjunto de casas aos redor do largo da capela, e as diversas propriedades rurais que abastecem com suprimentos alimentícios a cidade de São Paulo. O patrimônio cultural então limita-se a uma concepção fragmentária e, mesmo no Brasil com o movimento crítico de 1922, assentará sobre as grandes obras, os edifícios maiores, o patrimônio que remete às oligarquias, grupos religiosos, bem como edifícios públicos e monumentos fundados aos heróis da pátria. O caso de Carapicuíba carrega essas amarras, sobretudo em relação ao plano religioso que assenta as próprias origens do aldeamento, mas é revolucionário no que tange a riqueza inicial dos levantamentos dos bens intangíveis, de uma proposta de valor sobre as formas que respeitava em grande medida a sua condição de antiguidade já convertido em vilarejo caipira e marcado pelas tradições sincréticas observadas. É pressuposto na pesquisa de Saia (1937) que os artefatos já em ruínas 
do aldeamento primitivo, datado do quinhentismo, tenham sido reconstruídos por volta do ano de 1727 (HENNE, 2015) e a capela em 1736 (IPHAN, 2016b). Além do valor simbólico de uma unidade singular do Brasil colônia e associada a presença de populações primitivas, a materialidade ali encontrada sugere "mãos indígenas" na sua (re)criação pelo trabalho, como as típicas estruturas em madeira que sustentam as telhas da capela de São João, no centro do conjunto. No arquivo Noronha Santos, do IPHAN, a descrição é dada pelo seguinte: "Capela missioneira em taipa de pilão e telhado em duas águas com madeiramento aparente. Foi reconstruída em 1736, substituindo a capela jesuítica original. Altar-mor de gosto popular e terça decorada na sacristia demonstram a mão indígena na sua construção" (IPHAN, 2016b - grifo nosso). Vê-se o destaque dado no próprio arquivo ao trabalho indígena associado a arte e a um artefato específico da forma arquitetônica do bem.

O tombo da Aldeia e da capela insere-se num contexto de dinamização metropolitana iniciado em fins de século dezenove e que se acentuaria até a plena industrialização e urbanização regional após 1950. No âmbito cultural, a valoração se enraíza no processo de colonização, englobando no estudo para o tombamento de Luís Saia (1937), a hibridização assentada fundamentalmente das técnicas construtivas. $\mathrm{O}$ tombo marca os primeiros anos da política patrimonial no Brasil e, mais particularmente, dos conjuntos urbanísticos. A conversão da Aldeia de Carapicuíba em patrimônio nacional reflete justamente o papel desempenhado por estes intelectuais, sobretudo de Luís Saia e, indiretamente, de Mario de Andrade, na construção de uma unidade em torno dos bens materiais imóveis que pudessem suplantar e contribuir setorialmente não apenas como uma identidade calcada no indígena primitivo, mas da mestiçagem do caipira na convergência multiétnica com o branco europeu, o negro africano e o índio americano. Trata-se, assim, de consolidar a própria defesa de Darcy Ribeiro (2006 [1955]) da formação do povo brasileiro, fortemente influenciada por esses simbolismos produzidos nas décadas de 1920 e 1930, em torno da identidade de um "povo novo" - mestiço e multicultural.

No minucioso, porém renegado estudo de $\mathrm{Saia}^{45}$ (1937), os detalhes levantados e as hipóteses acerca das permanências da Aldeia de Carapicuíba são contundentes, ainda assim limitados ao plano material. Afinal, o olhar sobre os bens culturais naquele período são evocados pelo monumento. No entanto, neste caso, já sugere-se o valor histórico da

\footnotetext{
${ }^{45}$ Saia explica que muitos erros e exageros foram cometidos no estudo de Carapicuíba e que jamais o publicaria. Porém, alerta da busca e procura contínuas desde documento, que mesmo tendo problema se verifica como um dos mais importantes, inclusive à propósito do tombamento do conjunto urbanístico da Aldeia.
} 
rugosidade patrimonial, ainda que criticamente associado a uma perspectiva colonialista. É esta análise minuciosa realizada pelo autor, que vai antever desde os padrões estruturais do sítio, sua morfologia, formas, até a influência étnica do colonizador, do jesuíta e do indígena nas técnicas e nos materiais empregados. Conjectura sobre as diversa funções que o aldeamento específico de Carapicuíba teve no processo histórico, buscando compreender não apenas sua permanência, mas a influência destes elementos na psicologia do pequeno povoado caipira. Entre o fim do sistema de aldeamentos, em meados do século dezenove e a passagem de Carapicuíba para vilarejo caipira, a redescoberta da Aldeia por ele e, posteriormente ao ato de tombamento, circunscreve-se na preservação do patrimônio material, além das famílias, da religiosidade e suas festividades, das condições proeminentes de isolamento, agora, mais uma vez, o plano institucional efetivadas pelo Estado. Não mais a Coroa sobre a rugosidade patrimonial, ou o colonizador, se não o moderno Estado Novo do Brasil.

Recai o tombamento ao fragmento da Aldeia, deixando a totalidade do entorno ou a unidade mais ampla do território, o que poderia atualmente estar preservada e, com isso, permitiria novas prospecções arqueológicas e o melhor conhecimento dos modos de viver das populações pretéritas, ou mesmo seguindo a tradição neocolonialista do temário patrimonial, das posições e as reais dimensões dos aldeamentos jesuíticos. Deve-se ressaltar que mesmo embasadas por Saia (1937), considerando as festividades de Santa Cruz e de Santa Catarina, as descrições oficiais sobre a área, mesmo as mais atuais inseridas nos cadastros do IPHAN e CONDEPHAAT, sequer aventam especificar o patrimônio cultural intangível. Estas tradições, se associando aos elementos materiais como elo estruturante ao entendimento das permanências, da atual existência da rugosidade patrimonial ali circunscrita, não estão inseridas plenamente numa narrativa institucional que assevere seu papel concretamente, ou que assegure razões institucionais de ser um dos elementos centrais na permanência da rugosidade patrimonial até os dia de hoje.

Além da importância do conjunto urbanístico da Aldeia de Carapicuíba possuir a antiga estrutura jesuítica de aldeamento, da morfologia, das formas antigas, de um substrato que resiste mesmo após sua destruição no século dezessete e reconstrução no século dezoito, outra particularidade deste conjunto chama atenção no estudo de Saia (1937). Trata-se, da peça horizontal, a terça da sacristia, da capela de São João Batista, que segundo ele teria sido “executada por gente antiga da aldeia, talvez mesmo índio, é certo que seja pintura mestiça, ainda que os habitantes de Carapicuíba a tenham como pintura indígena." (SAIA, 1937, p. 
30). Em nota na nova publicação do texto nos cadernos técnicos do IPHAN regional São Paulo, existe uma retificação indicando que esta peça seria, na verdade, o antigo mastro onde se fincava a bandeira para as festividades religiosas da aldeia, conforme Luiz Dias de Andrade e José Saia Neto. O esclarecimento é uma vez mais ratificado por José Saia Neto que em comunicação por e-mail informa em detalhes o seguinte:

\begin{abstract}
A consideração de que a terça seria uma peça estrutural decorada, remanescente de uma possível solução original da capela, foi feita num momento inicial no IPHAN e mesmo do envolvimento do velho [Luís Saia] com os trabalhos de restauração. Pode ter contribuído (e isto é apenas uma suposição) o fato então conhecido da marcante influência indígena nas obras de arte das missões gaúchas, que o Lucio estava estudando. Mas é fato que as circunstâncias que marcaram a experiência de Carapicuíba tornam esta participação, ao menos na escala em que se deu no sul, bastante improvável. Por outro lado há que se considerar que os mastros são, via de regra de madeira de menor qualidade, visando uma durabilidade relativamente curta; além disto, a influência da arte e cultura indígena na região, no século XIX, já estava irremediavelmente assimilada pela cultura caipira. $\mathrm{O}$ que muito possivelmente ocorreu foi que, numa das inúmeras reformas do telhado, verificou-se a necessidade de se substituir a terça, como estas intervenções são precárias do ponto de vista dos recursos financeiros e humanos, um mastro disponível certamente seria bastante oportuno. Ainda que tenha sido caprichosamente decorado pela comunidade. Durante a restauração, com a possibilidade de analisar a peça com mais proximidade e cuidado, sua origem dúbia foi enfim reconfirmada. O interessante deste trabalho do Saia é que incorporou muito da metodologia utilizada pela Missão de Pesquisas Folclóricas, com o registro da festa de Sta. Cruz, de mobiliário, de equipamentos domésticos, de técnicas construtivas, da utilização de materiais etc. (Entrevista concedida em junho de 2016).
\end{abstract}

Fatidicamente, no entanto, no Arquivo Noronha Santos (IPHAN, 2016a) prevalece a relevância da capela justamente pela razão da mão indígena, o que, pois, decorre duas considerações. A primeira, mais simples e pragmática, é a de que há urgência de atualização das informações por parte do IPHAN no Arquivo Noronha Santos, já que este é um dos mais importantes e populares meios de acesso aos dados sobre os bens tombados. A segunda consideração, mais complexa, reside novamente sobre a centralidade das festividades religiosas, pois mesmo não sendo a terça necessariamente preparada para aquela função, ela evidencia ser relativamente antiga, comprovando a secularidade das festas religiosas no local, por fim, ao mesmo tempo colocando em dúvida se, de fato, não necessariamente foi o indígena que ainda vivia ali que não a desenhou ou exerceu influência. Na oportunidade em que acompanhamos as festividades de Santa Cruz no ano de 2016, o mastro foi desenhado pela artista plástica Alaide Di Pietro e a estrutura de madeira no telhado da capela é totalmente outra (Figuras 26, 27, 28). 
Estrutura do telhado da sacristia - Igreja de São João Batista em 1936

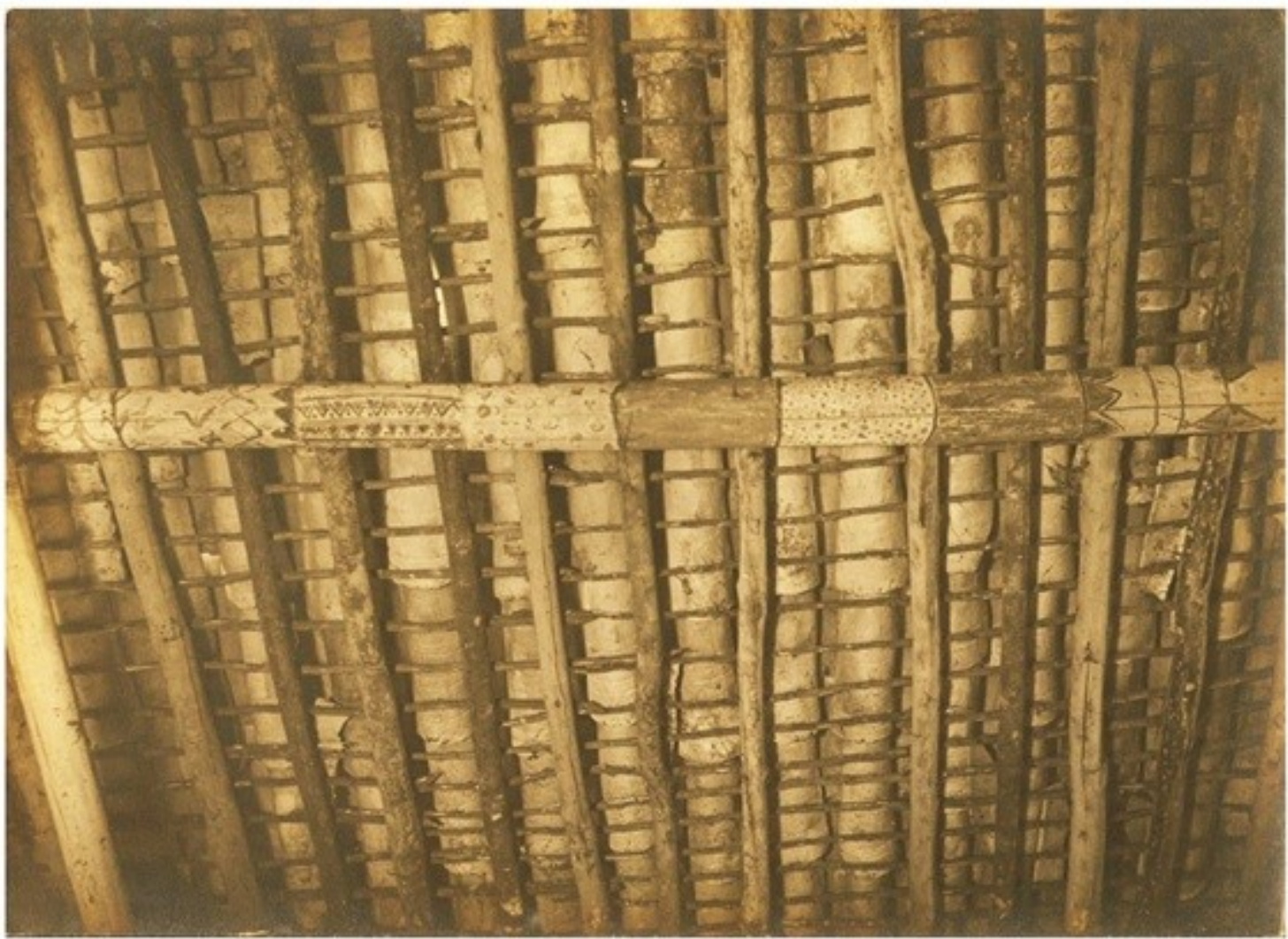

Figura 26: Detalhe da terça decorada, mestiça, com desenhos indígenas e que teria sido obtida possivelmente do mastro que sustentava as bandeiras das festas religiosas na Aldeia de Carapicuíba.

Fonte: Acervo Fotográfico IPHAN - Rio de Janeiro.

Nova estrutura do telhado da sacristia - Igreja de São João Batista em 2016

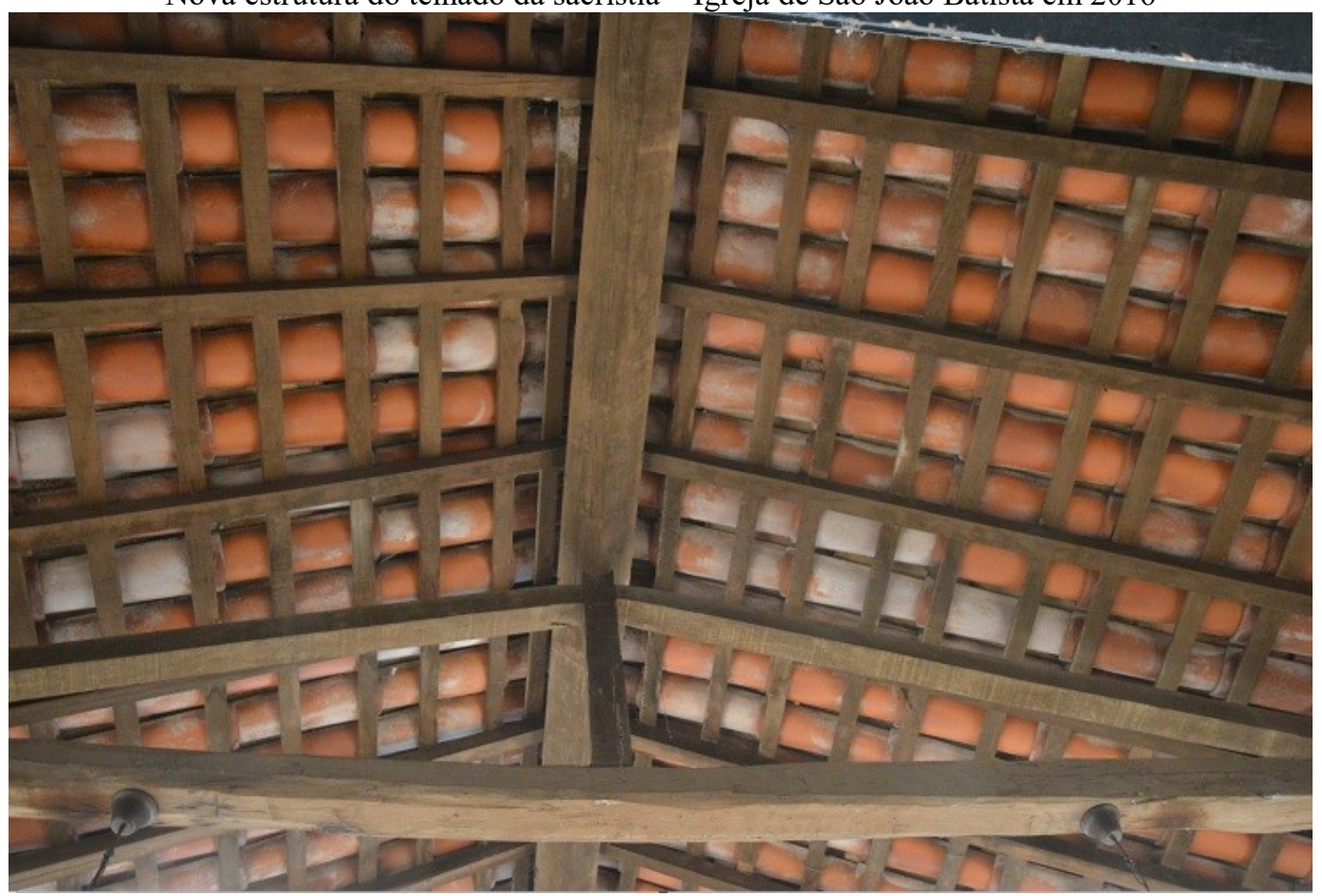

Figura 27: Detalhe da terça decorada, mestiça, com desenhos indígenas e que teria sido obtida possivelmente do mastro que sustentava as bandeiras das festas religiosas na Aldeia de Carapicuíba.

Fonte: Foto do autor, 2016. 
Detalhe do mastro que inaugura as festividades de Santa Cruz na Aldeia de Carapicuíba - 2016
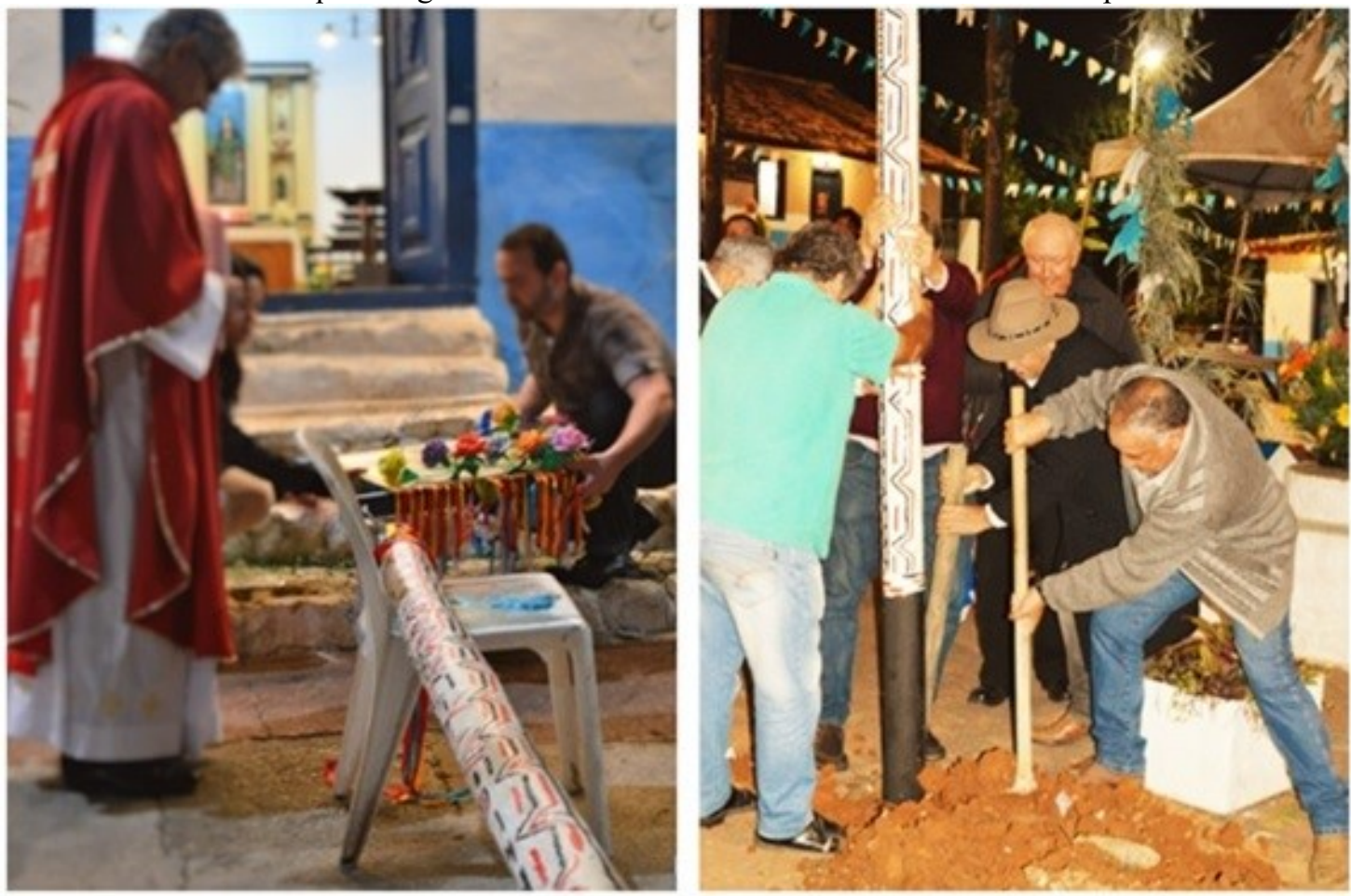

Figura 28: As pinturas com traços indígenas são tradicionalmente produzidas no mastro com a bandeira de Santa Cruz. No detalhe, à esquerda, festeiros colocam a bandeira no mastro decorado. À direita, festeiros fixam o mastro na lateral do cruzeiro e em frente à igreja de $\mathrm{S}$. J. Batista.

Fonte: Fotos do autor, 2016.

A atualidade das políticas patrimoniais ganha amplitude de abarcar ilimitados bens, materiais e imateriais, assumindo uma perspectiva mecânica e repetitiva que, se amplia as possibilidades de reconhecimento sobre a diversidade, torna-se paralelamente uma máquina de consagração patrimonial, a maquinaria patrimonial (JEUDY, 2005; COSTA, 2011). Naquele momento, a Aldeia de Carapicuíba ressurgia como a mais preciosa reminiscência primitiva do território paulista, associada a uma releitura do índio, da miscigenação étnica, da construção da brasilidade e a identidade nacional. E não são poucos os problemas e conflitos que passaram a decorrer após o tombamento entre os organismos, instituições intergovernamentais e a população local e entorno. No entanto, talvez seja mesmo esse processo um dos responsáveis pela preservação do conjunto frente ao processo de metropolização que se instalaria na região pelo surto demográfico, industrial e urbano de São Paulo mais detalhado nos capítulos seguintes. De fato, a normatização do espaço da Aldeia pelo Estado é apenas uma faceta da modernização por qual passaria este território nas décadas seguintes, emancipado e constituindo-se gradativamente num típico subúrbio de São Paulo. 


\section{PARTE 03}

\section{CARAPICUÍBA DE SUBÚRBIO A PERIFERIA: RUGOSIDADES PATRIMONIAIS NOS LIMITES DA METRÓPOLE}

\section{CAPÍTULO 05: Carapicuíba de subúrbio à periferia: rugosidades patrimoniais}

Nos capítulos anteriores, em relação ao processo de metropolização e consolidação da Grande São Paulo, especialmente a situação de Carapicuíba, é possível sintetizar alguns pontos importantes que marcarão a passagem dos núcleos de assentamentos pretéritos, aldeamentos, povoamentos caipiras para a dinamização e a integração orbital ao grande centro urbano. Essas passagens permeadas pelas forças inerciais antepassadas, materiais e imateriais, que consolidam as rugosidades patrimoniais em seu movimento de supressão, superposição e acumulação.

O primeiro refere-se à localização do Planalto Paulistano e mais especificamente de São Paulo e seus arredores, estabelecidos estrategicamente na rede geográfica de trajetos e caminhos, que substanciaram a expansão territorial e a consolidação da colônia portuguesa na América: no assentamento, no apresamento indígena, na produção agropecuária, na comercialização, na logística primitiva de transporte dos bens, no envio de riquezas e mercadorias aos portos. Na dinâmica histórica e geográfica, Carapicuíba decorre deste momento, ativamente alimentada pelos anseios coloniais no segundo período.

O segundo associa-se propriamente a consolidação da unidade política e administrativa paulistana, pela centralidade exercida quando da conversão de São Paulo em vila pela Coroa, a primeira numa região planáltica. Neste momento, além dos caminhos, a gestão territorial da capitania está circunscrita ao núcleo de São Paulo, tendo aporte dos aldeamentos indígenas (jesuíticos e do padroado real) com trabalho, segurança e alimentação. A permanência do aldeamento de Carapicuíba é verificada pela função basilar que ocupa em relação a São Paulo e região. Trata-se de uma rugosidade patrimonial que é estabelecida predominantemente de supressões e superposições do colono ao nativo, ainda que em menor grau de acumulação. 
O terceiro relaciona-se numa circunstância já posterior à Revolução Industrial na Europa, com a instalação das primeiras indústrias no Brasil e a modernização dos sistemas de tráfego e de transporte verificada no território paulista. Financiado pela acumulação primitiva da cultura canavieira mas, fundamentalmente, do café, capaz de estruturar as bases materiais que alimentariam a concreta metropolização espacial posterior. $\mathrm{O}$ dinamismo econômico propiciado pelo café e a pré-industrialização paulista, marca a decadência dos aldeamentos, com Carapicuíba e outras unidades caindo no ostracismo, do qual deriva, especificamente neste recorte, a cultura caipira. E que, mesmo em relativo isolamento do núcleo metropolitano, o serve como reduto espiritual e, em certa medida, com produtos básicos da roça, manufaturados e artesanais. No limite, este período marca de forma latente a acumulação de rugosidades patrimoniais, com a utilização das ruinas pela nova sociedade em curso, como pela hibridização cultural que resulta o caipira, paralelamente às superposições e supressões.

O quarto momento verifica-se com o processo urbano-industrial, pós-1950. Contexto em que São Paulo se consolida como metrópole nacional e que este capítulo destina-se a esmiuçar em relação à formação territorial de Carapicuíba enquanto subúrbio paulistano. Nisto, explicando a conjuntura de “implosão-explosão" urbana (LEFEBVRE, 2012), em que os subúrbios são formados e, posteriormente, convertidos em enormes periferias, com graves problemas sociais, mas como no passado, ainda alicerçando o centro metropolitano.

A primeira parte recai sobre o conjunto destas transformações no recorte empírico em questão, da ampliação e melhoramentos na rede de transporte, da emancipação e fragmentação dos municípios suburbanos, bem como de sua articulação com São Paulo. No caso de Carapicuíba, reflete o espraiamento urbano no entorno da Estrada de Ferro Sorocabana, bem como as unidades habitacionais construídas nos limites com Osasco, integrando as duas cidades e consolidando a efetiva conurbação com São Paulo. No plano do temário patrimonial mais especificamente, o espaço da Aldeia de Carapicuíba passa por profundas tensões, empreendidas pelo inchaço populacional, pela favelização e a ocupação desenfreada e ilegal do território. Além disso, pelas próprias ações preservacionistas, que instauram normas e políticas conflitantes com os moradores e a municipalidade. A segunda parte, principia a análise da industrialização e a "implosão-explosão" urbana empreendidas numa escala nacional, mas cujo recorte passa a ser paulatinamente São Paulo. Neste processo, busca-se compreender o fenômeno de metropolização, sua regulamentação e sua unidade regional que inclui Carapicuíba. Período de dinâmico crescimento populacional, expansão das 
atividades produtivas e que se encerra ao generalizar a periferização dos subúrbios, tangenciando a discussão da última parte do capítulo.

No âmbito das rugosidades, as permanências são ora mantidas pelas tradições que animam os lugares e que resistem a duras penas, estando vinculadas pela contínua banalização dos ritos e manifestações, além das tradições locais, das soluções técnicas mais simples, do ostracismo, quando agora o papel institucional do IPHAN e das políticas urbanas devem ser considerados centrais na "manutenção" da Aldeia, se não pela constância de sua presença, ao menos, pelo papel que desempenha a normatização do espaço como patrimônio nacional e das políticas públicas urbanas em curso. Qualidade que marcaria para sempre o valor e os significados daquele pequeno conjunto de construções.

\subsection{Emancipação de Carapicuíba: rugosidades patrimoniais do subúrbio paulistano}

A década de 1940 marca a ruptura, a cisão das forças processuais históricas e geográficas do lugar. Uma radical transformação advém da sua cristalização nuclear enquanto subúrbio, influenciada pela emergência do novo centro produzido ao norte, nas margens da ferrovia, junto as de extração mineral, a manutenção e operação da linha de ferro, bem como a produção pecuário-frigorífica. Integrando a Aldeia de Carapicuíba num eixo perpendicular à ferrovia, com acesso a Cotia e outros municípios ao sul, como também a rodovia Raposo Tavares. Essa nova dinâmica, com maior integração metropolitana e geográfica pelos sistemas de transporte e pela confluência populacional entre os núcleos a oeste de São Paulo, trouxe a fragmentação político-administrativa, a qual tornaria o município de Carapicuíba relativamente autônomo e, pois, potencializaria a normatização do território visando objetivos técnicos do planejamento, bem como a permeabilidade corporativa do modo de produção capitalista.

Esta permeabilidade, no caso de Carapicuíba, não estará concentrada necessariamente na produção industrial, ou comercial, mas na da terra. Ao contrário de Osasco e Barueri na produção industrial, ou Cotia com a produção hortifrutigranjeira, Carapicuíba transformou-se num grande mercado de terras à oeste da capital, cuja renda diferencial, devido a ilegalidade dos empreendimentos, a ausência de infraestrutura e a distância das atividades industriais e comerciais, a transformou num reduto imobiliário para as classes trabalhadoras. Soma-se, pois, a auto-construção, feita com precariedade aos fins de semana, ou horários de pequena 
folga do trabalho para selar o perfil periférico funcional de Carapicuíba, ocupando praticamente a totalidade do território e a transformando numa típica cidade dormitório e mais dependente ao longo dos anos do centro metropolitano.

Segundo dados do recenseamento de 1940, Cotia possuía uma população total de 8.594 habitantes. Se considerar que Carapicuíba ainda estava subordinada administrativamente a este município, sua população total não deveria passar de dois mil habitantes. No limite, em 1951, quando foi inaugurada a segunda estação da EFS nos arredores de Santa Terezinha, pode-se pensar já numa demanda populacional mais efetiva por moradia que se integrasse pelas linhas com a capital, com a expansão dos loteamentos e de infraestrutura mínima, como apontado no capítulo anterior. No entanto, a ampliação industrial e diversificação produtiva de São Paulo, juntamente com a atração populacional de outras regiões, em busca de trabalho e oportunidades, além da intensa urbanização verificada, não foi um fenômeno com inclinação apenas sobre o território de Carapicuíba. De fato, a expansão centrífuga da capita ${ }^{46}$ se estabelecia por todos os troncos ferroviários e, em segundo plano, das rodovias. Conforme Azevedo (1958), Langenbuch (1971), Meyer, Grostein e Biderman (2013), as ferrovias acabaram por estruturar a organização do território metropolitano da Grande São Paulo.

\footnotetext{
Polarizado pela cidade de São Paulo, o sistema ferroviário organizou as forças centrífugas da expansão metropolitana e, simultaneamente, reforçou a hegemonia da capital enquanto polo centralizador. O sistema era composto então por cinco principais ferrovias: a São Paulo Railway, a Companhia Paulista, a Estrada de Ferro Central do Brasil, a Companhia Mogiana e a Estrada de Ferro central do Brasil. Esse importante sistema foi montado em poucas décadas e favoreceu a urbanização dos bairros centrais da capital enquanto expandia o território metropolitano. Como uma infra-estrutura de caráter eminentemente econômico, o sistema ferroviário implantado na segunda metade do século XIX estava voltado, sobretudo, para o transporte de carga. Mais tarde ganhou características de serviço público, na medida em que se tornou o mais importante meio de transporte de passageiros para os municípios do entorno e mesmo para os bairros mais afastados da cidade. Do ponto de vista intra-urbano, o sistema ferroviário abriu a chamada 'frente oeste' de desenvolvimento da cidade (MEYER; GROSTEIN; BIDERMAN, 2013, p. 35).
}

\footnotetext{
${ }^{46}$ Langenbuch (1971, p. 174) explica que, na verdade, o tronco da Sorocabana é um dos que menos concentrava população na década de 1940, representando 6,5\% dos moradores dos arredores paulistanos. Ainda segundo ele, “o fato, sem dúvida, se relaciona com o pequeno número de trens suburbanos instituídos pela ferrovia durante o período em estudo, situação esta agravada pelo fato de em toda faixa industrializada existir apenas uma estação, a da Barra Funda. A Sorocabana realmente pouco oferecia aos moradores suburbanos em potencial.”.
} 
Grande parte dos arredores de São Paulo, pouco antes da emancipação do município de Carapicuíba ${ }^{47}$, já estão integrados geograficamente numa mancha urbana contínua, fazendo com que os preços da terra se elevem em toda região, sobretudo nas proximidades das ferrovias que concentravam em seu entorno os barracões industriais emergentes (SELINARDI-SAMPAIO, 2009) ${ }^{48}$. Conforme Langenbuch (1971, p. 176) “[...] a especulação se volta com interêsse nunca visto para os arredores paulistanos da época.”. O autor ainda explica a formação de cinturões residenciais que ultrapassam os limites municipais, divididos basicamente em unidades residenciais e industriais. "[...] Formam-se nítidos e definidos subúrbios industriais e residenciais." (LANGENBUCH, 1971, p. 176). Os limites da urbanização verificados neste período, que ainda antecede a 1950, se expandem à oeste de São Paulo, alcançando extensões cada vez mais amplas do território, da depressão periférica e planalto ocidental paulista, moldando a rede urbana em torno dos trilhos e estações, bem como das grandes propriedades de produção cafeeira e outros gêneros agrícolas (MONBEIG, 1998).

Para Godoy e Bray (2003), além da importância das ferrovias no sentido de impulsionar e reestruturar a rede urbana no interior - produzindo novas cidades, ou gerando outros arranjos espaciais, alteram-se ainda profundamente as relações de trabalho e de produção. Estas, disciplinam o trabalhador, a sua organização de vida e, por fim, o próprio modo de agir e pensar em sociedade. A ampla mercantilização da terra completa este quadro, com a produção de pequenas unidades, lotes e loteamentos, esboçando claramente os preceitos da geometrização cada vez mais precisa do espaço) e que concretiza extrair o máximo de valor sobre a terra, tornando-a plenamente eficaz na reprodução das relações

\footnotetext{
${ }^{47}$ Ainda Distrito de Barueri, após desmembramento deste último de Santa de Parnaíba e de Carapicuíba em relação à Cotia: Lei 233 de 24-12-1948, criado com sede no povoado de mesmo nome e com terras do distrito de Barueri. Desmembramento: Lei 8092 de 28-2-1964, elevado oficialmente à município de Carapicuíba (SEADE, 2016).

48 Ao fazer um balanço da industrialização de São Paulo na década de 1950, Selingardi-Sampaio (2009, p. 64) explica que o traço mais marcante deste processo reside justamente na hegemonia industrial da capital paulistana em relação ao país. E, ainda, "como principal centro industrial e único espaço metropolizados paulista, o tecido industrial mais denso e melhor articulado do estado (as empresas criavam laços de coalescência com o território), e concentrando atributos e recursos para o grande salto quantitativo e qualitativo que daria nos anos e décadas seguintes: (i) nas escalas urbana, regional e nacional, como núcleo da área de metropolitana mais rica e ativa do país, detentora de maior força de polarização; (ii) na esfera econômico-industrial, fosse potencializado sua expansão industrial e as correlatas economias de aglomeração; fosse estendendo, progressivamente sua área de polarização industrial para territórios próximos e, ainda, para alguns mais distantes; fosse atuando como força comandante da inovação/reestruturação produtiva que, em breve, iria atingir as principais regiões do estado." (SELINGARDI-SAMPAIO, 2009, p. 64).
} 
sociais (HARVEY, 2013). Sobressaindo São Paulo como centro urbano e industrial do Brasil, aprofundando as desigualdades regionais, perfazendo "uma divisão regional do trabalho, onde a Região Nordeste apareceu como mercado de mão-de-obra para a indústria do Sudeste, e o Norte e Centro-Oeste como regiões de expansão da fronteira agrícola dirigida pelo Estado.” (GODOY; BRAY, 2003, p. 199).

Pensar Carapicuíba no contexto de metropolização de São Paulo neste período deve arrastar algumas relativizações. A primeira, sobre o papel da ferrovia que mesmo em 1951, com a inauguração da segunda estação, ambas ainda estavam relativamente distantes do antigo núcleo, marcado pela Aldeia, bem como das áreas primitivas de adensamento. Esta distância fragmenta em duas unidades seu território: ao norte, a "nova Carapicuíba" - urbana, com novos moradores, novos hábitos e em ligação direta pelo trem com a capital; ao sul, o antigo núcleo de aldeamento, a Aldeia de Carapicuíba, fazendas e sítios - rural, com antigos moradores, ligados às raízes e tradições locais, por vezes em ligação mais forte com Cotia e arredores do que com a capital. Ao sul, o transporte mecanizado era dependente das linhas de ônibus, ou indiretamente pelo trem, que demandava baldeação ${ }^{49}$. Portanto, a integração de Carapicuíba antes de sua emancipação deve ser considerada polarizada e com características diferentes para cada porção do seu território e com cada grupo social em questão.

As diferentes unidades territoriais de Carapicuíba, desde o princípio da dinamização econômica pela chegada dos trilhos da Sorocabana em fins do século dezenove e a criação da primeira estação para transporte de passageiros em $1926^{50}$, estavam relacionadas por um arranjo produtivo em comum. Antes mesmo da estação de passageiros ser fundada, havia uma cancela para o carregamento de areia que era extraída e alimentava as construções cada vez maiores em São Paulo (TENÓRIO, 2003). Observa-se, com isso, a escala comercial do porto de areia, que passou a ser ampliada com essa nova possibilidade. Isso, não explica necessariamente a interconexão entre as duas unidades de Carapicuíba, em verdade, revela o papel desta área em relação à região polarizada por São Paulo, cuja função neste momento, além das tradições e religiosidade buscadas na Aldeia, realiza ao norte, nas proximidades do

\footnotetext{
49 Afinal, como explica Langenbuch (1971, p. 177) “as maiores distâncias, a circulação rodoviária ainda não gera subúrbios, mas origina 'povoados-entroncamento', o que revigora os já existentes. Estes povoados encerram uma vocação de núcleos povoadores do desenvolvimento suburbano, que contudo somente se revelaria no próximo período".

50 Conforme Pimentel (2006, p. 32) a primeira estação de Carapicuíba, criada em 1921 e só aberta a passageiros em 1926, denominava-se Sylviânia. "Portanto, aquela que viria a se tornar a principal estação de trem do município, por alguns anos não se chamou estação Carapicuíba (como atualmente). Isso porque naquela época a vila que despontava tinha o nome da fazenda que abrangia toda aquela região, Sylviânia.
} 
Tietê, a extração de recursos essenciais ao desenvolvimento da metrópole, que era acentuada conforme crescia São Paulo e seus arredores. Aqui permanece a relação de interdependência que marca a capital em relação aos seus subúrbios desde os aldeamentos. Porém, especificamente acerca da interconexão entre as duas unidades territoriais de Carapicuíba no período, emerge pelo estabelecimento de dois frigoríficos, que além de servir a capital e concentrar o rebanho regional, favorece já as fazendas locais, inseridas ao sul do distrito e que passam a se dedicar mais intensivamente a produção pecuária, ou em serviços demandados por esse arranjo econômico.

Como explica Pimentel (2006, p. 31) "a área atualmente ocupada pelo Conjunto Habitacional (COHAB) correspondia ao Sítio da Fazenda Velha (de propriedade de Delphino Cerqueira), conhecido como 'Campo da Boiada', local destino à engorda dos animais". Tenório (2003, p. 91) detalha que o embarcadouro do trem da vila Sylviânia era marcado pelo barulho das máquinas e dos carros de boi. “[...] Em 1921, foi construído um embarcadouro de gados que seguiam para o descanso de 15 por 15, em nove currais, no Campo da Boiada, atual COHAB, de onde eram conduzidos para o abate no Frigorífico Municipal do Km 21.” (TENÓRIO, 2003, p. 91). De fato, praticamente todas as grandes e adensadas unidades territoriais contemporâneas da cidade foram neste período fazendas importantes ao abastecimento de São Paulo, rompendo em grande medida o ostracismo que ficara em fins de oitocentos e princípios do novecentos. Tenório (2003) também evidencia a presença de outras fazendas locais destinadas a abastecer os dois frigoríficos, um de suínos e outro de bovinos, provando o caráter agroindustrial de atividades produtivas, que estavam sendo modernizadas e ampliadas logo que as novas demandas metropolitanas cresciam.

Como o braço escravo, ou do trabalho compulsório do índio exigido junto aos aldeamentos, a atividade de engorda, abate e distribuição de carnes, extremamente necessárias e importantes, apesar das condições degradantes e os impactos que revelam, foram segregadas e estavam localizadas distantes dos centros consumidores. À Carapicuíba não apenas serviu o primeiro propósito, de aldeamento que sustentaria as piores e mais essenciais necessidades de São Paulo, como se reproduziu historicamente essa função, continuando a servir ao polo com outras funções deletérias. Ainda que se argumente no plano cultural a importância da função religiosa e simbólica de seus espaços sagrados e suas festividades, a banalização do caipira, ou do próprio subúrbio, sugere tensões entre os grupos sociais, além do estabelecimento de um conteúdo pejorativo a uma realidade com fortes traços de ruralidade e das tradições, como também um papel pouco nobre nas execuções de atividades econômicas, ainda que essenciais. 
Além dos frigoríficos, outras duas atividades produtivas em Carapicuíba se interpenetram para servir a cidade-polo. A primeira, como anteriormente citada, baseia-se na extração de areia e argila das margens do rio Tietê, bem como de um de seus meandros abandonados que formou o Lago de Carapicuíba. Destacado tanto por Costa Junior (1987), Tenório (2003), como por Pimentel (2006), o porto de areia é outro elemento importante na economia de Carapicuíba em paralelo à expansão industrial de São Paulo. Em segundo plano, a extração alimenta a criação de uma segunda atividade, ligada à transformação destes recursos, como as pequenas olarias e, por fim, a seu armazenamento e comercialização. Conforme este último autor, "comum em diferentes trechos do rio Tietê, a extração de areia era uma atividade necessária ao crescimento urbano de São Paulo.” (PIMENTEL, 2006, p. 71). Como os frigoríficos, a extração de areia é uma atividade extremamente impactante e danosa ao meio. Tenório (2003) destaca uma cratera aberta nas proximidades do atual centro de Carapicuíba, fruto da atividade e que incorreu a um conflito judicial, entre proprietário e arrendador. Mesmo antigas, as atividades de extração dos recursos minerais das margens do Tietê foram constantes, servindo posterior e continuamente a outras atividades ainda menos nobres.

\begin{abstract}
Nesse período, segundo esta pesquisa, Delphino Cerqueira arrenda parte das terras que margeavam o leito do rio Tietê a João Zeferino Ferreira Veloso, que deu início ao processo de exploração do Porto de Areia. Como em diferentes trechos do rio Tietê, as atividades de exploração de areia eram necessárias ao crescimento urbano de São Paulo, e voltadas principalmente para a construção civil. A retirada de cascalho, usado até pouco tempo atrás para o asfaltamento de ruas e avenidas, juntamente com a retirada da areia serão uma fonte comercial importante nessa localidade. Essa atividade mineradora cresce consideravelmente nesse período, valorizando muito esta área, a ponto de a Estrada de Ferro Sorocabana ceder uma cancela para o embarque desse produto, diante da alta demanda [...] (PIMENTEL, 2014, p. 50).
\end{abstract}

$\mathrm{Na}$ tipologia de Langenbuch (1971), uma das mais importantes classificações sistemáticas da estruturação metropolitana de São Paulo, Carapicuíba aparece ora como subúrbio urbano, ou mais especificamente, como "subúrbio-estação" 51 (cuja estação de Sylviânia na Figura 29 é o marco), ou ora em referência à Aldeia como subúrbio rural,

\footnotetext{
51 São os tipos de subúrbios mais numerosos, relacionam-se ao papel das ferrovias em seus territórios e no processo de metropolização. "Surgiam em tôrno de estações ferroviárias. [...] São típicos subúrbios-estação: [...] Suzano, Mauá, Ribeirão Pires, Osasco, Carapicuíba, [...]. Os citados se localizam em redor ou em contacto com a estação, junto a qual se desenvolveu o centro comercial, de maior ou menor expressão." (LANGENBUCH, 1971, p. 262 - grifo nosso).
} 
"subúrbio-ex-vilarejo" " Na Figura 30, o mapa da área edificada da Grande São Paulo e arredores, de 1962 (LANGENBUCH, 1971), permite observar precisamente o adensamento estabelecido no entorno das estações atuais de Carapicuíba e de Santa Terezinha, que se dirige ao sul, pela Avenida Inocêncio Seráfico, até a altura da Aldeia de Carapicuíba. Nele ainda é possível observar diversos núcleos que são formados ao longo das linhas férreas, como também uma malha urbana consolidada e homogênea nos rebordos de São Paulo. E, cujos vetores da urbanização, irradiam do centro da capital para todas as direções.

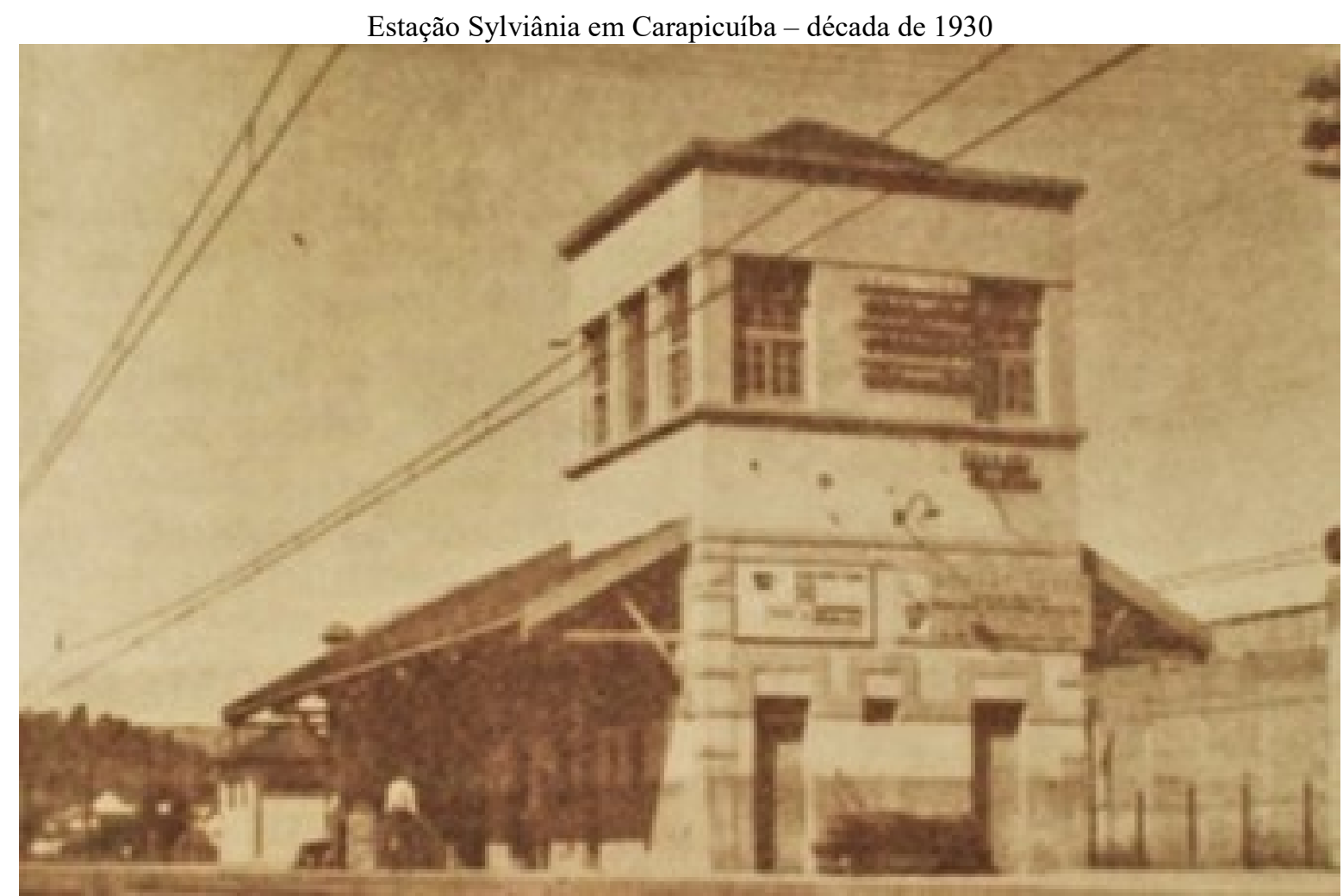

Figura 29: Marco da Formação Histórica e Geográfica de Carapicuíba - Estação Sylviânia. Fonte: Plano Diretor do Município de Carapicuíba, Lei n. 3.074/2011

52 "Trata-se dos núcleos surgidos em volta de pequenos aglomerados rurais, nos quais o modesto equipamento local parece ter exercido papel polarizador. Pudemos distinguir como tais: Piraporinha e Aldeia de Carapicuíba.” (LANGENBUCH, 1971, p. 263 - grifo nosso). 
São Paulo e Arredores em 1962

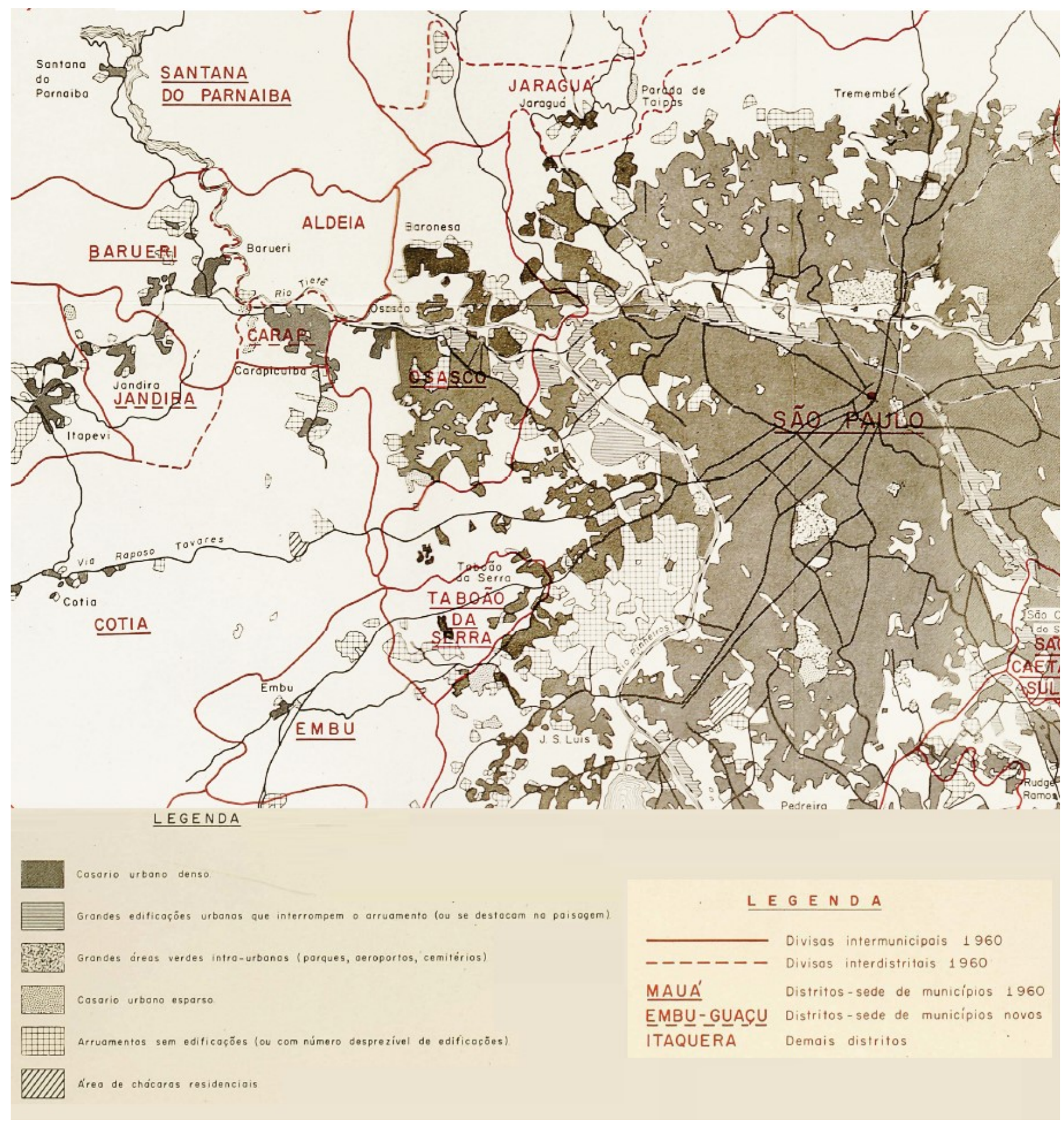

Figura 30: São Paulo e arredores em 1962. Em Carapicuíba se avolumam as edificações à norte, no entorno da EFS e ao longo da Av. Inocêncio Seráfico (antiga estrada da Aldeia), que interliga as estações com a Aldeia de Carapicuíba. Apesar de ter maior densidade e população que Barueri em 1962, Carapicuíba é ainda seu distrito.

Fonte: Langenbuch (1971). Editado pelo autor (segmentação focal da zona oeste), 2016. 
Ainda que distantes, ambos setores de Carapicuíba, tendem a uma articulação rodoviária, que tipifica a fusão posterior da cidade ao longo da estrada hoje chamada Avenida Inocêncio Seráfico, que vai de ponta-a-ponta do município. Langenbuch (1971), ao estabelecer sua tipologia ligada à estruturação metropolitana de São Paulo, considera praticamente todos os núcleos nos arredores da capital. Mesmo não aprofundando especificamente sobre o caso de Carapicuíba, o autor lembra que a Aldeia seria um destes entroncamentos rodoviários que, de certa forma, comandam a aglutinação de novos loteamentos com os subúrbios já criados. No caso, seria justamente naquele período a Avenida Inocêncio Seráfico este canal ou eixo indutor da expansão suburbana concentrada ao norte (novos loteamentos, empresas, comércio e dinâmica urbana conduzida pela linha férrea da EFS) em relação ao sul, cujo limite era a Aldeia e onde localizavam-se os pontos de ônibus. Junto a esses nódulos pretéritos e vias, integram-se novos loteamentos e moradores. A Aldeia e os pontos rodoviários em seu entorno unificavam toda a área pelas estações, ou outros terminais rodoviários em Cotia, Barueri, e Osasco. Essa realidade pode ser observada na Figura 31, em outro dos mapas da obra "Estruturação da Grande São Paulo" (LANGENBUCH, 1971), quando o autor identifica e traça um fluxo de ônibus dos principais núcleos metropolitanos de São Paulo. Junto a expansão centrífuga de São Paulo, houve a proliferação de núcleos suburbanos, majoritariamente associados aos "subúrbios-estação". Estes novos núcleos, mais interligados à São Paulo, ou outras localidades tornadas agora mais dinâmicas com a presença das linhas férreas, fizeram com que pequenas vilas ou aglomerados se tornassem distritos de outros municípios, recém-criados ou não. O caso de Carapicuíba é emblemático na cristalização de condição suburbana, pois mesmo já havendo o núcleo da Aldeia, este se desenvolve em razão do novo núcleo servido pela ferrovia. Portanto, a sua suburbanização tem basicamente estes dois movimentos, um gerador e outro dinamizador, que integrados posteriormente darão uma qualidade municipal ao território, emancipado, porém interdependente historicamente de São Paulo. Se os benefícios da emancipação são concretos, contraditoriamente, o papel funcional deste subúrbio em especial reservará graves problemas pela explosão demográfica posterior, bem como da estagnação econômica que se verifica pela ausência de indústrias e sua condição de subúrbio-residencial ou dormitório ${ }^{53}$.

\footnotetext{
${ }^{53}$ Fluxo pendular de pessoas, que trabalham nas cidades vizinhas durante o dia e retornam ao fim da noite.
} 
183

Arredores de São Paulo - Ônibus Suburbanos Intermunicipais - 1965

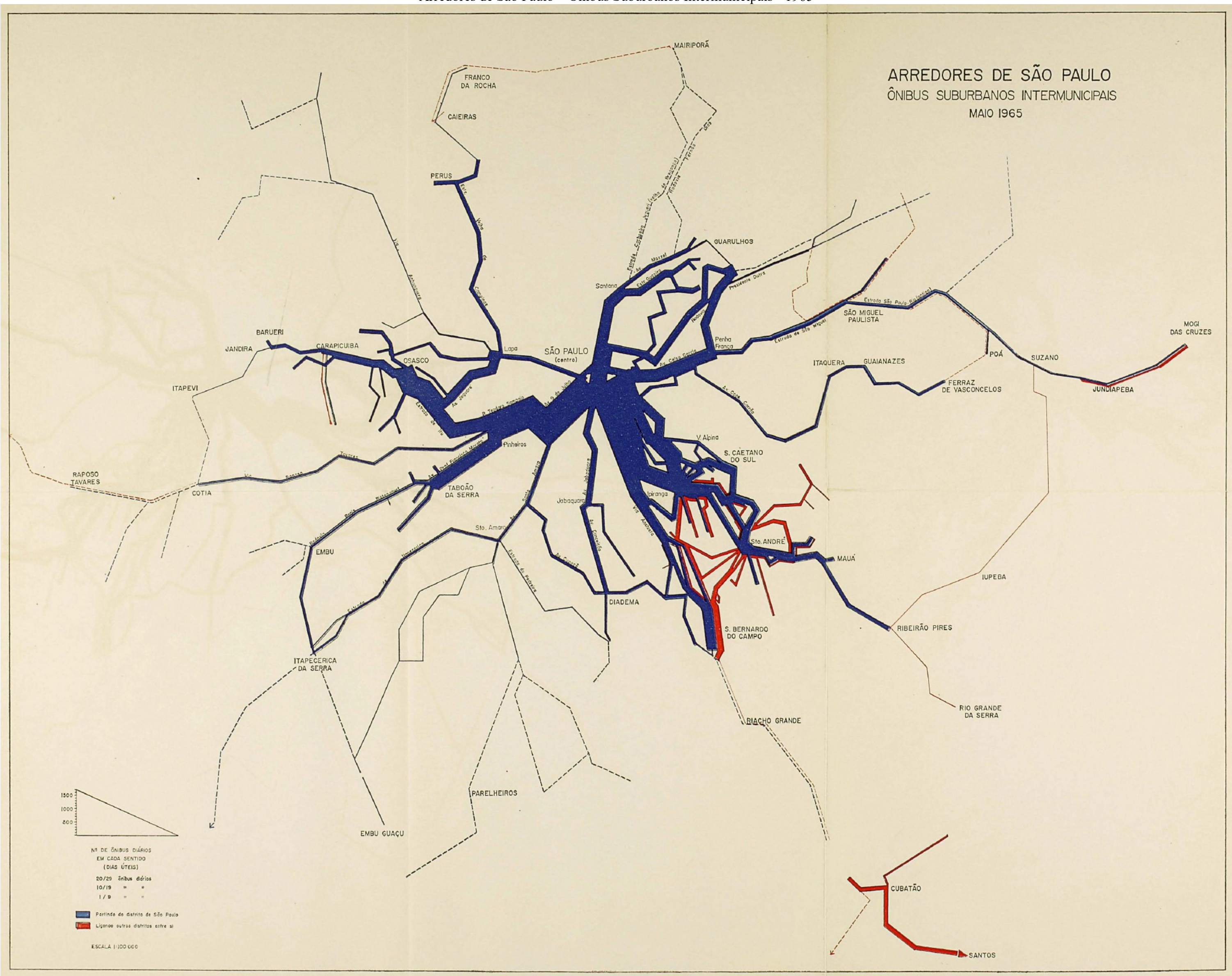

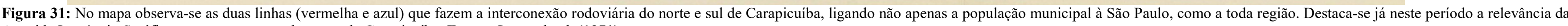
Avenida Inocêncio Seráfico entre os setores sul e norte de Carapicuíba. Fonte: Langenbuch (1971). 
No caso de Carapicuíba, desmembra-se de Cotia em 1948, tornando-se distrito do recém-criado município de Barueri, ficando nesta condição por 16 anos, até o desmembramento de Barueri, emancipação em 1964 e criação do município em 1965. A separação inicial de Cotia em favor de Barueri revela a polarização que já havia em favor de São Paulo, dada pela estação ferroviária presente em Barueri desde 1875, três anos após a fundação da EFS. Quando da efetiva emancipação de Carapicuíba, em 1964, a cidade já possuía duas estações ${ }^{54}$, uma aglomeração consolidada e o papel caracteristicamente suburbano, funcionando como núcleo dormitório, ou subúrbio residencial para expressar os termos usados por Langenbuch (1971). "Por abrigar uma população que trabalhava em outros municípios da Grande São Paulo, convencionou-se por caracterizá-la como "cidade-dormitório"” (CARAPICUÍBA, 2012, p. 12). Ainda que assim classificada, no setor econômico, as atividades industriais na região de Carapicuíba emergem desde a década de 1920, com a criação da fábrica de fiação em 1925, denominada Fiação Sul-Americana ${ }^{55}$ (TENÓRIO, 2003; PIMENTEL, 2014).

A emancipação de Carapicuíba na década de 1960, é outro fato comum do processo de suburbanização metropolitana ligada a São Paulo. O aglomerado-polo expande, afetando diretamente os pequenos nódulos populacionais no entorno da capital, cujo raio de influência é ampliado para o interior, além mesmo do Planalto Paulistano. Não se trata apenas de uma mancha efusiva que avança do centro para a periferia, mas de polinucleamentos, que incorporados aos sistemas modernos de transportes e infraestruturas, crescem juntando-se progressivamente numa conurbação complexa. Metrópole que em princípios da década de 1960 já ultrapassa os 5 milhões de habitantes, alcançando população em 1970 superior a 8 milhões, ultrapassando recentemente 20 milhões de habitantes conforme dados organizados na tabela 03 .

\footnotetext{
54 Outra questão importante do processo de metropolização que incorpora definitivamente Carapicuíba à São Paulo, reside precisamente no fato de haver a ampliação em mais uma estação de trem na cidade em 1951, quando a maioria dos municípios do interior do estado, a partir de 1940, perdiam gradativamente os trilhos e estações em favor do novo modal de transporte, estabelecido pelas rodovias e estradas. Isso caracteriza Carapicuíba já totalmente à capital, que nos idos dos anos 1970 seria normativamente incorporada à Grande São Paulo.

55 “A industrialização da cidade é marcada no ano de 1925, com a presença dos imigrantes, quando Alberto Kenworthy funda a Sociedade Anônima Indústrias Kenworthy, sucedida pela Fiação Sul Americana, que funcionava no $\mathrm{km} 25$ da Estrada Velha de Itu. Entretanto, aquela foi a primeira indústria de grande porte da cidade e não se situava em Carapicuíba. Hoje, em decorrência da criação do Município Carapicuíba, Barueri perdeu a extensão territorial, e a Vila Lourdes, da qual fazia parte a Vila Sul Americana, torna-se parte da cidade.” (PIMENTEL, 2014, p. 52).
} 


\begin{tabular}{|c|c|c|c|c|c|c|c|c|}
\hline \multirow[b]{2}{*}{ Anos } & \multicolumn{2}{|c|}{ Município de São Paulo } & \multicolumn{2}{|c|}{ Região Metropolitana de São Paulo } & \multicolumn{2}{|c|}{ Estado de São Paulo } & \multicolumn{2}{|c|}{ Brasil } \\
\hline & População & $\begin{array}{c}\text { Taxa de } \\
\text { Crescimento } \\
\text { Geométrico } \\
\text { Anual }\end{array}$ & População & $\begin{array}{c}\text { Taxa de } \\
\text { Crescimento } \\
\text { Geométrico } \\
\text { Anual }\end{array}$ & População & $\begin{array}{c}\text { Taxa de } \\
\text { Crescimento } \\
\text { Geométrico } \\
\text { Anual }\end{array}$ & População & $\begin{array}{c}\text { Taxa de } \\
\text { Crescimento } \\
\text { Geométrico } \\
\text { Anual }\end{array}$ \\
\hline \multirow[t]{2}{*}{1872} & 31.385 & & - & & 837.354 & & 10.112 .061 & \\
\hline & & 4,1 & & - & & 2,8 & & 2,0 \\
\hline \multirow[t]{2}{*}{1890} & 64.934 & & - & & 1.384 .753 & & 14.333 .915 & \\
\hline & & 14,0 & & - & & 5,1 & & 1,9 \\
\hline \multirow{2}{*}{1900} & 239.820 & & - & & 2.282 .279 & & 17.318 .556 & \\
\hline & & 4,5 & & - & & 3,6 & & 2,9 \\
\hline \multirow[t]{2}{*}{1920} & 579.033 & & - & & 4.592 .188 & & 30.635 .605 & \\
\hline & & 4,2 & & - & & 2,3 & & 1,5 \\
\hline 1940 & 1.326 .261 & & 1.568 .045 & & 7.180 .316 & & 41.236 .315 & \\
\hline \multirow[t]{2}{*}{1950} & 2.198 .096 & & 2.622 .786 & & 9.134 .423 & & 51.944 .397 & \\
\hline & & 5,6 & & 6,1 & & 3,6 & & 3,1 \\
\hline \multirow[t]{2}{*}{1960} & 3.781 .446 & & 4.739 .406 & & 12.974 .699 & & 70.119 .071 & \\
\hline & & 4,6 & & 5,6 & & 3,2 & & 2,9 \\
\hline \multirow[t]{2}{*}{1970} & 5.924 .615 & & 8.139 .730 & & 17.771 .948 & & 93.139 .037 & \\
\hline & & 3,7 & & 4,5 & & 3,5 & & 2,5 \\
\hline \multirow[t]{2}{*}{1980} & 8.493 .226 & & 12.575 .655 & & 25.040 .712 & & 119.002 .706 & \\
\hline & & 1,2 & & 1,9 & & 2,1 & & 1,9 \\
\hline \multirow[t]{2}{*}{1991} & 9.646 .185 & & 15.444 .941 & & 31.588 .925 & & 146.825 .475 & \\
\hline & & 0,9 & & 1,6 & & 1,8 & & 1,6 \\
\hline \multirow[t]{2}{*}{2000} & 10.434 .252 & & 17.878 .703 & & 37.032 .403 & & 169.799 .170 & \\
\hline & & 0,8 & & 1,0 & & 1,1 & & 1,2 \\
\hline 2010 & 11.253 .503 & & 19.683 .975 & & 41.262 .799 & & 190.755 .799 & \\
\hline
\end{tabular}

Tabela 03: Evolução da população e taxa de crescimento geométrico anual da cidade de São Paulo, RMSP e estado de São Paulo. Fonte: Secretaria de Desenvolvimento Urbano de São Paulo. 
Nesta mesma tabela ainda é possível observar que a média da taxa de crescimento geométrico decenal, entre 1950 e 1960, ultrapassa 6\% na RMSP, enquanto 5\% no município de São Paulo. Índices superiores ao do estado de São Paulo e quase três vezes maiores que o restante do Brasil. Mais do que crescer e concentrar, as metrópoles sofrem mudanças qualitativas, o que para Santos (2013b) a urbanização ganharia novos conteúdos e dinâmica, condicionados pelas modernizações do território que explicam esta nova situação. No caso da RMSP, Scarlato (2014) explica que o crescimento do seu espaço urbano passa de $130 \mathrm{~km}^{2}$ em 1940 para $420 \mathrm{~km}^{2}$ em 1954, se expandindo radialmente e integrado a um complexo sistema de transporte ferroviário e rodoviário. Ainda que em menor expressividade na concentração industrial que outras vias, a zona oeste neste período, servida pela antiga Sorocabana e a rodovia Raposo Tavares, constituem um importante sistema concentrador da produção, interligando antigos núcleos nos arredores de São Paulo, como também o interior do estado. Este sistema torna-se ainda mais pujante e completo com a contínua reestruturação das vias arteriais, grandes avenidas e, sobretudo, na década de 1970 com a construção da rodovia Castelo Branco (o acesso direto a esta rodovia em Carapicuíba, no entanto, levaria alguns anos após sua inauguração). "A estrutura radial concêntrica do plano de São Paulo, integrada a todo esse complexo sistema de transporte rodoviário/ferroviário, centro polarizador de uma vasta rede urbana, gerou uma verdadeira 'implosão' dos seus espaços interiores." (SCARLATO, 2014, p. 446).

Agrupados em seis unidades por Langenbuch (1971), Carapicuíba seria justamente um dos municípios com mais acentuado crescimento demográfico, quando regionalizado o município junto a Barueri e Aldeia, chegariam a um percentual de $1002 \%$ de crescimento entre 1940 e 1960. Reside neste processo uma polarização importante estabelecido pela ferrovia, mas que não necessariamente acompanha o desenvolvimento suburbano gerado por ela. A atração das estações nem sempre proporciona condições favoráveis de habitação e transporte. Sendo que a circulação rodoviária complementa o processo, realizando a ponte dos bairros mais afastados, os núcleos antigos, com as estações ferroviárias, ou estações rodoviárias com hierarquia superior (LANGENBUCH, 1971, p. 258).

A suntuosidade da concentração populacional, convergindo ao fenômeno da macrocefalia urbana, pode ser observada quando na década de 1970 praticamente metade da população do estado de São Paulo se concentra na região metropolitana 
correlata. Concentração e centralidade se confundem na RMSP, num caldeirão econômico, de intensa industrialização e mescla cultural entre modos de viver trazidos pelos estrangeiros e grupos regionais vindos de todo território brasileiro, sobretudo do Nordeste. Sendo contraditório, à primeira vista, que ao mesmo tempo em que as cidades se integram geograficamente estas se fragmentam político-administrativamente. Conforme Langenbuch (1971, p. 232), “em certo sentido a pulverização políticoadministrativa dos arredores paulistanos constitui um paradoxo, pois o processo se verifica exatamente quando se aceleram as fusões territoriais entre alguns núcleos suburbanos, e aumentavam as relações entre outros.”. Este parcelamento suburbano é verificado com certa intensidade desde 1940, quando a Grande São Paulo possuía 10 municípios, passando em 1950 a 17 municípios, em 1960 com 30 unidades e, por fim, em 1670 com 36, inclusive Carapicuíba (LANGEBUCH, 1971).

Ainda no período que antecede a emancipação de Carapicuíba, Costa Junior (1987) destaca o desenvolvimento da Vila Sylviânia, com os loteamentos e onde continuamente haviam construções, "nos altos dos morros aparecem as igrejas que pouco a pouco esta velha Carapicuíba foi tomando ares de Cidade." (COSTA JUNIOR, 1987, p. 05). O mapa da Figura 30 anterior evidencia em 1962 uma densidade elevada de casas nesta área em especial, ultrapassando inclusive os arredores da Aldeia, que torna-se neste prospecto, um subcentro de Carapicuíba. Também a figura 31, com o mapa mostrando a densidade de fluxo cada vez maior entre Carapicuíba e São Paulo, além das cidades regionais vizinhas. Ainda conforme o autor supracitado, em 1950 a população de Carapicuíba era de aproximadamente 7 mil habitantes, somados os moradores da Aldeia. Em uma década, em 1960, esse valor aumenta para 17 mil habitantes (COSTA JUNIOR, 1987), crescimento, pois, de 242\%, quando em 1970 chega a 54.873 habitantes (IBGE, 2016), passando em pouco mais de duas décadas a um aumento populacional de mais de $783 \%$. População que em princípios do século manteve-se isolada, predominante caipira, passa a ter forte presença do imigrante europeu, com o desenvolvimento de diversas atividades agrícolas no território. Como decorre em muitos subúrbios paulistanos, houve a chegada dos imigrantes, que além dos italianos e japoneses (CONDEPHAAT, 1981), cabe destacar os árabes, russos, húngaros, alemães e portugueses ${ }^{56}$. Após cessar a vinda dos imigrantes, com o fim da

\footnotetext{
56 Além da influência cultural como um todo, sobretudo em relação aos traços mais urbanos dessas populações, a marca dos novos habitantes (imigrantes) está materialmente gravada em toda cidade de
} 
Segunda Guerra Mundial, intensifica-se a vinda de migrantes brasileiros de diversas regiões, sobretudo Nordeste. Conforme Pimentel (2006, p. 37), "além dos piauienses, a cidade abrigou cearenses, pernambucanos, baianos, entre tantos outros nordestinos, e também muitos mineiros e paranaenses.". Dos novos habitantes, conforme explica Costa Junior (1993, p. 07), vem gente de todo lugar em busca de pequenos lotes de terra, ou para residir posteriormente nos conjuntos habitacionais, armando barracos em áreas devolutas, ou ocupando terrenos baldios. Com a cidade se expandindo para todo lado, emergem "[...] habitações as mais diversas, impossível de se imaginar, cobrindo morros e baixadas, várzeas e beiras de córregos e os bairros, as 'vilas' ou 'jardins' se esparramaram abrangendo quase todo o território municipal que não tem zona rural, tem apenas zona urbana.” (COSTA JUNIOR, 1993, p. 07).

\footnotetext{
Gradualmente, imigrantes estrangeiros (italianos, japoneses e outros) e depois migrantes do Estado de São Paulo e de outros Estados estabeleceram-se na região, tornando minoria os paulistas da própria área. Passam então a predominar os sítios de produção hortifrutigranjeira que a partir da década de cinquenta são absorvidos no processo de industrialização. Mais recentemente a área, em torno da Aldeia, vem sendo transformada pela exploração imobiliária, com o estabelecimento de chácaras residenciais e industriais. Ainda que cercada pela urbanização desenfreada, a Aldeia de Carapicuíba se mantém com seu rico folclore e como patrimônio cultural de indiscutível favor (CONDEPHAAT, 1981).
}

No que tange essa "manutenção" da Aldeia, deve-se realizar um paralelo da passagem de sua condição de bem patrimonial para o monumento institucionalizado. Tal condição é deduzida dos conflitos que permeiam a intervenção do SPHAN naquele espaço em relação à população que ali vivia há muitos anos e sem ter necessariamente a dimensão da "relevância" histórica e artística para a memória nacional. Aparentemente, o valor que havia ligava-se a memória coletiva, em razão das tradições religiosas e da centralidade que havia para aquela comunidade (ponto de ônibus, escola, igreja, festividades). Com o ato de tombamento em 1940 esses modos de viver foram radicalmente alterados, simultaneamente ao processo de urbanização-metropolização do território. A patrimonialização resulta dessa "consciência urbana", criação moderna e institucionalizada de uma nova brasilidade, na qual a Aldeia ganhava representatividade. 
O reconhecimento institucional da Aldeia de Carapicuíba deriva de levantamentos realizados em anos posteriores, tantos pelos estudos de Saia $(1937)^{57}$, que precedem o tombamento junto ao levantamento técnico do SPHAN $^{58}$ em 1938, quanto posteriormente pelas equipes do $4^{\circ}$ Departamento do Patrimônio Histórico e Artístico Nacional (4 $4^{\mathrm{o}}$ DPHAN/SP $)^{59}$, atual $9^{\mathrm{a}}$ Superintendência Regional do IPHAN (9 SRIPHAN/SP). Nesta fase, pós-tombamento, já é possível a observação direta de levantamentos detalhados e diretrizes para a preservação do conjunto urbanístico. Uma das notas técnicas mais antigas encontradas, provavelmente da década de $1950^{60}$, evidencia que do seu aspecto primitivo conservaria apenas a estrutura retangular no qual se organizam as casas e igreja. Por isso, segundo ainda a nota do $4^{\circ} \mathrm{DPHAN} / \mathrm{SP}$ ressalta "[...] pura e simplesmente o seu aspecto externo melhorando os elementos encontrados", dos quais está destacado o telhado, portas, janelas e calçamentos. Detalhe importante em outra das notas na mesma pasta supracitada reside no entendimento da Aldeia como monumento jesuítico e colonial, justificando não apenas seu tombamento e a preservação, mas também uma concepção unitária, fragmentada e sintomática dos valores visuais, estéticos e arquitetônicos do conjunto.

Percebe-se, além disso, que os documentos mais primitivos do SPHAN encontrados no arquivo, refletem problemáticas e conflitos verificados com a modernização da Aldeia. Essas tensões derivam de diversas instâncias, sendo importante salientá-las, pois ainda persistem, com será detalhado mais adiante: em primeiro plano a dificuldade com os moradores locais, pois o tombamento e as orientações futuras tornavam-se um entrave ao acesso de serviços e intervenções necessárias às habitações; em segundo, a municipalidade, executando obras e bem-

\footnotetext{
${ }^{57}$ Documento integral obtido no Arquivo da $9^{\text {a }}$ SR - IPHAN/SP - Pasta 00073-0218-T-39-10/11(4).

58 O Serviço do Patrimônio Histórico e Artístico nacional (SPHAN), criado em 1937, passa em 1946 a denominar-se Departamento do Patrimônio Histórico e Artístico Nacional (DPHAN). Em 1970 o DPHAN se transforma no atual Instituto do Patrimônio Histórico e Artístico Nacional (IPHAN). As referências são, pois, diferentes em cada período, respeitando as denominações de cada contexto.

${ }^{59}$ Em 1946 o SPHAN passa a ser denominado de Departamento do Patrimônio Histórico e Artístico Nacional (DPHAN). Em 1970 o DPHAN se transforma em Instituto do Patrimônio Histórico e Artístico Nacional (IPHAN). Em 1990 é extinto o Minc, também o SPHAN/IPHAN e a Fundação Nacional Pró-Memória (FNPM), com a criação do Instituto Brasileiro do Patrimônio Cultural (IBPC), instituição que fícou responsável pelo patrimônio cultural até 1994, voltando então a ser IPHAN.

${ }^{60}$ Nota sem data, presume-se pelo conjunto de documentos da Pasta levantada que seja da década de 1950. Documento integral obtido no Arquivo do IPHAN/SP - Pasta 00064-0218-T-39-1/11. Conjunto Arquitetônico e Urbanístico (Tombamento).
} 
feitorias na área fora das conformidades técnicas e arquitetônicas do conjunto; em terceiro, das empresas privadas e públicas de transporte, iluminação, telefonia, visando munir a área com seus serviços e descaracterizando paisagisticamente o "monumento". Outra manifestação de contrariedade do órgão revela-se em relação ao desvio da estrada que passava pela área interna da Aldeia, que estava não apenas em desacordo com os moradores que ali tomavam o ônibus, mas também com o departamento de trânsito que visava atender o fluxo e mobilidade nesta área. Por fim, saliente nos arquivos e registros é o caso da iluminação pública da Aldeia. Primeiro pela instalação de postes, fiação e lâmpadas, em fins de dos anos 1960, logo depois pela retirada empreendida em 1971 conforme orientação do SPHAN, mas em desacordo com a municipalidade, os moradores e a empresa de energia.

Neste momento inicial, que inicia a década de 1940, subentende-se tão somente pelos ofícios, termos, notas e correspondências, uma ação efetiva do $4^{\circ}$ DPHAN na Aldeia de Carapicuíba. Trabalho pioneiro do órgão, que ao longo desta década já demonstra apreensão dos moradores acerca de seu papel institucional, como da condição de mudança das propriedades ao se tornarem patrimônio da União, bem como da vida cotidiana da população ali inserida. Entende-se que pois mais vertical e absoluta que fossem as decisões, orientações e intervenções do SPHAN na área, isto fez com que os moradores desde cedo percebessem o espaço diferenciado que residiam ou conviviam. Para referenciar alguns casos relevantes desta compreensão pelos moradores, cita-se o pedido de Sebastião P. da Silva, em 28 de junho de 1943, tendo a necessidade de reformar sua casa, como em vinte de março de 1945 o morador Francisco M. de Camargo também solicita ao $4^{\circ}$ DPHAN reforma de uma das paredes da casa do finado Virgílio O. de Jesus. Outros documentos compreendidos entre 1942 e 1950 revelam uma exaustiva quantidade de pedidos por reformas e feitorias ${ }^{61}$, as quais, algumas, o DPHAN demorava em torno de até cinco anos de avaliação e emissão da autorização. Disso reside um descontentamento histórico com o órgão, como se presume pelo tempo, mas também ao registrar as entrevistas de antigos moradores ou em livros como o de Henne (2015).

\footnotetext{
61 A documentação completa está disposta atualmente na $9^{a}$ Superintendência Regional do IPHAN/SP. Arquivo: Pasta 00064-0218-T-39-3/11(1) (2) (3). Conjunto Arquitetônico e Urbanístico (Intervenção em Bens Imóveis Tombados).
} 
Avolumam-se na década de 1950 orçamentos e notas discriminadas para reformas do conjunto da Aldeia, além de especificamente das casas 01, 11, 13 (Figura 32), entre outras, que conforme levantamentos realizados, estavam em situação de precariedade e foram cirurgicamente reconstruídas. Se a dimensão pública esboçada pela patrimonialização da Aldeia, na primeira década após seu tombamento, trouxe a apreensão dos moradores que alterar imóveis ou agir sem permissão na propriedade lhes traria gravames, parece que na segunda década o abandono foi resultado direto das dificuldades que o órgão possuía em manter aquele espaço, considerando que o poder público mais que fiscalizar ou "dificultar" a sua preservação, deveria também subsidiar as intervenções necessárias. Disso resulta um conjunto de ações ao longo da década de 1950 na Aldeia de Carapicuíba, tanto no conjunto, como nas casa em particular. Esse momento embasa a proposição de uma possível mudança de comportamento dos moradores e do próprio órgão de preservação frente à gestão dos bens patrimonializados, que de fato, até o fim da década de 1940, intervenções e ações de conservação e preservação parecem estar restritas aos habitantes, do que propriamente das instituições públicas. Concluindo que a década de 1950, em decorrência do volume de ofícios, notas e projetos planejados e executados na Aldeia, indica o papel mais presente e central $^{62}$ do DPHAN em operações estruturais e efetivas do conjunto no sentido de manter efetivamente os bens em meio as tensões já mencionadas anteriormente (Figura 32).

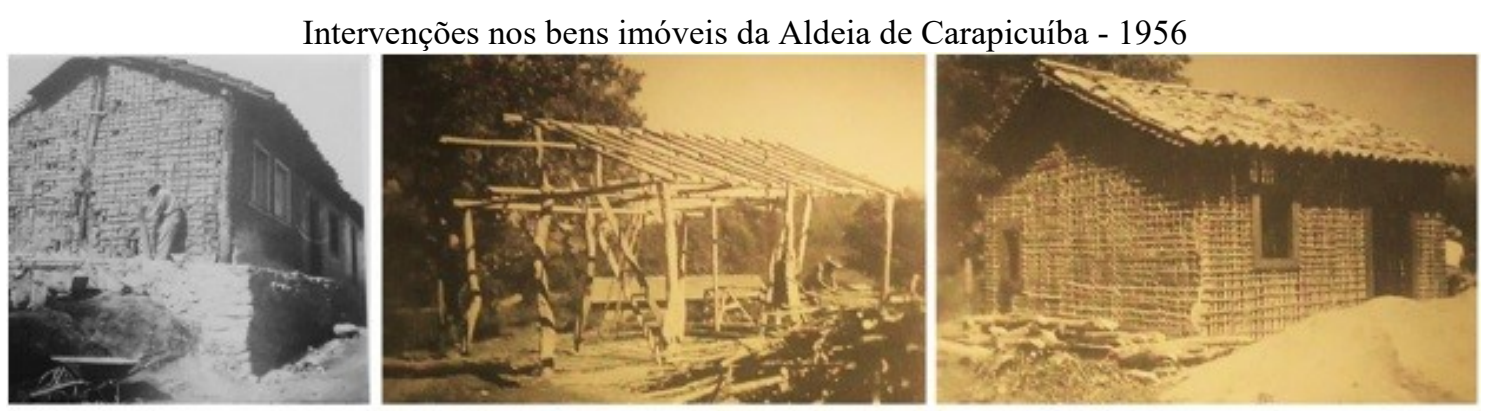

Figura 32: Fotos de 1956 revelam intervenções contínuas de preservação da Aldeia de Carapicuíba, inclusive de reconstrução da casa 01 ao centro e direita e da parede lateral na casa 13 à esquerda.

Fonte: Fotos de Germano Graeser, obtida em Andrade (2006). Organizadas e editadas pelo autor, 2016.

\footnotetext{
62 "No século XIX se consolidaram dois modelos de política de preservação: o modelo anglo-saxônico, com o apoio de associações civis, voltado para o culto ao passado e para a valorização ético-estética dos monumentos, e o modelo francês, estatal e centralizador, que se desenvolveu em tono da noção de patrimônio, de forma planificada e regulamentada, visando ao atendimento de interesses políticos do Estado. Esse último modelo predominou entre os países europeus, e foi exportado, na primeira metade do século XX, para países da América Latina, como o Brasil e Argentina, e, após a Segunda Guerra Mundial, para as ex-colônias francesas.” (FONSECA, 1997, pp. 62-63 - grifo nosso).
} 
As diretrizes de intervenção no conjunto parecem acompanhar compassadamente o contexto brasileiro da política patrimonial no período. Esforçam-se na criação e posterior manutenção de símbolos nacionais, calcados em conjuntos arquitetônicos e obras específicas de valor singular. Estes símbolos são permeados pelo conceito de arte que, na prática, remete os bens culturais a um passado colonial, de instituições e grupos hegemônicos, caracteristicamente materiais, ou de "pedra e cal". Quando da emergência de elementos tipicamente populares, passavam rapidamente a carregar narrativas heroicas e fatuais ligadas às mesmas classes dirigentes. Portanto, bens culturais que levam em verdade um valor histórico, porém unidirecional, material e carregado ideologicamente. Se monumento e patrimônio diferenciavam-se em teoria, na prática eles tornavam-se uma coisa só. Como destaca Rubino (1996, p. 105) "ao retirar igrejas, casas e pontes do anonimato, o SPHAN conferiu ao país não apenas um passado, mas sobretudo seu passado". Nesta fase inicial da política patrimonial, como explica Malhano (2002), “[...] a proteção dos monumentos e de prédios históricos representa a preservação do passado que, efetiva e subjetivamente, reforçam". No caso de São Paulo, os tombamentos, como prática central da política patrimonial brasileira, nos primeiros anos do SPHAN, acabaram justamente por privilegiarem as casas bandeirantes e igrejas jesuíticas, dos quais, sem dúvida, Carapicuíba teve destacada importância. Criticamente, Rubino (1996) mostra que essa construção do passado brasileiro pela política patrimonial no período apagou grande parte do potencial que São Paulo expressava, relegando-a na marginalidade do patrimônio nacional.

\footnotetext{
A inexistência do século XX paulista apaga os rastros das massas de imigrantes que substituíram a mão-de-obra escrava nas fazendas de café. $\mathrm{O}$ ciclo econômico que prosperou na Primeira República é esquecido e, junto com ele, paradoxalmente, a intensa experiência urbano-industrial que permitiu a capital paulista abrigar um movimento de arte moderna, que uma vez rotinizado, está na história anterior da própria política cultural brasileira. A proposta de Mario de Andrade estava vinculada aos desafios que a cidade de São Paulo não cessava de lançar, e à sua experiência cosmopolita de intelectual polivalente. No estado de Mario de Andrade, o que se preservou não foi a 'pauliceia desvairada'. Nesse estado separatista, que nunca foi corte e tampouco teve riquezas coloniais, o SPHAN só poderia ter olhos para usando um termo ressentido do próprio Mario de Andrade - toscas casas bandeiristas e capelas jesuíticas (RUBINO, 1996, p. 102).
}

Os documentos na $9^{\mathrm{a}}$. SRIPHAN/SP revelam justamente a preocupação em ordenar o conjunto segundo padrões construtivos originais, restaurações e 
dimensionamentos técnicos para a preservação das casas, ou da estrutura do vilarejo. Observa-se, de certa maneira, interessante avanço sobre o valor histórico dos bens e o tratamento quase sempre do conjunto da Aldeia e dos blocos de casas que a compõem. No entanto, ainda nesta primeira fase, o avanço é limitado em relação ao restante da cidade, gerando dois núcleos ou centros, ainda que estes estivessem relativamente articulados e cada vez mais integrados com São Paulo no processo de metropolização. $\mathrm{Na}$ verdade, umas das principais caraterísticas do tombamento, a partir da monumentalização do conjunto da Aldeia de Carapicuíba, perpassa os esforços de sua individualização, orientando mesmo a reestruturação das vias rodoviárias locais para que os fluxos de veículos, cada vez mais intensos, não impactasse os bens, restringindo outras modernizações que com o tempo foram se desenvolvendo paralelamente à preservação.

$\mathrm{Na}$ década de 1960, as transformações decorrentes da metropolização de Carapicuíba traz à tona sérios problemas com as ocupações irregulares no entorno da Aldeia. As melhorias de infraestrutura disponíveis e requeridas pela população passaram a ir de encontro com as de conservação e preservação dos bens. Não apenas na Aldeia, mas nos bairros adjacentes e que determinadas ações visando a preservação lhes afetava diretamente, como mudanças das vias, ou a passagem de cabos da rede elétrica ou postes. No conjunto, diversas notificações, na forma de ofício, tanto do $4^{\circ}$ DPHAN, quanto da Procuradoria do Estado de São Paulo e Delegacia do Serviço do Patrimônio da União emergem na década solicitando remoções e impedindo intervenções pontuais sobre as casas, fachadas, portas, ou janelas. Estas ações se estendem nas décadas seguintes, com subsequente adensamento.

Por fim, cristaliza-se o subúrbio em Carapicuíba, integrado plenamente a São Paulo, emancipando-se em um dos muitos municípios da Grande São Paulo. Dessa construção política e administrativa, no processo urbano, deriva ainda o tombamento e a criação do espaço normatizado da Aldeia de Carapicuíba, para além do planejamento e a gestão do município. O que reverbera na supressão daquilo tudo que simplesmente não foi eleito uma singularidade capaz de preservar ou digno de exemplificar a brasilidade em construção. Essa supressão, no entanto, não é plenamente operada e algumas tradições, como as festividades religiosas e profanas de Santa Cruz, continuam a ser realizadas e a perpetuar antigos costumes locais. A passagem para a década de 1970 marcará uma nova fase do mesmo movimento, que tenciona o rural pelo urbano aos 
limites, onde se estabelecerá os conjuntos habitacionais e concretizará institucionalmente a metrópole de São Paulo.

Em Carapicuíba, grande impulso populacional também é verificado na década de 1970, com a instalação dos conjuntos habitacionais promovidos por políticas intergovernamentais entre a federação, o estado de São Paulo e os municípios organizados na RMSP. Nesta fase, a renda da terra será mais dinamizada, convertendose num grande negócio o empreendimento imobiliário nos subúrbios paulistanos. Elemento que, em Carapicuíba, terá a profusão indutiva da metropolização paulistana sentido oeste e que marcará a plena conurbação da mancha urbana entre São Paulo, Osasco e Carapicuíba, para além dos arredores das linhas férreas, como também, transformará a cidade numa das mais adensadas periferias metropolitanas de São Paulo. Se a metropolização de São Paulo é acompanhada pela autonomia política dos municípios, via emancipação e desmembramento dos territórios das unidades maiores, os problemas agravados pela precariedade ou ausência dos serviços públicos tornaramse outra face do processo. Em princípios da década de 1970, com crescimento da população entre 1940 e 1960 de mais de 364\% para a RMSP e, especialmente, no trecho entre Barueri e Carapicuíba de mais de 1000\%, o processo de periferização se acentua, cujo vetor de deslocamento se estabeleceria junto a alternativa de construção dos conjuntos habitacionais nos limites dos subúrbios. Neste momento, "o sistema ferroviário, obsoleto e abandonado pelo poder público, sem investimentos modernizadores, permanece [...] como elo entre a cidade de São Paulo e as periferias pobres e distantes [...]” (MEYER; GROSTEIN; BIDERMAN, 2013, p. 41).

Na década de 1970, era comum vermos caminhões apinhados de móveis, sacos e malas, que descarregavam em Carapicuíba. Era uma verdadeira avalanche de pessoas provenientes das migrações brasileiras, atraídas pela industrialização de São Paulo, e como na Capital não encontravam a facilidade de acomodação, procuravam a periferia da cidade, os subúrbios, e os apartamentos da Cohab que lhes propiciavam o acolhimento e segurança (TENÓRIO, 2003, p. 188).

Como evidencia o Gráfico 03, Carapicuíba, que até 1950 possuía 7 mil habitantes passa em 1970 para mais de 54 mil, chegando em 1980 a uma população total de 185.822 citadinos. A RMSP, como um todo, passa neste período de uma 
população de 2.696.031 para 8.172.542. A relação estabelecida entre Carapicuíba e São Paulo pelas linhas férreas continua a ser importante, mas a posição de Osasco deve ser destacada. Não apenas no que tange às dimensões do trabalho operariado nas firmas ali presentes, nem somente na diversidade comercial que apresentava, mas no próprio nascer, já que Carapicuíba não possuía até pouco tempo uma maternidade. A ausência de bancos, comércio, administração pública, educação, praticamente tudo antes da emancipação concentrava-se nos municípios vizinhos, ou em São Paulo. Carapicuíba integra um "eixo de urbanização em colar" (LANGENBUCH, 1971), dinamicamente ligada à cidade-polo da metrópole ${ }^{63}$, chegava a 1970 permeada pela precarização que a assinalaria na passagem veloz de um subúrbio cristalizado, para uma periferia dramática do subdesenvolvimento pós-colonial. Não foram poucos os momentos das entrevistas realizadas em que a precariedade do território emergia nas mais emocionadas experiências de (sobre)viver nos arredores de São Paulo, como a passagem seguinte.

Chegava no ponto de ônibus e tinha que levar uma sacolinha com o sapato dentro da sacolinha e deixar outro escondido, era tanto mato que você achava que tinha o privilégio de deixar o sapato escondido no mato e pegar depois. [...] Minha mãe era assim, ela tinha um sapato pra ir trabalhar porque ela trabalhava no Hospital Brigadeiro em São Paulo né e outro sapato para chegar porque era amassar barro, mas isso que eu tô dizendo é no centro, tipo assim, tem uma avenida que quem mora aqui há muitos anos conhece que e a avenida Sandra Maria, a rua né no caso essa Sandra Maria pra você ter uma ideia ela sai no Toufic ${ }^{64}$ que é escola central ali né que é o Toufic Joulian que é escola já antiga, ela era metade até o centrinho ela era asfaltada até metadinha, metade pra lá era barro e era considerado centro, então a gente usava dois sapatos, a gente usava metade até o centro que ia amassar barro e depois era outro sapato (Entrevistada 01, 54 anos, Moradora da Vila Dirce).

63 'Do 'cinturão de urbanização intercalar' [Osasco, Taboão da Serra, São Bernardo do Campo, Diadema, Itaquera, São Miguel Paulista...] se destacam quatro tentáculos quatro tentáculos, comandados pela ferrovias extra-regionais antigas, tentáculos esses caracterizados pela sucessão de aglomerados pouco distanciados entre si. Chamemo-los eixos de urbanização em colar. [...] Alguns núcleos menores se desenvolveram um tanto quanto apartados da ferrovia, mas apoiados em 'subúrbio-estação': Vila Serpa em Caieiras, Vila Dirce e Aldeia de Carapicuíba em Carapicuíba. Os dois últimos citados correspondem ao mais expressivo caso de desenvolvimento suburbano perpendicular, verificado no domínio dos eixos de urbanização em colar.” (LANGENBUCH, 1971, p. 298).

64 Escola Estadual Toufic Joulian. Trata-se de uma das escolas mais antigas de Carapicuíba, localizada na região central, precisamente na Av. Rui Barbosa, 820 - Centro. Proximidade também dos trilhos, mas que como afirma a moradora, um espaço vivido permeado pela precariedade, o abandono e os desafios do subúrbio e da periferia paulistana. 
População de Carapicuíba após desmembramento de Barueri em 1964

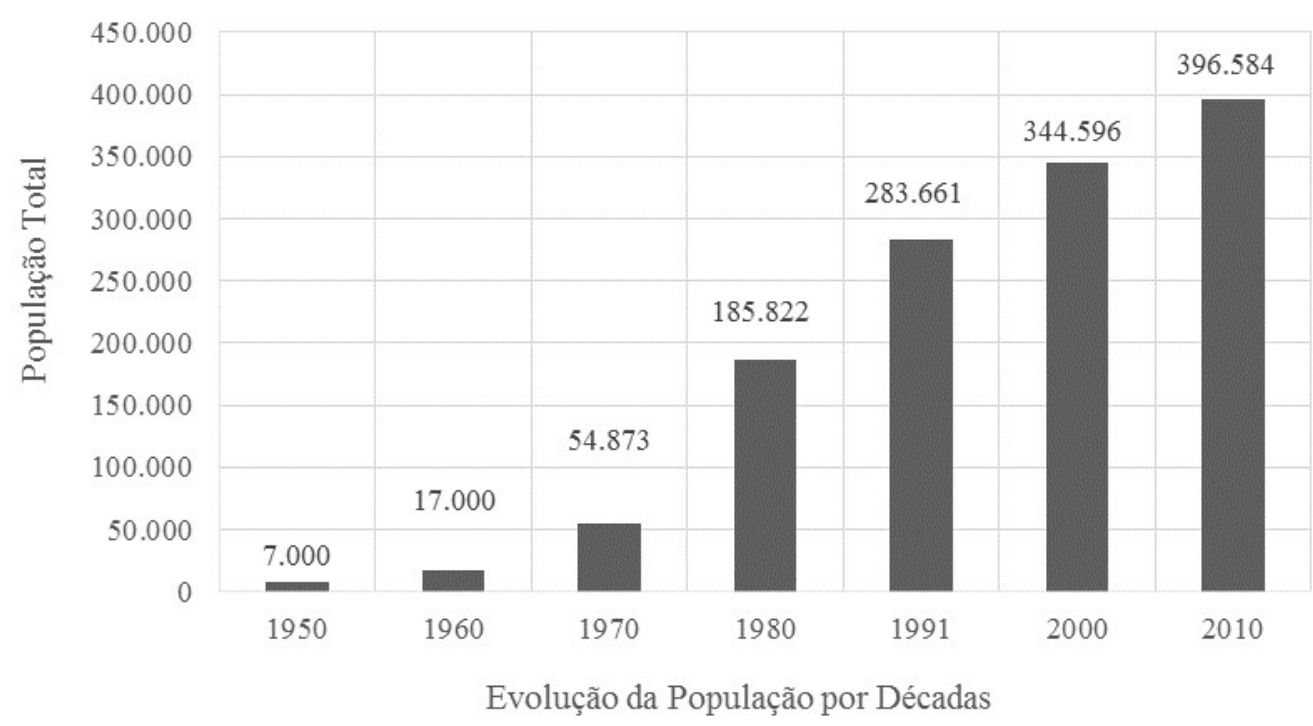

Gráfico 03: Evolução da população de Carapicuíba entre 1950 a 2010.

Fonte: Anos de 1950 e 1960 dados obtidos em Costa Junior (1987) e Langenbuch (1971) respectivamente. Para o restante, dados do IBGE - Evolução da Divisão Territorial do Brasil - População por Município (1872 a 2010). IBGE - Censo, 2010. Organização do autor, 2016.

As condições precárias com que se desenvolvia a região intensificam-se ao longo da década de 1970. Com a instalação ao longo de praticamente uma década do Conjunto Habitacional Castelo Branco pela Companhia Metropolitana de Habitação de São Paulo (COHAB-SP) houve grande incremento populacional, não apenas daqueles que vieram ocupar as 8.742 unidades habitacionais, subdivididas em quatro complexos habitacionais, mas simultânea ou posteriormente ocupando áreas diversas, adquirindo pequenos lotes clandestinos, terrenos irregulares, ocupando um espaço estratégico da metrópole no que tange as oportunidades de emprego, mas sofrendo intensamente com a periferização e precariedade urbana. Para Santos (2012b), estes processos de crescimento, que demandam rápidas modernizações dos territórios no mundo subdesenvolvido, alteram brutalmente a lógica interna das cidades. Requer esforços de equipamentos, infraestruturas e de trabalho descomunal, sendo, no entanto, utilizada e apropriada por poucas indústrias e grupos capitalistas com condições de articular as escalas espaciais da produção, do trabalho, de mercados e estados. Favorece, pois, tipos de mundialidade e modernizações perversas, que no caso de São Paulo podem ser observadas pela concentração produtiva e o desenvolvimento desigual. 
Tomemos o exemplo de São Paulo. Em 1969, os maiores estabelecimentos industriais (com mais de quinhentos empregados) constituíam 4,5\% do número total. Eles empregavam $44,7 \%$ do conjunto de trabalhadores fabris e eram responsáveis por $52 \%$ do valor da produção e $51,5 \%$ do valor da transformação. Em 1975, as maiores indústrias eram somente 1,5 do total, mas forneciam um percentual de emprego semelhante ao de 1969 (cerca de $44 \%$ ), já com um valor produzido que se aproxima dos 69\%. Isso significa que a produção se concentrou em um número pequeno de estabelecimentos que, por sua vez, se tornaram maiores e cada vez mais multinacionais. A internacionalização da economia leva a uma concentração financeira e econômica, traduzida pelas alterações das funções urbanas e por modificações brutais da lógica interna da cidade (SANTOS, 2012b, p. 45).

Somente a COHAB Castelo Branco, iniciada a construção em princípios de 1970 e parcialmente finalizada em $1976^{65}$, passou a ocupar mais de 7,5\% da área territorial de Carapicuíba, tomando o antigo campo da boiada, área da prefeitura de São Paulo, permutada pela COHAB e financiamento do Banco Nacional da Habitação (BNH) que passou abrigar milhares de famílias vindas de todos os cantos do Brasil. Constituindo uma das mais vultosas operações urbanas no município, as construções contribuíram diretamente para um dos maiores incrementos populacionais da RMSP, quando Carapicuíba atingiu taxas geométricas de crescimento que superaram 26,5\% (IBGE, $1970,1980)$.

Trata-se, no período, do maior crescimento de todos os municípios da RMSP, que teve em média um crescimento geométrico anual no período de $4,4 \%$, destacandose Jandira, Diadema, Embu, e Santana de Parnaíba, todos com índices superiores a 10\% anual de crescimento e com concentração à oeste. Em 1980 a RMSP possui população total de 12,5 milhões de habitantes, praticamente metade dos 25 milhões de todo o estado de São Paulo (Tabela 04). A proliferação de habitações populares se estendeu predominantemente pelos empreendimentos da COHAB-SP e da Companhia de Desenvolvimento Habitacional e Urbano do Estado de São Paulo (CDHU). Carregando preceitos técnicos e pouca participação popular, as políticas foram centralizadas e verticais na gestão do território. A estratégia do Conselho de Desenvolvimento da

\footnotetext{
65 "Diversas dificuldades fizeram com que, nos anos seguintes ao seu início, o conjunto ficasse relegado ao abandono. A recuperação do conjunto foi iniciada em fevereiro de 1976 pela pr6pria COHAB-SP. Por volta de outubro do mesmo ano foram entregues 324 casas; em abril de 1977 ficaram prontos 816 apartamentos; em agosto mais 532 casas e em dezembro do mesmo ano mais 1872 apartamentos." (GARCIA, 1982, p. 06-07).
} 
Grande São Paulo, por meio do Plano Metropolitano de Desenvolvimento Integrado da Grande São Paulo (PMDI-GSP), na década de 1970, foi concentrada nos eixos leste e oeste da RMSP, direcionando a expansão urbana em consideração das limitações físicas ao norte e as reservas de água ao sul. Nesta perspectiva, multiplicaram-se nestes setores metropolitanos os loteamentos populares e empreendimentos habitacionais orientados pelo Estado, mas não necessariamente munidos de equipamentos básico e típicos do sistema urbano.

\begin{abstract}
A precariedade tem sido atributo permanente das periferias metropolitanas. A partir dos anos 70, no momento em que que o Estado passa a produzir habitação social adotando a tipologia dos grandes conjuntos, essa situação se agrava, pois os projetos reproduziram as deficiências e carências urbanísticas típicas das regiões periféricas. Em cada uma dessas situações - quer nos espaços produzidos pelo poder público, quer naqueles resultantes da ação privada - verificam-se os processos espoliativos de ocupação das áreas de expansão urbana que resultaram em precariedades específicas dos ambientes construídos, legando um tecido urbano desestruturado e carente de atributos de 'cidade'. Essa precariedade material tem duplo registro. Por um lado está associada ao processo de produção dos espaços residenciais para a população de baixa renda, e por outro à insuficiência crônica de investimentos públicos na escala requerida, sendo ainda reforçada pelo descaso com a qualidade dos espaços construídos. Tem, portanto, relação com três aspectos decisivos: com o destino social dessas áreas, com a distribuição desequilibrada dos investimentos públicos na cidade e com a ausência de uma política de desenvolvimento urbana que equacione a expansão da metrópole (MEYER; GROSTEIN; BIDERMAN, 2013, p. 51).
\end{abstract}

No que tange a aquisição da área de mais de 2.623.500,00 $\mathrm{m}^{2}$ de Carapicuíba pela $\mathrm{COHAB}$, evidencia-se que não foi um processo simples, na verdade, carregado de conflitos entre a municipalidade preocupada com os efeitos do vertiginoso crescimento populacional e a relativa estagnação econômica frente Osasco e Barueri. Por outro lado, os interesses verticais do estado, buscando pelo planejamento ${ }^{66}$, estabelecer ou orientar os vetores de expansão da metrópole (Figura 33).

\footnotetext{
66 “Acreditava-se, nesse período, na permanência de um processo contínuo de concentração das atividades econômicas e da população na RMSP, considerando provável que as vantagens locacionais e o desenvolvimento urbano e econômico a partir do Município de São Paulo se extravasariam para os demais municípios da RMSP e destes para a macrometrópole, e assim por diante, integrando os municípios da região entre eles e com a sua área de entorno.” (DENISO, 2015, p. 02).
} 
Perspectiva da COHAB Castelo Branco em Carapicuíba - década de 1970
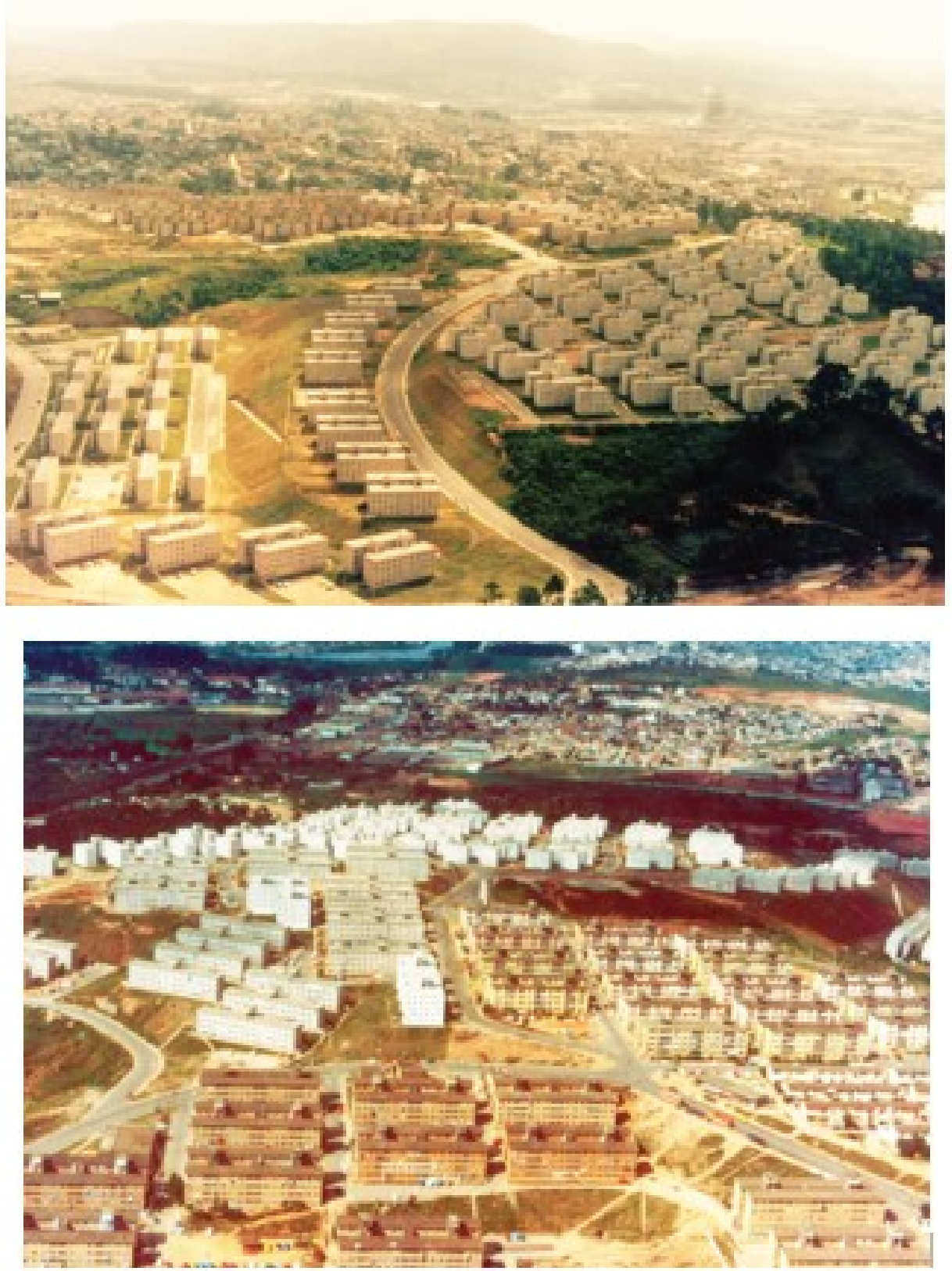

Figura 33: Instalações da COHAB-SP induziram a expansão urbana e perpetuaram a função residencial e de cidade dormitório à Carapicuíba.

Fonte: Plano Diretor Participativo do Município de Carapicuíba, 2012.

Na edição de 30 de maio de 1976 do jornal Estado de São Paulo, uma das matérias destaca o adiamento das construções da $\mathrm{COHAB}$ em razão de liminar judicial em favor da prefeitura municipal. Conforme explica a matéria, a preocupação residiria na já desfavorável função de Carapicuíba como cidade dormitório, com uma economia pouco desenvolvida e que a vinda dos conjuntos habitacionais perpetuaria essa condição 
fatídica. "Pressionada pela falta de empregos, a Prefeitura pretende desestimular o crescimento demográfico de Carapicuíba." ${ }^{\text {67 }}$. Assim também, ao estudar a reabilitação dos conjuntos habitacionais, Otero (2009) identifica em outra matéria, em 1983 no mesmo jornal, que a população recém instalada nos edifícios da $\mathrm{COHAB}$ pedem socorro às autoridades diante da precariedade urbana do local ${ }^{68}$. Segundo ele, as condições de moradia dos conjuntos pouco diferenciavam das favelas e ocupações irregulares na periferia da RMSP. A precariedade também se estendia para as condições de infraestrutura da área, perpassando os próprios edifícios, onde muitos foram implodidos anos mais tarde por problemas estruturais irreparáveis (OTERO, 2009). Para Pimentel (2014, p. 72), o caso de Carapicuíba é expressivamente relevante na transformação periférica induzida pela $\mathrm{COHAB}$ e as casas da $\mathrm{CDHU}$, transformando-a numa cidade dormitório, considerando a distância desta nova população do trabalho e dos serviços essenciais.

[...] Outro ponto a ser destacado neste quesito diz respeito ainda aos grandes conjuntos habitacionais construídos pela Companhia Metropolitana de São Paulo - Cohab, concentrando aproximadamente $19 \%$ da população total do município [...]. Carapicuíba possui a segunda maior "Cohab" do Brasil. Embora este termo "cidade dormitório" possa ser questionado por alguns estudiosos, essa é uma denominação bastante usual quando nos referimos ao município, isso porque leva-se em conta o movimento de deslocamento pendular de seus moradores rumo, em uma primeira demanda, aos centros industriais e comerciais e de seu entorno: Osasco, São Paulo, Barueri, entre outros. Esse perfil periférico, motivado principalmente pela quase inexistência de espaços industriais e um comércio local pouco desenvolvido, força os seus moradores a se deslocarem em busca de trabalho nos outros centros já citados (PIMENTEL, 2014, p. 72).

Na Figura 34, o mapa de áreas urbanizadas elaborado pela Emplasa (1975), no sentido de subsidiar os Planos Diretores de Desenvolvimento Integrado da Grande São Paulo (PDDI/GSP), especificamente neste caso dos municípios da zona oeste, expressa o volume urbano em Osasco e Carapicuíba, em fase de integração metropolitana.

\footnotetext{
${ }^{67}$ O ESTADO DE S. PAULO. Questão judicial adia construção de 5.400 casas. In: O Estado de São Paulo (jornal), 30 de maio de 1976, p. 37.

68 O ESTADO DE S. PAULO. Moradores de Carapicuíba reclamam. In: O Estado de São Paulo (jornal), 13 de maio de 1983 , p. 15.
} 
Áreas Urbanizadas Zona Oeste da RMSP - Emplasa (1975)

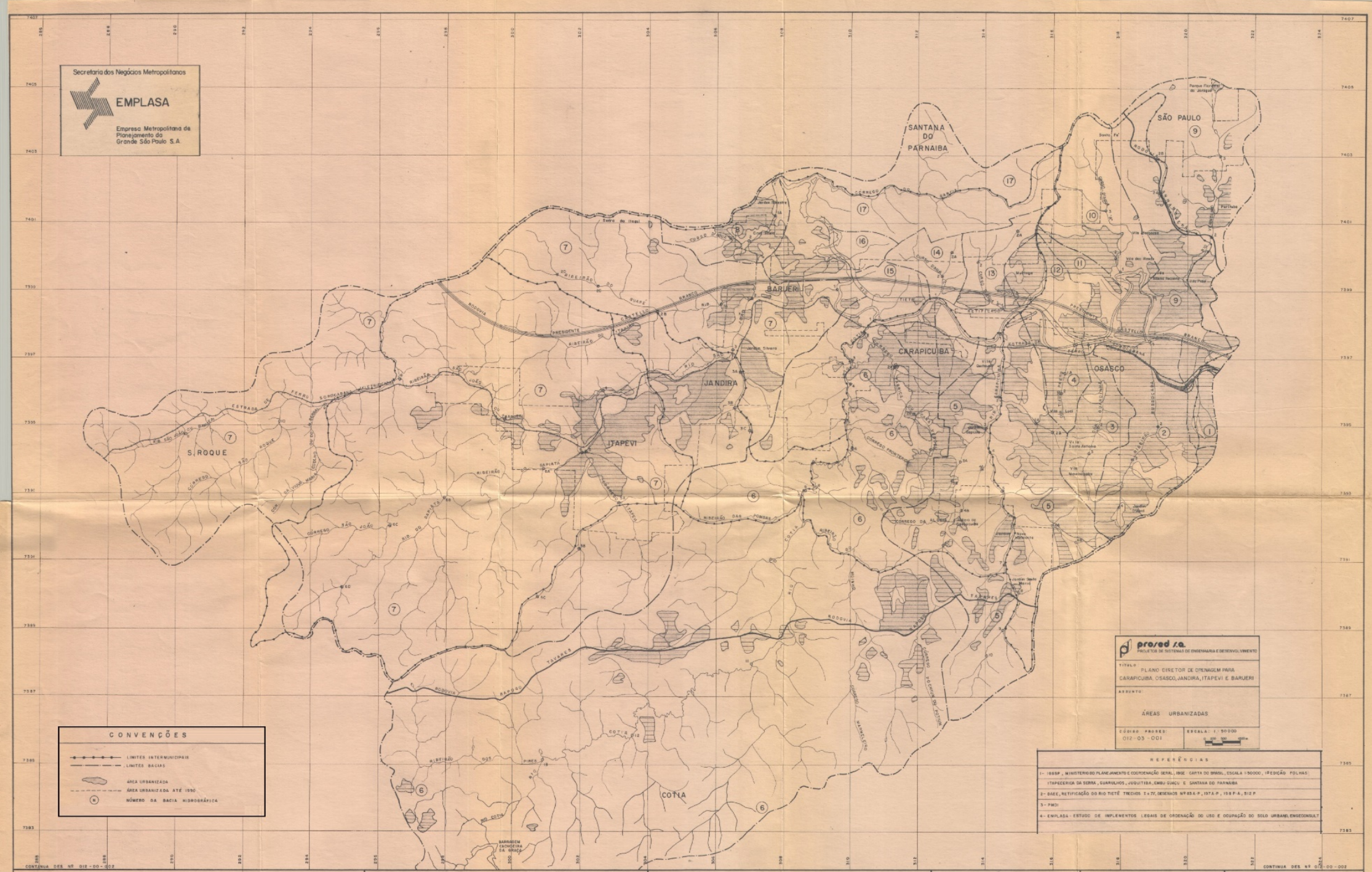

Figura 34: Plano Diretor - Mapa de Drenagem... (Áreas Urbanizadas) - evidencia a densa urbanização a oeste da RMSP em 1975, destacando-se Carapicuíba e Osasco. Fonte: EMPLASA, 1975 -Acervo Digital Emplasa. Organizado e editado pelo autor, 2016. 
O mapa mostra que mesmo sem necessariamente finalizados, ou completamente entregues, as habitações das COHAB's e CDHU já representam próximo ao centro e a leste densa ocupação física e populacional no território de Carapicuíba. Maior ocupação se estabelece de norte a sul, em relação à estação de trem e a Aldeia de Carapicuíba. A mancha urbanizada se estabelece mais amplamente a norte, ao longo da ferrovia, avolumando-se nas estações vizinhas de Barueri, Jandira e Itapevi, respectivamente. Observa-se ainda neste mapa que os municípios mais próximos da cidade-polo, São Paulo no caso, possuem maiores núcleos urbanizados, em que Carapicuíba se desenvolve também pela proximidade com Osasco, subcentro da metrópole na porção oeste. Como explica Pimentel (2006, p. 40), além das COHAB's, a década de 1970 marca o avanço da urbanização para o espaços mais distantes da ferrovia no município, com aumento de autoconstruções e um modelo tipicamente periférico de crescimento. De fato, ao sul o acesso pela rodovia Raposo Tavares (SP-270) desde antes da segunda metade do século passado já interligava a RMSP ao interior do estado. Além da Vila Dirce e adjacências, que já se desenhavam antes de década de 1970, "novos bairros surgiram na cidade, como o Jardim Ana Estela, Cidade Ariston, Vila Menck, e, a partir da década de 1980, como o Parque Jandaia e o Parque Santa Tereza.” (PIMENTEL, 2006, p. 41).

Como as implicações modernizadoras da suburbanização em relação ao cinturão caipira de São Paulo, que provocaram diversas tensões no meio tradicional e cujo resultado em Carapicuíba foi o tombamento do antigo aldeamento jesuítico, além de acentuar o debate em torno das rugosidades patrimoniais, a década de 1970 que reverbera na periferização da cidade, designa ainda um ajustamento maior destes elementos com as próprias políticas urbanas. A mudança operada no plano urbano passa estar compassada com os preceitos complexos em que se inseria a discussão patrimonial, desde a Carta de Veneza (1964) e a propagação de referências internacionais que tangenciavam o respectivo tema, até a incorporação teórica de historicidade ao conjunto das cidades.

Choay (1997, p.12) explica que a partir da década de 1960 “(...) os monumentos históricos já não representam senão parte de uma herança que não para de crescer, com a inclusão de novos tipos de bens e com o alargamento do quadro cronológico e das áreas geográficas no interior das quais esses bens se inserem. A Carta de Veneza (1964) é o expoente documental capaz de traduzir e justificar a assertiva de Choay (2006). A tendência de englobar cada vez mais elementos no rol patrimonial parece ser evidente. "A sensibilidade e o espírito crítico se dirigem para problemas cada vez mais complexos e diversificados. 
Agora é chegado o momento de reexaminar os princípios da Carta (de Atenas, 1931) para aprofundá-las e dotá-las de um alcance maior em um novo documento" (CARTA DE VENEZA, 1964).

$\mathrm{Na}$ análise de Fonseca (1997), as consequências do desenvolvimento urbano-industrial e do processo de metropolização no país reforçavam as tensões no âmbito do patrimônio cultural, dificultando institucionalmente as bases criadas pelo movimento modernista na década de 1920 e trazendo à tona outras demandas simbólicas e sociais que culminaram com a criação do IPHAN em 1970. Mais que a diversidade trazida pela metropolização, historicamente, mesmo as rugosidades patrimoniais normatizadas, em grande parte ligadas aos resíduos construtivos do século dezoito, já haviam sido apropriadas por novos conteúdos e grupos sociais, que simplesmente foram ignorados pelas políticas pretéritas. No caso da Aldeia de Carapicuíba, uma das mais importantes evidências da contradição entre a norma que sugere preservação e a realidade concreta que mostra sua depredação, situa-se no evento do roubo ou desaparecimento dos sinos da capela de São João Batista em 1973, quando sujeitos se apresentaram pretensamente como servidores do IPHAN e conseguiram retirar os sinos com a justificativa de sua manutenção, sem nunca mais trazê-los de volta ${ }^{69}$. O pressuposto institucional valeu-se para a subtração de um bem que demarcava o sistema de cotidianidade da população, possivelmente sobre o falso pretexto de sua manutenção. Ao sabor do fato, a atitude da superintendência do IPHAN em São Paulo foi fechar a capela, privando ainda mais os moradores de seus bens culturais e das condições mínimas de sociabilidade.

Agregar essa diversidade que crescia com a expansão da cidade incluía uma questão ainda mais complexa, que residia no reconhecimento de um conjunto maior de bens, como preconizava a Carta de Veneza (1964) e uma visão de totalidade que era fugidia das restritas dimensões do passado. No Brasil é do mesmo modo contraditório que os preceitos internacionais trazem a valorização da diversidade no plano patrimonial, quando as políticas urbanas e culturais estabelecidas pelo golpe militar são verticais e impositivas, legando discursos e práticas que não apenas deixam de confluir, como são concorrentes. Apesar de um discurso comum na atualidade, até meados dos anos setenta do século passado as políticas

\footnotetext{
69 Ao analisar essa questão dos sinos por meio de jornais locais, Faccio (2010) não consegue chegar a uma conclusão dos fins tomados pelos sinos. Ao tratarmos com antigos moradores acerca do assunto não obtivemos respostas concretas do paradeiro dos sinos. Tudo leva a crer que este bem foi furtado. Uma perda irreparável, considerando sua explicitação nas entrevistas enquanto elementos centrais na demarcação do tempo cotidiano no passado da Aldeia.
} 
urbanas e do patrimônio estavam diametralmente separadas. A metropolização, passa não apenas a integrar cidades numa unidade regional mais ampla, como assevera o compasso político em planos de desenvolvimento conjunto, como o PDDI da RMSP formulado entre fins da década de 1970 e princípios da década de 1980, quando, inclusive, haverá orientações específicas aos diferentes bens culturais nas mais diversas cidades da região metropolitana de São Paulo por meio da Empresa Metropolitana de Planejamento da Grande São Paulo (EMPLASA).

Trata-se daquilo que Sant'Ana (2014) atribui a passagem da cidade-monumento à cidade-documento, cujo valor patrimonial perpassa o aspecto singular, excepcional, estético, que no Brasil está relacionado a busca de uma identidade nacional e, posteriormente, para as dimensões de permanência e de diversidade social, as quais remetem a integração com as políticas urbanas. Ainda conforme Sant'Ana (2014) ao analisar os livros do tombo do IPHAN, esse momento avança da valoração artística como critério de seleção (que vai de 1938 a 1950), perpassando o valor paisagístico e a ampliação de áreas protegidas (principalmente ao longo de 1960 e 1970) e, por fim, alcança discursivamente a valorização da área urbana como um documento, da história urbana e da sociedade brasileira (entre 1980 e 1990). Na prática, o direcionamento estratégico da Aldeia se mostra limitadamente a esses preceitos apenas nos planos de gestão territorial. Em verdade, o que se reproduz são os valores ainda calcados no fragmento, na singularidade, na colonialidade do poder, onde entorno sequer conseguia se efetivar como ambiência e em que as prioridades de preservação, como no passado, estavam distantes de Carapicuíba. Dialeticamente, o processo de periferização urbana reverbera na marginalização das rugosidades patrimoniais da Aldeia, tomando as formas-conteúdos das vilas e favelas vizinhas, carregando a modernidade ao avesso.

Hoje tá tudo mudado. Antes era o sino aqui que avisava a hora de começar e de parar. Era tudo bem isolado, não tinha todos esses bairros aqui em volta. [...] Usava muito carro de boi, ali na esquina, tá vendo, onde é a casa da cultura, antes era uma vendinha. [...] Aqui era bom demais, as festas tinha muita gente, era outro tempo. (Entrevistado 16, morador da UIT Vila Dirce, antigo morador da Aldeia, 63 anos). 
A década de 1980 marca um importante período de transição política do país. Trata-se do período de redemocratização, com a saída das forças militares do cenário político, a promulgação de uma nova constituição e a realização de eleições diretas. "[...] $\mathrm{O}$ descontentamento com o regime militar era reforçado pela situação econômica e social. O Brasil era um caldeirão repleto de movimentos e organizações por irromperem na cena política, como adiante o processo constituinte revelaria de forma surpreendente e ampla." (COELHO, 2009, p. 162). Com a emergência das questões políticas e sociais, o espectro cultural toma dimensões privilegiadas para pensar "novas identidades coletivas" (FONSECA, 1997), tornando-se num "[...] instrumento fundamental para os grupos sociais que as constróem, e que, muito frequentemente contestam a legitimidade dos 'patrimônios históricos e artísticos nacionais'.” (FONSECA, 1997, p. 195).

Neste momento, mais que mapear e realizar um esforço de institucionalizar bens e justificar a ação dos organismos patrimoniais a partir de uma identidade, cabia discutir os critérios de valoração, compreendendo criticamente o patrimônio cultural "[...] tanto de seu caráter acumulativo quanto das omissões, deturpações e reduções ideológicas a que ele está inevitável e contingencialmente submetido.” (FALCÃO, 1984, p. 33). O que é explicado por Fonseca (1997) numa dimensão histórica da cidade que não se resume apenas à sua arquitetura, abrangendo as adaptações realizadas pelo trabalho humano, adequando o espaço às suas necessidades (FONSECA, 1997, p. 230).

\subsection{Implosão-explosão urbana e as rugosidades-monumentos-documentos}

A urbanização da sociedade (SANTOS, 2013b), em termos de sua industrialização, no caso brasileiro, só deve ser pensada efetivamente a partir de 1950 (MOREIRA, 2005). Isto em razão da generalizada supressão da formação espacial anterior, com a inversão espacial da população entre campo e cidade, mas da superação de indústrias tradicionais de bens de consumo pelas de bens de produção e sua diversificação, ainda pela maior integração do território nacional no que tange a produção, distribuição e o mercado consumidor. $\mathrm{O}$ que marca uma divisão territorial do trabalho, que consolida não apenas o comando do campo pela cidade, como de São Paulo em relação a indústria e do controle do espaço nacional (MOREIRA, 2005, p. 17). Nesse processo se efetiva a tríade industrialização-urbanização- 
metropolização, que principiada no passado, como observado nas centralidades do poder e dos territórios, terá uma resposta intensa e plena em torno de novos modos de viver, de trabalhar e de se relacionar com a natureza dos objetos e os objetos da natureza.

Santos (1980) evidencia amplas diferenças da urbanização dos países desenvolvidos e subdesenvolvidos. Segundo ele, no primeiro caso, a cidade é integrante viva e de crescimento gradativo, enquanto que nos países subdesenvolvidos o processo de urbanização teria sido arrolado como um "corpo estranho", “alógeno", “(...) inserido em um meio com o qual estabelece relações descontínuas no espaço e no tempo." (SANTOS, 1980, p. 97). Se nos países desenvolvidos a urbanização acompanha a industrialização, nos subdesenvolvidos ela acompanha determinados interesses ampliados do capital, em suas diversas revoluções técnico-científicas e de expansão rumo a novos mercados e oportunidades. Afinal, como denuncia Carvalho (1997), muitos conflitos e perversidades resultam justamente das condições produtivas nas relações postas pela marginalidade do capitalismo nos países não desenvolvidos e de sua urbanização generalizada.

Causa que levou esses países a multiplicação de pequenas cidades e a hipertrofia de cidades específicas, resultando na macrocefalia urbana ${ }^{70}$ e o parasitismo do setor terciário, em desequilíbrio com a industrialização mais ampla e a precária permanência cultural de estruturas tradicionais. Ao mesmo tempo em que se observa a multiplicação de pequenas cidades com a modernização pós-guerra, a polarização do sistema urbano ainda permanece compondo grandes núcleos de produção e controle do território, concomitantemente a periferização e as críticas condições de vida daqueles que resistem aos sistemas urbanos vivendo no campo. Na América Latina, até meados da década de 1950, praticamente metade da população era analfabeta. Os países possuíam baixos índices de urbanização e industrialização, com estrutura territorial baseada nas grandes propriedades rurais, na dependência econômica, a propósito de ampla hibridização e arranjos culturais de várias

\footnotetext{
${ }^{70}$ A macrocefalia (do grego $\mu \alpha \kappa \rho v ́ \varsigma$ - grande e $\kappa \varepsilon \varphi \alpha ́ \lambda \eta$ - cabeça) é um conceito aplicado em Geografia ao desequilíbrio na rede urbana, dotando determinadas cidades de atratividade e polarização das funções econômicas e sociais de um território nacional. Os resultados desta produção espacial têm sido dramáticos, com a concentração demográfica (inchaço populacional) e a criação de megacidades que não atendem serviços básicos, como os de transporte, saneamento, ou habitação. Com mais de $10 \%$ de toda população brasileira, a RMSP pode ser pensada neste sentido, sobretudo quando ampliada sua escala para a Macrometrópole Paulista (incluindo outras RM's estaduais adjacentes) ou, ainda, a RMRJ que daria concretude a noção de megalópole, abrangendo numa pequena porção do país mais de $1 / 4$ da população e a maior parte dos segmentos produtivos modernos do país. Ainda que com a globalização não sejam mais coerentes certas generalizações acerca da relação entre rede urbana e o nível de desenvolvimento de um país, tal polarização macrocefálica ainda pode ser observada em países, como Argentina, Colômbia e Uruguai.
} 
naturezas. Estas características formaram os ingredientes destes novos centros urbanos, reunindo arranjos peculiares, dramas e soluções próprias diante da nova organização histórica.

Nesse prospecto, o sentido do conceito de “implosão-explosão" urbana, trazido por Lefebvre (2012), ainda que importante referencial teórico da evolução urbana e da cidade, prescinde de criticidade analítica para pensar a particularidade brasileira e de parte dos países latino-americanos. Em suas conjecturas acerca do desenvolvimento da cidade em diferentes regimes de tempo, ele estabelece linearmente a passagem de uma rara "cidade política" para uma recorrente "cidade comercial", que passa à "cidade industrial" e chega até a "zona crítica”, onde se aproximaria da utópica e virtual sociedade urbana. A implosão-explosão urbana situa-se neste esquema, posteriormente à inflexão do rural pelo urbano, após a formação da cidade industrial e entre a zona crítica é que se estabeleceria generalizadamente essa expansão do "tecido urbano" e plena subordinação do campo à cidade.

Na maioria dos países desenvolvidos da Europa essas passagens são longas e bem delimitadas, enquanto na América Latina elas estão superpostas pela velocidade que se desenvolveram no pós-guerra. A divisão territorial do trabalho da qual resulta formasconteúdos destas novas cidades e metrópoles também não serão as mesmas daquelas pretéritas dos países europeus (SANTOS, 1980). E a especificidade do fenômeno deve ser apontada como meio de apreensão da atual fase de desenvolvimento desses países. Do mesmo modo, as dimensões culturais são ainda mais complexas e diferenciadas, considerando, por exemplo, apenas no continente americano, uma diversidade de países em que sobressaíram, apesar do fato colonial, identidades nacionais totalmente distintas. Essa diferença de modernização é também responsável pela especialização e hierarquização de funções, sendo que "os resultados estão numa estreita relação com os interesses do sistema em escala mundial e também em escala local, regional ou nacional.” (SANTOS, 1985, p. 32).

Essa problemática da "implosão-explosão" urbana ainda deriva do debate entre os termos e as noções de "subúrbio" e "periferia" pensados no Brasil, onde procurou-se estabelecer diferenças estruturais por diversas referências, tomando o caso específico de São Paulo (LANGENBUCH, 1971; 2001; BONDUKI; ROLNIK, 1979; KOWARICK, 2001; MARTINS, 2001; BURGOS 2008; FRABETTI, 2013; MARQUES, 2015), bem como defender a passagem de um a outro fenômeno, conforme alteram-se as dinâmicas espaciais nas cidades e metrópoles no atual contexto histórico. Trata-se assim, de compreender o subúrbio como definidor da integração dos cinturões e áreas adjacentes à cidade-polo na 
integração metropolitana, enquanto a periferia seria uma fase avançada, que comporta o subúrbio, mas não limita-se a localizações e não pode ser pensada sem o processo de desenvolvimento desigual e combinado que permeia a industrialização-urbanizaçãometropolização em curso pós-1950.

O crescimento das cidades, do número e de população, contrasta com a desintegração, a desarticulação e o isolamento regional dos hinterlands verificados no Brasil passado. Os centros de produção industrial estão neste momento em estreita ligação com os grandes núcleos populacionais que se desenvolviam gradativamente, próximos dos mercados consumidores, assim como dos principais nódulos da rede de fluxos de produtos, bens e pessoas, que viabilizavam, inclusive, relações internacionais mais dinâmicas. Sobressai, pois, uma contínua acumulação das rugosidades. Além disso, sobreposições serão contínuas e pujantes, com as respectivas supressões de formas-conteúdos, pois mesmo com algum padrão notadamente moderno e de alguma densidade sobreposta às infraestruturas passadas, esta fase implicará mudanças radicais das cidades suburbanas.

Espacialmente, a população vivendo no campo e cidade se inverte. Não se trata exclusivamente de uma inversão populacional rural-urbana, simplesmente como ilustrado no Gráfico 04 seguinte, mas uma combinação de migrações internas, inter-regionais, de núcleos menos dinâmicos para as novas áreas economicamente pulsantes. Também de permanências, de rugosidades que convivem do passado distante, superpostas e acumuladas nas cidades metropolizadas. Neste caso, é justamente o processo industrial o elemento econômico determinante, bem como o estabelecimento de desigualdades regionais profundas - criando valor e acumulando vantagens aos territórios já produtivos em favor do gradativo empobrecimento relativo das áreas estagnadas (SINGER, 1978). Além disso, a carga cultural de diferentes regiões mesclam-se numa unidade de múltiplas expressões, com a acumulação e a superposição de rugosidades patrimoniais, as quais ainda incluem os traços de ruralidade em sua complexidade regional. 
Evolução da População Urbana e Rural do Brasil entre 1960 e 2010

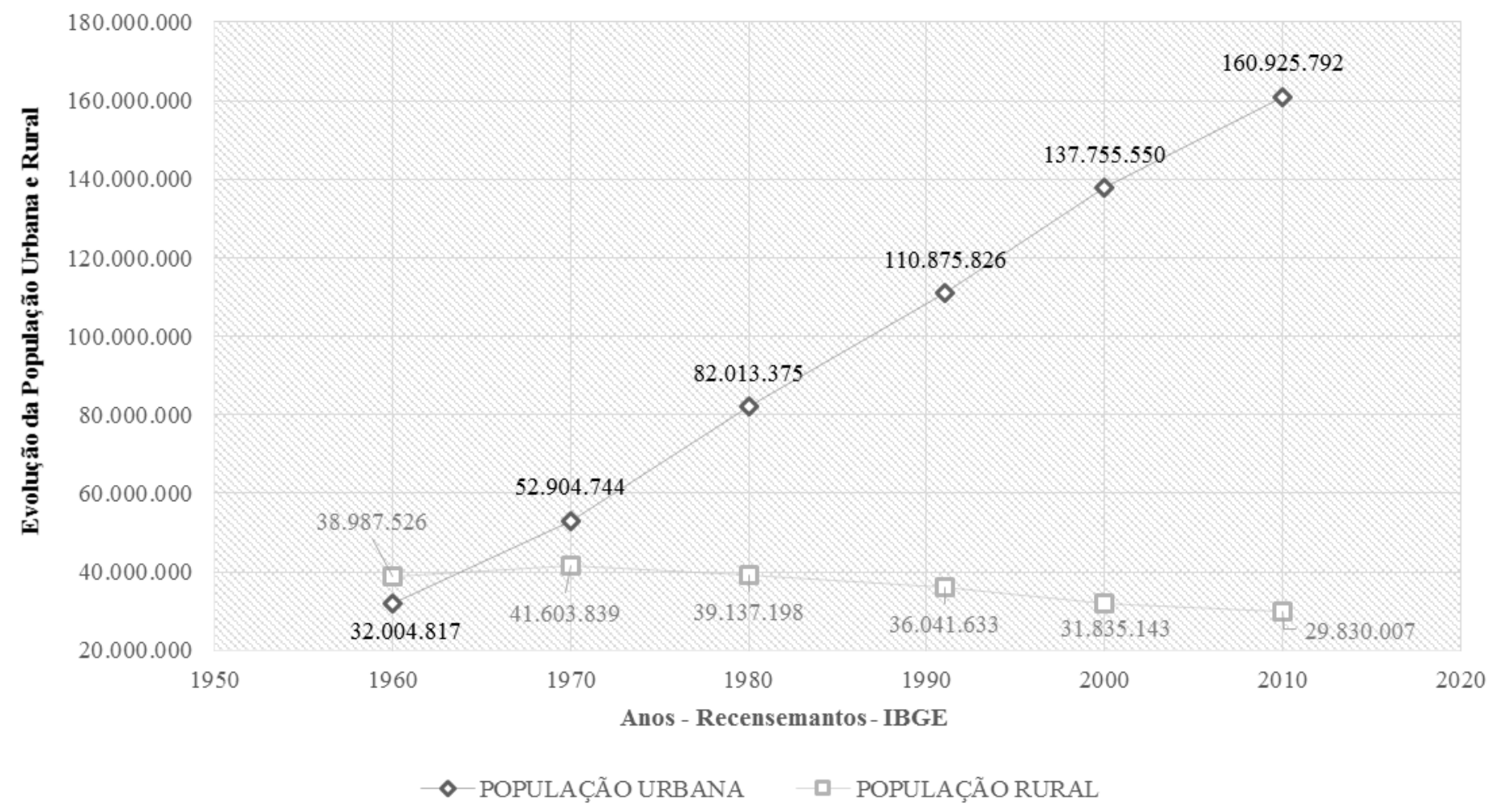

\begin{tabular}{|c|c|c|c|}
\hline DÉCADAS & POPULAÇÃO URBANA & POPULAÇÃO RURAL & POPULAÇÃO TOTAL \\
\hline 1960 & 32.004 .817 & 38.987 .526 & 70.992 .343 \\
\hline 1970 & 52.904 .744 & 41.603 .839 & 94.508 .583 \\
\hline 1980 & 82.013 .375 & 39.137 .198 & 121.150 .573 \\
\hline 1991 & 110.875 .826 & 36.041 .633 & 146.917 .459 \\
\hline 2000 & 137.755 .550 & 31.835 .143 & 169.590 .693 \\
\hline 2010 & 160.925 .792 & 29.830 .007 & 190.755 .799 \\
\hline
\end{tabular}

Gráfico 04: Evolução da população urbana e rural do Brasil.

Fonte: IBGE, Censo Demográfico 1960,1970, 1980,1991, 2000 e 2010. Organização do autor, 2016. 
De fato, além das elevadas taxas de fecundidade e aumento da expectativa de vida, que se coadunam com a melhoria de infraestruturas, sobretudo no âmbito de saneamento básico, o fator migratório é imperativo à compreensão do incremento populacional das cidades no sudeste, sobretudo São Paulo e Rio de Janeiro neste período, que ainda antecede a criação institucional e normativa das regiões metropolitanas. Esse ponto é de extrema relevância no sentido de melhor situar a condição de existência de uma população que não é totalmente combalida pelo fenômeno urbano, mas que dialeticamente vai edificar e dar conteúdo a essa formação sócio-espacial em desenvolvimento. Entre 1960 a 1980 as principais áreas de emigração foram predominantemente a região nordeste, além dos estados de Minas Gerais, Espírito Santo, Santa Catarina e Rio Grande do Sul em menor proporção. As áreas de atração eram os núcleos industriais, localizados principalmente nos estados de São Paulo e do Rio de Janeiro (OLIVEIRA; ERVATTI; O’NEILL, 2011).

É sob a ótica crítica das disparidades urbanas e regionais, que acabam condicionando grande massa popular a migrar para outras regiões de industrialização consolidada, em busca de melhores condições de vida, forçando o Estado nacional a subsidiar ações desenvolvimentistas e políticas públicas em regiões cuja economia ficara estagnada e onde a população decrescia substancialmente. O Gráfico 05 evidencia em 1960 o descompasso evolutivo da população nos modernos centros de dinamização econômica, daqueles antigos ou muito dependentes dos principais. A representação gráfica destes últimos, na escala utilizada, destoam amplamente dos primeiros e se homogeneízam numa continuidade crescente, porém balanceada, sem grandes amplitudes. Deve-se destacar o papel do Brasil central que, devido a modernização do campo, passa a ter na expansão de diversas cidades o controle regulatório e administrativo da produção. A atratividade desta área, em razão de um política de integração territorial, destacadamente com a construção de Brasília, aumenta circunstancialmente, fazendo com que Goiânia e a nova capital representem não apenas núcleos nodais da nova rede urbana, mas fundamentalmente da consolidação de uma mancha orgânica de novas cidades do agronegócio criadas. Além de buscar sanar os desequilíbrios regionais, outra ação necessária pautava-se nos problemas no desenvolvimento desigual dentro das próprias regiões metropolitanas, exigindo a normatização das unidades na década de 1970. 
Processo Urbano-Industrial: Quadro Evolutivo da População Brasileira nas Maiores Capitais Estaduais (1960-2010)

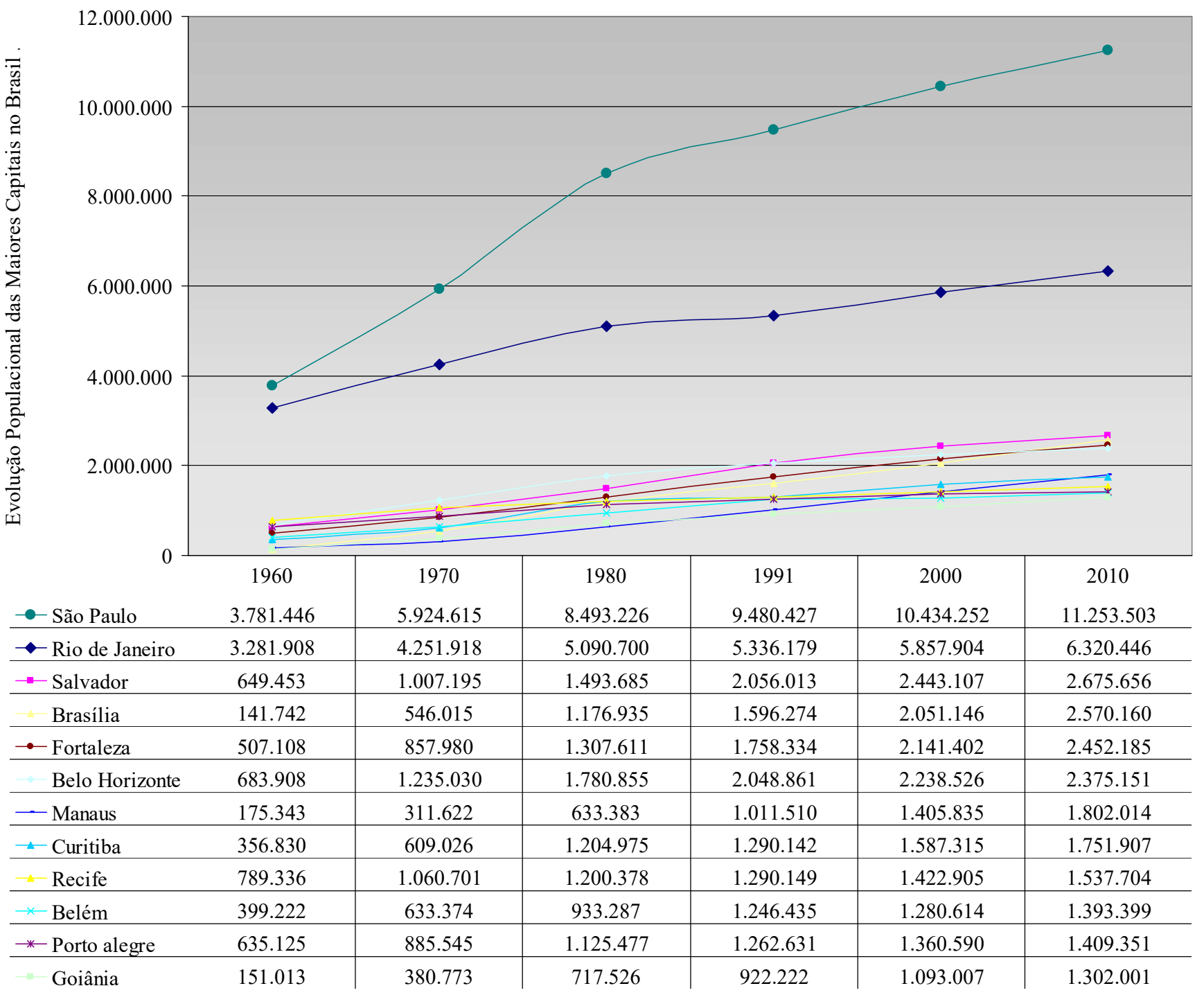

Gráfico 05: Processo Urbano-Industrial: Quadro Evolutivo da População Brasileira nas Maiores Capitais Estaduais (1960-2010) Fonte: IBGE, Censo Demográfico 1960, 1970, 1980, 1991, 2000 e 2010. Organização do autor, 2016. 
Evolução das cidades no Brasil entre 1970 e 2010

\begin{tabular}{|c|c|c|c|c|c|c|c|c|c|}
\hline $\begin{array}{c}\text { Unidades da } \\
\text { Federação } \\
1970 \\
\end{array}$ & $\begin{array}{c}\text { Número de } \\
\text { Municípios } \\
1970\end{array}$ & $\begin{array}{c}\text { Unidades da } \\
\text { Federação } \\
1980\end{array}$ & $\begin{array}{c}\text { Número de } \\
\text { Municípios } \\
1980\end{array}$ & $\begin{array}{c}\text { Unidades da } \\
\text { Federação } \\
1990\end{array}$ & $\begin{array}{c}\text { Número de } \\
\text { Municípios } \\
1990\end{array}$ & $\begin{array}{c}\text { Unidades da } \\
\text { Federação } \\
2000\end{array}$ & $\begin{array}{c}\text { Número de } \\
\text { Municípios } \\
\mathbf{2 0 0 0} \\
\end{array}$ & $\begin{array}{c}\text { Unidades da } \\
\text { Federação } \\
2010\end{array}$ & $\begin{array}{c}\text { Número de } \\
\text { Municípios } \\
2010\end{array}$ \\
\hline Território de Rondônia & 2 & Território de Rondônia & 7 & Rondônia & 23 & Rondônia & 52 & Rondônia & 52 \\
\hline Acre & 7 & Acre & 12 & Acre & 12 & Acre & 22 & Acre & 22 \\
\hline Amazonas & 44 & Amazonas & 44. & Amazonas & 62 & Amazonas & 62 & Amazonas & 62 \\
\hline Território de Roraima & 2 & Território de Roraima & 2 & Roraima & 8 & Roraima & 15 & Roraima & 15 \\
\hline Pará & 83 & Pará & 83 & Pará & 105 & Pará & 143 & Pará & 143 \\
\hline \multirow[t]{2}{*}{ Território do Amapá } & 5 & Território do Amapá & 5 & Amapá & 9 & Amapá & 16 & Amapá & 16 \\
\hline & & & & Tocantins & 79 & Tocantins & 139 & Tocantins & 139 \\
\hline Ter. Fernando de Noronha & 1 & Ter. Fernando de Noronha & 1 & & & & & & \\
\hline Maranhão & 130 & Maranhão & 130 & Maranhão & 136 & Maranhão & 217 & Maranhão & 217 \\
\hline Piauí & 114 & Piauí & 114 & Piauí & 118 & Piauí & 221 & Piauí & 224 \\
\hline Ceará & 142 & Ceará & 141 & Ceará & 178 & Ceará & 184 & Ceará & 184 \\
\hline Rio Grande do Norte & 150 & Rio Grande do Norte & 150 & Rio G. do Norte & 152 & Rio G. do Norte & 166 & Rio G. do Norte & 167 \\
\hline Paraíba & 171 & Paraíba & 171 & Paraíba & 171 & Paraíba & 223 & Paraíba & 223 \\
\hline Pernambuco & 164 & Pernambuco & 1641 & Pernambuco & 168 & Pernambuco & 185 & Pernambuco & 185 \\
\hline Alagoas & 94 & Alagoas & 94 & Alagoas & 97 & Alagoas & 101 & Alagoas & 102 \\
\hline Sergipe & 74 & Sergipe & 74 & Sergipe & 74 & Sergipe & 75 & Sergipe & 75 \\
\hline Bahia & 336 & Bahia & 336 & Bahia & 415 & Bahia & 415 & Bahia & 417 \\
\hline Minas Gerais & 722 & Minas Gerais & 722 & Minas Gerais & 723 & Minas Gerais & 853 & Minas Gerais & 853 \\
\hline Espírito Santo & 53 & Espírito Santo & 53 & Espírito Santo & 67 & Espírito Santo & 77 & Espírito Santo & 78 \\
\hline Rio de Janeiro & 64 & Rio de Janeiro & 64 & Rio de Janeiro & 70 & Rio de Janeiro & 91 & Rio de Janeiro & 92 \\
\hline Guanabara & 1 & & & & & & & & \\
\hline São Paulo & 571 & São Paulo & 571 & São Paulo & 572 & São Paulo & 645 & São Paulo & 645 \\
\hline Paraná & 288 & Paraná & 2901 & Paraná & 323 & Paraná & 399 & Paraná & 399 \\
\hline Santa Catarina & 197 & Santa Catarina & 197 & Santa Catarina & 217 & Santa Catarina & 293 & Santa Catarina & 293 \\
\hline \multirow[t]{2}{*}{ Rio Grande do Sul } & 232 & Rio Grande do Sul & 232 & Rio G. do Sul & 333 & Rio G. do Sul & 467 & Rio G. do Sul & 496 \\
\hline & & Mato Grosso do Sul & 55 & Mato G. do Sul & 72 & Mato G. do Sul & 77 & Mato G. do Sul & 78 \\
\hline Mato Grosso & 84 & Mato Grosso & 55 & Mato Grosso & 95 & Mato Grosso & 126 & Mato Grosso & 141 \\
\hline Goiás & 221 & Goiás & 223 & Goiás & 211 & Goiás & 242 & Goiás & 246 \\
\hline Distrito Federal & 1 & Distrito Federal & 11 & Distrito Federal & 1 & Distrito Federal & 1 & Distrito Federal & 1 \\
\hline BRASIL & 3953 & BRASIL & 3991 1 & BRASIL & 4491 & BRASIL & 5507 & BRASIL & 5565 \\
\hline
\end{tabular}

Tabela 04: Evolução do número de cidades no Brasil entre 1970 e 2010 - efetiva industrialização, urbanização e metropolização do país.

Fonte: IBGE - Evolução da Divisão Territorial do Brasil (1872-2010) - 2011. Organização do autor, 2016. 
Como evidenciam o Gráfico 05 e Tabela 04, além do aumento da quantidade de municípios criados, em pouco mais de uma década, a população de Brasília já saturava os limites populacionais planejados para o Distrito Federal, chegando a mais 500 mil habitantes. Esta realidade é apresentada por Paviani (1996; 2010), mostrando não só o crescimento da população, mas da violência e da pobreza, da suburbanização e posterior periferização, que não mais se limitam ao território do Distrito Federal, abrangendo também os estados de Goiás e Minas Gerais e dando a atual configuração da Região Integrada de Desenvolvimento (RIDE) do Distrito Federal e Entorno, alcançando hoje mais de 4 milhões de habitantes (IBGE, 2015).

No ano de 1970 o índice de urbanização do Brasil chega a 56\% (IBGE, 1970; IPEA, 2006), levando em consideração o número total residente, onde cinco cidades possuíam mais de 1 milhão de habitantes: São Paulo, Rio de Janeiro, Salvador, Belo Horizonte e Recife. Outras capitais, como Fortaleza e Porto Alegre, já bem próximas deste valor, com mais de 800 mil habitantes cada, conforme dados elencados no Gráfico 05, além de alcançar um total de 5.565 municípios em todo território nacional. Cidades estas tomadas individualmente, sem os respectivos subúrbios, que só serão mais tarde regulamentados enquanto regiões metropolitanas. A divisão territorial tem vertiginoso aumento, passando de 2.766 municípios na década de 1960 e chegando a 3.953 municípios em 1970, um aumento de 1.187 municípios em uma década, destacados na Tabela 03. Essa densidade e concentração de população, dinamizada por uma pujança industrial, de serviços e de ampla estrutura comercial, emerge na vida cotidiana dos centros urbanos trazendo outras relações sociais.

Em fins dos anos 1970 e princípios de 1980 o percentual de população urbana chega a 65\%, igualando-se a taxas de urbanização de países europeus desenvolvidos. Mas, ao contrário da condição de desenvolvimento destes últimos, a lógica prevalecente nas grandes cidades é o caos. Mais contraditório é, sem dúvida, o caso de São Paulo, com mais de 6 milhões de habitantes no princípio da década de 1970, acompanhada da deterioração das condições de vida da maior parte de sua população. Analisando diversos dados neste período, como nível de renda, mortalidade infantil, demanda habitacional, consumo alimentar, entre outros, Camargo et. al. (1976) revelam um agravamento das condições de vida da população inserida em São Paulo e seus arredores. "O processo de desenvolvimento recente redundou no empobrecimento, não só em termos relativos mas inclusive em termos absolutos, de consideráveis parcelas das classes trabalhadoras." (CAMARGO et al., 1976, p. 57). A riqueza 
era concentrada pelo empresariado burguês, em que pese alguns operários mais especializados que passavam a se beneficiar de uma condição financeira mais confortável.

O contraste entre a sofisticação do consumo de uma minoria e as condições precárias de vida da maioria tende a ampliar-se. O modelo de expansão industrial, verificado nos últimos 15 anos, apoiou-se justamente na produção de artigos de consumo durável e de luxo, destinado aos estreitos círculos de renda média e alta. Os estratos inferiores, excluídos desse mercado de consumo, pagaram não obstante alto preço. A deterioração das condições de vida da maioria da população trabalhadora acentuouse, enquanto a economia do país crescia a uma significativa taxa de $10 \%$ ao ano, dando origem ao que, por muitos, foi designado "milagre brasileiro". Mas que tipo de milagre é esse, em que o desenvolvimento significa piorar a vida da maioria da população? (CAMARGO et al., 1976, p. 59).

Concorda-se com Singer (1973) que a razão dos problemas, bem como seus resultados perversos, não são determinados pela "explosão demográfica” apenas, ou propriamente da metropolização das cidades, mas como consequência do desenvolvimento capitalista no país: concentrando capitais e a riqueza; pulverizando a pobreza e marginalização da/na cidade para obtenção de alta exploração do exército industrial de reserva (obtenção plena da mais-valia); especulação fundiária, submetida a criação de altos valores pelos empreendedores imobiliários e os proprietários da terra urbana. Para Singer (1973), o crescimento das metrópoles apenas evidencia ainda mais os desequilíbrios econômicos e sociais historicamente estabelecidos pela processo colonial e do desenvolvimento industrial dependente dos países centrais. Trata-se, pois, de uma força inercial, agravada pelas escalas que alcançava o fenômeno de metropolização. "O crescimento acelerado das metrópoles em países não desenvolvidos acentuou e tornou mais perceptível uma série de desequilíbrios, principalmente entre procura e oferta de habitações e serviços urbanos, que compõe uma problemática urbana específica.” (SINGER, 1973, p.117).

No caso de São Paulo, a urbanização de Carapicuíba carrega todos os problemas sociais e econômicos inerentes às grandes periferias paulistanas, ou de países subdesenvolvidos mais amplamente. Produz, em verdade, o drama da metropolização como simetria oposta de polos de riqueza e de valorização que seletivos espaços de São Paulo perpetuam. Emergem barracos, favelas e os conjuntos de baixa renda que sistematicamente se deterioram, junto aos graves problemas ambientais, associados, entre outros fatores, da ocupação de encostas com elevado índice de declividade, ausência de saneamento, tratamento de esgoto e áreas adequadas para disposição de resíduos domésticos e industriais, resultando na contaminação dos canais hídricos generalizadamente. Se as habitações cumprem o papel 
da precariedade do uso do solo urbano, as atividades econômicas associadas à extração de areia, que com tempo passa a conformar definitivamente a Lagoa de Carapicuíba, completam a trajetória que perpetuaria uma das cidades mais problemáticas do Brasil até os dias atuais ${ }^{71}$ (Figura 35). Frente aos graves problemas, singela é a problematização que justifica o planejamento integrado de Carapicuíba à RMSP pela EMPLASA (1981):

Com seus 185 mil habitantes registrados em 1980 e $44 \mathrm{~m}^{2}$ da área, Carapicuíba apresenta uma das maiores densidades demográficas da RMSP. Este fato se agrava com a pequena oferta de empregos em seu território e reduzida receita municipal. Dado o seu alto crescimento populacional, que é acompanhado de harmônica e ordenada evolução econômica, urbana e social, há necessidade fundamental da adoção, ao nível legislativo, de uma política de desenvolvimento integrada (EMPLASA, 1981, p. 10).

Paisagens de Carapicuíba - Conversão do Subúrbio em Periferia de São Paulo
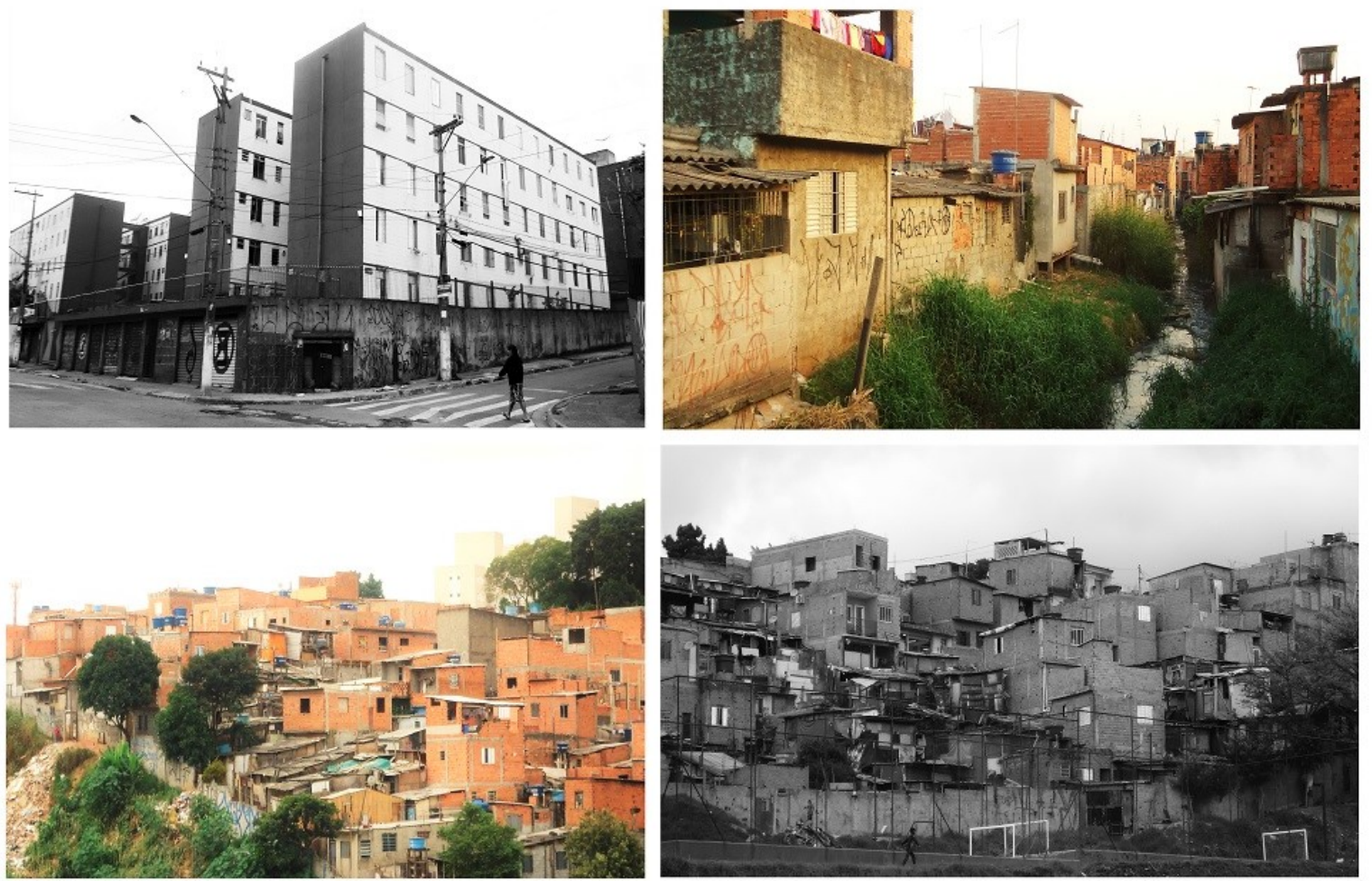

Figura 35: Imagens revelam as formas da paisagem urbana de Carapicuíba, após consolidação do subúrbio a sua periferização que perdura até os dias contemporâneos.

Fonte: Fotos do autor, 2014.

${ }^{71}$ Carapicuíba é uma das cem cidades mais vulneráveis social e economicamente do Brasil. Compõe o grupo chamado G100, constituído pela Frente Nacional dos Prefeitos (FNP) e que reúne cidades com mais de 80 mil habitantes, de baixa renda e alta vulnerabilidade socioeconômica. 
As transformações urbanas que compreendem Carapicuíba, além do plano econômico e político, marcam grandes mudanças culturais. As relações tradicionalmente estabelecidas passam a ser tensionadas pela emergência de uma nova população que carrega consigo os regionalismos e amplas diferenças de hábitos e costumes. O tempo lento do subúrbio caipira, de escalas relativamente restritas do vilarejo, onde todos e todas, de forma direta ou indireta, eram conhecidos, ora estabelecendo laços de compadrio e amizade, ora de familiarização ou de inimizade, muda radicalmente. Os modos de habitar, de se relacionar, de se transportar, de se alimentar... tudo é significativamente tencionado pela nova velocidade estabelecida da modernidade, dando novas dimensões espaciais e temporais à metrópole e interpenetrando profundamente os munícipes de Carapicuíba.

[...] Era diferente sim. Todo mundo era conhecido, muito amigo, subia no ônibus parecia uma família, tudo junto, as pessoas que moravam se cumprimentavam, bem caloroso, eram poucas pessoas, tudo conhecido. Quando cresceu na época isso aí perdeu. Agora a gente não sabe quem é quem, não confia, porque aqui tem muito problema, violência [...] (Entrevistada 02, moradora da UIT Vila Dirce, 65 anos).

Olha a gente ia a pé, até tinha ônibus mas a gente normalmente ia a pé, a gente cortava caminho tinha as trilhas e a minha mãe limpava à igreja aí depois aqui tinha umas chácara que tinha muita goiaba. Goiabeira e ai a gente pegava uma sacola cheia de goiaba pra minha mãe fazer doce a goiabada e o lanche que a gente levava pra escola Japão e goiabada caseiro que ela fazia, era muito gostoso então era assim, era uma vida muito gostosa, diferente do que ela é hoje [...] (Entrevistada 03, moradora da UIT Aldeia de Carapicuíba, 54 anos).

[...] Aqui era o sossego que a gente tinha no interior. Aqui no bairro, aqui um conhecia o outro, o outro conhecia o um. (Entrevistado 04, morador do Centro, 76 anos).

Mais uma vez, no entanto, estas transformações não estão necessariamente restritas à uma ou outra cidade, mas a maior parte dos subúrbios paulistanos. No entanto, algumas poucas conseguiram necessariamente conservar ou preservar conjuntos de formas ou unidades de períodos pretéritos. De fato, a tensão por novos loteamentos, espaços industriais e comerciais, colocaram abaixo se não a maior parte, relevantes bens até então materializados no subúrbio. Em Carapicuíba, o período entre a cristalização do núcleo suburbano desde fins do século dezenove até 1950, junto a efetiva emancipação em 1964 e a incorporação normativa à Região Metropolitana de São Paulo em 1967 (lei estadual) ${ }^{72}$ e 1973 (lei

72 É no ano de 1967, pelo decreto 47.863, que o então governador de São Paulo, Roberto C. de Abreu Sodré, criava o Conselho de Desenvolvimento da Grande São Paulo ${ }^{72}$, presidido pelo Governador do estado, como órgão de caráter consultivo para assuntos atinentes ao desenvolvimento da Área Metropolitana de São Paulo. Estabelecia-se neste decreto os limites espaciais da Grande São Paulo, compreendida em sua demarcação preliminar pelos municípios de Barueri, Brás, Caieiras, Carapicuíba, Cajamar, Cotia, Diadema, Embu, Embu 
federal $)^{73}$, marca a passagem de muitas mudanças, das quais o modo de vida rural para o urbano é, sem dúvida, uma das mais significativas.

A passagem de uma ordem espacial tipicamente rural para a urbana não se realiza tão somente pelas transformações materiais, técnicas e do mundo do trabalho, ainda que elas sejam centrais e rebatam em outras instâncias do social. Elas afetam diretamente o plano das tradições, das subjetividades, da cultura em seu sentido mais amplo e, pois, todo o sistema de significações que se explicam nos modos de viver. Mesmo com a velocidade empreendida na metropolização de Carapicuíba, as mudanças não foram realizadas abruptamente, permanecendo as rugosidades patrimoniais, quer pela organicidade e adaptações no plano cotidiano dessa população, quer pela direta ação do Estado, das normas, das classes sociais, famílias e instituições com objetivos mais pragmáticos em relação à produção do espaço.

\begin{abstract}
Eu sempre venho de carroça [sobre o transporte usado na ocasião da Festa de Santa Cruz na Aldeia de Carapicuíba]. Tenho os cavalos, deixo num pasto aqui perto de casa, desde criança eu mexo com isso, costume da família. Duro que eu fico preocupado de largar ele ali em baixo, agora aqui roubam de tudo, podem levar alguma coisa da carroça até o próprio cavalo. [...] Conversa com o tio ali, ele tá de carona hoje, mas trabalhava desde a época do campo da boiada, melhor amansador de cavalo de Carapicuíba e região. (Relato colhido de um dos familiares de festeiros em 04 de maio de 2016, em meio à Festa de Santa Cruz na Aldeia de Carapicuíba).

Aqui todo mundo me conhece por Toninho Boiadeiro. Venho na festa desde muito tempo. Tem pouco hoje, lotava demais, e olha que não tinha nem luz, imagina, era luz da fogueira, frio, e uns bambus com fogo em cima ali perto do bar [aponta para o atual bar de motoqueiros, casas de números 01 e 02 , antigo restaurante de empadas chilenas]. Aqui era chão batido, uma poeira só que levantava, mas bonito de ver, sabe? Eu era daqui mesmo, trabalhava ali no matadouro do 21, vinha tudo de cavalo, charrete, o povo vinha de longe, quermesse bonita, cheia, tinha até aqueles guardachuva de doce [...] (Relato colhido de um dos antigos familiares de festeiros em 04 de maio de 2016, em meio à Festa de Santa Cruz na Aldeia de Carapicuíba)
\end{abstract}

Sem ignorar as transformações no mundo do trabalho, da propriedade da terra e da intensa urbanização, este fato, por si só, não dá conta de qualificar a complexidade que

Guaçu, Ferraz de Vasconcelos, Francisco Morato, Franco da Rocha, Guarulhos, Itapecerica da Serra, Itapevi, Itaquaquecetuba, Jandira, Mairiporã, Mauá, Moji das Cruzes, Osasco, Poá, Pirapora do Bom Jesus, Rio Grande da Serra, Ribeirão Pires, Santana do Parnaíba, Santo André, São Bernardo do Campo, São Caetano do Sul, São Paulo, Suzano, Taboão da Serra.

${ }^{73}$ A materialização da política nacional neste tema, em especial, é dada com o ato de sanção legal de oito regiões metropolitanas em 1973: Belém (com 2 municípios); Belo Horizonte (com 14 municípios); Curitiba (com 14 municípios); Fortaleza (com 5 municípios); Porto Alegre (com 14 municípios); Recife (com 09 municípios); Salvador (com 08 municípios); São Paulo (com 37 municípios). E, em 1974, da unificação do Rio de Janeiro e Guanabara, cria mais uma região metropolitana, a do Rio de Janeiro (GOUVÊA, 2005). 
carrega o espaço geográfico. Sobretudo na contemporaneidade, em que o modo de produção ressignifica as cidades, regiões e países, segundo estratégicos interesses, mas também incorporam dialeticamente a própria condição de resistir a ele. Diversos são os casos, como os redutos agrícolas e um modo de vida relativamente camponês que sobrevive em plena mancha urbana paulistana. Ao revés, muitos exemplos podem ser indicados de cidades, que mesmo distantes das metrópoles, possuem aspectos relativamente semelhantes a uma grande cidade, inclusive, com a própria negação dos vínculos rurais em razão de um potencial significado de modernidade vinculado pelos padrões de urbanidade.

A questão do patrimônio cultural, para além mesmo do exemplo setorial, é uma das mais importantes qualidades deste processo. Além de permear todas as atividades produtivas, já que os bens estão diretamente enraizados pelos sujeitos nos territórios, o fato é que a cultura não necessariamente expressa a forma direta e mediata no espaço geográfico. Mas revelam em seus conteúdos o plano intangível das representações, das diversas temporalidades que guardam as tradições, os sentimentos de pertencer, os de existir e as condições de reprodução da vida em sociedade. Mesmo que marcadamente pressionada pelas relações de produção, a cultura exerce relativa autonomia da economia, transportando no espaço elementos e fenômenos residuais, rugosidades patrimoniais que, por vezes, não estão configuradas nas narrativas históricas oficiais, mas gravadas efetivamente no corpo e na mente dos indivíduos e grupos.

Olha aí, essa casa mesmo é de 1953, um patrimônio aqui, ninguém sabe, só a gente daqui mesmo. Tudo do patrimônio é lá sobre a Aldeia. Pois aqui era tudo pasto, aí era um campo de futebol bem grande, ia até aquela esquina, saudade viu? Da família só fiquei eu, aqui cresceu demais, mas a gente não esquece, não esquece nada [...]. (Entrevistado 06, morador da UIT Centro, 64 anos).

Rapaz, eu gosto daqui, cresci no bairro, tudo que conquistei foi aqui, com muita luta, sabe? Não tinha nada, era tudo precário, a gente vivia como dava. [...] Lembrança é dos amigos, da família, do CSU né, do futebol, da rapaziada lá. Eu não tenho intenção de mudar, aqui fiz minha vida. (Entrevistado 07, morador da UIT Cidade Ariston, 45 anos).

Em Carapicuíba, porém, fundem-se muito particularmente os planos do patrimônio cultural, tanto do intangível, quanto do material, se é que uma separação seja coerente. Realidade que carrega desde os alicerces coloniais da formação territorial da maior metrópole brasileira, até as especiais tradições e modos de viver historicamente no quadrilátero da 
Aldeia. Contribui não apenas ao pensamento multiescalar e dialético da produção particular das famílias locais, do próprio município, ou da RMSP, mas da sua condição universal estabelecida nas estratégias coloniais, na renda da terra, na reserva de mão de obra, ou na consolidação de uma das maiores aglomerações espaciais do planeta. Ao mesmo tempo, permanecendo parte das festividades tradicionais, os ritos, as relações entre as famílias que desde muito tempo guardam relíquias imateriais nas tantas memórias que as envolvem.

Ao considerar vários documentos, mapas, relatórios, estudos e levantamentos técnicos, além dos diálogos com a população local, as análises levam a considerar a centralidade dos elementos normativos, que não apenas contextualizam o desenvolvimento das rugosidades nas décadas de 1980 até hoje, como detalham intervenções precisas de restauro e orientação dos moradores locais desde 1940. A reflexão é sobreposta também às políticas estabelecidas na escala municipal em congruência com os da região metropolitana, bem como as recomendações internacionais que subsidiam o pensamento e as práticas de conservação, preservação e difusão do patrimônio cultural desde então. Outro elemento que se descortinou, tornada central nas análises, foi a Festa de Santa Cruz na Aldeia, uma proeminência da sacralização do rito e do espaço, que permite rememorações e relações combinadas entre antigos moradores em meio as festividades.

A metropolização de Carapicuíba, historicamente operada em favor de São Paulo, passa à condição institucional, do qual a gestão e o planejamento de seus territórios estão normativamente encadeados a entidade regional. Em grande medida, a política urbana agora estará compassada à política cultural, onde o papel da Aldeia desponta como central nos primitivos planos de desenvolvimento territorial e do qual o PDDI de 1981 destaca. Ele deriva da institucionalização da metrópole paulista, de um processo mais amplo de debates em torno das primeiras políticas metropolitanas travadas em São Paulo, que deriva no zoneamento do conjunto como área de interesse especial, por seu valor histórico. Este documento legal acaba por apoiar mais amplamente o desenvolvimento metropolitano e, por sua vez, orienta o parcelamento e regularização do uso do solo de Carapicuíba, instituído pela Lei 714, de 25/04/1984. De fato, entre as décadas de 1960 e 1980, ainda que pioneiro e incipiente, além do DPHAN, depois o IPHAN, como também o CONDEPHAAT ${ }^{74}$ (que tomba o conjunto ex-

\footnotetext{
${ }^{74}$ No estado de São Paulo é criado o Conselho de Defesa do Patrimônio Histórico, Arqueológico, Artístico e Turístico - CONDEPHAAT, por meio da Lei $\mathrm{n}^{\circ}$ 10.247, de 22 de Outubro de 1968. O conselho foi instituído com a finalidade de proteger, valorizar e divulgar o patrimônio cultural no estado de São Paulo. Estas atribuições foram confirmadas, em 1989, pela Constituição do Estado de São Paulo, através do Artigo 261, deliberando que
} 
officio em 24/07/1974) atuarem diretamente sobre o conjunto, a municipalidade, bem como a entidade regional representada pela EMPLASA, passam a integrar comissões no sentido de racionalizar e qualificar as premissas de preservação da Aldeia de Carapicuíba. Esta, cada vez mais pressionada em relação à explosão demográfica em curso e, por consequência, a ocupação irregular do entorno, bem como das intervenções modernizantes em todo conjunto. Se a retórica da perda é fundamental aos projetos políticos da Aldeia enquanto documento da história nacional, os conflitos com os moradores locais se acentuavam pelas novas restrições estabelecidas no acesso e usufruto das modernizações.

Contraditoriamente, essas políticas se acentuam concomitantemente ao abandono institucional da área nos anos anteriores. Em ofício ${ }^{75}$ da direção da $9^{a}$ DRSPHAN ao Ministério da Cultura (MINC), datado de 1986, notificando sobre as proposições de planejamento da EMPLASA e o enquadramento do conjunto urbanístico e arquitetônico da Aldeia na lista de prioridades e interesses do Programa de Recuperação e Revitalização de Núcleos Históricos do MINC, é possível ratificar as proposições aventadas anteriormente. Pois, no referido documento, exaspera-se o caráter da tensão exercida pela metropolização. Num primeiro ponto acerca do trânsito que gradativamente impacta os bens, depois pelas ocupações irregulares no entorno, descaracterizando a paisagem nos limites do monumento tombado e, ao final, a precária condição do próprio conjunto, referindo-se mais especificamente às casas, como ilustra a Figura 36.

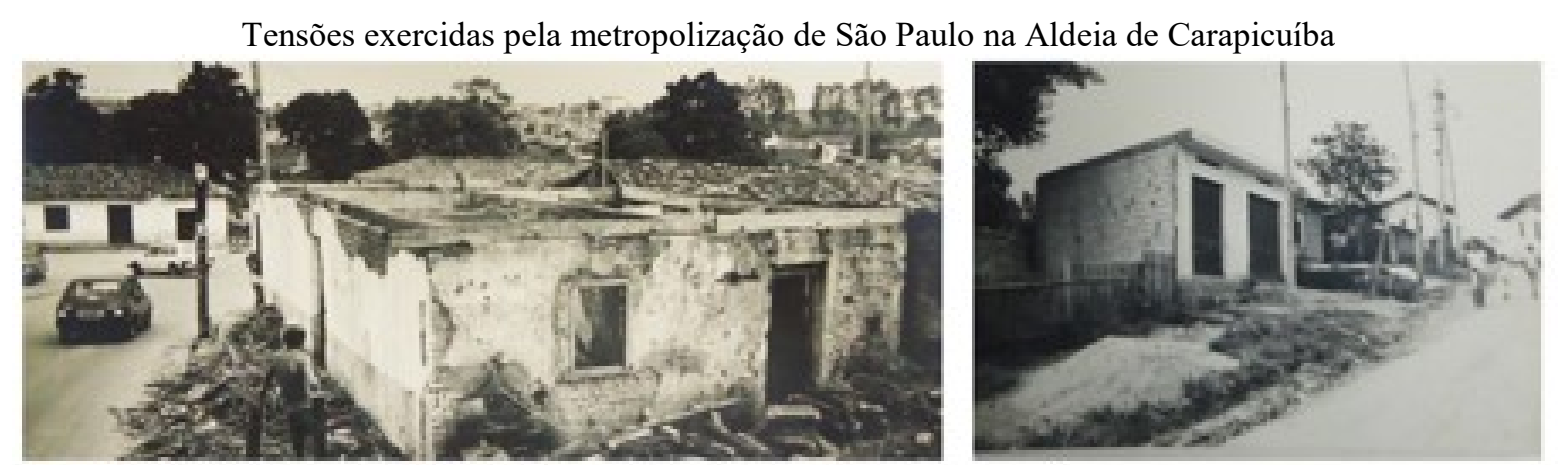

Figura 36: À esquerda, imagem da casa 16, parcialmente destruída. À direita, imagem de uma casa de alvenaria, situada às margens do conjunto.

Fonte: $9^{\text {a }}$ SRIPHAN/SP - 1983. Organizado pelo autor, 2016.

o "Poder Público pesquisará, identificará, protegerá e valorizará o patrimônio cultural paulista, através do Conselho de Defesa do Patrimônio Histórico, Arqueológico, Artístico e Turístico do Estado de São Paulo.” (CONDEPHAAT, 2010).

75 Ofício número 177 (?) de 08 de agosto de 1986 (SRDPHAN/FNPM). Disposta atualmente na 9a Superintendência Regional do IPHAN/SP. Arquivo: Pasta 00064-0218-T-39-5/11(5). Conjunto Arquitetônico e Urbanístico (Intervenção em Bens Imóveis Tombados). 
A justificativa do órgão em defesa do monumento frente à metropolização neste documento é complementada por outras alegações, como a da singularidade da Aldeia, ao tratar-se do único conjunto de edificações tombadas pelo SPHAN no estado de São Paulo que seria testemunho dos primeiros séculos de colonização. Exalta-se, outra vez mais, o caráter reduzido geograficamente de conjuntos tombados em âmbito federal em São Paulo. Ainda conforme o ofício supracitado, pela relativa simplicidade e fragilidade do conjunto, mereceria atenção especial considerando a sua importância histórica. Essa separação e individualização da Aldeia de Carapicuíba da totalidade urbana-metropolitana, faz dela uma anomalia, a qual seus moradores, gradativamente são surpreendidos com ações verticais e pouco democráticas sobre seus espaços de vida. O que para Scarlato e Costa (2013) representaria um deslocamento de pensamentos e práticas, que agravam a perda da existência histórica e memorial, ao tentar segmentar e separar o fragmento da totalidade sem a ela retornar os fatos ante as contradições e identidades que revelam a cidade. Esta segmentação da Aldeia de Carapicuíba privilegiaria a salvaguarda fragmentária, que reverbera a história da cidade numa história institucional, catalisada formalmente em bens específicos, desconsiderando que ela só se revela em relação ao todo.

Os limites ampliados da metropolização fazem com que os requerimentos e pedidos diversos de intervenção a $9^{\text {a }}$ SRIPHAN/SP deixem as pequenas obras pontuais dos moradores, para agora se concentrarem na avaliação sobre pedidos de criação de loteamentos adjacentes e áreas industriais pela municipalidade, como o Parque Jandaia, ou o Distrito Industrial. As discussões ainda concentram-se, por fim, nas novas demandas modernizantes da área, o que poderia impactar diretamente o conjunto, porém, dialeticamente, quando já se estabelecia a sua degradação pelo relativo abandono dos próprios órgãos públicos e a incapacidade técnica, procedimental e financeira dos moradores na preservação. Já em princípios da década de 1990, como evidenciam as imagens das Figuras 38 e 39, obtidas por levantamento de equipe técnica do IPHAN, as condições arquitetônicas e urbanísticas da Aldeia mantinham-se, como na década anterior, bastante precárias, inclusive com o avanço de postes, fios elétricos, ocupações e construções modernas que gradativamente iam descaracterizando paulatinamente a tão buscada originalidade do conjunto.

Mesmo as orientações legais, como a mudança do fluxo de veículos, permaneciam sem qualquer alteração, prevalecendo o descompasso dos projetos e estratégias elencadas 
conjuntamente em relação às práticas exercidas naquele espaço. Ao longo dos levantamentos, observa-se que além das premissas teóricas assentadas no fenômeno de urbanização e do processo de metropolização, emergem importantes pistas das tensões exercidas pelas novas dinâmicas de aglomeração e do sistema cultural sobre as rugosidades patrimoniais de Carapicuíba. Tensões estas que não apenas resultam da destruição de parte das formas geográficas tombadas, ou das mudanças funcionais dos espaços, mas também de sua reprodutibilidade técnica, ou da manutenção da própria paisagem. Se num momento estas ações são coordenadas e orientadas por técnicos do patrimônio, base institucional que pensa normativamente e aplica consolidadas diretrizes internacionais, em outro sobressaem soluções alternativas da população, das quais condicionam a reprodução da vida em grupo e se cristalizam na precariedade de sua sobrevivência (Figuras 37 e 38).

Impactos resultantes da metropolização na Aldeia de Carapicuíba - 1991
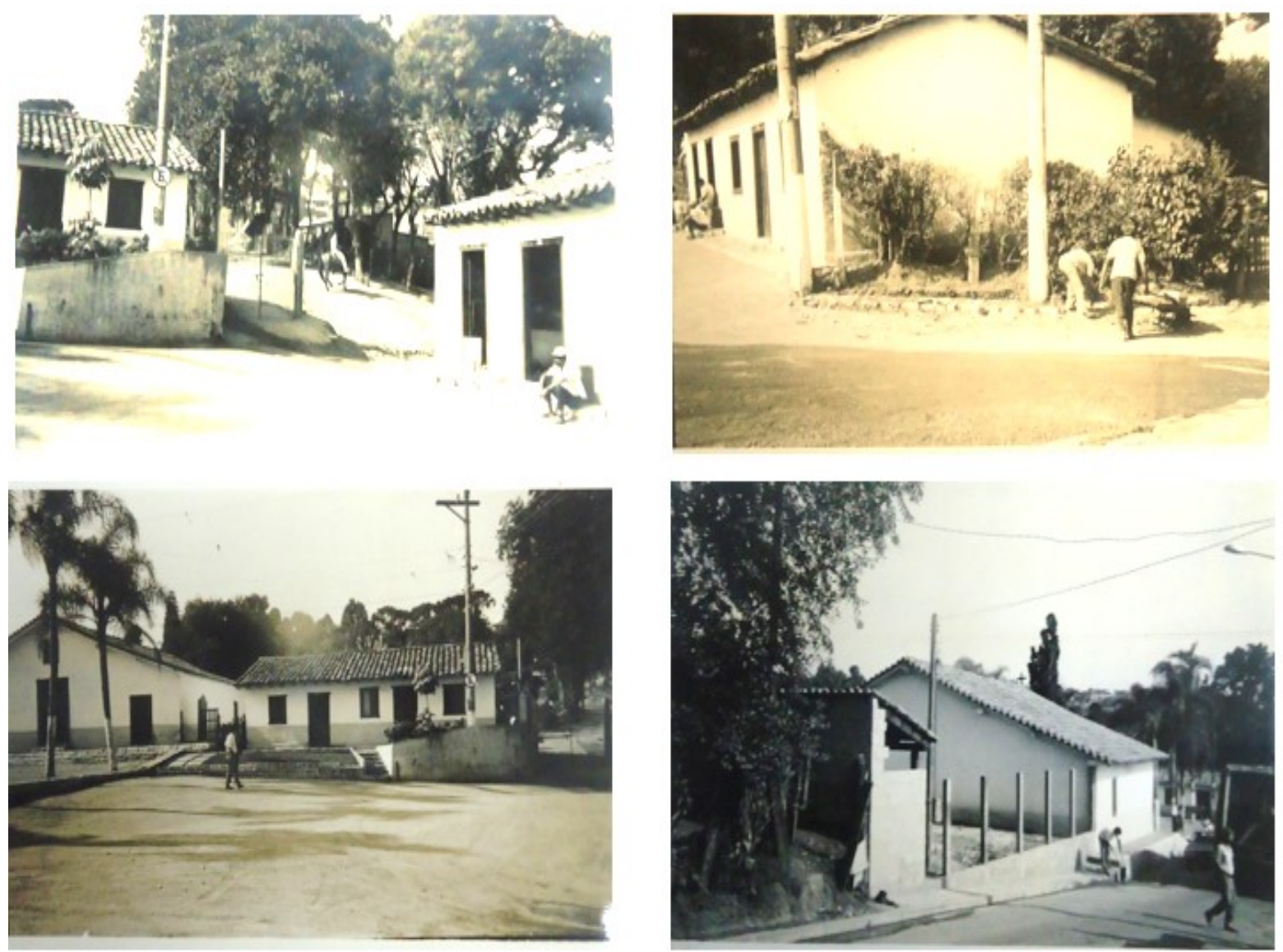

Figura 37: Fotos mostram diversas descaraterizações sofridas entre as décadas de 1970 e 1980: postes, calçamentos, cobertura do solo por massa asfáltica e novas construções.

Fonte: 9a SRIPHAN/SP - 1991. Organizadas pelo autor, 2016. 


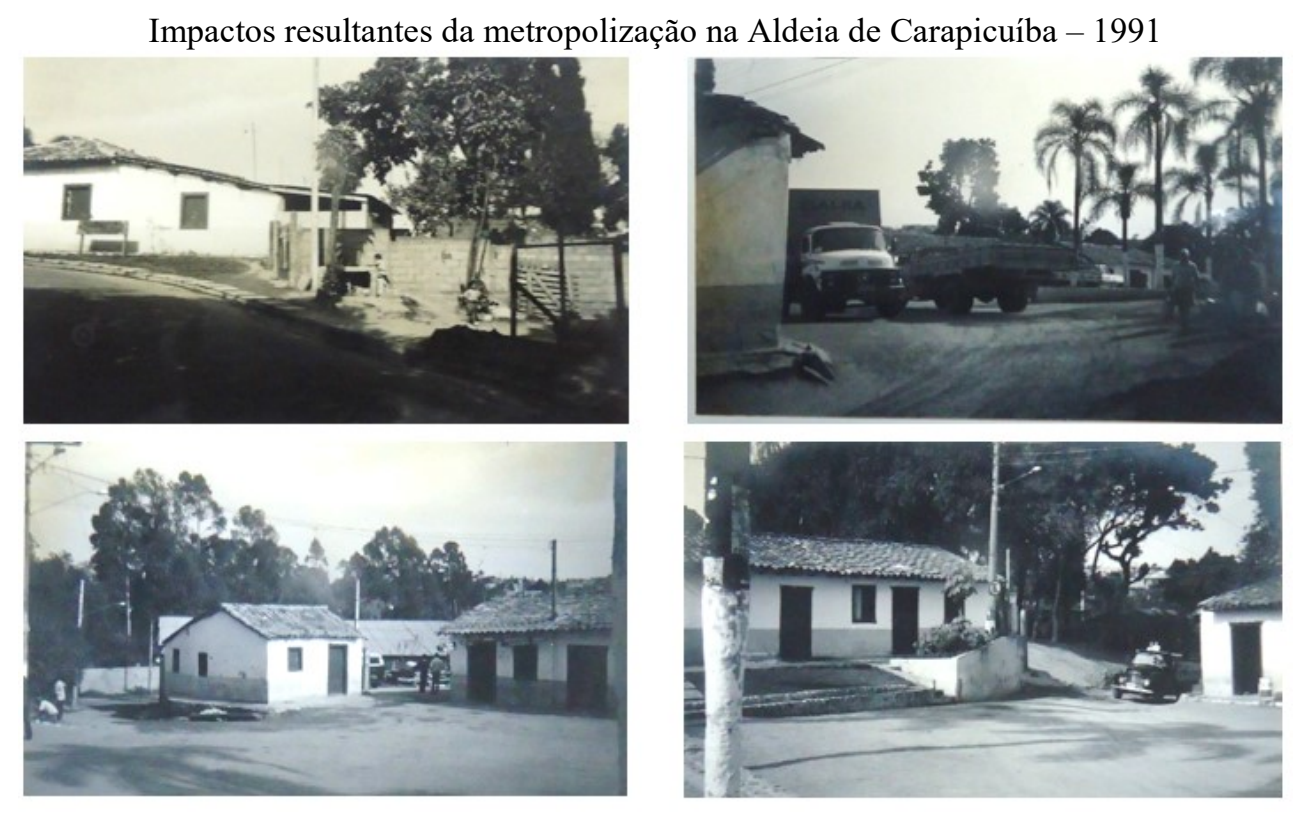

Figura 38: Fotos mostram diversas descaraterizações sofridas entre as décadas de 1970 e 1980: postes, calçamentos, cobertura do solo por massa asfáltica e novas construções.

Fonte: $9^{\text {a }}$ SRIPHAN/SP - 1991. Organizadas pelo autor, 2016.

No primeiro plano, das formas e espaços em microescala, várias adaptações foram realizadas nas casas sem devida orientação, ou em outros casos em que não houve soluções dos moradores, respeitando-se o tombamento e as bases institucionais, as condições eram de abandono e precariedade. No segundo plano, da escala metropolitana, havia em curso, em toda a área do entorno e grande parte dos subúrbios paulistanos, o processo de favelização, consumado pela periferização de todo território de Carapicuíba, do qual a Aldeia não era poupada. Além disso, praticamente todas as diretrizes do PDDI (1981), ou aquelas estabelecidas na década anterior pelo plano diretor municipal, não haviam sido efetivamente realizadas, como o desvio do trânsito da Aldeia, ou a criação de espaços mais adequados visando o estacionamento de veículos, ou a realização de atividades menos impactantes. Obras de modernização se efetivaram contrariamente às orientações dos planos, como o asfaltamento do largo, ou a construção de um amplo degrau para proteção do cruzeiro jesuíta diante do trânsito pesado pela Aldeia. Em terceiro plano, do fenômeno urbano, a reprodução do drama nos subúrbios paulistanos verificava-se nos graves problemas econômico-sociais, materializados tanto pelo desenvolvimento desigual das regiões em escala nacional, quanto pelas determinações da divisão territorial do trabalho nas perversidades observadas fundamentalmente nos países subdesenvolvidos.

Por fim, no período de periferização de Carapicuíba, que se acentua entre as décadas de 1970 até fins da década de 1990, resistem grande parte dos bens diante do relativo 
abandono institucional e das modernizações que se operam em seu entorno, ou que se estabelecem no próprio conjunto urbanístico e arquitetônico demarcado e instituído. No caso imaterial, plano que talvez mais tenha se transformado neste contexto, cabe destacar, novamente, a continuidade da Festa de Santa Cruz como elemento central da valorização simbólica e funcional do espaço que se perpetuava no tempo. Cabe destacar ainda o papel da entidade federal após tombamento, além de órgãos estaduais, metropolitanos e municipais que passam gradativamente a apoiar projetos e ações sobre o patrimônio cultural ali situado. Esta realidade permite defender, uma vez mais, que se não diretamente, ao menos indiretamente o Estado potencializou a permanência de algumas rugosidades patrimoniais, ligadas sobretudo ao conjunto arquitetônico e que constituiu ideologicamente a produção de valor dos bens ali edificados. Não tão efetivo, porém, foi a ênfase nas circunstâncias imateriais e dos simbolismos enraizados na cultura caipira e das tradições religiosas.

Elementos que, todavia, as famílias conservavam por mais de um século naquele lugar e que concomitantemente a preocupação institucional com as formas geográficas da Aldeia, iam mantendo como podiam as tradições seculares. Os desdobramentos da vida cotidiana moderna impactavam diretamente esta realidade, que nos leva a acreditar que a concretização das festas e tradições só foi possível graças aos esforços coletivos das famílias que tiveram seus filhos e netos ainda iniciados nas atividades pretéritas, mantendo-se em pleno século vinte e um. O que, no entanto, não assegura plenamente a reprodução mais contemporânea destas manifestações culturais pelas novas gerações. Se foram estas manifestações condições operantes mais fundamentais da permanência do pequeno povoado caipira, do conjunto relativamente isolado e com importantes funções religiosas, "descoberto" e descrito por Luís Saia em 1937, com a normatização estabelecida pelo Estado em 1940, a dinâmica de atuação institucional e a de expansão metropolitana, levam a questionar qual exatamente seria o papel da população local nestes novos tempos? Se foi condição fundamental da preservação no passado, com a realização dos ritos e a reprodução das tradições religiosas e profanas no espaço da Aldeia, fortalecendo laços e rememorando sua unidade, como isso funcionaria precisamente em períodos mais recentes? $O$ evento da patrimonialização altera em que sentido esse papel historicamente exercido pelos moradores na permanência do espaço e reprodução das relações sociais? Estas questões são algumas à balizar as reflexões seguintes e que se concatenam também no capítulo final da tese. 


\subsection{Os conceitos de subúrbio e periferia para pensar as rugosidades na metrópole de São Paulo}

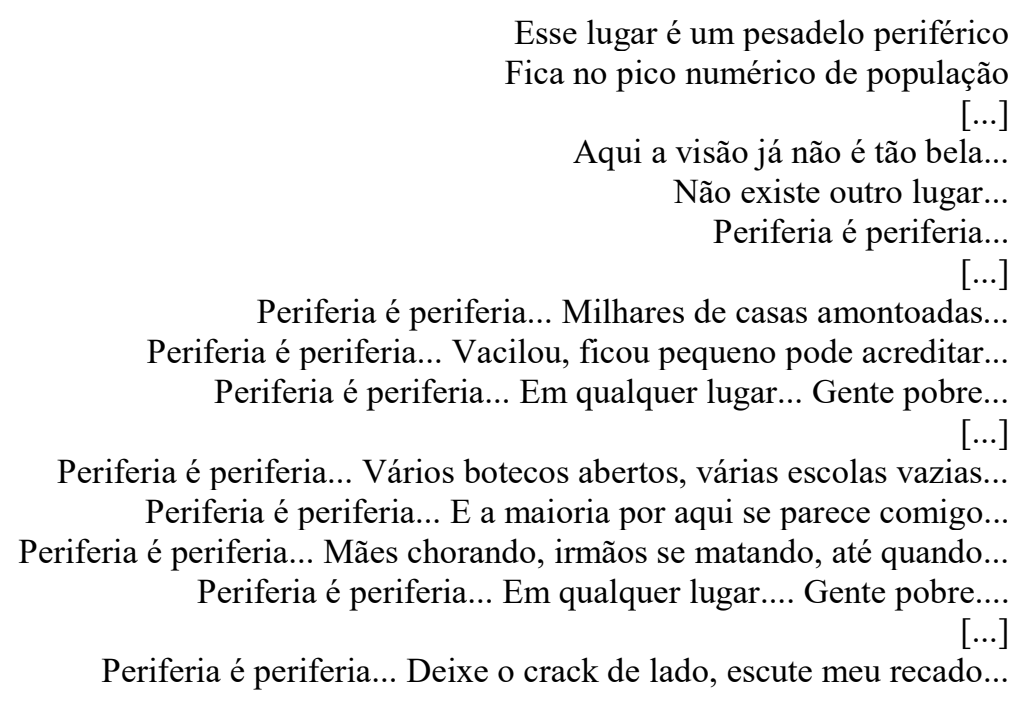

Esse lugar é um pesadelo periférico pico numérico de população

Não existe outro lugar.

Periferia é periferia...

$[\ldots]$ eriferia Vacilou, ficou pequeno pode acreditar..

Perifé . . Vários botecos abertos, várias escolas vazias... é periferia Mães chorando, irmãos se matando, até quando...

(RACIONAIS MC'S - Periferia é periferia)

A letra "Periferia é periferia" do grupo de rap paulistano "Racionais $M C$ 's" evidencia algumas qualidades fundamentais do fenômeno de periferização resultante do fenômeno urbano-metropolitano. O pesadelo de viver às margens da civilidade, nas grandes aglomerações humanas de um país subdesenvolvido, com prevalência da pobreza e violência, são focos musicados pelos artistas que cresceram e vivem no Capão Redondo, uma das maiores áreas periféricas de São Paulo. A visão da paisagem, segundo eles, já não é tão bela: lixo, viciados, drogados, botecos, escolas vazias. O trabalho precário e marginalizado, que ocupa o tempo da população, permite que seus filhos sejam cooptados pelo crime, pelo tráfico, perpetuando a reprodução dos graves problemas sociais que afligem esses lugares. Fruto do modo de produção e da urbanização contemporânea, a periferia se concretiza em múltiplas escalas. São, pois, fatos urbanos, concretudes do processo de metropolização, subconjuntos das grandes cidades. Uma unidade, no entanto, se sobressai, "periferia é periferia em qualquer lugar" e "a maioria aqui se parece comigo". Respectivamente, universalidade e relações de pertencimento pela semelhança despontam na música, mostrando a unidade, as relações de familiaridade e de vínculos sociais.

Slums é o termo anglo-americano que Mike Davis (2006) atribui às novas formas de habitar e sobreviver num submundo de pobreza generalizado. Trata-se de uma das facetas da generalização do fenômeno urbano, a generalização das favelas, dos barracos, o "climatério urbano" em que se ultrapassa na atualidade a marca de um bilhão de seres humanos empobrecidos nas cidades, sobretudo dos países subdesenvolvidos, mas não apenas nelas. Tal realidade desponta no filme "O Ódio" de Mathieu Kassovitz, analisado por Harvey (2013), 
em relação aos subúrbios franceses, cenário onde há maior convergência de semelhanças, do que propriamente diferenças da situação de vida periférica entre o mundo desenvolvido e subdesenvolvido. Em uma das cenas é possível observar a surpresa dos jovens da periferia, que protagonizam o longa-metragem, ao recebem tratamento cavalheiro e cordial dos policiais no centro de Paris, em relação à truculência que agem nos espaços marginais da capital. Os três jovens amigos que vivem na periferia parisiense ainda carregam origens conflitantes: o primeiro ascendente africano, o segundo judeu e o último árabe, todos, porém, tem na marginalização do êxodo uma raiz identitária, assim como uma trajetória geográfica comum que os une. Assim também, o que dizer dos guetos étnicos e de pobreza no Brasil, ou Estados Unidos (países tão diferentes)? Musicados pela banda de rock carioca O Rappa, há um trabalho cuidadoso em exprimir essas semelhanças no refrão: "tudo, tudo, tudo, tudo igual / Brixton ou Bronx ou Baixada / Salve o jazz, baião e os toques da macumba também"76. Seus versos apontam para as universalidades do gueto em vários pontos do planeta, da exclusão, ou da segregação étnico-espacial que se agrava, sem restrição, nos grandes centros metropolitanos. Se a generalização do urbano traz novas dinâmicas sociais é este fato que obriga também novas reflexões em relação às cidades nas ciências humanas e sociais. A sociedade urbana (LEFÈBVRE, 2012), enquanto uma hipótese teórica central é uma importante baliza, assim como as hipóteses abaixo colocadas, que do mesmo modo carrega uma carga de ambiguidade e não encerram qualquer discussão, ou tese. Tornam-se, em verdade, um ponto de partida e não um ponto final.

\begin{abstract}
A urbanização assumiu as raias de uma hiperurbanização, especialmente a partir da década de 1950, tendo o ritmo de urbanização sofrido uma aceleração que originou uma grande revolução ecológica, política, econômica e social na organização espacial da população mundial. A proporção da população global em crescimento que vive nas cidades duplicou em trinta anos, e observamos atualmente maciças concentrações espaciais de pessoas numa escala até agora julgada inconcebível. Vêm se formando cidades e sistemas urbanos mundiais (como os que surgem, por exemplo, em toda a Europa) que têm tido rápidos efeitos de transformação no funcionamento da economia política global. Os centros urbanos e suas regiões metropolitanas tornaram-se entidades competitivas bem mais importantes na economia mundial, com todo tipo de consequências políticas e econômicas (HARVEY, 2013, p. 94).
\end{abstract}

Os modelos espaciais clássicos, destacadamente o de centro e periferia, são colocados em xeque frente ao fim das antigas dicotomias urbano-rural (em que as noções de campo e cidade passam por novas conceituações: ruralidades e urbanidades no que tange ao sistema

\footnotetext{
${ }^{76}$ Brixton, Bronx Ou Baixada. O Rappa. Compositor: Marcelo Yuka e Nelson Meirelles - DRX - LPA.
} 
cultural; em relação à aglomeração torna-se comum o termo "rurbano" - junção entre espaços aglomerativos e difusos da cidade e do campo; no plano econômico, a revolução verde moderniza o campo, gerando a agroindústria e novas cidades rurais, entre outras dimensões que podem ser exploradas), como também entre as escalas geográficas local-global (cidades globais, cidades mundiais, teorização sobre as redes, seus fixos e fluxos). O peso da história também parece padecer frente à era dos "pós" ("pós-moderno", "pós-industrial", "pósurbano") e das distopias. Elementos que indubitavelmente confrontam o pensar dos conceitos de periferia e de subúrbio, que mudaram radicalmente com a expansão do fenômeno urbano e o crescimento das cidades.

Em verdade, no âmbito da lógica dialética todos os modelos podem e devem ser colocados em prova. O modelo, como mera tautologia representativa da imaginação, da criação abstrata e subjetiva do ser social, é uma produção frágil e contextual da cultura: seja ele religioso, científico e até filosófico. Como sinaliza Harvey (1992), logo na tese introdutória de sua mais representativa produção, as mudanças em curso no mundo contemporâneo são seletivas e parciais, cujos propósitos ainda continuam a ser o da reprodução das relações capitalistas, bem como da força de trabalho numa nova dimensão internacional, mais complexa e reestruturada espacialmente. “[...] Essas mudanças, quando confrontadas com as regras básicas de acumulação capitalista, mostram-se mais como transformações da aparência superficial do que como sinais do surgimento de alguma sociedade pós-capitalista ou mesmo pós-industrial inteiramente nova.” (HARVEY, 1992, p. 08).

Soja (1993) também desmantela tais conjecturas, ao evidenciar as reestruturações espaço-temporais como momentos recentes estabelecidos pela necessidade de ampliação do modo de produção capitalista em meio a uma série de crises contínuas ${ }^{77}$ no pós-guerra. Assim, pois, o fim de uma era, do passado, não pode ser jogado fora ou descartado e, portanto, a história como presente é o pilar crítico do desenvolvimento capitalista das cidades

\footnotetext{
77 “[...] Mais especificamente, elas podem ser vistas como uma cadeia complexa de crises: na divisão internacional do trabalho estabelecida e na distribuição global do poder político e econômico; nas funções expandidas e hoje claramente contraditórias do estado nacional; nos sistemas previdenciários keynesianos e nos contratos sociais estabilizadores entre governos, empresas e a mão de obra organizada; nos padrões de desenvolvimento regional desigual que se haviam tornado tão solidamente estabelecido dentro do dos países no século anterior; nas formas de exploração das mulheres, das minorias e do meio ambiente natural; na morfologia espacial, na industrialização e no financiamento financeiro das cidades e das áreas metropolitanas; na concepção e na infraestrutura do meio ambiente construído e do consumo coletivo; e nos modos como as relações de produção capitalistas se imprimem na vida cotidiana, desde o processo de trabalho no local de trabalho até a reprodução da vida, da mão de obra e do poder patriarcal na família e no lar.” (SOJA, 1993, p. 194-195).
} 
na nova ordem urbano-global (COSTA et. al., 2015). Harvey (2013) é ainda mais crítico, ao ver diversas narrativas trazerem a globalização como fenômeno atual da reestruturação capitalista, quando, em verdade, este se opera no mínimo desde a expansão colonial no século quinze. E, contraditoriamente, ao tempo em que se realiza uma drástica organização geográfica, falsamente destituída de conflitos e tensões, em favor da fluidez e permeabilidade do modo de produção, mais visíveis ficam as lutas entre classes e entre os lugares, que "com muita frequência se interpenetram, e que o capitalismo pode muitas vezes conter a luta de classes por meio de uma estratégia de dividir para governar aplicada a essa luta" (HARVEY, 2013, p. 85).

Entendendo estas mudanças pela ótica de diversas intervenções estruturais das cidades e o novo arranjo espacial do urbano, gestados a partida década de 1970, é necessário que se faça uma reflexão crítica de que, apesar de avanços, as relações nas grandes cidades continuam a favorecer a reprodução ampliada da condição de desigualdade, onde as novas etapas selam o retrógrado padrão de pobreza e acumulação extremos (ARANTES, 2002). Altera-se os contextos, reestrutura-se a produção, que é concentrada e, depois, pulverizada, e se perpetuam intervenções de todos os níveis e escalas nas cidades, adaptadas a fluidez do capital e dos grandes projetos internacionais para seletivos territórios. Passamos de uma cidade que condiciona a produção de valor e a acumulação, para uma metrópole que é em si o próprio valor de troca materializado enquanto mercadoria, sendo geridas e consumidas para a acumulação em todo planeta. Portanto, altera-se determinadas relações importantes, mas a mesma lógica produtiva se perpetua outra vez mais, sobre diferentes ângulos, novas práticas e denominações.

\footnotetext{
Ora, a impressão que se tem é que, apesar da nova fraseologia interativa, estamos diante da reposição da armadilha clássica do subdesenvolvimento (ou seja, da modernização sem desenvolvimento, isto é, sem homogeneização social), a velha dualidade brasileira, elevada aliás agora a paradigma da polarização mundializada. Aliás, salta à vista antecipada do skylíne do terciário avançado qual será o padrão que servirá de parâmetro para a valorização recuperadora, o estilo característico da riqueza, por definição não universalizável, do núcleo orgânico do sistema. Esta antena global tampouco irradiará socialmente também, como nunca foi o caso, noutros períodos de reprodução de nossa pobreza em massa, do padrão cosmopolita de consumo das elites periféricas, a cujos requisitos a modernização vinha então atender (ARANTES, 2002, p. 69).
}

No movimento globalizante e globalizador do capital, como drenar todas as especulações criadas em torno de fins e de começos que se teorizam na operação diacrônica das novas posições estabelecidas pelos objetos geográficos? Ou pelas funções despertadas 
indissociavelmente entre uma e outra forma em suas articulações multiescalares? Se a literatura internacional compreende e classifica como subúrbios as cidades e áreas administrativas geograficamente marginais, distantes porém interligadas regionalmente a cidade-polo metropolitana, influenciando escritos em todos os países ao longo do último do século, é a noção de periferia que será edificada como melhor retrato das contradições urbanas do modo de produção capitalista nos países subdesenvolvidos. E, no extremo, da própria conversão do subúrbio em periferia, quando os limites territoriais do grande centro passam a ser virtuais diante do processo de conurbação e a metabolização do aglomerado numa única mancha urbana.

Ao conjecturar acerca da compressão espaço-tempo, Harvey (1992) fundamenta importantes hipóteses das novas dimensões geográficas estabelecidas com o avanço tecnológico dos meios de transporte, de locomoção e mobilidade, mas também das unidades regionais criadas com objetivos econômicos, políticos e culturais. Traduzidas pela noção de “ideologias geográficas”, Moraes (1988, p. 93) explica que a construção das identidades regionais carregam falsas comunidades de interesse. Isso é particularmente importante no caso da pesquisa, considerando que muitos valores locais, nem sempre são concretamente aqueles históricos, mas atuam tão somente aos objetivos corporativos que se constroem na união entre capital e Estado. O que merece cuidado, pois a pulverização destes projetos modernizantes, ou a criação de condições para a difusão dos interesses hegemônicos, só é possível em favor de uma aceitação, uma mentalidade aliada aos fragmentos, cujos regionalismos ou nacionalismos, junto a instalação dos meios técnicos, permitem um fluxo ainda mais intenso de mercadorias, pessoas e serviços, operando simultaneamente como difusores de comportamentos, padrões de vida e modos de se relacionar. Enquanto as limitações geográficas (rugosidades patrimoniais, barreiras, fronteiras, contornos políticoadministrativos), bem demarcadas das periferias ou áreas suburbanas passam a ser tensionadas e reconfiguradas. A metrópole é extrapolada em uma nova dinâmica de limites fragmentados e interconectados, reais e virtuais, onde seus impactos em países subdesenvolvidos, no rebordo marginal do sistema mundo, merece atenção pela peculiaridade destes processos. Ali, as condições de vida revelam o drama que a retórica da modernidade e das ideologias geográficas não exaltaram ou deixaram de explicitar em diferentes fases do processo histórico.

Tal eficácia advém do fato de esses valores servirem à fragmentação da organização popular. As entidades restritas obstaculizam a soldagem dos interesses políticos dos 
dominados, em escalas maiores. O regionalismo é, assim, um grande instrumento de separação e de diferenciação. Observa-se que a identidade pelo espaço, ao mesmo tempo que cimenta concepções nacionais ao nível das classes dominantes, atua na dispersão dos dominados, em seu secionamento no território. Para as elites, o nacional como horizonte geográfico para as classes populares, o local ou no máximo o regional como perspectiva de espaço. Portanto, a concepção do território unindo ou dividindo os sujeitos políticos (MORAES, 1988, p. 101).

Esta fragmentação da organização popular é operada a todo vapor nas grandes cidades, em todo planeta. Do que resulta uma série de concepções e limites conceituais entre espaços marginais, que na prática, derivam da espoliação contínua do trabalho e da terra, mas que na teoria são focos de reivindicações e de projetos ambíguos e diferenciados, ou, por outro lado, clientelistas, populistas e orientados a interesses particularizados de grupos sociais. Porém, antes de entrar propriamente na análise teórico-conceitual das noções de subúrbio e periferia na contemporaneidade, vale um retrospecto que intenta subsidiar um pouco mais sobre seu entendimento e aplicação. Na visão clássica de George (1983), a princípio, a noção de subúrbio desponta enquanto uma unidade territorial, que carrega um sentido deliberadamente pejorativo; daquilo que está fora da cidade, ou seja, desprovido do privilégio dos citadinos. Estes últimos, isentos de obrigações, direitos e deveres. "O subúrbio é, originalmente, e juridicamente, o bairro suburbano que escapa às taxações e obrigações da cidade, mas também de seus privilégios e de sua proteção." (GEORGE, 1983, p. 76). Esta designação é apropriada pela condição de não-cidade que deriva o aldeamento em cinturão caipira, ou mesmo nos limites da industrialização de São Paulo em que Carapicuíba esteve a parte do fenômeno urbano e das civilidades despertadas por ele. O pejorativo remete as tantas falas que os mais velhos moradores indicavam da ausência de infra-estrutura, da designação de "pé sujo" e da distância propriamente que viviam da cidade, de São Paulo.

Em grande parte da Europa ou Estados Unidos, o subúrbio é um bairro distante da cidade e não se configura propriamente como um município ou distrito. Este conceito também perde no tempo a conotação pejorativa, tipicamente europeia diga-se de passagem, ganhando significação de uma área de expansão urbana simplesmente, um centro em particular e, mais atualmente, espaço valorizado, de refúgio das mazelas urbanas e das grandes cidades. $\mathrm{O}$ sentido clássico trazido por George (1983), no entanto, passa a ser mais adequado em certa medida ao conceito de periferia atualmente, no que tange sua carga negativa inicial, ou como no Brasil enquanto qualidade do trabalhador. Esta última qualificação emerge nos discursos e nas formas de agir reforçando em diversas ações, um projeto identitário de classe. Porém, para George (1983), a ideia de periferia estaria associada à de ausência e, pois, de dependência 
local de estruturas regionais, não havendo uma ambivalência de ganhos e perdas que o subúrbio expressaria. O que converge também com as ideias de Martins (2001), que vê a necessidade de separar conceitualmente subúrbio e periferia, entendendo, pois, cada problema que essas unidades possuem em particular.

[...] De todo modo, as zonas periféricas são desprovidas de quadros financeiros, administrativos, culturais, acima da escala estritamente local. Elas são, então, reatadas organicamente, por laços complementares, com a cidade, ou formam complexos arbitrados pela cidade e no interior dos quais efetuam trocas de produtos e serviços (GEORGE, 1983, p. 79).

O problema da periferia é o problema do tumulto da ocupação, o da urbanização patológica, da exclusão, da falta de efetivas alternativas no mundo urbano. $\mathrm{O}$ problema do subúrbio é hoje essencialmente o problema da velhice, do encontro de políticas públicas para lidar com os idosos e, sobretudo, para que continuem tendo crescente acesso a um modo de vida em desenvolvimento, propriamente urbano, que aponta na direção do bem estar social. O problema da periferia é o do desenvolvimento econômico. O problema do subúrbio é o do desenvolvimento social, o da realização ampla das promessas do desenvolvimento econômico que o subúrbio já conheceu. Isso significa, em grande parte, uma revolução cultural (MARTINS, 2001, p. 79).

Mesmo sendo diferentes, periferia e subúrbio podem ser coincidentes. Este é um ponto central, já que a expansão da pobreza, da cidade informal e "não planejada", do desenvolvimento desigual, em vários países e regiões, se materializa nos subúrbios, sobrepondo aspectos muitas vezes remanescentes da cultura rural com a marginalidade periférica produzida pelo sistema urbano. "Os conceitos de subúrbio e periferia reportam-se a realidades diferentes, embora às vezes possam ser coincidentes." (LANGENBUCH, 2001, p.89). As periferias se esparramam desde algumas décadas aos subúrbios, criando uma unidade totalmente compacta e complexa, que pode ser exemplificado com o caso da expansão do Capão Redondo entre São Paulo e Embu das Artes, ao sudeste da RMSP, ou mesmo entre Osasco e Carapicuíba, na zona oeste, em meio a expansão dos conjuntos habitacionais. No entanto, se o limite administrativo é fundamental na caracterização de subúrbio, a periferia não depende necessariamente de uma localização, menos ainda da formalidade jurídica e normativa de estar contida no perímetro urbano, de um núcleo da região metropolitana, ou áreas rurais. Esta pode estar no centro de Paris, ou no subúrbio de Mumbai, no centro de São Paulo, ou nos limites da metrópole, como Itapevi (município da RMSP), ou em Parelheiros (extremo sul do município de São Paulo). 
Periferia não pressupõe a intercalação entre ocupação urbana incipiente e campo, que nos subúrbios se não for mais verificada hoje, já ocorreu no passado. Pelo contrário, a periferia pode ser caracterizada por elevada densidade de construções urbanas e pessoas, quase sem deixar espaços abertos em seu permeio. Também não há nenhuma vinculação com limites administrativos, que no caso dos subúrbios pode ou não ser considerada fundamental. Quando se fala em periferia, quase sempre o pensamento recai em espaços de uso residencial (com o pequeno equipamento de comércio e serviços necessários ao atendimento local), raramente se incluindo áreas industriais na concepção mental, enquanto para os subúrbios, tanto geógrafos franceses como americanos, seguidos pelos brasileiros propõem até classificações funcionais, adjetivando-os: residenciais, industriais recreativos, hortícolas, etc. Além disso, o termo periferia é empregado em várias escalas diferentes (LANGENBUCH, 2001, p. 89).

Para Bonduki e Rolnik (1979) é importante definir periferia como parte do território da cidade com baixa renda diferencial. Segundo os autores, as noções geográficas de periferia (margem, distância do centro), ou sociológicas (habitação das classes trabalhadoras) seriam insuficientes sem esta perspectiva econômica da renda fundiária e sua valorização relacional pela presença de equipamentos urbanos. Recentemente, ao estudar a construção social do conceito de periferia, utilizando como recorte a metrópole de São Paulo, Tanaka (2006) chega à conclusão de que sua maior contribuição carrega "carga conceitual contida na noção sociológica de singularidade de uma sociedade subdesenvolvida" (TANAKA, 2006, p. 138 grifo nosso). Trata-se da cidade informal, distante da regulação e controle do Estado, mas que dialeticamente nutri a cidade formal e só existe em relação a esta. Assim, portanto, sua generalização é muito dificultada, já que cada favela, cortiço e conjuntos de barracos, mesmo contendo elementos comuns, tem na dimensão relacional, da qual dialoga-se com Bourdieu (1999), de cidades e contextos específicos o quadro fundamental de suas características.

Segundo ainda autora supracitada, o conceito de periferia sofreu esvaziamento ao longo da década de 1990, o que hoje seria insuficiente arcabouço explicativo da realidade urbana, um descompasso do prospecto teórico em relação à realidade empírica. Segundo ela, o conceito de periferia perdeu seu referencial analítico, sendo incapaz de dar sentido as lutas e movimentos sociais urbanos (TANAKA, 2006, p. 154). Discordamos em grande medida, acreditando do poder de universalização que todo conceito tem, ao menos provisoriamente, bem como no papel identitário e de pertencimento que hoje ganham as periferias em todo planeta. No entanto, em grande medida, se em alguns países os subúrbios são referências de qualidade de vida, integrado à vida urbana da cidade-polo, com certas facilidades de acesso aos serviços e equipamentos públicos e privados, no Brasil ele se confunde por esses aspectos supracitados (renda diferencial do solo urbano, distância das instituições e equipamentos públicos, além de serviços como os de segurança, saúde, ou educação) com a própria 
dimensão de periferia. Trata-se, pois, de uma confusão comum no Brasil, considerando que mesmo o uso político generalizado da noção de periferia, esta possivelmente já vem sendo uma das características do subúrbio, ou de algumas cidades suburbanas, que passaram a receber e concentrar grande parte dos trabalhadores e as populações mais pobres que ali foram se instalando ao longo das últimas décadas do século passado.

Tanaka (2006) ainda insiste que "[...] a produção da periferia explicada pela superexploração da força do trabalho não tem mais o sentido anterior, na medida em que hoje não é mais suficiente explicar a pobreza urbana pelo rebaixamento dos salários dos trabalhadores industriais" (2006, p. 154). De fato, a periferia mudou, talvez não seja explicada exclusivamente pela relação estruturada entre centro-periferia, ou as condições de trabalho do passado, e mesmo talvez pela diferença de renda fundiária. Porém, negá-la como concreticidade espacial da exclusão e, ainda, dissociar desigualdade social da desigualdade urbana (acesso à terra e benefícios da urbanização), justificando sua fragilidade explicativa hoje é desperdiçar anos de formulação teórica e a contribuição de diversos intelectuais latinoamericanos na prática de projetos urbanos nestes espaços. Mais além, é perder o potencial que a noção de periferia ganhou no senso comum e hoje empreende certa unidade identitária e simbólica. Essas dimensões implicam no sentimento de pertencer, grandeza social representada não apenas como reflexo das intenções político-partidárias, ou mera ideologia populista, mas na produção da vida cotidiana, nas diversas atividades práticas. Consequentemente reproduzidas, estas ações podem ser retratadas em alguns versos musicais de "Fim de Semana no Parque" do grupo Racionais MC's, do início da década de 1990 e mais recentemente, com torcedores organizados reverenciando as favelas e periferias em escala mundial, frente a mídia de massa (Figura 39). O que leva a reflexão se as dimensões de periferia se ampliaram, foram reestruturadas, concretamente se moveram para outras áreas e municípios, ou atingiram o plano imaterial dos modos de viver, elas devem ser profundamente analisadas, o que não obriga, e talvez nem seja possível, esvaziar a discussão conceitual de periferia sem o aporte de autores e da realidade ulterior. 
Milhares de casas amontoadas ruas de terra esse é o morro a minha área me espera gritaria na feira (vamos chegando!).

Pode crer eu gosto disso mais calor humano.

Na periferia a alegria é igual,

é quase meio dia a euforia é geral,

é lá que moram meus irmãos meus amigos,

e a maioria por aqui se parece comigo,

e eu também sou bam bam bam e o que manda,

o pessoal desde às 10 da manhã está no samba.

Preste atenção no repique, atenção no acorde

$[\ldots]$

(Racionais MC's - Fim de Semana no Parque - Letra: Mano Brown e Edy Rock) ${ }^{78}$

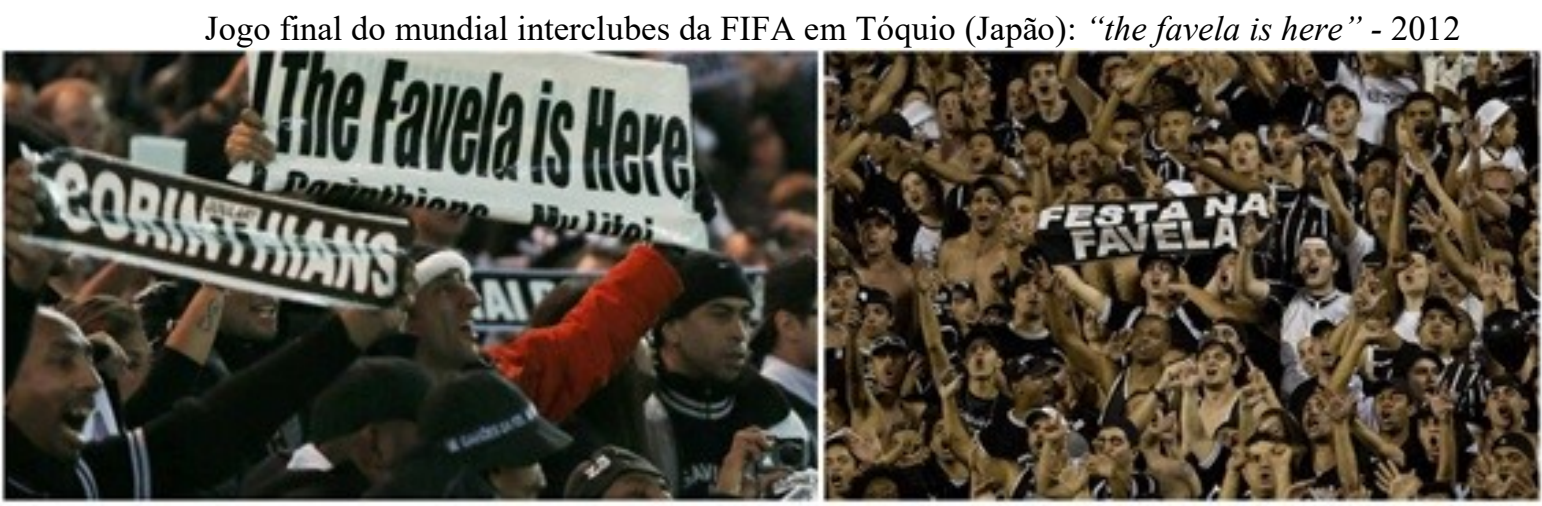

Figura 39: A noção de periferia ganhou o senso comum e hoje empreende certa unidade identitária e simbólica daqueles que sobreviveram anos na precariedade e exclusão das favelas e nos limites do espaço urbano nos países subdesenvolvidos. No detalhe, as imagens mostram a torcida organizada do Corinthians (clube de futebol de São Paulo) com cartazes exaltando sua condição de favelados, condição típica da periferia. Clube da massa, sua torcida organizada Gaviões da Fiel transformou-se em movimento social e é cada vez mais comum observar a expressão favela passando de uma significação pejorativa para outra de batalha, força e resistência.

Fonte: Revista Exame e Blog Maloqueiro Sofredor. Disponível em:

Revista Exame <http://exame.abril.com.br/negocios/noticias/gestao-alca-corinthians-ao-topo-de-receitas-e-ibope>.

Blog Maloqueiro Sofredor: <https://maloqueiroesofredor.wordpress.com/2010/08/.>. Acesso em fev. 2016.

Martins (2001) insiste que a generalização das noções de periferia aplicadas ao subúrbio tornou-se um problema, considerando as particularidades históricas de cada unidade espacial. Segundo ele, "[...] os problemas são completamente diferentes nesses dois diferentes espaços." (MARTINS, 2001, p. 79). De tal maneira que a periferia, segundo o autor, virou uma espécie de doutrina populista e partidária, que funcionaria como barreira ideológica

\footnotetext{
${ }^{78}$ Ao fim da música "Fim de Semana no Parque" há participação especial de Netinho de Paula, do grupo de pagode Negritude Júnior, que exalta lugares das periferias na própria música, como se observa: "Pode crer Racionais Mc's e Negritude Junior juntos, vamos investir em nós mesmos mantendo distância das drogas e do álcool. Aí rapaziada do Parque Ipê, Jd. São Luiz, Jd. Ingá, Parque Ararí, Váz de Lima, Morro do Piolho e Vale das Virtudes e Pirajussara É isso aí mano Brown (é isso ai Netinho paz à todos)". Netinho em seu grupo de música, formado nas Conjuntos Habitacionais (COHAB's) de Carapicuíba, também exalta em suas letras a vida nestes espaços, mostrando as festas e encontros nas COHAB's.
} 
poderosa, em conflito com as populações regionais. Todavia, com os estudos de Kowarick (1979), a noção de periferia torna-se predominante para explicar e referenciar o espaço de vida do trabalhador, enfatizando a espoliação urbana (ausências e precarização do mundo urbano aos trabalhadores - moradia, saneamento, transporte...). Do mesmo modo que Burgos (2008), defende-se que a ideia de subúrbio ficou anacrônica em relação a periferia, justamente em razão do avanço do tecido urbano metropolitano, onde a extensão do espaço tornou-se homogêneo e funcional à reprodução social integradas ao centro e adjacências do núcleo urbano. Segundo Frabetti (2013), Kowarick também foi precursor a utilizar o termo periferia para expressar "[...] zonas urbanas marcadas pela auto-construção das casas proletárias, tendo sido pioneiro no uso desse termo" (FRABETTI, 2013, p. 10). Mais que isso, na própria substituição terminológica de subúrbio para periferia de forma generalizada (FRABETTI, 2013).

De difícil delimitação, Frabetti (2013) faz um esforço teórico e metodológico de retratar as noções de subúrbio e periferia. Segundo o autor, por existir na literatura uma confusão entre os conceitos é necessário, como pensa Martins (2001), distingui-los e delimitálos. Entende-se, porém, que este problema é causado pela diferença que existe na urbanização dos países desenvolvidos em relação aos subdesenvolvidos, fundamentalmente entre Estados Unidos e a América Latina. Do ponto de vista geográfico, enquanto nos Estados Unidos e Europa, os subúrbios são áreas mais distantes dos centros urbanos, na transição com os espaços rurais e ocupados por uma classe média no refúgio dos males urbanos, na América Latina e, mais especificamente no caso do Brasil, a aglomeração suburbana está logo no entorno metropolitano, dos nódulos macrocéfalos da rede urbana. Integrados à economia metropolitana, estes municípios suburbanos ou espaços com graves problemas sociais tipicamente periféricos estão localizados nos limites de enclaves condominiais e do próprio centro de São Paulo. "Neste caso, diferente do que o corre no entorno das metrópoles norteamericanas, o subúrbio no Brasil é caracterizado como área de segregação, e não de autosegregação urbana.” (FRABETTI, 2013, p. 10).

Semelhante é a reflexão de Langenbuch (2001), explicitando que nos Estados Unidos o subúrbio (suburb) é reconhecidamente, científica e popularmente, um espaço distante do centro urbano, porém integrado à cidade. O ponto-chave é, pois, a separação administrativa do subúrbio do centro e suas margens. Neste país, ele representa o espaço de vida cotidiana das classes médias e altas. "É claro que também há subúrbios habitados por pessoas de menor renda, mas esses fogem ao estereótipo.” (LANGENBUCH, 2001, p. 88). No caso da França, 
historicamente avulta o meio rural, associado inclusive a uma etimologia: distante, porém sobre às ordens administrativas urbanas (banlieue). Com a expansão das malhas urbanas, os limites tornaram-se virtuais entre municípios, vilarejos e povoados. Todavia, os termos continuam, tanto em um e outro país, prevalecendo a formalização das divisas administrativas e, pois, o reconhecimento diferenciado de cada unidade urbana. Ao contrário, no Brasil e talvez mesmo por força de nossos geógrafos e geógrafas, a dimensão de subúrbio não é restrita ao viés administrativo. Conforme Langenbuch "ao contrário daqueles países, os municípios são até superdelimitados com relação à sua sede, é comum que boa parte das bordas incompletamente urbanizadas, mesmo em grandes cidades, fiquem dentro de seus limites administrativos." (2001, p. 87). O autor ainda traz exemplos importantes, como o estudo de Aroldo de Azevedo dos subúrbios orientais de São Paulo (AZEVEDO, 1945), que incluem áreas do município de São Paulo e que são tradicionalmente consideradas periferias. Mais uma vez, estas dificuldades de delimitação resultam das virtualidades entre as demarcações administrativo-municipais, o que neste caso se aproxima mais caracteristicamente de pensamento da metrópole na ótica do espaço concebido (LEFÈBVRE, 2006).

À medida que as aglomerações metropolitanas vão crescendo, os subúrbios mais antigos são inteiramente engolfados pela massa edificada compacta e contínua da cidade, pouco ou nada se diferenciando dos bairros urbanos, permanecendo como ‘subúrbio' no imaginário popular [...] (LANGENBUCH, 2001, p. 88).

No passado, "o subúrbio estava mais distante", suprindo a cidade-polo com seus produtos agrícolas e de base. Com as mudanças nas formas de organização e produção, a evolução dos meios de transporte e dos sistemas de infraestruturas, cidades num raio geográfico cada vez maior vão estar integradas mais intensamente aos centros metropolitanos. Esta perspectiva locacional do subúrbio parece resvalar em outra noção central de distinção espacial; a periferia. No sentido tomado de Martins (2001), o subúrbio também concentra o exército industrial de reserva, quando seu crescimento e expansão vinculam-se com a dinâmica de industrialização e a instauração concreta do processo de metropolização. É o espaço onde está concentrado o trabalhador. A ausência de infraestrutura urbana é comum nestes locais, porém existe certa organicidade entre um mundo rural em transformação, com a presença de chácaras, a produção agrícola, de extração mineral e grandes áreas verdes. Alguns destes mesmos pontos são, contraditoriamente, pensados por Kowarick (1979) como central às periferias, excetuando a historicidade do subúrbio marcada por traços do mundo rural. 
Este subúrbio, dissecado pelos trabalhos de Azevedo (1945), do cinturão verde (SEABRA, 1973), das chácaras ou caipira como denominados por Petrone (1995), incluíam setores de São Paulo e municípios adjacentes com funções específicas e em comum, que por estas características descritas anteriormente, não pode ser plenamente compreendido exatamente como hoje. No entanto, mesmo diante das radicais mudanças nos termos geográficos em relação à distância do centro urbano e do trabalho (ampliação das localizações influenciadas pela metrópole), ou nas questões sociológicas pela presença da classe trabalhadora (exclusão/segregação - hoje também as classes mais abastadas vivem nos subúrbios em enclaves de segurança e lazer), pensamos que ainda haja coerência em classificar por esta designação as cidades no entorno de São Paulo. Estas mudanças, ainda são operadas pela instância econômica, em que a renda diferenciada da terra (BONDUKI; ROLNIK, 1979) se inverte, ou passa por outras lógicas, das quais a periferização continua sendo uma das mais destacadas (marginalidade, segregação, pobreza e violência) e, mais recentemente, os enclaves urbanos (redutos condominiais de luxo, servidos por rodovias privadas de alta velocidade), como também modernizações substanciais decorrentes da desconcentração industrial (saneamento, mobilidade e habitação).

O entorno metropolitano possuía valores de terra mais baixos, que se valorizavam conforme se aproximava dos espaços centrais. A presença de infraestruturas e instituições nestas áreas centrais forçava a valorização do solo urbano, fazendo com que a classe trabalhadora buscasse na margem da metrópole sua habitação. Com a expansão da mancha metropolitana, o raio suburbano se amplia, a franja marginal aumenta e as antigas áreas delimitadoras passam a ser rigorosamente muito complexas de diferenciação ou de qualificação como as feitas por estes autores supracitados. Mesmo diante da topologia clássica desenvolvida para cada unidade suburbana da RMSP de Langenbuch (1971), na atual fase da sua metropolização, seria de difícil correspondência com a realidade contemporânea, mesmo que ainda seja imprescindível para a compreensão da estruturação da grande São Paulo. Assim também, de trabalhos pioneiros do IBGE, publicados na Revista Brasileira de Geografia sob coordenação de Speridão Faissol.

As cidades que explodem no mundo em desenvolvimento também entretecem novos e extraordinários corredores, redes e hierarquias. Nas Américas, os geógrafos já mencionam um leviatã conhecido como Região Metropolitana Ampliada Rio-São Paulo (RMARSP), que inclui as cidades de tamanho médio no eixo viário de 500 quilômetros entre as duas maiores metrópoles brasileiras, assim como a importante 
área industrial dominada por Campinas; com uma população atual de 37 milhões de habitantes, essa megalópole embrionária já é maior que Tókyo-Yokohama (DAVIS, 2006, p. 16).

Martins (2001) defende que o subúrbio é a negação da periferia, pois o primeiro seria o espaço da ascensão social, enquanto o segundo o espaço da falta de alternativas de vida. No entanto, esta perspectiva muito se aproxima de um passado bucólico dos subúrbios, das chácaras, dos imigrantes com suas propriedades familiares, as tradições regionais, que praticamente inexistem no presente, ou que permanecem como rugosidades patrimoniais coexistindo precariamente a outros fenômenos tão ou mais marcantes. Assumindo uma postura relacional e de interdependência na pesquisa acerca de subúrbio e periferia, mesmo acreditando que existem diferenças e que essas são fundamentais para os distintos encaminhamentos políticos de cada espaço, não há acordo num distanciamento tão amplo como sugere Martins (2001, p. 79). Mesmo que o conceito de subúrbio ainda esteja mais restrito ao âmbito acadêmico, ou propriamente na reflexão do espaço concebido, ele não deve ser ignorado pela geografia, ou mais pragmaticamente nas políticas públicas associadas ao planejamento urbano e gestão do território. E mesmo que criticamente conforme Martins (2001) ele venha há alguns anos sendo confundido pelo partidarismo político, que o embaraça com as favelas e guetos, ou mesmo as periferias, na prática da representação social, do senso comum e, até mesmo nas dimensões lógicas-formais essa separação não existe. O que se separa de fato são as qualidades deste subúrbio, ou das tantas periferias, que passam a conter além dos instâncias sociais clássicas (fator geográfico/localização, social/trabalho/habitação, econômico/renda diferencial), outras variáveis, sobretudo culturais.

Não à atoa, observa-se a cada dia fracassos nas políticas públicas por ignorar não apenas o universo dos conceitos, mas fundamentalmente as suas inexatidões concretas em cada particularidade periférica, ou suburbana. Mesmo diante de uma dada estrutura de tempo, sob a égide do modo de produção capitalista e suas verticalidades nos territórios, Diadema, São Caetano, Guarulhos, Carapicuíba, todos municípios suburbanos de São Paulo, possuem trajetórias únicas, que sintetizam suas comunidades, o trabalho de sua população na produção do espaço, da cidade. E, mesmo que certas características sejam semelhantes nestas unidades suburbanas, elas tornaram-se escassas, ou insuficientes de enquadramento pleno na atualidade.

O mesmo questionamento é levado a cabo por Rosa (2009) sobre as periferias, tratadas formalmente pelos estudos urbanos como dicotomias em relação à cidade - formal x informal; 
norma x exceção; regular x irregular; legal x ilegal. A autora examina justamente se essas abordagens dualistas não residiriam na própria consolidação das problemáticas condições de vida da população pobre das periferias, considerando ações pontuais, intermitentes e clientelistas das políticas públicas. Assim, considera que "não deixaria escapar as relações extremamente dinâmicas e móveis que caracterizam na prática tais fronteiras, em especial no contexto mais recente de produção das cidades, recaindo, muitas vezes, em interpretações - e intervenções - homogeneizantes sobre as favelas e periferias?” (ROSA, 2009). Esse questionamento é importante por mostrar a complexidade e os limites que a concepção de periferia traz à reflexão de uma teoria geral sobre as mesmas, ou a flexibilização de seus preceitos frente a cada caso e situação.

\begin{abstract}
A noção de uma periferia uniforme, ocupada por um grupo socialmente homogêneo - "os pobres" -, marcada pela ausência de equipamentos e serviços urbanos, vem sendo sistematicamente contraposta. A começar pela concepção de periferia como 'território sem Estado', propalada, ainda hoje, por grande parte da literatura: algumas dessas pesquisas têm demonstrado que, nas duas últimas décadas, houve um investimento público significativo nas áreas periféricas da cidade, especialmente em termos de infra-estrutura, serviços e equipamentos urbanos, o que teria sido acompanhado pela melhoria dos indicadores sociais dessas áreas (ROSA, 2009, n.p.).
\end{abstract}

Publicação recente do CEM, organizado por Marques (2015), oferece uma compilação de artigos, dos quais muitos tratam justamente de problematizar as transformações socioeconômicas e dos grupos sociais na metrópole de São Paulo. Em um destes textos, Marques (2015, p. 198) mostra inclusive uma tendência de elitização nas periferias da metrópole. Um pouco diferente do sentido aqui assumido, pois o termo periferia utilizado pelo autor tem ao longo do texto sentido estritamente "geográfico" (margens, distanciamento) onde o subúrbio acabaria por se enquadrar mais plenamente, sem que para isso o autor nomeie como tal. Lembrando que aqui se assume a noção de periferia com dimensões sociais, econômicas e culturais, além mesmo do fator locacional. No entanto, mesmo apontando os enclaves de riquezas nas margens da metrópole, reconhece ainda a permanência da concentração de pobreza nestes setores mais distantes do centro metropolitano (MARQUES, 2015).

[...] Os processos recentes sugerem ser necessário escapar cada vez mais de interpretações duais, abrindo espaço para existência de diversos tipos de espaços (e grupos sociais) intermediários na metrópole. Isso não significa o completo 
desaparecimento de uma de uma estrutura grosseiramente radial e concêntrica em suas dimensões mais gerais, e muito menos das desigualdades socioespaciais que caracterizam São Paulo de maneira tão intensa, mas a sua recomposição em padrões mais complexos e contínuos (MARQUES, 2015, p. 05).

Utilizando de análises fatorais, por base de indicadores e o entrecruzamento de diversos dados e informações, Marques (2015) chegou a importantes resultados sobre os padrões de classes nas fronteiras da RMSP que, em grande medida, corroboram com sua defesa, onde prevalece não só a complexidade, como ainda a heterogeneidade de espaços e grupos sociais nestes locais ao longo dos últimos anos. De tal maneira, que classificados os grupos sociais (conforme renda, moradores por domicílio, raça, escolaridade, entre outros indicadores) e espacializados os dados, o autor oferece um mapa ilustrativo destes processos, como pode ser observado na Figura 40.

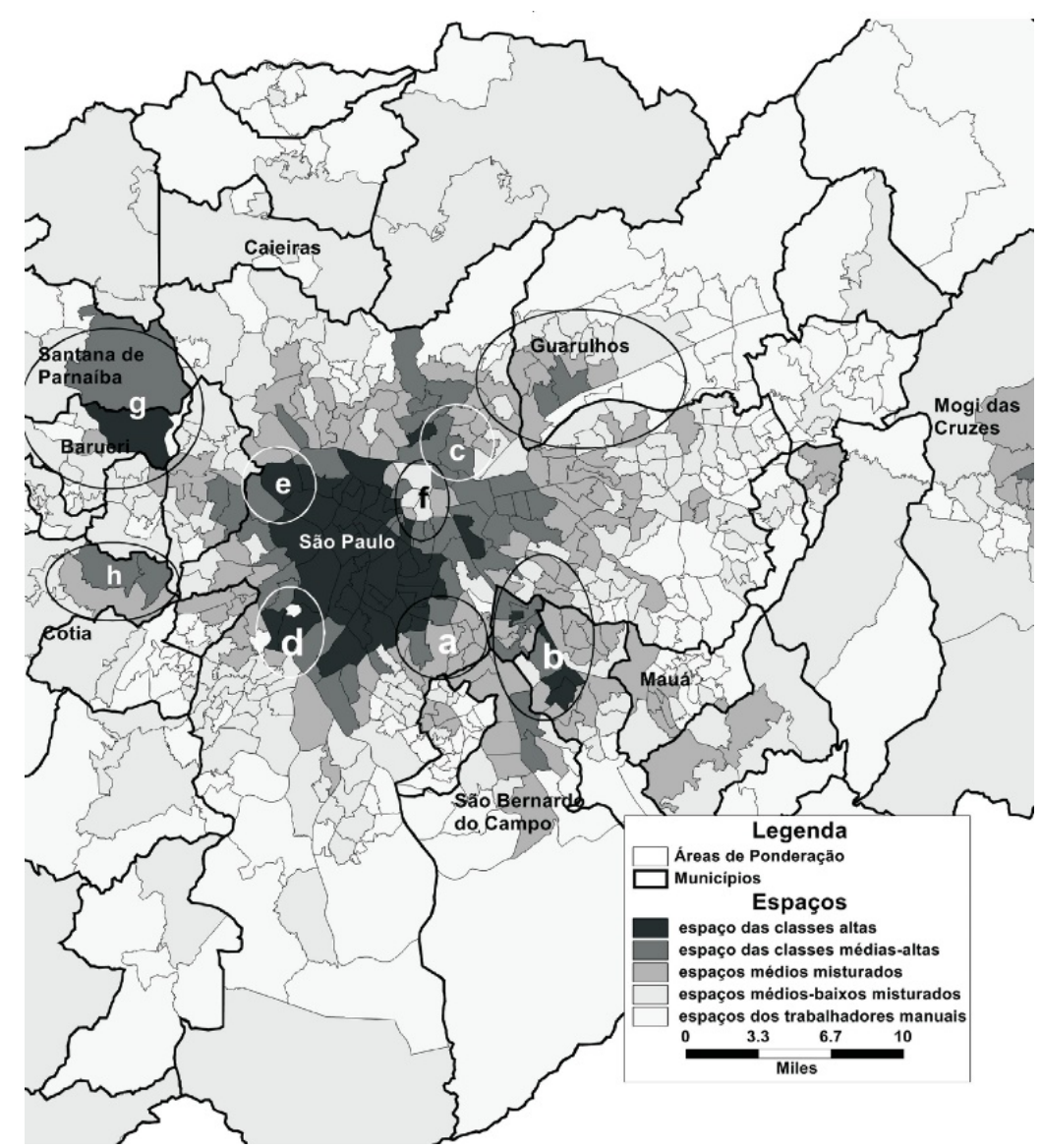

Figura 40: Complexidade das classes e grupos sociais na RMSP indicam necessidade de repensar a geografia das periferias e subúrbios considerando novos fatores sociais, econômicos, políticos e culturais.

Fonte: Marques (2015, p. 196). 
A interdependência entre centro e periferia ainda se faz fundamental, no entanto a efervescência de novos nódulos e dinâmicas nestas relações traz à tona condição singular na firmação de múltiplos núcleos na rede de localidades intrametropolitanas. Mesmo em uma metrópole como São Paulo, onde os limites entre as cidades já não sejam tão evidentes, ainda prevalece a existência de uma hierarquia, um escalonamento metropolitano qualitativo, que vai desde suas formas, reveladas pela paisagem, até dimensões políticas e ideológicas associadas às funções desempenhadas por cada localidade, em cada cidade. Ou seja, cada unidade do todo tem, portanto, sua particularidade. E, tamanha é a expressividade das aglomerações suburbanas e periféricas nos países subdesenvolvidos, que a sua complexidade atual, bem como a diversificação das classes sociais estabelecidas nestes espaços suscitam algumas ponderações que conduzem as reflexões posteriores sobre o caso empírico de Carapicuíba.

Primeiro, os subúrbios, enquanto unidades espaciais históricas, devem ser considerados em suas particularidades, ou seja, nas suas condições únicas no âmbito multiescalar (regional, nacional e internacional) que contemplem seus processos sociais, políticos, econômicos e, fundamentalmente, culturais. A dimensão universal que o conceitua, que o aproxima das realidades americanas, europeias e em todo mundo subdesenvolvido, deve estar compassada com a formalidade administrativa do planejamento e a gestão das metrópoles (governança urbana). Neste sentido, considerando certos limites formais e normativos apenas.

Segundo, a superposição entre subúrbio e periferia deve ser pensada quando o elemento locacional sobressair, além de certa homogeneidade social que configure um e outro. Ou seja, dimensões sociais conexas às geográficas e históricas de lutas e de reprodução à margem da cidade formal, da incapacidade de usufruto da civilidade urbana, da realização e da qualidade de vida usurpada, segregada, restrita aos centros e núcleos mais valorizados e seletivos economicamente do espaço urbano. Fala-se pois, num subúrbio densamente precarizado, que socialmente se aproxima das periferias ou favelas (mesmo com as melhorias de infraestrutura e das condições de trabalho nos últimos anos), e não daquele da vida rural, das chácaras ou, mais recentemente, dos enclaves elitizados ou das grandes redes de condomínios. Nisso, subúrbio e periferia fundem-se num conceito prático, num projeto mais amplo de reivindicações unitárias. Enquanto pensá-los apenas pelas complexidades e heterogeneidades (muito associado à dimensões formais e administrativas do planejamento estatal) torna a tarefa de compensações e justiça social muito mais difíceis e distantes. Caindo, 
em grande medida, na crítica sobre a teorização das várias classes e modos de produção (capitalismos distintos), da qual não somente Harvey (2013) ataca de forma contundente, mas que Massey (2009) protela criticamente das variações das teorias a cada situação específica.

Terceiro, a noção de periferia não depende necessariamente de sua posição geográfica, sua ordem é estabelecida fundamentalmente pelas instâncias sociais, culturais-ideológicas, econômicas e políticas, cuja margem reside igualmente no sentido de segregação, pobreza e ilegalidade. Fenômeno que sintetiza as desigualdades no desenvolvimento e na produção do espaço urbano, e que dialeticamente só existe em relação à riqueza, ao trabalho e a cidade formal, aos enclaves de segurança, natureza e lazer produzidos em espaços tão próximos geograficamente, quanto socialmente distantes. No que concerne à organização espacial, do planejamento territorial, faz-se necessário administrativamente uma distinção da periferia com o subúrbio, o que na prática e no espaço percebido (das representações sociais) nem sempre estará separado, ou mesmo diferenciado. Mas, nos planos, a periferia é de São Paulo, de Osasco ou Carapicuíba, ou seja, ela se faz presente de maneira particularizada em cada unidade e sob certo desígnio da metrópole, da cidade-polo às cidades suburbanas. Destas últimas, algumas das quais tomadas por grandes favelas e áreas de risco, que marcam o desenvolvimento suburbano juntamente com o processo de metropolização de São Paulo.

Os preceitos teóricos, noções, categorias e conceitos até aqui traçados funcionam como lentes que auxiliam e sintetizam o olhar sobre o real, ou seja, as dimensões contemporâneas da metropolização, das permanências geográficas, das rugosidades patrimoniais, que incitam o entendimento mais amplo de sociedade brasileira em conexão com as particularidades da RMSP. Nisso, destacadamente dos bens históricos e culturais, assim como o potencial de transformação e de resistência que possivelmente oferecem frente as forças modernizantes. Estas forças acometem a urbanização num mero elemento reprodutivo do modo de produção capitalista, reificando as relações sociais, enquanto o patrimônio cultural representaria um elemento essencial enquanto barreira ou estímulo conflituoso das rugosidades, que trazem os embates e proposições nos/dos lugares de outras lógicas e racionalidades. 


\section{CAPÍTULO 06: Múltiplas e Atuais Temporalidades Sobrepostas em Carapicuíba}

Este capítulo sintetiza o presente, no contínuo diálogo entre referencial empírico com os fundamentos teóricos, da metropolização ao patrimônio cultural. Enquanto unidade metropolitana, de subúrbio à periferia de São Paulo, Carapicuíba passa por importantes modernizações, onde o patrimônio cultural converte-se num grande potencial para novas atividades produtivas, junto à permanência das tradições, bem como a resistência e adequação frente a este movimento. É a superposição residual de espaços e a convivência desigual dos diferentes sistemas de tempo que permitem as condições e qualidades contemporâneas deste lugar. Trata-se assim de uma particularidade, ou aquilo que Santos (2012a) chamou de tempo espacial de cada lugar.

A estrutura da cidade, munida de infraestrutura e instalações que, em grande medida, foram sendo ajustadas no descontrole de seu crescimento e na resolução de parte de seus dramas, concatena adaptações simples, junto às novas necessidades e padrões modernos. Se o asfalto chega, ele preenche apenas as condições pretéritas da rua, revelando uma simbiose entre a fluidez dos veículos automotores com vias estreitas, compactas e sem integração. De fato, essas formas se impõem às grandes intervenções modernizadoras pelas condições históricas de sua constituição e reproduz em Carapicuíba sua iminente sina de cidadedormitório, ou uma rugosidade patrimonial ignorada na margem metropolitana, em que os setores econômicos se desenvolvem limitados aos setores de serviços e do comércio. Junto, carrega as dificuldades de um sistema ambiental comprometido pelos usos e abusos da metrópole, em compasso com às habitações precárias, o adensamento demográfico e a conversão das grandes favelas em bairros. No plano simbólico, a periferia ganha identidade, ganha qualidade, aproxima-se das virtualidades lefevrianas da urbanização total, ou da urbanização do território como postula Santos (2013b), porém convivendo com diversos problemas que historicamente lhes foram perpetuados enquanto alicerces de São Paulo. Na colônia como aldeamento-marginal que protegia e fornecia mão-de-obra ao núcleo-central, posteriormente por novas demandas de insumos, que iam da construção civil que edificaram São Paulo, aos gêneros alimentícios que mantinham parte da grande metrópole. As novas condições despertadas sempre convivem com velhas relações, velhas formas-conteúdos, as quais ora resistem ao movimento total das modernização e suas consequências, ora são absorvidas por este movimento no sentido de dinamizarem e potencializarem as próprias estruturas do modo de produção, porém com uma nova roupagem e adaptadas narrativas. 


\subsection{Carapicuíba entre a urbanização social e a urbanização do território}

Entre 1960 e 1980 a cidade de São Paulo passa de 3,7 milhões de habitantes para 8,4 milhões. Assim também, verifica-se no Rio de Janeiro uma população que em pouco mais de duas décadas cresce de 3,2 milhões para pouco mais de 5 milhões de habitantes. Aumento, sem dúvida, substancial, que marca materialmente a solidificação do urbano sobre o rural, das atividades industriais que também incorporam o campo, além das funções urbanas ligadas a uma nova dinâmica de trabalho e de vida como um todo. É neste contexto de explosão demográfica e da estruturação metropolitana brasileira que se estabelece os limites da cidade industrial para a metropolização do território. Configura-se a "implosão-explosão" (LEFEBVRE, 2012), com dinâmica concentração urbana, êxodo rural, ampliação da extensão do tecido urbano e subordinação do rural-agrário pelo urbano-industrial. Trata-se da passagem para a nova ordem espaço-temporal, técnico-científica-informacional (SANTOS, 2006), e a urbanização da sociedade (SANTOS, 2013b).

Entre 1980 e 1991, intervalo dos censos realizados pelo IBGE, revela-se um saldo migratório negativo da RMSP em 205 mil pessoas, “[...] o município de São Paulo reverteu seu posto de atração populacional ao registrar uma perda superior a 700 mil habitantes [...]" (DEDECCA, MONTALI, BAENINGER, 2009). Com a RMSP mantendo ainda uma taxa de crescimento geométrico anual positivo, porém a taxa média acima de 4,5\% entre 1970 e 1980 , declina para 1,86\% entre 1980 e 1991, “[...] e esta redução continuou entre 1991 e 2000 (1,64\%), atingindo 0,97\% anuais entre 2000 e 2010." (RIBEIRO et al., 2012, p. 07). Neste mesmo prospecto, indicam Oliveira et al. (2011, p. 29) que "nos últimos anos da década de 1980 e nos anos 1990 observou-se uma diminuição no volume desses migrantes e a formação de novos fluxos migratórios, incluindo se, nesse contexto, as migrações a curta distância e aqueles direcionados às cidades médias." As principais regiões metropolitanas desaceleram seus crescimentos, sobretudo após o ano 2000, sendo as cidades suburbanas e as periferias que mantém em grande medida o incremento positivo do crescimento.

A essa tendência decorre outra, de ampla metropolização em várias regiões brasileiras, passando de nove o número original, para dezenove regiões metropolitanas oficialmente criadas até o ano 2000 e até 2015 somam-se setenta regiões metropolitanas criadas oficialmente $^{79}$ (IBGE, 2015). Fenômeno que junto a estagnação ou diminuição do crescimento populacional nas metrópoles principais, como Rio de Janeiro e São Paulo, Santos (2013b)

\footnotetext{
${ }^{79}$ Apêndice 06 (Regiões Metropolitanas no Brasil - 2015).
} 
designou de "desmetropolização". Em outras palavras, a desmetropolização sintetizaria a repartição dos antigos núcleos de população com os mais recentes, realizando a "involução" metropolitana, não apenas com crescimento populacional menor da cidade polo, ou núcleo, de forma inferior à sua região, mas pela substituição da produção fabril pelos serviços associados às novas tecnologias, às pesquisas e desenvolvimento. Neste processo, as metrópoles brasileiras que realizaram o movimento de concentração, agora continuam a se desenvolver pela dispersão e o controle de grande parte da produção realizada no território nacional. São Paulo, neste sentido, estaria presente por "dissolução" em todas as outras metrópoles, sendo onipresente na articulação dos fluxos e das redes estabelecidas na integração do território. Estaríamos deixando a própria urbanização da sociedade para a urbanização do território (SANTOS, 2013b).

Esta urbanização do território provoca ampliação dos equipamentos e infraestruturas territoriais, que desde os anos 2000 teria resultado num aumento de mais de 430 quilômetros quadrados de área urbanizada na RMSP, alcançando aproximadamente 2.200 quilômetros atualmente de malha metropolitana (MEYER et al., 2013, p. 45). Fenômeno que pode ser melhor ilustrado pelas dimensões espaciais alcançadas nos Mapas 06 e 07 seguintes.

A despeito das áreas mais adensadas da RMSP, cidades como Carapicuíba e Diadema ainda mantiveram saldos positivos, mas já em significativa redução comparativamente às décadas anteriores (IBGE, 1980; 1991). Considerando a região metropolitana, o crescimento populacional no período entre os dois censos foi de $22,9 \%$, marcado espacialmente pela expansão das periferias na capital e cidades vizinhas, cuja população residindo em favelas teve crescimento de 120\% em pouco mais de uma década (MEYER, et al., 2013). Em Carapicuíba, os saldos positivos referem-se às construções da COHAB ao longo da década de 1970, que junto ao relativo baixo preço do solo urbano induziu não apenas a vinda de moradores aos apartamentos populares ao longo dos anos de 1980, mas a procura por loteamentos e, por conseguinte, habitações precárias as mais diversas em todo território municipal, sobretudo nos seus limites com Jandira, Osasco e Barueri. Deve-se destacar uma ampla ocupação irregular e de favelização no município, como destaca o Mapa 08, respectivamente com as Zonas Especiais de Interesse Social (ZEIS) e os Padrões de Ocupação do Solo Urbano. 


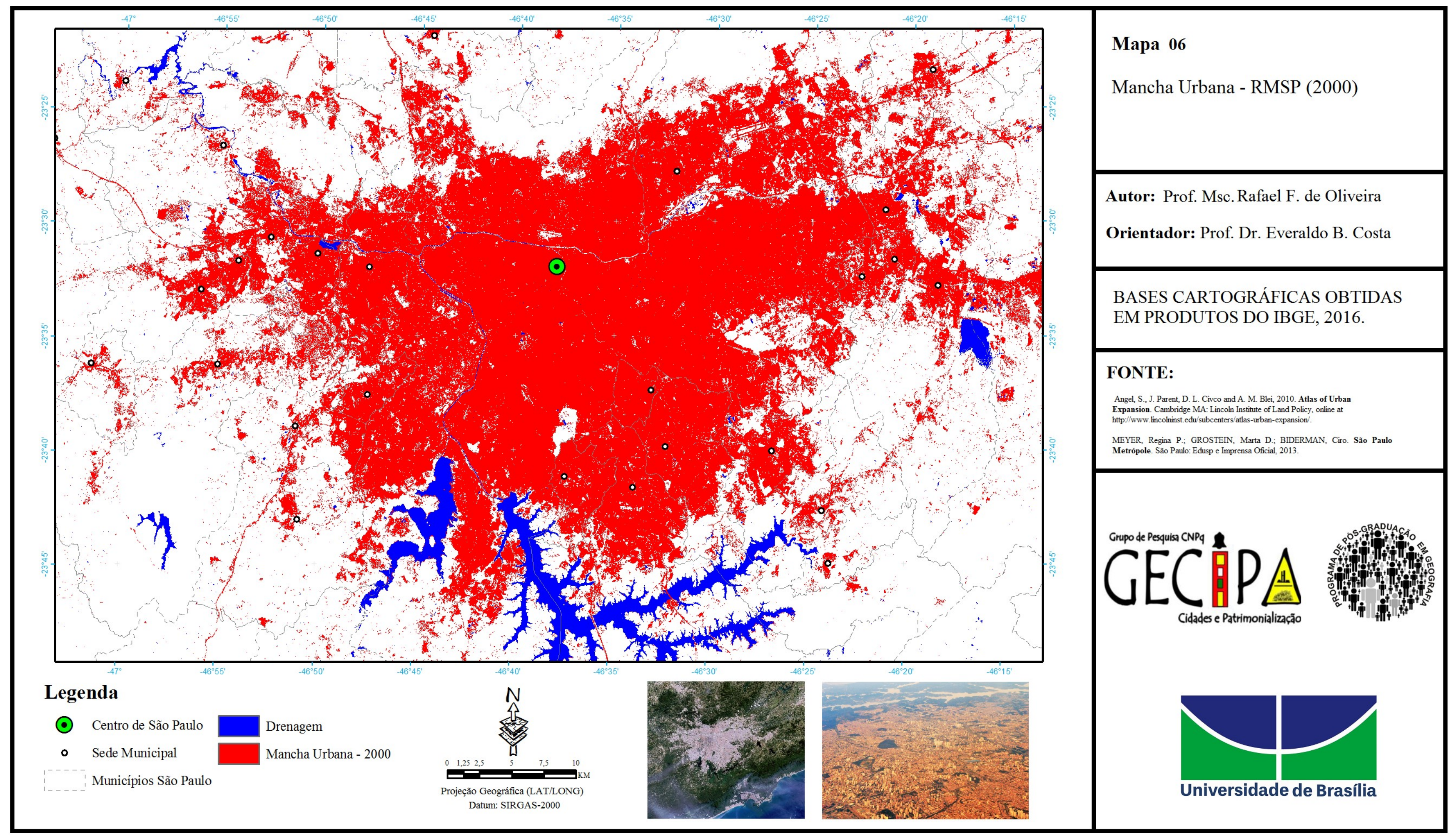




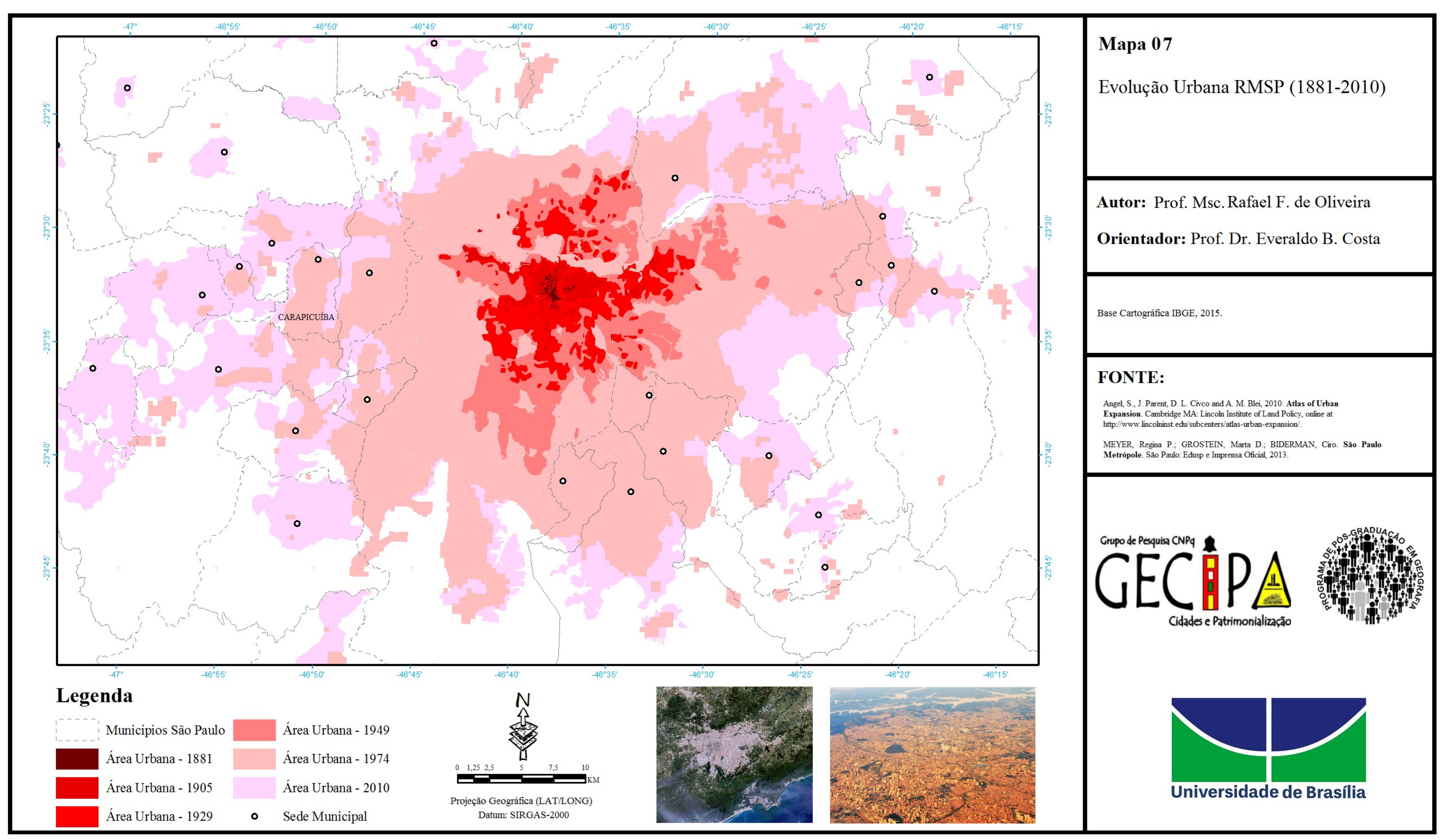




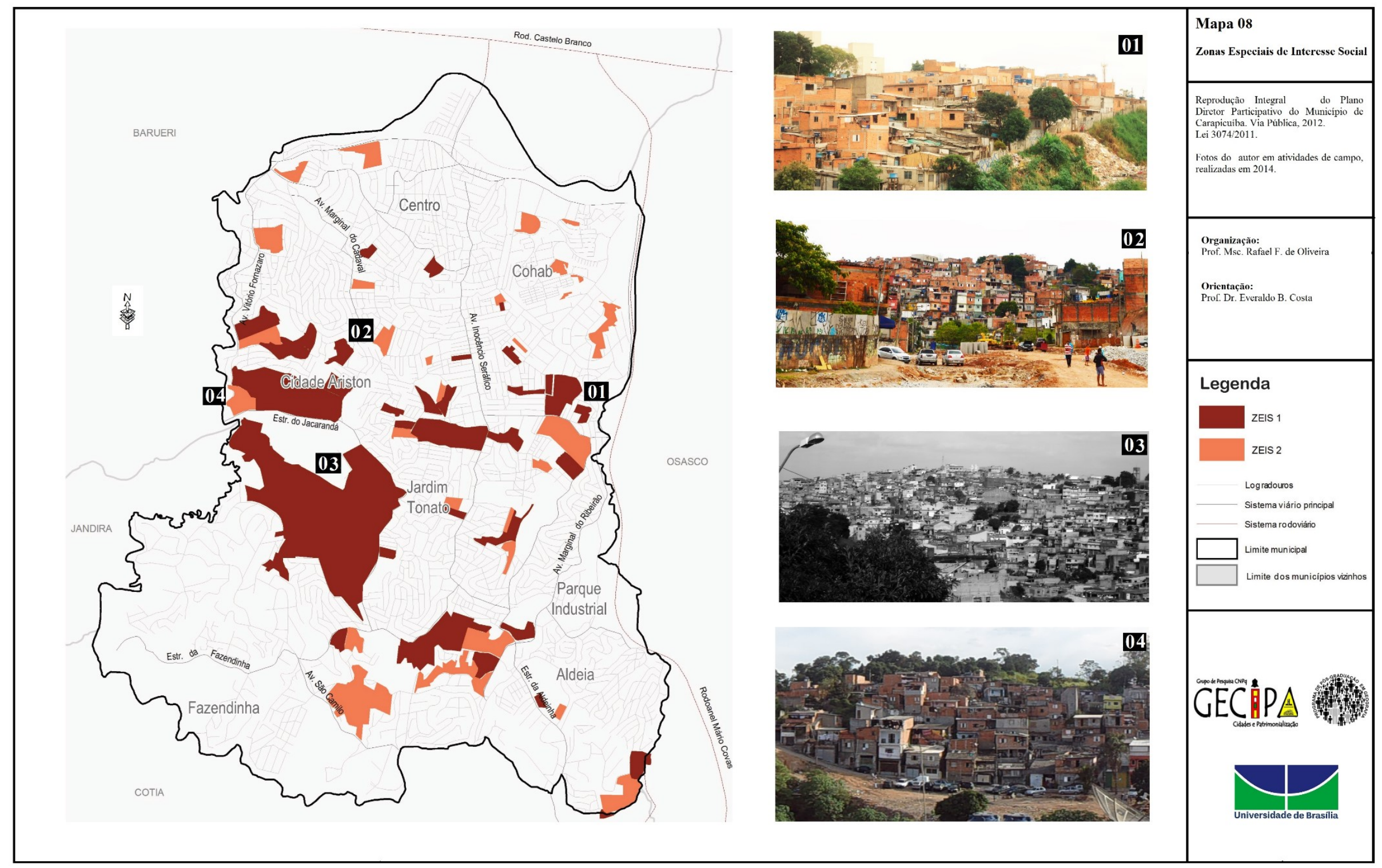


Como indicado no mapa 06 e nas imagens obtidas em campo, em praticamente todos os setores da cidade há presença de núcleos e habitações da população de baixa renda (ZEIS 1 e 2$)^{80}$, como ao longo da linha férrea e das estações de trem, destacando-se a já consolidada Vila Municipal (Figura 41). A expansão periférica, apesar da preponderância de camadas mais pobres e vulneráveis da população, também foi concretizada por setores intermediários e nobres da sociedade. Em Carapicuíba e ao redor da Aldeia, numerosos foram os bairros que surgiram neste período, ou que cresceram rapidamente, como Santa Tereza, Vila Industrial, Parque Jandaia, Jardim Angélica, Maria Beatriz e Novo Horizonte. Com explicam Meyer et. al. (2013, p. 220) "a concomitância na ocupação de áreas urbanas por classes sociais muito distintas do ponto de vista socioeconômico tem sido frequente tanto em setores de urbanização recente quanto em setores de urbanização mais antiga”.

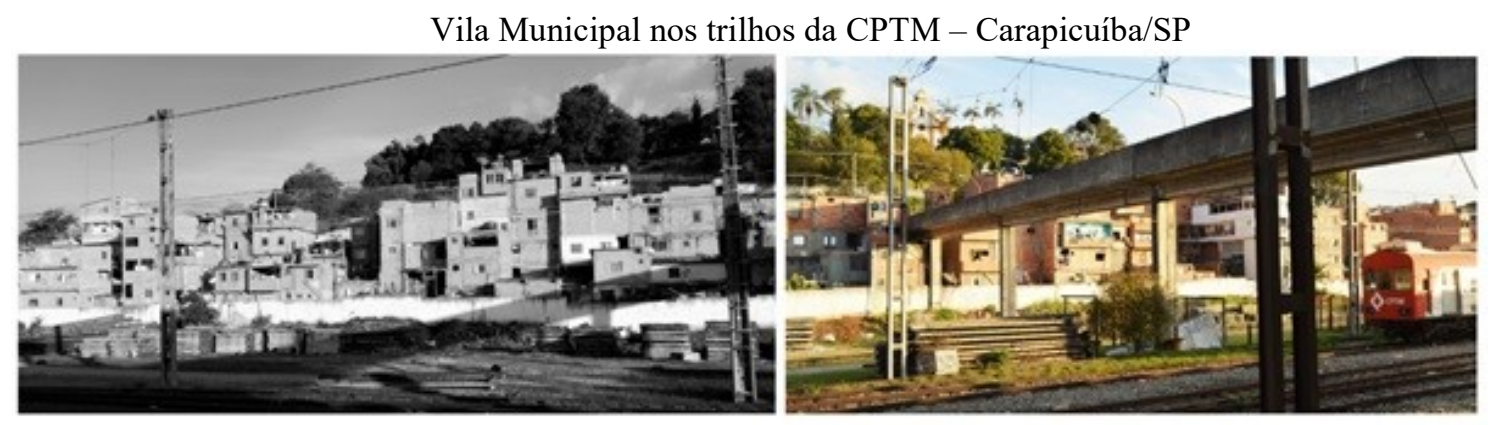

Figura 41: O conjunto de habitações subnormais se estende ao logo de praticamente toda linha da CPTM em Carapicuíba. No detalhes, perspectiva mas proximidades da estação de trem de Santa Terezinha. Na parte superior da imagem à direita, destaca-se o edifício da igreja de Santa Terezinha, abaixo habitações precárias e a locomotiva sentido capital.

Fonte: Fotos do autor em campo, 2013 e 2016.

Dialeticamente, como no passado entre a antiga Aldeia de Carapicuíba e os novos bairros e loteamentos adjacentes à ferrovia Sorocabana, neste período o polo diferencial urbano, no que tange tanto a elementos econômicos aos culturais, se desenvolve entre os condomínios da Fazendinha e Granja Viana, de alta renda e que de certa forma concentram considerável área verde ao sul, e na outra porção norte e central do território as COHAB's, os novos loteamentos ou antigos que se expandem, tornando Carapicuíba numa cidade cuja

\footnotetext{
${ }^{80}$ Conforme o Art. 60 da lei 3074/2011 (Plano Diretor Municipal), as Zonas Especiais de Interesse Social ZEIS são demarcadas a partir da existência de: I. Favelas; II. Habitações coletivas precárias; III. Parcelamento e loteamentos irregulares de baixa renda; IV. Conjunto habitacional de promoção pública; V. conjunto de unidades habitacionais precárias; VI. Imóveis não edificados ou subutilizados com potencial de ocupação por Habitação de Interesse Social.
} 
densidade supera 10 mil habitantes por quilômetro quadrado. A Aldeia de Carapicuíba, na palavra de um dos moradores locais ${ }^{81}$, sintetiza o lugar como um portal entre as desigualdades, "o limite entre riqueza e pobreza". No entanto, apesar da proximidade física, prevalece ampla distância econômica e social entre favelas e condomínios residenciais, “[...] e não chega a gerar formas de inclusão social ou urbana, uma vez que cada um dos grupos está assentado em sistemas urbanos isolados.” (MEYER et. al., 2013, p. 220). Esse contraste é parcialmente revelado pela prefeitura municipal, quando destaca a diferença de densidade populacional no estudo realizado que fundamenta o Plano Diretor Participativo Municipal, regulamentado pela lei 3074/2011.

\begin{abstract}
É importante destacar, no entanto, que a distribuição da população no território de Carapicuíba não é homogênea, com amplos contrastes entre as áreas de maior e menor densidade. Verifica-se que os bairros ao norte e no centro - Ariston, Capriotti, Roseira, Vila Menck, Vila Cretti - são mais densos, com atenção especial para a Cohab Carapicuíba, cuja implantação foi uma das causas do crescimento populacional intenso nos anos 1970 e hoje conta com altíssima densidade demográfica. Também os bairros ao longo da Avenida Inocêncio Seráfico, que corta Carapicuíba de norte a sul e constitui uma centralidade linear no município, apresentam altas densidades. Em contraste, os bairros na porção sul de Carapicuíba - como a Fazendinha, São Camilo, Granja Viana e parte da Aldeia - são menos adensados. Organizados em condomínios horizontais, abrigam a população de mais alta renda do município e mantêm importantes áreas verdes. O centro, próximo à linha férrea, não é uma área de grande aglomeração populacional devido ao predomínio de imóveis para uso comercial (CARAPICUÍBA, 2012, p. 15).
\end{abstract}

Em Carapicuíba, a taxa de crescimento que era de 12,9\% entre 1970 e 1980, passa de 1980 a 1990 para 3,92\%, chegando ao fim da primeira década deste século a 1,78\%, conforme ilustra o Gráfico $06^{82}$. A redução, porém, nesta fase, não impediu a expansão das favelas e de graves problemas sociais, evidenciando que a problemática metropolitana não reside exclusivamente na explosão ou na contingência demográfica (SINGER, 1978).

\footnotetext{
${ }^{81}$ Agente Cultural, 35 anos. Entrevista realizada em julho de 2016.

${ }^{82}$ A população de Carapicuíba vem crescendo de forma consistente desde 1970, superando 369 mil habitantes no recenseamento de 2010. Embora se verifique um crescimento em relação a 2000, este se deu em ritmo menor do que nas décadas anteriores. Entre 1980 e 1991, a taxa geométrica de crescimento populacional foi de 3,92\% ao ano, enquanto na última década não chegou a 1\%. De 1981 e 1990, o município ganhou 87 mil habitantes, enquanto que entre 2000 e 2009 o incremento populacional foi de menos de 26 mil. (CARAPICUÍBA, 2012, p. 15).
} 


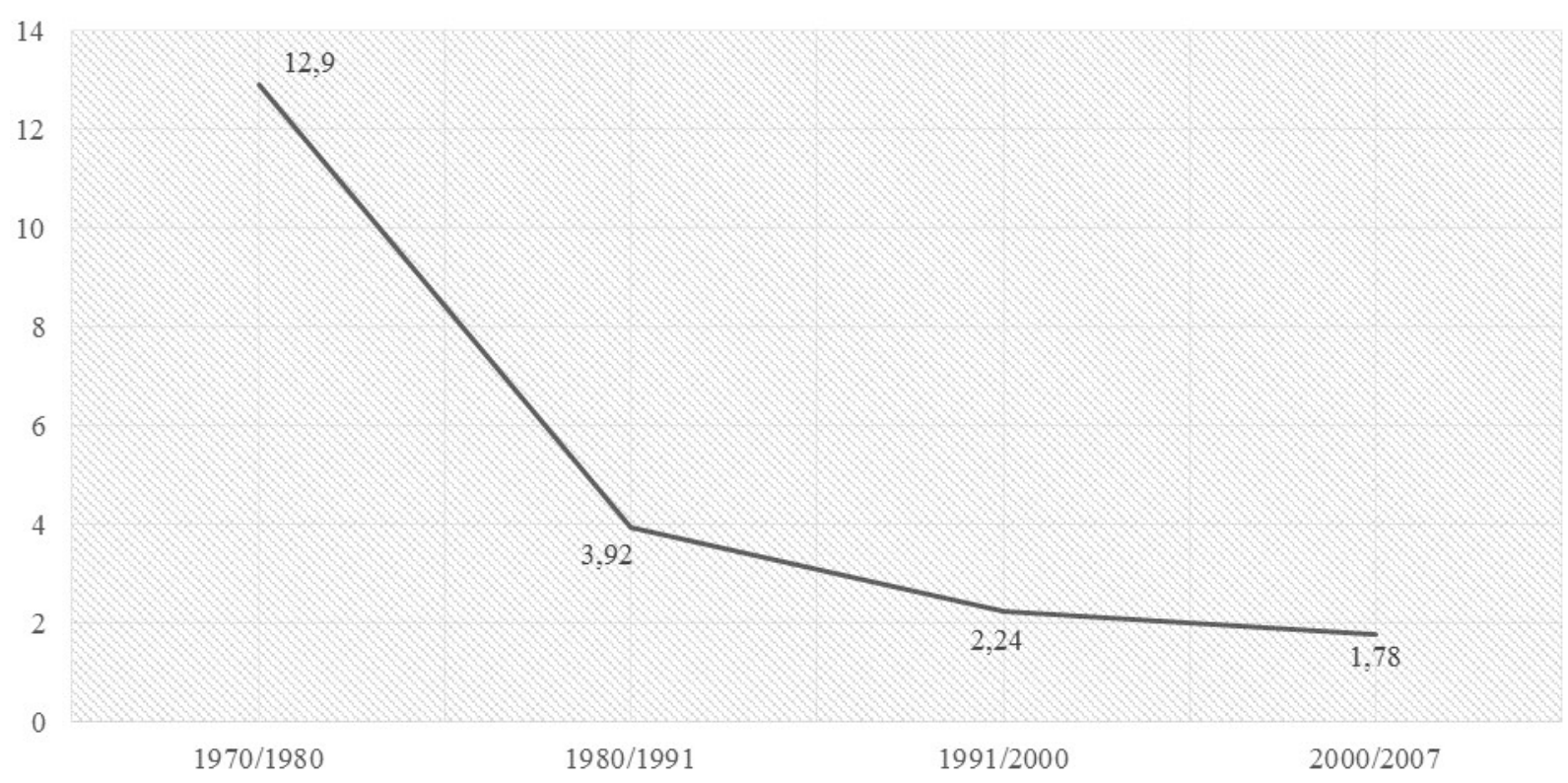

Gráfico 06: Taxa de Crescimento Populacional (\% a.a.) em Carapicuíba. Fonte: IBGE (1970, 1980, 1991, 2000, 2007); Dedecca et al (2009).

Apesar da generalidade que possa emergir de um discurso mais amplo e crítico sobre a qualidade e eficácia dos serviços públicos nas cidades brasileiras, no caso de Carapicuíba as contradições perfazem a sobreposição da precariedade junto ao desenvolvimento de novos serviços e atividades econômicas. Somadas, marcam toda a cidade, porém, o que se espelha na totalidade da paisagem urbana são condições estruturais regulares, insuficientes e precárias dos padrões de ocupação. Outro ponto a se destacar é a situação do comércio e dos serviços que passam efetivamente a dotar Carapicuíba com uma vida mais independente da capital, como serviços bancários, lojas de departamento, supermercados, redes de fast food, academias, entre outras estruturas ligadas propriamente ao mercado de bens de consumo que convergem hoje para a construção no novo shopping na UIT Vila Dirce área do Parque Planalto (Figura 42). Os serviços públicos, também precários, se avolumam com a construção de postos de saúde mais descentralizados, bem como a rede de transportes que vai sendo integrada regionalmente, tanto pela construção de novas vias - como a Rodovia Mario Covas (Rodoanel trecho Oeste) - quanto por meio da ampliação e melhorias das avenidas e ruas locais. São, uma vez mais, infraestruturas e serviços que perpetuam um amplo conjunto de novas relações e valores gerados no entorno de São Paulo, que em Carapicuíba marca a passagem da urbanização da sociedade (relações superestruturais, sistema ideológicocultural), à urbanização des seus territórios (sistema de infraestruturas). 
Cidade precária e ilegal justaposta a modernização e sofisticação dos serviços em Carapicuíba

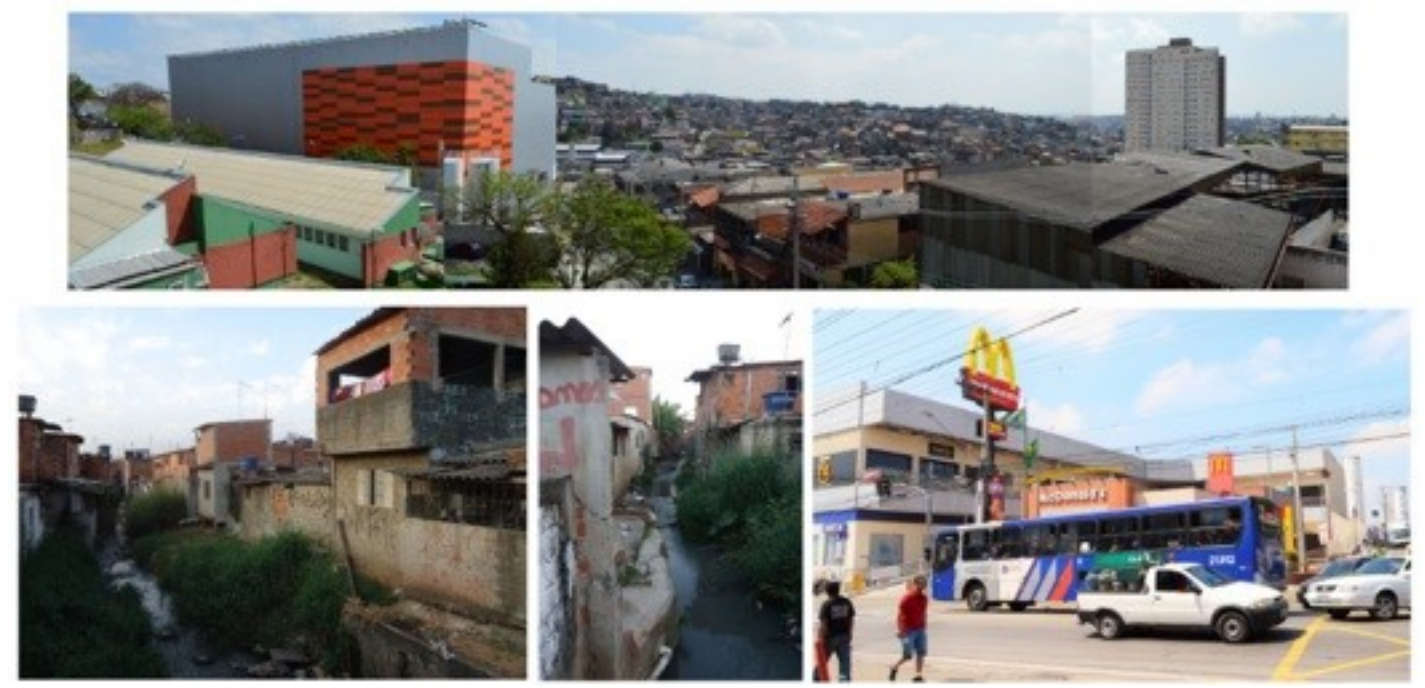

Figura 42: Nas proximidades do Parque Vila Planalto a presença de modernos serviços comerciais, bancos, franquias e o novo shopping em meio às favelas e casas autoconstruídas com esgoto à céu aberto na Vila Planalto, UIT Vila Dirce, Carapicuíba (RMSP). Fonte: Fotos do autor em campo, 2016.

Ainda que limitados, os serviços atendem em grande medida o consumo e necessidades básicas da população, o que antes restringia-se às cidades regionais, ou propriamente São Paulo. As modernizações se efetivam tanto nas escalas regionais, quanto locais, ou seja, de infraestruturas instaladas dando novos rumos e sentidos metropolitanos, quanto em âmbito local dos bairros e vilas em Carapicuíba. Repercutindo nas relações sociais, que se reverberam na criação de novos enclaves imobiliários e industriais - como a área da Fazendinha, com uma população de alta renda, ou ainda mais recentemente, na instalação do condomínio Alphaville, além da própria Granja Viana nos limites do território com Cotia, ou o distrito industrial, paralelo ao rodoanel e pouco menos de um quilômetro da Aldeia. Articuladas com São Paulo pela rodovia Castello Branco ao norte, rodovia Raposo Tavares ao sul e interligadas pelo sistema Rodoanel, permitem dinâmica fluidez de pessoas e mercadorias, inclusive com outras rodovias e regiões metropolitanas de São Paulo, sobretudo da Macrometrópole Paulista. São, pois, significativas às mudanças, trazendo ainda para o novo contexto urbano uma organização que interioriza na RMSP os serviços e atividades, antes exclusivos ao centro, ou às cidades regionais como Osasco ou Barueri.

No entanto a sina periférica e de cidade- dormitório permanece. Na esteira da análise econômica e social da Macrometrópole Paulista ${ }^{83}$, segundo as funcionalidades de cada

${ }^{83}$ Aglomeração urbana, que concentra quatro regiões metropolitanas contíguas (São Paulo, Baixada Santista, Sorocaba, Campinas e Vale do Paraíba e Litoral Norte, além de duas aglomerações urbanas (Jundiaí e Piracicaba). "São 173 municípios que concentravam, em 2010, 73,3\% do total da população paulista, 83,4\% do 
unidade deste grande conjunto urbano, distribuídas por uma tipologia elaborada pelo entrecruzamento de dados por Meyer et. al. (2013), ainda classificam Carapicuíba no grupo de cidades-dormitórios, mais especificamente no subgrupo de baixa renda. O estabelecimento desta classificação se baseia nas mais baixas faixas de renda, além de ausência de funções industriais ou de serviços mais amplos e sofisticados, como também das limitações dos equipamentos culturais e de lazer. Aranha (2005) ao destacar a capital São Paulo como município atrativo ou polo principal dos deslocamentos pendulares metropolitanos, revela a exponencial diferença entre núcleos de dispersão, o qual Carapicuíba é um dos mais destacados. A diferença substancial os que saem e entram no seu território é de uma proporção aproximada de 6 mil pessoas que entram em relação aos quase 65 mil que saem diariamente pelas diversas modalidades de transporte, segundo as necessidades de trabalho, serviços, ou lazer, não apenas a São Paulo, como para Barueri e Osasco no eixo oeste da RMSP (ARANHA, 2005).

Lembrando casos de municípios típicos na RMSP, como o de Francisco Morato, Itaquaquecetuba e Carapicuíba, Meyer et. al. (2013, p. 256) apontam situações empíricas exemplares de expansão da população favelada e dos municípios-dormitório na Grande São Paulo. Explicando que mesmo possuindo uma série de conjuntos habitacionais produzidos pelo Estado, prevalece a precariedade urbana e o baixo valor imobiliário, com concentração da "[...] população de baixa renda sem oferecer postos de trabalho na escala necessária." (MEYER et. al., 2013). Em levantamento de campo realizado, por meio do questionário qualificado de opinião semiestruturado, aplicado a população local, a prevalência de pessoas economicamente ativas que atuam fora de Carapicuíba é marcante em todos os seis setores da cidade. Áreas como a da Aldeia, Fazendinha, ou Vila Dirce, o percentual relativo ultrapassou $65 \%$ do total entrevistado, ou seja, não excluindo aposentados, pensionistas, desempregados e estudantes. Revela portanto que, mesmo com a ampliação e diversificação de atividades econômicas desenvolvidas nos últimos anos, Carapicuíba não perdeu um de seus aspectos funcionais mais importantes na escala regional metropolitana, que é o de ser uma cidadedormitório.

No entanto, como advertido por Ojima, Silva e Pereira (2007), a maioria das cidades com grandes fluxos pendulares diários, sobretudo negativos, que as caracterizariam enquanto 
cidades-dormitório, não possuem necessariamente uma relação de baixa dinâmica econômica e de qualidade de vida. Ainda que no caso de Carapicuíba, a combinação de IDH e PIB per capita $^{84}$ seja extremamente inferior aos municípios da Grande São Paulo, o que faz com que a mesma possua divisas limitadas e oferta ainda mais restrita de serviços públicos, a presença de luxuosos condomínios e áreas de alto padrão de chácaras também contrastam com o perfil periférico do município. Mesmo neste perfil de setores extremamente vulneráveis social e economicamente, as habitações hoje já passam a receber serviços básicos, como rede de água e esgoto, recapeamento asfáltico, calcamentos e luz elétrica (IBGE, 2010; EMPLASA, 2010). De fato, os únicos setores enquadrados com uso padrão urbano de ocupação considerado bom no município localizam-se ao sul (CARAPICUÍBA, 2012), nos setores das UIT's Fazendinha e Aldeia de Carapicuíba, esta última, no entanto, mais heterogênea, destacadamente com melhor índice e qualidade de vida (Figura 43). Porém, mesmo nestas áreas avizinham-se os assentamentos precários, como as do Jardim Tonato e Ana Estela localizados nos limites da Fazendinha.

Padrões de ocupação e assentamentos precários em Carapicuíba - 2010

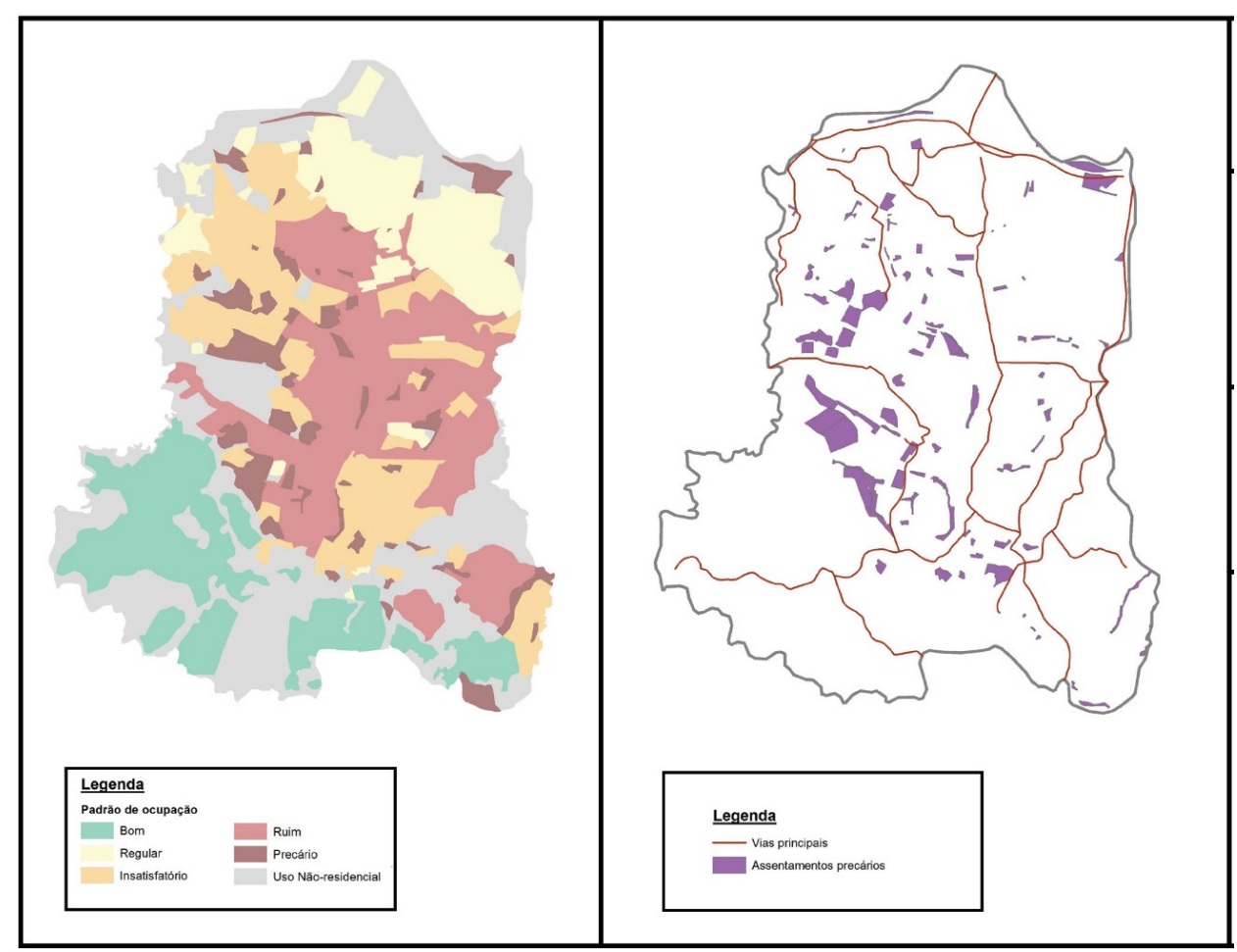

Figura 43: Padrões de ocupação e assentamentos precários nos mapas indicam apenas partes do setor sul do município de Carapicuíba com padrões adequados de ocupação e relativa ausência de assentamentos precários. Fonte: Plano Diretor Participativo do Município de Carapicuíba. Via Pública, 2012.

${ }^{84}$ PIB per capita 2013 de R\$ 11.442,26 e IDHM 2010 de 0,749 (IBGE, 2010; PNUD, IPEA, FPJ, 2013). 
Os diversos investimentos públicos em infraestrutura, mobilidade, saneamento e habitação, importantes para a melhoria das condições de vida na cidade, realizados nos últimos trinta anos, não foram suficientes à plena superação dos dramas vividos na periferia da região metropolitana de São Paulo. Se não para a expansão de um novo modelo privado e corporativista de planejamento e gestão do espaço urbano (SANTOS, 2013b). O que no caso de Carapicuíba faz com que sua tipologia no âmbito da RMSP, passe efetivamente da tradicional funcionalidade suburbana para periférica, de condição rural e das tradições que resistem até meados dos anos de 1950, para o urbano-dormitório de baixa renda (MEYER et al., 2013), em que a maior parte da população espoliada (KOWARICK, 1979) permanece relegada do direito à cidade (LEFÉBVRE, 2001).

\footnotetext{
Nas últimas décadas houve o agravamento das condições gerais de inserção urbana dessa população, o que pode ser constatado nas novas características ao padrão periférico, isto é, a multiplicação de loteamentos em áreas impróprias, o crescimento expressivo das favelas na região metropolitana e o acentuado crescimento populacional nos município-dormitório, ao mesmo tempo em que se acentuam os contrastes em alguns municípios metropolitanos, que recebem investimentos imobiliários expressivos na formação de núcleos autônomos com qualidade de vida diferenciada em relação à predominante nos municípios onde se instalam (MEYER, et al., 2013, p. 66).
}

Em Carapicuíba, estas novas dinâmicas metropolitanas - derivadas do processo de reestruturação espacial asseverada na década de 1970 e ao longo das décadas de 1980, 1990 e anos 2000 - contraditoriamente carregam importantes modernizações inerentes ao aumento da produção, escoamento e consumo de mercadorias na metrópole, mas também carregam problemas estruturais de desigualdade, pobreza e violência urbana, sob a égide de uma racionalidade fragmentária, alienante e normativa entre o trabalho, o cotidiano e a cidade.

\subsection{Intervenções urbanas e o novo contexto do Aldeia de Carapicuíba (1980-1990)}

De fato, o viver cotidiano é paulatina e simultaneamente separado do mundo do trabalho, mas dependente de suas determinações, perpetuadas em padrões de vida e de comportamentos dirigidos estruturalmente para e pelo consumo, do qual o patrimônio cultural torna-se mais um elemento potencial. No caso da Aldeia, o patrimônio emerge de seus bens materiais e as tradições ali manifestadas na década de 1980, que rompe com a antiga política 
federal de preservação, calcada numa concepção monumentalista e posteriormente de valor histórico (em Carapicuíba a passagem entre rugosidade-monumento à rugosidade-documento nunca se efetivou plenamente), passando às recentes concepções de rugosidade-instrumento, ou seja, uma forma-conteúdo capaz de ser manipulada, gerida e controlada por interesses que perfazem o planejamento e a governança urbana (de forma incompleta e precariamente).

Não é coincidência que se articulam concretamente diferentes interesses sobre este espaço de memória nacional ao longo dos anos de 1980. Marcados pelas orientações e compatibilização das diretrizes metropolitanas para expansão urbana como garantia da preservação do patrimônio ambiental (EMPLASA, 1979), desenvolvidos plenamente no PDDI (EMPLASA, 1981) e, posteriormente, na Lei de Uso e Ocupação do Solo (EMPLASA, 1986). O espaço da Aldeia de Carapicuíba, fragilizado pela ausência das políticas públicas ao longo de décadas, além das limitações orçamentárias e as dificuldades de intervenção nos bens pelos moradores, passa a integrar uma nova estratégia no âmbito do território metropolitano. Estratégia cuja centralidade deriva de seu valor histórico e cultural, agora sistematizado precisamente no zoneamento em unidades geometricamente mapeadas e associadas mais efetivamente a um uso potencial econômico-turístico, de atividades institucionais e de serviços comerciais correlatos, que de uma ação conjunta estabelecida entre as diferentes entidades estatais (destacadamente a municipalidade através de suas secretarias, além de parte da sociedade civil organizada, a EMPLASA e o CONDEPHAAT no âmbito estadual e, por fim, o SPHAN/IPHAN em nível federal). As orientações legais estabelecidas, fracionando o território da Aldeia de Carapicuíba em restrições de uso e ocupação do solo por zonas $^{85}$ (Mapa 09), fundamentam uma década de intensas intervenções na área, não limitadas apenas ao largo, mas a um perímetro mais amplo, que irá convergir com a criação do Parque Municipal da Aldeia de Carapicuíba no ano de 1996.

\footnotetext{
${ }^{85}$ ZPH: Zona de Preservação Histórica; 


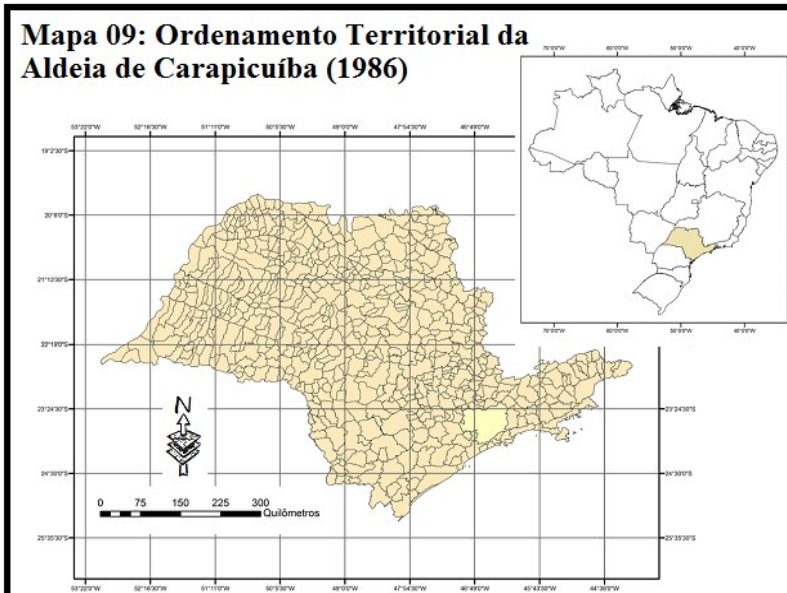

Legenda

Rodovias Principais

( Sede de Municípios (RMSP)

5 Região metropolitana de São Paulo

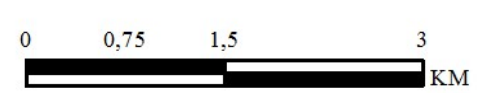

Projeção Geográfica (LAT/LONG) Datum: SIRGAS-2000

\section{GECAPA

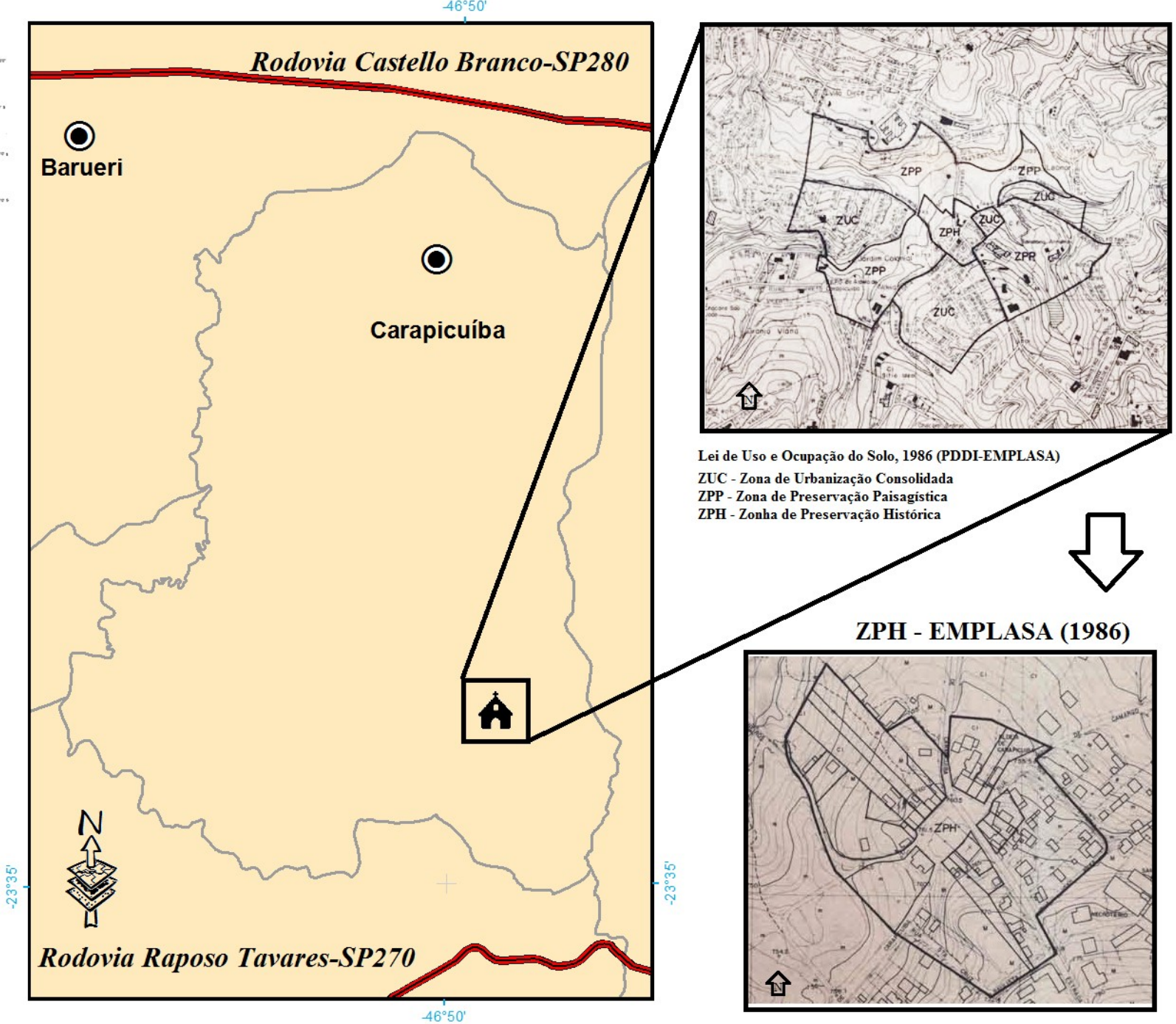


Essas intervenções foram recorrentes, pontuais, mas gradativas entre 1982 a 1989 (Figura 44), pelo Programa de Recuperação e Revitalização dos Núcleos Históricos (PRRNH/Fundação Nacional Pró-Memória/MinC-MDU). Das quais destacam-se reformas estruturais das casas, com apoio das entidades e dos próprios moradores, bem como o estabelecimento de recomendações à população e orientações dos órgão superiores à municipalidade. Cabe destacar a reconstrução da casa 16 e reformas importantes na igreja, além de obras diversas, como nas casa 5 e 15, com telhados trocados por equipe conduzida pelo CONDEPHAAT - ainda assim, nos arquivos observam-se que os projetos executados não foram plenamente suficientes para a manutenção da Aldeia, considerando anos de abandono $^{86}$.

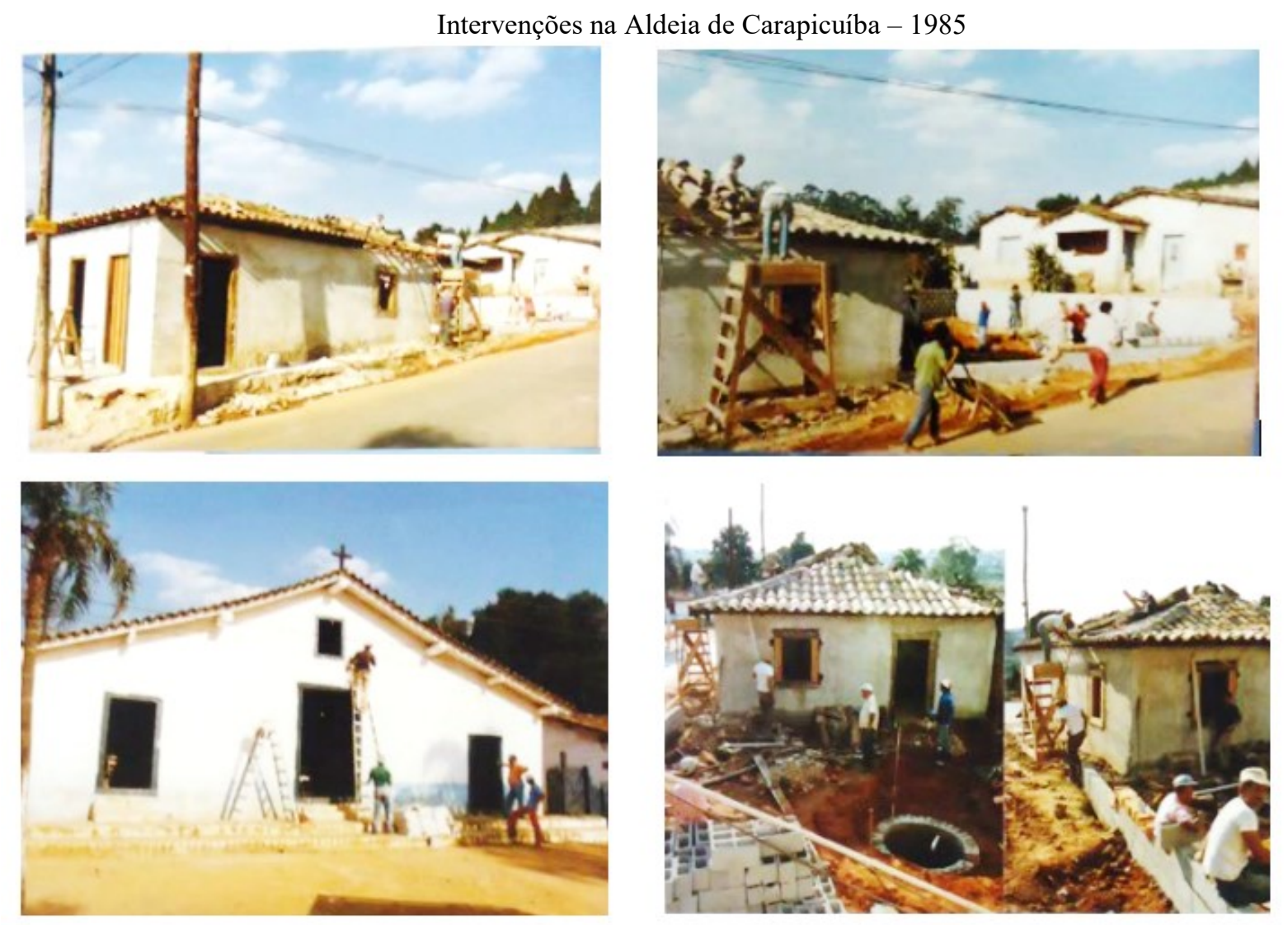

Figura 44: Reformas no conjunto urbanístico da Aldeia de Carapicuíba e capela de São João Batista, 1985 PRRNH/SPHAN/6Fundação Nacional Pró-Memória/MinC-MDU.

Fonte: Arquivo $9^{\text {a. }}$.SRIPHAN/SP.

Apesar do PRRNH ser considerado um fracasso (SANT'ANNA, 2014), na Aldeia os acordos de cooperação foram importantes para a concretização de intervenções importantes.

\footnotetext{
${ }^{86}$ Conforme documentação obtida no Arquivo da 9a SR - IPHAN/SP - Pasta 00068-0218-T39 5/11(1-6).
} 
Mais do que propriamente uma política voltada exclusivamente para os bens materiais, o programa foi concebido na gestão de Aloísio Magalhães como meio de promoção social, pelo empoderamento da população, passando da instância tutora e fiscalizadora, para funções de orientação, negociação e como promotora de atividades nestes espaços (SANT'ANNA, 2014). O que, todavia, os arquivos não revelam ter ocorrido no caso da Aldeia, se não as mesmas intervenções que já decorriam desde a década de 1940. Nisso, contudo, há plena concordância do fracasso da política do PRRNH, considerando conjuntamente naquele período o fracasso do planejamento integrado e as recomendações das diretrizes urbanas que só se efetivariam problematicamente mais de uma década depois, ao menos no plano da infraestrutura, porque o incentivo ao controle social ou do apoio àquela população praticamente inexistiu.

Se as reformas foram frequentes pelo SPHAN no período, com o apoio inclusive do CONDEPHAAT, igualmente os moradores iam adaptando a estrutura interna das pequenas habitações seculares às necessidades modernas. Destas, cabe destacar a melhoria do piso, do forro e pequenas construções que viabilizavam a sobrevivência naquele espaço. Os relatos de Henne (2015), acerca da vida e cotidiano de seus familiares no espaço da Aldeia, evidenciam o papel daquela comunidade na sua manutenção. Ela explica que as tensões não eram restritas apenas aos moradores, mas com a própria igreja, ao lembrar quando Luís Saia mandou fechar a capela de São João Batista por um dos santos ter sido retirado dali, ou quando determinou que obras de melhorias fossem colocadas ao chão, brigando com o padre e moradores. Mesmo perante tantas restrições e conflitos gerados em torno de uma gestão compartilhada de seus bens com o Estado, ou mesmo, por vezes, das limitações verticais que sofriam diante do abandono de políticas públicas, os moradores resistiam e persistiam em buscar soluções que por vezes feriam o Decreto-lei $n^{\circ} 25 / 1937$, ao mesmo tempo em que lhes possibilitava viver minimamente com conforto e permanecer efetivamente ocupando aquele lugar.

Não havia um entendimento entre o técnico e os moradores do quadrilátero; o diálogo era muito difícil e até hostil. Para os habitantes das casinhas de pau-a-pique preservar era melhorar, colocar piso nas casas, azulejos, forro, pois acreditavam que modernizando as casas, além de conseguirem um maior conforto, estavam cuidando daquilo que eles haviam deixado de herança para eles. A relação dos habitantes da Aldeia com o patrimônio material era existencial; eles tinham uma relação de pertencimento em relação ao espaço que ocupavam. Desta forma, sentiam-se à vontade para usufruir como quisessem daquele local. Já para o IPHAN, a Aldeia havia se tornado um bem cultural e, como tal, teria que ser valorizado e preservado, mas esses valores eram ignorados pelos moradores e faltava comunicação e entendimento entre as partes. (HENNE, 2015, p. 67 - grifo nosso). 
Em outra escala, as transformações na metrópole derivadas da desconcentração espacial da indústria paulista ao longo dos anos de 1980, tornava-se mais um entrave na manutenção da Aldeia. Não somente pelas transformações materiais do tecido urbano necessário à produção industrial, a qual o aldeamento já estava acuado e restrito, como ainda no próprio sistema urbano de relações funcionais acomodados, que já era crítico frente aos choques de valores. Emergem novas demandas por um distrito industrial no município. Além da expansão imobiliária induzida pelo Estado, agora representantes patronais e empresas de médio e grande porte articulam-se com a municipalidade em favor de subsídios para as novas instalações industriais. No ano de 1988, é desenvolvido um projeto de criação de zona industrial nas adjacências da ZPP da Aldeia. O qual encontrou dificuldade por parte da inadequação legal do PDDI (EMPLASA, 1981) e da Lei de Uso e Ocupação do Solo (EMPLASA, 1986), bem como na análise do IPHAN. O Ofício 112/SENJ/89 (3977/88) pede aprovação de empresa de aerossóis na área de entorno, assim como pede sugestões "[...] que não só atropelem instalações de indústrias em nosso território, mas que, abram perspectiva para instalações de outras, que contribuam na economia e no progresso, especialmente, visando ampliação do número de empregos." ${ }^{~}{ }^{2}$. O teor do ofício supracitado revela as tensões entre a administração de Carapicuíba em relação ao bem tombado e sua área de entorno, como às leis e instituições que contribuem para sua preservação. Este documento é taxativo por manifestar a oposição entre preservação e progresso, este último ligado às noções de crescimento econômico e de ampliação de empregos, no que a Aldeia transparece nos termos enquanto um enclave, uma rugosidade de difícil plasticidade às cirúrgicas medidas urbanas e de infraestrutura. Revela ainda o campo de lutas estabelecido por moradores preocupados com suas casas e tradições, as instituições em relação ao que estabelece a lei e o papel da memória nacional, as empresas e a gestão municipal de forma corporativa no sentido de ampliar lucros e divisas respectivamente.

Um dos fatores negativos elencados pelo SPHAN em relação à instalação do distrito industrial na ZPP seria justamente a ausência de estudos que justificassem a alteração da Lei de Uso e Ocupação do Solo, bem como da ausência de rede sanitária que afetaria as condições de salubridade ambiental naquela área, afora inadequações com a própria legislação urbana e

\footnotetext{
${ }^{87}$ Ofício 112/SENJ/89 (3977/88). Arquivo da 9a SR - IPHAN/SP - Pasta 00068-0218-T39 5/11(1-6).
} 
que exigiria uma reformulação geral dos termos legais de difícil materialização. No entanto, em carta de esclarecimento dirigida ao município, o diretor da $9^{a}$.SRIPHAN/SP, explica que o patrimônio cultural não é um entrave ao desenvolvimento, ou propriamente a industrialização e os benefício sociais que dela podem derivar. Neste documento ${ }^{88}$, o arquiteto Victor Hugo Mori informa as condições de instalações do distrito, entendendo a possibilidade de pequenas instalações, o respeito a legislação e a implantação de infraestrutura necessária. Com certeza, ciente da precariedade do espaço da Aldeia e dos desafios que a instituição possuía com as limitações orçamentárias do período de crise no país, Mori aproveita o ensejo consultivo para pressionar os gestores e os interessados. Recomenda assim que em contrapartida às instalações, que houvesse em definitivo o desvio da estrada da Aldeia como já havia no plano da Cia. de Metro, bem como a ampla arborização da área, inclusive incitando a participação da iniciativa privada nestas ações e colocando à disposição a equipe e assessoria do SPHAN.

A instalação do distrito se efetiva, mas sem acatar todas as recomendações elencadas anteriormente pelo SPHAN. Em 1991, em relatório de vistoria na Aldeia, o técnico Luís Saia Neto (9 .SRIPHAN/SP), problematiza as condições do patrimônio pelos seguintes apontamentos: (a) aumento do tráfego de veículo pelo espaço da Aldeia; (b) ocupação acelerada e desordenada do entorno; (c) intervenções sem orientação nos bens tombados; (d) poluição visual por cabos elétricos e de telefone na Aldeia. Observa-se, portanto, que as tentativas anteriores foram, de certa maneira, frustradas de um acordo mais efetivo entre as entidades. A velocidade com que o processo de ocupação dessas áreas se define marca escalas mais amplas de periferização, por qual sobrevinha todo o município ao longo da última década, que mesmo com a cooperação interinstitucional seria de difícil combate.

Esses problemas derivam de uma dinamização do espaço urbano de Carapicuíba, compreendido pelas pesquisas por meio da nova ligação a rodovia Castello Branco, integrando-a mais plenamente ao centro e adjacências do núcleo metropolitano, o que já acontecia com a rodovia Raposo Tavares ao sul. No plano intra-urbano, com o asfaltamento da avenida Inocêncio Seráfico, realizado em parte na década de 1980, e depois pelo Plano de Pavimentação Participativa (PPP) em princípios da década de 1990 (TENÓRIO, 2003). O asfaltamento da avenida é um marco para a população residente no entorno, sobretudo na unidade territorial da Vila Dirce e adjacências, quando os entrevistados relataram de forma

\footnotetext{
${ }^{88}$ Documento datado e assinado em 1989. Arquivo da 9a SR - IPHAN/SP - Pasta 00068-0218-T39 5/11(4).
} 
pormenorizada da precariedade que viviam sem ele no passado. Contraditoriamente, intervenções que passavam a sobrecarregar o fluxo de veículos pesados ao longo da Aldeia, como de toda cidade em expansão, para grande parte dos moradores do município elas traziam benefícios inestimáveis ligados a urbanidade como qualidade que nunca tiveram.

[...] se o centro era barro imagina os outros bairros né, era só terra, demorou para progredir Carapicuíba, viu, demorou! (Entrevistado 08, morador da UIT Vila Dirce, 58 anos).

Aqui, que você tá vendo, era tudo barro, pó, sujeira... Foi no governo do prefeito Fuad, ele arrumou muitos inimigos aqui, retirou muita gente, clientes não podiam entrar aqui no comércio, cimentou tudo, o asfalto nós pagamos por parte da avenida, criou muitos inimigos mesmo, principalmente petistas [...] (Entrevistado 09, morador da UIT da Vila Dirce, 55 anos).

Dois anos depois, em 1993, a situação parece ser ainda mais grave, quando no ofício $102^{89}$ da prefeitura de Carapicuíba ao Instituto Brasileiro do Patrimônio Cultural (IBPC) ${ }^{90}$ também aponta a seriedade de problemas estruturais na Aldeia, como a destruição por cupins das madeiras, criticando a ausência do CONDEPHAAT e da necessidade de apoio técnico e de acompanhamento pela instituição. Esse pedido de socorro se consolida numa força tarefa entre as entidades, que culmina alguns anos mais tarde com a criação do Parque da Aldeia, no ano de 1996. Um convênio foi firmado entre o Ministério da Cultura no plano federal com contrapartida do município de Carapicuíba. Das ações, as desapropriações abrangeram um área considerável, que foi do topo da colina até o fundo de vale, com mais de cem famílias expropriadas, uma parte realocada e com a criação de uma lagoa. Tudo isto junto da execução do antigo projeto de desvio do trânsito da Aldeia, o recapeamento e nivelamento do largo, assim como ampliação da área arborizada, capaz de ambientar os bens tombados e servir para o lazer e atividades que o parque sugeria. Sucederam em anos seguintes diversas manutenções no conjunto urbano da Aldeia por parte das instituições, fazendo permanecer o bem cultural em meio ao lazer e entretenimento do parque. Somados, as obras de relativo vulto entre a instalação do parque e as reformas necessárias à manutenção do patrimônio tombado

\footnotetext{
${ }^{89}$ Arquivo da 9 a SR - IPHAN/SP - Pasta 00068-0218-T39 5/11(5).

${ }^{90}$ Em 1990 é extinto o Minc, também o SPHAN e a FNPM, com a criação do IBPC, instituição que ficou responsável pelo patrimônio cultural até 1994.
} 
chegaram a aproximadamente cem mil reais para o governo federal, conforme documentos levantados na $9^{\mathrm{a}}$.SRIPHAN/SP${ }^{91}$.

\begin{abstract}
Naquela ocasião, (primeiro mandato do atual prefeito Fuad Chucri - sic) o prefeito resolveu implantar um 'antigo projeto urbanístico' de iniciativa do IPHANEMPLASA. Este projeto visava executar na Estrada da Aldeia que ligava a Raposo Tavares com o centro da cidade um desvio de modo a não permitir o cruzamento de caminhões e ônibus no pátio da aldeia jesuítica. Esta proposta propunha, além do desvio viário, a criação de um parque no entorno da Aldeia demolindo-se todas as construções clandestinas (cerca de uma centena) que envolviam o monumento. A implantação do parque se iniciou com esses recursos do convênio com o Ministério da Cultura. [...] Considerando a implantação do Parque da Aldeia uma ação municipal exemplar no campo da preservação do patrimônio cultural, exemplo este, que deveria ser seguido por outros municípios sem grandes recursos financeiros, o IPHAN tem procurado colaborar modestamente para valorização e preservação e preservação desta joia do urbanismo brasileiro. [...] (Informação Técnica da 9a. SRIPHAN/SP ao Ministério Público Federal).
\end{abstract}

Mesmo compreendendo as dificuldades da preservação e a precariedade do caso de Carapicuíba, em entrevista concedida, José Saia Neto, um dos técnicos da IPHAN que mais se dedicou neste período aos trabalhos na Aldeia, explica a importância do parque no sentido de proteger o entorno do bem tombado e, portanto, a garantia ainda precária da preservação do conjunto urbanístico pela instituição em conjunto com a gestão municipal naquele período.

\begin{abstract}
O tombamento e restauro tem garantido precariamente a preservação do conjunto. A sensibilidade de um antigo Prefeito, Sr. Fuad Chucre, garantiu a preservação do seu entorno imediato, que estava perigosamente ocupado, com a criação do parque. Por fim, algumas famílias moradoras garantem uma certa diversidade de ocupação e as manifestações culturais que dão vida ao local (José Saia Neto, entrevista concedida em junho de 2016).
\end{abstract}

Estas intervenções empreendidas pelo município de Carapicuíba, se teve total anuência e apoio dos órgãos patrimoniais, como pode ser observado na passagem supracitada do IPHAN, para os moradores resultaram em muitos transtornos e conflitos. As tentativas de retomar, ou manter as formas pretéritas do aldeamento jesuítico, passaram a tencionar um patrimônio cultural concebido pela cultura híbrida do caipira e do subúrbio, que os moradores adquiriram com o longo tempo ai vivendo. Isso incluía, por exemplo, a retirada dos coqueiros que estavam há muitos anos e eram adorados pela comunidade. Segundo Henne (2015, p. 80), mesmo provando por registros fotográficos que os coqueiros ali permaneciam por quase um século, não conseguiu mantê-los. Porém, ainda segundo a autora, um governo depois, a

\footnotetext{
${ }^{91}$ Arquivo da $9^{\text {a }}$ SR - IPHAN/SP - Pasta 00068-0218-T39 5/11(5).
} 
comunidade conseguiu que os coqueiros fossem devolvidos (HENNE, 2015). No plano intangível, os procedimentos técnicos afrontavam os simbolismos e tradições, como a derrubada do cruzeiro para reforma e a sua disposição no chão da Aldeia, nesta mesma intervenção, concomitante com a estruturação do parque.

[...] Havia a necessidade de tirarem o Cruzeiro para a realização daquele serviço [cimentar o piso do pátio]. Me lembro que quando vi o cruzeiro jogado no chão passei muito mal [...]. Tia Nenê estava indignada e comentou que ele que ele [o prefeito] não sabia a força que a Cruz tinha, que ele estava brincando com coisa muito séria. [...] Me lembro que ela falou: 'Helenice, Santa Cruz é poderosa, esse povo não sabe com o que eles estão mexendo, eles não têm fé em nada, estão destruindo a nossa Aldeia. Esse nariz de tucano (se referindo ao prefeito Fuad) quer acabar com a Aldeia. (HENNE, 2015, p. 81).

Deve-se ponderar que essas intervenções, sobretudo a criação do Parque da Aldeia, acatando os projetos estabelecidos na década de 1980 pelo PDDI, além dos produtos de debates interinstitucionais, é fruto de uma política mais ampla frente a periferização que Carapicuíba enfrentava e não apenas do patrimônio cultural. A precariedade urbana exigiu medidas urgentes e radicais, das quais espaços de lazer e entretenimento tornavam-se pauta das tentativas de modernizar o território e subsidiar um modo de vida mais intensamente permeado pela metropolização. Junto aos problemas de periferização no entorno Aldeia somavam-se as verticalidades institucionais sobre as rugosidades patrimoniais que ainda abrigavam muitas famílias no década de 1990. E, ao revés, com a centralidade conquistada pelo patrimônio cultural no período, concomitantemente foi a evasão das famílias do pequeno vilarejo, junto as dezenas de famílias retiradas do entorno para a criação do parque. "Por falta de uma política pública adequada à preservação, como já comentei, perdeu-se o que há de melhor em um patrimônio histórico que é o ser humano. [...] Hoje quem chega para visitar a Aldeia, durante o dia imagina estar em um local abandonado, pois não há um só local para fazer um lanche.” (HENNE, 2015, p. 31).

A criação de áreas públicas, de lazer e cultura, foram concretizadas em maior parte entre 1993 e 1996, com a inauguração do Parque dos Paturis, nas proximidades com Osasco e as COHAB's, o Parque da Vila Planalto - importante elemento redutor do impacto das chuvas e catalisador da drenagem entre as UIT's Vila Dirce e Centro - e mais recentemente, a criação do Parque Gabriel Chucre (Mapa 10), este último disposto na área onde ficava o antigo lixão do município, no contorno da lagoa. E, por fim, do Parque da Aldeia, que marca o entorno do conjunto tombado do aldeamento - igualmente isolando o patrimônio cultural e as áreas nobres do avanço urbano periférico (Mapa 11). 


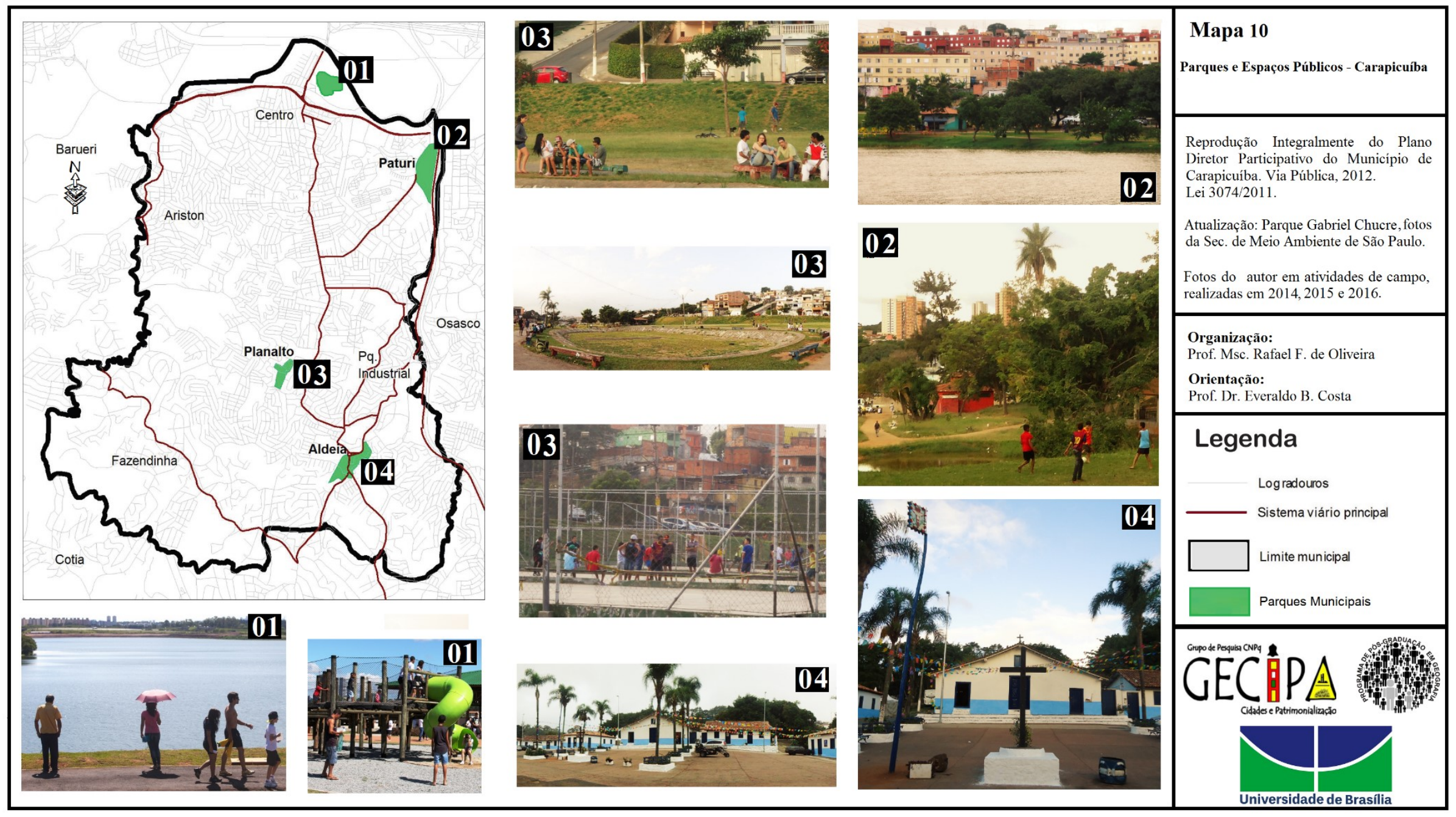




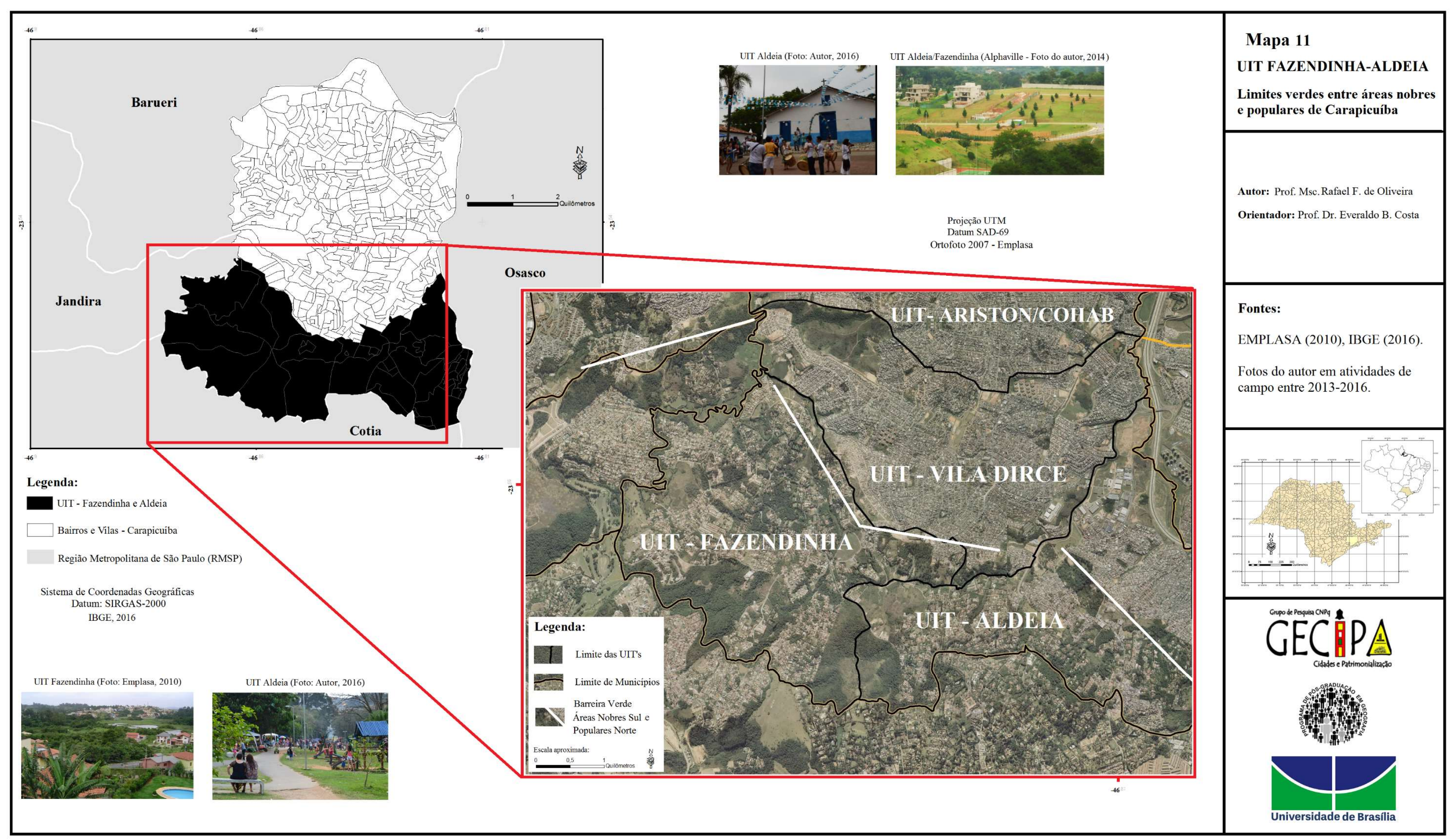


Mudança fundamental se opera de um discurso de perda ligado ao monumento para a rugosidade-documento, que para além da preservação da unidade, ao mesmo tempo gera um questionamento sobre sua visibilidade por meio do conceito de paisagem. Nesta perspectiva, emerge a necessidade do delineamento das áreas envoltórias, nas novas concepções daquilo que deveria ser a área do entorno de um bem tombado, já que a orientação “(...) centrada no conceito de visibilidade, implica mais ainda que a anterior [edifícios e obras particularizadas] na colaboração dos moradores para ser implementada" (FONSECA, 1997, p. 231). Sem dúvida, a expectativa de vultosos retornos econômicos, fizeram com que muitos espaços passassem por incrementos de infraestrutura e melhorias funcionais da paisagem à mobilidade, porém criando tensões e nítidas fronteiras entre turistas e a população local, inclusive com esvaziamentos sazonais das áreas e setorização das relações sociais (CIFELLI, 2005; OLIVEIRA, 2012). Uma série de desafios sendo gradativamente despertada no âmbito da "teoria patrimonial", que agora passa englobar maiores fragmentos e unidades territoriais, como da "prática patrimonial", cuja relação entre os sujeitos e seus espaços passa a ser dinamicamente hierarquiza, quantificada, mediatizada, objetificada por projetos alheios às populações inseridas nestes territórios, ou a grupos sociais historicamente hegemônicos.

É necessário pontuar que para além mesmo da crítica a economia política, cuja reprodução das relações sociais depende de um amplo conjunto estrutural, permeado entre outras categorias pela vertente ideológica-cultural, a cidade só recentemente passou a ser tratada no conjunto como um bem cultural. Contraditoriamente, a normatização operada nos territórios indica que essa possibilidade só é cada vez mais concreta a partir dos interesses produtivos indagados pela criação de novas necessidades germinadas massivamente pelo mercado do lazer e entretenimento. Numa primeira etapa de reflexão acerca da necessidade de salvaguardar a memória e, portanto, da manutenção de determinadas construções humanas, a cidade não foi objeto de referência em políticas de preservação, até mesmo porque suas funções nunca tiveram qualquer relação de valor histórico. Só mais tarde foram concebidas como obras que materialmente eram capazes de revelar a identidade da nação, da cultura, da sociedade. Mas ainda incapazes de uma perspectiva integrada de desenvolvimento urbano (OLIVEIRA, 2012).

Concomitantemente, em 1996 é inaugurado no Parque da Aldeia a sede da organização não governamental da OCA - Escola Cultural, com atividades recreativas e educativas às crianças e jovens da região. Atuando com projetos sociais, as atividades na Aldeia pela OCA tornam-se frequentes, buscando conscientizar estudantes sobre a 
importância daquele espaço e, num viés cultural calcado nas tradições afro-brasileiras, como a capoeira e o maracatu, dar maior qualidade e complexidade ao processo educativo e aos novos tempos de Carapicuíba. As diversas visitas ao local evidenciam que hoje são os alunos e agentes de cultura desta instituição, junto com a comunidade, a desenvolver efetivamente práticas neste espaço.

Outro marco legal no âmbito municipal é efetivado no ano de 1998 na transformação do espaço da Aldeia e adjacências, por meio de decreto municipal, numa Área de Preservação Ambiental (APA). Neste processo, aviltado pela população local, revela-se o papel operacional da comunidade frente à expansão urbana desenfreada sobre o aldeamento, assim como a degradação ambiental do entorno. Mais que isso, o papel central que as questões ambientais emergentes traduzem numa prática cada vez mais compassada com os interesses políticos e sociais, que não se exprimem apenas nos interesses da preservação dos recursos naturais, mas aqueles ligados diretamente a cultura e sua reprodução. No caso, especificamente pela comunidade de moradores do bairro Santa Terezinha, nas proximidades da Aldeia, que em ofício ao CONDEPHAAT, revela a luta pela aprovação do decreto pelo município e as dificuldades enfrentadas por conflitos de interesse com a atual gestão municipal ${ }^{92}$. Na verdade, desde a década de 1980 a Sociedade de Amigos do Bairro da Aldeia de Carapicuíba esteve a frente de vários pleitos e alternativas para a "proteção da Aldeia", inclusive com a criação de políticas de preservação junto a municipalidade (FACCIO, 2010).

A tensão que perpassa os antigos moradores não se encerra apenas com o IPHAN ou a gestão administrativa do município, mas entre eles e os novos moradores que agora margeiam o espaço da Aldeia. Destes, cabe destacar algumas falas que mostram importantes disputas pela realização de atividades culturais no pátio da Aldeia. Em um dos casos, uma das moradoras explicitou a importância da realização da cultura caipira no lugar, da vinculação histórica e que outras manifestações, como o funk ou o forró, poderiam descaracterizar o patrimônio cultural. Percebe-se nitidamente o espaço de luta que se estabelece politicamente em torno das manifestações e práticas culturais, a qual a Associação Sarabaquê - ligada às famílias Camargo e Leite, que possuem o direito de uso da maioria das habitações e que há mais de um século perpetuam os rituais religiosos e profanos da comunidade - buscam

\footnotetext{
92 Anexo 04 - Notificação da associação de moradores do entorno da Aldeia (1998) ao Condephaat e Iphan: denúncias de depredação e problemas na Aldeia de Carapicuíba.
} 
priorizar além das festas de Santa Cruz e Santa Cruzinha, também a romaria e o festival de viola caipira que ocorre no primeiro sábado de cada mês. Além da Associação, a OCA tem livre circulação, pela presença que se efetiva com o espaço construído na área do Parque e pelo apoio que dão continuamente à comunidade. Em outras falas, as dimensões do patrimônio cultural emergem como extremamente negativas, rivalizando com o desenvolvimento e todas as possíveis positividades da modernidade. Em uma das entrevistas, no bairro da Aldeia, em sua ZUC, um morador explicou diversos problemas em relação ao conjunto tombado, como a dificuldade de ampliação de atividades comerciais, ou do pleno desenvolvimento para o bairro.

\begin{abstract}
Eu não gosto. Perdemos muita coisa boa aqui por causa da Aldeia. Veja lá, os bairros perto do centro, tem Extra, tem posto de gasolina, mercados e um monte de coisa. Aqui a gente precisa pelo menos ir lá na Vila Dirce, pegar a Inocêncio que é complicado. Eles não pensaram nisso, porque se pensassem na gente iam ver que o que precisamos é de comércio, de trabalho. Agora, ali mesmo tem o parque, até aí tudo bem, porque parece mesmo que muita gente usa, mas e a Aldeia? Nada. Nada mesmo, só um monte de coisa que impede aqui. Não tem turismo, ninguém vai nem na igreja, porque pelo que sei nem tem nada mais lá. [...] O povo preferia que derrubasse, o bairro parou. (Morador do Jardim Marilu - UIT da Aldeia, aposentado, 58 anos).
\end{abstract}

Em fins dos anos de 1990 outras intervenções sobre a Aldeia continuam a ocorrer junto as já analisadas anteriormente, mas é nesse mesmo ano de 1998 que, a par de relatoria e registro fotográfico sobre as irregularidades constatadas pelo IPHAN (Figura 45), iniciam-se amplas reformas. Intervenções estratégicas que foram executadas por empresa de engenharia e que abrangiam ampla reforma tanto da capela, quanto do pátio, além de telhados, como as das casas 20 e 21. Esta ação é sugestiva, inicialmente pelas precárias condições observadas na figura subsequente, quanto ao compasso das políticas urbanas que complementam à instalação do parque. Sem dúvida, esta foi uma das mais vultosas intervenções no espaço do aldeamento até então, considerando especialmente o conjunto urbanístico da Aldeia, desde seu tombamento em 1940. Ao contrário das reconstruções cirúrgicas, de ações pontuais nas casas ou na capela, observa-se uma preocupação mais ampla com o conjunto ${ }^{93}$.

\footnotetext{
${ }^{93}$ Anexo 05 - Ofício do Iphan (1998) à prefeitura de Carapicuíba acerca de execução de obras e restauros na Aldeia.
} 


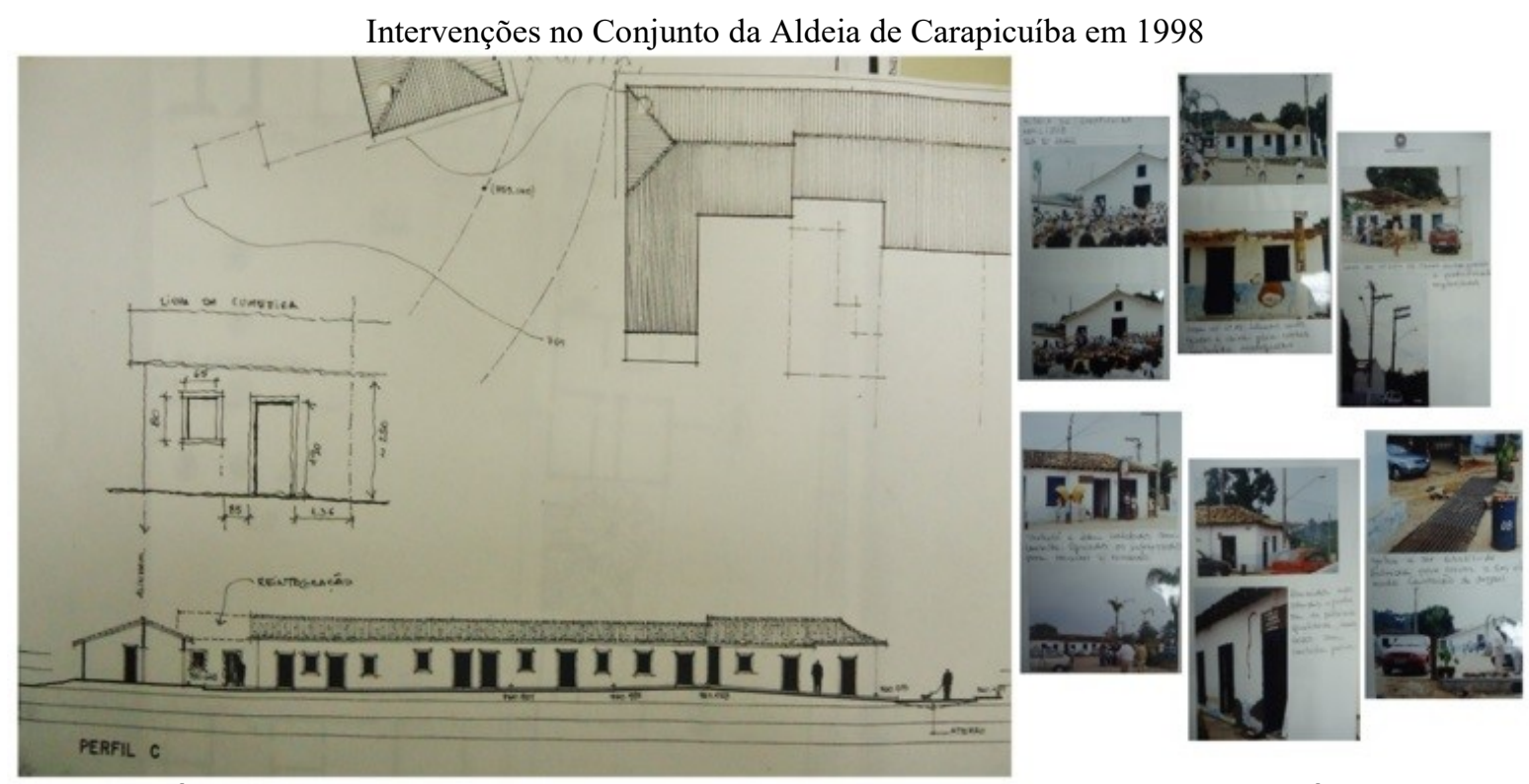

Figura 45: À esquerda, planta e perfil de parte da Aldeia utilizado no projeto de restauração. À direita, relatório fotográfico com irregularidades e algumas obras iniciadas.

Fonte: Arquivo $9^{\mathrm{a}}$.SRIPHAN/SP.

No entanto, Henne (2015) denuncia a péssima qualidade dos serviços executados no convênio realizado entre a prefeitura de Carapicuíba e o Ministério da Cultura por meio do IPHAN. Tal afirmação parece ter coerência, primeiro porque que se desdobra cinco anos mais tarde uma nova requalificação do espaço, com gastos elevados para um local que sempre esteve relativamente à margem das políticas federais de preservação. Em segundo plano, mais tarde, há pedido de explicações do Ministério Público federal (MPF) sobre as obras executadas à $9^{\mathrm{a}}$.SRIPHAN ${ }^{94}$, provavelmente por algum tipo de denúncia realizada e que não fora possível identificar precisamente nos arquivos. Segundo a autora, além do serviço de dedetização de cupim ter sido ineficiente, “[...] para a confecção dos madeiramentos dos telhados e das cumeeiras foram usadas madeiras de péssima qualidade, tanto é que, a maioria dos moradores após pouco tempo depois teve que refazer os telhados senão já estaria tudo no chão.” (HENNE, 2015, p. 85). Essas tensões são, portanto, permanentes, sobretudo ao longo das últimas décadas do século passado.

Entre os dois decênios finais do século passado, é verdade, ampliam-se as intervenções locais, que vão de restauros e reformas pontuais, no limite à reestruturação urbana resultante no desvio da estrada e criação do parque da Aldeia. No entanto, esvaziam-se as tradições do lugar, as quais resistem de forma precária diante da urbanização do território e, agora,

\footnotetext{
${ }^{94}$ Arquivo $9^{\text {a }}$.SRIPHAN/SP, no processo $n^{\circ} .01506000219 / 2003-31-$ Vol. II/II.
} 
pensadas para um plano mais simbólico e potencial do turismo e atividades culturais, do que propriamente como a rememoração ou estreitamento de laços familiares e de amizade. Menos ainda acerca da religiosidade que permeava todas as atividades, dificuldade que, como comprovado, também deriva de ações da própria igreja na resistência de manutenção das antigas práticas ali realizadas. A citação seguinte evidencia exatamente algumas dessas transformações.

[...] E aí ficou um negócio meio ruim porque no começo você ia lá encontrava todo mundo e de repente você começa a frequentar um lugar que você não conhece ninguém então você tende a se afastar né e as festas também passaram a não ser boas como eram antigamente e o que que tinha aqui em Carapicuíba? Tinha o cinema, hoje em dia nem cinema tem mais. [Sobre a festa de Santa Cruz, na Aldeia de Carapicuíba] Então, assim... antigamente lotava o pátio de estudante que vinha fazer trabalho, filmar, tinha mais barraquinhas, barraca de comida tradicional, então fazia quentão, o pessoal tomava muito quentão, comia churrasquinho , porque era época de inverno, em maio já é frio em São Paulo né, então mexia com a economia também né, hoje o pessoal não faz barraquinha porque não tem público e vai investir o pouco que tem e não tem público pra consumir que ele comprou (Entrevistada 10, moradora da UIT Aldeia de Carapicuíba, 58 anos).

Como se apreende, a população mais antiga de Carapicuíba processa na década de 1990 a derrocada das próprias relações sociais que se estabelecem em torno de festas e atrações populares, permeadas ou não pela religiosidade. As mudanças operadas no cotidiano trazem novos modos de vida, que pouco se comunicam com o passado suburbano e ligado à cultura caipira, se não num espectro folclórico e simbólico, que apesar das práticas que efetiva e, pois, das novas relações que gera, sugere uma dinâmica acumulativa, porém mais independente das rugosidades espaciais. De tal maneira, a dança de Santa Cruz da Aldeia passa a ser representada em diferentes espaços, com subsídios de programas e políticas públicas, num prospecto cultural que é totalmente diferente da ligação religiosa e espacial que possuía no passado. Como é o caso da romaria, em que mesmo havendo sobreposição entre sagrado e profano, torna-se preponderante, gerando nos grupos mais antigos ligados às tradições conflitos de difícil mensuração, não apenas em Carapicuíba, mas em outras realidades.

Como no passado, as ações dos órgãos patrimoniais, assim como a governança metropolitana expressada no planejamento e gestão do sistema urbano, seja no âmbito estadual ou municipal, perpetuam uma lógica preservacionista estritamente sobre os bens materiais, ou de "pedra e cal". Limitadas a ações de restauros e orientações técnicas nos acordos ministeriais com a municipalidade, observando-se um distanciamento do Estado com a comunidade e suas tradições. Situações que reverberam nos tantos conflitos, limitados aqui 
na descrição dos casos mais emblemáticos. A frenética busca pela originalidade dos objetos, principalmente a das formas arquitetônicas construídas, suas técnicas de taipa de pilão, ou pau-a-pique, às formas coloniais do retângulo jesuítico calcado nas Leis das Índias, aliadas ao potencial instrumental de ser objeto turístico ou peça decorativa (que nunca se efetivou concretamente), abandonaram possibilidades mais democráticas e coletivas de apreensão do patrimônio cultural da Aldeia e, portanto, de sua própria preservação.

\subsection{Da rugosidade-monumento-documento a rugosidade-instrumento (2000-2014)}

As renovações urbanas em Carapicuíba marcam um novo tempo e cristalizam no espaço, além de formas geográficas destinadas à fluidez do capital, em paralelo, do mesmo modo, equipamentos de lazer e áreas recreativas, que passam a fazer parte do cotidiano do trabalhador. Destarte, a própria lógica dos bens culturais, expressão das tradições locais, vão sendo convertidas em expressões instrumentais, que se associam aos anseios do entretenimento e do espetáculo. No caso da Aldeia, claramente indicado pela criação na área adjacente ao pátio um amplo anfiteatro para shows e atividades culturais. Além disso, o surgimento de um restaurante chileno com a venda de empadas, um ateliê de artes, a criação posterior do estacionamento, bem como o desvio do fluxo de trânsito local. Cada vez mais segregada da cidade, seja pela barreira constituída por densa vegetação instalada, pelos limites do parque e das expropriações realizadas, ou pelo fluxo de trânsito alterado, a rugosidade patrimonial da Aldeia ganha novos contornos, em que sobressaem narrativas e anseios em torno de uma autonomia calcada em novas atividades produtivas no local.

No movimento histórico em que se insere o patrimônio nacional da Aldeia, a tentativa de reintegrar plenamente suas dimensões universais é observada ano de 2001, quando se verifica em memorando do coordenador do GT-IPHAN, ligado ao Monumenta ${ }^{95}$, solicitando à $9^{\text {a }}$.SRIPHAN/SP indicação de monumentos para a possibilidade de integrar o regulamento

\footnotetext{
95 Programa de acordo de empréstimo e cooperação internacional entre o governo federal, através do Ministério da Cultura e o IPHAN com o Banco Interamericano de Desenvolvimento (BID). O Monumenta tem por objetivo o desenvolvimento do patrimônio cultural brasileiro associado aos sítios e conjuntos urbanos (DUARTE JUNIOR, 2010). O Monumenta é "símbolo primaz da universalização do patrimônio cultural brasileiro, [...] um representante, no Brasil, das ações globais de requalificação e renovação de centros de cidades antigas do mundo [...] (COSTA, 2011, p. 17).
} 
operativo do programa. A indicação é relativa a possibilidade deste espaço agregar investimentos do acordo de cooperação entre Ministério da Cultura com o Banco Mundial (BID). Ao trazer os fundamentos preservacionistas praticados internacionalmente, o programa é considerado um importante rebatimento das ações globais na escala dos locais (COSTA, 2011). De tal maneira, considerando a relevância dos bens inseridos na Aldeia ${ }^{96}$, estes passam a compor uma listagem inicial de possíveis projetos a serem executados pelo Monumenta.

De fato, ao estabelecer indicadores que pudessem classificar e hierarquizar objetivamente as áreas passíveis de desenvolvimento dos projetos ${ }^{97}$, a Aldeia de Carapicuíba obteve a melhor classificação do estado de São Paulo. Além dos problemas já elencados anteriormente, fatores como pluralidade, descentralização, diversidade e risco, foram determinantes para que a mesma ocupasse a $16^{\mathrm{a}}$. colocação entre os 94 sítios ranqueados como prioritários a receberem os projetos de todo Brasil (à frente, inclusive, das primeiras cidades a receberem os recursos e projetos do Monumenta). Interessante nesse processo é observar o enquadramento pelo programa em relação a Aldeia, listado pelo aspecto de interesse ao patrimônio indígena, quando na verdade essa perspectiva seria muito questionável e relativa mais propriamente a patrimônio colonial, desde que se considere o aldeamento enquanto um cativeiro. A posição da Aldeia de Carapicuíba na listagem final mostra sítios históricos até então com pouco destaque das políticas patrimoniais brasileiras (DUARTE JUNIOR, 2010).

Diante da incapacidade revelada de sustentar importantes contrapartidas exigidas pelo programa, sobretudo por ser um dos municípios com menor orçamento da RMSP e do espaço da Aldeia contar com poucos moradores ou empresários capazes de arcar com parte dos custos das intervenções, o acordo final entre os vinte e seis conjuntos excluiu o aldeamento de Carapicuíba. O que revela o caráter do Monumenta em privilegiar áreas com certa vocação para a dinamização econômica e de maior representatividade monumental, cuja crítica de Costa (2011) é contundente por traduzir o caso de Ouro Preto-MG, Patrimônio da

\footnotetext{
${ }^{96}$ Dado suas características históricas (tanto no plano da origem do monumento, quanto pela integralidade de suas formas atuais), dos riscos decorrentes da expansão urbana descontrolada sobre a área (conforme apontam EMPLASA, IPHAN ou a própria municipalidade) e, por fim, das dificuldades de uma cidade periférica e cuja população é impossibilitada de intervenções (isso, no entanto, não era um fator positivo para o Monumenta, ainda que um dos critérios de seleção dos projetos fosse a situação de risco, na prática o que se concretizou foram projetos cujos municípios e agentes privados puderam pagar).

97 Conforme Duarte Junior (2010), os critérios de seleção consideraram os seguintes aspectos: pluralidade; descentralização; homogeneidade; diversidade; singularidade; vazio cronológico e risco.
} 
Humanidade, onde o programa restaurou 19 monumentos e 34 imóveis privados. Se analisarmos friamente os valores investidos nas restaurações em Ouro Preto pelo Monumenta, veremos que apenas os custos da obra executada na Capela das Dores chega a ser maior que todo o montante gasto com obras na Aldeia de Carapicuíba desde seu tombamento em 1940. Seletividade de investimentos claramente identificada na escala das cidades de Ouro Preto e Diamantina por Costa (2011), que ampliada à escala nacional evidenciará contradições ainda maiores, consagrando os já reconhecidos lugares do patrimônio, que se perpetuam pela legitimidade de políticas governamentais e por investimentos em setores restritos do espaço urbano ou por aqueles que conseguirem pagar por parte destas ações. Mesmo não sendo selecionada, verifica-se a contínua tentativa de imprimir à Aldeia a consagração de seus bens patrimoniais, ressignificando seus conteúdos e materializando uma lógica produtiva que essa reserva de valor ainda guarda.

Se consideradas com criticidade a forma institucional de atuação do IPHAN em relação a preservação da Aldeia de Carapicuíba, no período em que Luís Saia conduziu ali os trabalhos e ações, as políticas mais contemporâneas dirigidas pelo órgão não deixaram de assim permanecer, fazendo dos habitantes locais alegorias animadas do pequeno conjunto isolado. Até hoje, o estudo de Luís Saia (1937) é um dos mais completos a considerar a estrutura material do conjunto arquitetônico, bem como das tradições e costumes ali praticados. Sem esquecer de importantes trabalhos sobre o folclore (PELLEGRINI, 1979) e propriamente sobre a Festa de Santa Cruz (ESCALANE, 1981). Essa ausência de ações, diálogos e políticas públicas fez com que no decorrer do tempo os munícipes de Carapicuíba, ou mesmo a própria comunidade inserida no aldeamento, estivessem quase sempre alheios aos planos nacionais das ações federais na área (que se reverbera no próprio desconhecimento das instituições de preservação, dos bens protegidos - Gráfico 07). 

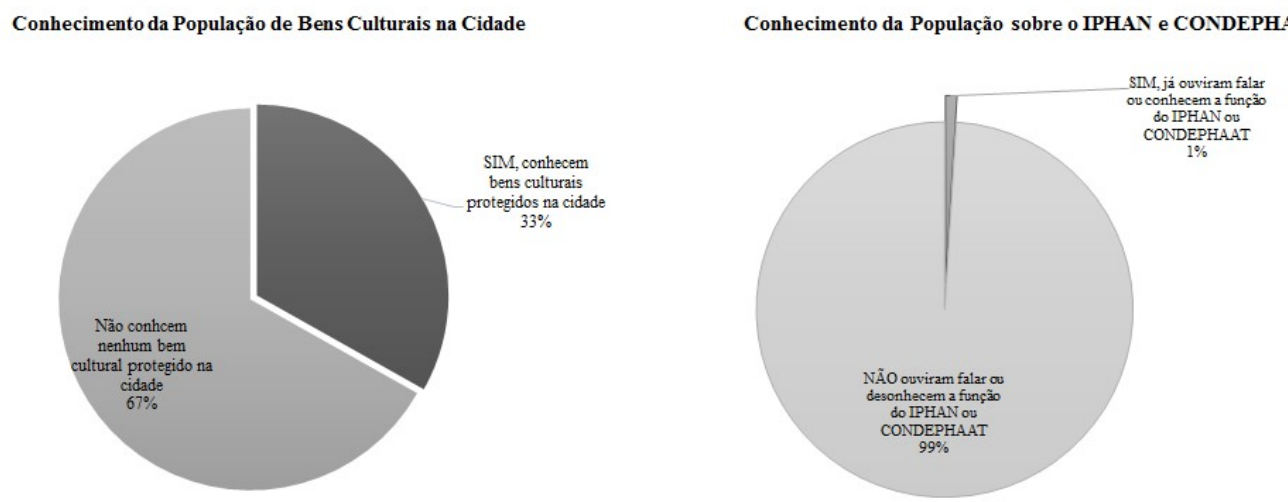

População Entrevistada que já foi a Aldeia de Carapicuiba

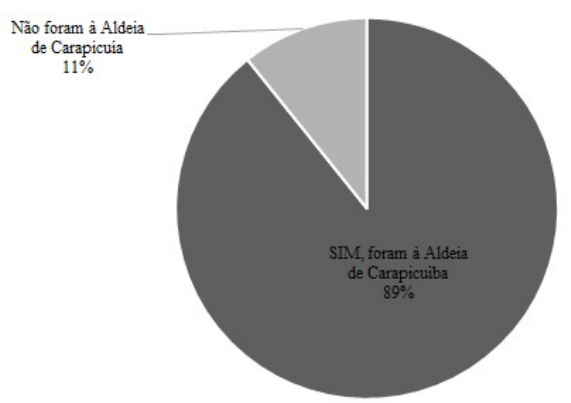

Gráfico 07: Desconhecimento das instituições e políticas de preservação do patrimônio cultural ${ }^{98}$. Fonte: Questionários semiestruturados aplicados nas UIT's pelo autor, 2016.

Da busca de perpetuar uma identidade nacional, que era impetrada pela reprodução dos dogmas arquitetônicos, das técnicas construtivas do colonizador português e da igreja católica, somam-se as várias tentativas de tornar o conjunto num recurso turístico, ou de atividades integradas aos serviços e atividades que o modo de produção passava a exigir, sobretudo numa metrópole como São Paulo, que ultrapassava seus 15 milhões de habitantes. Trata-se, muito genericamente, do conceito usado por Sant'Anna (2003) da "cidade-atração", ligado às intervenções potenciais de instrumentalização do espaço para as novas atividades produtivas em jogo. Segundo a autora supracitada (SANT'ANNA, 2003), ao analisar a preservação de centros históricos em São Paulo, Rio de Janeiro e Salvador no período da década de 1990, explica que

O foco da preservação esteve, principalmente, na valorização, recuperação e reconstituição minuciosa de fachadas principais, com grande ênfase na reconstituição e até reinvenção de elementos concebidos como de especial valor patrimonial. As operações de conservação caracterizam-se inda pelo uso de

\footnotetext{
${ }^{98}$ Valores obtidos através dos 205 questionários semiestruturados aplicados nas UIT’s de Carapicuíba.
} 
estratégias de isolamento entre o novo e o antigo, verificando-se a tendência de se operar em pólos extremos, isto é, ou por meio da produção de pastiches ou de formas absolutamente contratantes. [...] Nos anos 90, imperou, portanto, uma concepção do patrimônio urbano de caráter facadista e concentrado em poucos elementos arquitetônicos. Essa concepção foi favorecida e reforçada pela lógica financeira e promocional que presidiu a montagem e a execução da maioria das operações e pelo vínculo dessas ações como entretenimento, com o lazer cultural e com o turismo de espetáculos. Decorreu ainda de uma falta generalizada com o papel informativo, documental e social do patrimônio (SANT'ANNA, 2003, p. 166168).

A terminologia cidade-atração não se ajusta plenamente à Aldeia de Carapicuíba, primeiro porque a formação do conjunto tombado remete ao contexto do Brasil Colônia, de uma instalação isolada espacialmente do campo ou da cidade. Mais tarde passa a ser compreendida como uma herança rural, mantida e preservada pela cultura caipira. Tornandose município somente após os idos da década de 1950, quando se emancipa e é integrada efetivamente a São Paulo pelas linhas de trem e sistemas rodoviários, é que o patrimônio comportaria as dimensões diretamente relacionadas ao plano urbano. Isso, no entanto, com narrativas que limitaram-se aos dois contextos iniciais, já que as narrativas do patrimônio exigiam a excepcionalidade histórica ou a representatividade central das dimensões identitárias nacionais em criação (o índio - o colonizador português - o jesuíta). Por isso, mesmo que reunida ao sistema urbano, desde o princípio da integração à Grande São Paulo, esta não expressa em suas formas-conteúdos aparentemente qualquer relação direta. Descompassada com o restante do entorno, dos condomínios e de habitações populares, das indústrias e das vias expressas, revela-se a pequena área, com paisagem de casas simples, ou um vilarejo, como denominou Langenbuch (1971), tornando incongruente um conceito de cidade ou centro histórico propriamente. Nesse sentido, enquanto conceito, a rugosidade patrimonial torna-se peça-chave ao referenciar um espaço que congrega traços rurais e urbanos, ou de exceção se quiser pensar o espaço do aldeamento enquanto cativeiro indígena, ou como um patrimônio cultural que carrega todas essas dimensões e mais as dos munícipes, que ali criaram seus próprios sistemas de representações.

Se não há ajuste do conceito, por outro lado, as ações empreendidas no espaço da Aldeia, assim como os resultados delas, se assemelham plenamente com a análise da autora sobre os centros históricos destas grandes metrópoles. Em Carapicuíba, mesmo a importância de criar um parque urbano no entorno dos bens tomados, gerando opções de lazer a empobrecida população local, resultou porém no estabelecimento de uma fronteira entre bairros ricos e pobres daquela unidade territorial, assim como entre frequentadores do parque 
em relação ao pátio da capela de São João Batista. O qual tornou-se num espaço pouco frequentado durante o dia e ocupado por moradores de rua durante a noite. No entanto, devese apontar a constante tentativa de sustentar a rugosidade patrimonial organizada, segura e preservada, com a presença constante do policiamento no local e pinturas periódicas das fachadas das casas e capela "[...] com vista à atração de atividades e usuários capazes de dinamizá-las economicamente e promover a valorização do parque imobiliário." (SANT'ANNA, 2003, p. 161). Tal valorização acompanhou o uso institucional do mobiliário na Aldeia pela secretária e casa da cultura, a biblioteca municipal e, atualmente, a secretaria de turismo de Carapicuíba. Uma base da polícia militar foi instalada, uma sede dos correios, além da posterior criação de duas associações: Sarabaquê de Difusão Cultural e Social e a Romaria Feminina de Carapicuíba.

Outra perspectiva é a ausência documental das tradições, da memória coletiva, que asseguraram por tanto tempo a permanência daquela rugosidade, como ainda se constituem num dos elementos mais importantes, tanto para a comunidade, quanto para a totalidade do município. Essa ausência não é expressada apenas por órgãos de preservação, como o IPHAN, ou CONDEPHAAT que pouco se reclinaram em munir gestores e moradores com ferramentas apropriadas para o preservação, mas também pelas instituições municipais, as universidades públicas e privadas, bibliotecas e até mesmo a igreja. Não há um museu na cidade, não existe arquivo público, as bibliotecas municipais possuem limitações documentais, a casa da cultura ou a própria secretaria de turismo diante de suas limitações reclinam-se ao limite em apoiar as festividades e as visitas de poucas escolas e universidades. A rugosidade monumento-documento permanece, porém as ações de instrumentalização não se efetivam plenamente, ainda que como pode se observar não cessarão as tentativas, o que sugere algumas reflexões traçadas no próximo subitem do capítulo.

A Aldeia e seu entorno expressam intensa metropolização, com a projeto de heliporto e a construção do rodoanel Mario Covas (Trecho Oeste), tornando-se estes símbolos materiais maiores do processo, marcando a paisagem com contrastes de tempos distintos que, de fato, são um continuum só. Em princípios do século vinte e um as articulações multiescalares da Aldeia de Carapicuíba são impactadas e rebatem não apenas tentativas de enquadramento num processo global em que o patrimônio cultural se pronuncia com a economia, com a política, o planejamento e a gestão metropolitanas. Estas carregam importantes e novas infraestruturas e articulações locais-nacionais-globais por meio da metropolização. Processo 
que continua a incidir em Carapicuíba e a flexionar os territórios às novas funções exigidas pela Grande São Paulo.

No ano de 2001 instala-se numa área com mais de 55 mil metros quadrados, nos limites da ZPP da Aldeia de Carapicuíba, uma base de helicópteros tida como referência mundial no segmento de heliportos, na manutenção e customização de aeronaves e em serviços de hangaragem, abastecimento, taxi aéreo, entre outras atividades estratégicas. De tal maneira, como os embates acerca do distrito industrial, quase uma década antes, as obras em curso naquele período foram paralisadas por embargo extrajudicial expedido pelo MPF, impetrada pelo IPHAN. Cabe ressaltar a justificativa da ação ao MPF, calcada na importância da Aldeia pela sua singularidade e excepcionalidade (já que permaneceu frente aos outros sítios paulistas), mas fundamentalmente pelo seu valor monumental e de técnicas construtivas e arquitetônicas (como a taipa de pilão ou estruturas portantes de madeira roliça). Quando, de fato, os mais prejudicados seriam justamente os moradores locais, com possível aumento do fluxo de trânsito nas vias adjacentes, mudança dos padrões de ocupação e uso do solo, além da poluição sonora.

\begin{abstract}
O embargo das obras de construção de um heliporto nas proximidades da Aldeia de Carapicuíba se justifica pela necessidade de se avaliar o impacto que $o$ empreendimento poderá causar ao conjunto tombado, com vistas a avaliar seu impacto visual assim como evitar os potenciais riscos à sua integridade e à sua conservação. [...] Trata-se de um conjunto de pouco mais de 20 singelas edificações, extremamente frágeis, último testemunho dos aldeamentos jesuíticos característicos da ocupação inicial do planalto paulista, as quais, ademais, constituem um verdadeiro repositório de técnicas construtivas tradicionais (taipa de pilão, pau a pique, tijolos de barro, estrutura portantes de madeira roliça, coberturas de telha capa e canal, etc). Contrariamente ao que ocorreu em São Miguel, Embú, Escada, onde somente as igrejas ou capelas sobreviveram, ou em Pinheiros, Santo Amaro, Tatuapé, ou São Paulo, onde pouco ou nada restou das instalações, esta aldeia é único remanescente urbanístico da primeira fase de ocupação do planalto paulista. Sua conservação e proteção é, portanto, especialmente necessária, exigindo cuidado e atenção redobradas. Neste sentido, está sendo realizado um grande esforço para que se criar ( $\mathrm{sic}$ ) em torno da aldeia um parque que a proteja até do convívio com as humildes, mas agressivas, habitações que caracterizam a periferia paulista (Justificativa do Pedido de Embargo do IPHAN ao MPF. Processo: 2001.61.00.007167-0).
\end{abstract}

Compreende-se que o sentido do discurso traduzido no documento citado é revelador em primeiro pelo desconhecimento da área em que se insere o aldeamento, já que o parque havia sido finalizado há mais de cinco anos. Depois, a narrativa marcadamente segregacionista, que separa o bem tombado do restante da cidade, isto é, das habitações periféricas que a circundam, porém nada se fala das chácaras, condomínios e empresas que ali 
também disputam espaço e território. Em terceiro, o culto ao monumento pelo seu valor histórico e de antiguidade ${ }^{99}$ (RIEGL, 2014 [1903]), em que a permanência do conjunto se diferencia de todos os outros casos. Por fim, ainda neste fragmento, a emergência do discurso da perda, o qual reitera e justifica que ações como as instalações modernas em jogo poderiam decretar o fim da pequena, singela e frágil Aldeia de Carapicuíba.

Após mandato de segurança requerido pela empresa HELIPARK e acolhimento do MPF as obras foram retomadas, já que o espaço localizava-se fora do perímetro de entorno considerado por lei municipal (PDDI, 1981, 1986). No entanto, a paralisação funcionou, estrategicamente, no sentido de uma avaliação pormenorizada dos impactos diretos e indiretos das instalações da base pelos órgãos de preservação, destacadamente o IPHAN e o CONDEPHAAT. Além disso, foram estabelecidos acordos e medidas entre os interessados, considerando principalmente o desvio dos voos da área tombadas, assim como cuidados preventivos em relação a poluição sonora, trepidações e outros impactos que por ventura afetassem diretamente o aldeamento. Em entrevista, no entanto, uma das moradoras locais explicou a existência do alto fluxo de aeronaves que cruzam ou circundam a Aldeia, além do barulho que fere o sossego daquele espaço. Impactos que na atualidade requerem novos diálogos entre os órgãos de preservação, a comunidade e a empresa por novos acordos e procedimentos.

Paralelamente, finalizam-se as obras do trecho oeste do rodoanel Mario Covas, nas proximidades da Aldeia de Carapicuíba, sobre o ribeirão Carapicuíba. Perfazendo nesta área o sistema Castello Branco/Raposo Tavares, com implantação de vias marginais e acessos aos municípios de Cotia, Osasco e Carapicuíba. A importância desta nova ligação rodoviária para Carapicuíba se insere no contexto de modernização paulatinamente maior do seu território. Seja pela integração com outros municípios da Grande São Paulo, na conectividade da via com o distrito industrial, ou pelas novas intervenções urbanas que se desenvolvem a partir da chegada de novos moradores (edifícios residenciais, loteamentos de chácaras e condomínios) e atividades nestas áreas (apresentações culturais, comércio e serviços mecânicos). Cada vez mais, portanto, estabelecendo uma nova cidade frente ao pequeno conjunto que, por sua vez, permanece com suas antigas formas, abrigando, porém, outros conteúdos e ações.

\footnotetext{
99 Pelos aspectos estéticos do monumento o valor de antiguidade pressupõe a intervenção arbitrária na sua existência, sem sofrer acréscimos, reduções, ou mesmo restituições que as forças naturais deterioraram. Ao valor histórico se acrescenta a possibilidade de intervenção a partir do momento em que o valor de antiguidade foi estabelecido, ou seja, sinteticamente, a partir do momento em que se qualifica o bem como um patrimônio cultural a ser preservado (RIEGL, 2014).
} 
Entre 2003 e 2004, da licitação ao início das obras, uma reforma estrutural na Aldeia é operada através do convênio Minc/SE/FNC de recursos dirigidos ao Projeto Conservação Preventiva de Bens do Patrimônio Histórico Artístico Nacional, conduzido pela 9 .SRIPHAN/SP sob a denominação de Projeto de Revitalização da Aldeia de Carapicuíba. Neste processo, entre outros documentos, a carta convite 03/2003 ${ }^{100}$ em suas descrições gerais, apesar do caráter informativo, considerando a especificidade do pleito licitatório e o convite de possíveis empresas em realizar as obras, pode ser considerada uma das mais completas descrições do espaço da Aldeia de Carapicuíba desde o texto original de Luís Saia em 1937. Além disso, pode ser considerada a obra estrutural mais cara e vultosa desde seu tombamento, onde a alocação de recursos chegou a mais de $\mathrm{R} \$ 139.000,00^{101}$. Se adicionados os valores aplicados nas intervenções em 1998, após inauguração do parque, em sete anos os investimentos do governo federal na área ultrapassam $\mathrm{R} \$ 200.000,00$, considerando, porém, mais os aditivos de contrapartida do município o valor é ainda maior.

Os valores parecem irrisórios para a preservação de um conjunto de bens culturais materiais e intangíveis com a relevância histórica da Aldeia, sobretudo quando comparados aos valores de projetos como o Monumenta, desenvolvidos em centros históricos de diversas cidades e que ultrapassam a casa dos milhões de reais. Trata-se, no entanto, de saliente incremento econômico ali investido e, como comprovam os documentos e relatos, jamais realizados no conjunto da Aldeia no passado. O que comprova o papel marginal no quadro do patrimônio nacional por ele ocupado, lembrando que São Paulo foi ignorado pela ausência da monumentalidade de suas construções quando esse pressuposto era um dos fundamentos do tombamento e das políticas públicas de preservação no período de pedra e cal, ou numa cidade periférica cuja funcionalidade carrega a sina da dependência e do desenvolvimento desigual que se perpetua em níveis regionais da metrópole nacional ao sistema mundo.

As imagens do relatório de restauro (Figura 46), submetidas ao IPHAN pela empresa contratada para realização das obras, comprovam uma vez mais a ênfase de atuação sobre o mobiliário. Das intervenções realizadas no "projeto de revitalização", constam serviços preliminares (mobilização e indicação), demolição e retirada (telhas, trechos de alvenaria, entulhos), estruturas e coberturas (madeiramentos, mobiliários), esquadrias (recuperação de

\footnotetext{
${ }^{100}$ Arquivo da $9^{a}$.SRIPHAN/SP - Processo 0506000219/2003-31 (Volume I).

${ }^{101}$ Arquivo da $9^{\text {a }}$.SRIPHAN/SP - Processo 0506000219/2003-31 (Volumes I e II).
} 
portas e janelas), revestimentos (pisos e pinturas diversas), imunização e limpeza (tratamento das madeiras e combate às formigas e cupins).

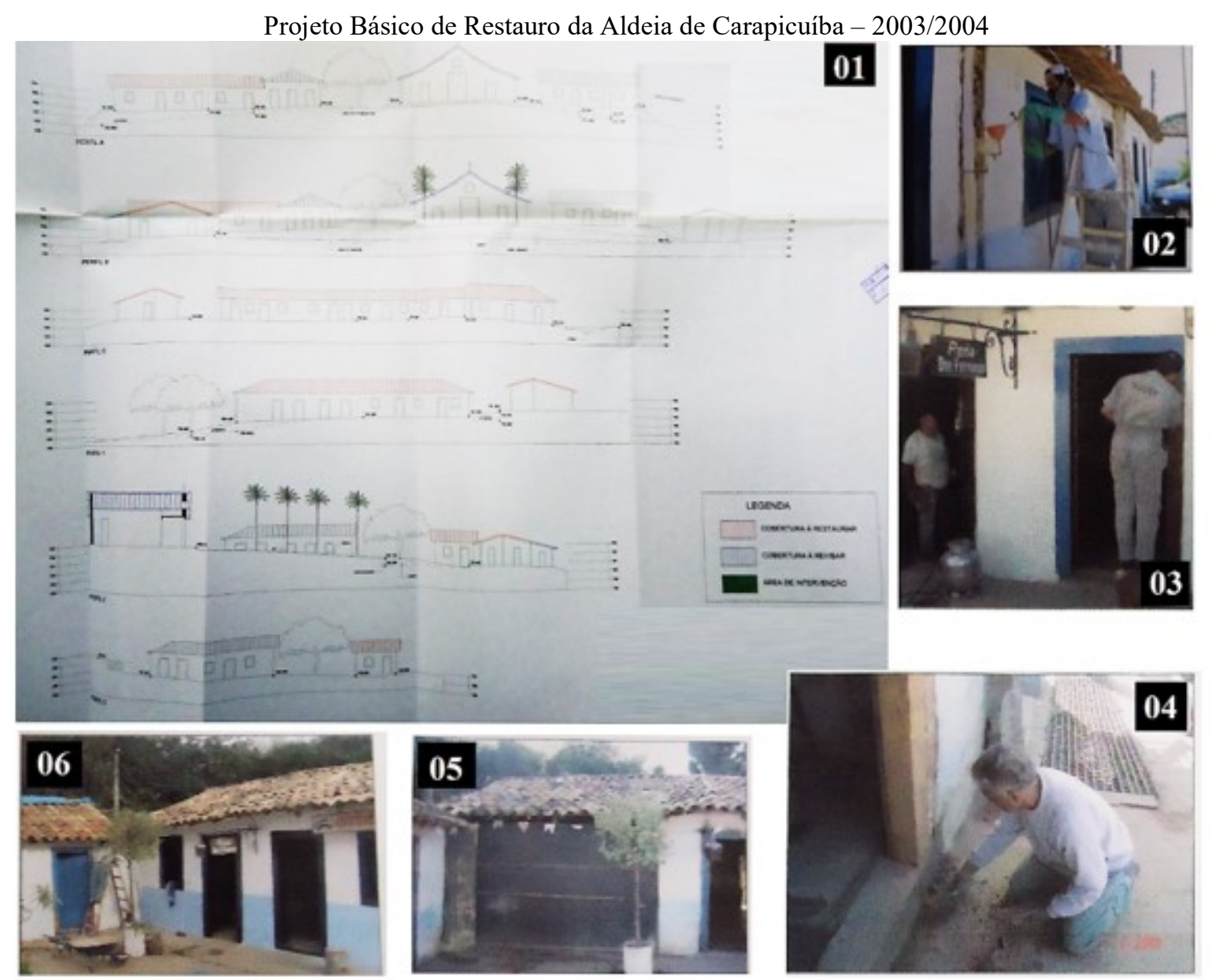

Figura 46: (1) Perfis das faces de intervenção do conjunto da Aldeia de Carapicuíba; (2) Aplicação de cupinicida; (3) Pintura de portas e janelas; (4) Restauro de batentes e soleiras; (5) Fachada casas 01 e 02 como encontrada antes da execução do projeto; (6) Fachada após reconstrução e restauro - 2004. Recursos Minc/SE/FNC.

Fonte: Arquivo da $9^{\text {a }}$.SRIPHAN/SP.

Uma das maiores intervenções foi a reconstrução quase que inteira das casas que abrigavam o restaurante nos números 01 e 02, que já haviam sido reconstruídas ainda na gestão de Luís Saia no SPHAN/SP, depois novamente na década de 1980 (provavelmente em 1986) ${ }^{102} \mathrm{e}$, agora, mais uma vez eram adequadas às condições pretéritas que possuíam e foram descritas no processo de tombamento. A envergadura das intervenções são ressaltadas pelo IPHAN em correspondência com o MPF, como segue:

102 Ao fazer um mapa com nome dos moradores da Aldeia, Escalante (1981) aponta como proprietários das casas 01 e 02 Bento Pereira, colocando entre parênteses que as duas casas ruíram. Por sua vez, fotos de fins da década de 1980 observadas com moradores e no arquivo da $9^{a}$.SRIPHAN/SP mostram a sua presença no conjunto. 
Desde 2004 o IPHAN tem trabalhado para a recuperação deste conjunto. A primeira etapa envolveu todas as construções voltadas para o pátio norte e biblioteca municipal no pátio oeste. Nesta segunda etapa que se conclui neste mês de março, foram restauradas todas as casas do pátio leste incluindo o Posto da Polícia Militar e do pátio sul, incluindo a reconstrução completa da cobertura do centro dos caixilhos e portas da Igreja. Quase todas as edificações foram parcialmente desmontadas, seus moradores transladados para as construções já restauradas, e posteriormente realocados em suas casas restauradas e tratadas contra xilófagos." (Relatório do IPHAN ao MPF - Representação 1.34.000.069.2004-75 requer informações das obras de 1998 e condições atuais do patrimônio cultural da Aldeia de Carapicuíba - grifo nosso).

Finalizado o projeto no ano de 2004, um ano depois é operada uma proposta de trabalho, com nova intervenção no espaço da Aldeia, agora na sua rede elétrica. Se as ações são pontuadas como de interesse da manutenção da qualidade paisagística, associada ao valor de antiguidade do monumento, novas tensões são despertadas com a população local, inclusive com a posterior saída do restaurante da Aldeia, frente aos embates com o IPHAN e moradores locais. Uma das moradoras explicou que a manutenção do restaurante ali era difícil pelas dificuldades que o proprietário tinha com as restrições interventivas limitadas nos espaços construídos. Explicou ainda que outro problema associava-se à dificuldade de estacionamento dos veículos, distante do local, além de que a presença dos carros no pátio gerava tensões com a comunidade, sobretudo nos festejos tradicionais da Aldeia. Ainda sobre as instalações elétricas, uma das últimas intervenções operadas na Aldeia no ano de 2014 foi a passagem dos cabos aéreos para o subsolo e implantação de nova iluminação do pátio por meio de amplos postes metálicos nos extremos da área.

\footnotetext{
A atual administração demonstrando interesse pela Aldeia resolveu efetuar a iluminação do pátio da Aldeia. Para isso foi preciso destruir parte do piso para efetuar obras subterrâneas. Tivemos uma Festa em que dançamos em meio a buracos e ferros. Mas, em nome da melhoria, aceitamos animadamente as mudanças. Tudo parecia muito bem até que, para nossa surpresa, de um dia para o outro, foram colocados postes enormes de ferro em toda a Praça, uma agressão aos nossos olhos." (HENNE, 2014, p. 86 - grifo nosso).
}

Como é passível de compreensão, as contínuas intervenções realizadas nas três últimas décadas na Aldeia de Carapicuíba, além das tentativas de enquadrá-la em projetos de maior vulto como o Monumenta, assentam-se sobre infraestruturas limitas ao pequeno conjunto tombado. Ora em reparos na área do pátio da igreja de São João Batista, ora em uma ou outra habitação, ora nos mobiliários, ou ainda acerca de instalações elétricas ou pontualmente em 
problemas mais urgentes que eram denunciados e protelados junto ao IPHAN. Ressalta-se, uma vez mais, a importância destas cirúrgicas e estruturais reformas, que apesar dos baixos valores empregados, revelam-se os mais importantes em toda história de atuação dos órgãos de preservação ou da municipalidade naquele espaço. Não apenas pelos investimentos em si, mas sobretudo pelas relações de conflito e tensão que se estabelecem concomitantemente com o entorno em conjunto destas operações. Seja diretamente, inicialmente pela criação do parque e a desapropriação de mais de uma centena de famílias da área, ou indiretamente pelas modernizações operadas no distrito industrial, do asfaltamento das vias laterais, do desvio do fluxo de veículos da Aldeia, dos novos moradores, ou por último, na instalação da base de helicópteros e o rodoanel.

Esta última fase, da contínua busca por unir a preservação da Aldeia com modernas atividades produtivas, a qual denominamos de rugosidade-instrumento, não foi concretamente realizada. Pelas análises in locu, leituras, diálogos com a população e dirigentes culturais do município, isso derivaria do esvaziamento da Aldeia, sobretudo pelas políticas públicas não possibilitarem efetivamente a permanência delas, dos serviços e moradores no local. Depois, por não haver apoio aos projetos e as tradições seculares que animam aqueles espaços, como o estabelecimento de cooperação e incentivos que propiciassem uma estrutura básica às festas e atividades religiosas da comunidade. Por último, a base do desenvolvimento calcada no turismo e na cultura frustrou-se, sobretudo pela dificuldade de acesso ao local, a violência que impera em Carapicuíba, mas também na ausência de projetos locais e em conjunto com outros municípios para ampliar a promoção da Aldeia e do parque como destino turístico na Grande São Paulo ${ }^{103}$.

Um importante parêntese deve ser colocado em relação a narrativa desenvolvida pelo circuito "Taypa de Pilão" em referência às cidades e objetos consagrados e explorados nas atividades turísticas. Em trabalhos anteriores, principalmente em Oliveira (2012), acerca do Roteiro dos Bandeirantes, pontuamos criticamente a ideologia geográfica traduzida pela imagem heróica dos bandeirantes em São Paulo, explorada e reproduzida sistematicamente pelas agências comerciais e empresas de turismo junto às secretarias municipais de cultura e turismo. No caso deste circuito, uma vez mais, prevalece o valor patrimonial sobre o bandeirante, às ideias de ampliação do território brasileiro, além dos arquétipos de fé, bravura

\footnotetext{
103 A criação forma, do circuito turístico "Taypa de Pilão", no ano de 2009 junto com Embu, Santana de Parnaíba, Barueri, Cotia e São Roque, anuncia a tentativa de potencializar o turismo na área, bem como na região como um todo, porém passados mais de meia década sem se concretizar efetivamente.
} 
e força lançados aos monumentos e cidades como sinônimos de uma história, que na verdade é irreal e ideologicamente comprometida com o subjugo colonial e a subordinação militar das expedições que assassinaram milhares de famílias indígenas, além da escravização de outros milhares (Figura 47).

Os roteiros de um dia já estão sendo comercializados pela Graffit Viagens e Turismo, com a proposta é divulgar a história do bandeirismo paulista, com visitas aos prédios tombados pelo Instituto do Patrimônio Histórico e Artístico Nacional (Iphan) e pelo Conselho de Defesa do Patrimônio Histórico, Arqueológico, Artístico e Turístico (Condephaat). Partindo do tema histórico, os roteiros de um dia ganham mais atrações dependendo da região e do município. [...] O Circuito Paulista Taypa de Pilão convida turistas para desbravar o interior do Estado e descobrir a verdadeira história de força, fé e coragem dos bandeirantes. Eles utilizavam as construções de taipa de pilão para o descanso nas caminhadas ao interior, com o fim de ocupar espaço e expandir o seu domínio (Matéria na página oficial da Prefeitura Municipal de Embu das Artes - grifo nosso).

Postal Rota Carapicuíba do Circuito Taypa de Pilão

\section{Rota Carapicuíba do Circuito Taypa de Pilão}

O Circuito Taypa de Pilão é composto de bens tombados pelo Instituto do Patrimônio Histórico Artístico e Nacional, representativos do periodo da colonização do entorno oeste metropolitano por jesuitas e bandeirantes, entre os séculos XVI e XIX. A Taypa de Pilão é a técnica construtiva que utiliza barro socado entre formas, caracteristica comum nos monumentos das cidades de Barueri, Carapicuiba, Cotia, Embu das Artes, São Roque e Santana de Parnaíba.

A Aldeia de Carapicuíba - fundada em 12 de outubro de 1580, fazia parte do projeto de Aldeamento Paulista ao redor de São Paulo de Piratininga, consistia em 12 aldeias, a de Carapicuíba é a única que preserva suas características iniciais. Seu traçado urbano, revela a solução construtiva dada pelos jesuítas naquele período, um núcleo de residências baixas, fechado de forma quadrangular, ladeando a capela e mantendo um cruzeiro ao centro do pátio. Tombada em 1940.

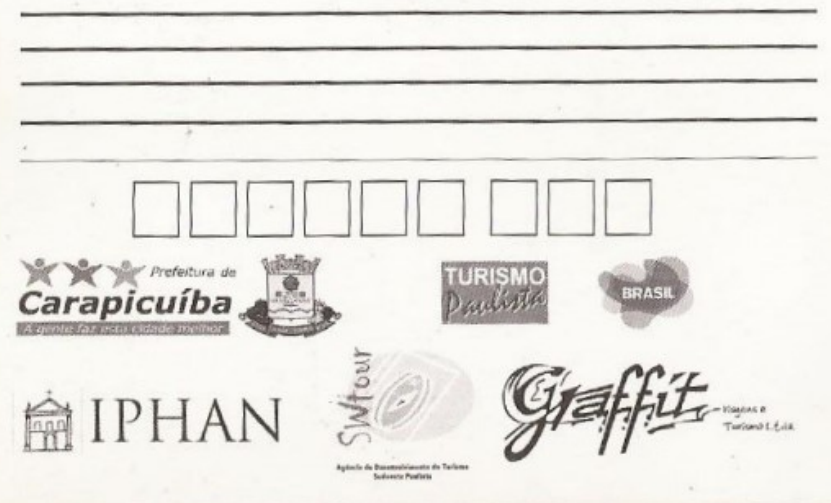

Visitas:

Contato: Secretaria de Cultura e Turismo

(11) 4186-0821 / 4186-6462

Graffit Viagens e Turismo

(11) $5549-9569 / 5083-4056$

www.taypadepilao.tur.br

Figura 47: Verso do postal "Rota Carapicuíba do Circuito Taypa de Pilão". Antiguidade, patrimônio histórico nacional protegido (tombado), bandeirantes, jesuítas, técnicas construtivas e colonização são algumas das qualidades exaltadas.

Fonte: Postal Circuito Taypa e Pilão, Prefeitura de Carapicuíba, 2013.

Traídos pela paisagem, longe do que promete o circuito, ainda que de alguma beleza estética, os turistas ao chegarem na Aldeia de Carapicuíba se deparam com o pequeno conjunto de casas térreas que circunda a capela, onde os edifícios remetem a um núcleo rural 
em meio à metrópole, do que a monumentalidade que possivelmente o desbravador teria produzido (Figura 48 e 49). Se, de fato, o valor histórico estivesse voltado para narrativa bandeirante, esta deveria ter um significado muito mais trágico que heroico. Afinal, no melhor dos cenários, os limites do culto a torturadores e assassinos, ou a um espaço de exceção, de aprisionamento e cativeiro, só pode prescindir mesmo a decadência desta sociedade. Onde, no entanto, a resignificação em torno da realidade concreta deste patrimônio traria condições de outra estratégia de desenvolvimento, superando a patológica narrativa que o circuito continua a insistir, e reforçando a criticidade nas funções do bandeirante e do jesuíta, recolocados nos persistentes problemas contemporâneos, muitos dos quais são originados desde a colonização nos territórios latino-americanos.

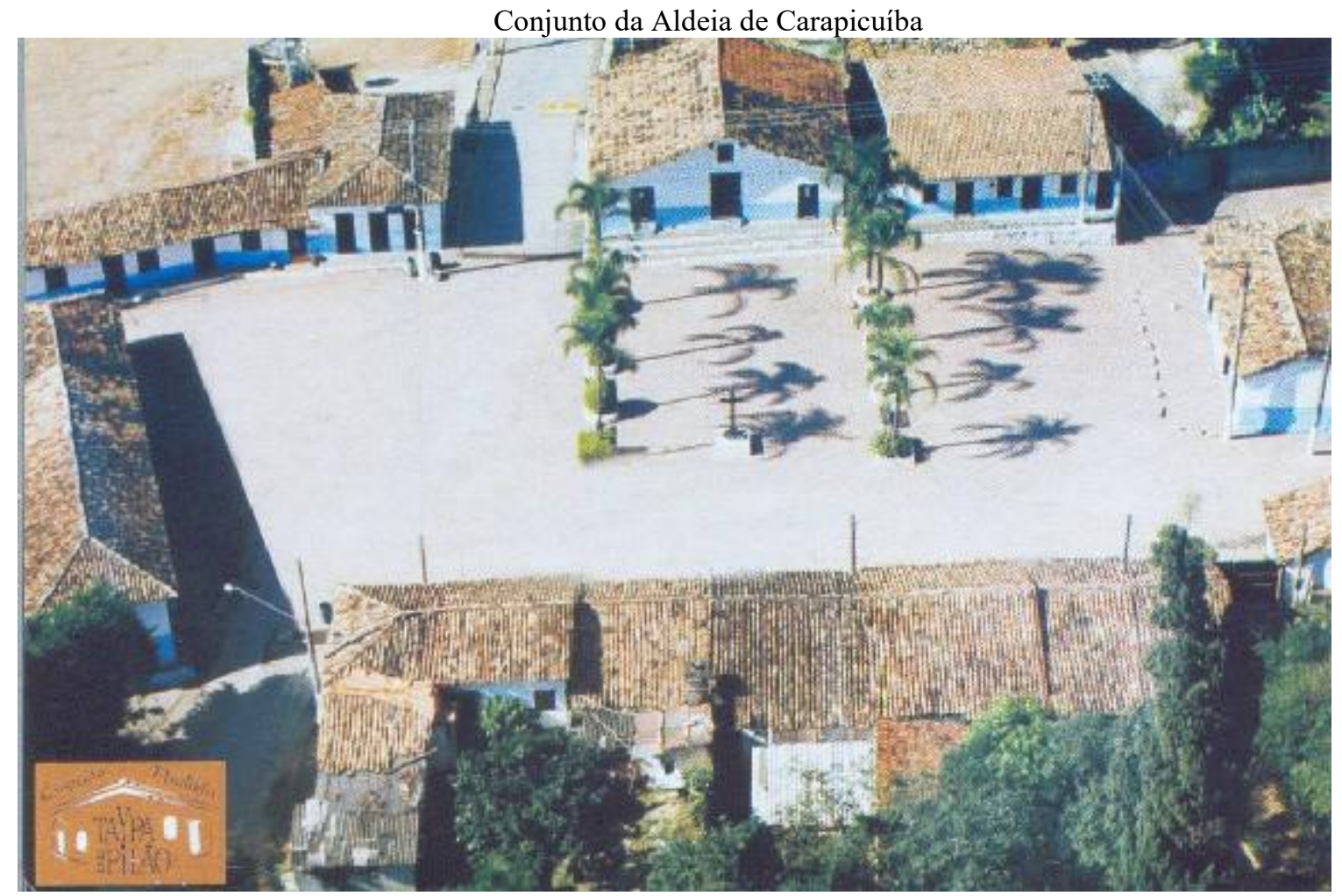

Figura 48: Perspectiva do conjunto urbanístico da Aldeia de Carapicuíba, rugosidade patrimonial. Fonte: Postal Circuito Taypa e Pilão, Prefeitura de Carapicuíba, 2013. 


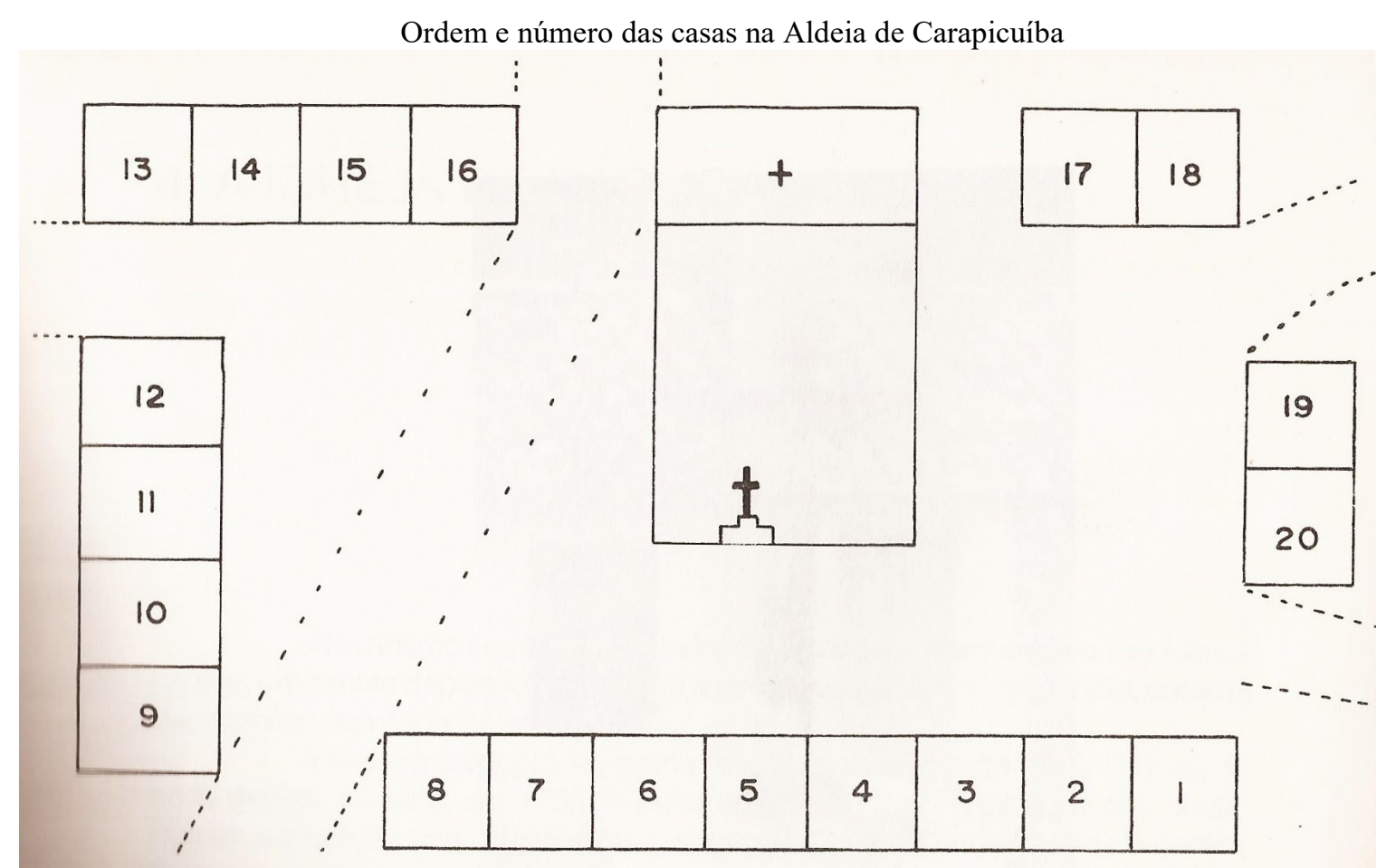

Figura 49: Croqui com a distribuição das vinte pequenas casas, a igreja e o cruzeiro da Aldeia de Carapicuíba. Fonte: Escalante, 1981.

Tornar formalmente o patrimônio cultural urbano num dos elementos do planejamento territorial, apesar de fundamental, não foi capaz de democratizá-lo em sua preservação. Os avanços discursivos são evidentes, no entanto a prática mostra que alguns dos principais problemas urbanos residem num planejamento territorial que prioriza valorizar certas unidades em detrimento de outras. Manifestando-se desde a escala de localidades relativamente pequenas, com seus núcleos históricos destacados do continuum urbano, até a reprodução mundialmente sistêmica dos processos por meio da Lista do Patrimônio Mundial (UNESCO) e de ações que se limitam aos interesses e esforços de (re)valorizações específicas do território. Como Costa (2011), compreendemos que “[...] a 'cidade histórica' deve ser pensada, planejada, enquanto totalidade urbana e não centrada no núcleo tombado, para assim se efetivar tanto a preservação do patrimônio quanto a prática do planejamento urbano." (2011, p. 143). Ao perceber a cidade de Carapicuíba em sua dimensão metropolitana, observará facilmente no âmbito de sua periferização, que não apenas as políticas patrimoniais foram ausentes ao núcleo principal, como a todo território municipal, ou mais criticamente, a ausência é a própria forma de conivência, de um abandono proposital que se faz para a produção diferencial de valores sobre os territórios. 
No ano de 2011, pode-se apontar para uma das mais importantes e diferenciadas políticas do IPHAN para a Aldeia de Carapicuíba: a contratação de consultoria para subsidiar a elaboração de normativas para sítios urbanos tombados no estado de São Paulo. Estas atividades desenvolvidas em várias cidades de São Paulo puderam ampliar o raio de ação e o olhar para além dos monumentos isolados, sistematizando dados e mapeando de forma integrada o entorno dos bens tombados. Os trabalhos ainda reclinaram-se em oficinas e atividades dialógicas com a comunidade, no intuito de sustentar a participação da população nos processos decisórios sobre futuras ações na área e, até então, pode ser considerado, no plano das políticas públicas, do planejamento e gestão urbana e do patrimônio cultural, algo inédito desde as estratégias do PDDI em Carapicuíba e diante das verticalidades praticadas. Apesar dos limites estabelecidos por um público alvo, que incluía servidores da prefeitura de Carapicuíba, moradores, usuários da Aldeia e representantes da OCA, as atividades trabalharam a conscientização, levantando, porém, anseios, potenciais de desenvolvimento e limitações que por ventura existissem. $\mathrm{Na}$ discussão que finda a rugosidade patrimonial de Carapicuíba materializada na Aldeia de Carapicuíba e, pois, na sua população e comunidade é que melhor será explorado o referido documento, além dos levantamentos primários obtidos ao longo da pesquisa. Trazendo uma perspectiva de leitura que transcende as intervenções e políticas públicas realizadas ao longo do tempo naquele espaço, porém, carregando essas ações e práticas nas relações e representações da população local.

\subsection{O novo espaço da Aldeia, o novo tempo de Carapicuíba: Patrimônio Cultural e Vida Cotidiana na Periferia de São Paulo}

Urge pensar a crise urbana, ou a urbanização crítica (DAMIANI, 2015), também como uma crise de identidade, cuja ausência do direito à cidade se reverbera concretamente na condição precária da entidade cultural, de práticas sociais não enquadradas ou limitadas ao sistema de cotidianidade imposto verticalmente pela vida moderna, bem como do potencial de desenvolvimento a partir de uma práxis horizontal e coletiva. Não se trata, portanto, de mera questão subjetiva, ou de uma exclusiva entidade do todo social, mas de um conjunto mais amplo, em que se concatenam também a economia, a política e o espaço geográfico como fundamentos indissociáveis da vida cotidiana. Objetificados e inertes no tempo e espaço, os referenciais de vida em Carapicuíba, cada vez mais efêmeros frente as transformações dos espaços e relações, perpetuam-se nos velhos mitos fundadores estabelecidos, os quais se 
concentram nas falas dos moradores em imagens difusas e ligados a história fatual e heróica do Brasil. No polo oposto, emergem permanências, práticas e atitudes plenas de consciência histórica, as quais reverbera o potencial de pensar, decidir e realizar coletivamente a cidade. Do mesmo modo, o papel da geografia na ativação destes potenciais, naquilo que Costa (2016) reitera dos "utopismos patrimoniais", enquanto meios de substanciar iniciativas localizadas e alternativas para além de ações estigmatizadas e predatórias dos territórios pelo modo de produção atual.

Para Costa (2011), o empoderamento dos bens materiais-simbólicos pela população seria capaz de sustentar o enfrentamento da patrimonialização global e, portanto, dar outro sentido para as políticas urbanas pelo ordenamento territorial. Para o autor, "sem a tensão eficaz dos polos local/global, sem a constante mutação dialética das determinações mediadoras e das questões intermediárias que ordenam o território urbano (...), não nos aproximamos da realidade que abarca a patrimonialização global.” (COSTA, 2011, p. 181). Esta tensão que se efetiva entre cultura e poder ainda perdura e é acentuada pela patrimonialização, agora numa outra perspectiva de significância, mas que ainda é tratada muitas vezes de forma neutra ou naturalizante sobre os conflitos sociais. E assim também decorre no polo dialético da preservação, pois talvez em menor proporção, já que tal quantificação é dificultada, restam muitos elementos, unidades e conjuntos de formas geográficas, ou conteúdos que não foram subtraídos totalmente pelo imperialismo e a lógica pervertida das modernizações. Neste sentido, a autora supracitada lembra da importância que as lutas sociais possuem para afirmação e fortalecimento das identidades, bem como das memórias como resistência frente a racionalidade econômica e produtiva contemporânea.

[...] afirmar e fortalecer identidades culturais que se encontram em risco em função das necessidades de expansão e modernização capitalista que avança sobre territórios de grupos sociais mais vulneráveis. [...] mobilizar memórias e patrimônio por meios destas lutas constituem formas de resistência contra a lógica do progresso e da racionalidade econômica, que defendem a constante 'renovação' da cidade, destruindo bairros como lugares de sociabilidade, para implantar novos eixos viários, grandes equipamentos da indústria cultural, ou formas de morar autosegregadas (SCIFONI, 2013 p. 527).

Em síntese, ao passo que é verificado o distanciamento dos sujeitos de sua produção material e espiritual, dos frutos do trabalho individual e coletivo, surgem interessantes possibilidades a partir de sua marginalidade frente ao sistema "sociometabólico do capital" (MÉSZÀROS, 2011). Do qual o patrimônio cultural remete as bases mais primitivas da 
construção institucional da identidade nacional e, assim, da condição de sua própria crítica, em que a Aldeia de Carapicuíba acaba por ter relevante papel neste processo, não apenas pelo reconhecimento institucional, mas pela permanência das tradições e laços que se estabelecem em seu redor. Isso, sem dúvida, coloca inúmeras questões desta construção, acerca da representação histórica e geográfica que o munícipe possui de sua cidade, mas fundamentalmente da reafirmação de outras dimensões até então subjugadas pela retórica patrimonial.

Nesse processo, inicialmente, emerge o papel da superestrutura, que opera orgânica e metabolicamente sobre a sociedade, no sentido ideológico de suplantar imaginários coletivos ligados a uma matriz identitária. Destacando-se, pela própria indicação dos entrevistados, numa história formal, compassada com os preceitos memoriais e sentidos de nação, geograficamente operados na ideia de formação territorial em escalas que vão do local ao global. Nos relatos, a unidade da Aldeia de Carapicuíba é capaz de integrar indiscriminadamente diferentes personagens e contextos explicativos, porém restrito a uma dimensão de ampla incursão pelo passado, de relações entre territórios e de certa harmonia cultural entre grupos sociais.

Esses fatos sugerem um espaço harmônico de convivência entre o índio e o jesuíta, em torno das necessidades coloniais de então. Pouco se aventa do caipira, do imigrante suburbano, ou da periferia enquanto unidade cultural. A festa de Santa Cruz torna-se quase sempre, por exemplo, um elemento central neste dimensionamento, ao considerar que ela resulta da mescla de diferentes culturas, corroborando para os mitos fundacionais de nossa miscigenação étnica. Esta realidade limita-se a escamotear as contradições perpetuadas pela escravização do índio em favor do colono português, da Coroa, ou da própria Igreja em busca de estabelecer pelos jesuítas uma nova organização social em territórios latino-americanos. Ou até mesmo, do papel que ela tem para os modos de uso do território na atualidade.

Deve-se pontuar, no entanto, que grande parte dos entrevistados diz não conhecer a história de Carapicuíba (Gráfico 08), isso invariavelmente em relação à idade, gênero, tempo de residência no município, nível de educação, ou qualquer classe que se queria qualificar os indivíduos. Fato que deve ser reconhecido por uma concepção de história que remete aos compêndios enciclopédicos de fatos marcantes e universalmente aceitos - os quais sugerem, uma vez mais, facetas reificadas dos bens patrimoniais que foram produzidas pelo esforço coletivo de toda essa comunidade. Vive-se, pois, uma história cuja a vida e o cotidiano destes 
entrevistados não relacionam-se diretamente com a cidade, mesmo estes habitando e trabalhando ali por tantas décadas. As dimensões de história, portanto, restringem-se a colonização epistêmica que impositivamente se apropriou dos fatos e explicações dos processos que produziram a atual realidade. Experiências, vivências do urbano, dimensões do trabalho, são perdidas em poucas citações, das quais relacionam-se às velhas narrativas fatuais, heroicas e dissociadas da concreticidade do real. Trata-se de uma dimensão de patrimônio-territorial ainda desvinculada do utopismo revelador das contradições, ou denúncia da exploração (COSTA, 2016) ${ }^{104}$.

\section{População que Conhece a História da Cidade}

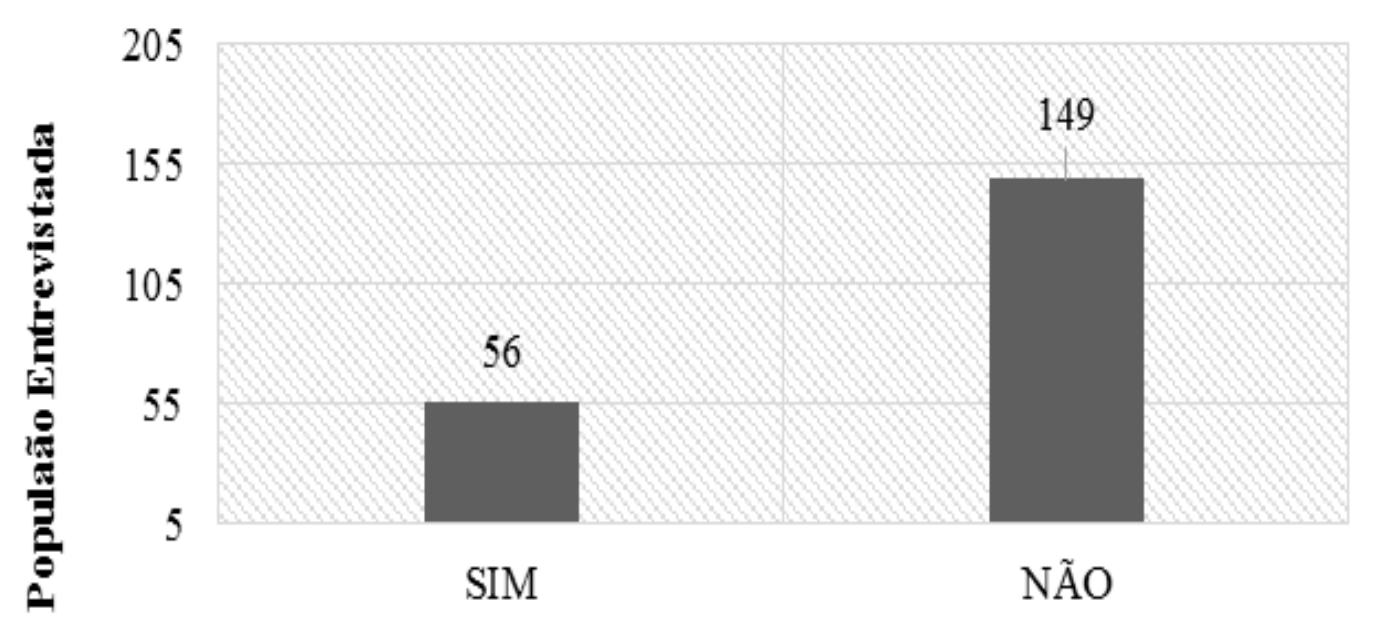

Gráfico 08: Resultado dos entrevistados que disseram conhecer ou não a história de Carapicuíba.

Fonte: Questionários semiestruturados aplicados nas UIT's pelo autor, 2016.

O fenômeno de "desconhecimento" da história torna-se numa questão indicativa de um processo de invisibilidade perante a construção da realidade espacial de Carapicuíba, convergindo na ausência das rugosidades (normatizadas ou ligadas à memória coletiva) sintetizar a diversidade e as dinâmicas dimensões de vida que se estabelecem neste território. Longe, pois, dos caipiras, da realidade suburbana e, ainda mais, do plano periférico que hoje reveste a cultura e o modo de viver nestes espaços. Ainda que múltiplas temporalidades se interponham na cidade, cujas manifestações e aprofundamento das entrevistas revelam, a

\footnotetext{
104 Conforme Costa (2016, n.p.), “concretamente, utopismos potencializam a realização de uma simultaneidade de práticas territoriais alternativas, com a liberdade de iniciativas localizadas; estimulam novos comportamentos situados de resistência às ações predatórias e de estigmas sobre o território".
} 
percepção é a de que a memória coletiva e os espaços simbólicos estejam descolados da história, ou pelo menos não a componham como algo importante e central. Cabe sublinhar a particularidade de alguns entrevistados que disseram conhecer a história, destacando a emancipação municipal como fato importante e mais representativo para Carapicuíba. O que não está distante, necessariamente, de um processo de fragmentação política mais ampla, quando o quadro de crescimento populacional da metrópole ultrapassava o primeiro milhão de habitantes e o planejamento e gestão corporativos dos territórios foram sendo divididos entre interesses os mais diversos. Além de algumas respostas dirigidas por moradores, em grande parte da própria Aldeia, em relação à memória de espaços representativos pelas relações com a família. E, ainda, de moradores de outros setores que revelam a importância da cidade em relação às amizades construídas, das experiências vividas coletivamente nos campos de futebol de várzea, nas igrejas e áreas públicas de Carapicuíba. Estes últimos patrimônios, vinculados às vivências e experiências no plano urbano, reiteram utopismos singularistas $e$ existencialistas (COSTA, 2016), que junto ao aprofundamento crítico e reversão das narrativas do espaço normatizado e precariamente universalizado da Aldeia convergem para estratégicas de resistências na periferia de São Paulo. No caso da Aldeia de Carapicuíba, ela resiste como uma rugosidade patrimonial cujo utopismo patrimonial singularista é, em si, o próprio bem normatizado, ora negligenciado frente a outros, com maior valor artístico ou suntuosidade, ora por carregar o drama indígena, a cultura caipira, as relações suburbanas e tradições que marcam um continuum histórico e alicerçaram a formação metropolitana de São Paulo. Um patrimônio-territorial localizado e capaz de expressar sua singularidade frente as universalidades da metrópole e da memória nacional, da qual a afirmação da existência social é um caminho de reafirmação de outras possibilidades de desenvolvimento para além dos modelos traduzidos por preceitos e intenções externas ou verticais.

Em segundo lugar, as infraestruturas em Carapicuíba, que incluem os equipamentos culturais e o tempo livre do trabalhador para o lazer e entretenimento, revelaram-se precários e ausentes. Se as transformações territoriais exigem sistêmicas mudanças ideológicasculturais, tão importante é a capacidade de as infraestruturas permitirem que essas novas relações utópicas sobre as rugosidades patrimoniais se efetivem concretamente. A urbanização do território de Carapicuíba, apesar dos problemas que as normas e a legalidade trouxeram para aqueles que dela foram capitaneados para fora da cidade, trouxe no entanto infraestruturas que não devem ser ignoradas por incondicionais melhorias relatadas ao longo dos levantamentos junto à população local. 
Sim ... melhorou, tem área de lazer, tem parques, escola, faculdade, mas mesmo assim eu acho que o governo não conseguiu conter, da minha infância eu acho que a violência foi um negócio marcante mesmo. [...]Abandonei o Paturi e por quais motivos? Então, o lugar está abandonado, já fui muito ali já, gostei muito de la também e tinha umas festas, eu ia muito lá aí né... [...]Não é só isso, depois aí o Paturi ficou abandonado e você passa lá é uma presença de abandono o pessoal usa muita droga. [...] Eu acho um lugar bonito ali só que você vai perdendo o gosto né, eu achei a Aldeia mais bonita, é mais longe, mas é mais interessante." (Entrevistado 11, morador da COHAB 05, 42 anos).

Quanto ao uso dos equipamentos culturais da cidade, ao levantarmos a frequência atual dos grupos de cada setor urbano em museus e espaços simbólicos da cidade - assim como a participação em festas populares, de associações de bairro, bem como uso de áreas de lazer, praças ou outros espaços públicos relevantes - percebe-se não somente um número pequeno de participantes ou usuários, mas o clamor de ausência e precariedade destes aparelhos no município e na própria região em que a população entrevistada vive e trabalha. O que pressupõem a máxima, de que os espaços de socialização e maior encontro social do passado, se esvaem diante de problemas estruturais tipicamente proporcionados pela condição de um espaço periférico o qual a cidade se transformou. No caso de parte desta população, com menor renda, implica a ausência e precariedade dos equipamentos públicos, de falta de recursos financeiros para o acesso às áreas mais distantes com melhor infraestrutura, além do tempo cada vez mais disputado pela precarização/flexibilização do seu trabalho que, dia após dia, passa a ser desenvolvido na própria periferia. Contraditoriamente, são, no entanto, os que mais indicaram utilizar os espaços elencados na pesquisa, assim como os menos críticos acerca de suas atuais condições ${ }^{105}$ (Gráficos 09 e 10).

\footnotetext{
${ }^{105}$ Entre outros casos, podemos citar três moradores da COHAB 2 que disseram pescar na Lagoa dos Paturis, assim como observamos banhistas na Lagoa do Parque da Aldeia e diversas disputas de futebol aos fins de semana em campos na cidade.
} 
Utiliza Parques ou Espaços Públicos ou Culturais

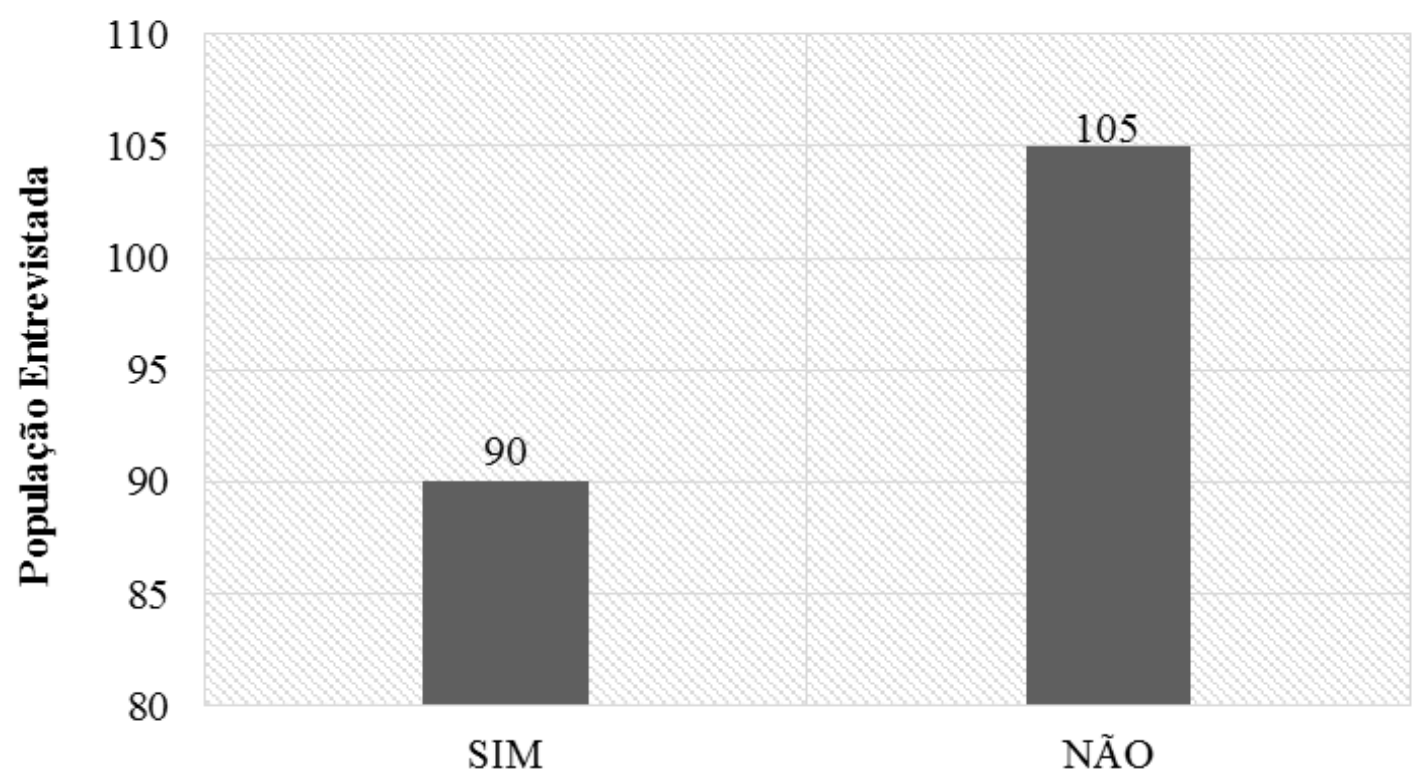

Gráfico 09: Entrevistados que disseram utilizar ou não equipamentos públicos e culturais de Carapicuíba. Fonte: Questionários semiestruturados aplicados nas UIT's pelo autor, 2016.

\section{Utiliza Parques ou Espaços Públicos ou Culturais por UIT's}

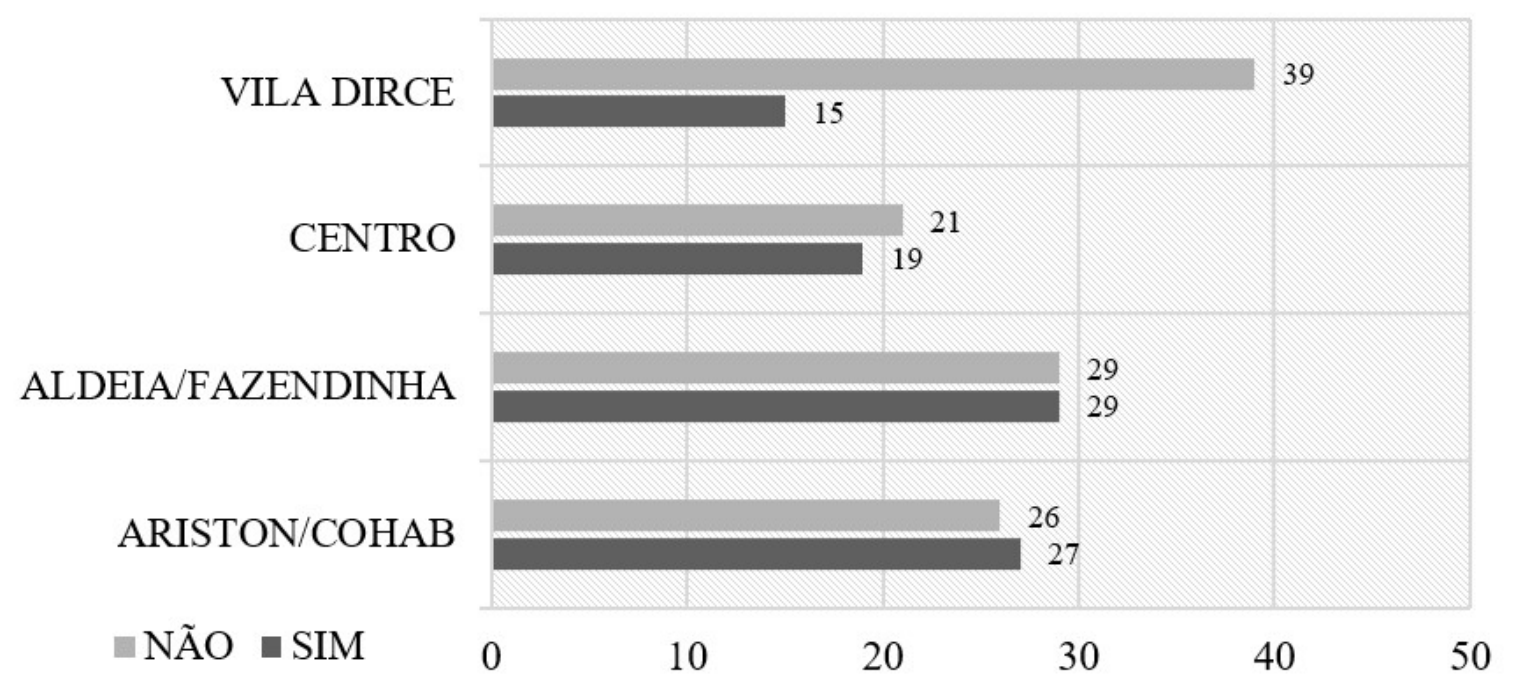

Gráfico 10: Entrevistados por UIT1s que utilizam ou não equipamentos públicos / culturais de Carapicuíba. Fonte: Questionários semiestruturados aplicados nas UIT's pelo autor, 2016.

Em verdade, outros espaços passam a sistematicamente ocupar a sociabilidade desta população, com várias citações dos shoppings e áreas comerciais, os primeiros nas cidades adjacentes, ou no próprio bairro e cidade (Gráficos 11 e 12). De fato, ao se analisar as quatorze Zonas Especiais de Interesse Cultural (ZEIC), estabelecidas pelo plano diretor 
municipal (CARAPICUÍBA, 2012), considerando uma cidade com aproximadamente 400 mil habitantes (IBGE, 2010), observará a insuficiência, carência e má distribuição destes pontos de cultura.

No Planalto não tem condição, só droga, está tomado por drogados, tá tudo abandonado lá. Coloca zero aí porque tem que melhorar muito as coisas, nunca mais fui não. O da Aldeia é até um pouco melhor, mas só de manhã mesmo, porque depois é complicado (Entrevistada 11, moradora da UIT Vila Dirce, 36 anos).

Encontro muito aqui na rua mesmo [Av. Comendador Dante Carraro], ou ali na rua Mauá, jogava muita bola no CSU, no bairro e na avenida aqui é tudo conhecido (Entrevistado 12, morador da UIT Cidade Ariston, 37 anos).

A presença, por mais crítica que seja deste conjunto, limita-se porém aos extremos do município, atingindo o setor norte nas proximidades do trilhos da CPTM e nos limites sul nas proximidades da Aldeia. Um grande vazio se estabelece entre o Centro e Vila Dirce, cuja ausência maior é constatada no setor da Cidade Ariston, COHAB's e limites do bairros Tonato, Menck e adjacências. Somado a isso, existem poucas bibliotecas municipais, onde os acervos são pequenos e não sistematizados, além da inexistência de museus públicos ou particulares (Figura 50).

\section{Espaços de Encontro - Valor Médio}

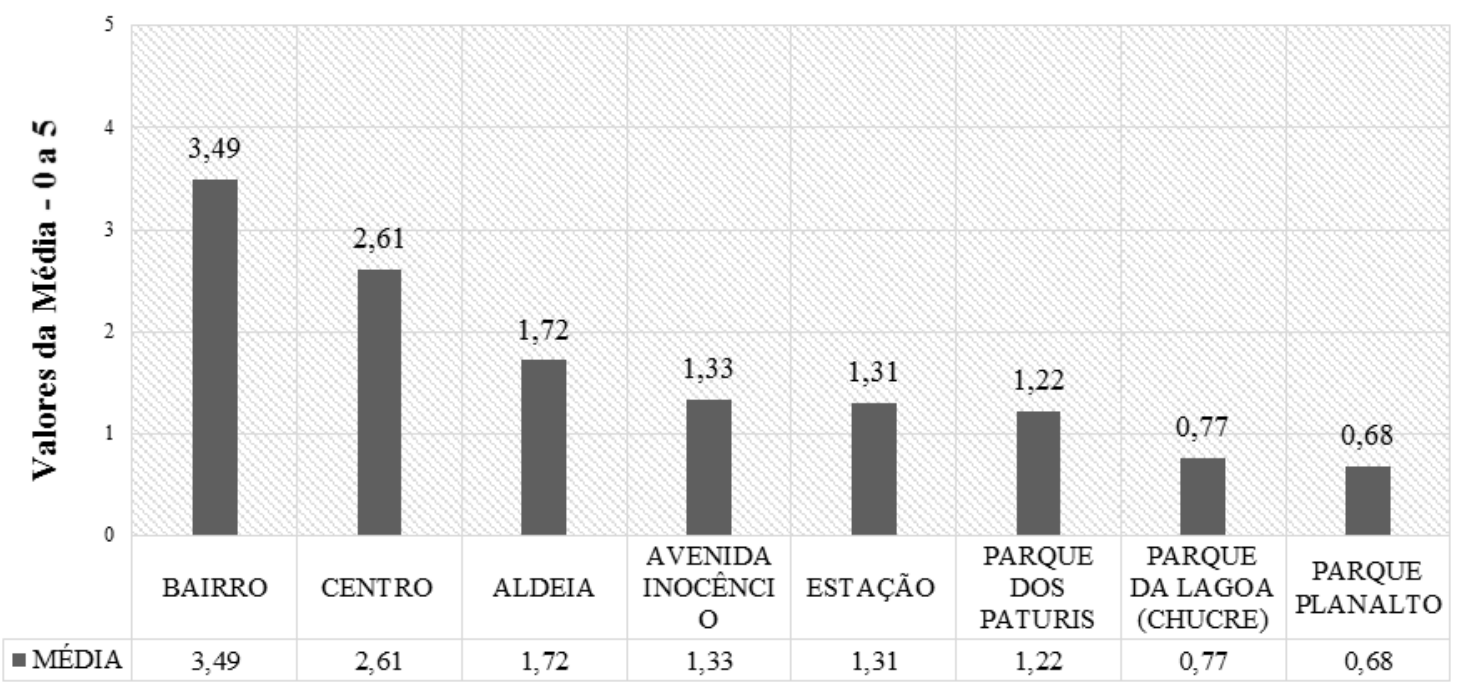

Gráfico 11: Espaços de encontro se realizam nos bairros e no cotidiano das estações e do comércio local ${ }^{106}$. Fonte: Questionários semiestruturados aplicados nas UIT's pelo autor, 2016.

106 Valores relativos às médias simples obtidas através dos questionários semiestruturados aplicados nas UIT's de cada espaço referencial da cidade. Variando entre 0 e 5 , os participantes da pesquisa foram solicitados a quantificarem os locais que mais encontravam amigos, familiares, ou pessoas conhecidas em Carapicuíba. 


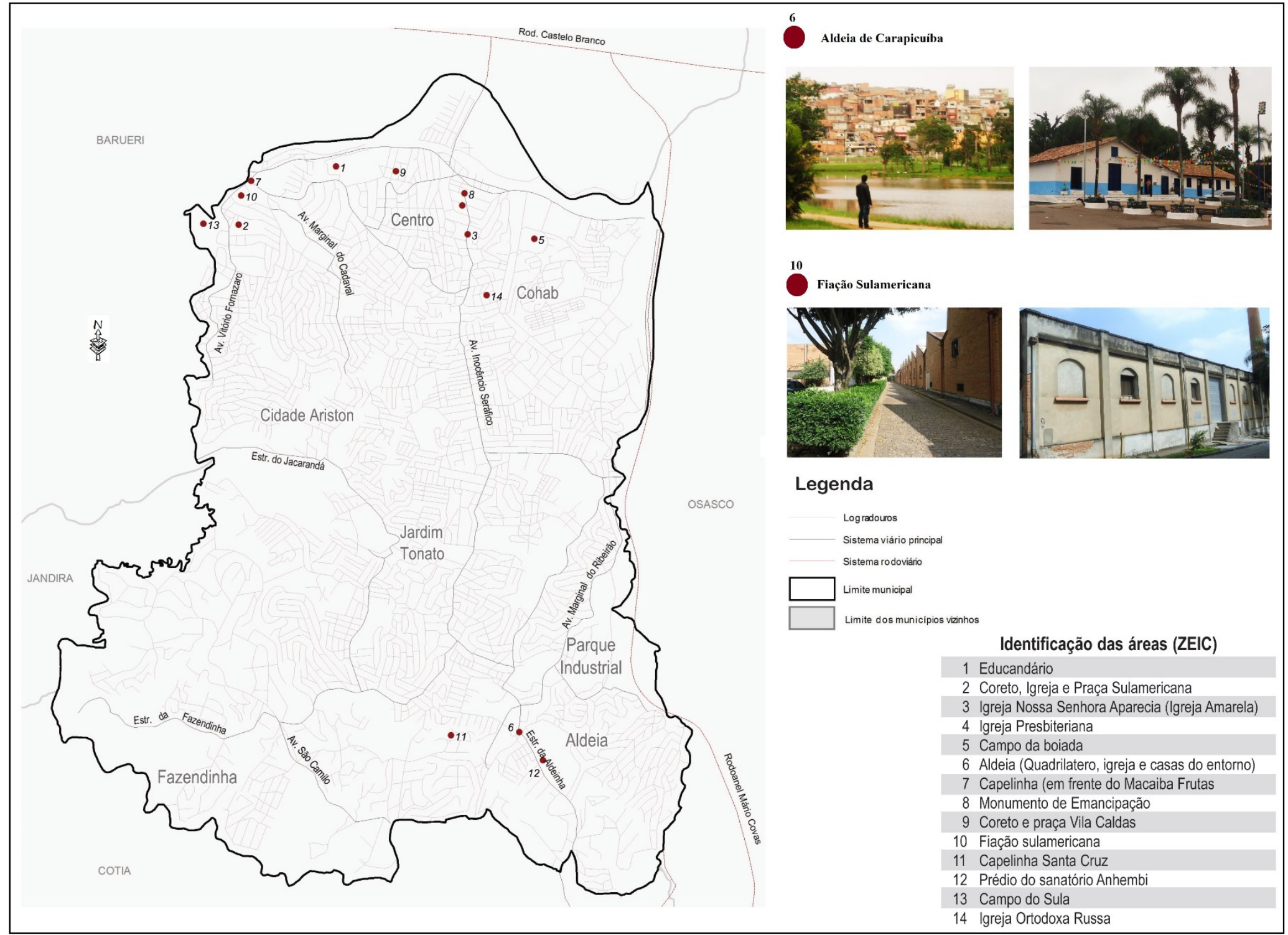

Figura 50: Distribuição irregular e insuficiente de equipamentos culturais no município de Carapicuíba. Fonte: Plano Diretor Participativo do Município de Carapicuíba. Via Pública, 2012. 
Os eventos culturais e festas tradicionais definham nas limitações orçamentárias e políticas do município, além de pouca, mas ainda importante iniciativa dos indivíduos, famílias e grupos locais. Portanto, se opera ínfima articulação nos espaços de encontros, transformados em espaços de passagens, sustentados por uma lógica padronizada de viver funcionalmente em redes, ativadas para o deslocamento trabalho-casa, ou estrategicamente para o consumo dirigido da população. São nestes espaços e momentos recorrentes os encontros, dados nas estações de trem e de ônibus, ao longo do percurso do trabalho, nos supermercados, ruas comerciais, ou avenidas da cidade - destacadamente no próprio bairro $(20,95)$, no centro $(15,67)$, avenida Inocêncio Seráfico $(8,03)$, estação ferroviária/rodoviária $(7,88)^{107}$.

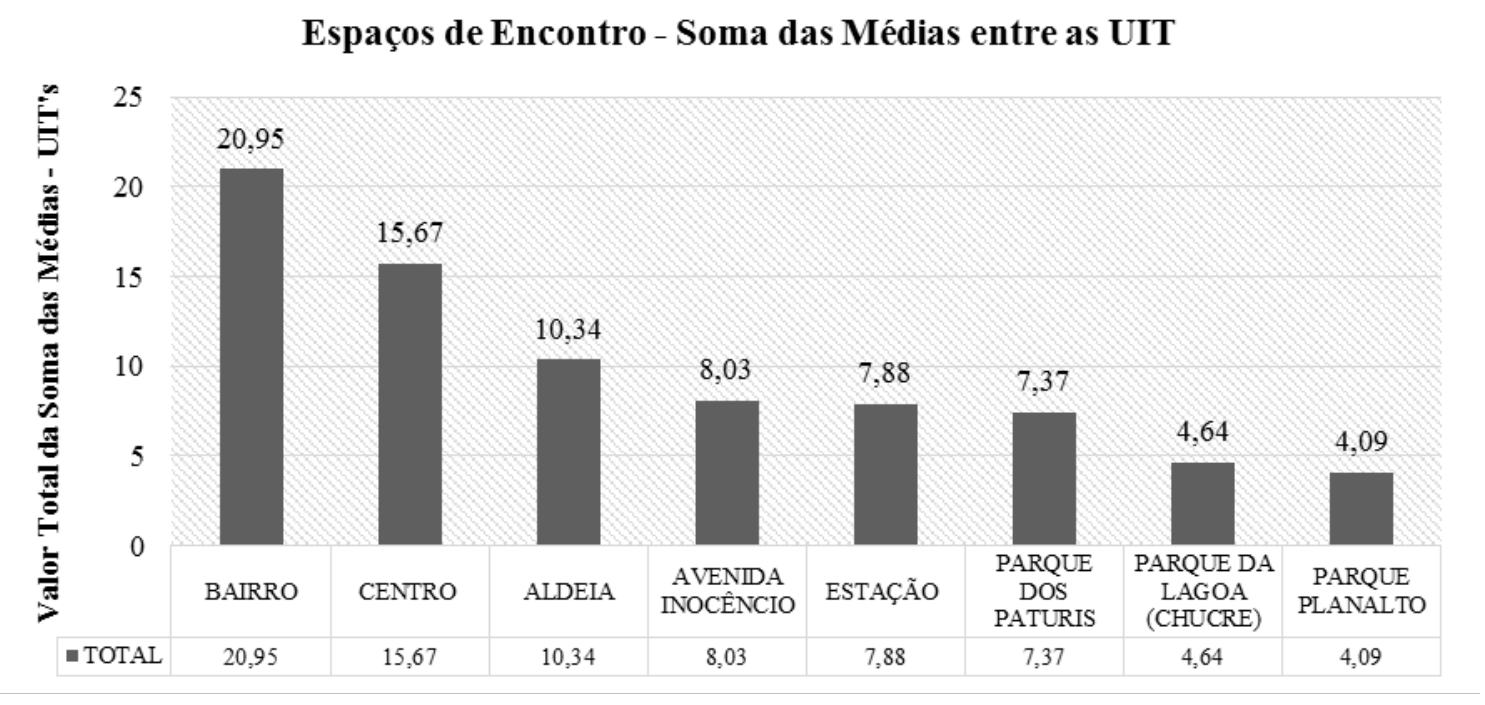

Gráfico 12: Espaços de encontro se realizam majoritariamente nos bairros e nos espaços do cotidiano. Fonte: Questionários semiestruturados aplicados nas UIT's pelo autor, 2016.

Por outro lado, o levantamento revela a representatividade da Aldeia em relação aos parques municipais, bem como a ausência de citações de outras áreas simbólicas que poderiam ter maior efetividade no uso cultural e socialização. A Figura 50 anterior, portanto, ao apresentar igrejas e monumentos evidencia que as ZEIC's são extremamente restritas e pontuais em Carapicuíba, indicando a ausência dos equipamentos que asseguram desenvolvimento educativo, cultural e entretenimento aos seus munícipes.

\footnotetext{
${ }^{107}$ Valores relativos às somas das médias obtidas através dos questionários semiestruturados aplicados nas UIT's de cada espaço referencial da cidade. Variando entre 0 e 5, os participantes da pesquisa foram solicitados a quantificarem os locais que mais encontravam amigos, familiares, ou pessoas conhecidas em Carapicuíba.
} 
Desdobra-se um nítido compasso de precariedades no sistema urbano, do qual a ausência ou insuficiência dos equipamentos culturais devem ser destacados. Tal fenômeno, no caldeirão de culturas que se hibridizam com o crescimento da cidade, colocam em cheque a cristalização e a permanência das próprias tradições. Ora pela mescla e competição, ora pelo esquecimento e abandono, ora ainda pela permanência precária por intermédio das resistências das famílias e comunidades organizadas do local. Esta criticidade foi tratada por Pellegrini (1979), ao analisar as transformações das expressões folclóricas na Aldeia em fins da década de 1970. Segundo o autor, as festas mais tradicionais ali realizadas, como a de Santa Cruz e Santa Cruzinha, passavam já por relativo esvaziamento, quando não ao desaparecimento, como é caso da festa de Santo Reis, considerando a morte dos mais velhos mantenedores dos festejos, bem como uma mudança profunda de relações que o sistema urbano havia carregado até ali, como a dessacralização e banalização dos ritos (PELLEGRINI, 1979).

Em diversas situações da pesquisa é possível considerar lacunas e fragmentos nas associações dos munícipes em relação com as festividades religiosas. Tanto que no caso da Festa de Santa Cruz, por exemplo, emerge em muitos dos entrevistados uma dissociação entre a dança realizada e os festejos religiosos e profanos no espaço da Aldeia. Transparece nas falas uma manifestação que, mesmo tendo origem no catolicismo - em razão da cruz, trataria hoje o papel de um espetáculo folclórico de Carapicuíba. O que sugere uma perda de referenciais dos moradores mais antigos, onde mesmo apesar da dessacralização em curso, a sua realização é justaposta e tradicionalmente ligada aos ritos religiosos. Helenice Camargo, produtora cultural e membro da Associação Sarabaquê de Difusão Cultural, uma das responsáveis pela realização dos festejos na Aldeia, problematiza uma série de questões que hoje permeiam a baixa procura e dificuldade de realização das festas. Destas, destacam-se a violência que aflige o local, especialmente no período noturno, quando se materializam as comemorações. Depois, também o esvaziamento do largo da Aldeia, pois os mais velhos se foram e os mais novos não tiveram o mesmo interesse. Além disso, lembra da falta de apoio das instituições, desde a igreja que permanece quase sempre fechada, ou das próprias entidades governamentais e, sobre o público que participa hoje das festividades, explica o seguinte: 
minha casa e aqui eu vendia o que eu quisesse: doce caseiro, churrasquinho, quentão, vinho quente, porque se eu quisesse colocar, eu fazia, eu vendia, porque tinha público. De repente foi isso ai foi esvaziando foi esvaziando e aí o pessoal deixou de vir. Não tem segurança, vem de carro não tem estacionamento, tem um aqui atrás, mas aí não tem segurança e o pessoal fica com medo de ser assaltado quando vai embora... nunca aconteceu mas quem não conhece Aldeia fica com medo de riscar o carro dele." (Helenice Camargo Henne, entrevista realizada em julho de 2016).

Em relação aos mais jovens, o desconhecimento, desinteresse e banalização se sobressaem, fenômeno do qual Pellegrini (1979) já havia constatado. Contudo, mesmo diante desta problemática, a grande maioria da população entrevistada disse conhecer pelo menos uma das festas realizadas no local. Destacando-se nos resultados tabulados a festa de Santa Cruz, Corpus Christi, a Romaria e São João, mas principalmente a encenação da Paixão de Cristo, promovida pela municipalidade e hoje na visão popular a mais importante festa da Aldeia $^{108}$ (Gráfico 13).

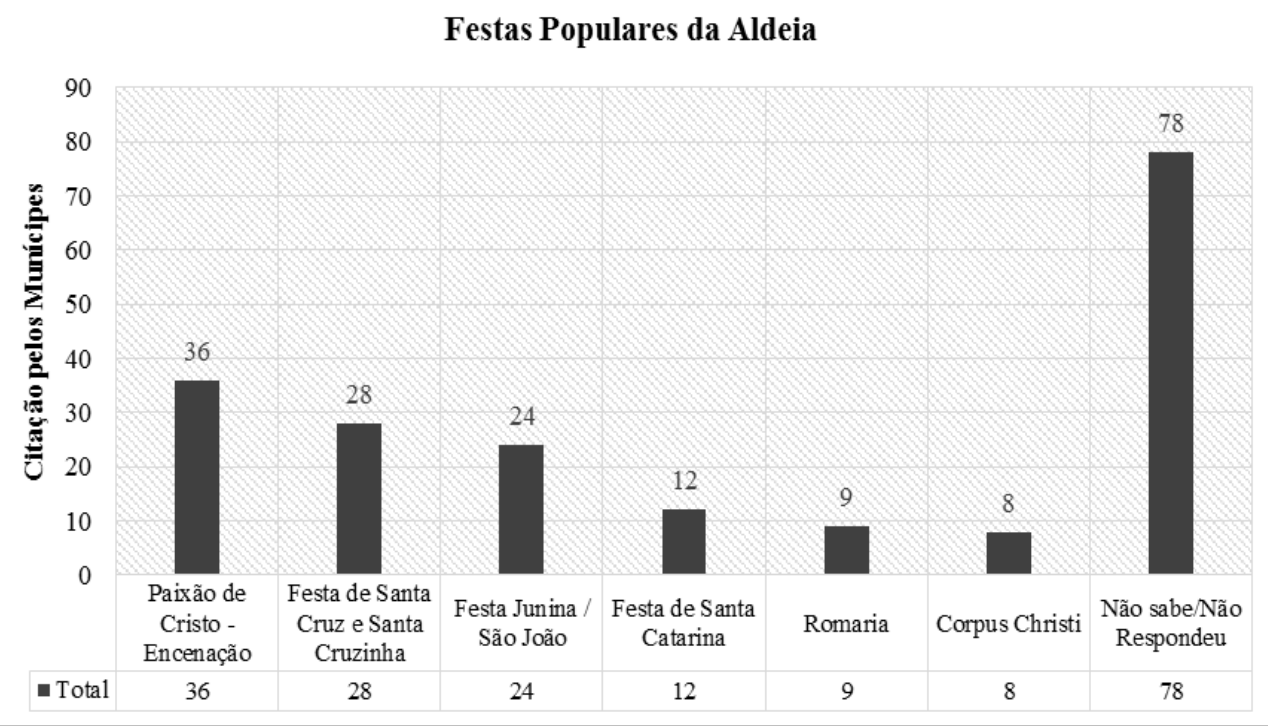

Gráfico 13: Festividades principais da Aldeia, segundo os moradores das UIT's em Carapicuíba. Fonte: Questionários semiestruturados aplicados nas UIT's pelo autor, 2016.

As razões que explicam a encenação ocupando tal posição provém não apenas da promoção do espetáculo teatral, acompanhado por ampla articulação municipal de suas

\footnotetext{
${ }^{108}$ Conforme o Jornal Metrópole, o evento da encenação, no ano de 2016, teria atraído mais de 40 mil pessoas à Aldeia. Para assistir entre os dias 2 e 3 de abril, "o evento foi produzido pela Prefeitura de Carapicuíba, por meio da Secretaria Municipal de Cultura e Turismo e contou com a participação de mais de 220 atores e atrizes entre profissionais e amadores. É importante ressaltar que todo o elenco participou do espetáculo voluntariamente." disponível em: <http://jornalmetropole.com.br/new/encenacao-do-drama-da-paixao-de-cristo-atrai-cerca-de-40mil-pessoas-no-teatro-de-arena-da-aldeia-jesuitica-de-carapicuiba/>. Acesso em jun. 2016.
} 
principais secretarias, mas de que a representação em si da peça independe exclusivamente de um público católico, de culto a determinados santos, ou propriamente das tradições religiosas historicamente realizadas naquele espaço. Isso traz à tona o interesse de uma diversidade de público, inclusive de outras vertentes religiosas, como protestantes, e parte considerável dos moradores da cidade, carentes de atividades culturais e espaços de lazer. Mas, destas tradições, as festividades de Santa Cruz são as principais manifestações preservadas ao menos desde o século dezoito até os dias atuais

A festa de Santa Cruz não tem origem em Carapicuíba. É uma comemoração religiosa ligada ao cristianismo e que remete inicialmente a Roma, provavelmente ao sétimo século depois de Cristo. Conforme explica Escalante (1981), citando Frei Basílio Rower, nas origens haviam duas festas, uma nas Gallias, comemorada em maio e outra em Roma, comemorada em setembro. De tal maneira, “[...] a festa remete aos primórdios do cristianismo, conservando as duas datas até os dias presentes." (ESCALANTE, 1981, p. 37). Nos dias atuais, em Carapicuíba, a festa de Santa Cruz continua a ocorrer em maio e em setembro. Neste último mês em proporções mais singelas, com o nome de Santa Cruzinha. Em verdade, a programação da festa de Santa Cruz é iniciada no dia 24 de abril, com a novena e finalizada com a zagaia ${ }^{109}$ no dia 04 de maio. Trata-se de uma comemoração milenar, a qual sedimenta relações e permeia o plano religioso e espiritual das comunidades onde se manifesta. Em todos estado de São Paulo existem festividades de Santa Cruz, sendo as mais tradicionais ligadas aos aldeamentos e, sobretudo, Carapicuíba.

Quanto ao surgimento da tradição de Santa Cruz em São Paulo, esta é muito antiga, de difícil delimitação. Deve ser assinalável sua antiga presença em Embu, Itaquaquecetuba, Cunha e Tatuí, além de Carapicuíba (ESCALANTE, 1981). Martins (2001) ao caracterizar os subúrbios lembra de sua infância permeada de festas religiosas como a de Santa Cruz. Albino (2014), ao fazer várias entrevistas com moradores de Osasco para tratar o rural naquela cidade, vislumbra a centralidade da festa em Carapicuíba para antigos moradores que participavam anualmente, o que sugere, uma vez mais, a centralidade da Aldeia como espaço da festa e tradição, e principalmente o envolvimento de grupos sociais num escala regional de participação. Nas obras de Escalante (1981), Henne (2015) e Tenório (2003), esta festividade em Carapicuíba remete ao padre Belchior de Pontes, o mesmo responsável pela reconstrução

\footnotetext{
109 Nome de origem indígena que provavelmente se associa às lanças indígenas e a hibridização da tradições festivas dos jesuítas e índios Guaianases. Relaciona-se hoje à dança final sagrada e profana da festa de Santa Cruz na Aldeia de Carapicuíba, quando há despedida e a evocação de forças para o próximo ano.
} 
da Aldeia no século dezoito. Outros vilarejos e núcleos populacionais oriundos dos aldeamentos revelam a permanência desta mesma tradição, mas com várias diferenças entre elas e, por vezes, com descontinuidades das comemorações, ainda que traços indígenas estejam presentes em todas elas (ESCALANTE, 1981, p. 42-45). Trata-se, pois, nas unidades de aldeamentos, dos esforços pela evangelização do índio, agregando elementos possíveis de sua própria cultura e suprimindo aqueles considerados mais profanos, como a reverência às fogueiras, então substituídas pelas cruzes e velas ${ }^{110}$. "O padre Belchior de Pontes, ao instituir o Sarabaquê, substituiu a fogueira, em torno da qual os indígenas dançavam, por uma cruz rústica de madeira; porém ainda hoje é acesa uma fogueira. É o fogo simbólico [...]" (ESCALANTE, 1981, p. 37).

Como posto nos capítulos anteriores, a consagração religiosa do espaço da Aldeia, no século dezenove e nas três primeiras décadas do século vinte, parece ter sido um elo fundamental da imaterialidade que permeia não apenas uma coesão social entre os moradores, convertendo o espaço em lugar pelas relações afetivas e as diversas experiências desenvolvidas, mas também da permanência estável da disposição geográfica das formas arquitetônicas do conjunto primitivo do aldeamento jesuítico. Tenório (2003), ao tratar em várias partes de sua obra acerca da Aldeia de Carapicuíba, mostra a necessidade de reverência a esse espaço, que segundo ele não guardaria apenas a secular igreja, mas a terra por onde tanta gente ilustre havia passado. Em suas palavras, "Carapicuíba é um templo! Templo de nossa história! Ali ninguém deve entrar de cabeça coberta. Todos devem descobrir-se em sinal de respeito. Porque ali está o começo, o alicerce, o tronco da nossa história: João Ramalho.” (TENÓRIO, 2003, p. 51).

O discurso textual de Tenório (2003) traz à tona múltiplos simbolismos do espaço da Aldeia quando o compara a um templo. Esse desígnio pode recair tanto ao plano sagrado, representado pela antiga igreja e as tradições religiosas a ela ligadas, quanto à perspectiva do profano, associada aos referenciais dos mitos fundadores brasileiros. Neste último caso, o autor lembra mais especificamente a figura de João Ramalho, colonizador que se hibridizou aos índios nativos e que está ligado à formação geográfica e histórica de São Paulo. Tal perspectiva desperta, uma vez mais em seu discurso, a hipótese da relevância histórica e religiosa da Aldeia de Carapicuíba. Considerando ser sua obra relativamente recente, do

\footnotetext{
110 Na pesquisa de mestrado de Pellegrini (1979), cita-se Manoel da Fonseca numa passagem que remete a colocação da cruz no centro do pátio da Aldeia de Carapicuíba, onde passavam os índios e religiosos a manifestarem cantos, danças e festividades ao redor do maior símbolo cristão.
} 
último quartel do século vinte, a relativa atualidade dos simbolismos na sacralidade da Aldeia de Carapicuíba, quanto na sua importância histórica descrita pelo autor. Todavia, agora pensada além do plano regional dos arredores paulistanos, quando da sua incorporação a lista nacional de bens históricos protegidos pelo Estado, ganhando assim uma escala mais ampla e integrada aos planos fundadores.

Como a obra de Tenório (2003) tem maiores qualidades descritivas do que propriamente analíticas, na sua perspectiva a dança de Santa Cruz, chamada popularmente de Sarabaquê, vincula-se a um ato de religiosidade, limitando o leitor a entendê-la nos limites do culto ou da fé cristã, ou católica mais precisamente. “A Dança de Santa Cruz, ou Sarabaque, conhecida como Sarabague ou 15 com 15, é apenas um ato de religiosidade, composto por danças e cânticos.” (TENÓRIO, 2003, p. 58). Quando, na verdade, possui uma dimensão cultural importante no sentido de dar sacralidade, conteúdos complexos que entremeiam sentimentos de pertencimento ou identidade e, no limite, a própria permanência preservada do espaço da Aldeia. Coloca-se em questão outra das suas proposições, de que após doutrinados os índios imitariam os passos ou as sucessivas etapas da dança. "Depois de doutrinados, os mesmos [índios] imitavam os passos da dança, num ritmo lento e repetitivo, ao som do recoreco, pandeiros, cuícas, puitas e viola. Houve, porém aculturação dos índios e negros pela mistura de instrumentos musicais.” (TENÓRIO, 2003, pp. 58-59). Na citação vê-se claramente alguns elementos contraditórios, pois muitos dos instrumentos utilizados são mesmo de origem indígena, ou africana, bem como os passos e rodas muito se assemelham a observações de danças que ainda são manifestadas em todo território brasileiro, por diferentes etnias indígenas.

Em síntese, a dança de Santa Cruz desenvolvida em Carapicuíba deriva da própria cultura indígena, sendo inserida a religiosidade cristã como mecanismo de persuasão, ou doutrinação à fé católica pelos jesuítas aos índios aldeados. Uma imposição colonial, vertical, porém, não sem haver agregação e carga residual da cultura colonizada. Sem a qual talvez não fosse plenamente possível a Igreja concretizar sua tarefa colonial complementar. Festa antiga, pois, marcada no espaço da Aldeia e no tempo da colônia, que transcendeu as gerações e continua contemporânea (Figuras 51 e 52). Mantida pela ação das famílias que a adotaram na transição para a cultura caipira e a cristalização suburbana de Carapicuíba. Diante da ausência de outros dados e de obras que aprofundem em específico acerca desta polêmica, interessante passagem de Henne (2015) converge plenamente para uma leitura da qual acredita-se ser mais coerente sobre a sua origem e desenvolvimento da festa de Santa Cruz. 

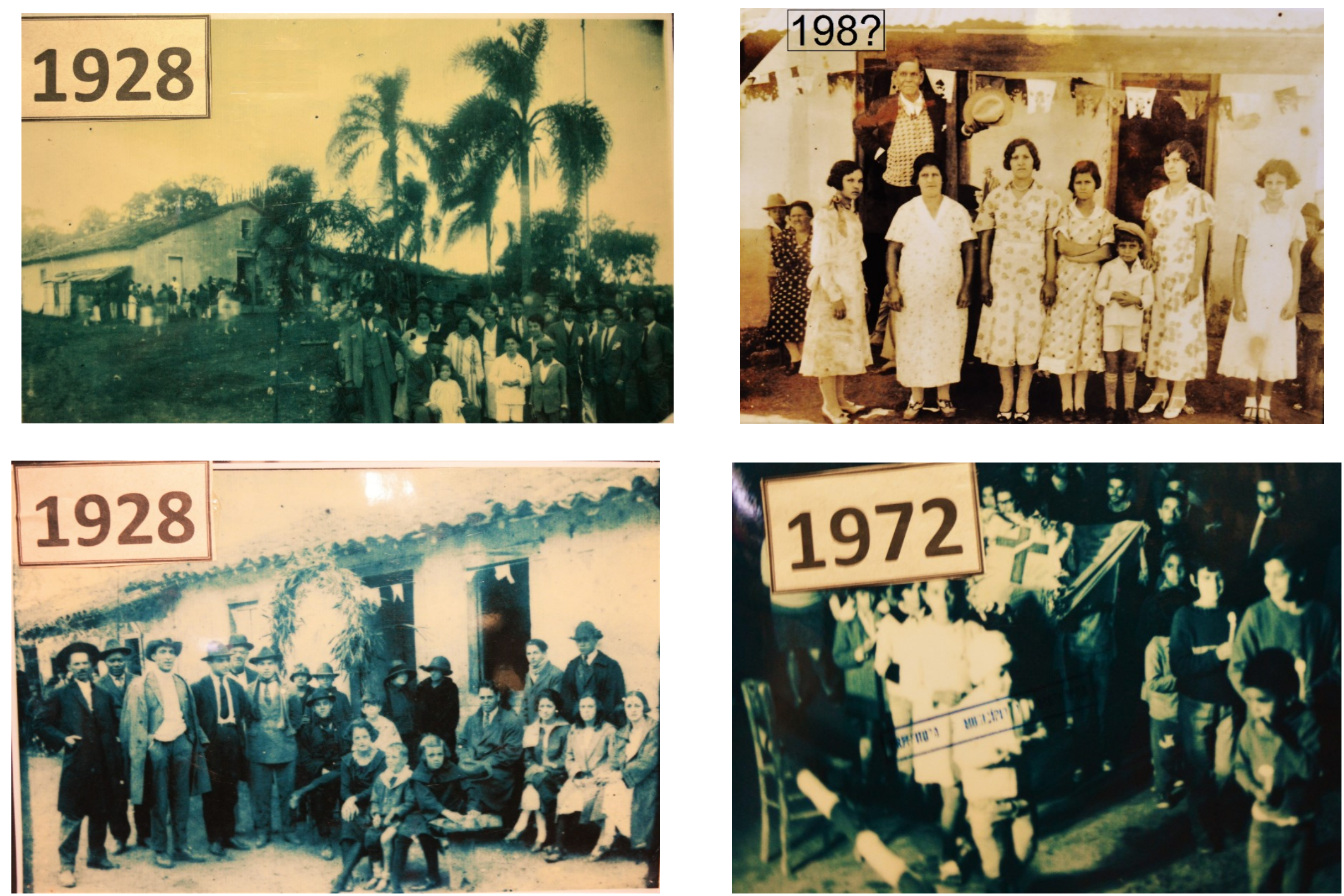

Figura 51: Diferentes momentos da festa de Santa Cruz na Aldeia de Carapicuíba.

Fonte: Acervo Fotográfico da Casa da Cultura de Carapicuíba e da Associação Sarabaquê de Difusão Cultural e Social. Editadas e organizadas pelo autor, 2016. 

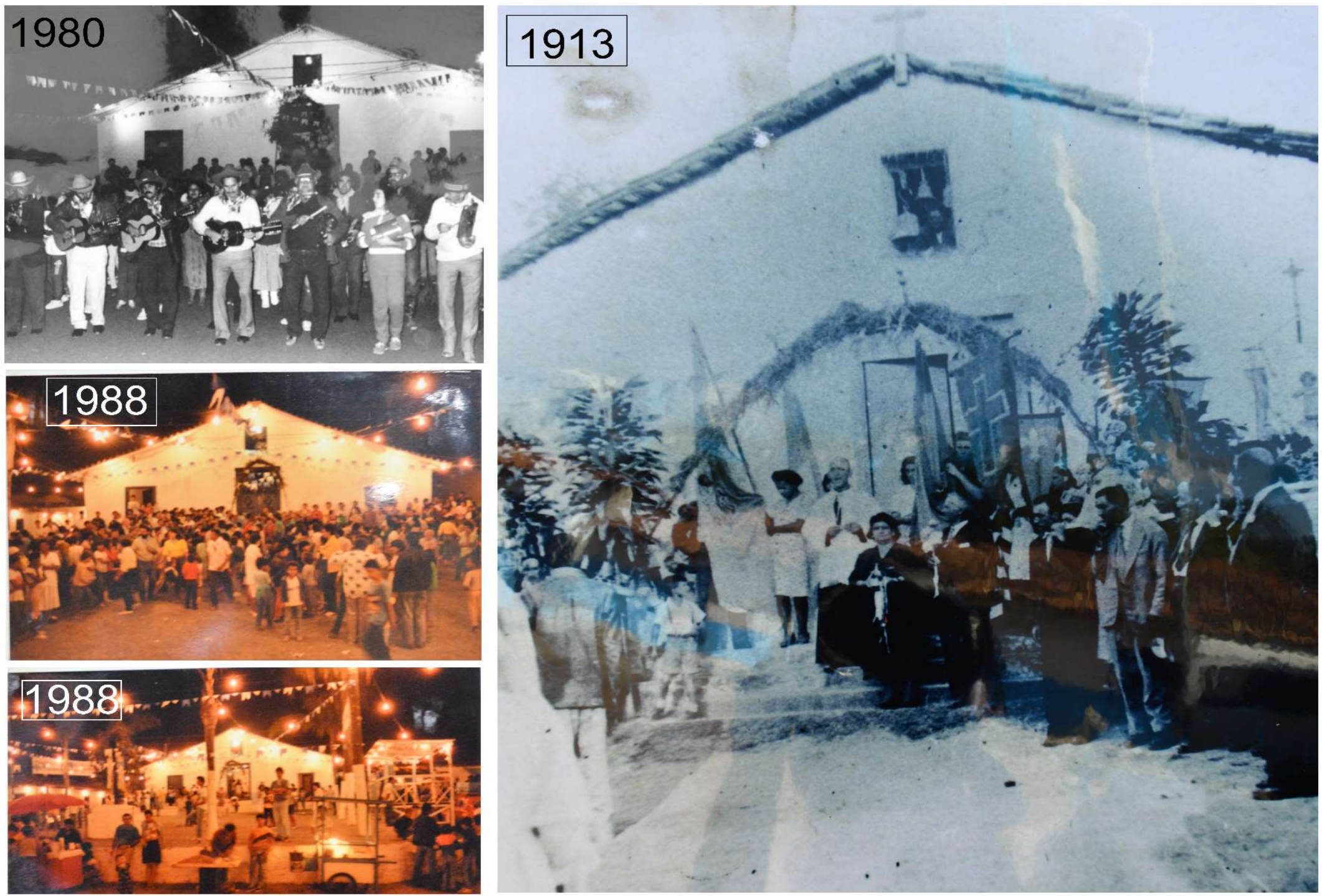

Figura 52: Permanência em diferentes momentos da festa de Santa Cruz na Aldeia de Carapicuíba.

Fonte: Acervo Fotográfico da Casa da Cultura de Carapicuíba e da Associação Sarabaquê de Difusão Cultural e Social. Editadas e organizadas pelo autor, 2016. 
Acredita-se que a Festa de Santa Cruz tenha sido uma forma encontrada pelos jesuítas para catequizar os indígenas. Assim, eles utilizaram-se da dança que já era comum aos indígenas e infiltraram a religiosidade através dos versos e da imagem da cruz. As festas de maio já eram comuns na Europa, com árvores frutíferas e flores enfeitando as casas. Aqui elas são substituídas pela cruz, que da mesma forma é toda enfeitada de flores ora naturais, ora em papel crepom, sendo assim o símbolo maior da festa (HENNE, 2015, p. 33).

É também a autora supracitada que ao fazer um livro de memórias da Aldeia, em torno do Sr. Mimi (seu pai) e Dona Nenê (sua tia), relata a complexidade que possui esse espaço, suas tradições e simbolismos, mas sobretudo, ainda que indiretamente, acerca das tensões emergentes ao longo dos últimos setenta anos em torno do IPHAN, da municipalidade e dos próprios moradores que ali se enraizavam. Com estas tensões e transformações, a dinamicidade da própria cultura, que faz com que a dança e as cantigas de Santa Cruz tragam sim elementos da tradição, porém permeada de renovados elementos introduzidos.

Diante do exposto é possível conjecturar de forma propositiva que a festa de Santa Cruz é um elemento cultural que fundamenta processos sociais mais amplos, estruturados categoricamente em razões políticas, econômicas, ideológicas, históricas e geográficas. Se a sua manifestação deriva dos contornos coloniais estabelecidos naquele território, cujo objetivo centrava-se na coerção do índio e que tinha por estratégia romper cada cômodo ou unidade de sentido que figurava o conjunto total de compreensão do universo pelo nativo, os ritos e cultos impostos resultam em fragmentos táticos deste processo. Isto se torna ainda mais complexo com a mescla cultural e a nova sociedade estabelecida em fins do oitocentos e princípios do novecentos.

Compreende-se que no princípio a imposição não pode ter havido sem que explicações coerentes fossem estabelecidas entre as razões práticas do mundo cristão e do mundo de entidades indígenas, estabelecendo uma mescla que, em último caso, compunha claramente uma hibridização, manifestadas nas tradições visíveis de um ou outro mundo. Tal realidade, dada no período colonial, em processo de transformação com o fim dos aldeamentos, em princípios dos oitocentos, não foi suficiente para que, mesmo no ostracismo e marginalização que ficaram essas unidades territoriais, as tradições, os hábitos e os costumes pudessem efetivamente desaparecer.

O que se apreende do caso de Carapicuíba é que as festividades permaneceram e são traços importantes à compreensão das rugosidades patrimoniais, desde a permanência material dos espaços sagrados, a imaterialidade da folia, até as funções de perpetuar outros conteúdos, 
que puramente a doutrinação exercida no período anterior. Isso em favor de que, apesar da iminente presença da Igreja nos festejos, uma nova centralidade organizativa e de apropriação das atividades passa a ser consolidada pelas família locais. Estes argumentos podem ser percebidos na descrição minuciosa de Henne (2015, p. 24-25) acerca das tradições de Santa Cruz na Aldeia de Carapicuíba, com muita propriedade, já sua relação com estas manifestações estão diretamente interconectadas por ser da família Camargo, uma das "guardiãs" de sua contínua materialização.

[...] Nós das famílias guardiãs desta tradição, participamos das Festas de Santa Cruz como se estivéssemos vivendo um outro momento, totalmente diferente do nosso cotidiano. Nós não apenas interpretamos a chegada dos jesuítas e a colonização dos indígenas, mas vivenciamos uma experiência cultural com certeza de outra ordem. [...] As Festas de Santa Cruz são as mesmas em todos os anos, mas são diferentes daquelas anteriores; a tradição é mantida e inovada. O fenômeno festivo aflora com a Dança de Santa Cruz que é capaz de atrair a atenção de indivíduos estranhos à festa e fazê-los se emocionar quando iniciam os primeiros passos (HENNE, 2015, p. 24-25)

A força desta população no sentido de manter as tradições e sua reprodução não é apenas o fio condutor da permanência, mas a própria rugosidade patrimonial capaz de animar e condicionar diretamente as relações entre os sujeitos e os objetos ali tombados. As famílias não estão completamente sós neste percurso de manutenção e reinvenção das tradições. A emancipação em 1964 traz a efetividade do poder municipal, como o tombamento o papel da entidade federal articulada ao estado. De tal maneira que o papel normativo do Estado, operando mais diretamente sobre o conjunto da Aldeia desde a década de 1940, apesar dos conflitos e tensões, apresenta organicidade ao longo do tempo, ora pela ausência, ora pelas soluções conjuntas com os agentes locais. Altera-se, pois, uma noção possivelmente reificada em torno dos objetos técnicos, dos bens tombados, do sítio em si, para uma visão de que a permanência continua residir como sempre nos sujeitos, nas instituições que os organizam, como na perspectiva da sua produção material e imaterial ao longo do tempo.

A rugosidade patrimonial permanece deste embate de construção e desconstrução, do qual a dinâmica entre supressões, superposições e acumulações revelam resistências, atos de permanência, que tangenciam a memória coletiva e influem nas vivências que dão cores e brilhos a um bem cultural convertido normativamente em monumento nacional. Reafirma-se as sobreposições de memória coletiva e memória nacional, já que as rugosidades patrimoniais são este misto inseparável de espaços vividos, concebidos e de representação (Figuras 53 e $54)$. 
Entrecruzam o sagrado e profano nas festividades de Santa Cruz da Aldeia de Carapicuíba
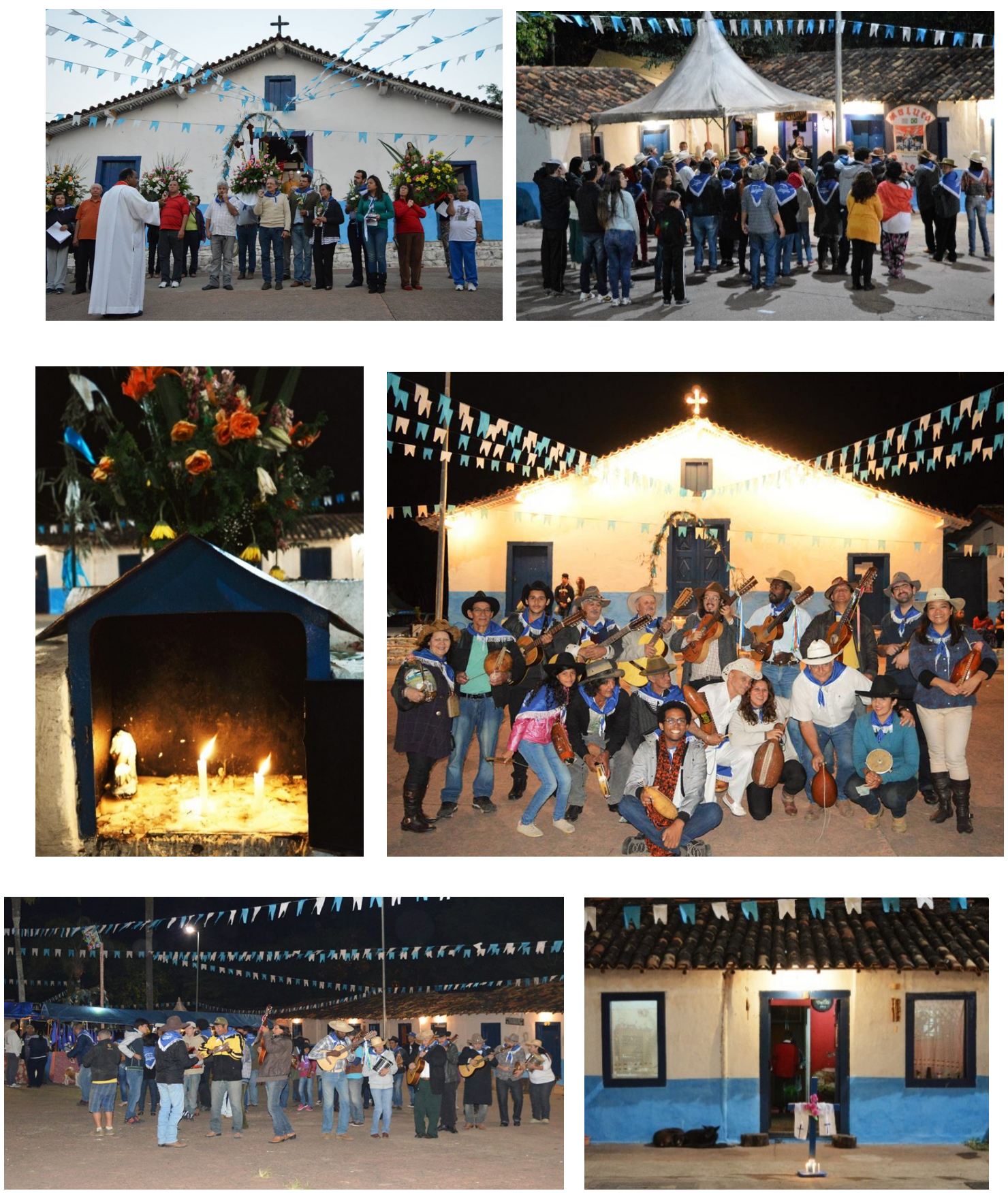

Figura 53: Nas imagens superiores, à esquerda procissão pela Aldeia; à direita Dança de Santa Cruz em frente ao bar de motoqueiros. Ao centro, à esquerda velas de orações postas ao pé do cruzeiro e à direita, festeiros em meio a Zagaia, dança de despedida, ao fim das festividades. Nas imagens inferiores, à esquerda festeiros dançando o Sarabaquê e à direita cruz enfeitada em frente uma das casas da Aldeia.

Fonte: Fotos do autor - Festividades de Santa Cruz, 2016. 
Preparo das Festividades de Santa Cruz na Aldeia de Carapicuíba
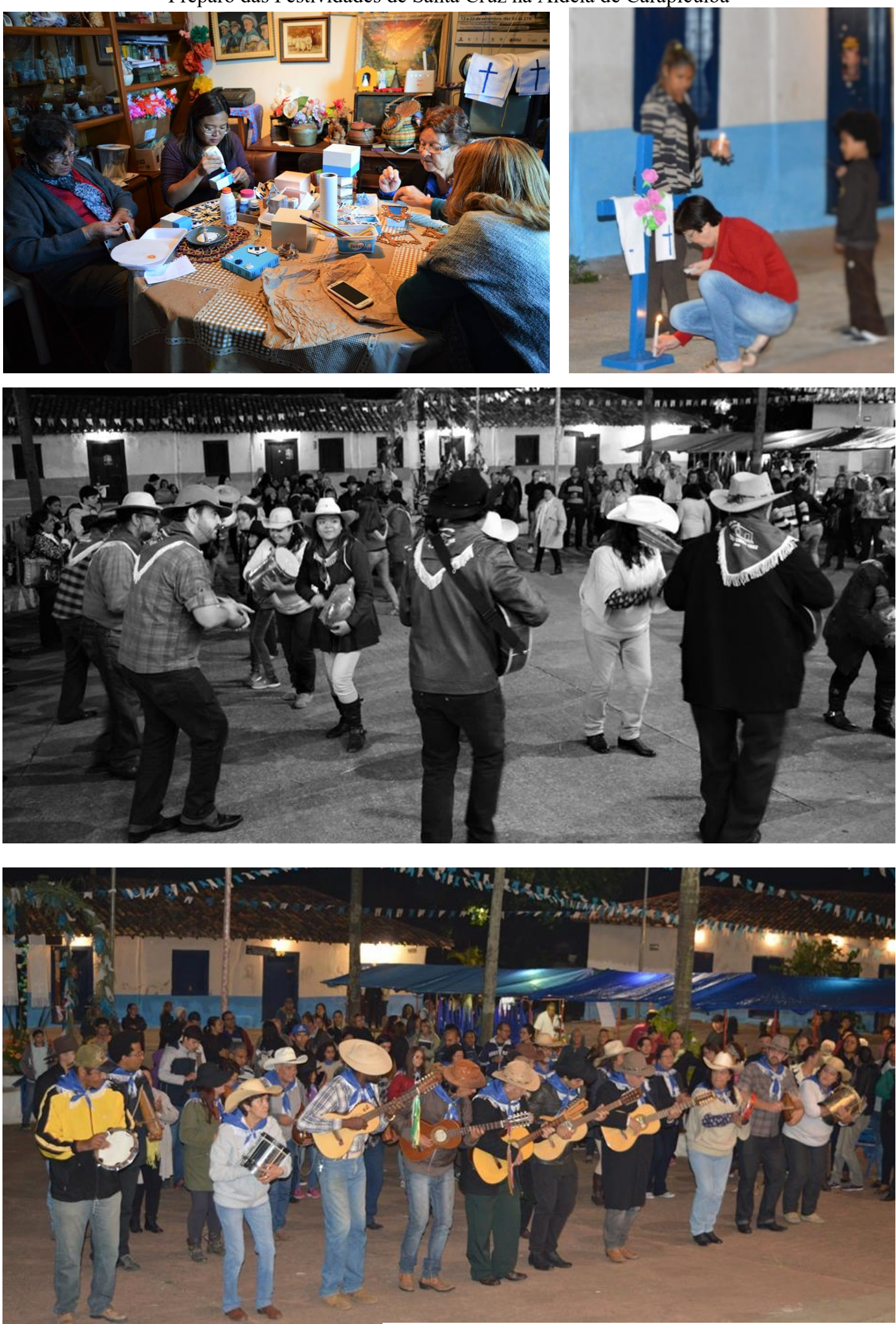

Figura 54: Nas imagens superiores, à esquerda confecção de artesanatos pelas mulheres na sede da Associação Sarabaquê de Difusão Cultural e Social - que são vendidos na quermesse da festa. A imagem superior direita, tradição das cruzes postas em frente as casas, cujos enfeites com rosas e outros apetrechos são aspectos fundamentais da tradição. Na imagem ao centro, coreografia em roda, no sentido anti-horário e em pares na dança de Santa Cruz. Na imagem inferior o Sarabaquê, dança sagrada, de saudação, feita linearmente pelos festeiros. Fonte: Fotos do autor nas festividades de Santa Cruz, 2016. 
Esta realidade se baseia na própria condição empírica estabelecida, de maneira integral, observada nas festividades do ano de 2016. Ali foi possível acompanhar todo o esforço das famílias, suas preocupações, angústias e realizações, tanto nos momentos prévios, como no desenvolver das atividades. Também o papel do poder público, diretamente da municipalidade, apoiando com a divulgação, com seus servidores presentes na organização, cedendo espaços institucionais para recepção dos festeiros e auxílio. Além da Igreja e sua comunidade, mantendo aberto diariamente o espaço da capela e realizando missas e cortejos ao longo dos dias de festividade. É, por fim, uma sinergia de ações, de articulações e preparos que convergem numa das mais antigas manifestações culturais do país e de São Paulo, congregando um público diverso, mas fundamentalmente uma conjunto de famílias da região em torno da Aldeia de Carapicuíba.

Na atualidade o reconhecimento mais amplo da população de Carapicuíba sobre o espaço da Aldeia ${ }^{111}$ associa-se às festividades religiosas da Romaria (tradição que hoje reúne o maior número de pessoas no local, que seguem juntas até a cidade de Pirapora do Bom Jesus), de Corpus Christi (com os tapetes enfeitados e procissão no local), de Páscoa (encenação da paixão de Cristo na concha adjacente à Aldeia) e, por fim, também as comemorações de Santa Catarina, Santa Cruz e Santa Cruzinha. Mas, não apenas, elas extravasam o plano sagrado, ou religioso, perfazendo em muitas falas e apontamentos as tradições caipiras e, para muitos outros, emerge como um importante espaço lúdico, de lazer e atividades físicas na cidade, ainda que simultaneamente indiquem também ser um parque perigoso a depender de horários e pontos específicos.

As tradições caipiras evidenciam a força da permanência cultural que preenche e sustenta o pequeno quadrilátero colonial. Este modo de vida, como destacado no capítulo anterior, deriva do fim do sistema de aldeamentos em Carapicuíba, com o relativo isolamento e ostracismo que permaneceu até por volta da primeira metade do século passado. Ou seja, matriz cultural anterior ao tombamento da Aldeia como patrimônio nacional e que concatena diferentes matrizes étnicas na formação histórica e geográfica do lugar e que alcança, em pleno século vinte um, importantes manifestações que permanecem, simbolicamente, permeando o cotidiano da população ali inserida, inclusive pela festa de Santa Cruz e Santa Cruzinha.

\footnotetext{
111 Levantamento feito pela aplicação qualitativa de questionários semiestruturados à população de Carapicuíba no ano de 2016. Resultados aprofundados no capítulo seguinte.
} 
Isso, portanto, não escapa do tratamento realizado anteriormente sobre a passagem espacial de Carapicuíba do subúrbio à periferia, mas amplia uma criticidade que se assevera até mesmo nas festas profanas mais atuais, como os rodeios (extintos na cidade), a festa nordestina (realizada com shows em espaço fechado, restrito e controlado), ou mesmo as religiosas das populações negras, destacadamente a de São Benedito e Nossa Senhora do Rosário $^{112}$ (com pequena adesão e reconhecimento da população de Carapicuíba, ainda que profunda conexão e relação entre diferentes grupos sociais que do sincretismo fazem uma das mais belas expressões da diversidade contemporânea da RMSP, como buscam ilustrar as Figuras 55, 56, 57, 58).

\section{Congada de São Benedito e N. S. do Rosário de Carapicuíba}

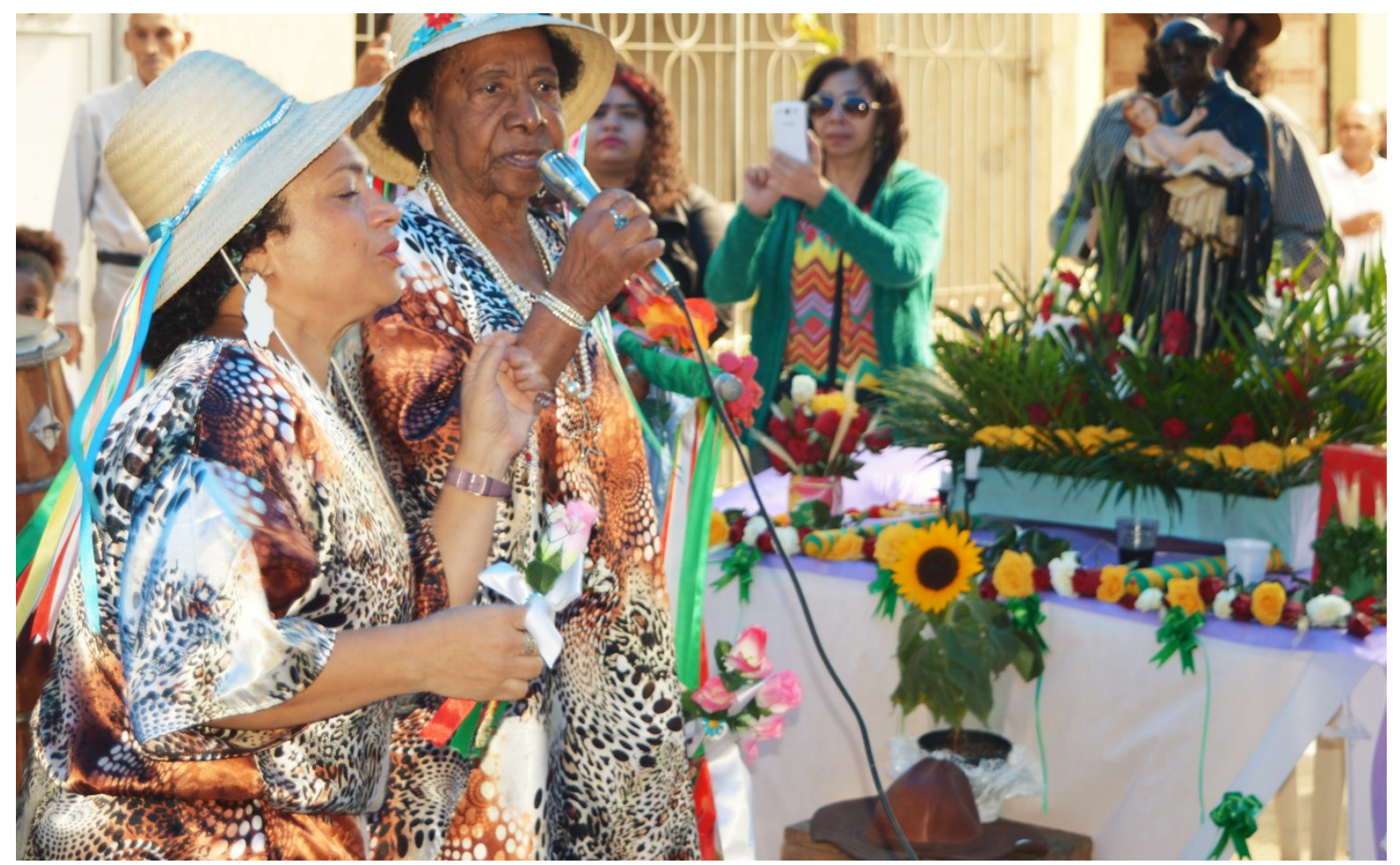

Figura 55: Congada na Vila Menck, chamada rememora antigos participantes falecidos. Ao canto direito imagem de São Benedito, abaixo chapéu do Boiadeiro no sincretismo da festa.

Fonte: Foto do autor, 2016.

\footnotetext{
112 Festas de grande participação da população negra de Carapicuíba. No ano de 2016 tivemos oportunidade de acompanhar as manifestações na Vila Menck, com a presença de grupos regionais de jongo, congada, capoeira, dança de reis e samba de roda.
} 
Roda de capoeira homenageia S. Benedito e a libertação dos escravos

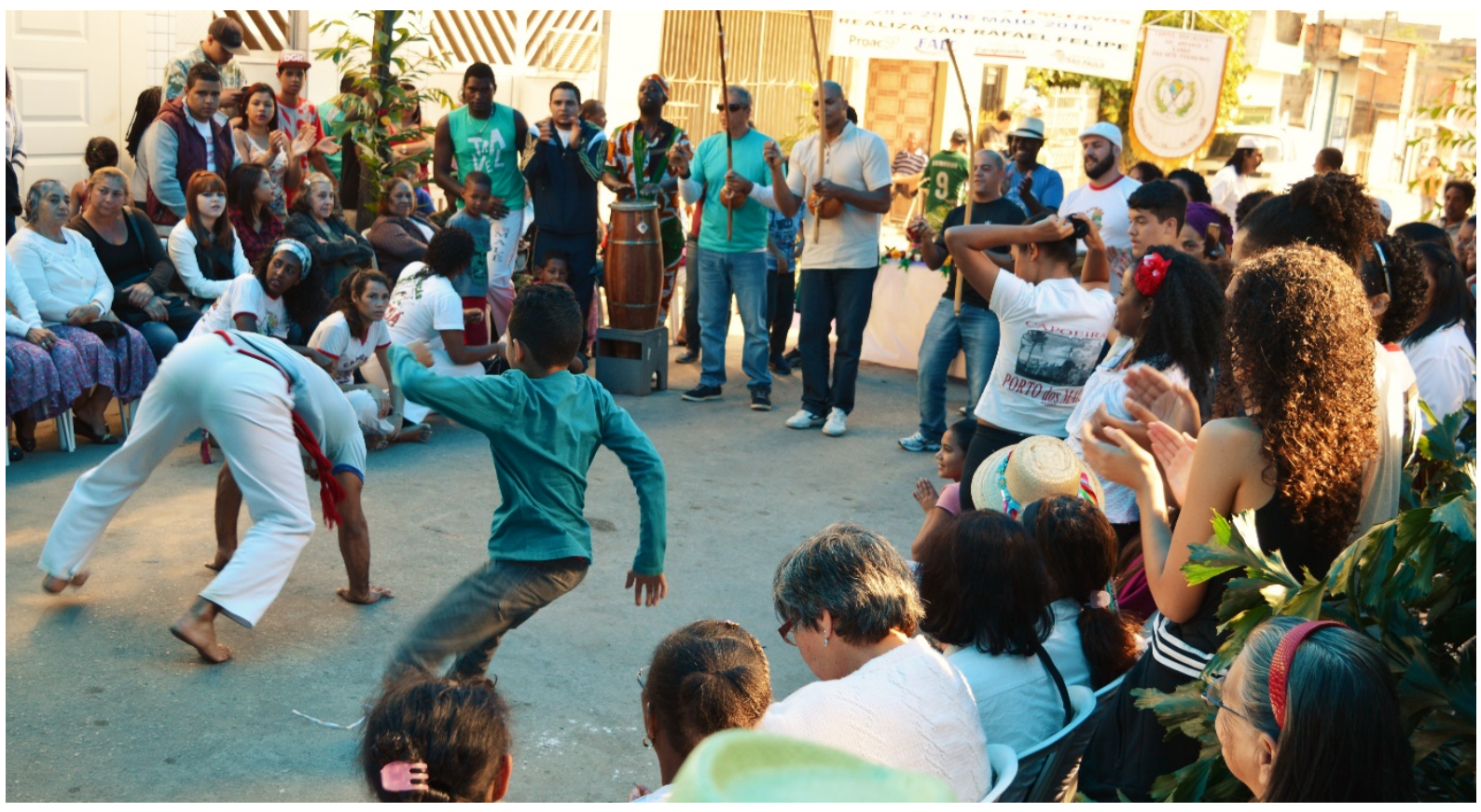

Figura 56: Capoeira no caldeirão de culturas em Carapicuíba - RMSP.

Fonte: Foto do autor, 2016.

Índios de diversas etnias na Festa de S. Benedito em Carapicuíba

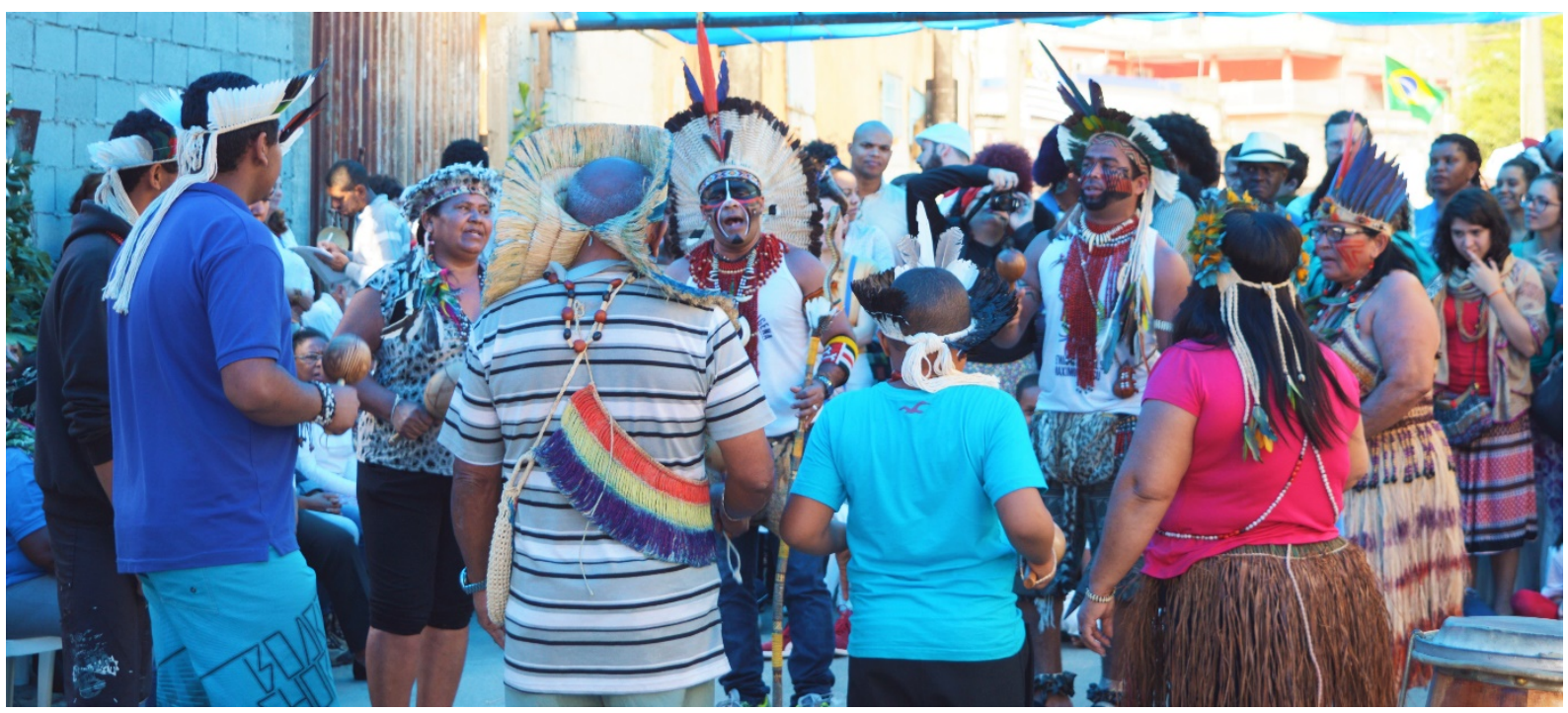

Figura 57: Danças lineares e circulares realizadas por índios de diversas regiões da Grande São Paulo, durante as festividades de São Benedito, Nossa Senhor do Rosério e Libertação dos Escravos em Carapicuíba - RMSP. Fonte: Foto do autor, 2016. 


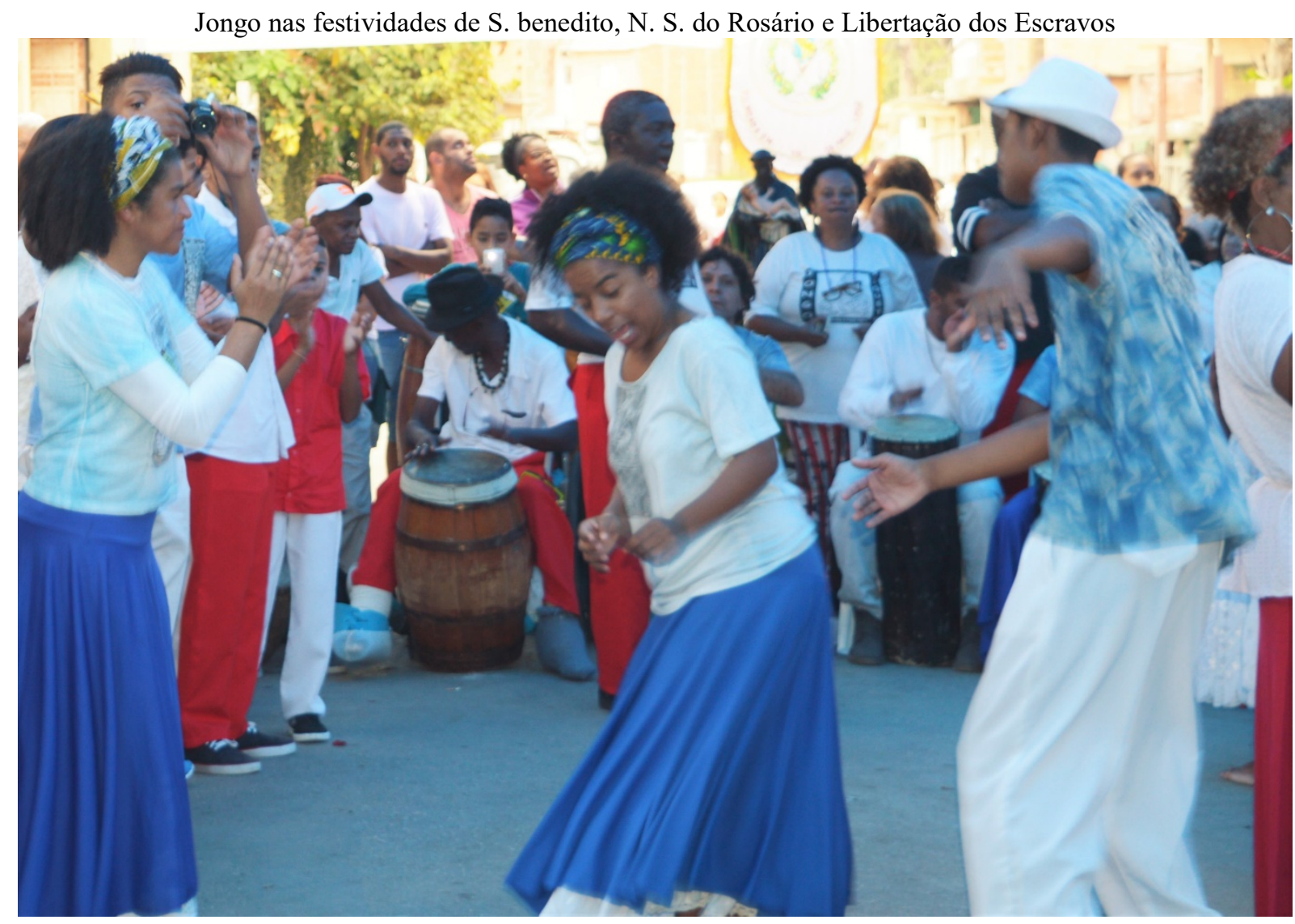

Figura 58: Jongo, com a participação das comunidades de São José dos Campos, Piquete e de Embu. Fonte: Foto do autor, 2016.

Compete destacar, no entanto, a permanência da tradicional saída da Romaria da Aldeia à Pirapora do Bom Jesus, realizada também por outros grupos da Grande São Paulo e residentes no interior, como Itu, Porto Feliz, Salto, Cabreúva e Tietê, que marcam anualmente as festividades religiosas e profanas tipicamente da cultura caipira paulista. Assim como, apesar das dificuldades apresentadas, as festas de Santa Cruz e Santa Cruzinha. As festas da Aldeia perduram, resistem mesmo diante da criticidade de uma urbanização totalitária. Afinal, elas são atos coletivos dos grupos sociais, que como explica Almeida (2102) reativam a "memória coletiva", imbricadas num contexto que perpassa o cerimonial e a diversão, onde sagrado e profano possuem ligações essenciais. Essas dissociações entre sagrado e profano não são reveladas nas falas de membros do grupo social reclinado na organização dos festejos, o que leva a crer fortes laços com a tradição pretérita e na organicidade do rito em relação às famílias e instituições responsáveis pela materialização das folias. Na comunidade de Santa Catarina, ou para grande parte de antigos moradores do bairro, a dimensão da festa é reveladora das crenças coletivas, cujos símbolos extravasam puramente o presente, ao se 
conectarem com representações do passado, rememorando antepassados, onde as expressões daquele território correspondem às experiências e realizações do grupo social. Portanto a festa reproduz relações espaciais e sociais dos grupos territorializados, instrumentalizando os fenômenos com seus ritos, normas, calendários e espaços de manifestações (ALMEIDA, 2012).

Deve-se reconhecer transformações neste processo. No passado, as celebrações de Santa Cruz calcavam-se fundamentalmente em atos religiosos, inclusive na dança do Sarabaquê como uma de suas determinações, enquanto hoje perpassa um sentido mais simbólico, que perpetua a presença das famílias e amigos integrados ao festejo profano e indistintamente à cultura caipira. No limite, conforme nos explicou um dos moradores, a própria igreja já não adere totalmente ao rito, lembrando que o padre enviado na ocasião de Santa Cruzinha, neste ano, se recusou a fazer todo o percurso da procissão entre as casas da Aldeia, o que gerou revolta por parte dos festeiros. Muito antes, Henne (2015) relata tensões entre a comunidade e um antigo padre que não aspirava seguir a tradição dos horários das missas que eram marcados e compassadas em função das manifestações profanas tacitamente constituídas. Considerando, por fim, a mudança do interesse, do público e dos sentidos das manifestações no tempo.

Ainda sobre as comemorações de Santa Cruz, nas falas de antigos moradores, assim como nos trabalhos acadêmicos revisados (PELLEGRINI, 1979; ESCALANTE, 1981; TENÓRIO, 2003; HENNE, 2015), há memória e descrição de uma festa de maiores escalas, diferenciada na ocasião de visitas de campo e observações por seu conteúdo e manifestação. Não simplesmente pela pequena adesão da população local às celebrações, mas aos conteúdos que sofreram influência direta do sistema urbano e de suas modernizações. Outro fator importante leva a crer que a perda de centralidade destes ritos traria a sobreposição de outras festividades, com caráter de maior agregação pelas condições exigidas na atualidade (forte aparato de segurança, recursos públicos-privados, investidos e infraestrutura básica).

Cabe ressaltar que, com exceção das festas conhecidas pela população, alguns entrevistados citaram a festa do dia do índio na Aldeia, que em certas ocasiões do passado foi muito celebrada naquele espaço, como foi possível constatar nos arquivos da $9^{\text {a }}$ SRIPHAN/SP. Ao aplicar os questionários na UIT da Aldeia ainda houve doze citações da festa de Santa Catarina, que segundo informações dos moradores é uma realização da comunidade que frequenta de forma mais assídua as missas e a igreja. Constatou-se, pois, que 
o maior conhecimento das festividades deriva dos moradores mais antigos e próximos da Aldeia. Por outra perspectiva, e considerando a totalidade dos questionários aplicados na cidade, a grande maioria desconhece qualquer rito tradicional, ou de sua história propriamente. Importante assinalar que mais de $85 \%$ dos 78 entrevistados que assim se pronunciaram são adultos com idades entre 18 e 34 anos, oriundos de outros municípios e que vivem relativamente distantes da UIT da Aldeia. Além disso, utilizam majoritariamente espaços de lazer e cultura em outras cidades da Grande São Paulo, destacadamente São Paulo, Barueri e Osasco respectivamente.

Chama atenção que mesmo a maioria da população entrevistada desconhecendo o IPHAN, o CONDEPHAAT e a presença de bens materiais tombados no município ${ }^{113}$, há pleno conhecimento da relevância histórica e, pois, cultural desta área em especial. Não apenas se destaca o conhecimento sobre o espaço, por mais criticamente que operemos na análise das falas dos moradores, mas também seu uso e a presença dos ritos e festejos tradicionais. É destacável que para uma grande parte da população abordada, sobretudo a mais jovem, o espaço da Aldeia de Carapicuíba destaca-se mais pela sua funcionalidade enquanto parque, ou seja, pelo lazer que propicia, do que propriamente pelo conjunto arquitetônico tombado. Do que, em outras palavras, poderia-se lembrar como um dos marcos patrimoniais do Brasil colônia, além da relevância da própria atividade institucional do patrimônio cultural nos primeiros momentos de sua criação. Uma das moradoras da Vila Dirce expressa que mesmo estando na região metropolitana de São Paulo, a área do parque da Aldeia se assemelha a uma atmosfera do interior.

\footnotetext{
Antigamente só tinha mato, era a Aldeia e em volta era tudo matão e no meio daquele mato tinha um lago que não era frequentado por que era muito sujo, agora faz uns 5 ou 6 anos foi feito o parque muito da hora, bonito, bacana você vai lá dá impressão que você tá lá em Itu no interiorzão de São Paulo, Sorocaba, lugar gostoso, você vai ali e fala: tô no interiorzão porque é um lago bom de andar em volta e gente andando pra caramba, o pessoal fica até tarde, calorzão fica embaixo das árvores depois da caminhada em vez de beber água por causa do calor pega uma cervejinha gelada, muito bom, muito legal! (Entrevistada 01, moradora da UIT Vila Dirce, 54 anos).
}

113 Dos 205 participantes da pesquisa, apenas 02 indicaram conhecer ou já ouvir falar do IPHAN ou CONDEPHAAT. Em relação a conhecer bens protegidos na cidade, 68 disseram conhecer alguma coisa, citando majoritariamente a Aldeia, além de outras poucas citações, como a Santa Terezinha, Oca e o Tancredão. 
Os questionários aplicados, assim como a realização de entrevistas, mostram de forma muito generalizada a participação de grande maioria dos munícipes em festejos no local, mas que se situam sobremaneira numa dimensão do passado, e não na atualidade. A vinculação entre as UIT's da Vila Dirce e da Aldeia é mais integrada, considerando a proximidade entre as unidades, como a formação pretérita de ambas, que decorre da expansão urbana paralelamente à avenida Inocêncio Seráfico. Isso reverbera numa relação dos entrevistados que é mais intensa com o espaço da Aldeia em relação às UIT's da Fazendinha, do Centro, $\mathrm{COHAB}$ e Ariston. A maior parte dos entrevistados que relataram jamais ter visitado o largo da Aldeia e desconhecer a relevância histórica e cultural da mesma, concentram-se no Centro e Ariston. Assim como o conhecimento das atividades ali praticadas variam em dois grupos: o primeiro ligado aos bairros e moradores mais antigos, que conhecem as festas religiosas mais tradicionais, como as de Santa Cruz, Corpus Christi, Santa Catarina e a Romaria; e um segundo grupo, de moradores e bairros mais novos da cidade que associam as festividades à Encenação da Paixão de Cristo (espetáculo realizado na concha adjacente ao largo da Aldeia, com grande investimento de recursos) e as festas juninas e os festejos de São João.

Focando e buscando compreender a dinâmica espacial da Aldeia também nas outras UIT's de Carapicuíba, para além das observações e diálogos travados exclusivamente com gestores e moradores da comunidade, observa-se uma tendência de falas e apontamentos da população pela prevalência de um espaço familiar, permeados por pessoas de todas as idades em busca de lazer e atividades físicas. Essa perspectiva acompanha uma das premissas majoritárias da passagem do espaço da Aldeia enquanto espaço das tradições e da história, para o espaço do uso público e do entretenimento (Gráfico 14).

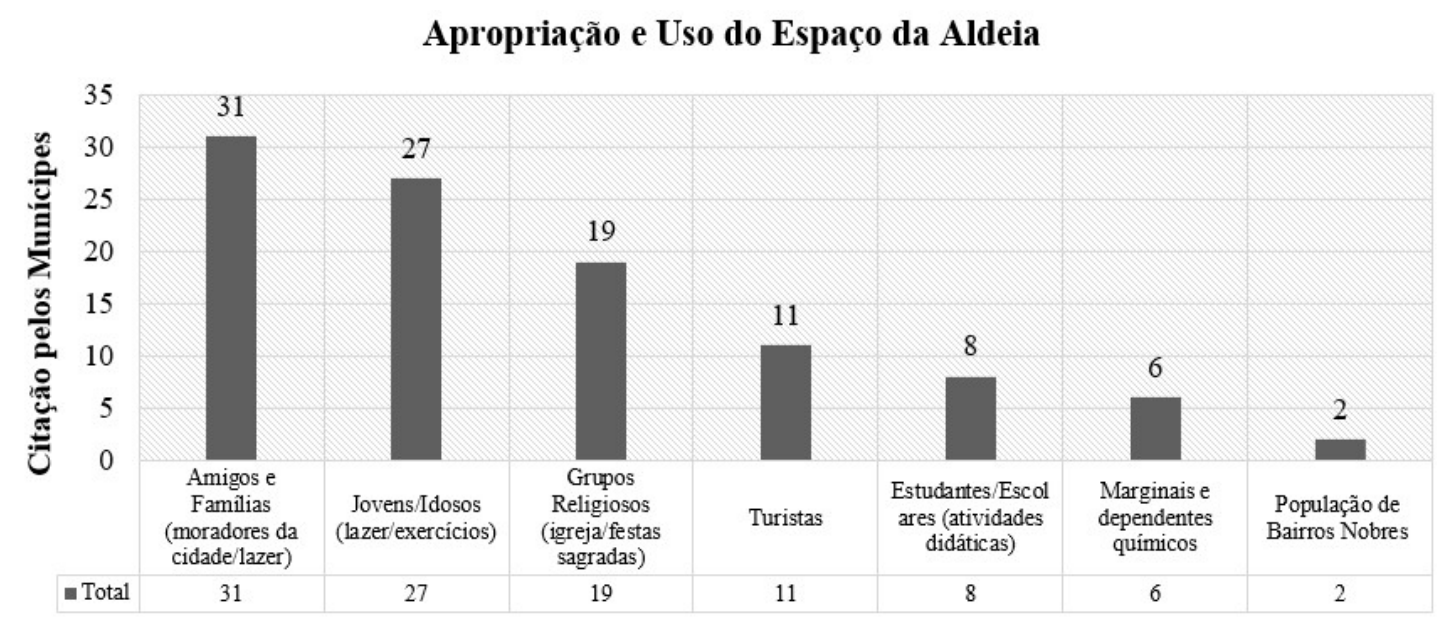

Gráfico 14: Representação dos usos do espaço da Aldeia pelos entrevistados. Fonte: Questionários semiestruturados aplicados nas UIT's pelo autor, 2016. 
Ainda que predominante a dimensão do lazer que o parque evoca, tanto nas entrevistas, quanto nas observações, o uso religioso e de tradições está superposto, inclusive por duplas citações e apontamentos, considerando que esta era uma questão aberta aos entrevistados ${ }^{114}$. Justamente, as mais citadas depois do espaço das famílias e do lazer, são as tradições, as festas e a religiosidade do lugar. Ao fim, aparece o turismo e atividades didáticas e pedagógicas realizadas por estudantes e professores. A convivência entre usos articula-se nas fragmentações operadas pela relativa autonomia de cada centralidade, delimitadas pelas UIT's. Em verdade, são poucos aqueles que se deslocam corriqueiramente do Ariston, nos limites com Barueri, ou do Centro para fazer uso do parque da Aldeia e de outros espaços de lazer e cultura da cidade, a não ser em eventos e festejos maiores. No cotidiano, o uso do Parque da Aldeia é realizado pelos moradores dos bairros locais, sobretudo nos fins de semana (Figura 59). Por vezes, mais facilitado é o deslocamento para o centro metropolitano, ou regiões centrais, que os próprios bairros de Carapicuíba. Observa-se aqui, uma certa regionalização estabelecida entre o setor norte, mais integrado ao centro metropolitano e regional pela proximidade com as linhas férreas, enquanto o setor sul, incluindo a Vila Dirce e parte do Ariston, é mais dependente de ônibus urbano e veículos particulares, que trafegam pelas vias arteriais e Raposo Tavares.

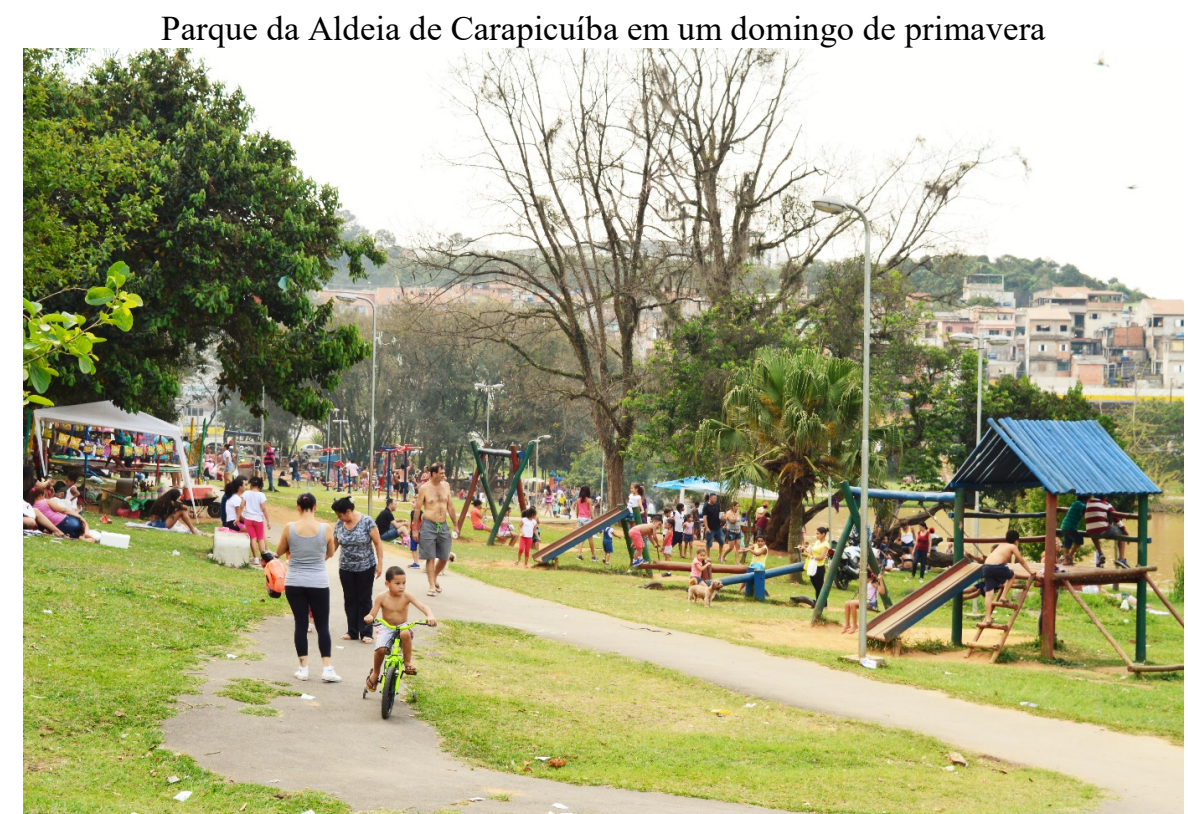

Figura 59: Parque da Aldeia de Carapicuíba, uma opção de lazer e sociabilidade de Carapicuíba-RMSP. Fonte: Foto do autor, 2016.

\footnotetext{
${ }^{114}$ Apêndice 01 - Questionários semiestruturados aplicados nas UIT’s de Carapicuíba.
} 
O processo de periferização, com a chegada de milhares de moradores, induzidos pelas políticas de planejamento e gestão do espaço urbano pelo Estado, fazem do território de Carapicuíba um retalho de centralidades, nem sempre conectados, tão pouco integrados a uma unidade comum, que uma cidade média ou pequena quase sempre apresentam. Os limites entre bairros e outras cidades tornam-se virtuais, constituindo-se numa dimensão política, mas sobretudo de relações que se estabelecem em torno da produção: do trabalho, do comércio e serviços, do que propriamente constata-se das tantas falas, de um passado em que as tradições, amizades e laços familiares desenvolviam-se em encontros e a identidade com bens materiais e intangíveis e que se constituíam na prática como patrimônio cultural. Sem negar, porém, as novas vivências ou experiências nestes antigos espaços, por mais que sejam instrumentalizadas e condicionadas organicamente pelas relações de produção, ou em projetos que buscam estabelecer novas lógicas permeadas por outras práticas culturais (como é o caso da OCA, na Aldeia - Figura 60).

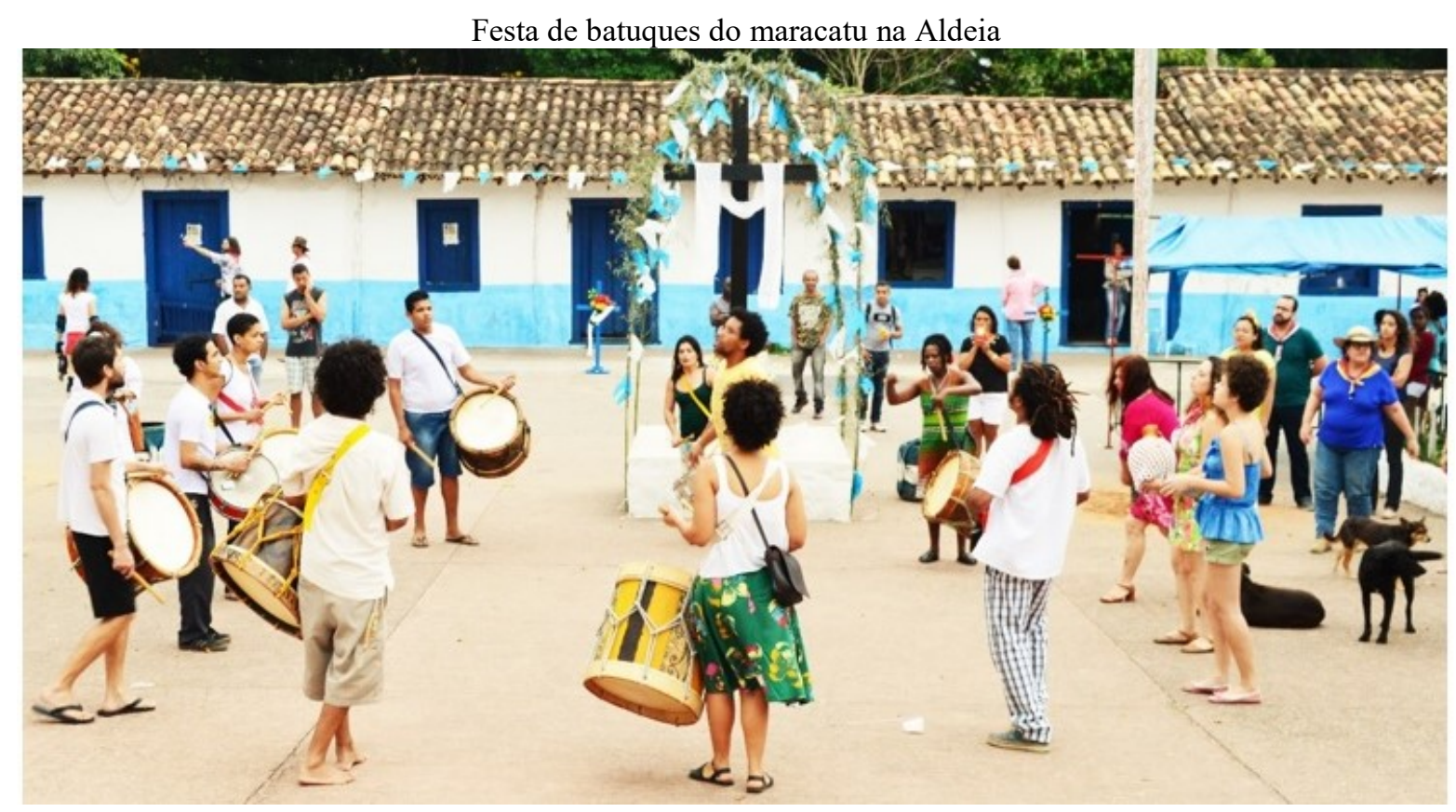

Figura 60: "A festa é de Sta. Cruzinha, mas a Aldeia é nossa!" - Gritou um dos percussionistas por ocasião da Festa de Sta. Cruzinha, 2016.

Fonte: Foto do autor, 2016.

Mesmo que precários, a manutenção das formas e o exercício de regulação e controle do espaço da Aldeia pelas instituições e políticas públicas foram sistematicamente contribuindo com os esforços da comunidade para a preservação dos traços da arquitetura e dos objetos geográficos, mas dialeticamente segregando o conjunto tombado do restante da 
cidade. Transformações que se processaram pelo isolamento das habitações e o pátio da capela do restante da cidade. Exceção apenas no caso da área de urbanização consolidada, na ZUC que integra bairros adjacentes, como o Jardim Marilu, Parque Santa Tereza, Jardim Lice, Vila Conquista e que não decorreram das expropriações realizadas entre 1993 e 1996. No que se refere às representações da população sobre as mudanças decorrentes na cidade nos últimos anos, as quais estão diretamente associadas à Aldeia, as infraestruturas foram as mais citadas e observadas como positivas ao longo de todo a atividade de pesquisa (Gráfico 15), nas diferentes unidades do seu território.

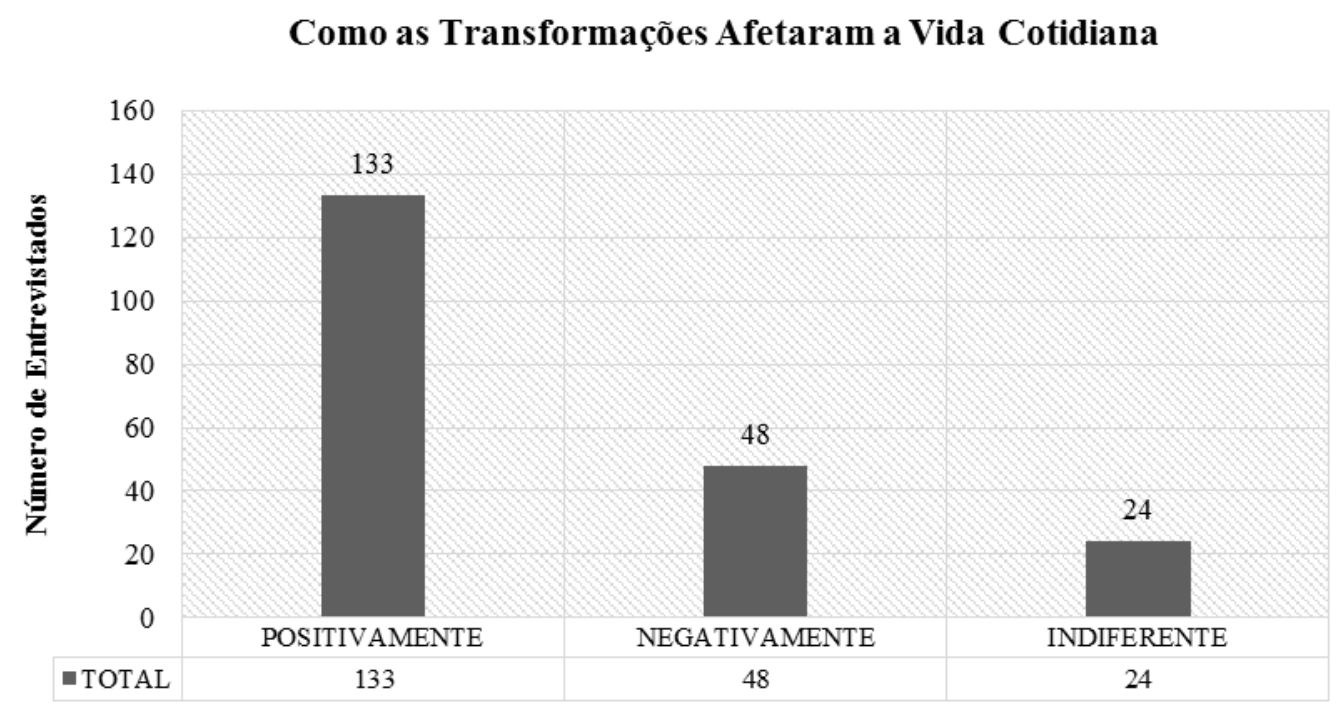

Gráfico 15: Como as transformações afetaram a vida da população de Carapicuíba entrevistada. Fonte: Questionários semiestruturados aplicados nas UIT pelo autor, 2016.

Ao longo dos questionários aplicados, a maior parte dos moradores, mesmo identificando avanços significativos na infraestrutura da cidade, entendendo a importância e apontando como positivas as transformações, explicavam que estas foram limitadas. Mais que isso, que a ausência de normas, de leis, de gestão e planejamento ao longo de anos criaram uma situação muito singular em Carapicuíba. Em verdade, a densidade demográfica do município, unida a ampliação do número de veículos automotores, junto às antigas formas urbanas - espontâneas ou criadas a partir de precárias e simples soluções - historicamente faz com que as alternativas de intervenção sejam extremamente complexas, bem como as alternativas de seus munícipes se estabeleçam em consensos tácitos pelas experiências com a cidade. 
No ano de 2015, outra intervenção importante é operada ao longo de toda avenida Inocêncio Seráfico, por meio de requalificação do seu calçamento. Esta operação de vulto estético passou a influenciar a mobilidade e a dinâmica local ao ampliar a área de pedestre revestida, porém, diminuindo as áreas de estacionamentos. Considerando a grande quantidade de atividades comerciais neste setor e a cultura do automóvel, bem como a frequência de ônibus metropolitano que interligam os nodais urbanos à estação ferroviária e a RMSP, tornou-se comum a invasão das calçadas pelos veículos, bem como reclamações advindas dos proprietários do comércio local.

\begin{abstract}
A cultura daqui de Carapicuíba ainda tem essa cultura de não obedecer à lei de trânsito, normas, Carapicuíba cresceu sem norma, desorganizada, então fícou essa cultura tanto que hoje a Inocêncio Seráfico ela já foi largada. Tem hoje bastante amarelinhos multando,eles não entendem que não podem subir na calçada, eles acham que calçada é lugar de carro e acabam subindo e reclamam se leva multa, é diferente quando levam para outra cidade eles vão pra Osasco... Carapicuíba sai daqui, vai pra Osasco e respeita bonitinho as normas de lá, Carapicuíba... a cidade aqui que não tem dono, todo mundo faz o que quer, então tem sim esse lado, agora com as multas de trânsito tá fazendo o Carapicuibano entender que tem que obedecer às leis de trânsito, também ficou meio sem normas até na questão dos animais mesmo [...] (Entrevistada 01, moradora da UIT Vila Dirce, 54 anos).

Virou cidade que não tem planejamento tem alguns bairros que foi planejado mas isso depois, os bairros planejados tem o que? 20 ou 30 anos que o bairro planejado aqui, tem o bairro planejado ali na Jandaia, outro bairro planejado a Cohab é planejado mas tirando isso Carapicuíba inteira não é planejado [...] (Entrevistado 13, morador da UIT Vila Dirce, 62 anos).
\end{abstract}

Quando não diretamente sobre o processo de urbanização, revelados pelos sistemas espaciais de aglomeração, densidade e de modernização do território, as falas situam-se especificamente sobre a gestão e o planejamento, bem como para elementos como melhorias no saneamento ambiental - incluindo aí drenagem urbana (controle de enchentes) - além da melhoria na mobilidade, habitação e áreas de lazer (Gráfico 16). Emerge, portanto, a representação de transformações ou mudanças ligadas diretamente à urbanização territorial do município, que sobressai nas muitas falas e observações realizadas. Estas, seguidas daqueles que não conseguem ver significativas mudanças na cidade, e outros que entendem que as maiores transformações foram no espectro econômico ou político - que associam-se com a 
urbanização e infraestrutura diretamente - e, depois, na educação, segurança e saúde quando, por fim, lembram ainda do lazer, cultura e entretenimento.

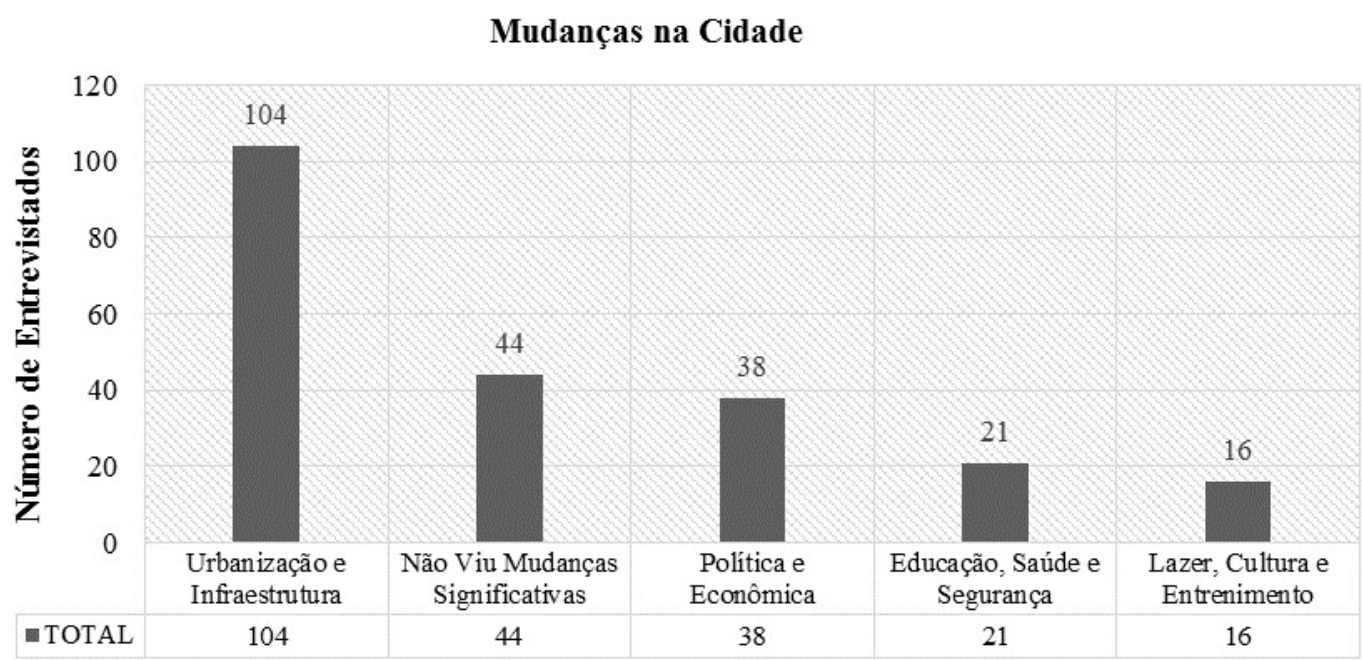

Gráfico 16: Mudanças importantes lembradas por moradores entrevistados de Carapicuíba. Fonte: Questionários semiestruturados aplicados nas UIT pelo autor, 2016.

Deve-se considerar que para grande parte da população as intervenções e modernizações que se processam nos sistemas urbanos são centrais para um município que por anos amargurou a ausência do Estado, a precariedade dos serviços públicos, assim como o drama de estar distante do acesso aos bens que a cidade potencialmente oferece. De maneira que dos 205 entrevistados, apenas 43 disseram ter uma relação sentimental com a cidade, considerando-a aqui não enquanto um objeto, como se verificou acerca da reificação de sua história. Neste caso, das relações sentimentais, estas sempre estiveram situadas nas relações, nas ações e no âmbito das amizades, das famílias, das práticas sociais. Essa identificação e relação com os espaços de Carapicuíba estabeleceram-se em favor de algumas citações mais comuns, como a da infância, de lembranças e experiências positivas, do acolhimento, de relações amorosas como namoro e casamento, além da convivência com amigos e familiares.

Moramos aqui há muitos anos, não tem como não gostar, faz parte da nossa vida esse lugar. Foi onde nasci e cresci. Passei toda infância aqui. Em Carapicuíba o povo é muito acolhedor, faz amizade fácil (Entrevistado 14, morador da UIT Cidade Ariston, 52 anos). 
Eu gosto sim, da COHAB principalmente. Você deveria perguntar mais do bairro, porque a cidade é muito grande. Veja, pois mesmo morando na Vila Creti, lá perto do centro, foi aqui na COHAB que fiz os amigos. É muito diferente a depender do lugar da cidade. Eu morava aqui antes, minha família ainda mora, eu sai. Mas é aqui que tenho os amigos e sempre que posso venho aqui. $\mathrm{A}$ COHAB aqui foi onde fiz minha vida. (Entrevistado 15, morador da UIT COHAB 02, 35 anos).

Além de aprovarem as últimas intervenções e assinalarem de que ainda há muito por ser feito, aproximadamente $84 \%$ dos entrevistados dizem gostar da cidade, variando qualitativamente aquilo que mais gostam tendencialmente a depender do bairro. Deve-se destacar, porém, citações de que Carapicuíba é uma cidade sossegada ou tranquila, das boas relações no bairro com as pessoas conhecidas e familiares e, por fim, do fácil acesso que possuem às grandes cidades, de São Paulo propriamente. Essas tendências variam conforme às UIT's, onde a Aldeia e Fazendinha destacam-se pelos apontamentos da presença de amplas áreas verdes, por exemplo, e onde no Centro Ariston e COHAB's sobressai o acesso aos centros urbanos da região metropolitana (Gráfico 17). Quanto ao caso do conjunto tombado da Aldeia apenas uma indicação, na própria UIT correlata, evidenciando uma vez mais o distanciamento da população de Carapicuíba com os bens culturais da cidade.

\section{O que mais gosta em Carapicuíba}

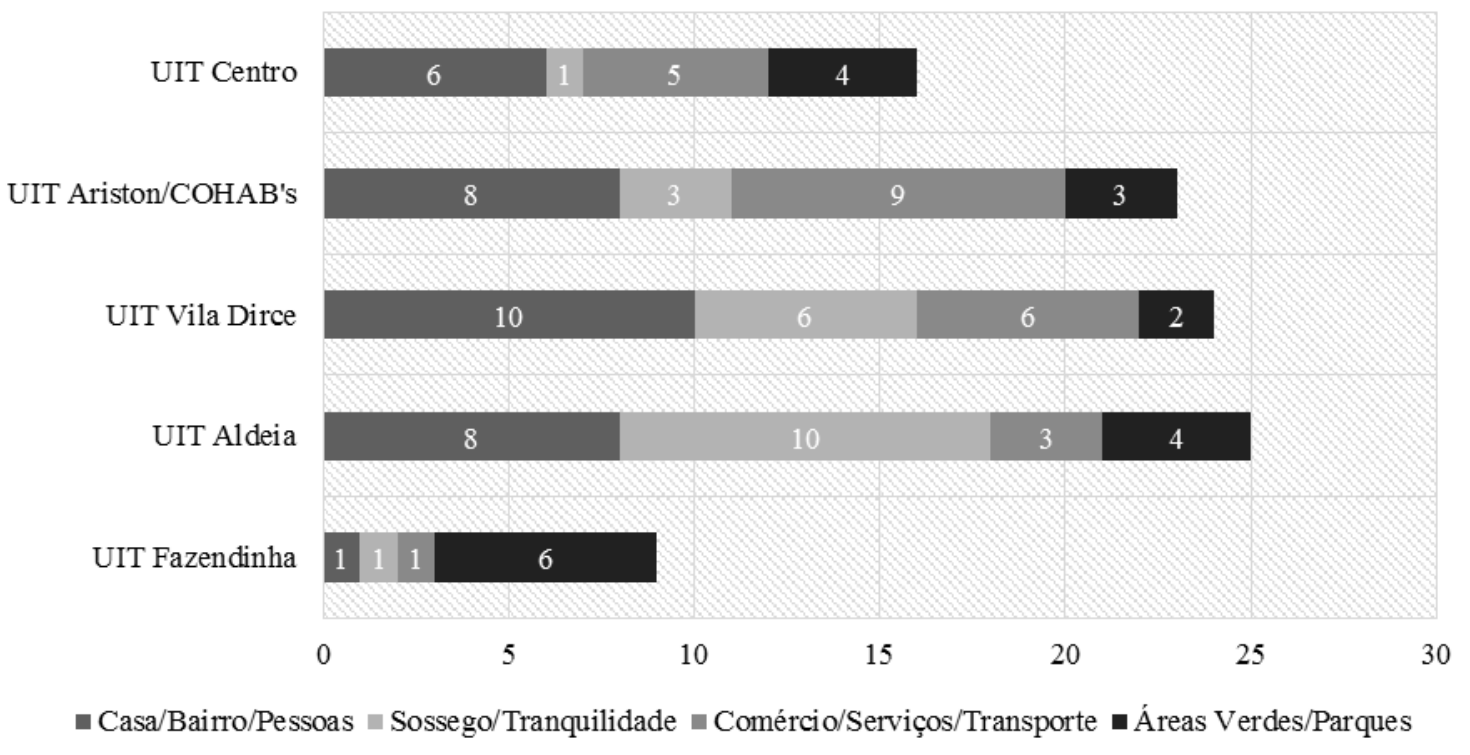

Gráfico 17: População entrevistada aponta o que mais gosta em Carapicuíba. Fonte: Questionários semiestruturados aplicados nas UIT's pelo autor, 2016. 
Estas variáveis são diagnósticas ao apontarem para o potencial que as políticas patrimoniais ainda não tocaram; o das vivências e experiências da população com a cidade e seus bens. O conhecimento da Aldeia como bem protegido da cidade - manifestado por 1/4 dos entrevistados - não implica necessariamente na consciência explícita de relações entre aqueles objetos com sua diária resistência pela presença e animosidade dadas pelos sujeitos. $\mathrm{O}$ espaço da cidade se revela algo positivo para população quando este remete à memória de experiências pessoais e, pois, coletivas, em torno de analogias com amigos e familiares, desde a infância aos dias atuais. Lembrando relativamente a centralidade dos equipamentos urbanos, que juntos potencializam os anseios e necessidades dessa grande diversidade de moradores (ligados a antiga condição rural, caipira, suburbana e atual de metrópole, cidade dormitório e de enclaves).

Diversidade que pode ser esclarecida pela crítica de um patrimônio cuja narrativa selecionou histórias que mais suprimem do que propriamente explicam, acumulam ou sobrepõem essa diversidade. Uma rugosidade que ainda hoje torna-se marginal ou refém dos preceitos mais arcaicos das políticas do patrimônio, enquanto documento ou símbolo de uma história universal, geograficamente particularizada no poder imperial sobre a colônia, no deleite da fatalidade acrítica do desbravamento bandeirante, da civilidade cristã, ou da apropriação produtiva de novas atividades mercantis pela démarche da arquitetura de taipa de pilão. O lúdico e o tempo livre, racionalizados em favor da plena capitalização da vida, transformam os encontros segmentados entre os semelhantes. O potencial de atividades e convivências materializadas nas/pelas rugosidades patrimoniais operam sistematicamente a musealização cristalizada e do uso institucional restrito e pouco diverso (órgãos públicos, museus, entre outras funções). Falta, junto a outra lógica de relações sociais, a integração à vida do trabalhador, a retomada do reconhecimento, o resgate das raízes de pertencimento concretizadas pela produção prática e cotidiana da cultura. Ou, drasticamente, a vida continuará a ressoar apenas os ecos do passado, enclausurada nas melhor das hipóteses no âmbito da casa, experimentando um mundo artificial e manipulada pelas ferramentas de comunicação e informação, quando não apropriada por mais trabalho expropriado.

Uma organização diferente do 'tempo livre', que transforma em prolongamento do trabalhado e do lucro, contribui para essa reformulação do público. Dos cafés da manhã de trabalho ao trabalho, aos almoços de negócios, ao trabalho, aos almoços de alguns dias aos jantares de sociabilidade rentável. O tempo livre dos setores populares, coagidos pelo subemprego e pela deterioração salarial, é ainda menos livre por ter que preocupar-se com o segundo, terceiro trabalho, ou em procurá-los (CANCLINI, 2006, p. 288). 
Simultaneamente, o potencial permanece resistente às distopias que levam-nos a suspeitar do fim da história, de uma condição sem voltas, de uma dinâmica de poder universal imposto verticalmente em todos os territórios, violando a complexidade do trabalho humano na produção de seus bens, de suas artes e de suas ciências. Essas utopias emergem das tantas falas indicativas que se impõem diante da segregação urbana e da ausência do direito à cidade, marcadas pela conquistas materiais realizadas do antigo barraco transformado em casa de alvenaria, da conquista do logradouro e das infraestruturas básicas que permitem o deslocamento e mobilidade, da relação simbólica com Carapicuíba que ganha substância de uma periferia que enfrenta e luta dia-a-dia contra as imposições severas e estruturais postas pelo modo de produção contemporâneo. Juntos, esses elementos, remetem aos utopismos patrimoniais (COSTA, 2016), ao partirem de uma profunda crítica e denúncia, até alcançarem a resignificação de uma narrativa história e geografia próprias dos territórios. 


\section{CONSIDERAÇÕES FINAIS}

As considerações acerca das particularidades da formação territorial brasileira pelo prisma dialético das universalidades que se interpenetram desde a colonização até a consolidação urbano-metropolitana, perpassam a compreensão das qualidades inerentes e essenciais dos processos em curso. Para isso, adotando no caso do fragmento empírico, das rugosidades patrimoniais e metropolitanas em Carapicuíba, os sentidos e finalidades da colonização do planalto paulistano, da consolidação do Estado-nação brasileiro, até o desenvolvimento da Região Metropolitana de São Paulo (RMSP) - cujo espraiamento pela implosão-explosão urbana e onipresença virtual incorpora e dinamiza praticamente a totalidade do território nacional - por meio dos desdobramentos institucionais da patrimonialização e das políticas urbanas. Na análise empreendida, a noção de rugosidade embasada em Milton Santos (1977; 2012d [1996]; 2012 [1978]; 2012c [1978]; 2013a [1978]) foi capaz de substanciar o olhar para as sucessivas formas-conteúdos que se interpenetram e cristalizam-se espacialmente nas diferentes etapas de desenvolvimento dos núcleos, cidades e metrópoles. $\mathrm{O}$ esforço de situar e empiricizar seus preceitos teóricos fundamentais realçam a necessidade de superar a noção pelo conceito estruturado e categorizado conforme a essência provisória da realidade. Nisto, compreende-se o papel do conhecimento produzido no âmbito disciplinar, de sua contribuição. Do mesmo modo, a contínua necessidade de colocar à prova esse conhecimento face ao dinâmico movimento da história depreende do esforço analítico e da possibilidade dual de decodificação do fenômeno: o primeiro, de refutar os preceitos teóricos, em razão da realidade que já não pode ser explicada por eles, e criar um novo arcabouço conceitual; o segundo, como no caso da tese, de reafirmar os preceitos teóricos estabelecidos, somando e ampliando os fundamentos, igualmente expandindo os limites reflexivos, analíticos e operacionais dos conceitos e temas de abordagem (o patrimônio na/da metrópole).

Carapicuíba e grande parte das cidades que compõe a metrópole paulista despontam desses embriões e nódulos fundacionais que perpassam intensamente todas as fases de desenvolvimento de São Paulo. Ainda que grande parte da produção material destas cidades tenha sido suprimida pelas modernizações, operadas pela recorrente industrializaçãourbanização dos territórios, a possibilidade do resgate das primitivas e atuais rugosidades patrimoniais marcam a apreensão das essências que alicerçaram a mais dinâmica metrópole 
do país, mas que nem sempre apresentam-se em suas condições materiais ou necessariamente livres de cargas ideológicas em suas existências. Esse foi, em grande medida, o esforço empreendido na pesquisa, compreendendo cinco eventos que marcam os períodos de formação, desenvolvimento e consolidação da Aldeia de Carapicuíba entre as supressões, superposições e acumulações que dialeticamente compreendem as rugosidades patrimoniais.

O primeiro evento marca a gênese das rugosidades patrimoniais de Carapicuíba, associada ao fenômeno de colonização e o estabelecimento de uma das unidades do antigo sistema de aldeamentos. Nela, constatou-se a configuração das supressões das formas e dos conteúdos pretéritos, no limite com a apropriação das formas cristalizadas e o esforço de sua contínua superposição. O segundo evento relaciona-se ao declínio dos aldeamentos e a conversão do aldeamento em vilarejo típico do cinturão caipira. Neste processo, identificou-se a latência das categorias de acumulação e superposição das formas-conteúdos, que caracterizaram mais intensamente a rugosidade patrimonial por sua "mestiçagem", sacralização e o relativo ostracismo que permanece até sua patrimonialização. O terceiro evento se estabelece com a transformação da Aldeia num típico subúrbio paulistano, e o tombamento do conjunto como patrimônio nacional pelo SPHAN. Esses eventos marcam a integração rodoferroviária da Aldeia de Carapicuíba com São Paulo e atuação recorrente do Estado em relação aos bens materiais e os modos de viver pela população naquele lugar. $\mathrm{O}$ quarto evento deriva da plena industrialização de São Paulo, quando realiza-se a implosãoexplosão urbana, com expansão e efetiva integração da malha urbana da capital com seus subúrbios. Os limites empobrecidos desta expansão integram a Aldeia, com a consolidação de ocupações irregulares, favelização e a contínua degradação do patrimônio tombado pela intensidade dos impactos causados e a ausência de políticas e ações institucionais para sua preservação. $O$ quinto evento refere-se à urbanização territorial, empreendida pela reestruturação produtiva de São Paulo, a instalação de infraestruturas que se consolidam parcialmente na cidade, além de intervenções mais amplas na Aldeia e entorno, no sentido de sua instrumentalização e preservação.

Com a pesquisa e contextualização sobre os aldeamentos paulistas, foi possível ratificar conexões estruturais entre tempos distintos no caso de Carapicuíba, desde o cinturão caipira, a formação dos subúrbios até a implosão-explosão urbana, que perpetuam semelhanças, continuidades e cisões histórico-geográficas: do trabalho espoliado; da renda diferencial da terra e de seus recursos intensamente explorados e mercantilizados; das forças inerciais impetradas por redes urbanas de poder; dos mecanismos de segregação e auto- 
segregação; da cultura como razão prática de resistência; da reprodução ampliada das relações de produção numa dilatada e sistemática divisão territorial do trabalho; do desenvolvimento desigual e concentrado; das possibilidades utópicas de vir a ser, despertadas por uma práxis revolucionária em que a cultura e espaços públicos têm papel central.

Em Carapicuíba, sua situação marginal não deriva apenas da distância geográfica, considerando sua relativa proximidade ao centro metropolitano, mesmo em tempos remotos, mas de funções deletérias que servem ao polo e que derivam desde os primitivos tempos coloniais. Estas funções exigiram formas geográficas nem sempre duradouras ou sofisticadas, pois a intermitência foi condição fundamental, seja pelas políticas de reordenamento territorial exercidas na colônia pela Coroa e a Igreja, ou posteriormente das políticas urbanas, metropolitanas e do patrimônio cultural. Essa sina não acompanha necessariamente os conteúdos, que na latência das acumulações e das superposições (tradições, ritos, modos de viver), germinaram profundas raízes nos sujeitos históricos que ali permaneceram no descompasso temporal da "modernidade concentrada" e avivaram as singelas habitações, a capela e seu largo, ao som de velhas violas, na transmissão oral musicada das lendas e crendices, na rememoração de seus antepassados, na vida simples hibridizada que subsistiu por até três gerações quando da flexão com o urbano e acolhimento do espaço pelo Estado por meio de sua patrimonialização.

O tombamento da Aldeia de Carapicuíba em 1940 como patrimônio nacional é um marco da incipiente política institucional na estruturação concreta da ideia de nação para o Brasil pós-colonial. Os sentidos dessa escolha referem-se aos potenciais identitários de representação das principais matrizes étnicas e culturais do povo brasileiro, que marcam e possibilitam a contínua difusão dos preceitos fundacionais calcados, mormente, nas ideologias históricas e geográficas do período. A constituição do Estado moderno exigia no plano cultural reforçar a internalização de uma universalidade cultural, uma unidade capaz de explicar e sustentar as relações de pertencimento e de legitimação das instituições estatais e classes sociais em processo de consolidação. As técnicas construtivas, o patrimônio barrococolonial, as igrejas e prédios maiores foram os fundamentos na escolha dessa incipiente política patrimonial.

A escolha da Aldeia como patrimônio nacional insere-se à década de 1930 na atmosfera do movimento modernista, de reinvenção plural da unidade nacional entre a cultura popular e erudita pensada pelo anteprojeto de Mario de Andrade ao SPHAN. O antigo espaço 
do aldeamento, conforme minucioso esforço analítico do estudo para o tombamento, realizado por Luís Saia sob orientação de Mario de Andrade em 1937, contemplou além das habitações, das formas geográficas ligadas ao plano de urbanização colonial e das técnicas construtivas, também a profundidade das tradições particulares da cultura hibridizada e sintetizada pelo caipira, como os festejos e expressões folclóricas da dança de Santa Cruz, ou os utensílios domésticos e as crendices populares de então (ferraduras nas portas, ou o símbolo de Sinhô Samão para a proteção da casa). Sem jamais ser publicado, o estudo é revelador do potencial de pluralidade e questões subjetivas à cultura e preservação no anteprojeto de Mario Andrade que, de forma concreta, trata-se no caso da Aldeia de um dos estudos mais bem caracterizados dessas acepção germinal e reveladora do valor histórico que o pequeno conjunto se impunha frente as grandes obras artísticas e arquitetônicas do barroco mineiro, mas fundamentalmente, da tentativa de clarificar a mescla entre culturas eruditas e populares, desde a dança do Sarabaquê, até o preenchimento coletivo das paredes externas de pau-a-pique das construções no sistema de mutirão, sempre indagadas a origem de técnicas e procedimentos que resvalam ora no colono, ou no religioso, ora no ameríndio, ou no afro-brasileiro.

Por ser o aldeamento um espaço colonial de exceção (estratégico ao poder imperial nas primeiras fases de assentamento), tanto o sentido de cidade como de monumento (tal qual é o caso de Ouro Preto), tornam-se inadequados ao emprego terminológico no caso da Aldeia de Carapicuíba no período que precede a 1940. Este, um pequeno fragmento histórico sem nunca efetivamente ser urbano ou rural até sua patrimonialização, é um território litigioso e de contradições perpetuadas ora pelo subjugo e escravização, ora pelas razões práticas de existência e o ato de sobreviver diante do isolamento e do ostracismo. As formas geográficas, essenciais às funções do cativeiro, da proteção militar, abastecimento e aos conteúdos ideológicos-culturais no processo de "amansar" e "cativar" o índio, tornam-se as rugosidades que mais tarde sustentam a possibilidade do existir, superpostas pelas funções e conteúdos acendidas no acúmulo com a produção do trabalho livre e o modo de vida a partir das hibridizações contínuas entre os grupos sociais.

Em um período de pouco mais de um século, entre o fim dos aldeamentos no dezenove e a plena integração de Carapicuíba enquanto subúrbio de São Paulo em meados do século vinte, a Aldeia enquadra-se nos limites do cinturão caipira. Nele, há um relativo isolamento do conjunto, do grupo social, que vai gradativamente preservar as rugosidades patrimoniais. Estas necessidades implicam não apenas em intervenções isoladas nas casas, mas no conjunto do espaço de convivência, em que as relações sociais são fortalecidas, predominantemente as 
religiosas, que passam a gradativamente sacralizar pelas tradições seculares o atual vilarejo caipira. Contexto tencionado por uma integração mais dinâmica dos núcleos históricos com São Paulo e outras centralidades urbanas regionais, que superpõe aos antigos caminhos às linhas férreas, articuladas hierarquicamente numa nova rede de produção, circulação e consumo. Trata-se de uma fase com importantes modernizações, com espraiamento da urbanização ao longo das linhas e estações de trem, cujas rugosidades patrimoniais foram paulatinamente suprimidas e superpostas para o atendimento de outra lógica de produção. Se o papel do uso cotidiano e das relações sociais no espaço da Aldeia foram determinantes a sua preservação, neste momento o Estado é quem dividirá essa função, exercida, porém, a partir de diversos conflitos, que culminariam, inclusive, na dilapidação da autonomia popular a propósito de seus territórios e, em certa medida, no próprio aniquilamento de alguns bens materiais, das tradições e simbolismos.

No contexto suburbano e de implosão-explosão urbana de São Paulo, verifica-se a generalização do fenômeno em Carapicuíba, com o adensamento e "explosão demográfica" pelas estratégias do ordenamento territorial que fragmentou o território de Carapicuíba numa nova unidade política-administrativa (emancipação em 1964), além de impulsionar a expansão da RMSP nos sentidos leste e oeste por meio da construção de milhares de habitações nas COHAB's e CDHU's, favorecendo a transformação funcional de muitos subúrbios em cidades-dormitórios, bem como a emergência de múltiplos problemas sociais. As políticas públicas favoreceram concomitantemente a especulação imobiliária, com a criação de muitos loteamentos irregulares por agentes privados, além da consolidação de bolsões de pobreza em áreas de risco em todos os setores do município. Milhares de trabalhadores passaram a integrar a dinâmica de vida na cidade, contribuindo para consolidar um caldeirão de culturas. No plano da Aldeia, este momento desponta em uma série de ações que visam integrar as políticas urbanas-metropolitanas às políticas culturais, considerando a pressão sofrida pelo espaço na intensificação do fluxo de trânsito, do crescimento de bairros e vilas no entorno, bem como nos limites do próprio quadrilátero do conjunto tombado.

As dimensões históricas e documentais das rugosidades se reafirmam nos planos e estratégias de planejamento, porém, na prática a Aldeia torna-se um contínuo objeto a ser apartado da expansão urbana em favor de sua preservação, bem como utilizado enquanto instrumento turístico e de atividades ligadas à cultura. $\mathrm{O}$ bem cultural passa a uma efetiva condição de bem patrimonial. Esta realidade, no entanto, além de não ser capaz efetivamente de impedir os conflitos entre a expansão metropolitana de São Paulo, a municipalidade, o 
SPHAN e comunidade ali residente, ainda os exaspera. De fato, as políticas pouco são eficazes no sentido de plenamente impedirem os impactos visuais, sonoros e paisagísticos que a urbanização trazia. Os projetos elaborados pelas instituições estatais no conjunto só sentirão algum efeito anos mais tarde, quando as intervenções são mais recorrentes no sentido de adequação dos bens ao conjunto do parque municipal, ou como potencial catalisador de novas atividades produtivas. No plano imaterial, mesmo com os preceitos modernos balizados internacionalmente, as ações na Aldeia ignoram o potencial da própria preservação pela manutenção das tradições e restringem as intervenções mais basilares às reformas pontuais do conjunto, ignorando as dificuldades enfrentadas de perpetuar ritos e festejos, ou de melhor sustentar o empoderamento de sua população em relação as relíquias ali presentes, que estavam em processo de desaparecimento ou pauperização diante do fenômeno urbanometropolitano e de periferização em curso.

No que tange as décadas mais recentes, cuja intensidade e pujança do crescimento metropolitano de São Paulo é refreado por sucessivas crises, com a desconcentração das indústrias e a produção de novas infraestruturas territoriais, o papel exercido por Carapicuíba ainda permanece num contexto universalmente compreendido como base metropolitana de sustentação. Mesmo com o conjunto das taxas de crescimento geométrico reduzidas, as cidades da periferia, com seus braços e condições limítrofes, darão incremento populacional a RMSP, animando o atual cenário, inclusive no contexto de maior complexidade dada pelas revalorizações espaciais e a instalação de sistemas condominiais e enclaves residenciais nos territórios da periferia. Este é o período de maiores intervenções no conjunto tombado, onde se efetivam parte dos planos de desenvolvimento pensados para a RMSP, Carapicuíba e, mais notadamente, para a Aldeia entre 1970 e 1980, e parcialmente realizados na década de 1990 e anos 2000 .

Os sentidos da Aldeia perpassam uma reconfiguração, operada no plano do cotidiano, imersos pela dessacralização do espaço, bem como por funções que deixam de ser a totalidade do habitar para as de entreter (desvinculação das festas e tradições com o espectro religioso) e as de abrigar serviços, repartições públicas e não governamentais. Esta mudança é recorrente das políticas urbanas e patrimoniais que não asseguraram a presença das famílias instaladas (ausência de uma política de empoderamento/controle social e as verticalidades restritivas na própria condição de adequar a vida sob a nova realidade metropolitana), bem como fragmentam o monumento de seu contexto urbano, do entorno direto, descolado da cidade como um todo. O advento e criação do parque da Aldeia, com as desapropriações e instalação 
de equipamentos públicos, perfaz uma dinâmica de transformações cujos campos de luta se estabelecem na apropriação dos espaços de lazer e cultura, ora pelas famílias tradicionais do lugar, ora pelas novas demandas cotidianas da diversidade metropolitana. Neste conjunto se sobrepõe os moradores de rua que do parque fizeram residência e da Aldeia um espaço de estar, aos munícipes que diariamente arranjam caminhadas, atividades físicas e destacam a centralidade das sociabilidades e encontros ali realizados. As rugosidades patrimoniais convertem-se numa plataforma, num substrato capaz de gerir festejos religiosos e profanos, os espetáculos e dramas cotidianos, as múltiplas temporalidades que continuamente resultam das supressões, superposições e acumulações.

Dialeticamente, as rugosidades patrimoniais de Carapicuíba, desde a gênese até o uso cotidiano contemporâneo, revelam um continuum que perfaz o desenvolvimento do próprio sentido e conteúdo urbano. Se não por caracterizar-se numa centralidade, ao menos por sustentar essa qualidade, com formas-conteúdos que apesar dos efeitos de sua fragmentação, são partes do urbano potencializadoras de sociabilidades e convivências, da possibilidade crítica de ressignificação e apropriação pelas condições contraditórias ou conflituosas que as rugosidades propiciam. Nem sempre explicitadas, as forças ideológicas valem-se do cotidiano para gradativamente operarem uma ideia reificada dos bens patrimoniais, suficientes para perpetuar uma visão acrítica e naturalizante das desigualdades e injustiças sociais. Concretamente, estas emergem no caso em questão até mesmo da simples e cômoda designação "Aldeia de Carapicuíba", terminologia prolixa, difusa e que remete ideologicamente a um significado passível de dúbio entendimento de suas funções e conteúdos pretéritos (uma pseudoconcreticidade). Aldeias eram espaços indígenas por natureza, ainda que a palavra já seja uma construção alegórica cujas origens são o Ocidente, a Europa, o português que historicamente generaliza o termo a pequenos núcleos de população até os dias atuais. Tão somente o sentido de aldeia situar-se-ia neste prospecto ideológico, ainda que mais generalizadamente possa ser compreensível como território indígena na particularidade linguística brasileira. O que o aldeamento, de forma alguma sugere. Valendose, porém, de estratégias políticas e econômicas mais efetivas, que juntas e combinadas às forças ideológicas, constituem dimensões de salvaguarda que segregam os bens das comunidades locais em favor de sua consagração nacional-universal de apropriação e fruição.

Isto requer considerar essas rugosidades patrimoniais do ponto de vista de suas singularidades, onde mesmo designada de Aldeia, a qualificação de aldeamento permeie os sentidos e seja suficiente de revelar o drama dos povos primitivos, numa consciência crítica 
dos preceitos da formação social, econômica e cultural do Brasil. Há que se considerar que a Aldeia de Carapicuíba é assim chamada há pelo menos duzentos anos, que implica numa raiz identitária que, apesar de carregar dificuldades pela significação difusa, remete às memórias e ao conjunto de sujeitos, famílias e grupos sociais que ali se enraízam e assim a denominam. Considerando isso numa possibilidade crítica de repensar aqueles bens patrimoniais na dimensão de sua população, o que não impede e é favorável de atacar os sentidos de acumulação que sugerem harmonia e distopia, em favor da tragédia de supressão e superposição que acarretou a quase extinção das sociedades indígenas destes territórios, da banalização do caipira, da segregação dos subúrbios acerca das possibilidades de fruição da cidade e do urbano, bem como a precariedade, violência e desumanização da periferia. Com isso, confirma-se com a pesquisa uma tendência histórica de ações que suprimiram parte da autonomia das populações moradoras da Aldeia. Trata-se de um dos polos dialéticos que evidenciam a gravidade, sobretudo do tempo contemporâneo, de perda da dimensão memorial do plano coletivo em favor de um espaço alegórico, vazio e "musealizado", um atrativo cultural do parque correlato, que esporadicamente serve instrumentalmente ao folclore e as manifestações religiosas cujas particulares são cada vez mais universais. Seu potencial de valorização para o mercado, apesar de nunca efetivamente se concretizar, resguarda-se nas oportunidades que desde meados dos anos de 1980 se pronunciam pela instalação de chácaras residenciais e condomínios nas proximidades da Aldeia, em que o parque passa a limitar/barrar a expansão periférica que se pronuncia historicamente ao longo do eixo arterial da avenida Inocêncio Seráfico (de norte a sul) e a catalisar as novas infraestruturas instaladas na área e entorno (que vão do Rodoanel, até a microescala de ampla iluminação e nivelamento com concreto do conjunto patrimonializado).

Por fim, é possível concluir a latência dos processos sociais envoltos na preservação da Aldeia de Carapicuíba desde os remotos períodos de sua gênese à atual metropolização. Configura-se num emblemático caso de permanência frente às modernizações operadas em São Paulo pela industrialização-urbanização-metropolização. Onde o papel de sua população foi fundamental pela resistência e perpetuação das memórias e tradições ligadas as rugosidades patrimoniais (tanto ao espaço material, quanto aos ritos religiosos e festejos profanos), mesmo diante dos conflitos despertados pela institucionalização e conversão monumental de seus bens culturais em patrimônio da memória nacional e dos processos urbanos em curso (inclusive com o esvaziamento da Aldeia), parte das famílias locais e dos núcleos adjacentes (os quais resultam, em parte, das políticas e ações de remoção) mantém 
relações cotidianas no espaço da Aldeia, o que a torna num espaço referencial e vivo para sua comunidade. Nos limites do tempo atual, existe uma preocupação pelo distanciamento e desinteresse na reprodução destes valores, destes modos de viver, destas práticas socioespaciais, o que ao longo dos diálogos e pesquisa se mostrou pelas vozes dos festeiros mais antigos, pelos sujeitos entrevistados, pela observação do esvaziamento das festas tradicionais e as incertezas advindas deste futuro onde se asseveram o desenraizamento, a impessoalidade, a banalização e a violência. Mais do que os limites dos bens culturais patrimonializados, a crise urbana acomete amplos setores da metrópole, o que requer uma práxis transformadora das políticas urbanas e patrimoniais na totalidade dos territórios, que vai das estratégias educacionais, do empoderamento e controle social, às condições equânimes de acessibilidade e direitos a cidade e suas infraestruturas instaladas. Esta talvez seja a única saída possível das prisões de um passado e presente perversos, que Milton Santos (2014) assevera em favor de um futuro "espaço do cidadão", permeado de justiça, o respeito a cultura e possibilidade de busca da liberdade. Eis o que deve cumprir o patrimônio cultural e a metrópole. 


\section{BIBLIOGRAFIA}

ABREU, Mauricio de Almeida. O estudo geográfico da cidade no Brasil: evolução e avaliação. In: CARLOS, Ana Fani A. (org.). Os caminhos da reflexão sobre a cidade e o urbano. São Paulo: Edusp, 1994.

. Sobre a memória das cidades. In: Anais do V Seminário de História da Cidade e do Urbanismo. Campinas: Unicamp (CD-ROM), 1998.

. Pensando a cidade no Brasil do passado. In: CASTRO, Iná Elias de; GOMES, Paulo Cesar da Costa; CORRÊA, Roberto Lobato (Orgs.). Brasil: questões atuais da reorganização do território. Rio de Janeiro: Bertrand Brasil, 1996. p. 145-184.

A apropriação do território no Brasil colonial. In: CASTRO, Iná Elias de; GOMES, Paulo Cesar da Costa; CORREAA, Roberto Lobato (Orgs.). Explorações geográficas: percursos no fim do século. Rio de Janeiro: Bertrand Brasil, 1997. p.197-245.

AB'SABER, Aziz Nacib. Geomorfologia do Sítio Urbano de São Paulo. Ed. Fac-Similar 50 anos. São Paulo: Ed. Ateliê, 2007.

ADAS, Melhem. Geografia da América: aspectos físicos e sociais. São Paulo: Moderna, 1982.

ADORNO, Theodor. Introdução à controvérsia sobre o positivismo na sociologia alemã. In: Textos escolhidos: seleção de Zeljko Luparie (Horkheimer, Adorno, Habermas) e Otília B. Fiori Arantes (Benjamin e textos de Adorno sobre Estética). São Paulo: Editora Abril, 1975.

ALVES, Glória da Anunciação. Paisagens metropolitanas. In: CARLOS, Ana Fani Alessandri; OLIVEIRA, Ariovaldo Umbelino de (orgs.). Geografias de São Paulo: Representação e crise da Metrópole. São Paulo: Contexto, 2015. p. 256-285.

. A requalificação do centro de São Paulo. Estudos Avançados. São Paulo, v.

25, n. 71, abril de 2011. p. 109-118. Disponível em: $<$ http://www.scielo.br/scielo.php?script=sci_arttext\&pid=S0103-

$40142011000100008 \& \operatorname{lng}=\mathrm{en} \& \mathrm{nrm}=\mathrm{iso}>$. Acesso em: out, 2016.

ALVES, Vicente Eudes Lemos. A obra de Humboldt e sua provável influência sobre a antropologia de Franz Boas. In: Geousp - espaço e tempo, São Paulo, No 18, pp. 67 - 79, 2005.

ANDRADE, Manuel Correia de Oliveira. Geografia, sociedade e cultura. Mossoró: Fundação Guimarães Duque, 1983.

ANDRADE, Manoel Correia de. Geografia: ciência da sociedade. Recife: Editora da UFPE, 2008.

ANDRADE, Antonio Luiz Dias. Aldeia de Carapicuíba. In: MORI, Victor Hugo; SOUZA, Marise Campos de; BASTOS, Rossano Lopes; GALLO, Haroldo (orgs.). Patrimônio: atualizando o debate. São Paulo: IPHAN, 2006. 
ANGEL, S.; PARENT, J.; CIVCO, D. L.; BLEI A. M. [2010]. Atlas of Urban Expansion. Cambridge MA: Lincoln Institute of Land Policy. Disponível em: $<$ http://www.lincolninst.edu/subcenters/atlas-urban-expansion/>. Acesso em: set. de 2013.

ANZOLIN, André Soares. Aldeias e aldeamentos no século XVI. In: BiblioAtlas: Biblioteca de Referências do Atlas Digital da América Lusa. Disponível em: $<$ http://hs.unb.br/atlas/Aldeias_e_aldeamentos_no_s\%C3\%A9culo_XVI $>$. Acesso em: mai. de 2016.

ARANHA, Valmir. Mobilidade pendular na metrópole paulista. In: Revista São Paulo em Perspectiva, v.19, n.4, p.96-109, out./dez.2005. Disponível em: < http://www.scielo.br/scielo.php?script=sci_arttext\&pid=S0102-88392005000400006>.

Acesso em mai. de 2016.

ARANTES, Otília. Uma estratégia fatal: a cultura nas novas gestões urbanas. In: ARANTES, Otília; VAINER. Carlos; MARICATO, Ermínia. [2000]. A cidade do pensamento único: desmanchando consensos. $3^{\text {a }}$. Ed. Petrópolis: Vozes, 2002. p. 11-74.

ARANTES NETO, Antonio Augusto. O patrimônio cultural e seus usos nas cidades contemporâneas. In: MORI, Victor Hugo; SOUZA, Marise Campos de; BASTOS, Rossano Lopes; GALLO, Haroldo (orgs.). Patrimônio: atualizando o debate. São Paulo: IPHAN, 2006.

ASCHER, François. Métapolis ou l'avenir des villes. In: Revue de géographie de Lyon Année. Volume 72, Numéro 2, 1997, p. 126.

ASCHER, François [1995]. Metápolis: acerca do futuro da cidade. Tradução de Álvaro Domingues. Oeiras: Celta Editora, 1998.

AZEVEDO, Aroldo de. Subúrbios orientais de São Paulo. Tese para Cátedra Geografia Humana - USP. Apresentada ao Concurso da Cadeira de Geografia Humana da FFLCH da Universidade de São Paulo. São Paulo, 1945.

AZEVEDO, Aroldo de. Embriões de cidades brasileiras. In: Boletim Paulista de Geografia (AGB), São Paulo, n. 25, 1957, p. 31-69.

AZEVEDO, Aroldo de (Org.). A cidade de São Paulo. Estudos de Geografia Urbana. Vol. IV - Subúrbios Paulistanos. São Paulo: AGB e Companhia Editora Nacional, 1958.

AZEVEDO, Aroldo de. Vilas e cidades do Brasil Colonial (Ensaio de geografia urbana retrospectiva). Terra Livre, São Paulo, n.10, jan/jul.1992. p. 23-78.

BACHELARD, Gaston. A formação do espírito científico: contribuição para uma psicanálise do conhecimento. Rio de Janeiro: Contraponto, 1996.

BARRETO, Ilson Juliano. O surgimento de novas regiões metropolitanas no Brasil: uma discussão a respeito do caso de Sorocaba (SP). Espaço e Economia [Online], $1 \mid 2012$. Disponível em: <http://espacoeconomia.revues.org/374DOI: 10.4000/espacoeconomia.374>. Acesso em: mar. 2016. 
BAUMAN, Zygmunt. Confiança e medo na cidade. Rio de Janeiro: Zahar, 2009.

BBC, Por fé e lucro, 'Estado Islâmico' promove onda de destruição de patrimônio histórico no Iraque. Reportagem publicada em 7 de março 2015. In: $<$ http://www.bbc.com/portuguese/noticias/2015/03/150307_destruicao_estado_islamico_iraqu e_rb>. Acesso em: abr. de 2016 .

BEAVERSTOCK, J. V.; SMITH, R. G.; TAYLOR, P. J.; WALKER, D. R. F.; LORIMER, H. Globalization and world cities: some measurement methodologies. In: Applied Geography, 20, 2000, p. 43-63.

BECKER, Elsbeth L. S. História do pensamento geográfico. Santa Maria: UNIFRA, 2006.

BECKER, Howard S. Segredos e truques da pesquisa. Rio de Janeiro: Zahar Editores, 2007.

BENACH, Nuria. Perspectivas culturais para o estudo das cidades. In: CARLOS, Ana Fani Alessandri; CARRERAS, Carles (orgs.). Urbanização e mundialização: estudos sobre a metrópole. São Paulo: Contexto, 2005. p. 70-80.

BENJAMIN, Walter. A obra de arte na era de sua reprodutibilidade técnica. In: Magia e técnica, arte e política: ensaios sobre literatura e história da cultura. Obras escolhidas. Vol. 01. $3^{\mathrm{a}}$. ed. São Paulo: Brasiliense, 1987. p. 165-196.

. Sobre o Conceito da História. In: Magia e Técnica, Arte e Política: ensaios sobre literatura e história da cultura. (Obras Escolhidas, v. 1). Tradução de Paulo S. Rouanet. 3.ed. São Paulo: Brasiliense, 1987. p. 222-234.

. Passagens. Tradução de Irene Aron e Cleonice Paes Barreto Mourão e revisão de Patrícia de Freitas Camargo. Belo Horizonte/São Paulo: Editora UFMG/Imprensa Oficial do Estado de São Paulo, 2006.

BOLLE, Willi. Fisiognomia da metrópole moderna: Representação da historia em Walter Benjamin. São Paulo: EDUSP, 1994.

BONDUKI, Nabil; ROLNIK, Raquel. Periferia da Grande São Paulo: reprodução do espaço como expediente de reprodução da força de trabalho. In: MARICATO, Ermínia (Org.). A produção capitalista da casa (e da cidade) no Brasil industrial. São Paulo: Editora AlfaÔmega, 1979. p. 117-154.

BORJA, Jordi; CASTELLS, Manuel. Local y global: la gestion de las ciudades em la era de información. Barcelona: Taurus Pensamiento, 2002.

BORDA, Orlando Fals. Uma perspectiva para as ciências sociais no terceiro mundo. In: Seleção de Textos da Associação dos Geógrafos Brasileiros (AGB). No 07, pp. 36-46. São Paulo, 1981.

BOURDIEU, Pierre. A miséria do mundo. Petrópolis: Editora Vozes, 1999.

BRUAND, Yves. Arquitetura contemporânea no Brasil. Trad. Ana M. Goldeberger. São Paulo: Perspectiva, 1981. 
BUENO, Beatriz Piccolotto Siqueira. Dilatação dos confins: caminhos, vilas e cidades na formação da Capitania de São Paulo (1532-1822). In: An. Mus. Paul. vol.17 n.2, São Paulo jul./dez. 2009.

BURGOS, Rosalina. Periferias urbanas da metrópole de São Paulo: territórios da base da indústria da reciclagem no urbano periférico. Tese (Doutorado em Geografia Humana). São Paulo: FFLCH/USP, 2008.

BUTLER, R. W. The concept of a tourist area cycle of evolution: implications for management of resources. In: Canadian Geographer, XXIV, 1, 1980.

CAMARGO, Cândido Procópio Ferreira de; CARDOSO, Fernando Henrique; MAZZUCCHELLI, Frederico; MOISÉS, José Álvaro; KOWARICK, Lúcio; ALMEIDA, Maria Herminia Tavares de; SINGER, Paul; BRANT, Vinicius Caldeira. São Paulo 1975: crescimento e pobreza. São Paulo: Edições Loyola/CEBRAP, 1976.

CANCLINI, Nestor Garcia. A globalização imaginada. São Paulo: Iluminuras, 2003.

[1997]. Culturas híbridas: estratégias para entrar e sair da modernidade. Tradução: Heloísa P. Cintrão; Ana R. Lessa. 4a . ed. São Paulo: Edusp, 2006.

A sociedade sem relato: antropologia e estética da iminência. Tradução Maria P. G. Ribeiro. São Paulo: EDUSP, 2012.

CANDIDO, Antonio [1964]. Os parceiros do rio bonito. Estudo sobre o caipira paulista e as transformações dos seus meios de vida. 11. ed. Rio de Janeiro: Ouro sobre Azul, 2010.

CANO, WILSON. Raízes da concentração industrial em São Paulo. Tese (Doutorado em Economia). Campinas: IFCH/UNICAMP, 1975.

CAPEL, Horácio. Filosofía y ciência en la geografía contemporánea. Barcelona: Barcanova, 1981.

CARDOSO, Fernando Henrique. FALETTO, Enzo. Dependência e desenvolvimento na América Latina: Ensaio de interpretação sociológica. $7^{\circ}$ ed. Rio de Janeiro: Editora LTC, 1970.

CARDOSO, Jorge de Jesus. Patrimônio ambiental urbano \& requalificação: contradições no planejamento do núcleo histórico de Santos. Tese (Doutorado em Geografia Humana). São Paulo: FFLCH/USP, 2007.

CARLOS, Ana Fani Alessandri. O espaço urbano: novos escritos sobre a cidade. São Paulo: FFLCH, 2007 .

. Dynamique urbaine et métropolisation, le cas de São Paulo. In: Confins, n. 2, 2008. Disponível em: <http://confins.revues.org/1502>. Acesso em mar. de 2016.

CARLOS, Ana Fani Alessandri; OLIVEIRA, Ariovaldo Umbelino. Geografia das metrópoles. São Paulo: Contexto, 2016. 
CARRERAS, Carles. Da cidade industrial à cidade dos consumidores: reflexões teóricas para debater. In: CARLOS, Ana Fani Alessandri; CARRERAS, Carles (orgs.). Urbanização e mundialização: estudos sobre a metrópole. São Paulo: Contexto, 2005.

CARVALHO, Pompeu Figueiredo. Laudos periciais e pareceres técnicos em parcelamento do solo e construção de habitações. In: MAURO, C. A. de. Laudos periciais em depredações ambientais. Rio Claro: LPM/DPR/IGCE/UNESP, 1997.

. Patrimônio histórico e artístico nas cidades médias paulistas: a construção do lugar. In: YÁZIGI, E.; CARLOS, A. F. A.; CRUZ, R. C. A.(orgs.) Turismo: espaço, paisagem e cultura. $2^{\text {a }}$ Ed. São Paulo: Hucitec, 1999.

Águas nas cidades: reflexões sobre usos e abusos para aprender novos usos. In: BRAGA, R.; CARVALHO, P. F. Recursos hídricos e planejamento urbano e regional. 2. ed. Rio Claro: Laboratório de Planejamento Municipal - DEPLAN /UNESP/IGCE, 2007. p. 09-36.

CASAL, Manuel Aires de. Corografia brasílica ou Relação histórico-geográfica do Reino do Brasil. Coleção Reconquista do Brasil. São Paulo: EDUSP, 1976.

CASTELLS, Manuel; BORJA, Jordi. As cidades como atores políticos. In: Novos Estudos. CEBRAP, n. 45, São Paulo, 1996.

CASTELLS, Manuel [1975]. A questão urbana. Rio de Janeiro: Paz e Terra, 2000.

CASTRO, Bernadete. Patrimônio cultural plural e singular: a dupla face da mesma moeda. In: COSTA, E. B.; BRUSADIN, L. B.; PIRES, M. C. (orgs). Valor patrimonial e turismo: limiar entre história, território e poder. São Paulo: Editora Outras Expressões, 2012. p. 37-46.

CASTRO, Iná Elias de; GOMES, Paulo Cesar da Costa; CORREAA, Roberto Lobato (Coord.). [1997]. Explorações geográficas: percursos no fim do século. Rio de Janeiro: Bertrand Brasil, 2006.

CAVAlCANTI, Agostinho P. Brito; VIADANA, Adler Guilherme. Fundamentos históricos da geografia: contribuições do pensamento filosófico na Grécia antiga. In: GODOY, Paulo R. Teixeira. (org.). História do pensamento geográfico e epistemologia em Geografia [online]. São Paulo: Editora UNESP; Cultura Acadêmica, 2010. p. 11-34.

CERVELLATI, Píer Luigi; SCANNAVINI, Roberto. Por que o centro histórico? Política e metodologia. In: FORTI, Reginaldo (org.). Marxismo e urbanismo capitalista. São Paulo: LECH, 1979. p. 119-118.

CHABOT, G. Las ciudades. Barcelona: Editorial Labor, 1972.

CHAN, Thomas; ROSÁRIO, Louise do. Delta do rio das Pérolas: a história notável do Delta. Macau: MacauLink, 2012. 
CHAUÍ, Marilena de Sousa. Brasil: mito fundador e sociedade autoritária. São Paulo: Fundação Perseu Abramo, 2000.

CHOAY, Françoise. Urbanismo: Utopias e realidades, uma antologia. Tradução: Dafne Nascimento Rodrigues. 6. ed. São Paulo: Perspectiva, 2005.

CHOAY, Françoise. A alegoria do patrimônio. 3 ed. São Paulo: UNESP, 2006.

CHORLEY, Richard J.; HAGGETT, Peter. Modelos integrados em geografia. Tradução: Arnaldo Viriato de Medeiros. São Paulo: EDUSP, 1974.

CHRISTOFOLETTI, Antonio. Geografia: da Antigüidade à Pós-Modernidade. In: Trimestral - Vol.1 no 2 - out/nov/dez 1997. Departamento de Geografia - Univ. Estadual de Maringá. Disponível em: $<$ http://www.miniweb.com.br/Geografia/artigos/geo_mundial/geo_antiguidade.html $>$. Acesso em: jul. de 2014.

CHUVA, Marcia; NOGUEIRA, Gilberto Ramos. (Orgs). Patrimônio cultural: políticas e perspectivas de preservação no Brasil. Rio de Janeiro: Mauad X : FAPERJ, 2012.

Preservação do patrimônio cultural no Brasil: uma perspectiva histórica, ética e política. In: CHUVA, Marcia; NOGUEIRA, Gilberto Ramos. (Orgs). Patrimônio cultural: políticas e perspectivas de preservação no Brasil. Rio de Janeiro: Mauad X : FAPERJ, 2012. p. 67-78.

CIFELLI, Gabrielli. Turismo, patrimônio e novas territorialidades em Ouro Preto - MG. Dissertação (Mestrado em Geografia). Campinas: IGE/Unicamp, 2005.

CLAVAL, Paul. A nova geografia. Coimbra: Livraria Almedina, 1987.

CLAVAL, Paul. O papel da nova geografia cultural na compreensão da geografia humana. In: ROSENDAHL, Zeny; CORREAA, Roberto Lobato. Matrizes da geografia cultural. Rio de Janeiro: EdUERJ, 2001.

CLAVAL, Paul. Geografia Cultural. Trad. Luís Fugazzola Pimenta e Margareth de Castro Afeche Pimenta. 3a . ed. Florianópolis: Ed. da UFSC, 2007.

COELHO, João G. Lucas. Depoimento sobre o tortuoso processo de abertura política. In: Padrós, Enrique Serra; BARBOSA, Vânia M.; LOPEZ, Vanessa A.; FERNANDES, Ananda S. (Orgs.). Ditadura de Segurança Nacional no Rio Grande do Sul (1964-1985): história e memória. v.4. Porto Alegre: Corag, 2009. p. 141-170.

CONSTANTINO, Carlos Adriano Santos. A COHAB-SP e uma nova política habitacional: o período 2001-2004. Dissertação (Mestrado em Arquitetura). São Paulo: FAU/USP, 2007.

CORRÊA, Roberto Lobato. Região e organização espacial. São Paulo: Ática, 1986.

CORRÊA, Roberto Lobato. O espaço urbano. São Paulo: Ática, 1995. 
CORRÊA, Roberto Lobato. Espaço, tempo e cultura. In: CORRÊA, Roberto Lobato. Trajetórias geográficas. $3^{\mathrm{a}}$ edição - Rio de Janeiro: Bertrand Brasil, 2005.

COSGROVE, Denis E. A geografia está em toda parte: cultura e simbolismo nas paisagens humanas. In: CORREA, R. L.; ROSENDHAL, Z. Paisagem, tempo e cultura. Rio de Janeiro: EdUERJ, 2004. p. 92-123.

COSGROVE, Denis E. Geography and vision: seeing, imagining and representing the world. London; New York: I.B. Tauris; New York: In the United States of America and Canada distributed by Palgrave Macmillan, 2008. In: $<$ http://site.ebrary.com/lib/univbrasilia/Doc?id=10267532 ->. Acesso em jun. 2014.

COSTA, Marco Aurélio; TSUKUMO, Isadora Tami Lemos (Orgs.). 40 anos de regiões metropolitanas no Brasil. Brasília: Ipea, 2013.

COSTA, Everaldo Batista. Refuncionalização de patrimônio cultural e a nova racionalidade da organização sócioespacial em núcleos urbanos tombados. In: Estudos Geográficos, Rio Claro, 6(2): 53 -73, 2008.

A dialética da construção destrutiva na consagração do patrimônio mundial: o caso de Diamantina (MG). Dissertação de Mestrado. São Paulo: DG/USP, 2009.

A concretude do fenômeno turismo e as cidades-patrimônio mercadoria: uma abordagem geográfica. Rio de Janeiro: Livre Expressão, 2010.

Totalidade urbana e totalidade-mundo. As cidades coloniais barrocas face à patrimonialização global. Tese (Doutorado em Geografia Humana). São Paulo: FFLCH/USP, 2011.

Cidades da patrimonialização global: simultaneidade totalidade urbana -

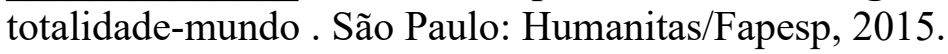

Utopismos patrimoniais pela América Latina, resistências à colonialidade do poder. In: XIV Coloquio Internacional de Geocrítica: Las utopías y la construcción de la sociedad del futuro. Barcelona, 2016. Disponível em: $<$ http://www.ub.edu/geocrit/xiv_everaldocosta.pdf $>$. Acesso em: set. de 2016.

COSTA, Everaldo Batista; SCARLATO, Francisco Capuano. Patrimônio da humanidade: universalismo de um apoderamento territorial soberano. In: COSTA, E. B.; BRUSADIN, L. B.; PIRES, M. C. Valor patrimonial e turismo: limiar entre história, território e poder. Editora Outras Expressões, 2012, p. 103-136.

COSTA, Everaldo Batista da; SUZUKI, Julio Cesar. Materialismo histórico e existência: discurso geográfico e utopias. Revista Espaço e Geografia, vol. 15, nº 1, 2012, p. 115-147.

COSTA, Everaldo Batista da; SUZUKI, Julio Cesar. A ideologia espacial constitutiva do estado nacional brasileiro. In: Anais do XII Colóquio Internacional de Geocrítica Independencias y construcción de estados nacionales: poder, territorialización y socialización, siglos XIX-XX. Bogotá, 2012. 
COSTA, Everaldo Batista da; STEINKE, Valdir Adilson. Cidades históricas do estado de Goiás, Brasil: uma agenda de pesquisa. In: Ateliê Geográfico - Goiânia-GO, v. 7, n. 2, p.164195 , ago/2013.

COSTA, Everaldo Batista da; ALMEIDA, Maria Geralda de; OLIVEIRA, Rafael Fabrício; RÚBIO, Rúbia de Paula. Realização social da natureza pelo turismo na Chapada dos Veadeiros. Confins [Online], 25, 2015. Disponível em: < http://confins.revues.org/10474>. Consultado em: nov. de 2015.

COSTA, Everaldo Batista da; LIMA, Luana Nunes Martins de; OLIVEIRA, Rafael Fabricio; RÚBIO, Rúbia de Paula; PANTOJA, Wallace Rodrigues. O mundo moderno em Hegel, Marx e Nietszche à luz de Henri Lefebvre: crítica espacial. In: Revista Cenário. Brasília, V.3, n.5, pp. 213 - 235. Dez. 2015 .

COSTA, Pedro Henrique Ferreira. O jovem Milton Santos: personagem do protótipo metodológico: revelar [matrizes clássicas originárias] para definir [Vanguarda, Universalidade e viés geográfico]. Tese (Doutorado em Geografia). Rio Claro: IGCE/UNESP, 2013.

COSTA JUNIOR, Miguel. Resumo Histórico de Carapicuíba. In: O Debate (Jornal). Ed. Agosto, n. 30. Carapicuíba, 1986.

- Emancipação político-administrativa de Carapicuíba. In: O Debate (Jornal). Ed. Agosto, n. 30. Carapicuíba, 1987.

março, n. 15, ano II ,1993.

Geografia Sumária de Carapicuíba. In: Nossa Folha (Jornal). 26 de

CURY, Isabelle. Cartas patrimoniais. 3 ed. Rio de Janeiro: IPHAN, 2004.

DAHER, Andrea. A conversão do gentio ou a educação como constância. In: VIDAL, D. G.; HILSDORF, M. L. S. Brasil 500 anos: tópicas em história da educação. São Paulo: EDUSP, 2001.

DAMIANI, Amélia Luisa. Cidades médias e pequenas no processo de globalização. Apontamentos bibliográficos. In: LEMOS, Amália Inés Geraiges; ARROYO, Mónica; SILVEIRA, Maria Laura (Orgs.). América Latina: cidade, campo e turismo. São Paulo: CLACSO, 2006.

DAMIANI, Amélia Luisa. Urbanização crítica e situação geográfica a partir da metrópole de São Paulo. In: CARLOS, Ana Fani Alessandri; OLIVEIRA, Ariovaldo Umbelino de (orgs.). Geografias de São Paulo: Representação e crise da Metrópole. São Paulo: Contexto, 2015. p.19-58.

DANTAS, Ana Claudia de Miranda. Cidades coloniais americanas. In: Arquitextos. Ano 05, jul. $2004 . \quad$ Disponível em: $<$ http://www.vitruvius.com.br/revistas/read/arquitextos/05.050/566>. Acesso em: mai. de 2016.

DAVIDOVICH, Fany. Metrópole e território. Metropolização do espaço do Rio de Janeiro. Cadernos Metrópole. São Paulo, n. 6, 2001, p. 67-77. 
DAVIS, Mike. Planeta favela. São Paulo: Boitempo Editorial, 2006.

DEAN, Warren. A industrialização de São Paulo. São Paulo: DIFEL, 1971.

. A ferro e fogo: a história da devastação da Mata Atlântica brasileira. Trad. Cid K. Moreira São Paulo: Companhia das Letras, 1996.

DEBOR, Guy. A sociedade do espetáculo: comentários sobre a sociedade do espetáculo. Trad. Estela dos Santos Abreu. Rio de Janeiro: Contraponto, 1997.

DEDECCA, Claudio; MONTALI, Lilia; BAENINGER, Rosana. Regiões Metropolitanas e Pólos Econômicos do Estado de São Paulo: desigualdades e indicadores para as Políticas Sociais. In: Estudos Regionais: Região Metropolitana de São Paulo. Campinas: FINEP/NEPP/NEPO/IE/UNICAMP, 2009. Disponível em: < http://www.nepo.unicamp.br/simesp/Site/Estudos/RMSP.pdf $>$. Acesso em: abr. de 2016.

DEFFONTAINES, Pierre. Como se constituiu no Brasil a rede de cidades. In: Boletim Geográfico, São Paulo (14): 141-148, 1944; (15), 1944, p. 229-308

DEMANGEON, Albert. Problemas de geografía humana. Barcelona: Ômega, 1956.

DENIZO, Valentina. Planos de desenvolvimento integrado para a Região Metropolitana de São Paulo (RMSP): uma história sem fim. In: Anais do XVI ENANPUR. Belo Horizonte: ANPUR, 2015.

DI MÉO, Guy. Introdução ao debate sobre a metropolização. Confins. Paris, v. 4, 2008. Disponível em: <http://confins.revues.org/5433>. Acesso em: abr. de 2016.

Processos de patrimonialização e construção de territórios. Geosaberes. Fortaleza, v. 5, número especial (1), dez. 2014. p. 3-23. Disponível em: $<$ http://www.geosaberes.ufc.br/seer/index.php/geosaberes/article/view/292/247>. Acesso em: abr. de 2016.

DINIZ FILHO, Luís Lopes. O "monumento dos bandeirantes": um estudo crítico sobre as relações entre espaço, política e cultura. In: Boletim Paulista de Geografia. São Paulo: AGB, 1992. p. 65-82.

- Certa má herança marxista: elementos para repensar a geografia crítica. In: MENDONÇA, Francisco; KOZEL, Salete. (Orgs.). Elementos de epistemologia da geografia contemporânea. Curitiba: UFPR, 2002.

DOBB, Maurice. A evolução do capitalismo. Rio de Janeiro: Zahar, 1983.

DOMINGUES, Ivan. Epistemologia das ciências sociais. São Paulo: Loyola, 2004.

DOSSÊ, François. História do estruturalismo. Tradução de Álvaro Cabral. Bauru: EDUSC, 2007. 
DUARTE JUNIOR, Romeu. Programa Monumenta: uma experiência em preservação urbana no Brasil. In: Revista CPC, São Paulo, n. 10, p. 49-88, maio/out 2010. Disponível em: < http://www.revistas.usp.br/cpc/article/view/15661>. Acesso em mai. de 2016.

DUNCAN, James S. Paisagem como sistema de criação de signos. In: CORREAA, Roberto Lobato. ROSENDAHL, Zeni. (Orgs.). Paisagens, Textos e Identidade. Rio de janeiro: EdUERJ, 2004.

EAGLETON, Terry. A ideia de cultura. Trad. Sandra C. Branco. São Paulo: EDUNESP, 2005.

ESCALANTE, Eduardo A. A Festa de Santa Cruz da Aldeia de Carapicuíba no Estado de São Paulo. Rio de Janeiro: MEC-SEC: FUNARTE: Instituto Nacional do Folclore: Secretaria de Cultura de São Paulo, 1981.

EURAQUE, Dário A. El golpe de Estado de 28 de junio de 2009, el patrimônio cultural y la identidad nacional en Honduras. São Pedro Sula: Centro Editorial, 2010.

EVASO, Alexander Sergio A refuncionalização do espaço. Revista Experimental Laboratório de Geografia Política e Planejamento Territorial e Ambiental, São Paulo: FFLCH/ DGEO/USP, Humanitas, 1999, p.33-54.

FACCIO, Neide Barrocá. A Aldeia de Carapicuíba e sua resolução de tombamento. In: Revista TÓPOS. V. 4, N², 2010, p. 60-108.

FALCÃO, José Arruda. Política cultural e democracia: a preservação do patrimônio histórico e artístico nacional. In: MICELI, Sergio (org.). Estado e cultura no Brasil. São Paulo: DIFEL, 1984.

FONSECA, Maria Cecília L. O patrimônio em processo: trajetória da política federal de preservação no Brasil. Rio de Janeiro: UFRJ; IPHAN, 1997.

FONSECA, Pedro Cezar Dutra. O processo de substituição de importações. In: REGO, José Márcio; MARQUES, Rosa Maria (Orgs.). Formação Econômica do Brasil. Organizadores: São Paulo: Saraiva, 2003.

FONTANELLA, Bruno J. Barcellos; RICAS, Janete; TURATO, Egberto Ribeiro. Amostragem por saturação em pesquisas qualitativas em saúde: contribuições teóricas. In: Cad. Saúde Pública. 24(1), p. 17-27. Rio de Janeiro, 2008.

FOUCAULT, Michel. Outros espaços. (Conferência no Círculo de Estudos Arquitetônicos, 14 de março de 1967). In: MOTTA, M. (org.). Michel Foucault. Estética, literatura e pintura, música e cinema. Forense Universitária, 1984.

FOUREZ, Gerard. A construção das ciências. Introdução à filosofia e a ética das ciências. São Paulo: EDUNESP, 1995.

FRABETTI, Giancarlo Livman. A metropolização vista do subúrbio: metamorfoses do trabalho e da propriedade privada na trajetória de São Caetano do Sul. Tese (Doutorado em Geografia Humana). FFLCH/USP: São Paulo, 2013. 
FRASER, Márcia Tourinho Dantas; GONDIM, Sônia Maria Guedes. Da fala do outro ao texto negociado: discussões sobre a entrevista na pesquisa qualitativa. In: Paidéia, 2004, 14 (28), 139 -152. Disponível em: < http://www.scielo.br/pdf/csp/v24n1/02.pdf >. Acesso em nov. de 2014.

FREITAG, Barbara. Teorias da cidade. 4. ed. Campinas: Papirus, 2012.

FREMONT, Armand. A região: espaço vivido. Coimbra: Almedina, 1980.

FREYRE, Gilberto [1936]. Sobrados e mucambos; Decadência do patriarcado rural e formação do urbano. 9 ed. Rio de Janeiro: Record, 1996.

FUNDHAM, Fundação Museu do Homem Americano. Pinturas Rupestres. In: $<$ http://www.fumdham.org.br/pinturas.asp>. Acesso em jul. de 2014.

FURTADO, Celso [1959]. Formação econômica do Brasil. 11 ed. São Paulo: Nacional, 1971.

GALVÃO JUNIOR, José Leme. Patrimônio cultural urbano: preservação é desenvolvimento. Dissertação (Mestrado em Arquitetura). Faculdade de Arquitetura e Urbanismo. Universidade de Brasília (UnB). Brasília: UnB, 2001.

GARCIA, Mauro Neves. Estudo da satisfação dos moradores do conjunto habitacional presidente Castelo Branco de Carapicuíba quanto ao conjunto. Dissertação (Mestrado em Administração). São Paulo: FGV, 1982.

GEORGE, Pierre. Geografia ativa. São Paulo: DIFEL, 1975.

Geografia urbana. São Paulo: DIFEL 1983.

GERALDES, Eduardo Simões A. Condições para a constituição de um patrimônio ambiental urbano. Propostas de focos qualitativos no centro de São Paulo. Tese (Doutorado em Geografia Humana). São Paulo: FFLCH/USP, 2006.

GHORRA-GOBIN, Cynthia. À l'heure de la deuxième mondialisation, une ville mondiale est-elle forcément une ville globale? Confins [Online] 5, 2009, posto online em 11 Abril 2009, URL : http://confins.revues.org/5726; Consultado em agosto de 2013.

GIDDENS, Anthony. Política, sociologia e teoria social: encontros com o pensamento social clássico e contemporâneo. Trad. de Cibele S. Rizek. São Paulo: Edunesp, 1998.

GIEDION, Sigfried. Arquitetura e comunidade. Lisboa: Livros do Brasil, 1955.

GODOY, P. R. T.; BRAY, S. C. Considerações sobre o espaço urbano no Brasil. In: GERARDI, Lucia Helena de Oliveira. (Org.). Ambientes - estudos de Geografia. Rio Claro SP: Programa de Pós-Graduação em Geografia, 2003, p. 185-200.

GODOY, Paulo R. Teixeira. (org.). História do pensamento geográfico e epistemologia em Geografia [online]. São Paulo: Editora UNESP; Cultura Acadêmica, 2010. 
GODOY, Paulo R. Teixeira. Uma reflexão sobre a produção do espaço. In: Estudos Geográficos, Rio Claro, 2(1): 29-42, junho - 2004. Disponível em: <www.rc.unesp.br/igce/grad/geografia/revista.htm>. Acesso em mai. 2014.

GOMES, Paulo Cesar da Costa. Geografia e modernidade. Rio de Janeiro: Bertrand Brasil, 1996.

GOMES, Paulo Cesar da Costa. Um lugar para a Geografia: contra o simples, o banal e o doutrinário. In: MENDONÇA, F. de A.; LOWEN-SAHR, M. da S. (Orgs.). Espaço e tempo: complexidade e desafios do pensar e do fazer geográfico. Curitiba: ADEMANAN, 2009.

GONÇALVES, Janice. O SPHAN e seus colaboradores. In: CHUVA, Marcia; NOGUEIRA, Gilberto Ramos. (Orgs). Patrimônio cultural: políticas e perspectivas de preservação no Brasil. Rio de Janeiro: Mauad X : FAPERJ, 2012. p. 145-158.

GONÇALVES, José Reginaldo Santos. A retórica da perda: os discursos do patrimônio cultural no Brasil. 2a . Ed. Rio de Janeiro: UFRJ, 2002.

GONÇALVES, José Reginaldo Santos. Antropologia dos objetos: coleções, museus e patrimônios. Rio e Janeiro: Museu Memória e Cidadania, 2007.

GONÇALVES, Maria Augusta Salin. Questões metodológicas e as ciências naturais e humanas. Síntese Nova Fase, V. 22 N. 70 (1995): p. 367-382. Disponível em: $<$ http://faje.edu.br/periodicos2/index.php/Sintese/article/viewFile/1111/1519>. Acesso em: out. de 2014.

GONÇALVES, Maria Flora (org.). O novo Brasil urbano: impasses, dilemas, perspectivas. Porto Alegre: Mercado Aberto, 1995.

GOUVÊA, Ronaldo Guimarães. A questão metropolitana no Brasil. Rio de Janeiro: Editora FGV, 2005.

GRAMSCI, Antonio. Poder, política e partido. São Paulo: Expressão Popular, 2012.

GRAVARI-BARBAS, Maria. O sangue e o solo. O patrimônio, fator de pertencimento de um território urbano. In: Geosaberes. Fortaleza, v. 5, número especial (1), p. 3 - 23, dez. 2014. Disponível em: $<$ http://www.geosaberes.ufc.br/seer/index.php/geosaberes/article/view/293/248>. Acesso em: abr. de 2016.

GURVITCH, Georges. As estruturas em sociologia. In: BASTIDES, R. Usos e sentidos do termo estrutura. São Paulo: Herder, 1971.

HALL, Stuart. A identidade cultural na pós-modernidade. Trad. Tomaz T. da Silva e Guaracira L. Louro. 11. ed. Rio de Janeiro: DP\&A, 2006.

HARVEY, David [1992]. A condição pós-moderna: uma pesquisa sobre as origens da mudança cultural. 24 ${ }^{\text {a }}$ ed. São Paulo: Loyola, 2013. 
HARVEY, David. A produção capitalista do espaço. Trad. de Carlos Szlak. São Paulo: Annablume, 2005.

. Space as a keyword. In: CASTREE, N.; GREGORY, D. (org.) David Harvey: a critical reader. Malden e Oxford: Blackwell. Tradução livre: Letícia Gianella. Revisão técnica: Rogério Haesbaert e Juliana Nunes, 2006.

[2000]. Espaços de esperança. 6a. ed. Trad. Adail U. Sobral e Maria S. Gonçalves. São Paulo: Loyola, 2013.

O enigma do capital: e as crises do capitalismo. Tradução de João Alexandre Peschanski. São Paulo: Boitempo, 2011.

HELLE, Cécile. Essai de mesure de la rugosité de l'espace: application à l'espace vauclusien. In: Espace géographique, tome 22, nº 4, pp. 346-352, 1993.

HENNE, Helenice Camargo. Sr. Mimi, Dona Nenê e as festas da Aldeia. São Paulo: Amiga, 2015.

HENRIQUE, Wendel. O direito à natureza na cidade: ideologias e práticas na história. Tese (Doutorado em Geografia). Rio Claro: IGCE/UNESP, 2004.

HOBSBAWN, Eric. A era dos impérios (1875-1914). Rio de Janeiro:Paz e Terra,1998.

HOBSBAWN, Eric; RANGER, Terence [1983]. (Orgs.). La invención de la tradición. Barcelona: Crítica Barcelona, 2002.

HORKHEIMER, Max. Teoria tradicional e teoria crítica. In: Textos escolhidos: seleção de Zeljko Luparie (Horkheimer, Adorno, Habermas) e Otília B. Fiori Arantes (Benjamin e textos de Adorno sobre Estética). São Paulo: Editora Abril, 1975.

HUMBOLDT, Alejandro. Cosmos: ensayo de una descripcion fisica del mundo. Madrid: Imprenta de Gaspar y Roige editores, 1874.

IANNI, Octavio. Uma cidade antiga. Coleção Tempo \& Memória. Campinas: Unicamp, 1996.

IPEA, Instituto de Pesquisa Econômica Aplicada. As capitais do sul continuam sendo as campeãs em bem-estar. 2006. Ano 3. ed 22. Disponível em: $<$ http://www.ipea.gov.br/desafios/index.php?option=com_content\&view=article\&id=994:cati $\mathrm{d}=28 \&$ Itemid $=23>$. Acesso em mar. 2016.

JABAREEN, Yosef Rafeq. Sustainable urban forms: their typologies, models, and concepts. Journal of Planning Education and Research. September 26, 2006. p. 38-52.

JEUDY, Henri-Pierre. Espelhos das cidades. Trad. Rejane Janowitzer. Rio de Janeiro: Casa da Palavra, 2005.

KHUN, T. S. A estrutura das revoluções científicas. São Paulo: Perspectiva, 1998. 
KOSIK, Karel [1963]. Dialética do concreto. Rio de Janeiro: Paz e Terra, 1976.

KOWARICK, Lucio. A espoliação urbana. Rio de Janeiro: Paz e Terra, 1979.

KOYRÉ, Alexandre. Galileu e Platão: do mundo mais ou menos ao universo da precisão. Tradução: Maria Teresa Brito Curada. Lisboa: Gradiva, 1986.

KRIPPENDORF, Jost. Sociologia do turismo: para uma nova compreensão do lazer e das viagens. Rio de Janeiro: Civilização Brasileira, 1989.

KUCINSK, Bernardo (et. al. orgs.). Bala perdida: violência policial no Brasil e os desafios para sua superação. São Paulo: Boitempo, 2015.

LACERDA, N. Mercados imobiliários em áreas pobres: singularidades, particularidades e universalidades. GEOgraphia, 14, abr. 2013. Disponível em:

$<$ http://www.uff.br/geographia/ojs/index.php/geographia/article/view/552/346>. Acesso em: 13 set. de 2013.

LACOSTE, Yves. Geografia do subdesenvolvimento. Coleção Terras e Povos. Tradução de T. Santos. São Paulo: DIFEL/EDUSP, 1966.

LARAIA, Roque de Barros. Cultura: um conceito antropológico. 14a ${ }^{\mathrm{a}}$. Ed. Rio de Janeiro: Jorge Zahar, 2001.

LANGENBUCH, Juergen Richard. Estruturação da grande São Paulo: estudo de geografia urbana. Ministério do Planejamento e Coordenação. Publicação 26, série A - Livros. Rio de Janeiro: IBGE, 1971.

- Depoimento. Espaço \& Debates - Revista de Estudos Regionais e Urbanos. NERU. Ano XVII - n. 42. Periferia Revisitada, 2001, pp. 85-91.

LE GOFF, Jacques. História e memória. Tradução Bernardo Leitão... [et al.]. 7.ed. Campinas: Editora da Unicamp, 2013.

LEFÈBVRE, Henri [1969]. Lógica formal/lógica dialética. Rio de Janeiro: Civilização Brasileira, 1975.

1976.

Hegel, Marx, Nietzsche: o el reino de las sombras. Madrid: Siglo XXI,

Sociologia de Marx. Trad. Carlos R. A. Dias. 2. ed. Rio de Janeiro: Forense-Universitária, 1979.

A sociedade burocrática do consumo dirigido (cap. 2). In: A vida cotidiana no mundo moderno. São Paulo: Ática, 1991.

O direito à cidade. Trad. Rubens E. Frias. São Paulo: Centauro Ed., 2001.

[1974]. The Production of Space. Translated by Donald Nicholson- Smith.

Malden: Blackwell Publishing, 1991. 
LEFEBVRE, Henri [1974]. A produção do espaço. Trad. Doralice Barros Pereira e Sérgio Martins. Primeira versão: fev. de 2006. Disponível em: $<$ http://www.mom.arq.ufmg.br/mom/arq_interface/1a_aula/A_producao_do_espaco.pdf $>$. Acesso em: abr. de 2016.

Espaço e política. Belo Horizonte: EDUFMG, 2008.

. Marxismo. Trad. Willian Lagos. Porto Alegre: L\&PM, 2010.

. Revolução urbana. Belo Horizonte: UFMG, 2012.

LEITE, Rogério Proença. Espaço público e política dos lugares: usos do patrimônio cultural na reinvenção contemporânea do Recife Antigo. Tese (Doutorado em Ciências Sociais). Campinas: IFCH/Unicamp, 2001.

LEMOS, Amália Inés Geraiges. A metropolização nos países do terceiro mundo. In: Revista do Departamento de Geografia. No 13, 1999. p. 07-36.

. São Paulo: metrópole financeira. In: CARLOS, Ana Fani Alessandri; OLIVEIRA, Ariovaldo Umbelino de (orgs.). Geografias de São Paulo: Representação e crise da Metrópole. São Paulo: Contexto, 2015. p. 271-313.

LEMOS, Carlos Alberto Cerqueira. O que é patrimônio histórico? São Paulo: Brasiliense, 2006.

LEMOS, Carlos Alberto Cerqueira; MORI, Victor Hugo; ALAMBERT, Clara Correia. Antiga Aldeia de Carapicuíba. In: SOUZA, M. C.; BASTOS, R. L. (Orgs.). Patrimônio 70 Anos. São Paulo: IPHAN, 2008.

LENCIONI, Sandra. Urbanização difusa e a constituição de megarregiões: o caso de São Paulo. In: E-metropolis. Rio de Janeiro n ${ }^{\mathrm{o}} 22$, ano 6, setembro, 2015. p. 6-15.

LIPOVESTSKY, Giulles; SERROY, Jean. A cultura-mundo: resposta a uma sociedade desorientada. São Paulo: Cia das Letras, 2011.

LOWENTHAL, David. Como conhecemos o passado. In: Projeto História. Trabalhos da Memória. Revista do Programa de Pós Graduados em História da PUC/SP. São Paulo, EDUC, n. 17, Nov/1998a, pp. 63-201.

$\overline{\text { Ediciones Akal, } 1998 b .}$

[1985]. El passado es um país extraño. Trad. Pedro P. Monroy. Madrid:

MALHANO, Clara E. S. M. de Barros. Da materialização à legitimação do passado: a monumentalidade como metáfora do Estado 1920-1945. Rio de Janeiro: Faperj/Editora Lucerna, 2002.

MANZINI, Eduardo José. Entrevista semi-estruturada: análise de objetivos e de roteiros. In: A pesquisa qualitativa em debate...anais/ II Seminário Internacional de Pesquisa e 
Estudos Qualitativos. Sociedade de Estudos e Pesquisa Qualitativa. Bauru: Universidade do Sagrado Coração, 2004.

MARICATO, Ermínia (Org.). A produção capitalista da casa (e da cidade) no Brasil industrial. São Paulo: Editora Alfa-Ômega, 1979.

As idéias fora do lugar e o lugar fora das idéias: planejamento urbano no Brasil. In: ARANTES, Otília; VAINER. Carlos; MARICATO, Ermínia. [2000]. A cidade do pensamento único: desmanchando consensos. $3^{\text {a }}$. Ed. Petrópolis: Vozes, 2002.

Para entender a crise urbana. São Paulo: Expressão Popular, 2015.

MARQUES, Eduardo. (Org.). A metrópole de São Paulo no século XXI: espaços, heterogeneidades e desigualdades. São Paulo: EDUNESP/CEM, 2015.

MARQUES, Eduardo. Os espaços sociais da metrópole nos 2000. In: (Org.). A metrópole de São Paulo no século XXI: espaços heterogeneidades e desigualdades. 1ed.São Paulo: Editora Unesp/CEM, 2015, v. 1, p. 173-198.

MARTINS, José de Souza. O cativeiro da terra. 4. ed. São Paulo: Hucitec, 1990.

. Subúrbio. Vida cotidiana e história no subúrbio da cidade São Paulo. São Paulo: Hucitec; Prefeitura de São Caetano do Sul, 1992.

. Depoimento. Espaço \& Debates - Revista de Estudos Regionais e Urbanos. NERU. Ano XVII - n. 42. Periferia Revisitada, 2001, p. 75-84 [Entrevista].

MARX, Murillo. Cidades brasileiras. São Paulo: Melhoramentos/EDUSP, 1980.

Cidades no Brasil: terra de quem? São Paulo: Nobel e EDUSP, 1991.

MASSEY, Doreen Barbara. Pelo espaço: uma nova política da espacialidade. Rio de Janeiro: Bertrand Brasil, 2009.

MELLO, João Manuel Cardoso de. O capitalismo tardio: contribuição a revisão crítica da formação e desenvolvimento da economia brasileira. Tese (Doutorado). Campinas: IFCH/UNICAMP, 1975.

MENA, Fernanda. Um modelo violento e ineficaz de polícia. In: KUCINSK, Bernardo (et. al. orgs). Bala perdida: violência policial no Brasil e os desafios para sua superação. São Paulo: Boitempo, 2015.

MENESES, Ulpiano T. B. de. A cidade como bem cultural - áreas envoltórias e outros dilemas, equívocos e alcance da preservação do patrimônio histórico urbano. In: MORI, Victor Hugo; SOUZA, Marise Campos de; BASTOS, Rossano Lopes; GALLO, Haroldo (orgs.). Patrimônio: atualizando o debate. São Paulo: IPHAN, 2006.

MÉSZÁROS, Istvan. Para além do capital: rumo a uma teoria da transição. Trad. Paulo C. Castanheira, Sergio Lessa. São Paulo: Boitempo, 2011. 
MEYER, Regina P.; GROSTEIN, Marta D.; BIDERMAN, Ciro. São Paulo Metrópole. São Paulo: Edusp e Imprensa Oficial, 2013.

MILLIET, Sergio. Roteiro do café e outros ensaios. 4. ed. São Paulo: Hucitec, 1982.

MOGIN, Olivier. A condição urbana: a cidade na era da globalização. Tradução Letícia M. de Andrade. São Paulo: Estação Liberdade, 2009.

MONBEIG, Pierre. Pioneiros e fazendeiros de São Paulo. São Paulo: Hucitec, 1998.

MORAES, Antonio Carlos Robert. A gênese da geografia moderna. São Paulo: Hucitec; Edusp, 1986.

MORAES, Antonio Carlos Robert. Ideologias geográficas: espaço, cultura e política no Brasil. São Paulo: Hucitec, 1988.

MORAES, Antonio Carlos Robert. Território e história no Brasil. 2. ed. São Paulo: Annablume, 2005.

MORAES, Antonio Carlos Robert. Notas metodológicas sobre metropolização e a metrópole paulistana. In: CARLOS, Ana Fani; OLIVEIRA, Ariovaldo Umbelino. Geografia das metrópoles. São Paulo: Contexto, 2016.

MORAES, Rubens Borba de. Contribuições para a história do povoamento em São Paulo até fins do século XVIII. In: Terra Livre, n. 10. São Paulo: Associação dos Geógrafos Brasileiros, 1992, p. 11-22.

MOREAU, Filipe Eduardo. Os índios na carta de Nóbrega e Anchieta. São Paulo: Annablume, 2003.

MOREIRA, Ruy. Sociedade e espaço no Brasil (as fases da formação espacial brasileira: hegemonias e conflito). Boletim Paulista de Geografia (AGB). São Paulo, n. 8, set. 2005. p. 7-31.

MORIN, Edgar. O método. vol.1. A natureza da natureza. Europa-América, 1991.

Ciência com consciência. Rio de Janeiro: Bertrand Brasil, 1999.

MUMFORD, Lewis. A cidade na história: suas origens, transformações e perspectivas. Tradução Neil R. da Silva. São Paulo: Martins Fontes, 2008.

NASCIMENTO, Flávia Brito; SCIFONI, Simoni. A paisagem cultural como novo paradigma para a proteção: a experiência do Vale do Ribeira-SP. In: Revista CPC, São Paulo, n. 10, maio/out 2010. p. 29-48.

NIGRO, Cínthia. Territórios do patrimônio: tombamentos e mobilizações sociais. In: CARLOS, Ana Fani Alessandri; LEMOS, Amália Inês Geraiges (orgs.). Dilemas urbanos: novas abordagens sobre a cidade. 2. ed. São Paulo: Contexto, 2005. p. 166-177. 
NIGRO, Cínthia. As dimensões culturais e simbólicas nos estudos geográficos: bases e especificidades da relação entre patrimônio cultural e geografia. In: PAES, M. T.; OLIVEIRA, M. R. S. Orgs. Geografia, turismo e patrimônio cultural. São Paulo: Annablume, 2010. p. 55-80.

OJIMA, Ricardo; SILVA, Robson B.; PEREIRA, Rafael H. Moraes. A mobilidade pendular na definição das cidades-dormitório: caracterização sociodemográfica e novas territorialidades no contexto da urbanização brasileira. In: Anais do V Encontro Nacional sobre Migrações. Campinas: ABEP, 2007.

OLIVEIRA, Antônio Tadeu Ribeiro; ERVATTI, Leila Regina; O’NEILL, Maria M. V. Caetano. O panorama dos deslocamentos populacionais no Brasil: PNADs e Censos Demográficos. In: OLIVEIRA, Luiz A. Pinto; OLIVEIRA. Reflexões sobre os Deslocamentos Populacionais no Brasil. Rio de Janeiro: IBGE, 2011.

OLIVEIRA, Francisco de. Economia brasileira: crítica à razão dualista. 4. ed. Petrópolis: Vozes, 1981.

OLIVEIRA, Rafael F.; SILVA, Paulo D. D. A reestruturação do espaço geográfico de Venda Nova do Imigrante - ES pelo turismo: ênfase sobre as atividades realizadas no espaço rural. In: Anais do XII Encontro de Geógrafos da América Latina (EGAL). Montevideo, 2009.

OLIVEIRA, Rafael Fabricio. Patrimônio histórico-cultural: transformações e usos no centro histórico de Itu-SP. Dissertação (Mestrado em Geografia). Rio Claro: IGCE/UNESP, 2012.

$\begin{array}{lllllll}\text { Revista Espaço \& Geografia, Vol.16, } & \mathrm{N}^{\mathrm{o}} 2, \quad \text { p. } & 751: 783, & 2013 .\end{array}$

ONU, Organização das Nações Unidas. Mais de 70\% da população mundial viverá em cidades até 2050. Disponível em: <http://www.onu.org.br/onu-mais-de-70-da-populacaomundial-vivera-em-cidades-ate-2050/>. Acesso em jul. de 2014.

ONU, Organização das Nações Unidas. Rio + 20: o futuro que queremos (fatos sobre as cidades). Edição de junho 2012 - Disponível em: <http://www.onu.org.br/rio20/cidades.pdf $>$. Acesso em: jul. de 2014.

ORTIZ, Renato. Cultura brasileira e identidade nacional. 5. ed. São Paulo: Brasiliense, 1994.

OTERO, Estevam Vanale. As possibilidades e os limites da reabilitação de conjuntos habitacionais em São Paulo. Dissertação (Mestrado em Arquitetura e Urbanismo). São Paulo: FAU/USP, 2009.

PAES-LUCHIARI, Maria Tereza Duarte. A (re)significação da paisagem no período contemporâneo. In: ROSENDAHL, Z.; CORREAA, R. L. (org.). Paisagem, imaginário e espaço. Rio de Janeiro: EdUERJ, 2001a, p. 9-28.

. Patrimônio cultural: uso público e privatização do espaço urbano. Geografia, Rio Claro, v. 31, n. 1, 2001, p. 29-60. 
A reinvenção do patrimônio arquitetônico no consumo das cidades. GEOUSP - Espaço e Tempo, São Paulo, n. 17, 2005, p. 95-105.

PAES-LUCHIARI, Maria Tereza Duarte. Centros Históricos - Mercantilização e Territorialidades do Patrimônio Cultural Urbano. GEOgraphia, Rio de Janeiro, ano 7, n. 14, 2006, p. 43-58.

PAES, Maria Tereza Duarte. Patrimônio cultural, turismo e identidades territoriais: um olhar geográfico. In: BARTHOLO, R.; SANSOLO, D. G.; BURSZTYN, Y. (org.). Turismo de base comunitária: diversidade de olhares e experiências brasileiras. Rio de Janeiro: Letra e imagem, 2009. p. 162-176.

. Introdução e apresentação. In: PAES, M. T. D.; OLIVEIRA, M. R. da S.

(orgs). Geografia, turismo e patrimônio cultural. São Paulo: Annablume, 2010.

PANSSARINI, Ivan; LOMBARDO, Magda; SILVA, Paulo D.; OLIVEIRA, Rafael F. Áreas verdes urbanas: um contraste social. In: Anais do IV Seminário Latino Americano de Geografia Física. Maringá: UEM, 2006.

PASSOS, Aruanã Antonio. Racismo de Estado: Michel Foucault e Hannah Arendt em perspectiva. In: Revista Húmus, no 9, Set/Out/Nov/Dez 2013, p. 43-58.

PAVIANI, Aldo. Brasília: moradia e exclusão. Brasília: Editora Universidade de Brasília, 1996.

Brasília, a metrópole em crise: ensaios sobre urbanização. 2. ed. Brasília: Editora Universidade de Brasília, 2010a.

Brasília, ideologia e realidade: espaço urbano em questão. 2. ed. Brasília: Brasília: Editora Universidade de Brasília, 2010b.

PAÜL I AGUSTÍ, Daniel. Las políticas culturales y sus repercusiones en la imagen de la ciudad. Scripta Nova. Revista Electrónica de Geografía y Ciencias Sociales, Barcelona: Universidad de Barcelona, 10 de marzo de 2013, vol. XVII, $\mathrm{n}^{\mathrm{o}} 432$. $<$ http://www.ub.es/geocrit/sn/sn-432.htm>. Acesso em: ago. de 2013.

PEET, Richard. Chapter 1 Introduction: geography, philosophy, and social theory. In: Modern geographical thougth. Oxford, UK e Malden, MA: Blackwell, 1999.

PELLEGRINI, Américo. Aldeia de Carapicuíba: folclore e mudanças. Dissertação (Mestrado em Artes). Escola de Artes - ECA/USP. São Paulo: USP, 1979.

PENEAU, Jean-Pierre. Des densités aux rugosités. Les modalités instrumentales d'une transposition. In: Cybergeo: European Journal of Geography, Informes temáticos, Les Bonnes Feuilles du PIRVILLES, 12 de abril 1996. Disponível em: $<$ http://cybergeo.revues.org/301>. Consultado em abr. de 2016.

PEREIRA, Paulo C. Xavier. Aldeamento Colonial e Aldeia Global: Uma Discussão Sobre Espaço e Poder em São Paulo (BR). In: XIII Coloquio Internacional de Geocrítica: El 
control del espacio y los espacios de control Barcelona, 5-10 de mayo de 2014. Disponível em: <http://www.ub.edu/geocrit/coloquio2014/Paulo\%20Cesar\%20Xavier\%20Pereira.pdf $>$. Acesso em: jan. 2016.

PETRONE, Maria T. S. A lavoura canavieira em São Paulo: Expansão e declínio (1765 1851). São Paulo: Difel, 1968.

PETRONE, Pasquale. A cidade de São Paulo no século XX. Revista de História. São Paulo, 1955, v. 10, números 21-22, p. 136-139.

. Aldeamentos paulistas. São Paulo: EDUSP, 1995.

. Palestra. In: Boletim Paulista de Geografia, n. 75. São Paulo: Associação dos Geógrafos Brasileiros, 1998, p. 44-63.

PIMENTEL, Alexandre Simões. Licença para contaminar: obra da calha do Tietê, autolicenciamento ambiental e a contaminação da Lagoa de Carapicuíba. São Paulo: ed. do autor, 2006.

A formação da periferia urbana metropolitana e a democracia socioespacial: a proposta de uso de Indicadores de Qualidade de vida (IQV) no Plano Diretor Participativo municipal de Carapicuíba (SP). Dissertação (Mestrado em Geografia). Campinas: IGE/UNICAMP, 2014.

PRADO JUNIOR, Caio [1942]. Formação do Brasil contemporâneo. Colônia. 11. ed. São Paulo: Brasiliense, 1971.

[1945]. História econômica do Brasil. 15. ed. São Paulo: Brasiliense, 1972.

QUAINI, Massimo. Marxismo e geografia. Rio de janeiro: Paz e Terra, 1979.

. A construção da geografia humana. Rio de Janeiro: Paz e Terra, 1983.

REGO, José Márcio; MARQUES, Rosa Maria. Formação Econômica do Brasil. Organizadores: São Paulo: Saraiva, 2003.

REIS FILHO, Nestor Goulart. Evolução urbana no Brasil. São Paulo: Livraria Pioneira Editora, 1968.

Guia de bens tombados: São Paulo. Rio de Janeiro: Expansã, 1982.

RIBEIRO, Ana Clara Torres. Apresentação. In: Cidades médias: produção do espaço urbano regional. SPOSITO, Eliseu S.; SPOSITO, Maria E. B. (orgs.). $1^{\circ}$ ed. - São Paulo: Expressão Popular, 2006.

RIBEIRO, Darcy [1995]. O povo brasileiro: a formação e o sentido do Brasil. São Paulo: Companhia das Letras, 2006.

RIBEIRO, Luiz César de Queiroz; MORELL, Maria Graciela Gonzáles; SABINO, Wilson. Os Estados e as Regiões Metropolitanas constitutivas do Observatório das Metrópoles 
no Censo 2010. Rio de Janeiro: Observatório das Metrópoles, 2012. Disponível em: $<\mathrm{http}$ //www.observatoriodasmetropoles.net/download/Os_Estados_e_as_RMs_no_Censo_20 10.pdf $>$. Acesso em fev. 2016.

RIBEIRO, Rafael W. Paisagem Cultural e Patrimônio. Rio de Janeiro: IPHAN, 2007.

RIEGL, Alois. O culto moderno dos monumentos: a sua essência e sua origem. Trad. Werner R. Davidsohn, Anar Falbel. São Paulo: Perspectiva, 2014.

RODRIGUES, Aryanne Audrey. Segregação residencial na Vila Cauhy: uma rugosidade espacial? Dissertação (Mestrado em Geografia). Universidade de Brasília, Brasília, 2015.

ROGERS, Richard; GUMUCHDJIAN, Philip. Cidades para um pequeno planeta. Lisboa: GG, 2001.

ROSA, Thaís Troncon. Favelas, Periferias: uma reflexão sobre conceitos e dicotomias. $\mathbf{3 3}^{\circ}$ Encontro Anual da Anpocs. Caxambu: APOCS, 2009. Disponível em: $<\mathrm{http}$ ://portal.anpocs.org/portal/index.php?option=com_docman\&task=doc_view\&gid=1767 \&Itemid=229>. Acesso em fev. 2016.

ROSEN, Gillad; WALKS. Rising cities: Condominium development and the private transformation of the metropolis. Geoforum Journal: 49, p. 160-172, 2013. Disponível em: $<$ http://dx.doi.org/10.1016/j.geoforum.2013.06.010>. Acesso em: ago. de 2013.

ROUSSEAU, M. Bringing politics back in: la gentrification comme politique de développement urbain? Autour des villes perdantes. Revue Espace et sociétés (la gentrification urbaine), 132-133, $\mathrm{n}^{\mathrm{o}} 1-2$, p. 75-90, 2008.

RUBINO, Silvana. O mapa do Brasil passado. In: Revista do Patrimônio Histórico e Artístico Nacional. n. 24, 1996. p. 97-105.

SABINO, Anderson; SIMÕES, Robson. Geografia e arqueologia: uma visão do conceito de rugosidades de Milton Santos. In: Revista de Arqueologia Pública, n.8, Dezembro 2013. Campinas: LAP/NEPAM/UNICAMP. Disponível em: $<$ http://www.nepam.unicamp.br/arqueologiapublica/artigos/artigo_graduacao_8.pdf $>$. Acesso em dez. 2014.

SAHLINS, Marshall David. Cultura e razão prática. Rio de Janeiro: Zahar, 2003.

SÁNCHES, Fernanda. A reinvenção das cidades para um mercado mundial. Chapecó: Argos, 2003.

SANT'ANNA, Márcia. A cidade-atração: patrimônio e valorização de áreas centrais no Brasil dos anos 90. In: SANTOS, Afonso Carlos Marques; KESSEL, Carlos; GUIMARAENS, Ceça. (org.). Livro do Seminário Internacional Museus e Cidades, vol. 1. Rio de Janeiro: Museu Histórico Nacional, 2003.

Da cidade-monumento à cidade-documento. A trajetória da norma de preservação de áreas urbanas no Brasil (1937-1990). Salvador: Oiti Editora, 2014. 
SAIA, Luís. Aldeia de Carapicuíba. São Paulo: IPHAN, 1937.

. Morada paulista. São Paulo: Perspectiva, 2012.

SAINT-HILAIRE, August de. Viagem à Província de São Paulo. Trad. Rubens B. de Morais. São Paulo: Livraria Martins Editora, 1972.

SANTOS, Boaventura de Souza. Um discurso sobre as ciências. Edições Afrontamento: Porto, 2001.

Crítica da razão indolente: contra o desperdício da experiência. v. 1: Para um novo senso comum: a ciência, o direito e a política na transição paradigmática. $5^{\mathrm{a}}$. ed. - São Paulo: Cortez, 2005.

SANTOS, Milton. Contribuição ao estudo dos centros de cidades: o exemplo da cidade de Salvador. In: Boletim Paulista de Geografia, pp. 17-30. São Paulo: AGB, 1959.

A totalidade do diabo: como as formas geográficas difundem o capital e mudam as estruturas sociais. Contexto Hucitec, p. 31-44, 1977.

- Espaço dividido: os dois circuitos da economia urbana dos países subdesenvolvidos. Rio de janeiro: F Alves, 1979.

. A urbanização desigual: a especificidade do fenômeno urbano em países subdesenvolvidos. Tradução Antonia D. Erdens e Maria A. da Silva. Petrópolis: Vozes, 1980.

1982.

Ensaios sobre a urbanização latino-americana. São Paulo: Hucitec,

Espaço e método. São Paulo: Nobel, 1985.

Por uma outra globalização: do pensamento único à consciência universal. 6.ed. Rio de Janeiro: Record, 2001.

. [1978]. O trabalho do geógrafo no terceiro mundo. 5 ed. Trad. Sandra Lencioni. São Paulo: EDUSP, 2013a.

[1993]. A urbanização brasileira. 5 ed. São Paulo: EDUSP, 2013b.

[2005]. Da totalidade ao lugar. São Paulo: EDUSP, 2012a.

[1994]. Por uma economia política da cidade: o caso de São Paulo. 2. ed. São Paulo: EDUSP, 2012b.

[1978]. Por uma geografia nova: da crítica da geografía a uma geografía crítica. 6. ed. São Paulo: EDUSP, 2012c.

[1996]. A natureza do espaço: técnica e tempo. Razão e emoção. 4. ed. São Paulo: Editora da Universidade de São Paulo, 2012d. 
SANTOS, Milton; SILVEIRA, Maria Laura. O Brasil: território e sociedade no início do século XXI. Record: Rio de Janeiro, 2001.

SANTOS, Milton; SILVEIRA, Maria Laura. Urbanização: cidades médias e grandes. . O Brasil: território e sociedade no início do século XXI. Record: Rio de Janeiro, 2001.

SANTOS, Regina Célia Bega. As condições de existência de parcelas da população trabalhadora: a questão da habitação. In: Boletim Paulista de Geografia. No 64, pp. 59-74. AGB: São Paulo, 1986.

SARMENTO, Alexandre Dellamura. Etapas do desenvolvimento econômico no Brasil um exercício Rostowiano. Dissertação (Mestrado). Faculdade de Filosofia, Letras e Ciências Humanas. Universidade de São Paulo. São Paulo: Universidade de São Paulo, 2008.

SASAKI, Masayuki. Urban regeneration through cultural creativity and social inclusion: rethinking creative city theory through a japanese case study. Cities: 27 (2010) S3-S9. Disponível em: <http://www.sciencedirect.com/science/article/pii/S0264275110000569\#>. Acesso em ago. de 2013.

SASSEN, Saskia. As cidades na economia mundial. São Paulo: Nobel, 1998.

SASSEN, Saskia; BOOST, Frank. A cidade: local estratégico para a indústria global do entretenimento. Revista Espaço e Debates (Estudos Urbanos e Regionais da FAU-USP), ano XII, 2001, no 41, p. 66-73.

SCARLATO, Francisco Capuano. População e urbanização brasileira. In: ROSS, Jurandyr L. Sanches. (org.). Geografia do Brasil. 6. ed. São Paulo: Edusp, 2014.

Busca do centro - o reencontro com a cidade. In: CARLOS, Ana Fani Alessandri; OLIVEIRA, Ariovaldo Umbelino de (orgs.). Geografias de São Paulo: Representação e crise da Metrópole. São Paulo: Contexto, 2015. p. 247-270.

SCIFONI, Simone. A Construção do Patrimônio Natural. 2006. Tese (Doutorado em Geografia Humana). São Paulo: FFLCH/USP, 2006.

2013. p. 515-528.

. Patrimônio cultural e lutas sociais. In: Espaço \& Geografia, Vol.16, №. 2,

SCOTT, Allan J. Capitalismo e Urbanização em uma Nova Chave. In: Geouerj. v. 2, n. 21, $2010 . \quad$ Disponível em: <http://www.epublicacoes.uerj.br/index.php/geouerj/article/view/1475/1235>. Acesso em: out. 2016.

SEABRA, Manoel F. Gonçalves. As cooperativas agrícolas mistas do estado de São Paulo. Tese (Doutorado em Geografia Humana). São Paulo: FFLCH/USP, 1973.

SEABRA, Odete C. de Lima. Os meandros dos rios nos meandros do poder: Tietê e Pinheiros - valorização dos rios e das várzeas na cidade de São Paulo. Tese (Doutorado em Geografia Humana). São Paulo: FFLCH/USP, 1987. 
. São Paulo: a cidade, os bairros e a periferia. In: CARLOS, Ana Fani Alessandri; OLIVEIRA, Ariovaldo Umbelino de (orgs.). Geografias de São Paulo: Representação e crise da Metrópole. São Paulo: Contexto, 2015. p. 271-313.

SEEMANN, Jorn. Em busca do lugar de Franz Boas na geografia cultural. In: Revista Espaço e Cultura. UERJ, nº. 19-20, p. 7-21, jan./dez. de 2005.

SELINGARDI-SAMPAIO, Silvia. Indústria e território em São Paulo: a estruturação do multicomplexo territorial industrial paulista (1950-2005). São Paulo: Alinea, 2009.

SEVCENKO, Nicolau. A questão cultural no embate de diferentes planos: metrópole, região, nação, mundo. In: GONÇALVES, Maria Flora (org.). O novo Brasil urbano: impasses, dilemas, perspectivas. Porto Alegre: Mercado Aberto, 1995.

SILVEIRA, Maria Laura. São Paulo: os dinamismos da pobreza. In: CARLOS, Ana Fani Alessandri; OLIVEIRA, Ariovaldo Umbelino de (orgs.). Geografias de São Paulo: Representação e crise da Metrópole. São Paulo: Contexto, 2015. p. 59-72.

SIMMEL, G. A metrópole e a vida do espírito. In: FORTUNA, C. (org.). Cidade, cultura e globalização: ensaios de sociologia. São Paulo: Celta Editora, 1997.

SINGER, Paul. Desenvolvimento econômico e evolução urbana: análise da evolução econômica de São Paulo. São Paulo: Editora Nacional e EDUSP, 1968.

$\overline{\text { Braziliense, } 1978 .}$

[1973]. Economia política da urbanização. 5. ed. São Paulo: Editora

SMITH, Neil. Uneven development. Oxford: Basil Blackwell, 1984a.

. A produção da natureza. Trad. Beatriz M. Pontes, Liliana B. R. Garcia e Lucia H. O. Gerardi. Geografia, Rio Claro, v. 09, n. 17-18, outubro, 1984b, p. 01-36.

A gentrificação generalizada: de uma anomalia local à regeneração urbana como estratégia urbana global. In: BIDOU-ZACHARIASEN, C. De volta à cidade: dos processos de gentrificação às políticas de revitalização dos centros urbanos. São Paulo: Annablume, 2006, p. 59-85.

SODRÉ, Nelson Werneck. [1977]. Introdução à geografia: geografia e ideologia. 5. ed. Petrópolis, RJ: Vozes, 1986.

SOJA, Edward W. Geografias pós-modernas: a reafirmação do espaço na teoria social crítica. Rio de Janeiro: Jorge Zahar, 1993.

SOLÍS TRAPERO, Eloy; UREÑA FRANCÉS, José María; CORROCHANO, Borja RuizApilánez. Transformación del sistema urbano-territorial en la región central de la España peninsular: la emergencia de la región metropolitana policéntrica madrileña. Scripta Nova Revista Electrónica de Geografía y Ciencias Sociales. Barcelona: Universidad de Barcelona, vol. XVI, $\mathrm{n}^{\mathrm{o}}$ 420. Disponível em: <http://www.ub.es/geocrit/sn/sn-420.htm>. Acesso em ago. de 2013. 
SORRE, Maximilien. Rencontres de la geographie et de la sociologie. Paris: Librairie Marcel Rivière et Cie, 1957.

SOUZA, Marcelo Lopes. Os conceitos fundamentais da pesquisa sócio-espacial. Rio de Janeiro: Bertrand Brasil, 2013.

SOUZA, Maria Adélia Aparecida. Estudos sobre a cidade no espaço regional e nacional: teoria e método. In: CARLOS, Ana Fani A. (org.). Os caminhos da reflexão sobre a cidade e o urbano. São Paulo: Edusp, 1994.

- Meio ambiente e desenvolvimento sustentável. As metáforas do capitalismo. Cronos, Natal-RN, v. 10, n. 2, p. 101-117, jul./dez. 2009.

. Território e lugar na metrópole - revisitando São Paulo. In: CARLOS, Ana Fani Alessandri; OLIVEIRA, Ariovaldo Umbelino de (orgs.). Geografias de São Paulo: Representação e crise da Metrópole. São Paulo: Contexto, 2015. p. 21-50.

SOUZA, Marise C.; BASTOS, Rossano L. (Orgs.). Patrimônio 70 Anos. São Paulo: IPHAN, 2008.

SPOSITO, Eliseu Savério. Geografia e filosofia: contribuição para o ensino do pensamento geográfico. São Paulo, SP: Ed. Unesp, 2004.

STENGERS, Isabelle. A invenção das ciências modernas. Tradução: Max Altman. São Paulo: Editora 34, 2002.

SUZUKI, Júlio César. Metamorfoses da expansão urbana na gênese da moderna cidade de São Paulo. In: CARLOS, Ana Fani Alessandri; OLIVEIRA, Ariovaldo Umbelino de (Orgs.). Geografias de São Paulo: representação e crise da metrópole. São Paulo: Contexto, 2015. p.131-156.

SUZUKI, Júlio César; COSTA, Everaldo B. Costa. Aglomerações urbanas brasileiras dos séculos XIX e XX: significados na produção do território. In: Anais do XII Colóquio Internacional de Geocrítica - Independencias y construcción de estados nacionales: poder, territorialización y socialización, siglos XIX-XX. Bogotá, 2012.

TANAKA, Giselle Megumi Martino. Periferia: conceito, práticas e discursos; práticas sociais e processos urbanos na metrópole de São Paulo. Dissertação (Mestrado). Faculdade de Arquitetura e Urbanismo. Universidade de São Paulo. São Paulo: FAU/USP, 2006.

TAVARES, Matheus Avelino; SILVA, Aldo Dantas da. Introdução ao pensamento de Milton Santos: reflexões sobre o "trabalho do geógrafo...". In: GEOUSP - Espaço e Tempo, São Paulo, n. 30, 2011. p. $139-148$.

THATAM, George. A Geografia no século XX. In: Boletim Geográfico. Ano XVIII, julhoagosto/1960, n. ${ }^{\circ} 157$. Transcrição original de Geography in the twentich Century - Edição de Grissith Taylor R. J. Harrison Church. Rio de Janeiro: IBGE, 1960.

TOLEDO, Benedito L. São Paulo: três cidades em um século. São Paulo: Duas Cidades, 1981. 
TRINDADE JUNIOR, Saint-Clair Cordeiro. Estratégias de desenvolvimento e discurso do 'declínio' em política de requalificação urbana no Brasil e na Europa. Cidades Revista Científica/Grupo de Estudos Urbanos. Vol. 7, n.11. p. 193-218, 2010.

. Estrutura, processo, função e forma: aplicabilidade à análise do espaço intraurbano. In: Ana Fani Alessandri Carlos. (Org.). Ensaios de geografia contemporânea: Milton Santos, obra revisitada. São Paulo: Hucitec, 1996, v. 1, p. 133-140.

VASQUES, Amanda. R.; MENDES, Auro. A. Refuncionalização de brownfields. In: GERARDI, Lucia. H. de O.; CARVALHO, Pompeu F. de. Geografia: ações e reflexões. Rio Claro: AGETEO, 2006.

VELHO, Otávio Guilherme (Org.). O fenômeno urbano. Rio de Janeiro: Zahar, 1967.

VITTE, Antonio Carlos; SILVEIRA, Roberison Wittgeinstein Dias. Natureza em Alexander von Humboldt: entre a ontologia e o empirismo. In: Mercator - volume 9, número 20, 2010: set./dez. p. 179 a 195

VIVANT, Elsa. L'instrumentalisation de la culture dans les politiques urbaines: un modele d'action transposable? Revue Espace et Sociétés (Villes et 'best practices'), 131, no 4, 2007, p. 49-66.

REIS FILHO, Nestor Goulart. Evolução urbana do Brasil (1500/1729). São Paulo: Edusp Livraria Pioneira Editora, 1968.

REIS FILHO, Nestor Goulart. Guia dos bens tombados: São Paulo. Rio de Janeiro: Exped, 1982.

RIBEIRO, Darcy. O povo brasileiro. A formação e o sentido do Brasil. $1^{\mathrm{a}}$. ed. $16^{\mathrm{a}}$. reimpressão. São Paulo: Companhia das Letras, 2006.

ROSEN, Gillad; WALKS, Alan. Rising cities: Condominium development and the private transformation of the metropolis. Geoforum Journal: 49 (2013) 160-172. Disponível em: $<$ http://dx.doi.org/10.1016/j.geoforum.2013.06.010>. Acesso em out. de 2013.

TENÓRIO, Pedro Aparecido. Carapicuíba. Passado e presente: 1580-2003. Carapicuíba: Secretaria Municipal da Educação, 2003.

WISSINK, Bart. Enclave urbanism in Mumbai: An Actor-Network-Theory analysis of urban (dis)connection. In: Geoforum Journal. 47 (2013) 1-11. Disponível em: $<$ http://www.sciencedirect.com/science/article/pii/S0016718513000444\#>. Acesso em ago. de 2013.

YÁZIGI, E.; CARLOS, A. F. A.; CRUZ, R. C. A.(orgs.) Turismo: espaço, paisagem e cultura. $2^{\text {a }}$ Ed. São Paulo: Hucitec, 1999.

YÁZIGI, Eduardo. Patrimônio ambiental urbano: refazendo um conceito para o planejamento urbano. In: CARLOS, Ana Fani Alessandri; LEMOS, Amália Inês Geraiges (orgs.). Dilemas urbanos: novas abordagens sobre a cidade. 2a . Ed. - São Paulo: Contexto, 2005. 
ZUKIN, Sharon. Paisagens urbanas pós-modernas: mapeando culturas e poder. In: Revista do Patrimônio Histórico e Artístico Nacional. N 24. IPHAN, 2006. p. 204- 219.

\section{FONTES DOCUMENTAIS NORMATIVAS (METROPOLIZAĊ̃̃):}

- ANUÁRIO ESTATÍSTICO DA SEGURANÇA PÚBLICA 2012. Secretaria de Segurança Pública do Estado do Amazonas - SSP/AM; Comissão de Análise da Criminalidade. n.1(jan./dez. 2012). Manaus: Editora UEA, 2013.

- EMPLASA, Empresa Metropolitana de Planejamento da Grande São Paulo S.A. Planos Diretores de Desenvolvimento Integrado GSP.06 - Carapicuíba: objetivos, diretrizes e programas do PDDI. Vol. I e II. São Paulo: SNM-Emplasa, 1981.

- EMPLASA, Empresa Metropolitana de Planejamento da Grande São Paulo. Lei de Uso e Ocupação da GSP e municípios. Carapicuíba (06): Minuta do Projeto de Lei de Uso e Ocupação do Solo da Aldeia de Carapicuíba. São Paulo: Emplasa, 1986.

- EMPLASA, Empresa Metropolitana de Planejamento da Grande São Paulo. Plano Macrometrópole Paulista 2040. Evento. Divulgação Observatório da Metrópole, 2014. Disponível em:

http://observatoriodasmetropoles.net/index.php?option=com_k2\&view=item\&id=858:planomacrometr\%C3\%B3pole-paulista-2040\&Itemid=163\&lang=pt $>$. Acesso em mai. de 2016.

- FUNDAÇÃO SEADE, Histórico da Formação do Município de Carapicuíba. In:

$<$ http://produtos.seade.gov.br/produtos/500anos/index.php?arq htm=historico/hist_10609.htm $>$. Acesso em: mai. 2016.

- PLANO DIRETOR de Drenagem dos Municípios de Carapicuíba, Osasco, Jandira, Itapevi e Barueri. Relatório Final. 2a. Parte. São Paulo: EMPLASA, 1976.

- PROJETO 4239 - Acervo Histórico. Uso do solo metropolitano e avanço na regulamentação do ordenamento e compatibilização de planos municipais. Sub-projeto compatibilização das diretrizes metropolitanas para expansão urbana, garantia da produção rural e preservação do patrimônio ambiental. Volume II (Acervo Histórico) - São Paulo: EMPLASA, 1979.

- PROJETO 7343/051 - Elaboração e acompanhamento técnico da implantação de planos diretores e leis de uso municipais. Subprojeto de elaboração do Plano Diretor de Desenvolvimento Integrado da GSP (PDDI) - Carapicuíba. Situação atual do município e perspectivas de desenvolvimento. São Paulo: EMPLASA, 1981.

- LEVANTAMENTO DE POTENCIALIDADES espaciais para Cultura da RMSP: Carapicuíba. São Paulo: EMPLASA, 1981.

- PLANO DIRETOR de Desenvolvimento Integrado do Município de Carapicuíba. Anexo PDDI. São Paulo: EMPLASA, 1981. 
- INVENTÁRIO DE BENS CULTURAIS da Região Metropolitana de São Paulo. Vol. 5 Outros exemplares. São Paulo: EMPLASA, 1986.

- PROJETO 7430/16 - Assistência Técnica aos Municípios. Minuta do Projeto de Lei de uso e Ocupação do Solo da Aldeia de Carapicuíba. São Paulo: EMPLASA, 1986.

- RELATÓRIO AMBIENTAL Preliminar do Rodoanel Metropolitano de São Paulo - Trecho Oeste. Governo do Estado de São Paulo. EMPLASA E DERSA, 1997.

- CARACTERIZAÇÃO DAS UNIDADES Territoriais de Carapicuíba - Segundo Unidades de Informações Territorializadas (UIT's). EMPLASA.

- LEI No 3.074, de 28 de abril de 2011. Institui o Plano Diretor Participativo e Sistema de Planejamento Integrado e Gestão Participativa do Município de Carapicuíba, nos termos dos artigos 182 e 183 da Constituição Federal, do capítulo III da Lei Federal n ${ }^{\circ} 10.257$, de 10 de julho de 2001 - Estatuto da Cidade e da Lei Orgânica de Carapicuíba.

- LEI COMPLEMENTAR N. ${ }^{0}$ 14, de 8 de junho de 1973. Estabelece as Regiões Metropolitanas de São Paulo, Belo Horizonte, Porto Alegre, Recife, Salvador, Curitiba, Belém e Fortaleza.

- PLANO DIRETOR PARTICIPATIVO e Indicador de Qualidade de Vida de Carapicuíba. São Paulo: Instituto Via Pública, 2012.

- PROJETO 7430/16 - Minuta da Lei de Uso e Ocupação do Solo da Aldeia de Carapicuíba. Dispõe sobre a preservação da Aldeia e Carapicuíba, através do disciplinamento do uso e ocupação do solo no conjunto histórico e áreas envoltórias. Elaborado pela EMPLASA.

- LEI ORGÂNICA DO MUNICÍPIO DE CARAPICUÍBA. Promulgada em 10/08/2006 pela prefeitura municipal e publicada em 11/08/2014 no jornal "Cidade em Alerta".

- INDICADORES METROPOLITANOS 2012: conjuntura social e econômica analisada pelos legislativos municipais, produzindo conhecimento e planejamento integrado para a Região Metropolitana de São Paulo. Parlamento Metropolitano. Elaborado pela Consultoria Técnica de Economia e Orçamento - CMSP.

- REGIÕES de influência das cidades 2007. Rio de Janeiro: IBGE, 2008. 201 p.. Disponível em: <http://www.ibge.gov.br/home/geociencias/geografia/regic.shtm?c=7>. Acesso em: ago. 2011.

- SÃO PAULO, DECRETO ESTADUAL N. 47.863 DE 1967. Dispõe sobre a criação do Conselho de Desenvolvimento da Grande São Paulo, do Grupo Executivo da Grande São Paulo e dá outras providências. Disponível em: $<$ http://governosp.jusbrasil.com.br/legislacao/223898/decreto-47863-67>. Acesso em fev. 2016. 


\section{FONTES DOCUMENTAIS NORMATIVAS (PATRIMÔNIO CULTURAL):}

- CONDEPHAAT, Conselho de Defesa do Patrimônio Histórico, Arqueológico, Artístico e Turístico. Cidades Históricas 09 (Carapicuíba). Secretaria de Estado da Cultura de São Paulo e Prefeitura Municipal de Carapicuíba, 1981.

- CONDEPHAAT, Conselho de Defesa do Patrimônio Histórico, Arqueológico, Artístico e Turístico. Bem Tombado Carapicuíba - Aldeia de Carapicuíba e Igreja de São João Batista. Disponível em: $<$ http://www.cultura.sp.gov.br/portal/site/SEC/menuitem.bb3205c597b9e36c3664eb10e2308c $\mathrm{a}$ /? vgnextoid=91b6ffbae7ac1210VgnVCM1000002e03c80aRCRD\&Id=783244e37d52c010 VgnVCM1000001c01a8c0 .>. Acesso em: fev. 2016.

- CONJUNTO ARQUITETÔNICO E URBANÍSTICO da Aldeia de Carapicuíba. Intervenção em Bens Imóveis Tombados. Arquivo: Pasta 00064-0218-T-39. 9a Superintendência Regional do IPHAN/SP.

- DADOS DO CADASTRO NACIONAL DE SíTIOS ARQUEOLÓGICOS. Carapicuíba. Registro em 2001 no Sist. Nac. de Patrimônio Cultural - SNPC. Centro Nacional de Arqueologia - CNA. IPHAN.

- INVENTÁRIO DO CONJUNTO ARQUITETÔNICO e Urbanístico de Carapicuíba. (Carapicuíba/SP). Localização Topográfica: AA01/M031/P01/ Cx.0603/ P.0003 / Env.01;02;03;04;05;06. Período: 16/05/1949 - 05/09/1986 Fotos: 16. Recortes/Jornais: 06. Mapas e Plantas: 14. Conteúdo: Histórico; cópia de fotografia; legislação; recortes sobre a capela de Carapicuíba; turismo; festa da aldeia.

- INVENTÁRIO CAPELA DE SÃO JOÃO BATISTA. (Carapicuíba/SP). Localização Topográfica: AA01/M031/P01/ Cx.0603/ P.0003 / Env.07;08;09;10. Fotos: 22. Mapas e Plantas: 01. Conteúdo: $\mathrm{O}$ dossiê contém documentação fotográfica e mapa.

- IPHAN/OBRAS/CASA. Casa: Aldeia de Carapicuíba-Parte 1. (Cotia/SP). Arquitetura Civil Localização Topográfica: AA01/M044/P06/ Cx.0424/ P.1852. Período: 1942 - 1956 Est. Conservação: Regular.

- IPHAN/OBRAS/CASA. Aldeia de Carapicuíba-Parte 2 (final). (Cotia/SP). Arquitetura Civil Localização Topográfica: AA01/M044/P06/ Cx.0425/ P.1853. Período: 1957 - 1959 Forma: Original, Cópia Est. Conservação: Regular.

- IPHAN/OBRAS. Conjunto Arquitetônico e Urbanístico da Aldeia de Carapicuíba. (Carapicuíba/SP). Localização Topográfica: AA01/M065/P01/ Cx.0963/ P.2612. N. do Processo: 0218-T-39. Fotos: S. Mapas e Plantas: S.

- IPHAN. Carta de Atenas. Atenas, novembro de 1933. Disponível em: < http://portal.iphan.gov.br/portal/baixaFcdAnexo.do?id=233>. Acesso em: jan. de 2015.

- IPHAN. Carta de Veneza. Veneza, de 25 a 31 de maio de 1964. Disponível em: < http://portal.iphan.gov.br/portal/baixaFcdAnexo.do?id=236>. Acesso em dez. de 2014. 
- IPHAN, Normas de Quito: Reunião sobre Conservação e Utilização de Monumentos e Lugares de Interesse Histórico e Artístico em nov/dez de 1967. Disponível em: < http://www.iphan.gov.br/baixaFcdAnexo.do?id=4677>. Acesso em mai. de 2014.

- IPHAN. Recomendação de Nairóbi. Nairóbi, 26-30 de novembro de 1976. Disponível em:< http://portal.iphan.gov.br/portal/baixaFcdAnexo.do?id=249>. Acesso em: ago. de 2014.

- IPHAN, Carta de Machu Picchu: Encontro Internacional de Arquitetos ocorrido em dezembro de $1977 . \quad$ Disponível em: < http://portal.iphan.gov.br/portal/baixaFcdAnexo.do?id=250 >. Acesso em: ago. de 2014.

- IPHAN. Declaração do México. Conferência Mundial sobre as Políticas Culturais, de 1982. Disponível em: < http://portal.iphan.gov.br/portal/baixaFcdAnexo.do?id=255 >. Acesso em ago. de 2013.

- IPHAN, Carta Petrópolis. Petróplis, $1^{\circ}$ Seminário Brasileiro para Preservação e Revitalização de Centros Históricos, em 1987. Disponível em: $<$ http://portal.iphan.gov.br/portal/baixaFcdAnexo.do?id=257>. Acesso em fev. de 2012.

- IPHAN, Carta de Washington. Washington, 1987: Carta Internacional para a Salvaguarda das Cidades Históricas de 1987. Disponível em: < http://portal.iphan.gov.br/portal/baixaFcdAnexo.do?id=258>. Acesso em ago. de 2012.

- IPHAN, Conferência de Nara, novembro de 1994: Conferência sobre a autenticidade em relação à Convenção do Patrimônio Mundial, de 06 de novembro de 1994. Disponível em: $<$ http://portal.iphan.gov.br/portal/baixaFcdAnexo.do?id=264>. Acesso em ago. de 2012.

- IPHAN, Patrimônio Imaterial, 2015: Texto integral no portal institucional. Disponível em: $<$ http://portal.iphan.gov.br/portal/montarPaginaSecao.do?id=10852\&retorno=paginaIphan >. Acesso: fev. 2015.

- IPHAN, Carta de Mar del Plata, 1997: Texto integral no portal institucional. Disponível em: $<$ http://portal.iphan.gov.br/uploads/ckfinder/arquivos/Carta\%20de $\% 20 \mathrm{Mar} \% 20 \mathrm{del} \% 20 \mathrm{Pla}$ ta\%201997.pdf>. Acesso: abr. 2016.

- IPHAN, Carta de Fortaleza, 1997: Texto integral no portal institucional. Disponível em: $<$ http://portal.iphan.gov.br/uploads/ckfinder/arquivos/Carta\%20de\%20Fortaleza $\% 201997$. pdf>. Acesso: abr. 2016.

- IPHAN, Recomendação de Paris, 2003: Texto no portal institucional. Disponível em: $<$ http://portal.iphan.gov.br/uploads/ckfinder/arquivos/Recomendacao\%20Paris\%202003.pdf>. Acesso: abr. 2016.

- IPHAN, Bens tombados. In: <http://portal.iphan.gov.br/pagina/detalhes/126>. Acesso em: abr. de 2016a.

- IPHAN, Arquivo Noronha Santos. In: < http://portal.iphan.gov.br/ans/>. Acesso em abr. de 2016b. 
- IPHAN, Arquivo Noronha Santos: Capela de São João Batista (Carapicuíba, SP). Disponível em: <http://portal.iphan.gov.br/ans/>. Acesso em: mai. 2016c.

- LISTA DOS BENS CULTURAIS Inscritos nos Livros do Tombo (1938-2012). Instituto do Patrimônio Histórico e Artístico Nacional. Departamento de Articulação e Fomento. Coordenação de Geral de Pesquisa e Documentação. Coordenação de Documentação e Informação. Arquivo Central do IPHAN, seção Rio de Janeiro. Rio de Janeiro: IPHAN, 2013.

- LISTA DE BENS TOMBADOS POR MUNICÍPIOS de São Paulo (2013). Conselho de Defesa do Patrimônio Histórico, Arqueológico, Artístico e Turístico do Estado. Unidade de Preservação do Patrimônio Histórico.

- PROCESSO DE TOMBAMENTO da Capela de São João Batista. Proc. 0221-T-39. Capela de São João Batista, Carapicuíba -SP.

- PROCESSO 0218-T-39 - Tombamento do Conjunto Arquitetônico e Urbanístico da Aldeia de Carapicuíba. 1940.

- PROCESSO 01506000219/2003-31. Obras de restauração da Aldeia de Carapicuíba. Volume I e II, 2003. Arquivo da $9^{\text {a }}$ Superintendência Regional do IPHAN/SP.

- PROCESSO ADM. 01506.001796/2011-51. Contratação de subsídio para elaboração e normativas para sítios urbanos tombados no Estado de São Paulo. Vol. I, II, III e IV, 2011. Arquivo da $9^{\text {a }}$ Superintendência Regional do IPHAN/SP.

\section{DOCUMENTOS CARTOGRÁFICOS (Cartas, Plantas e Mapas Históricos)}

- ATlAS DigitAl DA AMÉRICA LUSA. Aldeias e aldeamentos no século XVI. Disponível em: <http://hhs.unb.br/atlas/Aldeias_e_aldeamentos_no_s\%C3\%A9culo_XVI $>$. Acesso em: mai. de 2016.

- BASE CARTOGRÁfICA GEORREFERENCIADA dos logradouros da Região Metropolitana de São Paulo. Edição de 2014. Centro de Estudos da Metrópole. São Paulo 2014.

- CARTAS GEORREFERENCIADAS com divisão territorial e demográfica da Região metropolitana de São Paulo. Disponibilizados pelo CEM, 2014.

- MAPA-INVENTÁRIO DE BENS CULTURAIS da RMSP (1986, Carapicuíba - Escala 1:30.000). São Paulo: EMPLASA, 1986.

- MAPA DO PLANO DIRETOR de Drenagem para Carapicuíba, Osasco, Jandira, Itapevi e Barueri (1976, Bacias Hidrográficas - Escala 1:50.000). São Paulo: EMPLASA, 1976.

- MAPA PDDI (Plano Diretor de Desenvolvimento Integrado da GSP - Carapicuíba). Programa Desvio da Aldeia de Carapicuíba (1981, Escala 1:2.000). Elaborado pela EMPLASA.

- MAPA DE USO DO SOLO de Carapicuíba (1980, Escala 1:10.000) PDDI - Plano Diretor de Desenvolvimento Integrado da GSP - Carapicuíba. Elaborado pela EMPLASA. 
- MAPA DE CONTROLE E PREVENÇÃO de inundações com base em tendências da expansão urbana (1980, Escala 1:25.000). Elaborado pela EMPLASA.

- MAPA DO PLANO DE PRESERVAÇÃO da Aldeia de Carapicuíba - Zona de Preservação Histórica (1973-1980, Escala1:2.000). Elaborado pela EMPLASA.

- MAPA DE DENSIDADE POPULACIONAL de Carapicuíba (base IBGE, 2010). Plano Diretor Participativo e Indicador de Qualidade de Vida de Carapicuíba. Prefeitura Municipal de Carapicuíba. Elaborado pelo Instituto Via Pública, 2012.

- MAPA DE EVOLUÇÃO URBANA de Carapicuíba (1580-2000). Plano Diretor Participativo e Indicador de Qualidade de Vida de Carapicuíba. Prefeitura Municipal de Carapicuíba. Elaborado pelo Instituto Via Pública, 2012.

- MAPA DE PADRÃO DE OCUPAÇÃO de Carapicuíba. Plano Diretor Participativo e Indicador de Qualidade de Vida de Carapicuíba. Prefeitura Municipal de Carapicuíba. Elaborado pelo Instituto Via Pública, 2012.

- MAPA DE HIERARQUIA VIÁRIA do Município. Plano Diretor Participativo e Indicador de Qualidade de Vida de Carapicuíba. Prefeitura Municipal de Carapicuíba. Elaborado pelo Instituto Via Pública, 2012.

- MAPA DE HIDROGRAFIA da Região do Sub-Comitê Pinheiros-Pirapora. Plano Diretor Participativo e Indicador de Qualidade de Vida de Carapicuíba. Prefeitura Municipal de Carapicuíba. Elaborado pelo Instituto Via Pública, 2012.

- MAPA DE RENDA ATUALIZADA por Bairros de Carapicuíba. Plano Diretor Participativo e Indicador de Qualidade de Vida de Carapicuíba. Prefeitura Municipal de Carapicuíba. Elaborado pelo Instituto Via Pública, 2012.

- MAPA DE ÁREA URBANIZADA e com vegetação. Plano Diretor Participativo e Indicador de Qualidade de Vida de Carapicuíba. Prefeitura Municipal de Carapicuíba. Elaborado pelo Instituto Via Pública, 2012.

- MAPA DE ZONAS ESPECIAIS de Interesse Ambiental. Plano Diretor Participativo e Indicador de Qualidade de Vida de Carapicuíba. Prefeitura Municipal de Carapicuíba. Elaborado pelo Instituto Via Pública, 2012.

- MAPA DE ZONAS ESPECIAIS de Interesse Cultural. Plano Diretor Participativo e Indicador de Qualidade de Vida de Carapicuíba. Prefeitura Municipal de Carapicuíba. Elaborado pelo Instituto Via Pública, 2012.

- MAPA DE ZONAS ESPECIAIS de Interesse Social. Plano Diretor Participativo e Indicador de Qualidade de Vida de Carapicuíba. Prefeitura Municipal de Carapicuíba. Elaborado pelo Instituto Via Pública, 2012.

- MAPA DE ZONAS ESPECIAIS de Assentamentos Precários. Plano Diretor Participativo e Indicador de Qualidade de Vida de Carapicuíba. Prefeitura Municipal de Carapicuíba. Elaborado pelo Instituto Via Pública, 2012. 
- MAPA DE CENTRALIDADES. Plano Diretor Participativo e Indicador de Qualidade de Vida de Carapicuíba. Prefeitura Municipal de Carapicuíba. Elaborado pelo Instituto Via Pública, 2012.

- MAPAS DOS ALDEAMENTOS E CAMINHOS ANTIGOS contidos em diversas obras, dentre as quais, na Geografia, de Pierre Monbeig, Aroldo de Azevedo, Pasquale Petrone e Juergen Richard Langenbuch.

- PLANTA DA RECONSTRUÇÃO HISTÓRICA e topográfica aproximada de São Paulo em 1850. Elaborado pelo Departamento Geográfico e Geológico de São Paulo. (Arquivo Público do Estado de São Paulo - Memória Pública).

- PLANTA DA CIDADE DE SÃO PAULO mostrando todos os arrabaldes e terrenos arruados (1924 - Escala 1:30.000). Elaborado pela Comissão Geográfica e Geológica. (Arquivo Público do Estado de São Paulo - Memória Pública).

- PLANTA CENTROS DE SAÚDE com Densidade de Habitantes em Carapicuíba (PDDI Plano Diretor de Desenvolvimento Integrado da GSP - Carapicuíba). Elaborado pela EMPLASA.

- PLANTA DA CIDADE DE SÃO PAULO e municípios circunvizinhos (1943 - Escala 1:50.000). Elaborado pela Repartição de Eletricidade da São Paulo Tramway Light \& Power Co. Ltd. (Arquivo Público do Estado de São Paulo - Memória Pública).

- PLANTAS DA CIDADE DE SÃO PAULO mostrando seu desenvolvimento (de 1810 a 1922 - Escala 1:20.000). Elaborado pela Comissão Geográfica e Geológica. (Arquivo Público do Estado de São Paulo - Memória Pública).

- SEADE, Fundação Sistema Estadual de Análise de Dados. Mapas históricos. Disponível em <www.seade.gov.br>. Acesso: mar. de 2016.

\section{LEVANTAMENTO DE DADOS ESTATÍSTICOS}

- CEM. Centro de Estudos da Metrópole. Base de dados: demografia, divisão territorial, bases cartográficas... São Paulo: CEM, 2014.

- CENSO DEMOGRÁFICO 2010. População residente em 2000 e população residente em 2010, por situação do domicílio, com indicação da população urbana residente na sede municipal, área total e densidade demográfica, segundo as mesorregiões, as microrregiões e os municípios. Rio de Janeiro: IBGE, 2011. Disponível em: $<$ http://www.ibge.gov.br/home/estatistica/populacao/censo2010/caracteristicas_da_populacao /resultados_do_universo.pdf>. Acesso em: fev. 2016.

- EMPLASA, Empresa Metropolitana de Planejamento da Grande São Paulo. UIT's Carapicuíba: dados socioeconômicos, socioambientais, caracterização de domicílios, uso do solo... 2011. 
- EVOLUÇÃO da divisão territorial do Brasil 1872-2010. Rio de Janeiro: IBGE, 2011. 261 p. (Documentos para disseminação. Memória institucional, 17). Disponível em: $<$ httpftp://geoftp.ibge.gov.br/organizacao_territorial/divisao_territorial/evolucao_da_divisao_t erritorial_do_brasil_1872_2010/evolucao_da_divisao_territorial_do_brasil_publicacao_compl eta.pdf>. Acesso em: fev. 2016.

- IBGE, Instituto Brasileiro de Geografia e Estatística. Censo Demográfico 2000. Características Gerais da População Resultados da Amostra Notas Metodológicas. Disponível em:

http://www.ibge.gov.br/home/estatistica/populacao/censo2000/populacao/censo2000_populac ao.pdf $>$. Acesso em: mar. 2016.

- IBGE, Instituto Brasileiro de Geografia e Estatística. Evolução da Divisão Territorial do Brasil $1872 \quad$ - 2010.2 Disponível em: $<$ http://www.ibge.gov.br/home/presidencia/noticias/imprensa/ppts/000000068418121020111 8380911960.pdf $>$. Acesso em: jan. 2016.

- IBGE, Instituto Brasileiro de Geografia E Estatística. Brasil: 500 anos de povoamento. Rio de Janeiro, 2000. p. 221. Disponível em: < http://brasil500anos.ibge.gov.br/estatisticas-dopovoamento/evolucao-da-populacao-brasileira.html>. Acesso em: jan. 2016.

- IBGE, Instituto Brasileiro de Geografia e Estatística. IBGE divulga as estimativas populacionais dos municípios em 2015. Sala de Imprensa, notícia de 28 de agosto de 2015. Disponível em:

http://saladeimprensa.ibge.gov.br/noticias?view=noticia\&id=1\&busca=1\&idnoticia=2972>. Consultado em fev. de 2016.

- IBGE, Instituto Brasileiro de Geografia e Estatística. Mapas e Bases Cartográficas. Disponível em: $<\mathrm{ftp}$ //geoftp.ibge.gov.br/organizacao_territorial/municipios_por_regioes_metropolitanas/Situ acao_2010a2019/>. Acesso em: fev. 2016.

\section{FONTES DOCUMENTAIS DIVERSAS}

- BRASIL. Constituição da República Federativa do Brasil 1988. Disponível em: < https://www.planalto.gov.br/ccivil_03/constituicao/constituicao.htm>. Acesso em ago 2016.

- CARAPICUÍBA, Prefeitura Municipal. Cartão Postal da Aldeia de Carapicuíba. Disponibilizado em campo pela Secretaria de Cultura (Casa da Cultura) e Secretaria do Turismo. Carapicuíba, 2015.

- EMBU DAS ARTES, Prefeitura Municipal. Circuito Paulista Taypa de Pilão. Disponível em: <http://www.embudasartes.sp.gov.br/noticia/ver/2037>. Acesso em ago 2016.

- ESTAÇÕES FERROVIÁRIAS do Brasil. Disponível em: $<$ http://www.estacoesferroviarias.com.br/s/staterezinha.htm>. Acesso em ago 2016.

- GRANJA VIANA, Movimento em Defesa da [2011]. Escândalo. Secretário do meio ambiente de Carapicuíba é contraventor ambiental. Disponível no canal: 
$<$ http://granjaviana.blogspot.com.br/2011/05/escandalo-secretario-do-meio-ambiente.html $>$. Acesso em mai de 2016.

- LISTA DE FONTES DE DADOS GEOGRÁFICOS. Disponível em: $<$ http://www.labgis.uerj.br/fontes_dados_busca.php?g=1>. Acesso em: mai 2016.

- PNUD, Programa das Nações Unidas para o Desenvolvimento. Índice de Desenvolvimento Humano Municipal Brasileiro. Brasília: PNUD, Ipea, FJP, 2013.

- O ESTADO DE S. PAULO. Questão judicial adia construção de 5.400 casas. In: O Estado de São Paulo (jornal), 30 de maio de 1976, p. 37.

- O ESTADO DE S. PAULO. Moradores de Carapicuíba reclamam. In: O Estado de São Paulo (jornal), 13 de maio de 1983, p. 15.

- O ESTADO DE S. PAULO. Carapicuíba, em SP, joga entulho até em área ambiental Geral. In: O Estado de São Paulo (jornal), 12 de maio de 2011. Disponível em: $<$ http://www.estadao.com.br/noticias/geral,carapicuiba-em-sp-joga-entulho-ate-em-areaambiental,718268>. Acesso em: mai 2016.

- SALTO, Prefeitura Municipal. Breve histórico da cidade de Salto. Disponível em: $<$ http://www.salto.sp.gov.br/?io=sP8IHF/9rZSUjAa4Yv4g+tpE\&s=v5+GfTyYNeDtMV7D+F $\mathrm{KqmZ} / \mathrm{A}>$. Acesso em: abr. 2016.

- SÃO PAULO, Empresa Paulista de Planejamento Metropolitano - Emplasa. Por dentro da Região Metropolitana de São Paulo-RMSP. Disponível em: $<$ http://www.emplasa.sp.gov.br/emplasa/RMSP/rmsp.pdf>. Acesso em: jan. 2016.

- UNODC, United Nations Drug Control Programme and the Centre for International Crime Prevention. Some 437,000 people murdered worldwide in 2012, according to new UNODC study. Dispnível em: < https://www.unodc.org/unodc/en/press/releases/2014/April/some437000-people-murdered-worldwide-in-2012-according-to-new-unodc-study.html $>$. Consulta em: fev. 2016.

\section{FONTES AUDIOVISUAIS}

- O RAPPA. Brixton, Bronx ou Baixada: álbum “o Rappa”. Gravadora Warner Music, 1994.

- O ÓDIO [La Haine]. Direção: Mathieu Kassovitz. França. Canal +. 1995. DVD (98min), NTSC, color.

- RACIONAIS. Periferia é periferia: álbum "sobrevivendo no inferno". Gravadora Cosa Nostra, 1997.

- RACIONAIS. Fim de semana no parque: álbum "raio x do Brasil". Gravadora Zimbabwe, 1993.

- SABOTAGE. Cocaína: álbum “rap é compromisso”. Gravadora: Cosa Nostra, 2001. 


\section{ANEXO 01 \\ NOTIFICAÇÃO Nº 316 (1939) SPHAN AO PREFEITO DE SÃO ROQUE/SP SOBRE O TOMBAMENTO DA ALDEIA DE CARAPICUÍBA}

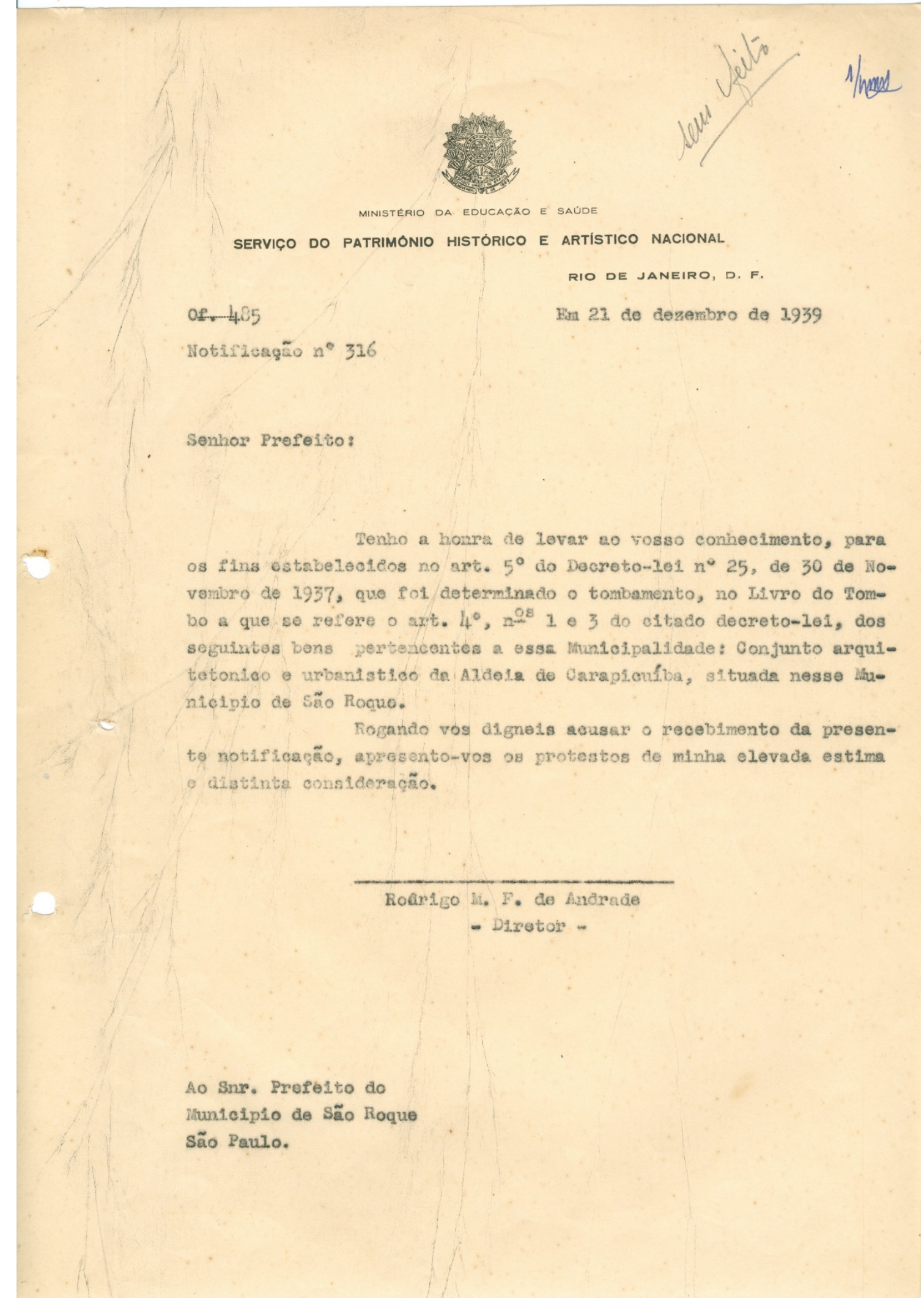


ANEXO 02

NOTIFICAÇÃO Nº 316 (1939) SPHAN AO PREFEITO DE COTIA/SP

SOBRE O TOMBAMENTO DA ALDEIA DE CARAPICUÍBA

Senhor Prefelto:

Tenho a honra de levar a vosso conhecimento, para os fins estabelecidos no art $5^{\circ}$ do Decreto-le $1 \mathrm{n}^{\circ} 25$, de 30 de novembro de 1937, que fol determinado o tombamento, no Livro do Tombo a que se refere $0 \operatorname{art}^{\circ} 4^{\circ}, \mathrm{n}^{\circ} 3$, do eitado decreto-le1, do Conjunto arquitetonico e urbanistico da Aldeia de Carapicufba, situada no Municipio de Cotia, do qual sois o alto representante legal.

Rogando vos digneis acusar o recebimento da presente notificação, apresento-vos os protestos de minha elevada estima e consideração.

Rodrigo M. F. de Andrade Diretor 
ANEXO 03

\section{NOTIFICAÇÃO Nº. 257 (1940) PREFEITURA MUNICIPAL DE COTIA AO SPHAN CONFIRMA ATO DE TOMBAMENTO DA ALDEIA DE CARAPICUÍBA}

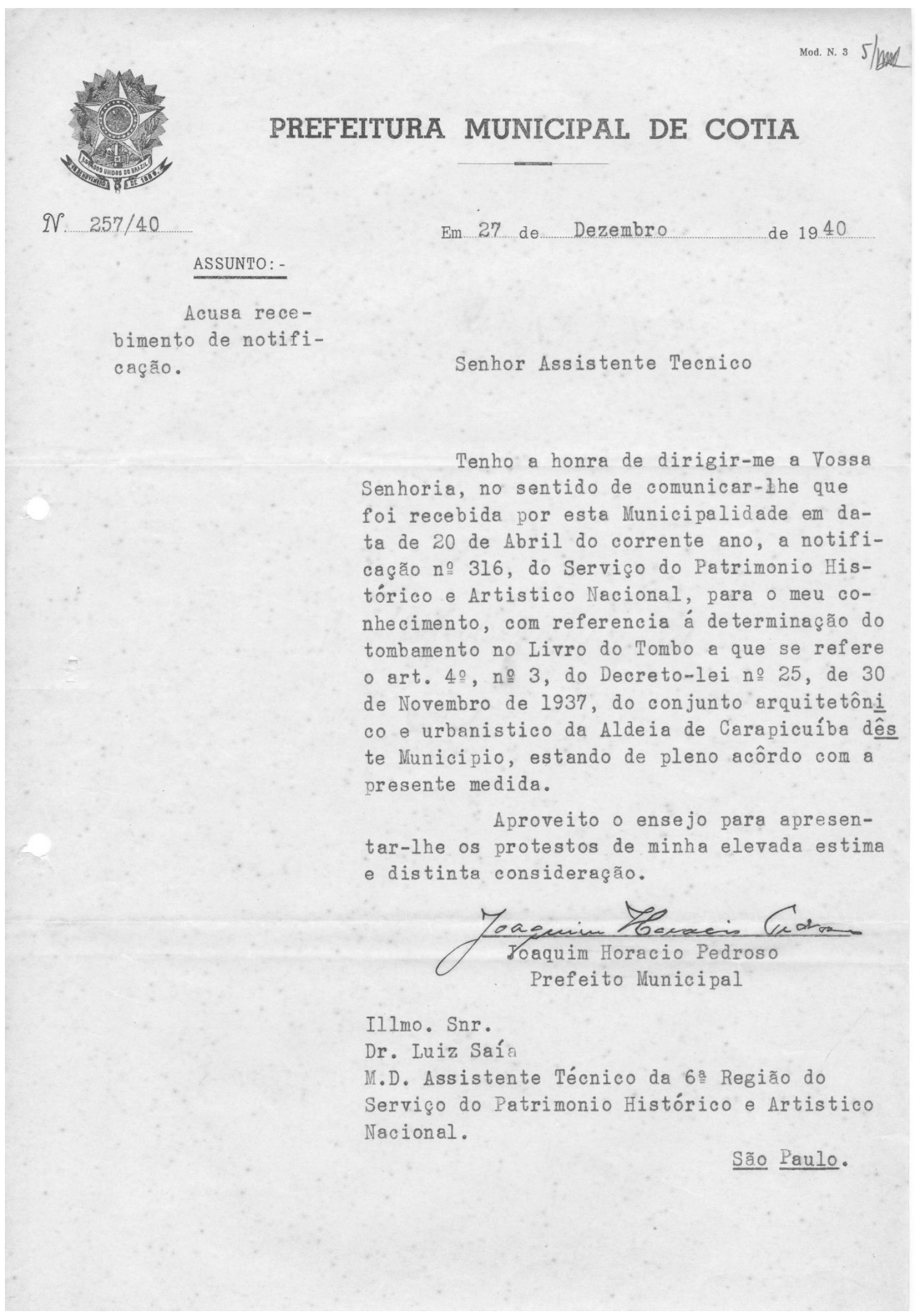




\section{ANEXO 04}

\section{NOTIFICAÇÃO DA ASSOCIAÇÃO DE MORADORES DO ENTORNO DA ALDEIA (1998) AO CONDEPHAAT E IPHAN - DENÚNCIAS DE DEPREDAÇÃO E PROBLEMAS NA ALDEIA DE CARAPICUÍBA}

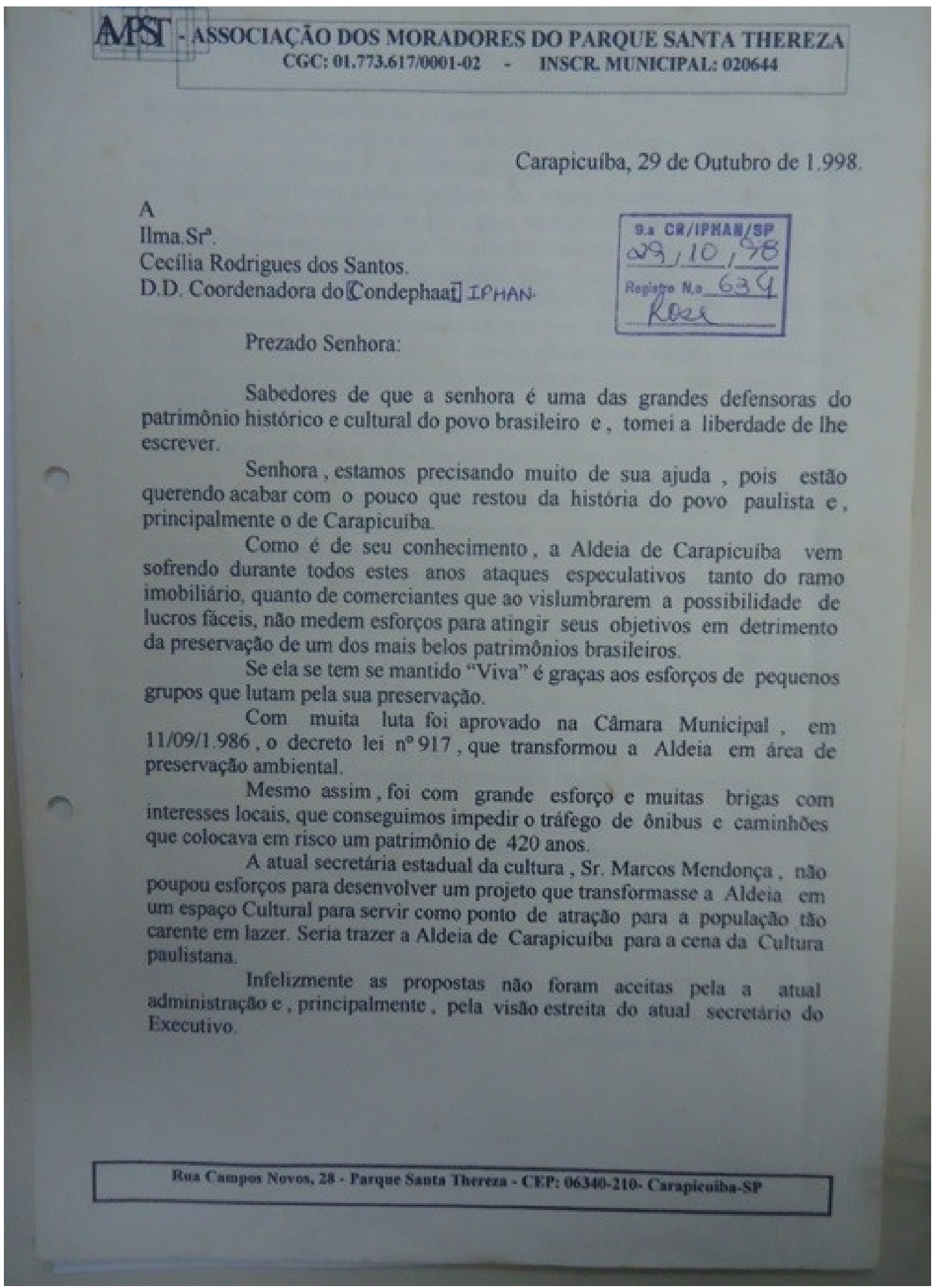


ANEXO 04

NOTIFICAÇÃO DA ASSOCIAÇÃO DE MORADORES DO ENTORNO DA ALDEIA (1998) AO CONDEPHAAT E IPHAN - DENÚNCIAS DE DEPREDAÇÃO E PROBLEMAS NA ALDEIA DE CARAPICUÍBA

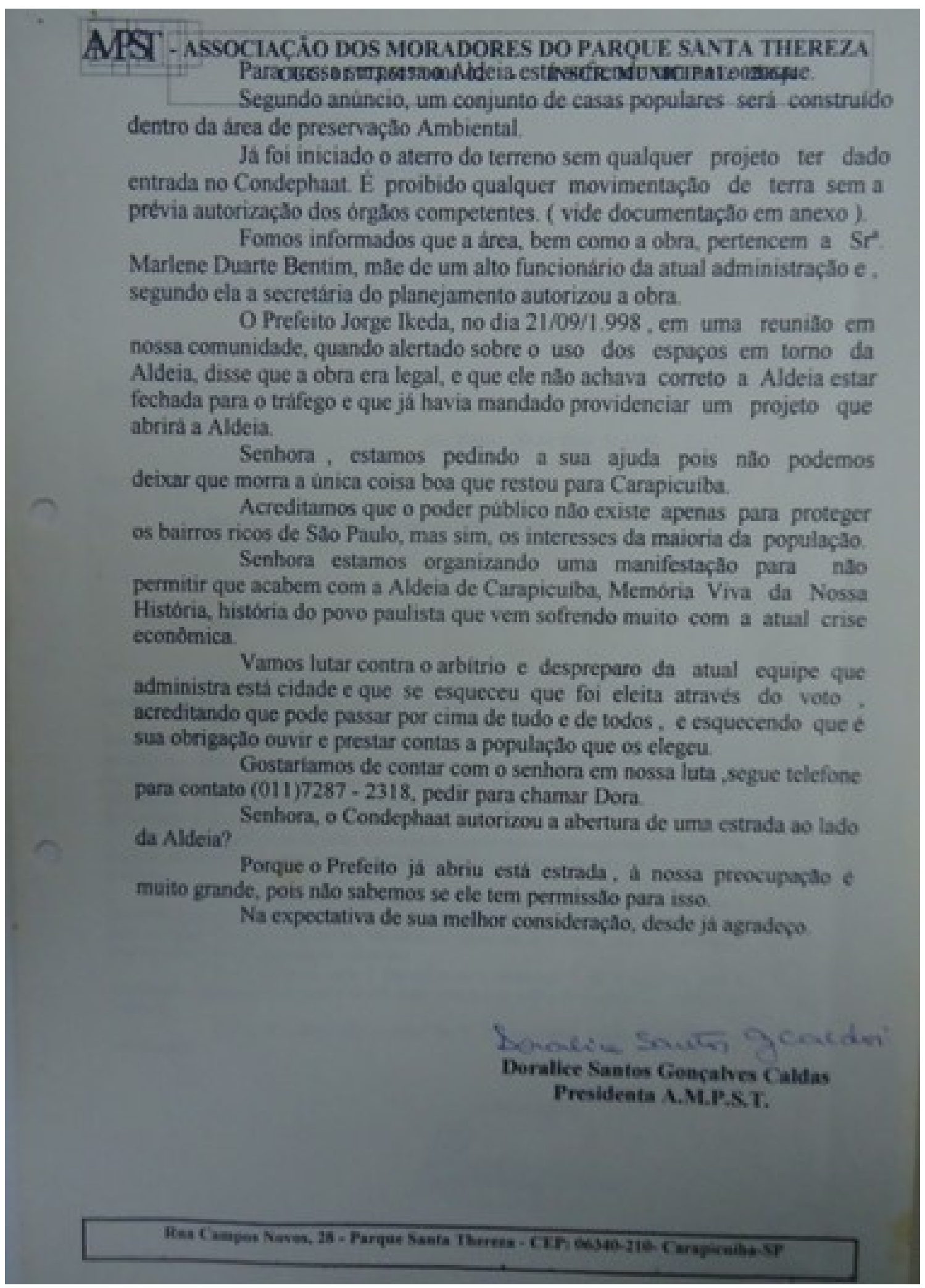




\section{ANEXO 05}

OFÍCIO DO IPHAN (1998) À PREFEITURA DE CARAPICUÍBA ACERCA DE EXECUÇÃO DE OBRAS E RESTAUROS NA ALDEIA

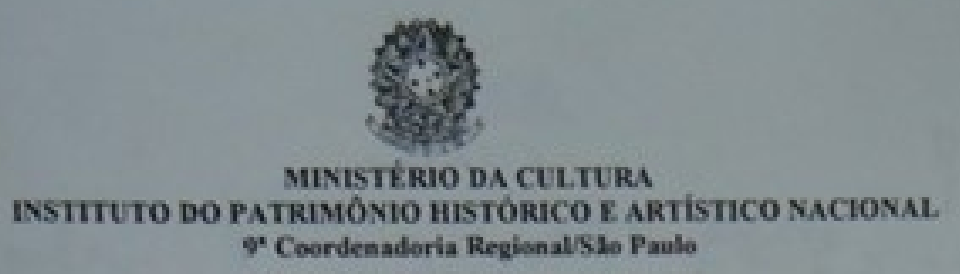

Sto Paulo, 26 de fevereiro de 1998.

Do : Arquiteto Victor Hugo Mori

94 Coordenadoria Regional do IPHAN

Fax (0I1) $8260744-8254285$

Para: Sr. Mário Augusto Ferreira - Secretário Municipal de Finanças

Prefeitura Municipal de Carapicuiba / SP

Fax : 4295876

Ref. : Restauração da Aldeia de Carapicuiba

Convénio Prefeitura e Ministério da Cultura

Acompanhamento teenico de obras

Sr. Secretário,

Fm conformidade com o Convênio assinado entre o Minc e esta Prefeitura, informamos que estivemos acompanhando as obras na Aldeia de Carapicuiba - monumento tombado pelo IPHAN em conformidade com o Decreto-Lei 25/37, e constatamos a execupalo dos servicos abaixo discriminados, de acordo com as orientaçōes técnicas do IPHAN:

Capela

- remoçlo do piso deteriorado da nave

- assentamento de piso de Lajota com dupla queima em todos os ambientes

- reparos em revestimentos

- revisalo da cobertura com substituição de madeiramento danificado

- execuclo de fechamento

- caiaçato

Pátio

- execuçlo da rede de captaçăo de água com caixas de recepslo e escoamento

Atenciosamente

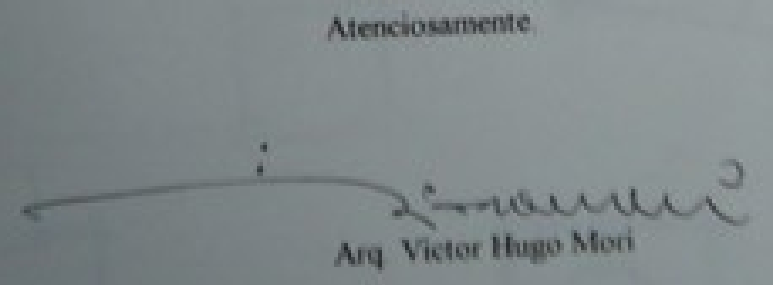




\section{APÊNDICE 01}

\section{QUESTIONÁRIO QUALIFICADO DE OPINIÃO SEMI-ESTRUTURADO APLICADO A POPULAÇÃO LOCAL - CARAPICUÍBA/SP}

\begin{tabular}{|c|c|}
\hline 1. DATA: & 2. LOCAL: \\
\hline 3. SEXO: & 4. IDADE: \\
\hline 5. OCUPAÇÃO: & 6. ESCOLARIDADE: \\
\hline $\begin{array}{l}\text { 7. MORA EM CARAPICUÍBA HÁ QUANTO TEMPO? } \\
(0-10) \quad(11-29) \quad(30 \text { OU MAIS ANOS) }\end{array}$ & 8. ORIGEM DA FAMÍLIA (REGIÃO DO BRASIL) \\
\hline 9. GOSTA DA CIDADE? (SIM) (NÃO) & 10. O QUE MAIS GOSTA? \\
\hline 11. TRABALHA EM CARAPICUÍBA? (SIM) (NÃO/ONDE?) & $\begin{array}{l}\text { 12. QUE TRANSPORTE MAIS USA PARA O } \\
\text { TRABALHO? }\end{array}$ \\
\hline $\begin{array}{l}\text { 13. VAI COM FREQUÊNCIA A SÃO PAULO/CIDADES DA RMSP? } \\
\text { (SIM) (NÃO) }\end{array}$ & $\begin{array}{l}\text { 14. RAZÃO DO DESLOCAMENTO ÀS CIDADES DA } \\
\text { RMSP? }\end{array}$ \\
\hline $\begin{array}{l}\text { 15. UTILIZA OS PARQUES E ESPAÇOS PÚBLICOS DA CIDADE? (SIM) } \\
\text { (NÃO) - CITAR O PRINCIPAL }\end{array}$ & $\begin{array}{l}\text { 16. PARTICIPA DE FESTAS POPULARES OU } \\
\text { RELIGIOSAS DA CIDADE? (SIM) (NÃO) - CITAR A } \\
\text { PRINCIPAL }\end{array}$ \\
\hline 17. CARAPICUÍBA É CIDADE PERIGOSA? (SIM) OU (NÃO) & $\begin{array}{l}\text { 18. CARAPICUÍBA É BOA PRA VIVER? (SIM) OU } \\
\text { (NÃO) }\end{array}$ \\
\hline $\begin{array}{l}\text { 19. CONHECE OU JÁ OUVIR FALAR DO IPHAN OU CONDEPHAAT? } \\
\text { (SIM) OU (NÃO) }\end{array}$ & $\begin{array}{l}\text { 20. EXISTE TURISMO EM CARAPICUÍBA? (SIM) OU } \\
\text { (NÃO) } \\
\text { EM QUE LUGAR? }\end{array}$ \\
\hline 21. CONHECE OS BENS CULTURAIS PROTEGIDOS DA CIDADE? & 22. SE SIM, PODERIA CITAR 1 OU 2? \\
\hline 23. JÁ FOI A PRAÇA DA ALDEIA? (SIM) OU (NÃO) & $\begin{array}{l}\text { 24. COM QUE FREQUÊNCIA VAI À ALDEIA NO } \\
\text { MÊS? } \\
\text { ( ) } 1 \text { OU MENOS ( }) 2(\text { ) } 3 \text { ( ) } 4 \text { VEZES }\end{array}$ \\
\hline $\begin{array}{l}\text { 25. NA SUA OPINIÃO QUAL É A FESTA MAIS } \\
\text { FAMOSA/IMPORTANTE DA ALDEIA? }\end{array}$ & $\begin{array}{l}\text { 26. NA SUA OPINIÃO QUE GRUPOS E PESSOAS } \\
\text { MAIS VISITAM A ALDEIA? }\end{array}$ \\
\hline \multicolumn{2}{|c|}{ 27. DE ZERO (0) A CINCO (5) CLASSIFIQUE OS LOCAIS QUE MAIS GOSTA EM CARAPICUÍBA: } \\
\hline \multicolumn{2}{|c|}{$\begin{array}{ll}\text { ( ) SEU BAIRRO } & \text { ( ) AVENIDA INOCÊNCIO SERÁFICO } \\
\text { ( ) CENTRO } & \text { ( ) PARQUE VILA PLANALTO } \\
\text { ( ) ALDEIA DE CARAPICUÍBA } & \text { ( ) ESTAÇÃO FERROVIÁRIA }\end{array}$} \\
\hline $\begin{array}{l}\text { 28. JÁ FOI EM MUSEU, CASA DA CULTURA OU ANTIQUÁRIO NA } \\
\text { CIDADE DE CARAPICUÍBA? }\end{array}$ & $\begin{array}{l}\text { 29. HOJE CONTINUA INDO EM MUSEU, CASA DA } \\
\text { CULTURA OU ESPAÇOS CULTURAIS DA CIDADE? }\end{array}$ \\
\hline 30. VAI EM IGREJAS? QUAL? FREQUENCIA. & $\begin{array}{l}\text { 31. JÁ PARTICIPOU DE MISSA NA IGREJA DA } \\
\text { ALDEIA? }\end{array}$ \\
\hline \multicolumn{2}{|c|}{ 32. DE ZERO (0) A CINCO (5) CLASSIFIQUE NA CIDADE ONDE COSTUMA ENCONTRAR AMIGOS E PESSOAS CONHECIDAS: } \\
\hline \multicolumn{2}{|c|}{$\begin{array}{lll}\text { ( ) SEU BAIRRO } & \text { ( ) AVENIDA INOCÊNCIO SERÁFICO } & \text { ( ) PARQUE DOS PATURIS } \\
\text { ( ) CENTRO } & \text { ( ) PARQUE VILA PLANALTO } & \text { ( ) PARQUE DA LAGOA } \\
\text { ( ) ALDEIA DE CARAPICUÍBA } & (\text { ) ESTAÇÃO FERROVIÁRIA } & (\text { ) OUTROS? QUAL? } \\
\end{array}$} \\
\hline 33. CONHECE A HISTÓRIA DE CARAPICUÍBA? (SIM) (NÃO) & $\begin{array}{l}\text { 34. O QUE ACHA MAIS IMPORTANTE NA } \\
\text { HISTÓRIA DE CARAPICUÍBA? }\end{array}$ \\
\hline $\begin{array}{l}\text { 35. A ALDEIA AJUDA DE ALGUMA MANEIRA A VIDA DAS PESSOAS } \\
\text { DE CARAPICUÍBA? }\end{array}$ & $\begin{array}{l}\text { 36. TEM ALGUMA RELAÇÃO SENTIMENTAL COM } \\
\text { O ESPAÇO DA ALDEIA? (SIM) (NÃO) - QUAL? }\end{array}$ \\
\hline $\begin{array}{l}\text { 37. TEM ALGUMA RELAÇÃO SENTIMENTAL COM ESPAÇOS DE } \\
\text { CARAPICUÍBA? (SIM) (NÃO) - QUAL POR QUAIS ESPAÇOS? }\end{array}$ & $\begin{array}{l}\text { 38. O QUE MAIS FALTA EM CARAPICUÍBA PARA } \\
\text { SE TRANSFORMAR NUMA CIDADE MELHOR? }\end{array}$ \\
\hline $\begin{array}{l}\text { 39. CONSEQUE APONTAR MUDANÇAS QUE OCORRERAM NA } \\
\text { CIDADE NOS ÚLTIMOS ANOS/DÉCADAS? }\end{array}$ & $\begin{array}{l}\text { 40. COMO ESSAS MUDANÇAS LHE AFETARAM? } \\
\text { POSITIVA, NEGATIVA OU INDEFERENTEMENTE. }\end{array}$ \\
\hline $\begin{array}{l}\text { 41. NA SUA OPINIÃO, O QUE CARAPICUÍBA TEM DE ESPECIAL EM } \\
\text { RELAÇÃO A QUALQUER OUTRA CIDADE? }\end{array}$ & $\begin{array}{l}\text { 42. MUDARIA DE CARAPICUÍBA? (SIM) OU (NÃO) } \\
\text { JUSTIFIQUE. }\end{array}$ \\
\hline
\end{tabular}

INTERESSA FAZER UMA ENTREVISTA MAIS COMPLETA FUTURAMENTE? CONTATO: 


\section{APÊNDICE 02}

\section{ENTREVISTA QUALIFICADA SEMI-ESTRUTURADA APLICADO A POPULAÇÃO DE CARAPICUÍBA/SP}

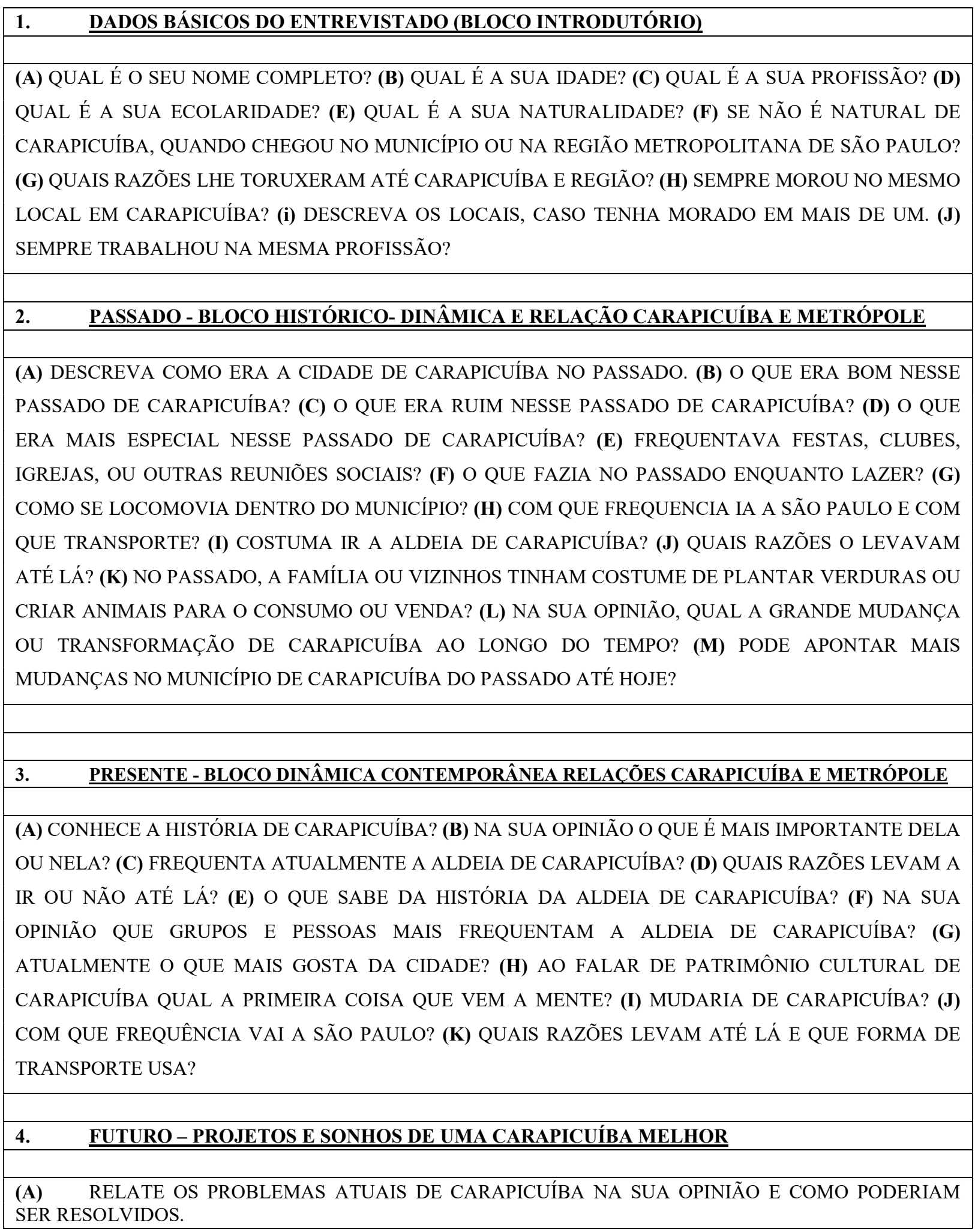




\section{APÊNDICE 03}

\section{TERMO DE CONSENTIMENTO LIVRE E ESCLARECIDO - TCLE}

Convidamos o(a) Senhor(a) a participar do projeto de pesquisa "Do Aldeamento Indígena ao Aldeamento Metropolitano em São Paulo", sob a responsabilidade do pesquisador RAFAEL FABRICIO DE OLIVEIRA. O projeto se desenvolve no âmbito do Doutorado em Geografia, no qual analisamos como se desenvolveu o processo de metropolização em Carapicuíba.

O objetivo desta pesquisa é compreender o processo de metropolização de Carapicuíba, enfocando o patrimônio cultural e as memórias de sua população.

$\mathrm{O}$ (a) senhor(a) receberá todos os esclarecimentos necessários antes e no decorrer da pesquisa e lhe asseguramos que seu nome não aparecerá sendo mantido o mais rigoroso sigilo pela omissão total de quaisquer informações que permitam identificá-lo(a), a não ser que opte por seu nome aparecer no trabalho.

A sua participação se dará por meio de entrevista semiestruturada, entre 30/06/2016 e 14/08/2016 com um tempo estimado de 1 hora para sua realização.

Os riscos decorrentes de sua participação na pesquisa são praticamente nulos, já que expressará sua experiência de vida. Se você aceitar participar, estará contribuindo para o conhecimento dos lugares sobre a óptica de seus moradores, com projetos assentados em suas demandas.

$\mathrm{O}$ (a) Senhor(a) pode se recusar a responder (ou participar de qualquer procedimento) qualquer questão que lhe traga constrangimento, podendo desistir de participar da pesquisa em qualquer momento sem nenhum prejuízo para o(a) senhor(a). Sua participação é voluntária, isto é, não há pagamento por sua colaboração.

Todas as despesas que você tiver relacionadas diretamente ao projeto de pesquisa (tais como, passagem para o local da pesquisa, alimentação no local da pesquisa ou exames para realização da pesquisa) serão cobertas pelo pesquisador responsável.

Caso haja algum dano direto ou indireto decorrente de sua participação na pesquisa, você poderá ser indenizado, obedecendo-se as disposições legais vigentes no Brasil.

Os resultados da pesquisa serão divulgados na Universidade de Brasília podendo ser publicados posteriormente. Os dados e materiais serão utilizados somente para esta pesquisa e ficarão sob a guarda do pesquisador por um período de cinco anos, após isso serão destruídos.

Se o(a) Senhor(a) tiver qualquer dúvida em relação à pesquisa, por favor telefone para: Rafael Fabricio de Oliveira ou Everaldo Batista da Costa, na Universidade de Brasília no telefone (61) 32732612, disponível inclusive para ligação a cobrar. Ou pelo e-mail: rafabricio@gmail.com.

Este projeto foi aprovado pelo Comitê de Ética em Pesquisa da Faculdade de Ciências da Saúde (CEP/FS) da Universidade de Brasília. O CEP é composto por profissionais de diferentes áreas cuja função é defender os interesses dos participantes da pesquisa em sua integridade e dignidade e contribuir no desenvolvimento da pesquisa dentro de padrões éticos. As dúvidas com relação à assinatura do TCLE ou os direitos do participante da pesquisa podem ser esclarecidos pelo telefone (61) 3107-1947 ou do e-mail cepfs@unb.br ou cepfsunb@gmail.com, horário de atendimento de 10:00hs às 12:00hs e de 13:30hs às 15:30hs, de segunda a sexta-feira. O CEP/FS se localiza na Faculdade de Ciências da Saúde, Campus Universitário Darcy Ribeiro, Universidade de Brasília, Asa Norte.

Caso concorde em participar, pedimos que assine este documento que foi elaborado em duas vias, uma ficará com o pesquisador responsável e a outra com o Senhor(a).

DESEJA TER SEU NOME PUBLICADO NO TRABALHO? （ ) SIM -- （ ) NÃO

Nome / assinatura

RAFAEL FABRÍCIO DE OLIVEIRA

Pesquisador Responsável

Nome e assinatura

de de 


\title{
APÊNDICE 04
}

\section{PARECER CONSUBSTANCIADO (PARTE) - CONSELHO DE ÉTICA UNB}

\section{$\Phi$ \\ UnB}

\author{
UNB - FACULDADE DE \\ CIÊNCIAS DA SAÚDE
}

Platoforma

Qrasil

\section{PARECER CONSUBSTANCIADO DO CEP}

\section{DADOS DO PROJETO DE PESQUISA}

Título da Pesquisa: DO ALDEAMENTO INDíGENA AO ALDEAMENTO METROPOLITANO EM SÃO Pesquisador: RAFAEL FABRICIO DE OLIVEIRA

Área Temática:

Versão: 2

CAAE: 55545216.6 .0000 .0030

Instituição Proponente: Instituto de Ciências Humanas

Patrocinador Principal: Financiamento Próprio

DADOS DO PARECER

Número do Parecer: 1.642 .352

Este parecer foi elaborado baseado nos documentos abaixo relacionados:

\begin{tabular}{|c|c|c|c|c|}
\hline Tipo Documento & Arquivo & Postagem & Autor & Situação \\
\hline $\begin{array}{l}\text { Informações Básicas } \\
\text { do Projeto }\end{array}$ & $\begin{array}{l}\text { PB_INFORMAÇŐES_BÁSICAS_DO_P } \\
\text { ROJETO 701423.pdf }\end{array}$ & $\begin{array}{c}07 / 07 / 2016 \\
16: 51: 13 \\
\end{array}$ & & Aceito \\
\hline $\begin{array}{l}\text { TCLE / Termos de } \\
\text { Assentimento / } \\
\text { Justificativa de } \\
\text { Ausência }\end{array}$ & carta_resposta_CEP.doc & $\begin{array}{c}07 / 07 / 2016 \\
16: 50: 33\end{array}$ & $\begin{array}{l}\text { RAFAEL FABRICIO } \\
\text { DE OLIVEIRA }\end{array}$ & Aceito \\
\hline $\begin{array}{l}\text { TCLE / Termos de } \\
\text { Assentimento / } \\
\text { Justificativa de } \\
\text { Ausência }\end{array}$ & TCLE_Oliveira.pdf & $\begin{array}{c}27 / 04 / 2016 \\
16: 15: 17\end{array}$ & $\begin{array}{l}\text { RAFAEL FABRICIO } \\
\text { DE OLIVEIRA }\end{array}$ & Aceito \\
\hline Outros & CartaProjeto_Oliveira.pdf & $\begin{array}{c}27 / 04 / 2016 \\
15: 17: 38\end{array}$ & $\begin{array}{l}\text { RAFAEL FABRICIO } \\
\text { DE OLIVEIRA }\end{array}$ & Aceito \\
\hline Declaração de & TermoResponsabilidade_Oliveira.pdf & $27 / 04 / 2016$ & RAFAEL FABRICIO & Aceito \\
\hline Pesquisadores & TermoResponsabilidade_Oliveira.pdf & $15: 15: 02$ & DE OLIVEIRA & Aceito \\
\hline $\begin{array}{l}\text { Declaração de } \\
\text { Instituição e } \\
\text { Infraestrutura }\end{array}$ & TermoConcordancia_Oliveira.pdf & $\begin{array}{c}27 / 04 / 2016 \\
15: 13: 52\end{array}$ & $\begin{array}{l}\text { RAFAEL FABRICIO } \\
\text { DE OLIVEIRA }\end{array}$ & Aceito \\
\hline Folha de Rosto & \begin{tabular}{|l} 
Folharosto02_Oliveira.pdf \\
\end{tabular} & $\begin{array}{c}27 / 04 / 2016 \\
15: 11: 46 \\
\end{array}$ & $\begin{array}{l}\text { RAFAEL FABRICIO } \\
\text { DE OLIVEIRA }\end{array}$ & Aceito \\
\hline Orçamento & CronogramaOrcamento_Oliveira.pdf & $\begin{array}{c}27 / 04 / 2016 \\
15: 08: 44 \\
\end{array}$ & $\begin{array}{l}\text { RAFAEL FABRICIO } \\
\text { DE OLIVEIRA }\end{array}$ & Aceito \\
\hline $\begin{array}{l}\text { Projeto Detalhado / } \\
\text { Brochura } \\
\text { Investigador }\end{array}$ & ProjetoPesquisa_Oliveira.pdf & $\begin{array}{c}20 / 04 / 2016 \\
13: 27: 46\end{array}$ & $\begin{array}{l}\text { RAFAEL FABRICIO } \\
\text { DE OLIVEIRA }\end{array}$ & Aceito \\
\hline Outros & Lattes_OrientadorCosta.pdf & $\begin{array}{c}20 / 04 / 2016 \\
12: 57: 19 \\
\end{array}$ & $\begin{array}{l}\text { RAFAEL FABRICIO } \\
\text { DE OLIVEIRA } \\
\end{array}$ & Aceito \\
\hline Outros & Lattes_Oliveira.pdf & $\begin{array}{c}20 / 04 / 2016 \\
12: 56: 27 \\
\end{array}$ & $\begin{array}{l}\text { RAFAEL FABRICIO } \\
\text { DE OLIVEIRA }\end{array}$ & Aceito \\
\hline Outros & \begin{tabular}{|l} 
InstrumentosPesquisa_Oiveira.pdf \\
\end{tabular} & $\begin{array}{c}20 / 04 / 2016 \\
12: 55: 45\end{array}$ & $\begin{array}{l}\text { RAFAEL FABRICIO } \\
\text { DE OLIVEIRA }\end{array}$ & Aceito \\
\hline Cronograma & Cronograma_Oliveira.pdf & $\begin{array}{c}20 / 04 / 2016 \\
12: 54: 00 \\
\end{array}$ & $\begin{array}{l}\text { RAFAEL FABRICIO } \\
\text { DE OLIVEIRA } \\
\end{array}$ & Aceito \\
\hline Outros & CartaRevisaoEtica_Oliveira.pdf & $\begin{array}{c}20 / 04 / 2016 \\
12: 53: 29 \\
\end{array}$ & $\begin{array}{l}\text { RAFAEL FABRICIO } \\
\text { DE OLIVEIRA }\end{array}$ & Aceito \\
\hline Outros & CartaEncaminhamento_Oliveira.pdf & $\begin{array}{c}20 / 04 / 2016 \\
12: 52: 50\end{array}$ & $\begin{array}{l}\text { RAFAEL FABRICIO } \\
\text { DE OLIVEIRA }\end{array}$ & Aceito \\
\hline
\end{tabular}

Situaçäo do Parecer:

Aprovado

Necessita Apreciação da CONEP:

Não

BRASILIA, 14 de Julho de 2016

Assinado por:

Keila Elizabeth Fontana

Endereço: Faculdade de Ciências da Saúde - Campus Darcy Ribeiro

Bairro: Asa Norte CEP: $70.910-900$

UF: DF Municíp 


\section{APÊNDICE 05 \\ SÍNTESE DA URBANIZAÇÃO NOS PAÍSES \\ DESENVOLVIDOS E SUBDESENVOLVIDOS}

\begin{tabular}{|c|c|c|}
\hline ASPECTOS GERAIS & PAÍSES DESENVOLVIDOS & PAÍSES SUBDESENVOLVIDOS \\
\hline Organização do Transporte & $\begin{array}{l}\text { Ferrovias e sistemas prévios ou simultâneos } \\
\text { a industrialização, tecnologia endógena, a } \\
\text { sua modernização acompanha e integra a } \\
\text { complexa rede de povoados e territórios, mas } \\
\text { não apenas a produção de mercadorias e } \\
\text { serviços (diversificação dos sistemas } \\
\text { principais: fluvial, ferroviário, rodoviário). }\end{array}$ & $\begin{array}{l}\text { Desvincula-se das estratégias de desenvolvimento } \\
\text { regional, instala-se tardiamente, de forma } \\
\text { dependente de tecnologia externa e com foco no } \\
\text { escamento da produção de matérias-primas } \\
\text { (ferroviário e, posteriormente rodoviário). }\end{array}$ \\
\hline Cidades e Região & $\begin{array}{l}\text { O desenvolvimento das cidades acompanha o } \\
\text { da própria região. As desigualdades são } \\
\text { tênues, campo e cidade se apresentam } \\
\text { simbioticamente como unidades } \\
\text { interdependentes de produção, distribuição e } \\
\text { consumo. }\end{array}$ & $\begin{array}{l}\text { Cidade e campo são isolados, dicotomizados, } \\
\text { perpetuando desequilíbrios e marcando o êxodo } \\
\text { rural e expansão das periferias urbanas. Amplas } \\
\text { desigualdades sociais passam a marcar os espaços } \\
\text { dos excluídos e das hegemonias que controlam a } \\
\text { produção. }\end{array}$ \\
\hline Espaços Urbanos & $\begin{array}{l}\text { Modernização arquitetônica, tecnologias } \\
\text { trazidas pelo vidro e aço dão novas formas às } \\
\text { cidades e áreas de controle, da produção e } \\
\text { influência política à nível mundial. Funções } \\
\text { de mobilidade e informação são conceitos- } \\
\text { chave na nova organização administrativa } \\
\text { das cidades, de suas empresas e firmas. } \\
\text { Destaca-se o planejamento estratégico, como } \\
\text { forte capital cultural e social. }\end{array}$ & $\begin{array}{l}\text { Novas cidades são criadas: do agronegócio, da } \\
\text { mineração e de grandes projetos privados dão à } \\
\text { tona de um espaço determinado pela produção de } \\
\text { commodities nos países subdesenvolvidos, na } \\
\text { efemeridade do movimento vertical e dos } \\
\text { interesses produtivos das externalidades globais. } \\
\text { Planejamento envereda aos interesses corporativos } \\
\text { e monopolistas de parte dos agentes internos e } \\
\text { externo }\end{array}$ \\
\hline Processo de Urbanização & $\begin{array}{l}\text { Longo, ritmo próprio, movimento dinâmico e } \\
\text { linear, desenvolvido ao longo dos séculos, } \\
\text { planejado e gerido pelo Estado. Cidades } \\
\text { integradas, apesar da centralidade dos } \\
\text { núcleos há certo equilíbrio de funções e de } \\
\text { aglomeração, com diversas cidades médias } \\
\text { que articulam e dão fluidez entre pequenas e } \\
\text { grandes aglomerações. Crescimento } \\
\text { equalizado na rede de cidades e no campo. }\end{array}$ & $\begin{array}{l}\text { Crescimento cumulativo das cidades - } \\
\text { macrocefalia. Concentração acentuada e veloz nos } \\
\text { núcleos urbano-industriais principais. Vertiginoso } \\
\text { adensamento demográfico, com poucas cidades } \\
\text { médias e muitas cidades, controladas e } \\
\text { dependentes das metrópoles (capitais, ou áreas de } \\
\text { produção). }\end{array}$ \\
\hline Especialização Urbana & $\begin{array}{l}\text { Cidades especializadas, responsáveis por } \\
\text { parte da produção, serviços e atividades } \\
\text { econômicas. Espaços fluidos permitem } \\
\text { intensa comunicação e interelações } \\
\text { complexas entre os núcleos urbanos. A base } \\
\text { de infraestrutura e transporte, qualificam o } \\
\text { espaço com amplos investimentos e trazem } \\
\text { vantagens diversas para as cidades, } \\
\text { engendrando seu desenvolvimento integrado } \\
\text { a outras áreas especializadas com forte } \\
\text { embasamento em pesquisa e tecnologias. }\end{array}$ & $\begin{array}{l}\text { Acúmulo de atividades em um único polo, ou em } \\
\text { poucos centros, hipertrofiando a infraestrutura, } \\
\text { heterogeneizando os territórios e causando } \\
\text { desequilíbrio regional. A concentração das } \\
\text { atividades produtivas é dada em polos industriais e } \\
\text { urbanos específicos (espaços polarizados). As } \\
\text { cidades são responsáveis, sobretudo, pela } \\
\text { regulação administrativa e comercial das } \\
\text { commodities, das relações internacionais e a } \\
\text { financeirização entre os fluxos econômicos. }\end{array}$ \\
\hline
\end{tabular}

Fonte: Lacoste (1966) e Santos (1980). Organizado pelo autor, 2016. 


\section{APÊNDICE 06}

\section{REGIÕES METROPOLITANAS NO BRASIL - ATUALIZADO (2015)}

\begin{tabular}{|c|c|c|c|}
\hline $\begin{array}{l}\mathbf{N}^{\mathbf{0}} \\
\mathbf{R M} \\
\end{array}$ & $\mathbf{U F}$ & $\begin{array}{l}\text { REGIÕES } \\
\text { METROPOLITANAS }\end{array}$ & CRIAÇÃO \\
\hline 1 & AL & RM Agreste & 30.11 .2009 \\
\hline 2 & $\mathrm{AL}$ & RM da Zona da Mata & 15.12 .2011 \\
\hline 3 & $\mathrm{AL}$ & RM de Caetés & 26.07 .2012 \\
\hline 4 & $\mathrm{AL}$ & $\begin{array}{l}\text { RM de Palmeira dos } \\
\text { Índios }\end{array}$ & 05.01 .2012 \\
\hline 5 & $\mathrm{AL}$ & RM do Médio Sertão & 08.08 .2013 \\
\hline 6 & $\mathrm{AL}$ & RM do Sertão & 26.07 .2012 \\
\hline 7 & AL & RM do Vale do Paraíba & 15.12 .2011 \\
\hline 8 & $\mathrm{AL}$ & RM Maceió & 19.11 .1998 \\
\hline 9 & $\mathrm{AM}$ & RM Manaus & 30.05 .2007 \\
\hline 10 & AP & RM Macapá & 26.02 .2003 \\
\hline 11 & $\mathrm{BA}$ & RM Feira de Santana & 06.07 .2011 \\
\hline 12 & $\mathrm{BA}$ & RM Salvador & 08.06 .1973 \\
\hline 13 & $\mathrm{CE}$ & RM Cariri & 26.06 .2009 \\
\hline 14 & $\mathrm{CE}$ & RM Fortaleza & 08.06 .1973 \\
\hline 15 & ES & RM Grande Vitória & 18.01 .2005 \\
\hline 16 & $\mathrm{GO}$ & RM Goiânia & 30.12 .1999 \\
\hline 17 & MA & RM Grande São Luís & 25.05 .2015 \\
\hline 18 & MA & $\begin{array}{l}\text { RM Sudoeste } \\
\text { Maranhense }\end{array}$ & 17.11 .2005 \\
\hline 19 & MG & RM Belo Horizonte & 08.06 .1973 \\
\hline 20 & MG & RM Vale do Aço & 04.01 .2012 \\
\hline 21 & MT & RM Vale do Rio Cuiabá & 27.05 .2009 \\
\hline 22 & PA & RM Belém & 08.06 .1973 \\
\hline 23 & PA & RM Santarém & 17.01.2012 \\
\hline 24 & PB & RM Campina Grande & 11.12.2009 \\
\hline 25 & PB & RM de Araruna & 21.01 .2013 \\
\hline 26 & PB & $\begin{array}{l}\text { RM de Barra de Santa } \\
\text { Rosa }\end{array}$ & 13.07.2012 \\
\hline 27 & PB & RM de Cajazeiras & 08.06 .2012 \\
\hline 28 & PB & RM de Esperança & 08.06 .2012 \\
\hline 29 & PB & RM de Itabaiana & 21.01 .2013 \\
\hline 30 & PB & RM de Sousa & 21.01 .2013 \\
\hline 31 & PB & $\begin{array}{l}\text { RM do V. do } \\
\text { Mamanguape }\end{array}$ & 21.01 .2013 \\
\hline 32 & PB & RM do Vale do Piancó & 06.07 .2012 \\
\hline 33 & PB & RM Guarabira & 12.07.2011 \\
\hline 34 & PB & RM João Pessoa & 30.12 .2003 \\
\hline 35 & PB & RM Patos & 27.12 .2011 \\
\hline
\end{tabular}

\begin{tabular}{|c|c|c|c|}
\hline $\begin{array}{l}N^{\mathbf{0}} \\
\mathbf{R M}\end{array}$ & UF & $\begin{array}{l}\text { REGIÕES } \\
\text { METROPOLITANAS }\end{array}$ & CRIAÇÃO \\
\hline 36 & $\mathrm{PE}$ & RM Recife & 08.06 .1973 \\
\hline 37 & PR & RM Apucarana & 12.01 .2015 \\
\hline 38 & PR & RM Campo Mourão & 12.01 .2015 \\
\hline 39 & PR & RM Cascavel & 12.01.2015 \\
\hline 40 & PR & RM Curitiba & 08.06 .1973 \\
\hline 41 & PR & RM de Umuarama & 22.08 .2012 \\
\hline 42 & PR & RM Londrina & 17.06 .1998 \\
\hline 43 & PR & RM Maringá & 17.07 .1998 \\
\hline 44 & PR & RM Toledo & 12.01 .2015 \\
\hline 45 & $\mathrm{RJ}$ & RM Rio de Janeiro & 01.07 .1974 \\
\hline 46 & $\mathrm{RN}$ & RM Natal & 16.01 .1997 \\
\hline 47 & $\mathrm{RR}$ & RM Central & 21.12 .2007 \\
\hline 48 & RR & RM da Capital & 21.12 .2007 \\
\hline 49 & RR & RM do Sul do Estado & 21.12 .2007 \\
\hline 50 & $\mathrm{RS}$ & RM da Serra Gaúcha & 30.08 .2013 \\
\hline 51 & RS & RM Porto Alegre & 08.06 .1973 \\
\hline 52 & $\mathrm{SC}$ & RM Carbonífera & 09.01 .2002 \\
\hline 53 & $\mathrm{SC}$ & RM Chapecó & 20.12 .2010 \\
\hline 54 & $\mathrm{SC}$ & $\begin{array}{l}\text { RM do Alto Vale do } \\
\text { Itajaí }\end{array}$ & 20.12 .2010 \\
\hline 55 & $\mathrm{SC}$ & RM do Contestado & 24.05 .2012 \\
\hline 56 & $\mathrm{SC}$ & RM do Extremo Oeste & 24.05 .2012 \\
\hline 57 & $\mathrm{SC}$ & RM Florianópolis & 09.09 .2014 \\
\hline 58 & $\mathrm{SC}$ & RM Foz do Rio Itajaí & 09.01 .2002 \\
\hline 59 & $\mathrm{SC}$ & RM Lages & 26.01 .2010 \\
\hline 60 & $\mathrm{SC}$ & $\begin{array}{l}\text { RM Norte/Nordeste } \\
\text { Catarinense }\end{array}$ & 06.01 .1998 \\
\hline 61 & $\mathrm{SC}$ & RM Tubarão & 09.01.2002 \\
\hline 62 & $\mathrm{SC}$ & RM Vale do Itajaí & 06.01 .1998 \\
\hline 63 & SE & RM Aracaju & 29.12 .1995 \\
\hline 64 & SP & RM Baixada Santista & 30.07 .1996 \\
\hline 65 & SP & RM Campinas & 19.06 .2000 \\
\hline 66 & SP & RM de Sorocaba & 20.06 .2014 \\
\hline 67 & SP & $\begin{array}{l}\text { RM do V. do Paraíba e } \\
\text { Litoral Norte }\end{array}$ & 09.01 .2012 \\
\hline 68 & SP & RM São Paulo & 08.06 .1973 \\
\hline 69 & $\mathrm{TO}$ & RM Gurupi & 05.04 .2014 \\
\hline 70 & TO & RM Palmas & 08.01 .2014 \\
\hline
\end{tabular}

Crescimento do número de Regiões Metropolitanas no Brasil. Destaque para os elevados números de regiões metropolitanas criadas nos estados do PR (8), AL (8), PB (9) e SC (10).

Fonte: IBGE, 2015 (Composição de RMs, RIDEs e Aglomerações Urbanas). Organização do autor, 2016. 